$$
\text { UNIVERSIDADE DE SÃO PAULO }
$$

FACULDADE DE ARQUITETURA E URBANISMO

DOUTORADO INTERINSTITUCIONAL EM ARQUITETURA E URBANISMO

FAUUSP - DAUUFC

\title{
DINÂMICAS URBANAS RECENTES \\ DA ÁREA METROPOLITANA DE FORTALEZA
}

Beatriz Helena Nogueira Diógenes 


\title{
Beatriz Helena Nogueira Diógenes
}

\author{
DINÂMICAS URBANAS RECENTES
}

\section{DA ÁREA METROPOLITANA DE FORTALEZA}

Tese apresentada à Faculdade de Arquitetura e Urbanismo da Universidade de São Paulo, como parte dos requisitos para obtenção do título de Doutor em Arquitetura e Urbanismo.

Área de Concentração: História e Fundamentos da Arquitetura e do Urbanismo

ORIENTADOR: Prof. Dr. Nestor Goulart Reis 


\section{AUTORIZO A REPRODUÇÃO E DIVULGAÇÃO TOTAL OU PARCIAL DESTE TRABALHO, POR QUALQUER MEIO CONVENCIONAL OU ELETRÔNICO, PARA FINS DE ESTUDO E PESQUISA, DESDE QUE CITADA A FONTE.}

E-MAIL: bhdiogenes@yahoo.com.br

Diógenes, Beatriz Helena Nogueira

D591d Dinâmicas urbanas recentes da área metropolitana de

Fortaleza / Beatriz Helena Nogueira Diógenes. - São Paulo, 2012. 360 p.: il.

Tese (Doutorado - Área de Concentração: História e Fundamentos da Arquitetura e do Urbanismo) - FAUUSP.

Orientador: Nestor Goulart Reis

1. Expansão urbana - Fortaleza (CE) 2. Urbanismo - Fortaleza (CE) 3. Áreas metropolitanas - Fortaleza (CE) I.Título 


\section{Agradecimentos}

Esta tese é resultado de quatro anos de muita pesquisa, trabalho árduo e dedicação. Nesse percurso, foram muitas as pessoas e instituições que colaboraram para sua realização, às quais expresso meus agradecimentos.

Em primeiro lugar, agradeço a Deus, que me deu forças para prosseguir, sempre. E aos meus pais, por terem me incentivado no caminho do saber e na disciplina do fazer.

Ao professor Nestor Goulart Reis, orientador desta tese, meus agradecimentos sinceros por sua atenção, por suas intervenções precisas, pela oportunidade e privilégio de compartilhar - em nossas incontáveis conversas - de seu vasto conhecimento e experiência no que diz respeito à história da urbanização brasileira.

Ao professor José Liberal de Castro, que me acompanhou de perto em mais essa etapa da minha trajetória acadêmica, com seus comentários criteriosos e leituras atentas dos capítulos da tese. A ele, que me transmitiu o interesse pela pesquisa e pela reflexão crítica, a minha estima e admiração.

Aos coordenadores do DINTER, professor Ricardo Bezerra, do DAUUFC, e professoras Marta Dora Grostein, Maria Cristina Leme e Maria Angela Faggin Pereira Leite, da FAUUSP, pela organização, condução e realização do Curso. Ao professor Ricardo Bezerra, um agradecimento especial pela ajuda decisiva na formatação final da tese.

Aos professores da FAUUSP, Maria Ruth Amaral de Sampaio, Celso Lamparelli, José Lira, Paulo Bruna, Hugo Segawa, Mônica Junqueira de Camargo, Csaba Deák e Suely Schiffer, responsáveis pelas disciplinas cursadas em São Paulo, que nos deram suporte nessa empreitada.

Agradeço aos membros da Banca de Qualificação, professores Maria Cristina Leme e Ricardo Hernán Medrano, pelas sugestões e orientações fornecidas naquela oportunidade, e pelas valiosas contribuições prestadas no decorrer da pesquisa.

À equipe do LAP/FAUUSP, em especial ao arquiteto Júlio Bentes e à professora Márcia Monteiro, companheiros do grupo de pesquisas "Urbanização dispersa e mudanças no tecido urbano", pela presteza em cooperar e trocar idéias sobre o tema.

O meu agradecimento ao Departamento de Arquitetura e Urbanismo da UFC, especialmente ao Chefe de Departamento, professor Joaquim Aristides de Oliveira, cujo apoio foi fundamental para a realização do Doutorado e elaboração da tese.

Aos professores do Departamento, José Sales, José Almir Farias, Romeu Duarte e Márcia Cavalcante, pelas conversas sobre Fortaleza e pelos textos e documentos cedidos para a pesquisa. E particularmente ao professor Ricardo Paiva, por partilhar interesses sobre as questões relativas à Cidade, pelas leituras seguidas e pelas observações pertinentes.

Aos amigos professores Clovis Jucá Neto e Roberto Castelo, que estiveram próximos em importantes momentos dessa caminhada, trazendo reflexões e ânimo decisivos, em muito ajudando a superar as crises diante deste desafio. 
Aos colegas do DINTER, companheiros de interesses e responsabilidades, pela rica troca de experiências, pelo agradável convívio durante as temporadas em São Paulo, pelas idéias compartilhadas. Uma menção especial à Margarida e à Lucila, que estiveram sempre próximas, e cuja amizade se fortaleceu e se consolidou nesta trajetória.

Aos estudantes de Arquitetura, Mariana Costa Lima - que me prestou inestimável colaboração, desde o início - Marina Rodrigues e Paulo André Frota, pela ajuda valiosa na coleta e organização dos dados, na elaboração das imagens, mapas e na formatação final da tese. A eles, o meu especial agradecimento e para quem desejo um futuro brilhante na profissão.

Ao professor José Antônio Lemenhe, responsável por despertar em mim o interesse pelas questões urbanas, por sua disponibilidade em contribuir com críticas, ideias e sugestões.

Aos colegas arquitetos Delberg Ponce de Leon, Joaquim Cartaxo, Francisco das Chagas do Vale Sales, Rodrigo Ponce de Leon, Vera Mamede, Vera Feijão e Armando Silveira, pelas valiosas informações fornecidas e pelos documentos e materiais cedidos para a pesquisa.

Ao Daniel Dantas, do IPECE, por disponibilizar mapas e dados indispensáveis para a realização do trabalho.

À Sylvia Cavalcante, amiga e profissional competente, pelas leituras, estímulo e sugestões oferecidas. Às amigas arquitetas Kátia Nobre e Marilena Carvalho de Souza, pela companhia em momentos de descontração, pela amizade e pela solidariedade.

À arquiteta e pesquisadora Andréa Tourinho, que mais uma vez me prestou significativa contribuição na fase final da tese, com seus comentários pertinentes e precisos, em seguidas conversas, tanto em São Paulo, como por telefone.

Não poderia deixar de mencionar a CPGFAU, em especial a professora Maria Lúcia Refinetti, pelo apoio concedido aos alunos do DINTER, a secretária Cristina Arguejo e a Diná Vasconcelos, pela colaboração no atendimento às diversas solicitações. E também às bibliotecárias Maria José Carvalho, da FAUUSP, e Neiliane Alves, do DAUUFC, pelo auxilio nas pesquisas nas bibliotecas.

Meu agradecimento reconhecido às minhas filhas Sarah e Mirna, cujo afeto, compreensão e carinho foram essenciais nesse percurso e me impeliram a continuar, sempre. Ao Pedrinho, pelo amor, incentivo e paciência demonstrados; porque mesmo de longe, esteve sempre muito perto. $E$, sobretudo, por fazer parte da minha vida.

Finalmente, agradeço à Universidade de São Paulo e à Universidade Federal do Ceará, instituições que me proporcionaram a oportunidade de participar do Doutorado Insterinstitucional; assim como ao Banco do Nordeste e à SECITECE - Secretaria de Ciências, Tecnologia e Educação Superior do Estado do Ceará, pelo apoio material concedido ao DINTER.

E a todos aqueles que, de diversas formas, contribuíram para a execução deste trabalho e tornaram essa conquista possível. A todos, o meu reconhecimento. 


\section{Resumo}

A pesquisa tem como objetivo principal estudar as formas de crescimento urbano da área metropolitana de Fortaleza, verificadas nas três últimas décadas (1980-2010). A investigação detalhada do processo preocupou-se em examinar e analisar as transformações relevantes ocorridas na estruturação do espaço urbano e metropolitano, buscando relacioná-las com os processos recentes de urbanização. O trabalho procurou, inicialmente, abordar aspectos teórico-conceituais referentes à urbanização contemporânea, quando foram buscados pressupostos teóricos necessários à compreensão da matéria, tentando correlacionar, sempre que possível, com as dinâmicas urbanas recentes da metrópole cearense. Em seguida, no sentido de melhor caracterizar o objeto de estudo, foram elaboradas uma descrição e uma análise da área metropolitana, investigando sua dinâmica socioespacial e dimensão econômica. Na sequência, foi enfocada e discutida sua forma de expansão urbana, a partir das transformações verificadas nas últimas décadas, tomando como base a análise dos diferentes vetores de crescimento urbano e metropolitano, com o intuito de verificar seu modo particular de desenvolvimento. Finalmente, optou-se por investigar com maior ênfase uma área em particular - o setor sudeste da Metrópole - onde se constatou ocorrerem espacialidades novas e padrões de tecido urbano diferenciados. Efetuada a análise dos diferentes vetores de expansão, ficou comprovada a hipótese de que o crescimento urbano atual da área metropolitana de Fortaleza já não se faz de modo homogêneo e apresenta dinâmicas próprias e diferenciadas, distintas do modelo centro-periferia, que predominou até a década de 1980-1990. O estudo demonstrou que existem, de fato, processos urbanos novos e inéditos e em conformidade com as formas mais recentes de urbanização, à semelhança do que ocorre em outras aglomerações urbanas do Brasil e do mundo. Essas dinâmicas são mais evidentes no setor sudeste da Metrópole, onde se verificam novos tipos de produção de centralidade e a presença de núcleos dispersos e descontínuos, formados por condomínios horizontais fechados e equipamentos turísticos, dispostos ao longo do litoral. Este setor pode ser caracterizado, no âmbito da Metrópole, como o mais representativo das novas formas de urbanização, indicando rupturas com o modelo tradicional de assentamento urbano. O propósito do estudo, enfim, foi identificar as características do processo de urbanização em curso, aprofundar essa análise e investigar as especificidades que esse conjunto de mudanças está assumindo na área metropolitana de Fortaleza. O exame da situação é fundamental para se buscar modos de lidar com essa nova realidade e para que sejam criados instrumentos que permitam subsidiar futuras propostas de planejamento e intervenções mais consistentes.

Palavras-chave: Fortaleza, Metrópole, Ubanização contemporânea, Expansão urbana. 


\section{Abstract}

This work's main objective is to study Fortaleza's metropolitan area urban growth patterns that have been observed in the last three decades (1980-2011). A detailed investigation of that process was concerned to examine and analyze relevant transformations occurring in the structure of urban and metropolitan spaces, focusing on relating them to recent urbanization processes. First, this study approaches theoretical and conceptual aspects related to contemporary urbanization, stating a theoretical understanding of the subject, and tries to correlate that, when feasible, to Fortaleza's recent urban growth. Then, in order to better characterize the object of study, a description and an analysis of this metropolitan area are made by investigating the dynamics and socio-economic dimensions of that metropolis. The following approach and discussion deals with actual urban expansion of Fortaleza from a perspective of observed transformations in these past decades, based on the analysis of different axes of urban and metropolitan growth, intending to verify their particular pattern of development. Finally, this work focus on a particular area, in greater detail - the southeastern part of the metropolis - where new spatialities and different patterns of urban fabric are found. After analyzing different axes of expansion, the hypothesis that current urban growth of Fortaleza's metropolitan area has not been occurring homogeneously and it presents a particular dynamic and a distinctive center-periphery model, which prevailed in 1980's, is accepted. Further, this study finds some evidence that, indeed, there are new and unprecedented urban processes in accordance to latest forms of urbanization, similar to what occurs in other urban areas of Brazil and of other countries. This dynamic is more evident in the southeastern sector of the metropolis, where there are new forms of centrality formation, and the presence of more scattered and discontinuous nuclei, consisting of condominiums and tourist facilities displayed along eastern seacoast. This sector can be characterized as the most representative within the metropolis in terms of new forms of urbanization, indicating disruption of traditional urban growth patterns. The purpose of this study, in short, has been to identify characteristics of the undergoing urbanization process, to deepen the analysis and to investigate the specific set of changes that are taking over Fortaleza's metropolitan area. To examine actual urban growth pattern is essential to, both, discover ways to deal with this new reality and create tools to support more consistent future planning proposals and interventions considering urban expansion, in order to ensure proper functioning and development of contemporary metropolises.

Keywords: Fortaleza, Metropolis, Contemporary Urbanization, Urban Expansion. 


\section{Sumário}

Agradecimentos

Resumo

Abstract

Lista de figuras

Lista de tabelas

Lista de abreviaturas

INTRODUÇÃO

\section{CAPÍTULO 1: A METRÓPOLE DE FORTALEZA NO CONTEXTO DA} URBANIZAÇÃO CONTEMPORÂNEA

1.1 A DINÂMICA URBANA RECENTE DA METRÓPOLE CEARENSE 31

1.2 ALGUMAS CONSIDERAÇÕES SOBRE O PROCESSO DE URBANIZAÇÃO CONTEMPORÂNEA

1.2.1 Um contexto de mudanças 35

1.2.2 Os estudos recentes sobre o tema 38

1.2.3 Uma nova nomenclatura? 45

1.2.4 A urbanização como processo 48

1.2.5 As mudanças e as permanências $\quad 50$

1.3 OS ESTUDOS SOBRE A URBANIZAÇÃO RECENTE NO BRASIL 51

1.3.1 As pesquisas sobre "urbanização dispersa e mudanças no tecido urbano" no âmbito nacional $\quad 53$

1.3.2 Sobre as metrópoles brasileiras $\quad 55$

1.4 AS NOVAS ESPACIALIDADES E OS DESAFIOS AO PLANEJAMENTO E GESTÃO 58

1.5 A REVISÃO TEÓRICA E O OBJETO DE ESTUDO 59

1.5.1 O referencial teórico e o enfoque específico 59

1.5.2 Sobre a importância das especificidades locais 60

\section{CAPÍTULO 2: FORTALEZA: A CONFIGURAÇÃO SOCIOESPACIAL DA METRÓPOLE CEARENSE}

2.1 A METROPOLIZAÇÃO DAS CIDADES BRASILEIRAS 63

2.2 FORTALEZA: DE CIDADE A METRÓPOLE - A DINÂMICA SOCIOESPACIAL 73

2.2.1 Antecedentes 73

2.2.2 A metropolização de Fortaleza $\quad 79$

2.2.3 A metrópole contemporânea $\quad 82$

2.3. A ESTRUTURAÇÃO DO TERRITÓRIO METROPOLITANO - A RMF 87

2.3.1 A composição da RMF: caracterização e integração entre os municípios 91

2.3.2 O Município de Fortaleza e o papel polarizador da Capital 97 
2.4 A DINÂMICA ECONÔMICA CEARENSE E A CONFIGURAÇÃO METROPOLITANA

2.4.1 As transformações econômicas no Ceará e na Metrópole

2.4.2 A atividade industrial

2.4.3 A atividade turística

2.4.4 Considerações acerca da dinâmica econômica atual da metrópole: o predomínio do setor terciário, a dinâmica imobiliária e o papel do Estado

2.5 A GESTÃO E O PLANEJAMENTO METROPOLITANO NA RMF

2.5.1 A questão da gestão metropolitana no contexto atual

2.5.2 A gestão metropolitana da RMF

\section{CAPÍTULO 3: A EXPANSÃO TERRITORAL DA METRÓPOLE CEARENSE E OS VETORES DE CRESCIMENTO URBANO E METROPOLITANO}

3.1. O CRESCIMENTO DAS CIDADES E OS VETORES DE EXPANSÃO URBANA

3.1.1 O caso de Fortaleza

3.2 OS VETORES DE CRESCIMENTO URBANO DA METROPOLE CEARENSE

3.2.1 Vetor 1 - O Distrito Industrial de Maracanaú

3.2.2 Vetor 2 - O corredor industrial da BR 116

3.2.3 Vetor 3 - O eixo litorâneo oeste e o CIPP

3.2.4 Vetor 4 - O setor sudeste

3.2.5 Quadro-resumo vetores

3.3 OS ANÉIS VIÁRIOS

3.3.1 Av. Perimetral

3.3.2 $4^{\circ}$ Anel Viário

\section{CAPÍTULO 4: DINÂMICA E ESPECIFICIDADES DO SETOR SUDESTE}

4.1 CARACTERIZAÇÃO DA ÁREA

4.2 UM BREVE HISTÓRICO DA OCUPAÇÃO DA ÁREA

4.3 AS DINÂMICAS DIVERSAS DE USO E OCUPAÇÃO DO SOLO

4.4 A PAISAGEM NATURAL

4.5 UMA ÁREA DE CENTRALIDADE EM EXPANSÃO 


\section{Lista de figuras}

\section{Capítulo 1}

Fig 1.1. Mapa RMF: dinâmicas urbanas recentes

Fig 1.2. Área de urbanização dispersa na Itália

Fig 1.3. Área de urbanização dispersa na França

Fig 1.4. Área de urbanização dispersa na Espanha

Fig 1.5. Área urbanização dispersa em Portugal

Fig 1.6 Área urbanização dispersa nos EUA

Fig 1.7 Área urbanização dispersa nos EUA

Fig 1.8 Edge city americana

Fig 1.9 Edge city americana

\section{Capítulo 2}

Fig 2.1 Av. Beira Mar (década de 1960)

Fig 2.2 Palácio da Abolição

Fig 2.3 Centro de Convenções

Fig 2.4 Novo aeroporto

Fig 2.5 Centro Dragão do Mar

Fig 2.6 Av. Washington Soares

Fig 2.7 Estádio Castelão

Fig 2.8 Acquario

Fig 2.9 Projeto Maranguapinho

Fig 2.10 Mapa RMF atual

Fig 2.11 Mapa RMF 1973

Fig 2.12 Mapa RMF 1986

Fig 2.13 Mapa RMF 1999

Fig 2.14 Mapa RMF 2009

Fig 2.15 Mapa RMF: população absoluta

Fig 2.16 Mapa Regiões de Influência IBGE (Fortaleza)

Fig 2.17 Mapa RMF: ligações viárias

Fig 2.18 Antiga Fábrica Siqueira Gurgel

Fig 2.19 Localização Zona Industrial Francisco Sá e Porto do Mucuripe

Fig 2.20 Conjunto Habitacional no Município de Maracanaú

Fig 2.21 Indústrias no Distrito Industrial de Maracanaú

Fig 2.22 Indústria Vulcabrás, na BR 116, no Município de Horizonte

Fig 2.23 Complexo Industrial e Portuário do Pecém

Fig 2.24 Mapa RMF: dinâmica industrial

Fig 2.25 Mapa RMF: litoral com praias

Fig 2.26 Complexo Beach Park

Fig 2.27 Águas Belas Golf Resort \& Spa 
Fig 2.28 Resort Vila Galé Cumbuco

Fig 2.29 Mapa Fortaleza: aeroporto e pontes

Fig 2.30 Ponte sobre o rio Cocó

Fig 2.31 Ponte sobre o rio Ceará

Fig 2.32 Mapa RMF: dinâmica do turismo

Fig 2.33 Mapa Fortaleza: centralidades

Fig 2.34 Mapa RMF: dinâmica do terciário

Fig 2.35 Mapa Fortaleza: shoppings centers

Fig 2.36 Mapa RMF: dinâmica imobiliária

\section{Capítulo 3}

Fig 3.1 Planta do Porto e Villa da Fortaleza, 1817 - Silva Paulet

Fig 3.2 Planta Exacta de Fortaleza, 1859 - Adolfo Herbster

Fig 3.3 Planta da cidade de Fortaleza e subúrbios, 1875 - Adolfo Herbster

Fig 3.4 Planta da cidade de Fortaleza, 1888 - Adolfo Herbster

Fig 3.5 Planta cadastral da cidade de Fortaleza, 1932

Fig 3.6 Levantamento aerofotogramétrico do Exército, 1945

Fig 3.7 Planta IBGE, 1956

Fig 3.8 Região Metropolitana de Fortaleza - AUMEF, 1977

Fig 3.9 Evolução urbana de Fortaleza, 1982

Fig 3.10 Região Metropolitana de Fortaleza - expansão urbana, 2000

Fig 3.11 Região Metropolitana de Fortaleza - 2011

Fig 3.12 Mapa RMF: os Vetores de expansão urbana

Fig 3.13 Mapa RMF: vetor 1

Fig 3.14 Vetor 1: marcação dos trechos

Fig 3.15 Vetor 1 - Trecho 1

Fig 3.16 Trecho 1 - Bairro Montese

Fig 3.17 Trecho 1 - Bairro Montese

Fig 3.18 Edifícios residenciais no bairro da Maraponga

Fig 3.19 Vetor 1 - Trecho 2

Fig 3.20 Trecho 2 - Edifícios no bairro da Maraponga

Fig 3.21 Trecho 2 - Favelas em área de risco

Fig 3.22 Vetor 1 - Trecho 3

Fig 3.23 Trecho 3 - Ceasa

Fig 3.24 Trecho 3 - comércio próximo à Ceasa

Fig 3.25 Vetor 1 - Trecho 4

Fig 3.26 Trecho 4 - indústrias DI Maracanaú

Fig 3.27 Trecho 4 - indústrias DI Maracanaú

Fig 3.28 Indústrias Distrito Industrial Maracanaú

Fig 3.29 Indústrias Distrito Industrial Maracanaú

Fig 3.30 Distrito Industrial de Maracanaú na RMF

Fig 3.31 Vetor 1 - Trecho 5 
Fig 3.32 Trecho 5 - rodovia/zona rural

Fig 3.33 Trecho 5 - rodovia/zona rural

Fig 3.34 Mapa RMF: vetor 2

Fig 3.35 Vetor 2: marcação de trechos

Fig 3.36 Vetor 2 - Trecho 1

Fig 3.37 BR 116

Fig 3.38 Trecho 1 - início BR 116

Fig 3.39 Trecho 1 - início BR 116

Fig 3.40 Vetor 2 - Trecho 2

Fig 3.41 Trecho 2 - Fábrica Fortaleza

Fig 3.42 Trecho 2 - Posto de fiscalização

Fig 3.43 Vetor 2 - Trecho 3

Fig 3.44 Trecho 3 - Fábrica AMBEV

Fig 3.45 Trecho 3 - olarias

Fig 3.46 Vetor 2 - Trecho 4

Fig 3.47 Trecho 4 - indústrias ao longo da rodovia

Fig 3.48 Trecho 4 - terrenos para indústrias na rodovia

Fig 3.49 Trecho 4 - indústrias ao longo da rodovia

Fig 3.50 Trecho 4 - indústrias ao longo da rodovia

Fig 3.51 Vetor 2 - Trecho 5

Fig 3.52 Trecho 5 - rodovia/zona rural

Fig 3.53 Trecho 5 - rodovia/zona rural

Fig 3.54 Mapa vetor 3: indicação das principais vias/eixos viários

Fig 3.55 Mapa RMF: vetor 3

Fig 3.56 Vetor 3: marcação de trechos

Fig 3.57 Vetor 3 - Trecho 1

Fig 3.58 Trecho 1 - av. Bezerra de Menezes

Fig 3.59 Trecho 1 - av. Mister Hull

Fig 3.60 Vetor 3 - Trecho 2

Fig 3.61 Trecho 2 - Favelas junto à rodovia

Fig 3.62 Trecho 2 - área de Manguezal

Fig 3.63 Vetor 3 - Trecho 3

Fig 3.64 Trecho 3 - Praia do Cumbuco

Fig 3.65 Trecho 3 - Praia do Cumbuco

Fig 3.66 Mapa via Estruturante

Fig 3.67 Vetor 3 - Trecho 4

Fig 3.68 Trecho 4 - via Estruturante

Fig 3.69 Trecho 4 - via Estruturante

Fig 3.70 Vetor 3 - Trecho 5

Fig 3.71 Cidade do Atacado - localização

Fig 3.72 Cidade do Atacado - maquete

Fig 3.73 Vetor 3 - Trecho 6 
Fig 3.74 Trecho 6 - CE 422

Fig 3.75 Trecho 6 - CE 422

Fig 3.76 CIPP

Fig 3.77 Plano Diretor CIPP

Fig 3.78 CIPP/Porto do Pecém

Fig 3.79 CIPP/Porto do Pecém

Fig 3.80 Porto do Pecém

Fig 3.81 Porto do Pecém

Fig 3.82 Mapa RMF: vetor 4

Fig 3.83 Vetor 4: marcação de trechos

Fig 3.84 Mapa Fortaleza: bairros residenciais de alta renda/ baixa renda

Fig 3.85 Comunidade do Dendê

Fig 3.86 Av. Washington Soares

Fig 3.87 Vetor 4 - Trecho 1

Fig 3.88 Trecho 1 - Av. Washington Soares

Fig 3.89 Trecho 1 - Av. Washington Soares

Fig 3.90 Casa condomínio Quintas do Lago

Fig 3.91 Condomínio Alphaville Eusébio

Fig 3.92 Vetor 4 - Trecho 2

Fig 3.93 Trecho 2 - condomínios horizontais no Eusébio

Fig 3.94 Trecho 2 - condomínios horizontais no Eusébio

Fig 3.95 Vetor 4 - Trecho 3

Fig 3.96 Trecho 3 - rodovia CE 040

Fig 3.97 Trecho 3 - rodovia CE 040

Fig 3.98 Vetor 4 - Trecho 4

Fig 3.99 Trecho 4 - rodovia CE 040

Fig 3.100 Trecho 4 - aviários na rodovia CE 040

Fig 3.101 Condomínio/ Porto das Dunas

Fig 3.102 Condomínio/ Porto das Dunas

Fig 3.103 Condomínio/ Porto das Dunas

Fig 3.104 Condomínio/ Porto das Dunas

Fig 3.105 Loteamento Porto das Dunas

Fig 3.106 Resort/ Porto das Dunas

Fig 3.107 Resort/ Porto das Dunas

Fig 3.108 Vetor 4 - Trecho 5

Fig 3.109 Porto das Dunas - foto aérea

Fig 3.110 Porto das Dunas - foto aérea

Fig 3.111 Mapa RMF: av. Perimetral e $4^{\circ}$ Anel Viário

Fig 3.112 Av. Perimetral

Fig 3.113 Av. Perimetral

Fig 3.114 Av. Perimetral

Fig 3.115 Localização cond.residencial Bairro Novo, no $4^{\circ}$ anel Viário 
Fig $3.1164^{\circ}$ Anel viário - anúncio Bairro Novo

Fig $3.1174^{\circ}$ Anel viário

Fig $3.1184^{\circ}$ Anel viário - armazéns

Fig $3.1194^{\circ}$ Anel viário - tráfego de caminhões

Fig 3.120 Mapa Fortaleza: densidade populacional por bairro

Fig 3.121 Mapa RMF: eixos viários

Fig 3.122 Mapa RMF: rodovias

Fig 3.123 Mapa RMF: ocupação

\section{Capítulo 4}

Fig 4.1 Mapa RMF: delimitação do setor sudeste

Fig 4.2 Setor sudeste

Fig 4.3 Setor sudeste e principais vias

Fig 4.4 Antigas salinas junto ao rio Cocó

Fig 4.5 Antigas salinas junto ao rio Cocó

Fig 4.6 Setor sudeste no Levantamento aerofotogramétrico de 1945

Fig 4.7 Setor sudeste no Plano Diretor para Remodelação e Extensão da Cidade (1947)

Fig 4.8 Setor sudeste na planta do IBGE (1956)

Fig 4.9 Setor sudeste no Plano Diretor da Cidade de Fortaleza (1962)

Fig 4.10 Setor sudeste na planta da AUMEF (1977)

Fig 4.11 Setor sudeste no PDDU FOR (1992)

Fig 4.12 Setor sudeste no PDDUA FOR (2004)

Fig 4.13 Sítio Colosso

Fig 4.14 Sitio Colosso

Fig 4.15 Praia do Futuro

Fig 4.16 Praia do Futuro

Fig 4.17 Mapa Fortaleza: bairros das classes de alta renda

Fig 4.18 Shopping Iguatemi década de 1980-1990

Fig 4.19 Shopping Iguatemi 2010

Fig 4.20 Levantamento aerofotogramétrico com diferentes usos (2011) - parte 1

Fig 4.21 Levantamento aerofotogramétrico com diferentes usos (2011) - parte 2

Fig 4.22 Levantamento aerofotogramétrico com diferentes usos (2011) - parte 3

Fig 4.23 Setor sudeste: principais usos

Fig 4.24 Concentração de apartamentos no trecho inicial da Av. W. Soares

Fig 4.25 Concentração de apartamentos no trecho final da Av. W. Soares

Fig 4.26 Uso Residencial - residências unifamiliares

Fig 4.27 Uso Residencial - condomínios horizontais fechados

Fig 4.28 Uso Residencial - condomínio Royal Park

Fig 4.29 Uso Residencial - assentamentos precários - Comunidade do Dendê

Fig 4.30 Uso Residencial - habitações multifamiliares próximas ao Iguatemi

Fig 4.31 Uso Residencial - habitações multifamiliares próximas ao Cambeba

Fig 4.32 Loja Tok Stok 
Fig 4.33 Shopping Via Sul

Fig 4.34 Uso Comercial e de Serviços - Shopping Iguatemi

Fig 4.35 Uso Comercial e de Serviços - Shopping Via Sul

Fig 4.36 Uso Comercial e de Serviços - Complexo Buena Vista

Fig 4.37 Uso Comercial e de Serviços - Loja Tok Stok

Fig 4.38 Uso Comercial e de Serviços - Restaurantes

Fig 4.39 Uso Comercial e de Serviços - Edifícios de escritório

Fig 4.40 Uso Comercial e de Serviços - Bancos

Fig 4.41 Unifor - Universidade de Fortaleza

Fig 4.42 Colégio Christus Sul

Fig 4.43 Uso Educacional - Unifor

Fig 4.44 Uso Educacional - FA7

Fig 4.45 Uso Educacional - Colégio Irmã Maria Montenegro

Fig 4.46 Uso Educacional - Colégio Ari de Sá

Fig 4.47 Uso Educacional - Colégio Farias Brito

Fig 4.48 Uso Institucional - Antiga sede do Governo estadual

Fig 4.49 Uso Institucional - Centro de Eventos

Fig 4.50 Uso Institucional - Fórum Clóvis Bevilacqua

Fig 4.51 Uso Institucional - Centro Administrativo do Cambeba

Fig 4.52 Condomínios no Eusébio

Fig 4.53 Condomínios no Eusébio - Quintas do Lago

Fig 4.54 Condomínios no Eusébio - Jardins Ibiza

Fig 4.55 Condomínios no Eusébio - Alphaville Fortaleza

Fig 4.56 Equipamentos Turísticos no Aquiraz - Porto das Dunas

Fig 4.57 Equipamentos Turísticos no Aquiraz - Aquiraz Riviera

Fig 4.58 Setor sudeste: recursos naturais

Fig 4.59 Parque do Cocó

Fig 4.60 Parque do Cocó

Fig 4.61 Parque do Cocó

Fig 4.62 Lagoa da Sapiranga, Lagoa da Precabura e Foz do rio Pacoti

Fig 4.63 Indicação de equipamentos diversos na Av. W. Soares

Fig 4.64 Av. Washington Soares

Fig 4.65 Av. Washington Soares

Fig 4.66 Av. Washington Soares

Fig 4.67 Av. Washington Soares

Fig 4.68 Av. Washington Soares

Fig 4.69 Av. Washington Soares

Fig 4.70 Centro de Eventos do Ceará

Fig 4.71 Loteamento fechado no Eusébio

Fig 4.72 Loteamento fechado no Eusébio

Fig 4.73 Condomínio fechado no Eusébio

Fig 4.74 Condomínio fechado no Eusébio 
Fig 4.75 Condomínio fechado no Eusébio

Fig 4.76 Condomínio fechado no Eusébio

Fig 4.77 Anúncios condomínios na CE 040

Fig 4.78 Stand de vendas condomínios na CE 040

Fig 4.79 Mapa do Eusébio: localização dos condomínios

Fig 4.80 Condomínio Alphaville Fortaleza

Fig 4.81 Condomínio Alphaville Fortaleza

Fig 4.82 Condominio Alphaville Eusébio

Fig 4.83 Rua de condomínios fechados no Eusébio

Fig 4.84 Rua de condomínios fechados no Eusébio

Fig 4.85 Foto aérea Eusébio 2003

Fig 4.86 Foto aérea Eusébio 2009

Fig 4.87 Mapa litoral de Aquiraz: principais rodovias de acesso

Fig 4.88 Prainha

Fig 4.89 Praia do Iguape

Fig 4.90 Porto das Dunas - paisagem natural

Fig 4.91 Porto das Dunas - paisagem natural

Fig 4.92 Ponte sobre o rio Pacoti

Fig 4.93 Loteamento Porto das Dunas 2000

Fig 4.94 Loteamento Porto das Dunas 2012

Fig 4.95 Complexo Beach Park

Fig 4.96 Complexo Beach Park

Fig 4.97 Resort/ Porto das Dunas

Fig 4.98 Resort/ Porto das Dunas

Fig 4.99 Condomínio de lazer/ Porto das Dunas

Fig 4.100 Condomínio de lazer/ Porto das Dunas

Fig 4.101 Condomínios no Porto das Dunas

Fig 4.102 Condomínios no Porto das Dunas

Fig 4.103 Ocupação Porto das Dunas

Fig 4.104 Ocupação Porto das Dunas

Fig 4.105 Porto das Dunas - indicação de empreendimentos à venda

Fig 4.106 Mapa Porto das Dunas com localização dos empreendimentos - Trecho 1

Fig 4.107 Mapa Porto das Dunas com localização dos empreendimentos - Trecho 2

Fig 4.108 Mapa com localização Porto das Dunas, Aquiraz e Fortaleza

Fig 4.109 Porto das Dunas

Fig 4.110 Aquiraz Riviera - Hotel D. Pedro Laguna

Fig 4.111 Carmel Charme Resort 


\section{Lista de tabelas}

Tabela 1 Índice de urbanização por região

Tabela 2 Regiões Metropolitanas brasileiras legalmente constituídas

Tabela 3 Índice de crescimento demográfico da cidade de Fortaleza de 1900 a 1970

Tabela 4 Região Metropolitana de Fortaleza - municípios e população

Tabela 5 Região Metropolitana de Fortaleza - densidade e taxa de urbanização

Tabela 6 Evolução Político-administrativa - Região Metropolitana de Fortaleza 1973/2009

Tabela 7 Empregos formais, por municípios - RMF - 2007-2010

Tabela 8 Renda per capita RMF

Tabela 9 Empresas industriais ativas, por tipo, segundo os municípios da RMF Ceará 2008-2009

Tabela 10 Fluxo turístico para Fortaleza (nacional e internacional)

Tabela 11 Movimentação Turística

Tabela 12 Valores (em US\$) de entrada de capital estrangeiro para o setor imobiliário -turístico em estados nordestinos (2001 - 2007)

Tabela 13 Taxa de crescimento do PIB 2009

Tabela 14 Oferta de empregos formais por subsetor de atividades, por municípios Estado do Ceará - 2007-2010

Tabela 15 Empresas de serviços, por atividade econômica, segundo os municípios da RMF

Tabela 16 Relação de indústrias instaladas e em funcionamento no CIPP

Tabela 17 Relação de indústrias em instalação no CIPP

Tabela 18 Loteamentos Fechados no Município do Eusébio (2000-2011)

Tabela 19 Condomínios horizontais no Município do Eusébio

Tabela 20 Empreendimentos situados no litoral de Aquiraz 


\section{Lista de abreviaturas}

\begin{tabular}{|c|c|}
\hline ABAV & Associação Brasileira de Agencias de Viagem \\
\hline ACAD & Associação Cearense dos Atacadistas e Distribuidores de Produtos Industrializados \\
\hline APA & Área de Proteção Ambiental \\
\hline ADECE & Agência de Desenvolvimento do Estado do Ceará \\
\hline AUMEF & Autarquia da Região Metropolitana de Fortaleza \\
\hline BID & Banco Interamericano de Desenvolvimento \\
\hline BNDES & Banco Nacional de Desenvolvimento Econômico e Social \\
\hline CEASA & Central de Abastecimento de Fortaleza S/A \\
\hline CBTU & Companhia Brasileira de Trens Urbanos \\
\hline $\mathrm{ClC}$ & Centro Industrial do Ceará \\
\hline CIPP & Complexo Industrial Portuário do Pecém \\
\hline COGERH & Companhia de Gestão de Recursos Hídricos \\
\hline DNIT & Departamento Nacional de Infraestrutura e Transportes do Ceará \\
\hline FDI & Fundo de Desenvolvimento Industrial do Ceará \\
\hline FIEC & Federação das Indústrias do estado do Ceará; \\
\hline FINOR & Fundo de Investimentos do Nordeste \\
\hline IBGE & Instituto Brasileiro de Geografia e Estatística. \\
\hline IPEA & Instituto de Pesquisa Econômica Aplicada \\
\hline IPECE & Instituto de Pesquisa e Estratégia Econômica do Ceará \\
\hline PDDU FOR & Plano Diretor de Desenvolvimento Urbano de Fortaleza \\
\hline PDDUA FOR & Plano Diretor de Desenvolvimento Urbano e Ambiental de Fortaleza \\
\hline PIB & Produto Interno Bruto \\
\hline PLAMEG & Plano de Metas Governamentais do Governo Virgílio Távora \\
\hline PLANDIRF & Plano Diretor de Desenvolvimento Integrado de Fortaleza \\
\hline PLANEFOR & Plano estratégico de Fortaleza e sua Região Metropolitana \\
\hline PNAD & Pesquisa Nacional de Amostra Domiciliar \\
\hline PRODETUR-NE & Programa de Desenvolvimento do Turismo do Nordeste \\
\hline RFFSA & Rede Ferroviária Federal S/A \\
\hline RMF & Região Metropolitana de Fortaleza \\
\hline RMSP & Região Metropolitana de São Paulo \\
\hline RIDE & Região Integrada de Desenvolvimento \\
\hline SEBRAE-CE & Serviço brasileiro de apoio às micro e pequenas empresas do Ceará \\
\hline SECOVI-CE & Sindicato das empresas de compra e venda, locação e administração de imóveis do Ceará \\
\hline SEINF & Secretaria Municipal de Desenvolvimento Urbano e Infraestrutura \\
\hline SEINFRA & Secretaria da Infraestrutura do estado do Ceará \\
\hline SEMACE & Superintendência Estadual do Meio Ambiente \\
\hline SETUR-CE & Secretaria de Turismo do Ceará \\
\hline SINE/CE & Sistema Nacional de Empregos do Ceará \\
\hline SINDUSCON-CE & Sindicato das Indústrias da Construção Civil do Ceará \\
\hline SUDENE & Superintendência de Desenvolvimento do Nordeste \\
\hline TMUT & Terminal de Múltiplo Uso \\
\hline ZPE & Zona de Processamento de Exportação \\
\hline
\end{tabular}


[...] la forme d'une ville change plus vite, hélas, que le coeur d'un mortel!

BAUDELAIRE, 1857 


\section{INTRODUÇÃO}


A tese, que tem como título Dinâmicas urbanas recentes da área metropolitana de Fortaleza, trata das transformações ocorridas no espaço urbano decorrentes do processo de expansão da metrópole cearense, ocorridas nas três últimas décadas (1980-2010). O trabalho almeja analisar e compreender as mudanças verificadas em sua configuração socioespacial, com base em um conjunto de investigações que abordam sua conformação atual e examinam, de maneira detalhada, seu processo particular de expansão urbana.

Diversos processos em curso atualmente na metrópole fortalezense resultam na produção de novos padrões de organização territorial. Assim, o quadro urbano, ora em formação, oriundo de investimentos públicos e privados, está assumindo configurações e singularidades que merecem ser registradas e analisadas em profundidade.

A pesquisa realizada procurou dar continuidade acadêmica às atividades de pós-graduação iniciadas pela autora em março de 2003 e sintetizadas na Dissertação de Mestrado intitulada: A centralidade da Aldeota como expressão da dinâmica intraurbana de Fortaleza, apresentada à FAUUSP em agosto de 2005. Na ocasião, foi elaborado um estudo sobre a atual dinâmica urbana da Capital cearense, com ênfase na produção do espaço urbano do bairro da Aldeota, zona residencial da classe de mais alta renda na cidade de Fortaleza, transformada, nas últimas décadas, em uma área de centralidade. O trabalho analisou a evolução urbana do bairro, relacionando as mudanças ocorridas nas formas de uso e ocupação do solo, bem como as consequentes interferências no respectivo espaço.

A dissertação teve como objetivo, portanto, compreender o processo de constituição daquela área da Cidade, envolvendo o estudo dos fatores que contribuíram para sua formação e desenvolvimento. Para tanto, foram levados em conta a observação das práticas urbanas, assim como os pressupostos teóricos formulados sobre o tema, buscando examinar a centralidade formada na Aldeota como uma questão urbana na cidade de Fortaleza. A pesquisa revelou que o desenvolvimento da área em estudo está vinculado ao próprio crescimento da Cidade, em curso de forma acelerada, assumindo configurações mais complexas e diferenciadas, que estão a exigir uma investigação mais aprofundada.

O trabalho levou a refletir sobre a forma de crescimento da Metrópole, preocupação que extrapola os limites do bairro e até do município de Fortaleza. A questão da Aldeota, verificou-se, constituía apenas uma das faces da transformação e adaptação da Metrópole às formas de uso e ocupação do solo ocorridas nas últimas décadas. Explica-se, deste modo, a escolha do tema, vista como forma de ampliar, numa tese de doutoramento, o objeto de estudo, direcionando para novas escalas urbanas.

Some-se ainda a isto a necessidade de aprofundamento teórico e metodológico requerido para a compreensão da problemática da metrópole contemporânea, suscitada pelas atividades de pesquisa desenvolvidas pela autora no Departamento de Arquitetura e Urbanismo da Universidade Federal do Ceará, assim também como aquelas elaboradas junto ao LAP, na FAUUSP, coordenadas pelo Prof. Dr. Nestor Goulart Reis'1.

\footnotetext{
${ }^{1}$ A autora integra o grupo de estudos "Urbanização dispersa e novas formas de tecido urbano", que atua junto ao LAP/ FAUUSP, sob a coordenação do Prof. Dr. Nestor Goulart Reis.
} 


\section{DELIMITAÇÃO DO OBJETO DA PESQUISA}

O recorte espacial proposto estabelece a porção do território tomada como referência para apreensão do fenômeno. No caso em estudo, esse recorte se relaciona com a expansão urbana ocorrida na área metropolitana de Fortaleza, isto é, à chamada Região Metropolitana de Fortaleza - RMF, composta atualmente por 15 municípios². No capítulo final da tese, porém, foi destacada uma área menor, correspondente ao setor sudeste da Metrópole, no qual se constataram mudanças mais intensas e mais significativas, correlacionadas com os processos de urbanização contemporânea, pelo que exigiu investigação mais detalhada e pormenorizada.

Como recorte temporal, foram analisadas as transformações ocorridas nos últimos 30 anos, desde meados da década de 1980-1990. Nos estudos elaborados acerca da urbanização contemporânea, esse período corresponde ao contexto geral de mudanças caracterizado pela globalização, reestruturação produtiva e avanços tecnológicos diversificados, que provocaram mudanças substanciais no espaço urbano. No caso de Fortaleza, compreende o início da fase conhecida como "Governo das Mudanças" ${ }^{\prime \prime}$, que marcou um novo ciclo de desenvolvimento no Estado e na Metrópole cearense. Esse período torna-se relevante porque marca a transição da Cidade para uma metrópole de porte, com importante papel no contexto regional e nacional, configurando também uma etapa em que se registraram transformações significativas no seu processo de urbanização e expansão.

A fim de contextualizar o objeto de pesquisa, foi necessária, entretanto, uma breve prospecção histórica, envolvendo a evolução urbana de Fortaleza e sua trajetória de desenvolvimento, desde o final do século XIX.

\section{OBJETIVOS}

O objetivo principal da tese é compreender as especificidades do processo de crescimento urbano e da expansão da área metropolitana de Fortaleza ocorrido nas ultimas três décadas (1980-2010) e sua inserção no contexto da urbanização contemporânea. O trabalho pretende identificar, examinar e interpretar as questões relacionadas com o crescimento fortalezense, buscando verificar as modificações ocorridas tanto no espaço urbano como no metropolitano, nesse período, além de registrar e descrever os atributos físicos e espaciais associados às transformações em curso.

Como objetivos específicos, propõe-se:

- investigar as mudanças recentes ocorridas no território metropolitano, identificando os padrões dominantes de urbanização e as diversas formas de ocupação, por meio da análise de sua configuração específica, conforme as características de cada um dos vetores de expansão urbana;

- identificar os fatores de mudança considerados determinantes para o entendimento da estruturação urbana atual da Metrópole, avançando com hipóteses explicativas dos processos que lhe deram origem; e

- avaliar os possíveis impactos dos investimentos advindos da atividade econômica e de infraestrutura propostos para cada um dos vetores de expansão, de modo a encontrar explicações para o modo como tem ocorrido a estruturação da Metrópole.

\footnotetext{
${ }^{2}$ Os municípios que compõem a RMF são: Fortaleza, Caucaia, Maranguape, Maracanaú, Pacatuba, Guaiuba, Eusébio, Aquiraz, Itaitinga, Horizonte, Pacajus, Chorozinho, S. Gonçalo do Amarante, Pindoretama e Cascavel.

3 "Governo das mudanças": denominação que o Poder Executivo local se conferiu, no período de 1987 a 2002, quando governaram o Estado Tasso Jereissati e Ciro Gomes.
} 
Esses objetivos foram perseguidos, levando-se em consideração alguns aspectos relativos à Metrópole cearense, tais como:

- a questão da macrocefalia de Fortaleza;

- a decadência do centro tradicional da Cidade e a formação de novas áreas de centralidade;

- o surgimento de novos padrões espaciais para diversas atividades produtivas;

- a formação de espaços fragmentados e desarticulados, típicos de áreas de urbanização dispersa;

- a adoção de novas formas de vida pela população, como a maior mobilidade;

- o surgimento recente de condomínios horizontais fechados na periferia metropolitana, voltados para uma população de maior renda;

- a segregação socioespacial proveniente da forma diferenciada de uso e apropriação dos espaços públicos e privados;

- as mudanças no mercado imobiliário e o reflexo no espaço urbano;

- a atuação do Estado vinculada aos grandes projetos estruturantes; e

- a manifestação espacial da atividade turística e as consequências para o espaço urbano: formação de núcleos dispersos ao longo do litoral, permeado com a implantação de equipamentos de lazer e turismo muitas vezes em áreas de reservas ambientais.

Tudo isso indica que a estrutura da Metrópole passa por um processo de adaptação aos novos tempos e apresenta atributos específicos que devem ser apreciados mais detalhadamente.

A tese almeja também levantar a possibilidade de contribuir com matéria acerca do crescimento urbano da metrópole fortalezense, uma vez constatar-se a escassez de documentação sobre o assunto e a ausência de estudos sistematizados acerca do tema, de fundamental importância para a compreensão da produção e estruturação do espaço urbano.

A relevância temática da pesquisa, portanto, fundamenta-se não apenas na necessidade de atualização teórica, mas também no propósito de se discutir o processo em curso, analisando sua dinâmica e modo particular de desenvolvimento e expansão, com base na observação das práticas urbanas, dos agentes sociais da urbanização e dos produtos imobiliários resultantes, procurando compreender formas de produção, apropriação e uso do solo na área metropolitana de Fortaleza.

A incerteza desses novos processos conta como outro aspecto a considerar, de tal modo que as técnicas tradicionais de planejamento não resultam tão eficientes como outrora. As mudanças verificadas têm sido tão rápidas, tão amplas e complexas que os atuais instrumentos de gestão, controle e planejamento urbano não se mostram em condições de oferecer alternativas adequadas para o correto desenvolvimento urbano. A análise do fenômeno é essencial para o entendimento dos desafios enfrentados pelas metrópoles contemporâneas, em vista das dificuldades de se elaborarem diagnósticos que permitam a busca de formas eficientes de planejamento e ação.

Almeja-se, portanto, elaborar um quadro atual das questões relacionadas com o crescimento da Metrópole cearense. O conhecimento do processo poderá servir de subsídio à proposição de novas políticas urbanas, com vistas a reformular os modos de tratar o espaço e proporcionar intervenções mais adequadas à cidade e à área metropolitana como um todo. 


\section{A HIPÓTESE}

A hipótese adotada admite que o processo atual de crescimento da Metrópole cearense configura uma nova forma de urbanização, diferente do modelo verificado anteriormente, até a década de 1980-1990, evidenciando transformações significativas na conformação dos espaços urbano e metropolitano. Na escala metropolitana, percebe-se uma polarização expressiva, representada pela Capital, bem como uma expansão que se desenvolve preferencialmente ao longo dos principais eixos viários - ou vetores - que partem do polo emissor. Cada vetor obedece à própria lógica de formação e tem o desenvolvimento ligado aos investimentos recebidos, configurando-se, em algumas áreas, espacialidades novas e padrões de tecido urbano diferenciados, em consonância com os processos de urbanização contemporânea.

Faz-se necessária, portanto, uma análise aprofundada, a fim de averiguar a atual dinâmica socioespacial da Metrópole cearense, investigando em que medida essa expansão ocorre, se de forma unicamente linear, ao longo dos eixos, ou se se verifica a existência de pólos ou núcleos mais expressivos em toda sua extensão, bem como quais as dinâmicas econômicas que incidem em cada um dos vetores, determinando novos arranjos espaciais.

Na tese, como premissa de trabalho, as análises detectaram que as mudanças verificadas no processo atual de urbanização de Fortaleza estão inseridas no âmbito da nova dinâmica econômica mundial ${ }^{4}$, evidenciada desde a década de 1980-1990, tanto no padrão produtivo industrial como no setor terciário, vinculadas ao avanço do capitalismo em sua nova fase. Aliados a isso, a informática, os avanços na comunicação, as inovações tecnológicas e a melhoria nos transportes possibilitaram a formação de novas espacialidades e cidades mais dispersas, condizentes também com as mudanças nos modos de vida da população.

Como um dos impactos da nova dinâmica global, nota-se, nas áreas metropolitanas em geral, uma tendência de redistribuição da população e das atividades produtivas pelo território, assim como se percebe o surgimento de novos programas e equipamentos urbanos, além de formas distintas de crescimento urbano e metropolitano, resultando em novas configurações espaciais.

\section{REFERENCIAL TEÓRICO}

Desde as últimas décadas do século $\mathrm{XX}$, os principais centros urbanos assistiram a uma expansão metropolitana intensa, revelando transformações ocorridas num curto intervalo de tempo, desde os anos 1980-1990. São mudanças de caráter social (econômico, político e cultural), advindas da globalização, das transformações do sistema produtivo, do desenvolvimento das atividades terciárias e da infraestrutura de transporte e comunicações, as quais incidem, em maior ou menor intensidade, sobre o espaço urbano.

\footnotetext{
${ }^{4}$ De acordo com Borja e Castells, a nova dinâmica econômica global é caracterizada por "uma economia na qual as atividades estrategicamente dominantes funcionam como uma unidade de nível planetário em tempo real ou potencialmente real (BORJA \& CASTELLS, 1997, p.24). Na economia, observam-se a descentralização das grandes empresas, desmembradas em unidades de gestão semi-autonômas, a proliferação de pequenas e médias empresas, a formação de redes de cooperação (...). Essa forma absolutamente flexível e dinâmica, mas ao mesmo tempo instável de atividade econômica, que caracteriza os novos processos de organização, gestão e produção do espaço" (BORJA \& CASTELLS, 1997, p.25). (traduziu-se)
} 
As cidades foram perdendo algumas das características principais que lhes foram atribuídas historicamente. Os aglomerados compactos e densos, fisicamente limitados e distintos dos territórios envolventes, são agora formações socioterritoriais complexas, de limites imprecisos e com tendências de crescimento cada vez mais dispersas.

Novas dinâmicas urbanas vêm sendo observadas de maneira diversa nos diferentes países, e, como resultado das mudanças ocorridas, as metrópoles incorporaram atributos urbanos novos, em determinados casos, até inéditos. Surgem novas realidades urbanas, que emergem no novo contexto de globalização e da sociedade da informação.

De fato, a expansão da metrópole trouxe grande complexidade para os espaços, ocasionando a fragmentação da centralidade e estimulando um modelo de urbanização mais disperso, decorrente também da segregação espacial e do aumento da mobilidade. O processo de urbanização contemporâneo caracteriza-se, pois, principalmente, pela dificuldade de mensurar e controlar a forma, os limites e o crescimento, uma vez que se estrutura de modo diferente do modelo dito tradicional. A cidade, antes compacta, ganha novas configurações.

O tema começou a despertar a atenção de estudiosos em diferentes partes do mundo. A reflexão sobre o desenvolvimento urbano e sobre as diferentes morfologias, resultantes do fenômeno, traz ao debate inúmeros conceitos acerca do assunto, patenteando sérios desafios para pesquisadores e gestores de políticas públicas neste início do século XXI.

As mudanças relacionadas com as novas formas de urbanização e com as alterações nos padrões de tecido urbano, bem como as novas formas de organização física e funcional adquiridas pela urbanização contemporânea é matéria de interesse de inúmeros autores. Esses estudiosos constatam, de maneira geral, que atualmente, áreas urbanas de diferentes tamanhos e diversidade de papéis vêm conhecendo transformações diversas que evidenciam, efetivamente, novas maneiras de produzir e se apropriar do espaço.

O fenômeno, também observado no Brasil em maior ou menor escala, em diferentes áreas urbanas e metropolitanas, tem-se transformado em objeto de reflexão por parte de pesquisadores que se dedicam ao estudo do tema.

Nesse contexto, a área metropolitana de Fortaleza tem igualmente conhecido, desde as últimas décadas, um processo intenso de urbanização, com evidente rebatimento no tecido urbano, o qual adquire formas diferenciadas, que pedem melhor investigação, consideradas as especificidades da área em estudo.

Essa investigação foi empreendida, de início, por meio de uma ampla revisão da literatura especializada, de modo a possibilitar o entendimento do fenômeno de maneira geral e situar o problema com relação a outros trabalhos pertinentes. Procurou-se descobrir como a matéria vem sendo tratada por pesquisadores diversos, a fim de que diferentes enfoques e perspectivas teóricas possam ser comparados, para escolha das proposições de maior relevância em relação ao tema proposto.

Na identificação de autores que tratam do tema da urbanização contemporânea, optou-se como ponto de partida pela teoria apresentada pelo Professor arquiteto Nestor Goulart Reis, em seu livro Notas sobre urbanização dispersa e novas formas de tecido urbano (2006), obra que aborda 
conceitos relativos ao assunto e trata "das mudanças que estão ocorrendo no processo de urbanização do Brasil, com ênfase no estado de São Paulo, a partir de 1970-1980, destacando as áreas metropolitanas e suas faixas envoltórias" (REIS, 2006, p.12).

A reflexão de Reis constituiu referência teórica fundamental para a elaboração da tese, tanto no que concerne à compreensão do processo de urbanização, como no que se refere aos estudos relativos à urbanização contemporânea e às novas características do tecido urbano.

Trabalhos de outros autores nacionais e internacionais, concernentes a questões relacionadas com a urbanização contemporânea, também foram investigados, o que permitiu a apreciação de diferentes maneiras de abordagem do tema. Como forma de atualização teórica e com o intuito de se conhecer l'état des questions com relação ao assunto, também foi objetivada uma pesquisa bibliográfica sobre publicações mais recentes relativas a experiências semelhantes, ocorridas em outros lugares do Brasil (e do mundo).

Nesse contexto, foram eleitas tanto as proposições de maior relevância com relação ao tema da tese, como as linhas teóricas que mais se aproximavam dos objetivos da pesquisa, isto é, aquelas mais voltadas para a análise urbana, com o intuito de contribuir na priorização de uma abordagem preferencialmente empírica, que enfoque as mudanças nos padrões do tecido urbano, sob a perspectiva da Arquitetura e do Urbanismo. Constituíram referência teórica relevante, no âmbito internacional, as contribuições dos pesquisadores europeus Monclús, Font, Portas e Secchi, por serem estudos elaborados por arquitetos, interessados em análises urbanas, envolvendo aspectos de maior afinidade com o objeto de estudo.

Os estudos do arquiteto chileno Carlos de Mattos também apresentaram pontos em comum com o tema proposto e seus enunciados foram devidamente considerados no decorrer do trabalho.

No âmbito nacional, além da obra do Professor Nestor Goulart Reis e de outros trabalhos de pesquisadores brasileiros, as análises elaboradas pela arquitetas Regina Meyer e Marta Dora Grostein nos livros São Paulo Metrópole (2004) e A leste do Centro (2010), acerca das dinâmicas urbanas recentes na Metrópole paulistana, revestem-se de especial importância. Foram adotadas como fonte de consulta e devidamente apreciadas e referenciadas, no sentido de se estabelecerem comparações com o caso em estudo.

No que concerne à história da cidade de Fortaleza e do seu processo evolutivo, realizaram-se consultas em obras de autores cearenses, sobretudo naquela do Professor arquiteto José Liberal de Castro, estudioso das origens e do desenvolvimento da Cidade e da arquitetura cearense; paralelamente, foram investigados teses e trabalhos de pesquisadores que se dedicaram a estudar questões relativas ao crescimento da Metrópole fortalezense.

\section{METODOLOGIA}

Como metodologia de pesquisa, a análise do espaço urbano constituiu a estratégia principal para identificar e examinar as transformações ocorridas no processo de crescimento urbano da área metropolitana de Fortaleza. O rebatimento do estudo nos diferentes vetores de expansão serviu de base para a compreensão do crescimento e expansão da Metrópole, e, assim, apreendê-la em sua totalidade. 
Cabe ressaltar que a análise foi empreendida tomando-se como base a situação atual, em busca de identificar e destacar os principais usos, os tipos de ocupação, os marcos simbólicos, os recursos naturais mais significativos, a atividade econômica predominante, os investimentos públicos e privados mais importantes, as principais concentrações, as intervenções mais recentes; ou seja, foram enfocados os fenômenos e práticas urbanas que acarretaram as principais alterações na configuração do espaço da Metrópole.

Essas mudanças, embora entendidas como partes de um mesmo processo, foram avaliadas em duas escalas, examinadas do geral ao local: na escala metropolitana, mais abrangente, ao se analisar a área metropolitana por inteiro; e na escala do tecido urbano, quando foi enfocado com mais detalhes um dos vetores de expansão, o vetor 4 , no qual foram investigadas as relações e mudanças significativas no espaço intra-urbano.

Como referencial empírico, apreciaram-se, portanto, as transformações - na tese, denominadas dinâmicas urbanas recentes - ocorridas no espaço urbano da área metropolitana de Fortaleza e, particularmente no setor sudeste da Metrópole, caracterizado por singularidades que contribuem para tornar a discussão geral mais complexa. Como objeto conceitual foi considerado o processo contemporâneo de urbanização, julgado segundo a óptica de vários autores, que desenvolveram teorias concernentes ao tema.

Os procedimentos metodológicos utilizados no desenvolvimento do trabalho constaram de:

1) pesquisa bibliográfica e documental, como suporte e fundamentação teórica, de modo a enfocar aspectos conceituais e conhecer o que de mais significativo já se publicou sobre o tema. Neste sentido, buscou-se investigar o processo de urbanização contemporâneo, a fim de entender como o fenômeno ocorreu em Fortaleza, marcado com suas especificidades.

Aspectos teóricos e conceituais ligados ao tema foram enfocados, apoiados em uma bibliografia nacional e internacional, com o intuito de proceder ao aprofundamento teórico e metodológico requerido para a compreensão da metrópole contemporânea.

Questões teóricas relacionadas à urbanização contemporânea, crescimento urbano e expansão, além de conceitos como metrópole, metropolização, urbanização difusa, urbanização dispersa, etc., necessários à compreensão e análise da realidade, foram examinados, para montagem de um quadro teórico sintético, relacionado com o objetivo do estudo, baseado no vasto acervo de informações obtido no desenrolar da pesquisa.

Efetuou-se também levantamento de material iconográfico e cartográfico que documenta a evolução e o crescimento da Cidade, além da análise da legislação urbana, de investigações em jornais e pesquisas em sites da Internet.

2) Pesquisa de campo; empreendida com observações e constatações in loco, em busca de verificar e analisar as diferentes mudanças ocorridas na estrutura urbana fortalezense e em sua área metropolitana, a fim de identificar as transformações mais relevantes e as novas formas de tecido urbano resultantes do processo de urbanização em curso. Nesse sentido, privilegiaram-se as mudanças no uso e ocupação do solo. Nesse percurso, foram investigadas as aglomerações urbanas, as vias de circulação, os grandes equipamentos industriais, comerciais e de serviço, bem como as áreas residenciais de distintos 
padrões, elementos estes que compõem a realidade espacial, assim como as relações de naturezas diversas que nela se estabelecem.

A pesquisa de campo foi continuamente complementada com a análise das imagens de satélite e acompanhada de ampla documentação fotográfica, a fim de registrar as diversas modificações ocorridas.

A investigação empírica, no âmbito de uma realidade social concreta, compreendeu também a obtenção de informações mediante contato direto com a população e agentes produtores do espaço, acrescida do levantamento de dados e de documentos. Neste sentido, foram realizadas entrevistas com arquitetos, urbanistas, dirigentes de órgãos públicos, investidores e promotores imobiliários, com o intuito de se proceder a avaliações das diferentes visões relativas às alterações por que passa a Metrópole, assim como investigar acerca dos investimentos propostos para a área.

Acrescentem-se, ainda, as pesquisas efetuadas em órgãos de planejamento e associações profissionais (Secretaria das Cidades, SEINF, SEINFRA, SETUR, FIEC, IPECE, SINDUSCON, SECOVI, IBGE)', com a finalidade de se obterem dados que serviram de apoio ao estudo. Foram examinados programas de desenvolvimento regional e urbano, planos e projetos urbanos de intervenção, por via da análise de documentos, mapas e memoriais descritivos, além de indicativos socioeconômicos, populacionais, índices de urbanização, etc., a fim de verificar as transformações no território e os padrões urbanos de ocupação.

Os dados e as informações obtidas foram devidamente selecionados, sistematizados, analisados e mapeados (conforme o caso), permitindo a formulação de conclusões e reflexões sobre o processo de expansão e reestruturação urbana da Metrópole cearense.

\section{ESTRUTURA DA TESE}

De acordo com a metodologia adotada, a estrutura do trabalho procurou seguir uma ordem que vai do geral ao particular, abordando inicialmente aspectos teórico-conceituais; em seguida, examina a transformação da Cidade de Fortaleza em metrópole de porte e suas formas de expansão; no final, elege uma área específica onde se evidenciam processos recentes relacionados às mudanças em curso, ocorridas em consonância com as formas contemporâneas de urbanização.

O capítulo inicial da tese trata, portanto, dos pressupostos teóricos relativos ao tema; os dois capítulos seguintes se referem à caracterização geral da Metrópole e seu processo de expansão; e o último capítulo se reporta particularmente ao setor sudeste, onde se evidenciam os padrões mais recentes e mais complexos de mudanças na urbanização.

O trabalho, elaborado na perspectiva de privilegiar as singularidades específicas do processo ocorrido na metrópole, trata das dinâmicas urbanas recentes como questões urbanas de atual relevância.

A tese ficou dividida em quatro capítulos, cujos respectivos interesses podem ser resumidos na seqüência.

$\overline{{ }^{5} \text { Consultar lista de }}$ abreviaturas. 
O primeiro capítulo, A Metrópole de Fortaleza no contexto da urbanização contemporânea, procurou abordar aspectos teórico-conceituais sobre a urbanização contemporânea, numa perspectiva ampla, tentando correlacionar, sempre que possível, com as dinâmicas urbanas recentes da área metropolitana de Fortaleza. Foram enfocados conceitos ligados ao tema e sua relação com os processos urbanos contemporâneos - tomados de forma geral - a partir das últimas décadas do século XX, de maneira a melhor compreender a urbanização em curso na área em estudo. A metodologia utilizada buscou investigar o assunto sob a óptica de diferentes autores, com o intuito de comparar enfoques e perspectivas teóricas distintas, privilegiando aquelas proposições de maior relevância e afinidade com relação ao tema proposto.

O capítulo segundo, Fortaleza: a configuração socioespacial da Metrópole cearense, após formular considerações acerca do processo de metropolização das cidades brasileiras, trata da caracterização geral do objeto de estudo - a metrópole cearense - abordando sua dinâmica socioespacial, seu próprio processo de metropolização, os municípios que compõem a Região Metropolitana de Fortaleza, sua dimensão econômica - com ênfase nas atividades industriais e de turismo - e a conseqüente repercussão no espaço urbano, assim como as mudanças recentes, que estão ocorrendo no território da RMF. Enfoca ainda a problemática da gestão metropolitana atual e questões ligadas ao planejamento urbano.

O terceiro capítulo, A expansão territorial da Metrópole cearense e os vetores de crescimento urbano e metropolitano, foi elaborado com vistas à expansão metropolitana de Fortaleza, estudada em função das transformações verificadas nas últimas décadas, tomando como base a análise dos diferentes vetores de crescimento urbano e metropolitano. O capítulo, que se apoiou principalmente na pesquisa de campo realizada, elabora um registro, descrição e análise das diferentes direções de crescimento, com o intuito de compreender as diversas dinâmicas em curso no processo de crescimento da Metrópole fortalezense. Todo o capítulo ampara-se no vasto acervo de informações obtido no decorrer da pesquisa, destacando as questões urbanas recentes verificadas no espaço metropolitano.

O quarto e último capítulo, Dinâmica e especificidades no setor sudeste, detém-se em um estudo mais aprofundado do vetor sudeste da Metrópole, identificado no capítulo anterior como o eixo mais dinâmico de expansão e o que apresenta mudanças mais significativas e padrões de ocupação urbana mais complexos, de conformidade com os processos de urbanização contemporânea. Em conseqüência, foi objeto de análises mais pormenorizadas e detalhadas. Assim, foram examinadas, na escala do tecido urbano, as formas de produção, apropriação, uso e transformações do espaço, verificando como ocorreu o processo de ocupação dessa área da Metrópole, identificando os novos e diferentes padrões de urbanização e os fatores que determinaram tal configuração.

Concluída a pesquisa, e de acordo com a hipótese inicialmente formulada, foram elaboradas Considerações Finais acerca da configuração atual da Metrópole cearense e seus diferentes padrões de expansão urbana, especialmente aqueles relacionados com os processos contemporâneos de urbanização. Foram também efetuadas reflexões atinentes às especificidades locais observadas, procurando inquirir quanto às tendências de desenvolvimento da área estudada. $\mathrm{O}$ trabalho pretendeu, enfim, oferecer uma contribuição metodológica e instrumental à compreensão do processo de crescimento urbano da área metropolitana de Fortaleza. 


\section{CAPÍTULO 1}

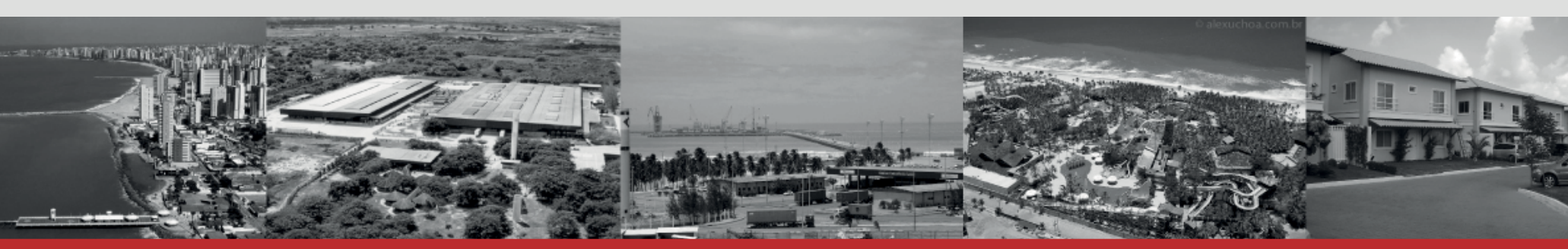

A METRÓPOLE DE FORTALEZA NO CONTEXTO DA URBANIZAÇÃO CONTEMPORÂNEA 
$\mathbf{O}$ capítulo pretende abordar aspectos teórico-conceituais acerca da urbanização contemporânea, numa perspectiva ampla, tentando correlacionar, sempre que possível, com as dinâmicas urbanas recentes da área metropolitana de Fortaleza. Serão enfocados conceitos ligados ao tema e sua relação com os processos urbanos contemporâneos - tomados de forma geral - a partir das últimas décadas do século XX, de maneira a melhor compreender o processo de urbanização em curso na área em estudo.

O capítulo se inicia com uma descrição breve da forma como tem ocorrido o crescimento urbano recente da Metrópole cearense, enfatizando as mudanças verificadas nas últimas décadas. A seguir, é apresentado um quadro sucinto, a fim de descrever o contexto de mudanças em que se insere o tema da pesquisa. Na sequência, são enfocados aspectos teóricos, a partir da revisão da literatura básica pertinente, de acordo com autores que se debruçam sobre o tema e definem as mudanças na urbanização que se tornaram evidentes nos últimos 30 anos. Das linhas teóricas estudadas, foram destacadas as que mais se aproximam dos objetivos da pesquisa, ou seja, aquelas voltadas preferencialmente para a análise urbana. Finalmente, são abordadas questões ligadas ao planejamento e controle relacionados a essas novas formas de organização territorial.

O objeto de estudo é novamente retomado ao final, ressaltando a importância de se investigar as particularidades próprias da urbanização recente da área metropolitana de Fortaleza.

Há de salientar-se que o referencial teórico abordado no capítulo tomou como base a literatura disponível sobre o tema, reportando-se ao que já se publicou sobre a matéria no âmbito da sociedade ocidental, sobretudo as pesquisas realizadas na Europa, Estados Unidos e América Latina.

\subsection{A DINÂMICA URBANA RECENTE DA METRÓPOLE CEARENSE}

Durante as últimas décadas, a área metropolitana de Fortaleza tem experimentado transformações bastante significativas em sua configuração socioespacial. O crescimento recente da Metrópole cearense aponta o surgimento de novas espacialidades e formas urbanas; os espaços já não se constituem como no passado, em mancha contínua, contida nos limites político-administrativos do Município, com zonas bem definidas, mas se compõem de uma aglomeração que extrapola esses limites, conformando um tecido urbano bem mais complexo, descontínuo, que se estende além da cidade consolidada.

De 1974, quando foi criada a Região Metropolitana de Fortaleza, para 2010, a população aumentou de 1.036 .779 para 3.610 .379 habitantes, concentrando, respectivamente, $23 \%$ e $42 \%$ da população do Estado, o que representa acréscimo expressivo.

Até o final da década 1970-1980, o crescimento da Metrópole cearense ocorria de maneira homogênea, conforme o modelo centro-periferia' ${ }^{1}$, comum a outras Metrópoles brasileiras, ou seja, com uma concentração crescente de população, atividades econômicas e investimentos públicos nas

\footnotetext{
${ }^{1}$ De acordo com Ribeiro \& Lago (1994), "a segregação social das camadas populares de menor renda, a autoconstrução das moradias e a precariedade das condições de consumo coletivo são apontados como definidores deste "padrão periférico". O modelo "periférico" relacionado à urbanização, portanto, é "caracterizado pela segregação social das camadas populares de mais baixa renda e suas características contextuais de habitação associadas às regiões mais distantes e desvalorizadas da cidade. "O termo 'periferização', passa a ser entendido, pois, como um paradigma teórico que abre mão da descrição física e trata da segregação das camadas sociais de baixa renda aos espaços periféricos da economia urbana." (OJIMA, 2004, disponível em http://www.labjor.unicamp.br/patrimonio/materia.php?id=98).
} 
áreas centrais e mais valorizadas, e, em volta, na periferia, o espaço era marcado pela precariedade ambiental e social, onde se localizava parte significativa da população de mais baixa renda. A metropolização de Fortaleza, no primeiro momento, ocorreu em conformidade com esse padrão, associada à localização de indústrias nessa periferia e à construção de conjuntos habitacionais e habitações populares em suas vizinhanças.

A Metrópole atual apresenta mudanças visíveis, expressas em suas paisagens, evidentes em suas reconfigurações espaciais, novas morfologias, usos e funções. Surgem periferias urbanas² de um tipo distinto daquelas que se formavam até a década de 1970-1980. No âmbito da área metropolitana, verifica-se um processo de realocação da população, de diferentes faixas de renda, que passam a ocupar áreas periféricas de baixa densidade ou áreas antes direcionadas para atividades agrícolas.

Fortaleza cresce agora sob o influxo de outras dinâmicas e de outras formas de produção do espaço, diferente do padrão "centro-periferia" de crescimento urbano, o que tem acarretado transformações significativas na conformação dos espaços urbano e metropolitano.

Essas mudanças se fizeram mais evidentes desde meados da década de 1980-1990. A Fortaleza atual difere radicalmente daquela dos anos 1970-1980, resultado, em grande parte, das mudanças produtivas, tecnológicas e sociais, verificadas desde então.

Desde as últimas décadas do século passado, o processo de crescimento das áreas metropolitanas, de modo geral, foi bastante acelerado, sobretudo nas metrópoles latino-americanas, como consequência de um determinante processo de globalização e reestruturação produtiva ${ }^{3}$, o que provocou "uma forte reestruturação na morfologia das urbes modernas." (DE MATTOS, 1999).

Fortaleza não se encontra alheia a esse processo. E, tal como outras metrópoles, passa por uma adaptação aos novos tempos, perceptível em vários aspectos, como: a descaracterização do centro tradicional e a constituição de novas áreas de centralidade, ensejando uma policentralidade; o surgimento de novos padrões espaciais para diversas atividades produtivas; a formação de espaços fragmentados e desarticulados; a adoção de novas formas de vida pela população, como a maior mobilidade; a segregação socioespacial proveniente da forma diferenciada de uso e apropriação dos espaços públicos e privados; as mudanças no mercado imobiliário e os reflexos no espaço urbano, a manifestação espacial da atividade turística e as conseqüências físicas, traduzidas por núcleos dispersos ao longo do litoral, aonde se instalam equipamentos de lazer e turismo de grande porte, muitas vezes em áreas de reservas ambientais.

\footnotetext{
${ }^{2}$ Desde meados da década de 1980-1990, o padrão periférico de urbanização nas cidades brasileiras, socialmente segregado e homogêneo, apresenta sinais de mudanças significativas. As franjas urbanas antes destinadas à população de mais baixa renda passam a ser ocupadas também pela classe média e, mais recentemente, nos anos 2000-2010, condomínios fechados destinados às classes com poder aquisitivo mais elevado também são construídos nas periferias, que passam a ser entendidas então não só como locus da segregação imposta às classes mais pobres, mas também da autossegregação de classes abastadas que fogem do núcleo metropolitano. Segundo Caldeira (2000), o surgimento desses condomínios e loteamentos faz parte de um novo padrão de segregação espacial e desigualdade social na cidade, substituindo aos poucos o modelo dicotômico centro-periferia.

3 O fenômeno da reestruturação produtiva resulta de determinações econômicas e de mudanças na base técnica de produção, ao longo da década de 1990-2000, que acarretaram alterações estruturais na indústria e nos serviços, bem como na estrutura ocupacional. Este novo momento é marcado por um confronto direto com a rigidez do fordismo. Segundo Harvey (1993, p.140), "ele se apoia na flexibilidade dos processos de trabalho, dos mercados de trabalho, dos produtos e padrões de consumo. Caracteriza-se pelo surgimento de setores da produção inteiramente novos, novas maneiras de fornecimento e de serviços financeiros, novos mercados e, sobretudo, taxas altamente intensificadas de inovação comercial, tecnológica e organizacional".
} 
Afora isso, a Metrópole apresenta algumas outras características específicas ${ }^{4}$, como a implantação do Porto do Pecém, inaugurado no ano de 2001, que tem estimulado o aumento da urbanização para o lado oeste; a criação de um corredor industrial na BR 116, com inúmeras indústrias instaladas ao longo da rodovia; a construção recente do Centro de Eventos, o surgimento de novas áreas de centralidade, o aparecimento progressivo de condomínios residenciais horizontais, sobretudo desde a década de 2000-2010, que configuram uma nova tipologia, gerando espaços mais fragmentados $^{5}$ (ver figura 1.1).

É evidente também o crescimento acelerado do setor sudeste da Metrópole, de ocupação mais recente, que tem como principal vetor de expansão a rodovia CE 040. Esse setor abrange uma diversidade de processos sociais, urbanísticos e ambientais que merecem estudo mais aprofundado ${ }^{6}$.

É relevante o papel da infraestrutura viária na expansão urbana e na localização de uma série de atividades implantadas, até poucas décadas atrás, em zonas periféricas da Cidade. Fatos novos produzem, por vezes, um contexto de dispersão territorial, que segue uma lógica de descontinuidade espacial e dilui, em algumas áreas, o limite rural-urbano 7 .

Observa-se, portanto, que a área metropolitana de Fortaleza se encontra em plena expansão e esta ocorre de forma diferenciada, altera sua dinâmica de crescimento, com o que estabelece novas relações espaciais entre centro e periferia.

O fenômeno verificado em Fortaleza se insere num processo mais amplo, que abrange a maioria das áreas metropolitanas ${ }^{8}$ contemporâneas. Assim sendo, faz-se necessária uma reflexão mais aprofundada sobre o tema, apreciando-se como a matéria é tratada por diferentes autores. Por tal razão, no item seguinte será apresentado um quadro sucinto que serve de panorama para compreender o contexto em que o objeto de estudo se circunscreve.

\footnotetext{
${ }^{4}$ Essas características e dinâmicas diversas mencionadas serão enfocadas com detalhes no decorrer da tese.

${ }^{5}$ A fragmentação refere-se à dimensão espacial do tecido urbano, quando a mancha urbanizada se configura em espaços desconectados e não conurbados, o que acentua a fragmentação social. Segundo Portas (2004, p.227), "a fragmentação é resultado da extrema diversificação das morfologias e tipologias dos tecidos edificados, da incompatibilidade das funções próximas, dos vazios urbanos e da presença dos espaços naturais que tenham resistido ao assédio das transformações."

${ }^{6}$ A dinâmica urbana e metropolitana verificada no setor sudeste da Metrópole será assunto abordado em capítulo à parte.

${ }^{7}$ Para Monte-Mór (2005, p.2), os adjetivos urbano e rural, referentes à cidade e ao campo, "ganharam autonomia apenas recentemente e dizem respeito a uma gama de relações culturais, sócio-econômicas e espaciais entre formas e processos derivados da cidade e do campo sem, no entanto, permitirem a clareza dicotômica que os caracterizava até o século passado. Ao contrário, cada vez mais as fronteiras entre o espaço urbano e o espaço rural são difusas e de difícil identificação".

8 Vale esclarecer que as dinâmicas e Processos que expressam as novas formas e configurações urbanas não estão restritos aos espaços metropolitanos, embora tenha sido neles que primeiramente ocorreram e com níveis de complexidade mais acentuados.
} 


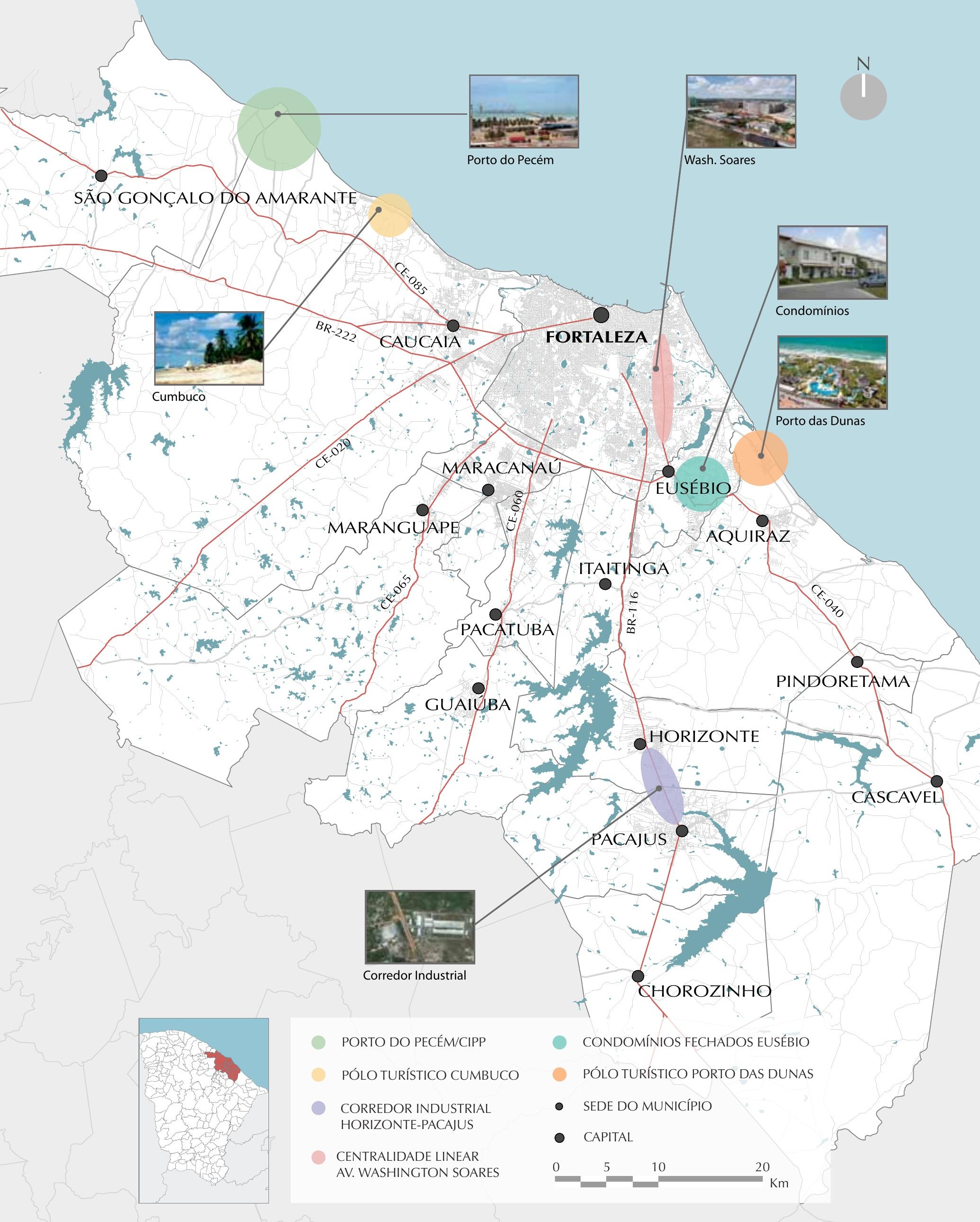




\subsection{ALGUMAS CONSIDERAÇÕES SOBRE O PROCESSO DE URBANIZAÇÃO CONTEM- PORÂNEA}

O desenvolvimento urbano das metrópoles contemporâneas tem ensejado investigações esclarecedoras acerca dos tipos e naturezas das novas espacialidades que surgem. Esses espaços revelam formas de distribuição territorial diferenciadas, bastante distintas daquelas préexistentes.

Presentemente, áreas urbanas de diferentes tamanhos e diversidade de papéis vêm conhecendo transformações intensas. Efetivamente, trata-se de novas maneiras de produzir e se apropriar do espaço, imbricadas no surgimento de sistemas urbanos com formas mais complexas e no crescimento de áreas metropolitanas, com o aparecimento de periferias novas e diversificadas.

Diante desse quadro, uma estrutura conceitual baseada na dicotomia centro-periferia, campo-cidade ou rural-urbano já não se mostra suficiente para descrever de maneira eficaz a realidade urbana atual. Essa dicotomia parece diluir-se a partir das transformações tecnológicas e sociais (econômicas, políticas e culturais) que marcaram as últimas décadas do século XX, com implicações territoriais nítidas e específicas, no plano internacional, nacional e local.

Faz-se necessário, portanto, aprofundar a reflexão teórica sobre a urbanização contemporânea, com o intuito de avaliar a intensidade das transformações que ocorreram nessas aglomerações e identificar as especificidades dos processos locais.

Como o assunto é bastante vasto e complexo, não se tem a pretensão de apresentar conclusões ou "fechar questões" sobre o tema, mas apenas enfocar os fenômenos urbanos recentes, com especial destaque na importância conferida à intensificação das pesquisas sobre a problemática urbana contemporânea.

Da mesma forma, convém esclarecer que não se trata de uma interpretação, de uma visão subjetiva, de uma abordagem valorativa ou de rejeição. Trata-se de constatar e registrar a existência de observações semelhantes acerca dos rumos tomados pela urbanização contemporânea, formuladas por autores de vários países e diversificadas correntes.

Este item tem por objetivo, portanto, desenvolver algumas considerações de caráter teórico-metodológico sobre as tendências da urbanização atual, a fim de que se possa melhor compreender como ocorre o processo de urbanização em curso na área metropolitana de Fortaleza.

\subsubsection{Um contexto de mudanças}

Não se afigura tarefa simples observar o que acontece no mundo, no que se refere à questão da urbanização no final do século XX e princípio do XXI. É incontestável, porém, a emergência de mudanças significativas, de várias tendências, que conformam a dinâmica urbana atual.

Constata-se, de início, uma elevação acentuada dos índices de urbanização, com um acréscimo expressivo da população urbana, evidenciando um novo estágio de organização da vida social do território: o da urbanização total ${ }^{9}$ (REIS, 2006, p.20). Segundo o autor, uma das características mais importantes da passagem do milênio "é o surgimento de sociedades nas quais desaparece a população rural e, ao mesmo tempo, os setores sociais urbanos se apropriam extensamente dos territórios ao seu redor, para implementação de seus modos de vida, agora de forma dispersa".

\footnotetext{
${ }^{9}$ Somente no Brasil, a população urbana passou de 36,2\% em 1950 para 81,2\% em 2010 (Censo IBGE).
} 
Sobre o panorama atual da urbanização, ele assinala:

No final do século XX estava claro que a industrialização nos conduzia à formação de sociedades plenamente urbanizadas e que essa urbanização já não apresentava as mesmas características do período anterior. O mundo urbano havia mudado, de modo amplo e em ritmo mais acelerado do que poderíamos prever algumas décadas antes (REIS, 2006, p.23).

Para muitos autores, que se dedicam a estudar as formas urbanas contemporâneas, o fenômeno que dá inicio a esse processo de transformações está ligado às intensas mudanças econômicas ocorridas que, por sua vez, estão relacionadas com a globalização ${ }^{10}$ econômico-cultural. Assim sendo, os novos arranjos espaciais são em grande parte decorrentes dessas mudanças "que incidem de forma decisiva na modificação da estrutura e do funcionamento urbano pré-existente, marcando o surgimento de uma nova paisagem e uma nova forma urbana." (DE MATTOS, 2004, p.177).

Além das mudanças na economia, o desenvolvimento tecnológico (telecomunicações) e a maior mobilidade, propiciada com o incremento dos transportes, permitiram novas formas de produção espacial urbana, que resultam na dispersão das cidades e dos espaços metropolitanos, formando periferias novas, distintas das tradicionais.

O ponto de partida das mutações observadas em grande parte das áreas metropolitanas do mundo inteiro foi fundamentalmente o fato de que o avanço da reestruturação-informacionalização-globalização se traduziu em uma progressiva decomposição e/ou desintegração de numerosos processos que até então tinham se desenvolvido principalmente em e entre economias nacionais, o que deu origem à sua reintegração em um âmbito supranacional, por meio de empresas que, nessa dinâmica, foram impulsionadas a se organizar e funcionar em rede (DE MATTOS, 2004, p.160).

Em síntese, esse novo contexto que caracteriza a organização social mundial desde as últimas décadas do século $\mathrm{XX}$, é resultado:

- da reorganização produtiva, como passagem para uma nova etapa na evolução do capitalismo - os novos estágios do comércio mundial, a novas maneiras de organização dos processos produtivos e a consequente penetração de modos mais complexos de organização capitalista;

- da modernização do sistema financeiro;

- da revolução informacional e da automação;

- da complexidade das mudanças tecnológicas que ganham força no panorama mundial;

- da ampliação do consumo e universalização dos hábitos e formas de vida urbana;

- da adoção de novos modos de vida por parte da população;

- do incremento da mobilidade; e

- da pressão crescente sobre a procura de recursos renováveis e culturalmente mais significativos.

\footnotetext{
${ }^{10}$ Anthony Giddens (1991) define a globalização como a conjunção destas mudanças tecnológicas e mercantis e a consolidação de mercados de natureza planetária, proporcionando a circulação global de dinheiro e informações, historicamente coincidentes com o desaparecimento da URSS e o esgotamento da divisão moderna do mundo bipolar. Por sua vez, Néstor Canclini (2007) a identifica como um processo que envolve múltiplos aspectos, como, por exemplo, a transnacionalização, em que há internacionalização da economia e da cultura, gerando empresas e movimentos cuja sede não se encontra territorializada numa só nação.
} 
Cabe ressaltar, portanto, que os avanços decorrentes dos processos de reestruturação produtiva" e das novas tecnologias de informação e comunicação, aliados às transformações na esfera do consumo $^{12}$ e da vida cotidiana, modificam a organização e o funcionamento das principais aglomerações metropolitanas, afetando sua dinâmica e configuração espacial. "Desse conjunto de mudanças decorre a presença crescente do que podemos chamar de 'novas territorialidades', com novas configurações para as formas materiais da urbanização" (REIS, 2007, p.40).

Os novos processos de formação dos tecidos urbanos surgem, pois, num quadro de mudanças estruturais profundas na dinâmica da produção, acumulação, circulação e consumo do capital'13. Aliada a isso, "a revolução técnico-científico-informacional transforma, em escala mundial, a relação entre a sociedade e seus espaços, compondo um complexo processo com novas lógicas de produção, também do espaço" (ANJOS, 2009, p.199).

As áreas de urbanização concentrada são agora associadas a áreas mais dispersas, resultado de uma urbanização ao mesmo tempo fragmentada e extensiva sobre o território. A ampliação e facilidade das tecnologias de comunicação e de transporte garantem a acessibilidade, de modo que se formam espaços urbanos cada vez mais extensos e descontínuos, porém ligados em rede.

A melhoria constante das infraestruturas de transporte facilita o deslocamento de bens, pessoas e informações por um território bem mais extenso.

A preponderância dos fluxos ${ }^{14}$ de informações, pessoas ou mercadorias em rede não coincide mais com a lógica tradicional dos lugares. Assiste-se a uma expansão intensa do caráter metropolitano, revelando transformações diferentes do que ocorria anteriormente.

Uma vez que a tecnologia informacional, marco transformador do modo de produção e da nova economia mundializada, está no centro das transformações em curso, devemos considerar que o processo de reestruturação do território metropolitano vem participando ativamente das mudanças instauradas no padrão tecnológico (MEYER, GROSTEIN \& BIDERMAN, 2004, p.20).

Diante deste quadro, intensifica-se o debate sobre as recomposições urbanas, surgidas sob o impacto das transformações recentes no capitalismo contemporâneo e das novas tecnologias de informação. São vários os autores que se dedicam a estudar as mudanças recentes nas aglomerações urbanas:

\footnotetext{
${ }^{11}$ A reestruturação produtiva está em curso desde o final dos anos 1980-1990, e mais intensamente a partir da segunda metade da década de 1990-2000, influenciando na alteração do cenário urbano, na redefinição dos espaços e na reconfiguração de territórios.

${ }^{12}$ A emergência da "lógica do consumo" que caracteriza a fase atual do capitalismo interfere não só na produção de bens, mas transforma quase tudo em mercadoria, inclusive o espaço. A atividade turística, por exemplo, tal como é exercida na atualidade, representa bem essa prática.

${ }^{13}$ As novas formas urbanas se materializam nos novos arranjos espaciais, relacionados à crescente internacionalização de certas atividades. Essas novas paisagens urbanas são marcadas cada vez mais por elementos relacionados a uma dinâmica internacionalizada, capaz de alterar bastante as configurações urbanas pré-existentes. No dizer de Milton Santos, "no mundo da globalização, o espaço geográfico ganha novos contornos, novas características, novas definições (...) A globalização, com a proeminência dos sistemas técnicos de informação, subverte o antigo jogo da evolução territorial e impõe novas lógicas" (SANTOS, 2000, p.79).

${ }^{14}$ O conceito de "espaço de fluxos" foi introduzido por Castells (1999) para designar a organização material urbana da sociedade contemporânea, na qual os fluxos (de capital, de informação, de tecnologia, etc.) são a forma predominante de relação. De acordo com o autor (1999, p.501), "os fluxos são a expressão dos processos que dominam nossa vida econômica, política e simbólica" e, para tanto, há uma nova forma espacial característica das práticas sociais que dominam e moldam essa sociedade em rede: o espaço de fluxos.
} 
As últimas inovações tecnológicas unidas a complexas mudanças de caráter econômico e social estariam dando como resultado uma ruptura generalizada nas pautas de localização de praticamente todos e cada um dos elementos que compõem as aglomerações urbanas, por distintas que elas sejam (MONCLÚS, 1998, p.8).

Essas mudanças, decorrentes das novas estruturas econômicas da sociedade, têm como conseqüência alterações decisivas nas paisagens urbanas e no modo de vida de seus habitantes (FONT, 1999, p.24).

\subsubsection{Os estudos recentes sobre o tema}

As várias faces da urbanização contemporânea consistem, de fato, num fenômeno mundial, que atinge as diversas sociedades, de diferentes culturas e, ante a ineficácia do instrumental teórico convencional de explicá-lo, os estudiosos das questões urbanas tentam apreender as complexas dinâmicas que afetam a urbanização recente, buscando definir suas causas e efeitos, bem como identificar as diversas tendências.

Esses processos, pois, são observados e diferentemente conceituados em distintas partes do mundo. Uma abundante bibliografia revê a questão da urbanização com base em critérios novos e, sobretudo, em novas avaliações.

Tudo se torna mais evidente, em especial desde a década de 1990-2000, quando aparecem inúmeros trabalhos, de vários autores, em diversas disciplinas, com a finalidade de analisar e explicar a lógica do desenvolvimento e das transformações que vêm ocorrendo no mundo urbano atual, chamando a atenção para o fato de que há mudanças significativas nas formas de crescimento das aglomerações urbanas.

Essses estudos resultaram em alguns modelos teóricos que buscam visualizar e explicar o fenômeno. De acordo com Reis (2006), alinham-se em duas correntes principais ${ }^{15}$ : uma delas mais voltada para estudos quantitativos e demográficos, que procura justificar a distribuição da população e atividades sobre o territorio em função de mudanças tecnológicas, com ênfase nos setores de transporte e comunicações; e outra, mais politizada, que busca explicar a organização espacial recente como consequência ou parte da reorganização produtiva, da nova etapa do capitalismo, traduzida agora como "capitalismo financeiro".

Em seus diferentes locais de origem, em seus respectivos países, pesquisadores se dedicam a observar e analisar o tema. Arquitetos, sociólogos e urbanistas europeus, como Nuno Portas, Javier Monclús, Manuel Solà-Morales, Bernardo Secchi, Francesco Indovina, Antonio Font, François Ascher, Giuseppe Dematteis, Thomas Sieverts, Peter Hall e Jordi Borja elaboraram estudos importantes de interpretação da metrópole europeia e desenvolveram análises e trabalhos relevantes sobre os novos fenômenos urbanos.

Para Javier Monclús, urbanista catalão que investiga a realidade metropolitana de Barcelona, percebe-se, de fato, nos últimos anos, "a eventual transformação da cidade compacta tradicional em um novo tipo de cidade, cada vez mais dispersa e fragmentada, como conseqüência dos processos

\footnotetext{
15 A primeira linha, ligada aos aspectos demográficos e quantitativos, é relacionada aos estudos realizados por pesquisadores dos Estados Unidos e a segunda, com perspectiva política, que procura explicar a reestruturação urbana como conseqüência da reorganização produtiva, é mais utilizada por pesquisadores europeus (REIS, 2006).
} 
de suburbanização recentes" (1998, p.5). Trata-se, conforme o autor, de um "novo ciclo da urbanização, caracterizado por uma redução do crescimento demográfico e pela expansão territorial dos usos urbanos". (MONCLÚS, 1998, p.11). Para ele, o advento da cidade dispersa é resultado do processo de ampliação das periferias, fenômeno que se torna cada vez mais generalizado no mundo.

Antonio Font, em sua obra La construcció del territori metropolità - morfogènese de la regió urbana de Barcelona (1999), analisa as mudanças na urbanização daquela área, desde meados do século XIX até o presente, com ênfase nas fases mais recentes, quando identifica na área um crescimento por dispersão, que caracteriza a Metrópole dos anos 1980-1990: "a descontinuidade física e a fragmentação territorial têm sido a expressão formal e funcional mais clara deste processo de difusão da atividade e da população sobre o território." (FONT, 1999, p.2).

Em seu livro, Font (1999, p.5) identifica alguns elementos explicativos do "comportamento" metropolitano atual:

- as novas tendências na localização das atividades;

- os novos processos de ocupação, os lugares de maior transformação;

- as novas dinâmicas e escalas de produção da cidade;

- as características dos novos artefatos metropolitanos;

- os impactos e efeitos sobre os tecidos urbanos originais;

- as estratégias que podem resultar das operações urbanísticas.

O autor ainda procura discutir e esclarecer os conceitos relativos à "dispersão" e à "difusão". Para ele, a dispersão é um conceito de natureza topológica e se refere à cidade estendida, fragmentada, enquanto a difusão urbana está ligada principalmente à difusão de um modo de vida, de valores urbanos (FONT, 2007). Destaca a necessidade de um aprofundamento desses processos, amparado na observação da realidade de cada lugar.

Para Bernardo Secchi (2004), entre os anos 1960 e 1980 do século XX, a cidade europeia "sai definitivamente de um período moderno para entrar noutro cujas linhas não estão ainda totalmente e nem sequer em boa parte definidas". Na Itália, ele trata o fenômeno como "urbanização difusa", ao referir-se à região do Vêneto ${ }^{16}$; e afirma que, em toda a Europa, a cidade difusa assumiu dimensões enormes, compreendendo regiões inteiras e parte do continente:

Com maior ou menor evidência, as cidades pareciam dispersar-se em uma espécie de nebulosa difusa sobre o território, da qual se torna difícil descrever a forma e a organização espacial, econômica e social, dizer onde se encontra o centro e a periferia e quais seriam as partes constitutivas e suas características. (SECCHI, 2004, p.146) (traduziu-se)

O autor destaca, ao se referir a certas regiões italianas, que

[...] houve uma radical mudança da natureza e das características da cidade, ao se conformar, na Itália, uma nova e extensa parte da cidade, diferente do passado, que alguns denominam de cidade difusa e que não constitui o lógico e necessário desenvolvimento da cidade moderna, nem tão pouco representa uma forma degradada desta. Eu denomino esta nova forma urbana, que abarca a cidade antiga,

\footnotetext{
${ }^{16}$ Para Secchi, o caso italiano lhe parece particularmente significativo e emblemático, pois considera que muitas das características da cidade européia se apresentam tal como são vistas na Itália. O Vêneto, segundo o autor, é uma das regiões "que primeiro incita, a partir dos anos setenta, o estudo das novas características do fenômeno urbano" (SECCHI, 2004, p.48).
} 
a cidade moderna e a cidade difusa sob o termo "cidade contemporânea", com a qual devemos nos enfrentar nos próximos anos (SECCHI, 2004, p.152). (traduziu-se)

Essa cidade contemporânea, no entender do autor, é a antecipação de "uma cidade nova, diferente daquelas, de um dos possíveis futuros da cidade. Esta é a razão pela qual o prefixo pós, que muitas vezes lhe é atribuído, habitualmente na acepção de pós-moderna não me parece admissível" (2004, p.146).

Os conceitos de urbanização difusa e cidade difusa já haviam sido utilizados por Francesco Indovina (1990) para apreciar e interpretar o fenômeno específico de organização do território, fazendo referência à região do Vêneto central, onde essa forma assumiu um caráter mais evidente. Para o autor, é preciso "interpretar tais transformações precisamente porque elas não se apresentam como uma continuação do fenômeno precedente, mas porque o fazem quase como uma mudança de Estado" (2004, p.49).

O sociólogo francês François Ascher, em sua obra Metapolis ou l'avenir des villes (1995), procura destacar a importância do desenvolvimento tecnológico, dos transportes e da comunicação na urbanização recente. Sua hipótese é a de que está surgindo uma nova forma urbana que parece ultrapassar e englobar, de diversos pontos de vista, as metrópoles que conhecemos até o presente. Ascher, um dos um dos principais pensadores contemporâneos sobre a cidade e as mudanças urbanas ocorridas nas últimas décadas, cunhou o termo metápolis para designar essas aglomerações conurbadas, extensas, descontínuas, heterogêneas e multipolarizadas, que revelam uma nova fase da urbanização.

Uma metápolis é o conjunto de espaços onde todos ou parte dos habitantes, das atividades econômicas ou do território estão integradas no funcionamento cotidiano de uma Metrópole. Uma metápolis constitui, da mesma forma, um único grande conjunto de emprego, de habitação e de atividades. Os espaços que compõem uma metapolis são profundamente heterogêneos e não necessariamente contíguos. Uma metápolis compreende pelo menos algumas centenas de milhares de habitantes (ASCHER, 1995, p.34). (traduziu-se)

Já em Os novos princípios do urbanismo (2001), o mesmo autor destaca mudanças tanto no processo como na forma urbana propriamente dita, as quais tornam imprecisos os limites entre o urbano e o rural e resultam nas grandes conurbações e em novas configurações de redes urbanas.

Thomas Sieverts (2009) constata que, atualmente, grande parte das regiões da Europa Central passa por um estado de dispersão, denominada por ele de zwischenstadt ou cidade difusa:

O tecido urbano tem crescido no espaço enormemente, com densidades muito mais reduzidas e menos coesão espacial do que na cidade histórica. Agora, na Europa, grandes partes das regiões urbanas podem ser consideradas como dispersas, como città diffusa ou zwischenstadt (SIEVERTS, 2009, p.301).

Giuseppe Dematteis utiliza as expressões periurbanização ${ }^{17}$ e difusão reticular para se referir às novas morfologias urbanas observadas nas cidades europeias:

\footnotetext{
${ }_{17}$ Para Dematteis $(1998$, p.4), "a perirubanização constitui a situação na qual o crescimento depende apenas das funções de serviço de um polo urbano inserido num contexto regional relativamente pobre, tanto de serviços, como de atividades produtivas. Já a difusão reticular (cidade difusa) é caracterizada por tecidos mistos, residenciais e produtivos (industriais, terciário-produtivos, agroindustriais e turísticos), derivados de dinâmicas endógenas do tipo 'distrito industrial', ou da descentralização metropolitana de raio mais amplo" (traduziu-se).
} 
Os recentes rocessos de periurbanização e de difusão reticular da cidade estão dando origem a periferias urbanas de um tipo muito distinto daquelas que haviam se formado na Europa desde a revolução industrial até a década de 1960. Estas novas periferias são o resultado de profundas mudanças nas estruturas territoriais urbanas, nas tecnologias da comunicação e da informação, na organização e na regulação social, pelas quais têm passado os países industrializados a partir dos finais da década de 1960 (DEMATTEIS, 1998, p.17) (traduziu-se)

Nuno Portas, que investiga as mudanças nas configurações territoriais em Portugal, principalmente nas regiões do norte, ressalta que por volta dos anos 1970-1980, o assunto já começava a preocupar os europeus. Em seus estudos, enfoca as novas relações centro-periferia, reportando-se às rupturas nos limites das cidades e das metrópoles. Também se refere às cidades como sistemas urbanos contínuos, ou sistemas em rede, as quais, no seu entender, constituem "verdadeiras nebulosas". Com base nessa análise, ele se volta para a questão central de interesse para os arquitetos: o trabalho a fazer e as possibilidades de intervenção.

Portas refere-se à cidade contemporânea como cidade alargada, ou seja, aquela com muitos centros:

A cidade alargada de hoje ainda precisa de centros, mesmo que esses centros não sejam nem se pareçam mais como os de antes. Mesmo que esses centros se multipliquem por distintas situações territoriais, liguem-se pelas novas acessibilidades e se relacionem funcionalmente e na identidade de imagem, não por serem parecidos uns com os outros, mas por certas complementaridades e também por certa competição entre eles (2001, p.123).

Um grupo de estudos dirigido pelo Professor Bernardo Secchi, que abrange diversos pesquisadores, entre os quais Nuno Portas, Álvaro Domingues, Francesco Indovina e Antonio Font, por meio de trabalhos locais e de situações territoriais representativas, formulou hipóteses e interpretações acerca das causas e transformações ocorridas no "habitat urbano europeu", elaborando assim uma espécie de "balanço" da urbanização contemporânea.

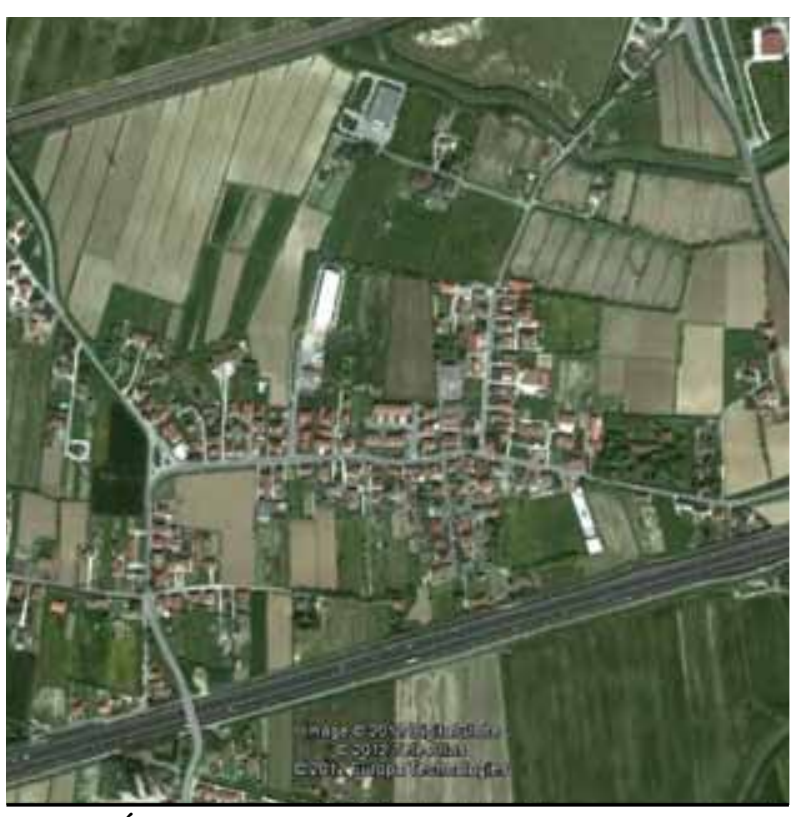

Fig. 1.2 Área de urbanização dispersa na Itália Fonte: Google Earth

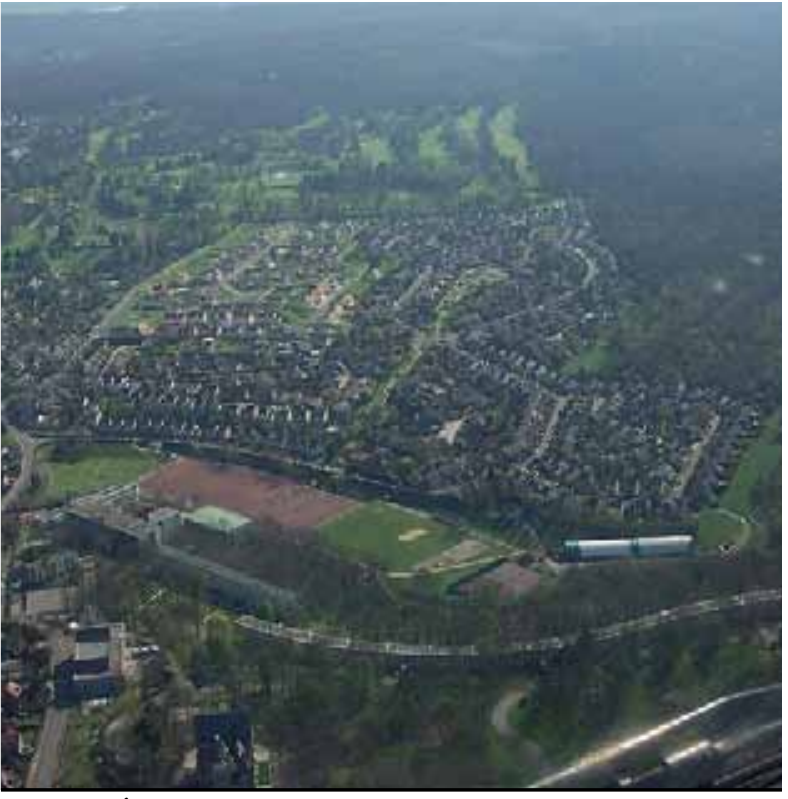

Fig. 1.3 Área de urbanização dispersa na França Fonte: http://en.wikipedia.org/wiki/ 


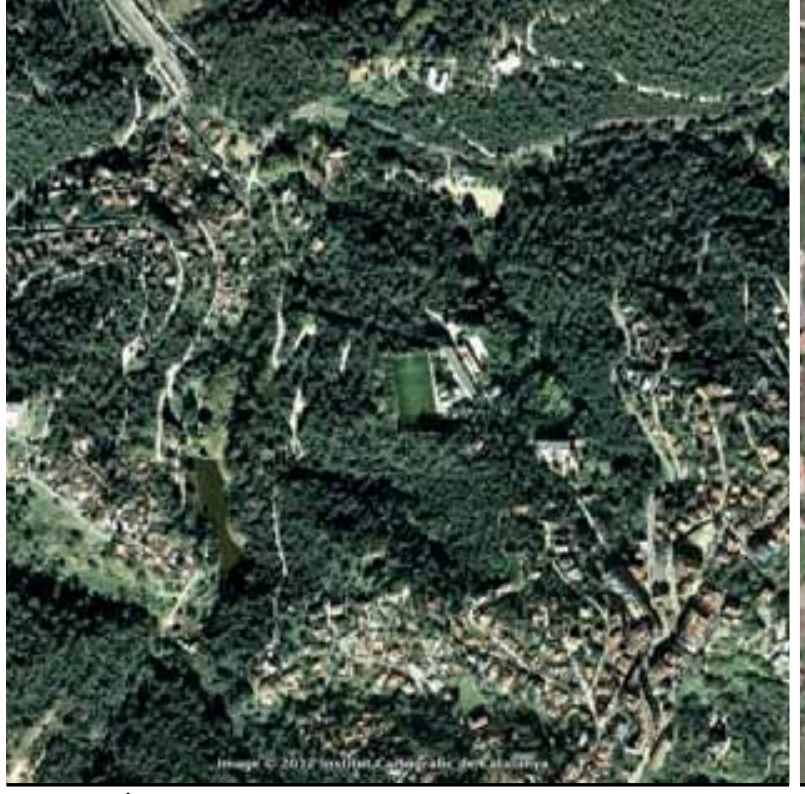

Fig. 1.4 Área de urbanização dispersa na Espanha Fonte: Google Earth

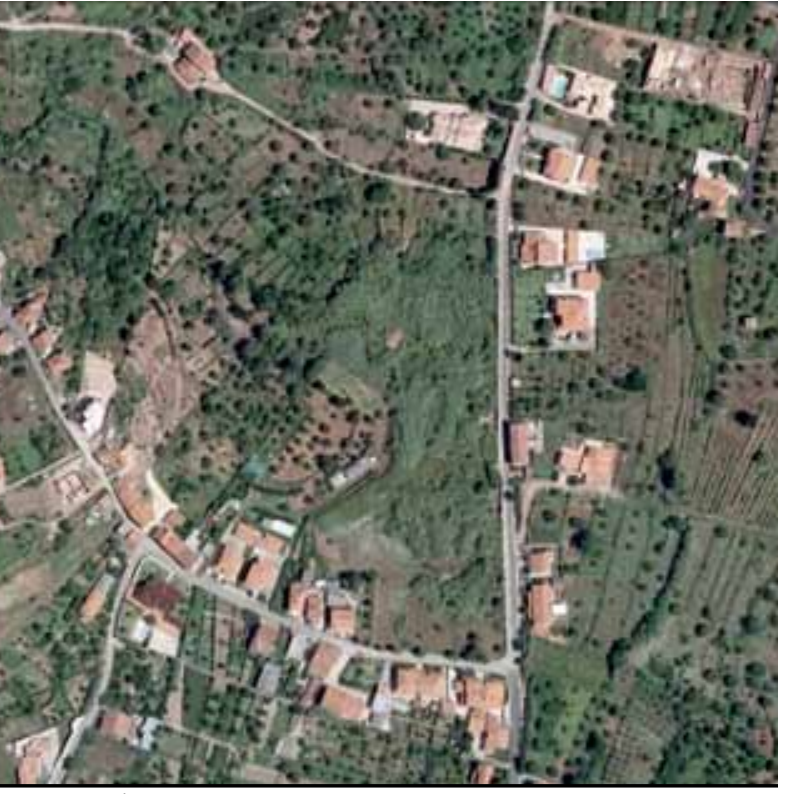

Fig. 1.5 Área de urbanização dispersa em Portugal Fonte: Google Earth

Não só na Europa, como também nas Américas, diversos pesquisadores igualmente estudam as novas formas de organização física e funcional adquiridas pela urbanização contemporânea; essa problemática já é uma constante na reflexão urbanística das últimas décadas.

Nos Estados Unidos, destacam-se os estudos de David Harvey, Edward Soja, Neil Smith, Saskia Sassen, Mark Gottdiener, Joel Garreau e Manuel Castells, todos empenhados em estudar as transformações por que passam as metrópoles atualmente, na tentativa de entender - e explicar - o novo espaço difuso da aglomeração contemporânea (ver figuras 1.6 e 1.7)

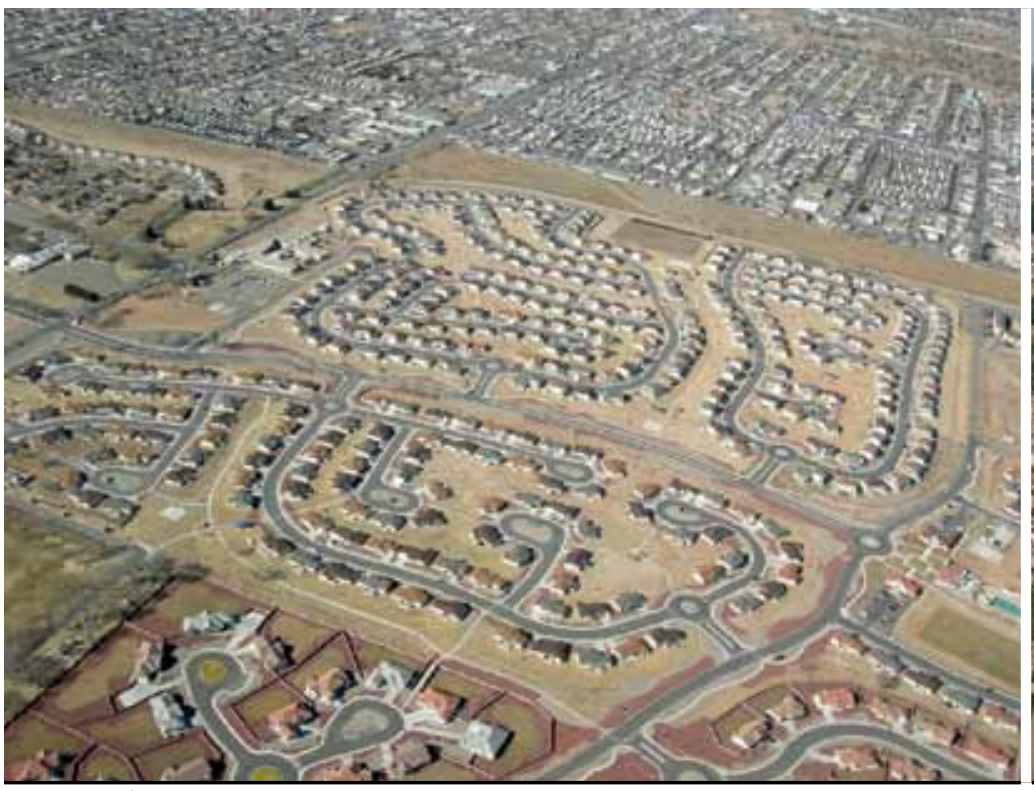

Fig. 1.6 Área de urbanização dispersa nos EUA Fonte: http://www.mbl.edu/news/features/feature_blackbirds.html

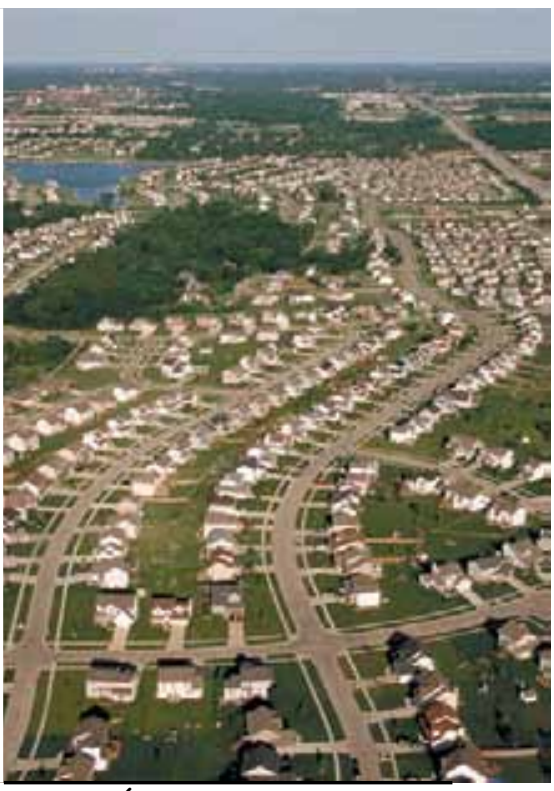

Fig. 1.7 Área de urb. dispersa nos EUA Fonte: http://lal.cas.psu.edu/ 
Os geógrafos Neil Smith, Edward Soja e Mike Davis tratam das novas práticas de intervenção na metrópole, concentrando seus estudos sobretudo na região de Los Angeles ${ }^{18}$, enquanto Harvey se dedica a analisar os processos de acumulação flexível e as formas espaciais resultantes.

Edward Soja, em sua obra Geografias Pós-modernas (1993) traz o debate da Pós- Modernidade no exame da aglomeração de Los Angeles:

Um processo espraiado e polinuclear de descentralização caracterizou a geografia histórica das cidades capitalistas desde o século XX. Sob muitos aspectos, Los Angeles foi e continua sendo um caso exemplar desse crescimento urbano/suburbano descentralizado. À medida que as sub-regiões industriais e residenciais mais antigas declinaram, a periferia regional se expandiu, nos últimos vinte anos, num ritmo que talvez não tenha sido superado em nenhum outro lugar do país (SOJA, 1993, p.252).

O autor, entretanto, chama atenção para o fato de que as mudanças não estão ocorrendo somente em Los Angeles, mas em maior ou menor grau, em todo o mundo. Ainda que adotem formas específicas, em lugares específicos, constituem processos gerais. Para ele, parece não haver dúvidas de que algo realmente excepcional está acontecendo na Metrópole moderna desde o último quartel do século XX.

Em seu livro Postmetropolis - critical studies of cities and regions (2000), Soja adota o termo pós-metrópole para caracterizar esse espaço. E justifica:

Elegi o uso de "pós-metrópole" (em oposição à metrópole moderna) como um termo geral para ressaltar as diferenças entre regiões urbanas contemporâneas e aquelas que se consolidaram nas décadas de meados do século XX. O prefixo pós marca a transição entre o que se convencionou chamar de Metrópole moderna e algo significamente diferente, novas formas pós-modernas e modelos de vida urbana que estão em constante duelo com os estilos bem estabelecidos de análises urbanas (2004, p.92).

Já Joel Garreau lançou o conceito de edge cities ${ }^{19}$ no final dos anos 1980-1990, consideradas por ele como núcleos do novo processo de urbanização e que se caracterizam pela presença de grandes áreas destinadas a escritórios, além de serviços. Sua definição empírica de edge city (cidade às margens) combina cinco critérios (GARREAU, 1991, p.6-7):

- ter 465 mil m² ou mais de espaços de escritórios de aluguel ("o local de trabalho da era da informação");

- ter 56 mil m² ou mais de espaço para ser alugado por lojas varejistas;

- ter mais empregos do que dormitórios;

18 Tal como ocorreu anteriormente com a cidade americana de Chicago, atualmente diversos estudos se debruçam sobre Los Angeles, considerada cidade-paradigma ou cidade-protótipo (embora essa classificação seja bastante controversa), provavelmente por sua forma de expansão, caracterizada pelo policentrismo e por suas formas de crescimento, de base econômica e por condensar várias tendências de maneira particularmente intensificadas. Segundo Frúgoli (2000, p.35), "Los Angeles se caracteriza por aspectos particulares, tais como: "o padrão amplamente descentralizado de urbanização, as transformações no espaço público, o modelo se segregação residencial, o extenso sistema de autopistas, a considerável diversidade étnica". Os diversos estudos sobre a cidade propiciaram o surgimento da chamada Los Angeles School, da qual fazem parte vários autores, como Mike Davis, Neil Smith e Edward Soja, que comenta a respeito da Metrópole americana: "Los Angeles é precursora e sintomática de mudanças no processo de urbanização que provavelmente afetarão toda grande região metropolitana do mundo, em épocas diferentes e com intensidades diferentes" (SOJA, 1993, p.167).

${ }^{19} \mathrm{O}$ autor assim justifica o emprego do termo "edge city": "I have come to call these new urban centers Edge City. Cities, because they contain all the functions city ever has, albeit in a spread-out form that few have come to recognize for what it is. Edge because they are a vigorous world of pioneers and immigrants, rising far from the old downtowns, where little save villages or farmland lay only thirty years before" (SOJA, 2000, p.4). 
- ser percebido pela população como um lugar; e

- não se parecer com a cidade de pelo menos 30 anos atrás.

O autor relata a proliferação desses lugares ao redor de Boston, Nova York, Detroit, Atlanta, Phoenix, Texas, sul da Califórnia, área da baía de S. Francisco e Washington D.C., formando áreas de trabalho e centros de serviços ao redor dos quais quilômetros e quilômetros de unidades residenciais cada vez mais densas e de uma só família organizam a vida familiar "centrada na casa".

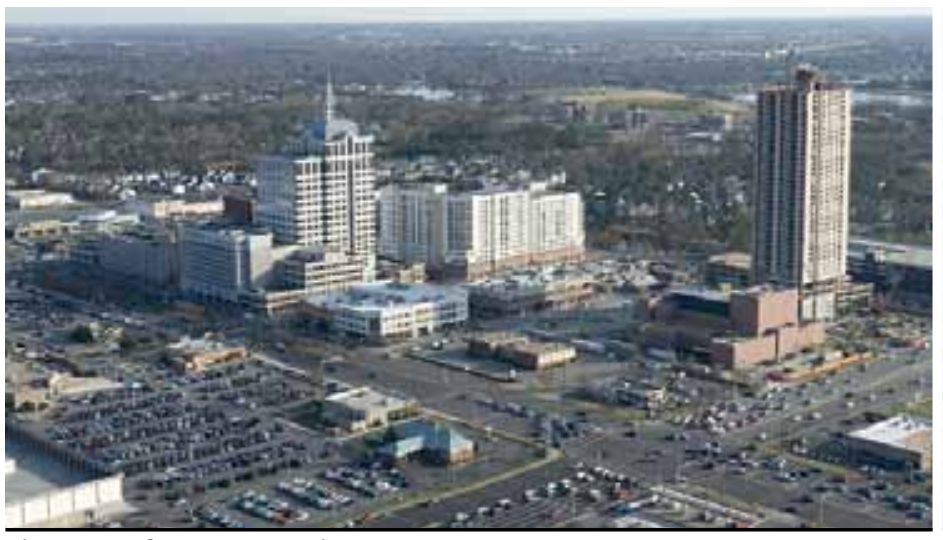

Fig. 1.8 Edge city americana

Fonte: http://www.skyscrapercity.com/showthread.php

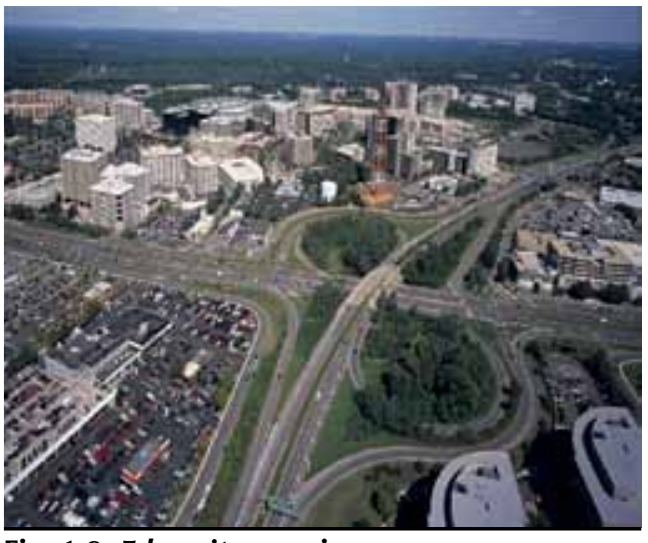

Fig. 1.9 Edge city americana

Fonte: http://www.lewishistoricalsociety.com/

Manuel Castells (1999) introduz o conceito de "espaço de fluxos" para entender a metrópole na atualidade. Segundo o autor, os fluxos de intercâmbio são os componentes essenciais da edge city norte americana e essa configuração espacial é sem dúvida muito específica dos Estados Unidos (ver figuras 1.8 e 1.9).

Ao se referir à cidade contemporânea, Harvey $(2004$, p.186) assevera que ela tem muitas camadas. "Forma o que poderíamos chamar de palimpsesto ${ }^{20}$, uma paisagem composta, resultado de diversas formas construídas, umas sobre as outras no transcurso do tempo."

Robert Fishman, professor de História e Planejamento Urbano em Michigan, foi um dos primeiros pesquisadores $^{21}$ a se dedicar ao estudo das mudanças recentes nas aglomerações urbanas. Em publicação posterior (2004), o autor adota os vocábulos "tecnoburb" e "tecnocity" para fazer referência ao espaço contemporâneo americano e assim justifica a criação da terminologia: "carecemos de um nome adequado para esta cidade nova que tem tomado forma nas periferias de nossos centros urbanos principais. Sugiro dois neologismos: o tecnoburb e a tecnocity" (2004, p.36).

Por tecnoburb me refiro a uma zona periférica, extensa, que surgiu como uma unidade socioeconômica viável. Disseminados ao longo de corredores de crescimento das autopistas, encontram-se centros comerciais, parques industriais, complexos de escritórios, hospitais, escolas e uma gama completa de tipologias residenciais. (ex: Silicon Valley, na Califórnia e a Route 128, em Massachussets) (...) O tecnoburb gerou a diversidade urbana sem a concentração urbana tradicional.

\footnotetext{
${ }^{20}$ A expressão palimpsesto relacionada à cidade foi utilizada primeiramente por André Corboz em 1983, no livro "El território como palimpsesto" e mais tarde retomada por Bernardo Secchi, quando afirma que "neste imenso arquivo de sinais possamos colher um vasto conjunto de intenções, de projetos e ações concretas de pessoas simples, de grupos restritos ou de inteiras sociedades" (entrevista ao portal Vitruvius, abril 2004 - ISSN 2175-6708).

${ }^{21} \mathrm{Em} \mathrm{1987,} \mathrm{Robert} \mathrm{Fishman} \mathrm{publicou} \mathrm{o} \mathrm{livro} \mathrm{Bourgeois} \mathrm{Utopias.} \mathrm{The} \mathrm{rise} \mathrm{and} \mathrm{fall} \mathrm{of} \mathrm{suburbia,} \mathrm{onde} \mathrm{descreve} \mathrm{e} \mathrm{analisa}$ as transformações ocorridas nos subúrbios americanos ao longo do século XX.
} 
Por tecnocity, refiro-me à região metropolitana completa em que se transformou com a chegada do tecnoburb. Em geral, ela conserva o nome de sua cidade principal. (IDEM) ex. Nova York: a vida econômica e social da cidade evita cada vez mais seu núcleo central hipotético. A tecnocity é verdadeiramente multicentrada, conforme o modelo criado inicialmente por Los Angeles. (traduziu-se)

No que se refere à América Latina, esse tipo de expansão urbana que começa a predominar no mundo inteiro adquire manifestações específicas nas cidades de economias emergentes, onde diversos núcleos urbanos, até então isolados, são absorvidos pela mancha urbana em expansão ou, simplesmente, incorporados à dinâmica metropolitana.

O arquiteto chileno Carlos de Mattos, da Pontifícia Universidade Católica do Chile, coordena um grupo de estudos que abrange pesquisadores de toda a America Latina, denominado "Globalização e expansão metropolitana", voltado para a investigação dos fenômenos urbanos recentes percebidos nas metrópoles latino-americanas. Ele tem publicado trabalhos relevantes, no sentido de analisar e explicar esta tendência na distribuição territorial das atividades produtivas e da população, em particular do crescimento metropolitano no seu país, abordando os casos de estruturação/ desestruturação dos mercados de trabalho e concentração e/ou dispersão territorial da população.

Em seu artigo Globalização, urbanização da economia e expansão metropolitana (1999), De Mattos se refere à expressão metrópole expandida para designar essa modalidade de crescimento urbano:

Talvez o traço mais relevante para caracterizar as áreas metropolitanas da época da globalização e desregulamentação seja uma incontrolável tendência à suburbanização e/ou periurbanização a partir dos núcleos urbanos originais, em um processo no qual a mancha metropolitana se expande de forma incessante, ocupando as áreas rurais que encontra, transbordando os limites urbanos definidos no momento anterior. Assim, a área urbana herdada no período do desenvolvimento, cujos limites apareciam desenhados de forma relativamente mais precisa e nítida, vai dando lugar a uma Metrópole-região, de fronteiras difusas, em continua expansão (1999, p.13).

Para o autor, "a cidade da globalização ocupa um território que continua se dilatando de forma dispersa e descontínua, ultrapassando e acabando com os limites e a morfologia pré-existentes, o que leva à formação de uma estrutura policêntrica de fronteiras móveis" (DE MATTOS, 2004, p.190).

\subsubsection{Uma nova nomenclatura?}

Diante dos processos descritos acima, os conceitos e as definições de cidade, metrópole, urbanização, região urbanizada, metropolização, etc. exigem novas reflexões e muitos autores, em seus estudos, consideram necessário propor novos termos para se referir às formas urbanas emergentes, "já que os utilizados anteriormente não seriam mais apropriados" (DE MATTOS, 2004).

Na busca de respostas sobre a compreensão desse fenômeno, surge uma nova nomenclatura, conforme foi visto, em função do objeto de estudo ou da interpretação individual de cada pesquisador. São propostas novas denominações, tais como: cidade informacional (CASTELLS, 1989), cidade difusa (INDOVINA, 1990, 2004), cidade global (SASSEN, 1991), metápole (ASCHER, 1995), cidade pós-moderna (AMENDOLA, 1997), metrópole desbordada (GEDDES, 1997), cidade reticular (DEMATTEIS, 1998), metrópole alargada (PORTAS, 2001), metrópole expandida (DE MATTOS, 1999), pós-metrópole (SOJA, 2000), cidade dispersa (MONCLÚS, 1998), zwischenstadt, ou cidade sem limites (SIEVERTS, 2009); 
além de outras, como megacities (HALL, 1966), global cities (FRIEDMAN, 1986 e CASTELLS, 1996), edge cities (GARREAU, 1991), tecnoburb ou tecnocity (FISHMANN, 1987), post-city age (WEBER, 1964).

Tudo isso são exemplos de como a literatura especializada trata a questão da urbanização recente. Observa-se, entretanto, que parece não ter surgido ainda uma nomenclatura específica e adequada para designar essa nova e distinta realidade.

A enorme quantidade de denominações conferida ao fenômeno revela tanto sua importância como também as diferentes percepções e concepções sobre o tema, além da busca de explicações por parte dos autores. A falta de consenso é, principalmente, resultado do caráter complexo da realidade urbana contemporânea.

Para Reis (2006, p.52) a terminologia baseada em sufixos e prefixos "não dá conta das mudanças em curso - apenas é eficiente em expressar a idéia de inovação. Nossa opção fica, portanto, vinculada ao conceito de processo de urbanização e à noção de processo de dispersão urbana" ${ }^{22}$.

Convém destacar o fato de que, sob qualquer denominação, resta a constatação de que o mesmo fenômeno se manifesta em diferentes lugares e que, "provavelmente, a confusão conceitual recaia na escala com que se olha e se reflete as peculiaridades locais e a realidade socioeconômica de cada país" (MONCLÚS, 1998, p.8).

Os diferentes termos utilizados e tantos outros se referem não só às diferentes situações e papéis das cidades e suas periferias, mas também "a lugares, tempos, culturas e contextos diversos", conforme destaca Secchi (2007, p.252). Cada uma das situações urbanas é específica e requer estudo próprio.

São grandes as dificuldades encontradas para descrever os tipos de organização urbana que estão surgindo, pela sua multiplicidade, fluidez e ineditismo. São tentadas explicações naturalistas, tecnicistas ou economicistas ${ }^{23}$, que não esgotam, todavia, a compreensão do fenômeno, haja vista cada uma delas se mostrar insuficiente para dar conta, de maneira eficaz, dos novos processos de urbanização. O fato é que são numerosas as forças agindo e provocando mudanças e impactos na configuração atual das áreas urbanas.

A urbanização da segunda metade do século XX mudou radicalmente a paisagem; o volume das próprias edificações, seu modo de implantação, as técnicas utilizadas indicam uma ruptura. As urbanizações recentes parecem escapar à lógica das cidades tradicionais e, por isso mesmo, desafiar os meios de análise de que nos valemos para explicá-las. (PANERAI, 2006, p.11)

De acordo com Meyer, Grostein \& Biderman, (2004, p.19), essa tarefa ainda está sendo elaborada: "é do trabalho de correlação entre os aspectos distintos e, sem dúvida, da observação dos elementos considerados semelhantes, presentes nas diferentes metrópoles de todo o mundo, que emergirá um novo conceito, abrangente e satisfatório".

Vale ressaltar, no entanto, o fato de que algumas características gerais importantes podem ser destacadas como comuns a esses espaços, algumas delas enunciadas por Sieverts (2007):

\footnotetext{
${ }^{22}$ O conceito de "dispersão urbana" será desenvolvido com detalhes no item 1.3.

${ }^{23}$ Segundo análise de Botelho (2009, p.278), há diferentes explicações sobre as causas das mudanças recentes na urbanização: a explicação naturalista, segundo a qual as transformações são conseqüência natural do crescimento das cidades; a explicação tecnicista aposta nos avanços tecnológicos, nos meios de transporte e comunicação, que possibilitam maior mobilidade, e a explicação economicista, que se fundamenta nas mudanças observadas recentemente na economia.
} 
- sua configuração decorre de características típicas de novos sistemas urbanos, que diferem do tecido tradicional: as grandes plantas industriais, os centros de distribuição, as áreas residenciais de baixa densidade, etc.

- têm uma forma típica e fragmentada de ampliar seus limites para espaços abertos e, ao mesmo tempo, permitir o acesso aos serviços por meio de uma eficiente infraestrutura de transporte;

- desenvolvem uma forma própria de natureza urbana; e

- desenvolvem a própria estética.

Outras podem ainda ser enumeradas:

- a tendência a uma dilatação progressiva dos limites externos das áreas fortemente aglomeradas, evidenciando uma fluidez ou dissolução dos limites urbanos;

- a expansão das cidades e dos espaços metropolitanos para escalas territoriais cada vez mais ampliadas;

- a emergência de morfologias espaciais que conformam uma urbanização descontínua ao tecido urbano da cidade compacta tradicional;

- a formação de um tecido urbano muito diferente do anterior, com configurações específicas;

- o surgimento de periferias urbanas de um tipo distinto daquelas que se formavam até a década de 1970-80; e

- a diminuição dos índices médios de densidade urbana, resultado da ampliação do tecido urbano, em comparação com o crescimento demográfico.

Além disso, algumas outras dinâmicas são percebidas na estruturação da metrópole atual, de maneira geral, como a produção de novas formas de centralização, com a descentralização progressiva das atividades, ensejando uma policentralidade; a fragmentação do território, com especialização das partes; a desconcentração e formação de áreas de urbanização dispersa, separadas no espaço, mas mantendo estreitos vínculos entre si, como partes de um único sistema urbano (REIS, 2006); o surgimento de áreas residenciais com baixas densidades, etc.

Entre as características mais frequentes ressaltadas nesses estudos que buscam entender as rupturas morfológicas em relação aos atributos de contiguidade, compacidade e limite do modelo histó-

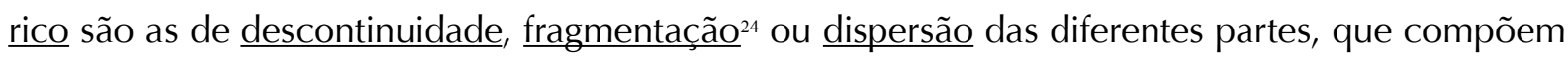
a atual aglomeração ou região urbana.

Por outro lado, vale ressaltar que, embora se possam determinar processos comuns ao que acontece, em termos de desenvolvimento urbano, na Europa, nos Estados Unidos e na América Latina, ao se analisarem esses fenômenos, faz-se necessária a devida cautela, em face das diferentes situações e contextos, próprios e específicos de região, de cada lugar, de cada país.

Trata-se, com efeito, de um processo que atinge várias cidades no mundo, mas que se apresenta com peculiaridades locais, resultantes das dinâmicas de cada formação socioespacial, do nível de desenvolvimento de cada país, de sua história, de sua cultura.

\footnotetext{
${ }^{24}$ No entender de Secchi (2005, p.241), "a dispersão e a fragmentação da cidade, primeiro nas suas periferias, depois em volta delas e depois, ainda, na cidade difusa, é aquilo que aumenta vertiginosamente a diversidade das situações e das experiências: a cidade se torna ao mesmo tempo concentração, reinvenção de suas partes mais antigas, modificações das partes mais modernas, densificação e rarefação, produção de novos lugares centrais, de densidade, proximidade e afastamento, de distancia separação".
} 


\subsubsection{A urbanização como processo}

As orientações e teorizações propostas por pesquisadores europeus e americanos constituem importantes contribuições ${ }^{25}$, e é pertinente estabelecer um diálogo teórico e metodológico acerca desses processos recentes de urbanização, mas deve-se ter sempre em conta as especificidades do que ocorre nas aglomerações latino-americanas e em especial nas brasileiras, que passam também por transformações rápidas e intensas, além de crescimentos demográficos acelerados, se comparados ao que ocorre, sobretudo, no mundo europeu.

Nesse sentido, convém esclarecer que os autores europeus, de modo geral, tendem a dar ênfase à forma urbana resultante desse fenômeno, como se percebe pela maneira como eles o designam, sempre com referência à "cidade": cidade dispersa, cidade difusa, cidade reticular, cidade-rede, megacidade, etc.

Entre os pesquisadores brasileiros que estudam o tema, especialmente o Professor Nestor Goulart Reis, a questão do processo é priorizada em relação à forma. A forma, como esclarece, é resultado do processo. E, ao tratar da dispersão urbana (REIS, 2006), destaca que esses fenômenos devem ser analisados como processo ${ }^{26}$, cujas características mudam no espaço e no tempo.

Para o autor, arquiteto e sociólogo de formação, o objetivo é estudar a urbanização como processo - uma vez que o urbano está sempre em transformação - assim como situar as consequentes alterações em processos históricos de mais longa duração, tomados como base para análises mais aprofundadas, abordagem que será adotada neste estudo.

Reis (2006, p.51) estabelece clara distinção entre as diferentes apreciações e ressalta que a urbanização é vista

[...] como processo, porque o objetivo é o transcorrer do fenômeno, as mudanças tanto quanto as permanências, o "vir a ser" tanto quanto o que existe, necessariamente sob uma perspectiva dinâmica. Nosso objetivo é o estudo do processo em curso, e não do objeto cidade. Até porque esta é um produto e um suporte do processo social, e como tal, também está em permanente mudança. Nosso objetivo é estudar os processos de apropriação, produção, uso e transformação do espaço urbano. (grifou-se)

O mesmo autor insiste ainda na preocupação em abordar o estudo da urbanização considerando-a como processo social ${ }^{27}$, ou seja, a urbanização é um "processo que se dá no conjunto da sociedade" e que se configura no espaço construído:

\footnotetext{
${ }^{25}$ A literatura europeia e norte-americana produz formulações teóricas e metodológicas que constituem referenciais importantes para ao caso brasileiro, desde que seja considerada a especificidade da sua formação socioespacial.

26 "A palavra cidade, com suas conotações fortes sobre os aspectos físicos, acrescida de adjetivos qualificativos, nos parece um recurso limitado para caracterizar as 'mutações de estado' que estão ocorrendo nas formas sociais e físicas da urbanização, em diversos países, na segunda metade do século XX e no início do novo milênio" (REIS, 2006, p.53). ${ }^{27}$ Nos anos 1960-1970 se inicia no país a produção de um conhecimento sistematizado sobre a cidade e a problemática urbana por parte dos arquitetos. Nesse período, destacam-se as atividades de pesquisa desenvolvida pelo Departamento de História da Arquitetura da FAUUSP, sob a coordenação do Professor Nestor Goulart Reis. "Os estudos referentes ao processo de urbanização ali desenvolvidos a partir dos anos 60 foram fundamentais para o embasamento teórico da produção do conhecimento sobre a cidade, que passa a ser analisada em um contexto social mais amplo, envolvendo os interesses dos grupos e classes sociais que nela atuam". (TOURINHO, 2004, p.238). "Na linha de estudos referente à urbanização, entendida como processo e não no sentido estrito de configuração física, mais vinculado ao termo urbanismo, fica a vertente sociológica adotada e desenvolvida naquele Departamento de História a partir da década de 1960 e que passou a caracterizar, então, grande parte dos estudos sobre a cidade". (TOURINHO, 2004, p. 247).
} 
[...] nosso objeto de estudo é o conjunto das relações sociais, isto é, das relações interpessoais (com suas dimensões econômicas, políticas, culturais e ideológicas). Nosso interesse é a compreensão da lógica da organização social, que conduz a determinadas formas de organização do território e sobretudo à lógica das decisões que levam à sua mudança, isto é, os projetos (REIS, 2006, p.53).

A urbanização, no entender de Reis, portanto, possui dimensão não apenas física - de extensão do tecido urbano, mas também social ${ }^{28}$, resultado de práticas econômicas, políticas e cultural-idológicas. E, "uma parte importante desse processo social se concentra na lógica ou razão da apropriação, produção, uso e transformação do espaço urbano" (REIS, 2006, p.52).

A metodologia adotada por essa linha teórica, a qual será utilizada nesta tese, "consiste em trabaIhar em escalas diversas, a partir do geral até o local, e em situar o processo no tempo, desde os primórdios da urbanização até os dias de hoje" (REIS, apud Medrano, 1997, p.52).

Vale mencionar, nesse sentido, o trabalho realizado pelo padre dominicano francês Louis Joseph Lebret, ao introduzir, em São Paulo, ainda na década de 1950, outra abordagem do fenômeno urbano que marcaria as gerações seguintes de arquitetos e urbanistas. O Pe. Lebret, juntamente com a equipe da SAGMACS ${ }^{29}$, fundada por ele, questiona a abordagem estritamente técnica e funcional do urbanismo e desenvolve uma metodologia nova para o entendimento da cidade como um fenômeno histórico e social (politico, econômico e cultural), trazendo "uma nova expectativa de inserção e resultados do trabalho profissional" (LEME, 1999, p.32) ${ }^{30}$.

A professora Rebeca Scherer, partilhando da mesma abordagem, ao referir-se à urbanização como processo social, acentua que "um processo social é também necessariamente um processo histórico. Dizer isso significa dizer que é um fenômeno dinâmico e que não incide igualmente nas diferentes sociedades e nem sobre as diferentes estruturas sociais" (1995, p.11).

Para Sposito (2001), da mesma forma, a urbanização consiste num processo socioespacial de larga amplitude histórica, que expressa e reproduz os modos de produção em diferentes épocas. E "esse processo tomou novos rumos com o desenvolvimento do capitalismo e seu padrão correlato de produção e consumo" (SPOSITO, 2001, p.86). Desse ponto de vista, continua a autora com relação às dinâmicas urbanas recentes, "reforça-se a compreensão segundo a qual há relações estreitas entre os processos mais amplos (sejam econômicos, políticos, sociais, culturais ou ideológicos) e

\footnotetext{
${ }^{28}$ Nesse sentido, a socióloga Sônia Barrios afirma que: "o espaço socialmente modificado pode ser compreendido como sendo "o conjunto de elementos materiais transformados pelas práticas econômicas, apropriados pelas práticas políticas e constituídos em significação pelas práticas cultural-ideológicas" (BARRIOS, 1986, p.19).

${ }^{29}$ O Pe. Lebret veio para o Brasil em 1946 para difundir o Movimento Economia e Humanismo e fundar os escritórios regionais da SAGMACS - Sociedade para a Análise Gráfica e Mecanográfica Aplicada aos Complexos Sociais em Recife, São Paulo e Belo Horizonte. Forma-se, então, nesse período, o grupo de urbanistas ligados ao Pe. Lebret, que vão compor o escritório técnico da SAGMACS em São Paulo, entre os quais destacam-se os arquitetos Celso Lamparelli, Francisco Whitaker Ferreira, Domingos Theodoro de Azevedo Neto e Miranda Esmeralda Martinelli, além de sociólogos, economistas e engenheiros. "Esses profissionais, com formação em diferentes disciplinas, têm uma expectativa de transformação social através do trabalho profissional" (LEME, 1999, p.33). Com a SAGMACS, "inaugurava-se, entre nós, a metodologia de pesquisa na forma de diagnóstico como base de planejamento. Além disso, a partir de então, todos os planos passaram a englobar a questão social como questão do planejamento" (TOURINHO, 2004, p.157).

${ }^{30}$ A publicação coordenada pela professora Maria Cristina da Silva Leme (Urbanismo no Brasil 1895-1965, 1999) propõe uma análise da formação do urbanismo nas cidades brasileiras no período de 1895 a 1965 e abrange valioso material documental acerca de planos, projetos e personagens do urbanismo brasileiro. O livro é resultado de um extenso trabalho, reunindo pesquisadores de oito cidades brasileiras: São Paulo, Rio de Janeiro, Salvador, Recife, Belo Horizonte, Vitória, Porto Alegre e Niterói. Aborda, de forma sistemática, a produção intelectual de urbanistas que atuaram nessas cidades e apresenta um relato sobre os diversos planos e projetos urbanísticos elaborados nesse período.
} 
a redefinição das formas espaciais" (IDEM, 2004, p.94.) Ao mesmo tempo, no seu entender, "uma dada forma espacial é também um dos elementos de redefinição dos processos econômicos, sociais, políticos ou culturais".

A autora distingue claramente o "par cidade-urbanização ${ }^{31 ",}$ quando ressalta que a urbanização é um processo "e a cidade, a forma espacial que expressa a dinâmica e a acumulação de tempos engendradas por esse processo" (SPOSITO, 2001, p.86).

A urbanização, portanto, é expressão de práticas sociais diversas (políticas, econômicas e cultural-ideólogicas), as quais atuam em conjunto e em contínua interação.

\subsubsection{As mudanças e as permanências}

Seguindo-se essa linha de raciocínio, acerca do "processo", há de se ressaltar que, se por um lado, existe uma real transformação das características urbanas e a emergência de uma nova configuração espacial, por outro, ainda é possível reconhecer a presença de uma considerável extensão de elementos vindos de etapas anteriores, que comprovam a continuidade ou permanência de determinadas características. São esses elementos de "permanência" que conferem o caráter particular das metrópoles do mundo, em seus diferentes graus de desenvolvimento.

Atualmente, verifica-se, segundo Meyer, Grostein \& Biderman (2004, p.19) uma coexistência de formas de organização urbana:

[...] a 'nova', que vai permeando o tecido urbano existente, obedecendo a novos padrões de relações socioeconômicas; e a 'velha', que sem receber nenhum estimulo renovador permanecerá presente de uma forma silenciosa e residual, sem sofrer nenhuma alteração significativa.

Desse modo, pode-se afirmar que as aglomerações urbanas de um modo geral estão passando por processos de transição bastante diversificados, específicos de cada lugar. Assim sendo, como adverte Portas (2004, p.227), "as descontinuidades/fragmentações que atribuímos aos novos tempos do urbano tomam formas e sentidos muito distintos, que merecem uma cuidadosa avaliação de suas dimensões e processos de formação".

Entende-se assim que alguns desses processos estudados não resultam totalmente novos. A Metrópole moderna não desapareceu. Ocorre que novos processos de urbanização e conformação espacial se sobrepõem aos existentes e a eles se integram, resultando por vezes em formas mais complexas.

Além disso, a "cidade herdada", no dizer de Portas, "também monocêntrica, compacta ou contínua, é consensualmente considerada como um patrimônio a conservar ou revitalizar nas suas diferentes componentes: social, cultural, infra-estrutural e econômica" (2003, p.16).

De acordo com Sposito (2004, p.395), "analisar a urbanização pressupõe, desse ponto de vista, reconhecer as múltiplas combinações possíveis entre permanências e mudanças, tantas combinações quanto cidades houver e quantos 'tempos' elas tiverem".

\footnotetext{
31 "A análise da relação entre a forma e o processo, é possível, a nosso ver, através dos estudos dos usos do espaço definidos pelas diferentes praticas. Sempre que observamos diferentes frações do espaço urbano, seja uma rua, uma praça, um centro comercial, estamos, segundo Lefebvre (1986), descrevendo um espaço social, ao qual corresponde uma pratica espacial que se expressa através da forma de uso desse espaço" (SPOSITO, 2001, p. 87).
} 
No âmbito das mudanças, pois, estão presentes os espaços novos e os que resistem, a cidade que muda e aquela que permanece, os processos inéditos e aqueles que se repetem. Identificar e analisar essas várias faces do cenário urbano é essencial para compreender o processo em curso.

\subsection{OS ESTUDOS SOBRE A URBANIZAÇÃO RECENTE NO BRASIL}

O processo recente de urbanização no Brasil, a exemplo do que ocorre em outras regiões do mundo, também assumiu feições e características diferentes em relação a períodos anteriores e é marcado, sobretudo nas áreas metropolitanas, pelo surgimento de novas periferias urbanas, bem mais complexas e diferenciadas das periferias ${ }^{32}$ que caracterizaram décadas anteriores. Constata-se, também, em determinadas áreas, uma reversão no ritmo do crescimento demográfico, perceptível nos núcleos centrais, exercido a taxas cada vez mais reduzidas, enquanto as periferias crescem a taxas elevadas.

Até o início dos anos 1980-1990, a maioria das metrópoles brasileiras experimentou um contínuo e acentuado crescimento demográfico e espacial. Desde então, algumas mudanças se fizeram observar e, atualmente, a extensão do tecido urbano assume formas diferenciadas, espacialmente dispersas, com crescente diversidade. Identificam-se, além das manchas contínuas urbanizadas, formas e processos descontínuos de urbanização dos espaços, denominados por Reis (2006) como "urbanização dispersa".

O fenômeno da dispersão urbana é estudado, no Brasil, com base na constatação da expansão do tecido urbano, com ocupação de áreas em descontinuidade com a conurbação principal, dotadas de extensos espaços livres, com a predominância de baixas densidades e que se apoiam nos diversos sistemas de estrutura viária.

Vários pesquisadores se dedicam a estudar a problemática urbana atual brasileira, investigando as novas formas de crescimento e os novos padrões físico-espaciais, verificados e discutidos em várias escalas, com o que contribuem para "a reflexão teórico-conceitual sobre o processo de extensão e espraiamento do tecido urbano" (SPOSITO, 2009, p.38).

O Professor Nestor Goulart Reis, conhecedor e estudioso do processo de urbanização brasileira em perspectiva histórica de longa duração $\mathrm{O}^{33}$, tem analisado as mudanças recentes, verificadas desde as últimas décadas do século XX, tomando como base o sistema urbano do Estado de São Paulo e suas áreas metropolitanas ${ }^{34}$.

\footnotetext{
${ }_{32}$ Até a década de 1980-1990, nas metrópoles brasileiras, "consolidou-se um padrão centro-periferia, com crescente adensamento de atividades econômicas, investimentos públicos e população nas regiões centrais mais valorizadas, circundadas pelo chamado padrão periférico de urbanização, fartamente documentado pela literatura, no qual prevalece a precariedade social e ambiental dos espaços que abrigam parte significativa da população trabalhadora" (COSTA, H., 2007, p.143).

${ }^{33}$ O Professor Nestor Goulart Reis dedica-se ao estudo da urbanização brasileira desde a década de 1960-1970, com diversas publicações na área de História e Teoria da Urbanização, do Urbanismo e da Arquitetura, entre as quais Urbanização e Teoria (1967) e Evolução Urbana no Brasil (1968). Desenvolveu um trabalho teórico e metodológico de grande consistência e inegável valor, que constitui referência fundamental no estudo sobre a matéria. O livro Urbanização e Teoria "serviu de referência para muitos estudos, devido ao seu caráter sintético, e ao mesmo tempo analítico, sobre as perspectivas em várias áreas do conhecimento acerca da urbanização, que se produziram naquele momento". (TOURINHO, 2004, p.248)

${ }^{34}$ Os resultados desses estudos estão reunidos na obra Notas sobre urbanização dispersa e novas formas de tecido urbano (2006) de sua autoria, e os estudos posteriores nas obras Brasil - Estudos sobre dispersão urbana (2007), Dispersão urbana - diálogo sobre pesquisas Brasil-Europa (2007) e Sobre Dispersão urbana (2009), todos organizados pelo autor.
} 
Reis utiliza preferencialmente a expressão "dispersão urbana" para tratar do fenômeno, pois lhe parece mais adequada para denominar os processos resultantes das transformações em curso, uma vez que "permite evidenciar as tendências à distribuição de pontos urbanizados sobre a totalidade dos territórios atingidos pelo processo, em meio a áreas tipicamente rurais, em direção a uma relativa homogeneização desses territórios" (2006, p.51). Como já foi salientado, o conceito de processo é sempre utilizado (e enfatizado) pelo autor, porque, segundo ele, "é mais adequado metodologicamente para o estudo de mudanças e permite a compreensão delas como o resultado de conjuntos de relações". Assim, chama a atenção tanto para as mudanças que ocorrem no atual processo de urbanização, como, de resto, para o processo geral de urbanização, pois decorrem não apenas de processos físicos, mas também de processos sociais que se confirmam no espaço.

De acordo com o autor (REIS, 2006, p.13), a dispersão urbana pode ser caracterizada:

- pelo esgarçamento crescente do tecido dos principais centros urbanos;

- pela formação de constelações ou nebulosas de núcleos urbanos ${ }^{35}$ e bairros, com diferentes dimensões, integradas em uma área metropolitana ou em um conjunto ou sistema de áreas metropolitanas;

- pelas mudanças nos transportes diários intrametropolitanos de passageiros; e

- pela difusão ampla de modos metropolitanos de vida e de consumo, também estes dispersos pela área metropolitana ou sistema de áreas metropolitanas.

No seu entender, são observadas diversas alterações na estrutura e no tecido urbano das aglomerações brasileiras, associadas às características da dispersão urbana, tais como: a intensificação da mobilidade espacial da população, que permite a organização do cotidiano numa escala metropolitana; a adoção de novas estratégias de ação do mercado imobiliário, com o surgimento de novos programas arquitetônicos e a implantação de empreendimentos de uso múltiplo; a alteração na relação entre espaços públicos e privados e os novos tipos de ocupação e gestão do espaço urbano, com diversificadas formas condominiais.

Para Reis, seus estudos têm como objetivo, ao apresentar os resultados das pesquisas, "a definição de políticas públicas, políticas empresariais e políticas profissionais, relacionadas aos processos de dispersão urbana e às mudanças de tecido urbano" (REIS, 2009, p.12), uma vez que a complexidade crescente dessas situações, conforme assinala o autor, deve ser objeto de uma sistematização, na qual se apontem definições claras do que é de competência dos poderes públicos no enfrentamento das práticas urbanísticas, por meio de planos e projetos relacionados às transformações em curso.

\footnotetext{
${ }^{35}$ Esses núcleos urbanizados, entretanto, estão separados da cidade tradicional, mas mantêm vínculos estreitos com as demais áreas da cidade, como parte de um único sistema urbano (REIS, 2006).
} 


\subsubsection{As pesquisas sobre "Urbanização dispersa e mudanças no tecido urbano" no âmbito nacional}

O Professor Nestor Goulart Reis estendeu posteriormente o seu estudo acerca da urbanização dispersa para outras regiões do País. Para tanto, contou com a participação de pesquisadore ${ }^{36}$ que investigaram o processo em seus locais de origem, estudos esses elaborados sob sua coordenação no LAP ${ }^{37}$ da FAUUSP, e que compuseram o Projeto Temático "Urbanização Dispersa e Mudanças no Tecido Urbano" ${ }^{38}$.

Conforme ressalta Reis (2011),

Estas contribuições procuram sistematizar, alinhar, indagar e/ou orientar políticas favoráveis para o equacionamento dos problemas constatados, discernindo campos e complexidades inscritas nos muitos e diversificados tipos de materializações do processo de urbanização, que são rebatidos no espaço e ocorrem na atualidade, evidenciando ainda, os processos e agentes que experimentam transformações motivadas pelo fenômeno da urbanização dispersa (REIS, 2011). ${ }^{39}$

A geógrafa Maria Encarnação Sposito, integrante do Grupo de Pesquisa que investiga o tema, assinala que se verificam, atualmente, novas formas de crescimento territorial urbano e acrescenta outras características que definem a urbanização dispersa, ou seja, a tendência à constituição de uma morfologia urbana descontínua, à formação de novos núcleos concentrados, que promovem uma estruturação polinucleada, e à relação do processo com a metropolização.

Tudo isso implica em novas formas de produção do espaço urbano e constituição de tecidos urbanos "marcados por descontinuidades territoriais e que geram, em muitos casos, dinâmicas que ampliam as formas de segregação socioespacial e propiciam fragmentação socioespacial" (SPOSITO, 2007, p.9).

A autora destaca ainda que esse espraiamento do tecido urbano, quer seja analisado ou conceituado pelo seu caráter de dispersão, difusão ou descontinuidade territorial, reavalia a distinção entre o que se considera campo e o que se tem por cidade $^{40}$.

\footnotetext{
${ }^{36}$ Integrante do grupo de pesquisas coordenado pelo Professor Nestor Goulart Reis, a arquiteta Marta Tanaka participou do projeto investigando os núcleos de urbanização dispersa no Município de São José dos Campos, São Paulo. A geógrafa Maria Encarnação Sposito estuda a expansão e o crescimento disperso em diversas cidades médias na região do noroeste do Estado. Em Minas Gerais, Heloisa Soares de Moura Costa analisa a expansão urbana que ocorre de modo relativamente disperso ao longo dos principais eixos viários ao sul da Região Metropolitana de Belo Horizonte, envolvendo áreas de mineração e preservação. No Rio de Janeiro, Ester Limonad registra a tendência de ocupação difusa em escala territorial em áreas rurais e/ou de preservação ambiental por diferentes tipos de condomínios fechados e loteamentos de segunda residência na área metropolitana do Rio de Janeiro, em particular na região serrana fluminense. Ainda no Rio de Janeiro se concentram os estudos de Maria de Lourdes Machado Costa, que pesquisa a dispersão urbana em diversos municípios do Estado e Júlio Bentes, que investiga a dispersão urbana no médio Paraíba fluminense. No eixo Brasília - Goiânia - Anápolis, A. C. Carpintero e Luci Clementino destacam o caráter disperso que marca e marcou a urbanização do Distrito Federal desde sua criação e que se verifica agora também na proliferação de condomínios e loteamentos na área da Região Integrada de Desenvolvimento Econômico do Distrito Federal e Entorno (RIDE-DF). A dispersão urbana decorrente da atividade turística nas RMs de Maceió, Florianópolis e Fortaleza são investigadas, respectivamente, por Márcia Monteiro, Francisco dos Anjos e Beatriz Diógenes.

${ }^{37}$ Laboratório de Estudos sobre Urbanização, Arquitetura e Preservação - LAP.

38 O projeto Temático "Urbanização dispersa e mudanças no tecido urbano", coordenado pelo Professor Nestor Goulart Reis teve seu inicio em 2003 e foi desenvolvido em duas etapas, tendo finalizado em 2008. Após o final do programa, a maioria dos participantes continua interagindo, analisando a dispersão urbana e as mudanças no tecido urbano nos diversos estados brasileiros. ${ }^{39}$ In: anais do XIV ENANPUR (2011).

40 "A unidade espacial da cidade, em contraponto ao campo, encontra-se em processo de dissolução, em função do espraiamento do tecido urbano e da diminuição relativa das taxas de densidade demográfica em espaços urbanos e periurbanos. Cada vez menos se percebe com clareza onde termina a cidade e começa o campo. Cada vez mais se intensificam os fluxos de pessoas e mercadorias entre espaços rurais e urbanos e o uso do tempo social cotidiano vem-se dividindo entre ambientes e paisagens que, segundo enfoques conceituais correntes, poderiam ser considerados como campo e como cidade" (SPOSITO, 2009, p 40).
} 
A arquiteta Heloisa Soares de Moura Costa estuda a expansão espacial recente do tecido urbano na Região Metropolitana de Minas Gerais, sobretudo sob a perspectiva das políticas urbanas e gestão metropolitana. Segundo a autora, essa expansão se verifica "com características simultâneas de dispersão e constituição de novas centralidades socioeconômicas e culturais (COSTA, H., 2009, p.55).

No que se refere às formas de gestão urbana, a autora ressalta que "a expansão dispersa e muitas vezes fragmentada do tecido urbano traz consigo o desafio da descoberta de formas de gestão consorciadas, colegiadas, negociadas e, como tais, fazem da relação entre espaço e política um elemento central ao debate" (IDEM).

Em Minas também se destacam os estudos do arquiteto Roberto Luís Monte-Mór, que introduziu o conceito de urbanização extensiva para caracterizar as formas urbanas que "nascem nas cidades e se estendem além delas, sobre os campos e regiões", conforme salienta o autor (MONTE-MÓR, 2007, p.246). No seu entender, esse "tecido" é uma manifestação socioespacial da organização urbano-industrial contemporânea, que "abarca, virtualmente, todo o espaço social" (IDEM).

Tenho chamado de urbanização extensiva esta materialização sócio-temporal dos processos de produção e reprodução resultantes do confronto do industrial com o urbano, acrescida das questões sociopolíticas e cultural intrínsecas à polis e à civitas que têm sido estendidas para além das aglomerações urbanas ao espaço social como um todo. É essa espacialidade social resultante do encontro explosivo da indústria com a cidade - o urbano - que se estende com as relações de produção (e sua reprodução) por todo o espaço onde as condições gerais de produção (e consumo) determinadas pelo capitalismo industrial de Estado se impõem à sociedade burocrática de consumo dirigido carregando, no seu bojo, a reação e organização políticas que são próprias da cidade. Essa é a realidade - a sociedade urbana - que se impõe hoje como virtualidade e objetividade no Brasil, constituindo-se em condição para a compreensão do espaço social contemporâneo (MONTE-MOR, 2005, p.8).

No Estado do Rio de Janeiro concentram-se as pesquisas da arquiteta Ester Limonad, que analisa a dispersão urbana em áreas "economicamente dinâmicas do interior fluminense, em que há uma predominância de atividades industriais e/ou de turismo de veraneio, com maior ênfase nas áreas próximas às rodovias de acesso" (LIMONAD, 2009, p.114).

A autora identifica características da urbanização dispersa nessas áreas, as quais manifestam uma organização espacial em rede de aglomerados urbanos com distintas dimensões e importância diversa. Como resultado de suas pesquisas, ela afirma que, dessa maneira,

[...] estabelecem-se novas relações e processos nessas áreas dinâmicas que contribuem para uma complexificação e diversificação da rede urbana, com espacialização dos aglomerados urbanos e rurais como lugares de consumo, lugares de produção e de moradia, o que gera de forma diferenciada, distintos impactos e problemas (LIMONAD, 2009, p.122).

Em um texto anterior, a mesma autora descreve com clareza algumas das principais particularidades da dispersão urbana:

Enquanto a cidade compacta de períodos precedentes apresentava uma estrutura simples com zonas bem definidas, essa estrutura se diversifica e complexifica conformando um tecido urbano que ultrapassa os limites da cidade. A urbanização na atual etapa, por conseguinte, é entendida, aqui, 
como um processo que não está mais restrito à cidade, que extravasa os limites da aglomeração física de edificações, infraestruturas e atividades, de fixos e fluxos, através das diversas práticas, táticas e estratégias dos distintos capitais e do trabalho para garantir sua reprodução (LIMONAD, 2006, p.33).

\subsubsection{Sobre as metrópoles brasileiras}

A constatação de que a realidade urbana brasileira se torna cada vez mais complexa e que a metropolização é um processo irreversível tem estimulado a intensificação das pesquisas sobre esse tema, com o intuito de compreender o papel das metrópoles em sua dimensão socioespacial e econômica no âmbito do território nacional. Estudos relevantes têm sido realizados por pesquisadores brasileiros, empenhados em investigar os fenômenos urbanos recentes e que constituem importante contributo para a compreensão das mudanças que se produzem no espaço urbano contemporâneo.

Uma vasta bibliografia, pois, tem sido produzida, no sentido de rever o crescimento verificado nas últimas décadas nas metrópoles, com base em critérios novos e, sobretudo, em novas avaliações de seu papel na estruturação da atual etapa do capitalismo pós-industrial. Esses novos papéis impuseram às metrópoles grandes transformações, tanto em seu funcionamento e desempenho, quanto em sua configuração espacial.

A metrópole contemporânea e, especificamente a Metrópole paulistana, são o tema da obra publicada pelas arquitetas Regina Meyer e Marta Dora Grostein e pelo economista Ciro Biderman: São Paulo Metrópole.41 Para os autores, "a metrópole é a forma de estruturação urbana que o desenvolvimento econômico contemporâneo tende a produzir em todo o mundo" (MEYER, GROSTEIN \& BIDERMAN, 2004, p.19). Ela constitui "um tipo urbano plurificado, um serviço global dirigido ao desenvolvimento do grande capital" e possui três características básicas: congrega enormes populações, é multifuncional e possui relações econômicas diferenciadas, tanto no âmbito nacional como no internacional.

Os autores, num trabalho amplo e minucioso, identificam e analisam as transformações urbanas pelas quais a Metrópole de São Paulo vem passando ao longo dos anos, especialmente desde a década de 1980-1990, destacando, de forma sistemática, as principais dinâmicas urbanas recentes do território metropolitano, que estão reestruturando seu espaço, dentre as quais a consolidação de novas centralidades, a emergência de novos setores empresarias de alto padrão, as novas formas de organização físico-funcional da atividade industrial e a difusão dos condomínios fechados como modelo habitacional.

Na obra, enfatizam as contradições do cenário metropolitano paulistano e a emergência de um novo padrão urbano, no qual se combinam a precariedade e a modernização, gerando um espaço próprio de um novo modelo de urbanização, denominado por eles de "modernização precária", o qual abrange o território qualificado e o território precário:

Essas configurações, longe de demarcar uma descontinuidade espacial ou um deslocamento temporal, evidenciam a presença de um novo padrão urbano, no qual a precariedade e a modernização surgem de for-

\footnotetext{
${ }^{41} \mathrm{O}$ livro é resultado de uma ampla pesquisa desenvolvida pelos autores junto ao LUME - Laboratório de Urbanismo da Metrópole da FAUUSP.
} 
ma imbricada, superpondo-se e gerando um espaço característico de um novo padrão de urbanização que propomos designar como modernização precária (MEYER, GROSTEIN \& BIDERMAN, 2004, p.11).

Em outro texto, Meyer \& Grostein (2006) constatam que, nas duas últimas décadas do século XX, as mudanças "já patentes no nível econômico e produtivo foram acompanhadas de alterações objetivas na estrutura e na organização física e funcional das regiões metropolitanas brasileiras":

Há, hoje, uma convicção que estamos vivendo novos padrões de urbanização metropolitana no Brasil e pode-se perceber a montagem de um novo quadro urbano (...) Até a década de 80, a criação e o crescimento das Metrópoles brasileiras, seguiram, em grande maioria, o modelo que podemos denominar de clássico - as novas organizações urbanas resultavam de um movimento de agregação de territórios, segundo o conceito de conurbação, gerando manchas unificadas e contínuas. Atualmente se observam novos arranjos espaciais e funcionais nos quais é muito freqüente haver grandes glebas desocupadas, que representam um hiato da urbanização (2006, p.47).

Em publicação recente (A leste do Centro, 2010), as mencionadas arquitetas prosseguem analisando processos urbanos da Capital paulista, relacionados a transformações de ordem econômica, sobretudo no padrão produtivo. Procedem a reflexões sobre a Cidade e analisam importantes dinâmicas vivenciadas recentemente pela Metrópole, sobretudo no chamado Vetor Leste do Centro, que abriga parcelas dos bairros do Brás, Pari, Moóca e Glicério. O objetivo principal da análise, conforme destacam, é fornecer diretrizes para os projetos urbanos e futuras propostas.

Ainda sobre a Metrópole paulistana ${ }^{42}$ contemporânea, cabe destacar os trabalhos de uma geração mais recente de pesquisadores arquitetos, como João Sette Whitaker Ferreira (São Paulo - o mito da cidade global, 2000), Eduardo Nobre (A expansão recente do terciário na marginal do rio Pinheiro, 2001), Andréa de Oliveira Tourinho (Do centro aos centros - bases teórico-conceituais para o estudo da centralidade de São Paulo, 2004) e Stamatia Koulioumba (São Paulo - cidade global?, 2002).

Esses estudos, vale salientar, embora se reportem à Metrópole São Paulo, envolvem abordagens essencialmente intraurbanas.

No campo da Geografia Urbana, também sobre São Paulo, destacam-se as pesquisas de Ana Fani A. Carlos (A Metrópole de São Paulo no contexto da urbanização contemporânea, 2009), Helena K. Cordeiro (A 'cidade mundial' de São Paulo e o complexo corporativo do seu centro metropolitano, 1993), Amélia Luisa Damiani (A Urbanização Crítica na Metrópole de São Paulo, a partir de fundamentos da Ceografia Urbana, 2009), Amália Inês Lemos (Dilemas Urbanos. Novas Abordagens Sobre a Cidade, 2006) entre outros.

Com relação ao estudo das metrópoles brasileiras de modo geral, a obra do arquiteto urbanista Flavio Villaça constitui referência fundamental, no que se refere a análises intra-urbanas. Na sua tese de doutorado, A estrutura territorial das Metrópoles brasileiras: áreas residenciais e comerciais (1979), ele analisa e interpreta o processo de reestruturação de quatro metrópoles

\footnotetext{
${ }_{42}$ Para Villaça, existe uma explicação que justifica a cidade de São Paulo ser preferencialmente objeto de estudos, em relação a outras cidades brasileiras: "Trata-se, por seu porte e complexidade, de um caso sui generis de centro metropolitano em todo o país" (VILLAÇA, 1998, p.266).
} 
do sul e sudeste do país ${ }^{43}$ durante um século. A tese deu origem ao livro publicado posteriormente: Espaço intraurbano no Brasil (1998), quando amplia a pesquisa, investigando a reestruturação do espaço intra-urbano de seis das principais metrópoles do País, as quais, segundo o autor, apresentam traços comuns de organização espacial. O estudo abrange as cidades de São Paulo, Rio de Janeiro, Belo Horizonte, Salvador, Recife e Porto Alegre. O tema é desenvolvido com amparo em uma dupla abordagem, ou seja: a análise comparativa entre as várias metrópoles e, ao mesmo tempo, a investigação de um amplo período histórico da formação de seus espaços.

São analisados os processos históricos de constituição das estruturas territoriais metropolitanas: as formas metropolitanas como um todo, os processos de conurbação e as direções preferenciais de crescimento da urbanização. São analisados também os processos de constituição das grandes áreas onde se segregam as nossas burguesias urbanas. Esses processos se destacam como os mais distintivos de nossas estruturas territoriais metropolitanas (VILLAÇA, 1998, p.13).

A reflexão contida no livro traduz-se como fonte de pesquisa essencial para se compreender a produção do espaço (intraurbano) contemporâneo das Metrópoles brasileiras.

Além dos pesquisadores independentes, vale salientar o trabalho realizado pelas distintas redes de pesquisas, que buscam explicações capazes de contribuir para o debate sobre o desenvolvimento das metrópoles.

No âmbito nacional, há de se destacar os estudos elaborados pelo Observatório das Metrópoles, que congrega grande número de pesquisadores ${ }^{44}$ de variadas instituições e universidades, coordenados pelo Professor Luiz Cesar Queiroz Ribeiro, preocupados em analisar, de forma sistemática e multidisciplinar, a problemática metropolitana brasileira, em seus diversos aspectos. Os trabalhos produzidos pelo Observatório constituem fonte de pesquisa fundamental para aqueles que investigam as transformações ocorridas em nossas metrópoles.

Afora os objetivos acadêmicos, o Observatório das Metrópoles "procura aliar suas atividades de pesquisa e ensino com a realização de atividades que auxiliem os atores governamentais e da sociedade civil na elaboração e implementação de políticas públicas"45.

Em Fortaleza, o Núcleo do Observatório foi criado em 2004 e abrange um grupo de professores dos Departamentos de Geografia, Teoria Econômica, Arquitetura e Urbanismo e Psicologia da Universidade Federal do Ceará, os quais estudam questões associadas ao desenvolvimento metropolitano do Ceará em suas diferentes áreas de conhecimento.

Todos esses estudos e muitos outros, que surgem a cada dia, constituem trabalhos de investigação, sob distintos enfoques disciplinares, que buscam compreender as dimensões e os desafios do multiforme território urbano contemporâneo.

\footnotetext{
${ }^{43}$ As metrópoles brasileiras analisadas na tese são: Rio de Janeiro, São Paulo, Porto Alegre e Belo Horizonte.

${ }^{44}$ O Observatório das Metrópoles abrange cerca de 200 pesquisadores de 50 instituições universitárias, governamentais e nãogovernamentais, entre os quais, Adauto Lucio Cardoso e Luciana Correa do Lago (Núcleo Rio de Janeiro), Susana Pasternak e Lucia Bógus (São Paulo), Rosa Moura e Olga Firkowski (Paraná), Jupira Mendonça e Luciana Teixeira de Andrade (Minas Gerais), Maria do Livramento, Maria Dulce Bentes Sobrinha e Alexsandro Ferreira C. da Silva (Natal), Clélia Lustosa da Costa, Eustógio Dantas, Vera Mamede e Renato Pequeno (Ceará) e outros ainda dos Estados de Pernambuco, Bahia, Pará, Goiás, Rio Grande do Sul e Espírito Santo.

45 www.pucsp.br/ponto-e-virgula/n7/artigos/pdf/pv7-35-omsp.pdf
} 
Esses trabalhos, em sua maioria, trazem especulações que tendem a ser pessimistas algumas, outras otimistas, e outras ainda, neutras ou apenas interrogativas, cada qual enfatizando uma perspectiva diferente da questão. O fato é que um ativo debate é suscitado em publicações acadêmicas acerca das consequências deste processo de mudanças.

\subsection{AS NOVAS ESPACIALIDADES E OS DESAFIOS AO PLANEJAMENTO E GESTÃO}

A velocidade das transformações que se vêm processando recentemente nas áreas urbanas e a maneira com que se verificam, extrapolam a capacidade de apreensão científica por um lado e, por outro, constituem um desafio para planejadores, administradores e representantes do poder local darem conta do que sucede.

O quadro atual da urbanização, por sua complexidade crescente, conduz a uma reflexão acerca dos rumos que tomam o planejamento e a gestão desses novos espaços.

No Brasil, a expansão urbana recente assume diferentes manifestações e apresenta formas e processos variados e particulares - seja como ampliação das periferias metropolitanas, seja por meio da multiplicação de pequenos aglomerados urbanos, seja sob a forma de polos ou enclaves industriais, de serviços ou turísticos, ou ainda pela formação de condomínios fora das áreas urbanas consolidadas.

Essas novas configurações urbanas suscitam algumas questões relevantes, como destaca Mítica (2007), que envolvem o meio ambiente (como o maior consumo energético, a ocupação de áreas de preservação, etc.), a participação do Estado (no seu papel de regulador e provedor da infraestrutura urbana, assim como na proposição de planos de desenvolvimento integrado), o mercado imobiliário (na oferta de novos produtos, relativos às novas demandas relacionadas aos novos modos de vida da população) e também a participação dos profissionais arquitetos e urbanistas (na proposta de novas soluções de transporte, novos equipamentos urbanos e na formulação de uma nova legislação, coerente com os novos processos).

Além disso, outras questões se evidenciam, tais como: as ligações das áreas de ocupação recente - de tecido urbano bastante diferenciado - com a cidade préexistente; a assimilação de novos modos de vida pela população, que redundam em novas formas de ocupar o espaço; a extensão da mancha urbana, que ocorre sem obedecer aos limites territoriais oficiais (municipais ou estaduais); a atuação do mercado imobiliário, com o surgimento de novas tipologias e empreendimentos de uso múltiplos; o aumento da mobilidade das pessoas, veículos e mercadorias, além das notícias e informações, o que implica na expansão da urbanização.

O cenário é ainda agravado pela elevação progressiva do preço da terra, pela ausência de áreas livres para se construir, pela intensificação dos níveis de consumo e das aspirações individuais, pela crescente segregação socioespacial e pela degradação do meio ambiente.

A compreensão desse quadro "parece escapar das formas já conhecidas de investigação, análise e interpretação do fenômeno da urbanização" (LIMONAD, 2007, p.186) e o grau de incerteza desses novos processos faz com que as técnicas tradicionais de planejamento não representem mais uma verdade absoluta. Faz-se necessário, pois, averiguar a complexidade da urbanização contemporânea, a qual abrange as muitas e diversas situações e formas de produção do espaço e ocupação do território. 
Constata-se, assim, a inequívoca obsolescência dos padrões correntes de controle e ação do Estado, em todos os níveis, sobre os novos espaços produzidos (REIS, 2006) e o que se busca é a necessária compreensão do processo, bem como a análise desses espaços, com vistas a criar mecanismos de intervenção e gestão, condizentes com a complexidade das novas formas urbanas.

A organização e a estruturação das aglomerações urbanas atuais, pois, exigem novos aportes teóricos e novas formas de planejamento e gestão, que permitam lidar com a complexidade alcançada pela urbanização contemporânea.

As pesquisas que ora se realizam, em sua maioria, pretendem assim fornecer dados e análises, a fim de mostrar perspectivas para o aprofundamento dos conhecimentos sobre as questões urbanas atuais e as mudanças recentes. Almejam ainda evidenciar possibilidades de elaboração de políticas públicas mais eficazes, capazes de oferecer mecanismos de ação que solucionem situações urbanas precárias e oferecer diretrizes para um desenvolvimento urbano apropriado.

Não resta dúvida que toda a problemática mencionada constitui um desafio para o planejamento e a gestão metropolitana, no sentido de se buscarem instrumentos capazes de levar os planejadores e executores de políticas públicas - com base no conhecimento da dinâmica e da lógica de organização e funcionamento da Metrópole contemporânea - a propor formas de atuação que garantam sua integração e desenvolvimento.

Como ressalta Limonad (2009, p.114), a complexidade e diversidade de situações, morfologias e tipos de urbanização que ora se apresentam "exigem novas posturas e metodologias de análise e, para avançar na discussão, urge estudar seus condicionantes e suas formas de expansão com base em alguns casos específicos".

O exame desta ampla e nova problemática formulou o objetivo desta pesquisa, dirigida para a compreensão do processo de urbanização recente da área metropolitana de Fortaleza - inserido no processo da urbanização contemporânea - a fim de descrever, caracterizar e analisar as transformações em curso.

\subsection{A REVISÃO TEÓRICA E O OBJETO DE ESTUDO}

\subsubsection{O referencial teórico e o enfoque específico}

Diante do exposto, fica a certeza de que a urbanização contemporânea manifesta complexas relações entre processo social e forma espacial, as quais resultam cada vez mais diferentes das que se observava há cerca de 40 anos.

No quadro teórico apresentado, procurou-se, de início, estabelecer um panorama sucinto acerca da urbanização recente e indicar como o tema é tratado por autores diversos, a fim de que pudessem ser comparados diferentes enfoques e abordagens, como também expandir a perspectiva de análise do pensamento de autores em cujas investigações e reflexões se insere a problemática apresentada. 
Faz-se, entretanto, necessário, eleger as proposições de maior relevância em relação ao tema da tese. Nesse sentido, foram escolhidas aquelas linhas teóricas que mais se aproximam dos objetivos da pesquisa, ou seja, aquelas voltadas preferencialmente para a análise urbana, a fim de que possam contribuir na priorização de uma abordagem preferencialmente empírica, que enfoca as mudanças nos padrões do tecido urbano, sob a perspectiva da Arquitetura e do Urbanismo.

De todos os estudos mencionados, portanto - sem desprezar as contribuições de outras áreas do conhecimento - consideram-se como referências teóricas relevantes, no âmbito internacional, as contribuições dos pesquisadores europeus Monclús, Font, Portas e Secchi, por tratar-se de estudos feitos por arquitetos, que elaboram análises urbanas, envolvendo aspectos de maior afinidade com o objeto de estudo.

Na América Latina, os estudos do arquiteto chileno Carlos de Mattos também representam pontos em comum com o tema proposto e seus enunciados serão devidamente considerados no decorrer do trabalho.

No panorama nacional, a obra do Professor Nestor Goulart Reis constitui fonte de pesquisa e suporte teórico fundamental para a elaboração da tese, tanto no que se refere à compreensão do processo de urbanização, como no que concerne aos seus estudos recentes relativos à urbanização contemporânea e às novas características do tecido urbano.

Os trabalhos realizados pelos pesquisadores integrantes do Projeto Temático "Urbanização Dispersa e Mudanças no Tecido Urbano" são igualmente enfocados de modo a se analisarem as semeIhanças e diferenças com a Metrópole fortalezense.

Da mesma forma, são apreciadas e referenciadas as análises elaboradas pelas arquitetas Regina Meyer e Marta Dora Grostein nas obras São Paulo Metrópole (2004) e A leste do Centro (2010) sobre as dinâmicas urbanas recentes na Metrópole paulistana, que serviram de parâmetro para comparações com a realidade cearense.

As contribuições teóricas desses autores serão devidamente retomadas ao longo da tese, de modo a servir de lastro às análises decorrentes das pesquisas empíricas realizadas.

\subsubsection{Sobre a importância das especificidades locais}

Questão outra a considerar, conforme já ressaltado, refere-se aos aspectos gerais da urbanização contemporânea e às especificidades próprias de cada região. Se as generalizações são importantes para conhecer e identificar o fenômeno em curso, já que há traços comuns nas áreas urbanas em todo o mundo, é preciso avançar e ressaltar as particularidades e distinções de cada lugar. Isto se impõe, porque - como bem assinalam Meyer, Grostein \& Biderman (2004, p.19) - "se, num primeiro momento as generalizações são inevitáveis, pois estamos revendo o instrumental teórico, num segundo momento é fundamental determinar a especificidade, captar a singularidade do processo".

A revisão teórica, ora elaborada, possibilitou o entendimento do fenômeno de maneira geral, conforme a visão de vários autores, enquanto permitiu a fundamentação e análise do objeto de estudo da tese, dedicado às transformações urbanas da área metropolitana de Fortaleza nas últimas décadas. Essas mudanças, vale ressaltar, estão inseridas no âmbito da urbanização de um país em 
desenvolvimento ou periférico ${ }^{46}$, como hoje denominam, no qual a organização metropolitana apresenta peculiaridades, quando comparada com o que ocorre em países desenvolvidos.

Esse percurso teórico, portanto, subsidia o objetivo desta tese, que é o de analisar as características das atuais dinâmicas urbanas em curso no território metropolitano cearense. Torna-se imperativo, pois, conhecer e interpretar criteriosamente os atributos físicos, espaciais e funcionais presentes na metrópole de Fortaleza, no contexto da urbanização contemporânea.

As questões são abordadas, a princípio, como parte de um processo mais amplo, porém, paralelamente ao avanço na pesquisa, serão enfocadas as especificidades e diferenças das respectivas áreas em questão e as formas urbanas resultantes. Almeja-se, com isso, a correta articulação entre o referencial teórico abordado e a realidade empírica do fenômeno.

Não basta, pois, apenas constatar a existência de um novo processo de urbanização e da consequente multiplicidade de formas no tecido urbano. Fazem-se necessários o aprofundamento das análises e a elaboração de estudos detalhados sobre as mudanças que ocorrem na configuração urbana, bem como nos modos de vida da população, assunto que será desenvolvido nos capítulos subsequentes, com base na análise empírica da área metropolitana de Fortaleza.

Assim, após esta reflexão teórica elaborada a partir da abundante bibliografia existente, tanto no plano internacional como no que se refere aos estudos nacionais, os próximos capítulos serão dedicados aos resultados da pesquisa empírica realizada, que enfoca o objeto de estudo, isto é, as mudanças verificadas no processo de urbanização recente da área metropolitana de Fortaleza.

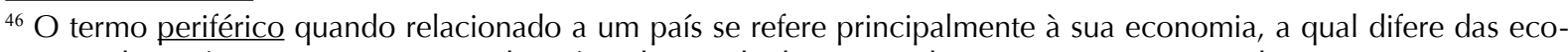
nomias dos países centrais, ou seja, de países desenvolvidos. Segundo Meyer, Grostein \& Biderman (2004, p.21), os países denominados periféricos são aqueles "que se situam na esfera marginal do capitalismo desenvolvido e, como rebatimento, onde o desenvolvimento metropolitano não garante melhores condições materiais de vida urbana para todos seus habitantes".
} 


\section{CAPÍTULO 2}

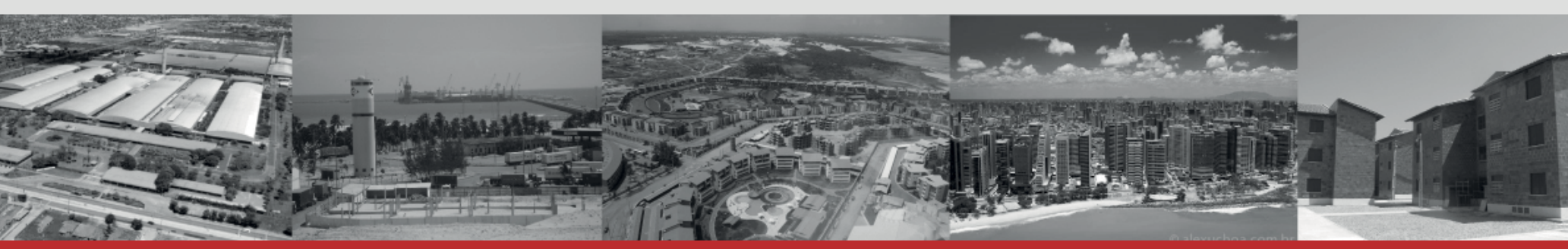

FORTALEZA: A CONFIGURAÇÃO SOCIOESPACIAL DA METRÓPOLE CEARENSE 
$\mathbf{O}$ processo de crescimento e expansão das cidades, de maneira geral, e da Metrópole cearense, em particular, como foi visto no capítulo precedente, relaciona-se de forma inequívoca com as práticas sociais desenvolvidas, envolvendo aspectos econômicos, políticos e culturais.

Com vistas a melhor caracterizar o objeto de estudo, o presente capítulo trata da configuração socioespacial da Metrópole, tendo como referência histórica marcante as três últimas décadas (1980-2010). Esse período torna-se relevante porque evidencia a transição de uma cidade ainda com resquícios provincianos para uma metrópole de porte, com importante papel no contexto regional e nacional, no que se refere a movimentos financeiros, sociais e culturais.

A dimensão econômica da Metrópole, por sua vez, é apreciada, na medida em que, em grande parte, é responsável pelo processo de metropolização, alterando e ampliando os espaços urbanizados. Finalmente, também é enfocada a importante questão da gestão metropolitana e como se manifesta a problemática no território cearense.

Antes da abordagem do objeto de estudo, porém, impõe-se tecer algumas considerações sobre a urbanização brasileira, designadamente, desde meados do século XX, e a consequente metropolização ocorrida no País, uma vez que "em uma perspectiva histórica de média ou longa duração, podemos notar que as mudanças que estão ocorrendo nos padrões urbanísticos são parte de um quadro mais amplo, de mudanças no processo de urbanização" (REIS, 2007, p.49). Ou seja, as questões atuais relativas ao espaço metropolitano no Brasil remetem ao processo de urbanização acelerado, que marcou a formação da sociedade urbana brasileira. A proposta é discutir os aspectos mais relevantes que podem ser extraídos de tal processo e que possam contribuir para o entendimento do objeto.

\subsection{A METROPOLIZAÇÃO DAS CIDADES BRASILEIRAS}

\section{A urbanização brasileira desde o terceiro quartel do século XX}

Ao longo da segunda metade do século XX, verificou-se em todas as regiões do mundo uma acentuada elevação dos índices de urbanização. O Brasil não fugiu à regra e hoje é um país essencialmente urbano, apresentando índices regionais que atingem 90\%. Um conjunto de fatores físicos e sociais (políticos e econômico) transformou o território nacional e concorreu para o predomínio do urbano. Por força desse fenômeno, ocorreram tanto um significativo adensamento populacional, como o surgimento de áreas metropolitanas e sistemas urbanos com formas mais complexas.

De acordo com Santos (2009, p.6), "a urbanização brasileira tornou-se praticamente generalizada a partir do terceiro terço do século XX, evolução quase contemporânea da fase atual de macro-urbanização e metropolização. O turbilhão demográfico e a terciarização são fatos notáveis."

Na década de 1960-1970, já se encontrava consolidado o modelo político e econômico esboçado desde 1945. Nesse período, acelera-se a urbanização no Brasil, sobretudo em vista da intensificação da industrialização iniciada na década anterior, uma das principais consequências da "política desenvolvimentista" do governo Juscelino Kubitschek.

O mercado interno surgido na década de 1940-1950, embora ainda incipiente, torna-se então uma realidade, provocando nova configuração no território. Após a construção de Brasília e a integração do 
mercado nacional, altera-se profundamente o arranjo do sistema urbano no território brasileiro. As escalas de operação passaram a ser outras, associadas a inovações na infraestrutura de energia e transporte.

A partir desse marco, o País aprofundou o processo de modernização. O espaço econômico amplia-se e é interpenetrado por empresas multinacionais de produção de bens de consumo duráveis e de bens intermediários, que escolhem as grandes cidades como meio técnico capaz de receber inovações tecnológicas e ramos produtivos mais avançados. De tal modo, a intensa urbanização ocorrida no Brasil desde aquele momento está diretamente relacionada à modernização econômica do País como um todo, mas também ao agravamento dos problemas socioeconômicos decorrentes da decadência econômica de determinadas regiões brasileiras.

Segundo Reis (1996), a partir de 1960 o Brasil vivenciou três movimentos que ocorreram de forma simultânea: a explosão demográfica, a explosão urbana e a explosão metropolitana; ou seja, a população cresceu, a população se urbanizou e a população se concentrou, embora esses movimentos não se tenham verificado de maneira homogênea, conforme assinala o autor.

O processo de urbanização no Brasil ocorreu de forma muito acelerada. Difere substancialmente do processo europeu, por exemplo, pela rapidez com que se verificou. Na Europa, a maioria dos países se tornou urbanizada entre a segunda metade do século XIX, sob os impulsos da Revolução Industrial, e a primeira metade do século XX. Além disso, a urbanização europeia foi menos intensa, mais lenta e gradativamente acompanhada da oferta de empregos urbanos, moradias, escolas, saneamento básico, etc. No Brasil, 70 anos foram suficientes para alterar os índices de população urbana: nos anos 1970-1980, os dados censitários já revelavam uma população urbana superior à rural. Desde então, esses índices cresceram se mantêm elevados' ${ }^{1}$.

A urbanização do País, entretanto, não ocorreu uniformemente por todo o território nacional, conforme se pode observar na tabela 1. Muito pelo contrário, ela se concentra sobretudo na região Sudeste, enquanto a região Nordeste apresenta os menores índices de urbanização.

TABELA 1 - ÍNDICE DE URBANIZAÇÃO POR REGIÃO (\%)

$\begin{array}{lllllc}\text { REGIÃO } & \mathbf{1 9 5 0} & \mathbf{1 9 7 0} & \mathbf{1 9 9 0} & \mathbf{2 0 0 0} & \mathbf{2 0 1 0} \\ \text { SUDESTE } & 44,5 & 72,7 & 88,2 & 90,5 & 92,9 \\ \text { CENTRO-OESTE } & 24,4 & 48,0 & 80,9 & 86,7 & 88,8 \\ \text { SUL } & 29,5 & 44,3 & 74,1 & 80,9 & 84,9 \\ \text { NORTE } & 31,5 & 45,1 & 57,8 & 69,9 & 73,5 \\ \text { NORDESTE } & 26,4 & 41,8 & 60,6 & 69,1 & 73,1 \\ \text { BRASIL } & \mathbf{3 6 , 2} & \mathbf{5 5 , 9} & \mathbf{7 2 , 3} & \mathbf{8 1 , 2} & \mathbf{8 4 , 4}\end{array}$

Fonte: IBGE, 2010

No ano de 1950, o índice apresentado pela região Sudeste (44,5\%) procedia principalmente das cidades do Rio de Janeiro e São Paulo, ambas com mais de dois milhões de habitantes na época.

\footnotetext{
${ }^{1}$ Segundo a Organização das Nações Unidas (ONU), no ano de 2005 o Brasil apresentou uma taxa de urbanização de $84,2 \%$ e, de acordo com algumas projeções, até 2050, a porcentagem da população brasileira que vive em centros urbanos deve chegar a 93,6\%. Em termos absolutos, serão 237,75 milhões de pessoas morando nas cidades do País em meados deste século. Por outro lado, a população rural terá caído de 29,46 milhões para 16,33 milhões entre 2005 e 2050.
} 
O índice de urbanização do País como um todo aumentou 2,6 vezes em 50 anos, passando de 36,2\% em 1950 para 81,2\% em 2000. Em 2010² foi registrado um índice de 84,4\%.

Vale ressaltar que o intenso crescimento da economia urbano-industrial, até o final dos anos 1970$1980^{3}$ foi, do ponto de vista espacial e social, extremamente desequilibrado. Muito concentrado no Rio de Janeiro e, principalmente em São Paulo, aumentou as desigualdades regionais, inclusive entre a cidade e o campo, pois não conseguiu gerar o número de empregos que atendesse ao aumento da sua força de trabalho. As migrações internas redistribuíam a população do campo para as cidades do Sudeste, São Paulo em particular. Apesar do grande incremento da economia até o final da década de 1970, as migrações internas, fruto dos desequilíbrios econômicos e sociais nas suas regiões de origem, acabavam por reproduzi-los nas regiões de destino.

Na década de 1980-1990, já se observava uma redução nas taxas de fecundidade urbana e uma sensível diminuição da migração rural-urbana.

\section{A metropolização das cidades brasileiras}

O ciclo de expansão da urbanização no País pode ser compreendido segundo um processo mais amplo, o da constituição das grandes regiões metropolitanas desde os anos 1970-1980. Essa problemática já fazia parte dos estudos de pesquisadores da FAUUSP na década de 1960-1970, conforme assinala o Professor Nestor Goulart Reis:

Essa questão nos preocupa desde o início dos anos 1960, quando São Paulo, sob o impulso de uma industrialização mais intensa, deixou de ser uma cidade, para se transformar em uma constelação de núcleos urbanos integrados em uma única metrópole. Naquela época iniciamos estudos para conhecer as características dessa nova configuração urbana, em um processo de mudança que alterava as relações básicas de nosso cotidiano, mas não era percebido de imediato pela população (REIS, 1996a, p.6).

No estudo das áreas metropolitanas, foi adotado o conceito de metropolização como uma configuração específica do processo de urbanização, a fim de explicar o fenômeno em curso, que consistia, no entender desses pesquisadores, numa forma particular de mudança social: "para nós, as áreas metropolitanas são a configuração mais característica da urbanização do século XX. Nesse caso, a metropolização deve ser o processo de sua formação" (REIS, 1996a, p.6).

Até esse momento, as aglomerações urbanas em geral eram formadas por um só núcleo e sua periferia, e se caracterizavam por determinados tipos de relações. Essas relações passaram a ser mais complexas: além do núcleo inicial, surgiram outros, ou seja, a unidade, o polo, passa a se constituir de vários núcleos, formando uma figura em forma de constelação.

Na realidade, o fenômeno não resulta apenas de uma somatória entre as partes, mas revela outro tipo de configuração social e física. As relações sociais se tornam então mais complexas, a mobili-

\footnotetext{
${ }^{2}$ Números do Censo 2010 divulgados pelo IBGE (Instituto Brasileiro de Geografia e Estatística) mostram que o crescimento brasileiro nas áreas urbanas em 20 anos aumentou em 45\%. O Brasil tem 50 milhões de habitantes a mais em suas áreas urbanas em relação aos números divulgados em 1991. Há 20 anos, eram 110.875 .826 as pessoas morando em áreas urbanas do país (ou 75,5\% da área total), contra os atuais (2010) 160.925 .792 habitantes (84,4\% da área total). ${ }^{3} \mathrm{Na}$ década de 1970-1980, registrou-se um intenso crescimento das aglomerações metropolitanas (notadamente aquelas do Rio de Janeiro e São Paulo). Enquanto a população total brasileira apresentava naquela década taxa de crescimento anual média de 2,48\%, a população das nove RMs cresceu 3,79\% ao ano (IBGE).
} 
dade se acentua, em razão das maiores distâncias, e o aparato administrativo e jurídico amplia-se. As áreas metropolitanas começavam a surgir no contexto nacional.

A equipe da FAUUSP, no "Seminário sobre a Habitação e Reforma Urbana", realizado em 1963, no IAB - Instituto de Arquitetos do Brasil, apresentou trabalho com proposta de alteração da Constituição de 1946, visando à criação de regiões metropolitanas, organizadas de tal forma que não fossem entendidas apenas como um somatório de municípios, mas como uma entidade nova, que correspondesse à complexidade da nova situação social verificada.

Nesse período, as características do fenômeno da metropolização só eram percebidas com clareza nas duas maiores cidades do País, Rio de Janeiro e São Paulo, as quais surgiam como configurações específicas no quadro geral da urbanização.

Posteriormente, o processo atingiu também outras regiões (Belo Horizonte, Salvador, Recife, Fortaleza, Curitiba e Porto Alegre), embora em diferentes escalas ${ }^{4}$. Não se tratava de um fenômeno isolado, mas de alcance nacional. Finalmente, na década de 1970-1980, durante o governo Médici (1969-1974), foram instituídas oficialmente as regiões metropolitanas no Brasil. Desde então, o fenômeno só se acentuou.

Na época, essas transformações na rede urbana brasileira já constituíam objeto de estudo de vários pesquisadores:

A tendência à formação de extensas áreas urbanizadas, através de crescimento dos núcleos isolados que passaram a formar uma só área edificada, levaram ao aparecimento das regiões metropolitanas, colocando à nossa frente mais uma série de problemas de interrelacionamento, polarização, distribuição de serviços e administração, entre outros (LOEB, 1975, p.142).

A institucionalização das regiões metropolitanas brasileiras ocorreu em duas etapas. A primeira, nos anos 1970-1980, como parte da política nacional de desenvolvimento urbano, quando foram criadas nove regiões metropolitanas ${ }^{5}$ - as RMs, abrangendo os principais centros nacionais - particularmente capitais de estados - e suas áreas de polarização direta. Tinham como objetivo a realização de serviços comuns de interesse metropolitano ${ }^{6}$, de maneira a constituir uma unidade de planejamento e gestão.

A segunda fase teve início com a Constituição Federal de 1988, que permitiu aos estados federados a competência de institucionalização de suas unidades regionais. Com isso, findava o modelo que criou regiões sobre as quais os estados não tinham autonomia para intervenção e se abriam possibilidades de incorporação das regiões metropolitanas em processos estaduais de planejamento regional. Afora isso, o Texto Constitucional incluiu outras categorias de organização regional além das regiões metropolitanas, como as aglomerações urbanas e as microrregiões. Essas novas unidades criadas

\footnotetext{
${ }^{4}$ Em 1970, a população da RM de São Paulo era de 8.139.037 habitantes, a da RM do Rio de Janeiro, 7.063.760, a de Salvador 1.147.821, a de Recife 1.791.322 e a de Fortaleza 1.036.799 habitantes.

${ }^{5}$ As oito primeiras regiões metropolitanas instituídas pela Lei Complementar Federal no 14 de 8 de junho de 1973 foram: São Paulo, Belo Horizonte, Porto Alegre, Recife, Salvador, Curitiba, Belém e Fortaleza. A Região Metropolitana do Rio de Janeiro foi instituída no ano seguinte, pela Lei Complementar n²0, de $1^{\circ}$ de julho de 1974, após a fusão dos antigos Estados do Rio de Janeiro e da Guanabara.

${ }^{6}$ Os "serviços comuns de interesse metropolitano" foram definidos pela Lei Complementar Federal 14 como: o planejamento integrado do desenvolvimento econômico e social; o saneamento básico (água, esgoto, limpeza pública), o aproveitamento de recursos hídricos e o controle da poluição ambiental; a produção e distribuição e gás combustível canalizado; o transporte e o sistema viário e o uso do solo.
} 
deveriam integrar a organização, o planejamento e a execução de funções públicas de interesse comum, embora mantendo os objetivos da etapa anterior.

Segundo Davidovitch (2003, p.57),

[...] a institucionalização da metrópole no País se constitui em um dos marcos de um projeto geopolítico de integração do território nacional e do desenvolvimento industrial com base em uma sociedade dominantemente urbana. Partia-se do pressuposto de que uma rede urbana funcionalmente independente e hierarquizada devia assegurar a consecução de metas comuns e o equilíbrio do sistema. Por sua vez, a expansão de redes técnicas de transporte, energia e comunicações garantiam o crescimento de um mercado interno de dimensão continental.

\section{Sobre metrópole e metropolização}

Antes de relacionar as metrópoles brasileiras propriamente ditas, convém abordar a questão da metropolização, assunto que merece especiais atenções de autores de vários campos, sejam cientistas sociais, arquitetos, geógrafos ou economistas, sobretudo em razão da crescente importância das metrópoles no mundo contemporâneo ${ }^{7}$, quando assumem papel primordial no atual contexto de mudanças. Esses espaços são vistos hoje como lugares centrais, onde se efetivam ações de mercados e outras operações globalmente integradas, além de conhecimento, serviços avançados e telecomunicações necessárias à implementação e ao gerenciamento das operações econômicas globais (SASSEN, 1998).

A metropolização é um fenômeno universal, caracterizado pelo elevado grau de concentração populacional e de atividades econômicas, em áreas urbanas, além da intensificação de funções terciárias e institucionais.

A palavra metrópole, do grego metropolis (meter + polis) significa cidade-mãe, ou ainda, segundo o Dicionário Houaiss, "capital ou cidade principal de país, estado ou província". O termo, de acordo com o geógrafo Marcelo Lopes de Souza (2005), é utilizado para designar "as cidades centrais de áreas urbanas formadas por cidades ligadas entre si fisicamente ou através de fluxos de pessoas e serviços que assumem importante posição econômica, politica e cultural na rede urbana da qual fazem parte".

O fenômeno da metropolização está também associado à concentração demográfica8 em determinadas regiões do País, quando algumas cidades crescem num ritmo superior ao das pequenas e médias aglomerações. De acordo com o IBGE, as áreas ou regiões metropolitanas podem ser definidas como "um conjunto de municípios contíguos e integrados socioeconomicamente a uma cidade central, com serviços públicos e infraestrutura comuns".

\footnotetext{
${ }^{7}$ As metrópoles atuais assumem importância crescente no mundo contemporâneo: o crescimento, a potência e a riqueza estão cada vez mais concentrados em um número limitado de grandes polos. As trocas ocorrem menos entre as nações do que entre esses polos que tendem a se organizar em redes, como uma economia de arquipélago, onde as zonas intermediárias são cada vez mais ignoradas. Para determinados autores (SOJA, 1993, CASTELLS, 1999), o conceito de metrópole associa-se, dentre outras, à ideia de cidade-região global e cidade global de Sassen (1991), que funcionam como nós espaciais (ou motores) essenciais da economia global e como atores políticos da cena mundial, centrais à vida moderna.

${ }^{8}$ Em 1970, as regiões metropolitanas brasileiras reuniam 24,3 milhões de pessoas; em 2000, passaram a contar com 67,8 milhões de pessoas, ou seja, esta população quase que triplicou em três décadas, representando 40,0\% do total do País. Em 2010 a população das RMs passou para 88,6 milhões, ou 46,4\% do total da população brasileira (IBGE).
} 
Para Reis (1996), a metropolização não é um dado, mas um processo, e deve ser entendida também como um processo social. Segundo o autor, a metropolização numa determinada região ocorre quando, entre duas ou mais aglomerações, contíguas ou separadas no espaço, se desenvolvem, em escala significativa, tipos de relações que correspondem a um único núcleo urbano.

A metropolização é um processo social característico do mundo contemporâneo, segundo o qual um conjunto de aglomerações urbanas desenvolve entre si relações tais que passam a constituir um sistema, cuja significação para a sociedade é maior do que a simples soma entre as partes. Esses sistemas assumem a forma de constelações (REIS, 1996, p.15).

De acordo com Moura et al (2004, p.4), a metropolização pode ser compreendida como "um momento de maior complexidade do processo de urbanização; um fenômeno que se refere muito mais aos modos de vida e de produção que à própria dimensão territorial das metrópoles."

Milton Santos (2009) destaca a ideia de que uma região metropolitana compreende áreas onde diversas cidades interagem com freqüência e intensidade, mostrando uma interdependência funcional baseada em infraestrutura urbana e na divisão do trabalho. E a metrópole, segundo o autor, é o "organismo urbano onde existe uma complexidade de funções capazes de atender a todas as formas de necessidade da população urbana nacional ou regional" (SANTOS, 2009, p.88).

A questão da metrópole e da metropolização também foi abordada por François Ascher, quando da sua participação no Seminário Internacional Centro XXI9. De acordo com o sociólogo francês,

[...] apesar da ausência de definição precisa, a noção de metrópole é hoje abundantemente utilizada, geralmente para qualificar as principais aglomerações urbanas de um país, que contam algumas centenas de milhares de habitantes, que são multifuncionais e mantêm relações econômicas com várias outras aglomerações estrangeiras (ASCHER, 2001, p.60).

Quanto à metropolização, ele destaca que o fenômeno, verificado mais recentemente, "não é apenas o crescimento e a multiplicação das grandes aglomerações, mas a concentração crescente, em seu seio, de populações, atividades e riquezas" (IDEM, p.61).

No que se refere à espacialização, a metrópole extrapola o âmbito local e alcança o regional, sendo formada por uma constelação de núcleos urbanos, tendo sempre por origem e centro um núcleo de maior importância, a partir do qual se desencadeia o processo.

O desenvolvimento da metrópole se faz não só pela concentração populacional, mas, sobretudo, pelo dinamismo das atividades; ou seja, uma região metropolitana é um conjunto de cidades ou núcleos que tendem a se unificar, funcionando como um só núcleo urbano de grandes proporções. Uma parcela considerável da população de cada um desses polos exerce atividades regulares em um ou mais dos outros polos, estabelecendo uma série de inter-relações entre os municípios, com o intuito de integrá-los, formando uma configuração global maior e mais complexa do que a simples soma de suas partes (REIS, 1996a).

\footnotetext{
${ }^{9}$ O Seminário foi realizado em São Paulo, no ano de 1995, pela Associação Viva o Centro, com o apoio da FAUUSP e da Agência Habitacional da ONU.
} 
Essas aglomerações - também chamadas áreas metropolitanas ${ }^{10}$ - crescem no contexto nacional e mundial como polos geradores de desenvolvimento e, simultaneamente, como polos de atração de atividades econômicas e de imigração populacional. Nesse sentido, de acordo com Moura et al (2004, p.4), a metrópole pode ser entendida como

[...] uma grande aglomeração dotada de equipamentos terciários superiores, comandando uma rede urbana e uma zona de influência extensa, cuja área administrativa correspondente passou a se chamar área metropolitana. Em essência multifuncionais, as metrópoles concentram parte crescente das riquezas, do poder econômico, dos capitais, do processo de acumulação, do PIB e das atividades estratégicas. Igualmente concentram as categorias sociais mais abastadas e os empregos mais qualificados. São o locus por excelência das relações sociais e econômicas. No entanto, é nas metrópoles que se observam também as maiores desigualdades socioespaciais.

É importante esclarecer, de antemão, a diferença entre aglomeração (ou área) metropolitana e região metropolitana" ${ }^{11}$. Enquanto a primeira corresponde à mancha de ocupação contínua ou descontínua diretamente polarizada por uma metrópole, a segunda (que pode ser maior ou igual a essa aglomeração) é sempre decorrente de uma ação desenvolvida pelo Estado, ou seja, a região metropolitana corresponde a uma área definida institucionalmente.

Para Limonad (2007), a expressão região metropolitana

[...] remete, via de regra, a uma idéia de grandes concentrações de população e de atividades em um espaço geográfico que compreende diversas divisões político-administrativas de nível local (municípios). Nesse espaço se desenvolvem interações sociais e econômicas diversas (mercado de trabalho, redes de empresas, cadeias de abastecimento, sedes administrativas de grandes empresas, etc.) que articulam as diversas localidades pertencentes à RM através de relações inter-urbanas e inter-regionais (LIMONAD, 2007, p.197).

Cabe ressaltar que a metropolização se apoia no sistema de transportes e comunicação, que determina as condições de crescimento e, uma vez iniciado o processo, intensifica-se a velocidade de mudanças em toda a região, com transformações significativas.

Enfim, entre as muitas consequências do modelo de urbanização brasileiro, a mais expressiva foi talvez o grande crescimento das regiões metropolitanas. Essas cidades, em virtude da sua importância econômica, nacional e regional, passaram a concentrar a geração de postos de trabalho e, conseqüentemente, despontam como áreas receptoras de intensos movimentos migratórios. Esse crescimento populacional demanda espaços para sua reprodução, sobretudo no que se refere a moradias. Assim, as metrópoles incorporam áreas rurais, expandindo suas manchas urbanas em direção aos municípios limítrofes, ampliando o espaço periférico metropolitano.

Se, por um lado, as metrópoles brasileiras crescem em importância institucional, econômica e demográfica, de outra parte, como em todas as cidades, veem aumentar consideravelmente a problemática social, sobretudo no que se relaciona à violência urbana, a qual está associada aos

\footnotetext{
${ }^{10}$ Aglomeração metropolitana (ou área metropolitana): corresponde à mancha de ocupação contínua ou descontínua diretamente polarizada por uma metrópole, onde se realizam as maiores intensidades de fluxos e as maiores densidades de população e atividades, envolvendo municípios fortemente integrados ou considerando parcialmente ou inteiramente área de um único município. A densificação de atividades e populações acontece nas áreas metropolitanas (OBSERVATÓRIO DAS METROPOLES, 2004, p.7).

${ }^{11}$ Nesta tese, no que se refere ao objeto de estudo - a metrópole de Fortaleza - a área metropolitana será considerada correspondente à Região Metropolitana de Fortaleza
} 
processos de segregação socioespacial, quando parte da população vive em espaços privilegiados enquanto outra parcela considerável vive formas de exclusão social.

Estudos recentes realizados, entretanto, comprovam que a maior parte ${ }^{12}$ das regiões metropolitanas brasileiras deixou de ser polo de intenso crescimento populacional, sobretudo nas últimas décadas. Da média anual de 3,8 \% nos anos 1970-1980, o crescimento das regiões metropolitanas baixou de 2\% na década de 1980-1990, para 1,9\% na década de 1990 e mantendo-se nesse índice em 2000, reduzindo-se a 1,2\% no período de 2000-2010, o que revela um decréscimo do ritmo da tradicional metropolização.

Esse fenômeno decorre de alguns fatores, além da própria queda da taxa de fecundidade da população. Registrou-se não só uma redução no fenômeno dos fluxos migratórios para as metrópoles como também observa-se que determinados setores produtivos tradicionalmente instalados nas aglomerações metropolitanas se deslocam, num processo de desconcentração, em direção a cidades de porte médio, localizadas em áreas dinâmicas do País, num movimento que parece desagregar o tecido metropolitano, mas, na realidade, expande suas hinterlândias.

Apesar da desaceleração da taxa de urbanização das metrópoles, de um modo geral, convém ressaltar que suas periferias continuam a crescer de forma intensa, enquanto as áreas centrais apresentam um certo esvaziamento populacional.

Em suma, a metropolização é, pois, resultado da maior "complexificação" do processo de urbanização, envolvendo a articulação de vários núcleos urbanos sob o comando de um deles e compreende não só o aumento demográfico da população, mas também o incremento das atividades e relações econômicas, que extrapolam o âmbito local e atingem o regional. E se, no primeiro momento, até meados da década de 1980-1990, o fenômeno da metropolização se relacionava com a concentração e a monocentralidade, identificada com o modelo centro-periferia, atualmente, a metrópole contemporânea caracteriza-se muito mais pela policentralidade, dispersão e fragmentação.

\section{As regiões metropolitanas brasileiras}

Com relação à realidade metropolitana brasileira, segundo levantamento realizado pelo Observatório das Metrópoles (2010) ${ }^{13}$, no sentido de "manter atualizado o universo metropolitano oficial", existem hoje no país 35 regiões metropolitanas (RMs) e três regiões integradas de desenvolvimento econômico (RIDEs) legalmente constituídas ${ }^{14}$. Essas regiões abrangem 444 municípios ${ }^{15}$ e estão distribuídas por 22 unidades da federação, incluído o Distrito Federal (ver tabela 2).

\footnotetext{
$\overline{12}$ Nas regiões metropolitanas de Salvador e Fortaleza, as populações cresceram com taxas mais elevadas entre todas as suas congêneres brasileiras nos períodos 1980-91, 91-2000 e 2000-2010, de acordo com o censo do IBGE. O desenvolvimento econômico das duas regiões, baseado, no caso de Salvador, nas atividades do polo petroquímico e no desenvolvimento de um polo turístico de considerável importância e, no de Fortaleza, também no turismo e na instalação de um parque industrial de bens de consumo final com relativa intensidade na utilização do fator mão de obra, sem dúvida deve ter contribuído, via migração, para o elevado ritmo de crescimento das respectivas populações residentes. ${ }^{13} \mathrm{O}$ estudo realizado pelo Observatório das Metrópoles foi elaborado com base nas informações em órgãos como o Ministério da Integração, o Governo Federal, as assembléias legislativas e os governos estaduais.

${ }^{14}$ De acordo com Ribeiro \& Garson (2010, p. 22), apesar de legalmente constituídas, desse conjunto destacam-se apenas 15 aglomerados urbanos dotados de fato de funções metropolitanas, ou seja, são aqueles "que apresentam características de tamanho, concentração de atividades econômicas e capacidade de interconexão próprias das novas funções de comando, direção e coordenação (...) Além disso, possuem funções econômicas próprias das metrópoles, com papel relevante na 'economia em rede' que se constituiu ao longo do processo de globalização e de reestruturação produtiva". São esses os 15 aglomerados urbanos: Belém, Belo Horizonte, Brasília (RIDE-DF), Campinas, Curitiba, Florianópolis, Fortaleza, Goiânia, Manaus, Porto Alegre, Recife, Rio de Janeiro, Salvador, São Paulo e Vitória. ${ }^{15}$ A população dos 444 municípios das RMs, segundo o IBGE (2010), atingiu 88,6 milhões de pessoas, o que representa $46,4 \%$ da população do país.
} 


\section{TABELA 2 - REGIÕES METROPOLITANAS BRASILEIRAS LEGALMENTE CONSTITUÍDAS}

\begin{tabular}{|c|c|c|}
\hline REGIÃO METROPOLITANA & ESTADO & POPULAÇÃO (2010) \\
\hline São Paulo & São Paulo & 19.683 .975 \\
\hline Rio de Janeiro & Rio de Janeiro & 11.835 .708 \\
\hline Belo Horizonte & Minas Gerais & 5.414 .701 \\
\hline Porto Alegre & Rio Grande do Sul & 3.958 .985 \\
\hline Recife & Pernambuco & 3.690 .547 \\
\hline Salvador & Bahia & 3.573 .973 \\
\hline Fortaleza & Ceará & 3.615 .767 \\
\hline Curitiba & Paraná & 3.174 .201 \\
\hline RIDE Brasília & Distrito Federal & 3.717 .728 \\
\hline Campinas & São Paulo & 2.797 .137 \\
\hline Belém & Pará & 2.101 .833 \\
\hline Goiânia & Goiás & 2.173 .141 \\
\hline Manaus & Amazonas & 2.106 .322 \\
\hline Baixada Santista & São Paulo & 1.664 .136 \\
\hline Vitoria & Espírito Santo & 1.687 .704 \\
\hline São Luis & Maranhão & 1.331 .181 \\
\hline Natal & Rio Grande do Norte & 1.351 .004 \\
\hline Maceió & Alagoas & 1.156 .364 \\
\hline João Pessoa & Paraíba & 1.198 .576 \\
\hline RIDE Teresina/Timon & Piauí & 1.150 .959 \\
\hline Norte/Nordeste catarinense & Santa Catarina & 1.094 .412 \\
\hline Florianópolis & Santa Catarina & 1.012 .233 \\
\hline Vale do rio Cuiabá & Mato Grosso & 833.766 \\
\hline RIDE Petrolina/Juazeiro & Bahia & 686.410 \\
\hline Londrina & Paraná & 764.348 \\
\hline Aracaju & Sergipe & 835.816 \\
\hline Maringá & Paraná & 612.545 \\
\hline Cariri & Ceará & 564.478 \\
\hline Vale do Itajaí & Santa Catarina & 689.731 \\
\hline Macapá & Amapá & 499.466 \\
\hline Vale do Aço & Minas Gerais & 615.297 \\
\hline Foz do (Rio) Itajaí & Santa Catarina & 532.771 \\
\hline Agreste & Alagoas & 601.049 \\
\hline Carbonífera & Santa Catarina & 550.206 \\
\hline Chapecó & Santa Catarina & 403.494 \\
\hline Sudoeste maranhense & Maranhão & 345.873 \\
\hline Lages & Santa Catarina & 350.532 \\
\hline Tubarão & Santa Catarina & 356.721 \\
\hline TOTAL & & 88.592.437 \\
\hline
\end{tabular}

Fonte: Observatório das Metrópoles e IBGE, 2010 
A metropolização avançou e se diversificou de maneira intensa no território nacional. Nos últimos anos surgiu no País um maior número de regiões metropolitanas, decorrentes de decretos estaduais, muitas vezes sem apresentarem, de fato, uma situação de aglomerado metropolitano que justifique sua instituicionalização ${ }^{16}$, o que faz suscitar uma reflexão sobre a pertinência dessa prática.

A geógrafa Rosa Moura, em seu artigo Intitucionalização de Regiões Metropolitanas: qual o sentido? (2006), questiona a legitimidade dessas ações, que se disseminaram progressivamente no território brasileiro. $\mathrm{O}$ artigo refere-se, principalmente, à problemática paranaense, mas aplica-se também a outras unidades da Federação:

É contínua a proposição, no âmbito do legislativo, de projetos de lei voltados à institucionalização de novas "regiões metropolitanas". Considerando que as assembléias legislativas são verdadeiras caixas de ressonância da problemática e necessidades da sociedade, esse acúmulo de projetos poderia estar revelando que o fato urbano das aglomerações é uma realidade em várias porções do território paranaense. Entretanto, o mapeamento dos projetos em tramitação mostra que muitas das unidades propostas estão longe de configurar aglomerados. Não estariam, então, sendo movidas por alguma inquietação por parte de municípios, talvez ligada à busca de alternativas ao desenvolvimento regional, e canalizadas para a faculdade estadual de criação de unidades regionais? (MOURA ET AL, 2006, p.1).

Assim, algumas questões se expressam, como a constatação da pouca articulação e integração entre os diversos municípios que compõem as RMs e, sobretudo, o fato de não se contar com ações adequadas de planejamento e organização dos novos espaços agora oficialmente aglomerados, bem como a falta de estratégias de desenvolvimento para as diferentes unidades.

O que se observa, portanto, é a multiplicação das regiões metropolitanas no território nacional, quando não há, efetivamente, uma política metropolitana. No entender de Moura et al (2006, p.12),

[...] o desenho atual da gestão metropolitana, colocado na Constituição, contém entraves de natureza institucional, política e de financiamento. Ainda não se tem clareza de como enfrentar a questão sob o desenho institucional posto, sem a repactuação da federação em torno da questão metropolitana. Os recortes metropolitanos criados não vêm a constituir uma dimensão política, além de que há uma gama de regiões sem um arcabouço que as estruture enquanto espacialidades articuladas. A falta de uma fonte de recursos permanente que apóie uma política nacional metropolitana é uma questão que tem de ser enfrentada, como outros mecanismos de financiamento possíveis, além de fundos etc.

É sabido, por outro lado, que as aglomerações metropolitanas brasileiras, em geral, estão longe de apresentar um mesmo desenvolvimento, tanto econômico quanto social. O ritmo de urbanização, as forças políticas, as funções econômicas, o processo histórico de ocupação, e especificidades de toda ordem, influenciam para que o Brasil abrigue uma rede metropolitana diferenciada e hierarquizada.

As regiões Sul e Sudeste, por exemplo, exibem uma rede de cidades complexa e diversificada, com sub-centralidades bem definidas, funções econômicas descentralizadas e capacidade de influência nacional e, de certo modo, global, tomando como referência as metrópoles de São Paulo,

\footnotetext{
16 "Ao longo dos anos, o quadro metropolitano oficial sofre alterações, tanto na composição interna das RMs com a inclusão e exclusão de municípios, quanto na criação de novas RMs. Verifica-se, sobretudo após a constituição de 1988, uma profusão de RMs no Brasil, sem critérios claros e objetivos consistentes, tanto na sua institucionalização, quanto na definição dos municípios que a compõem". (MOURA ET AL, 2006, disponível em: http://www.ipardes.pr.gov.br/ojs/ index.php/revistaparanaense/article/view/64/68)
} 
do Rio de Janeiro e de Belo Horizonte ${ }^{17}$. No Norte, pelo contrário, a rede urbana é mais rarefeita, com concentrações em Manaus e Belém, e com economia industrial ainda pouco consolidada e graves problemas sociais. O Nordeste, desde os anos 1970-1980, já apresentava três aglomerações metropolitanas (Recife, Salvador e Fortaleza) que exerciam forte influência regional. Nos últimos anos, mais oito RMs passaram a compor a rede: as capitais Natal, João Pessoa, Maceió, Aracaju e S. Luís e mais Cariri (CE), Agreste (AL) e Sudoeste Maranhense (MA), além das RIDEs Teresina/ Timon e Petrolina/Juazeiro - todas apresentando nítidas diferenciações com relação às anteriores.

As primeiras RMs do Nordeste - Recife, Fortaleza e Salvador - firmaram-se nas últimas décadas como polos centralizadores das atividades industriais desenvolvidas na região e tornaram-se, consequentemente, detentoras de parcela considerável da população e da renda regional.

Segundo o estudo realizado pelo IPEA ${ }^{18}$, a Região Metropolitana de Fortaleza surge como aglomeração metropolitana polarizada por uma metrópole nacional que, desde as últimas décadas, registra crescente expansão, com expressivo contingente demográfico. Apresenta, além disso, significativa expressão econômica, política e cultural no atual contexto de mundialização econômica, assunto que será enfocado com detalhes no item a seguir.

\subsection{FORTALEZA: DE CIDADE A METRÓPOLE - a dinâmica socioespacial}

Questões gerais relacionadas à Metrópole cearense serão tratadas neste item. Com a exposição, pretende-se melhor caracterizar o objeto de estudo da tese, abrangendo aspectos históricos, sociais (econômicos, políticos e culturais) e espaciais que determinaram seu crescimento e expansão, buscando, sempre que possível, relacioná-las com o contexto nacional.

Antes de se iniciar a análise dos diferentes atributos da Metrópole cearense contemporânea, faz-se necessária uma breve prospecção acerca da sua evolução urbana, com o intuito de verificar, de maneira sucinta, como ocorreu o desenvolvimento material do Ceará (e de Fortaleza), dos primórdios até a década de 1970-1980. Enfim, saber-se como a cidade provinciana transformou-se em metrópole, matéria que será tratada nos dois itens seguintes.

\subsubsection{Antecedentes}

\section{Breves notas sobre a ocupação do Ceará colonial e a emergência de Fortaleza no século XIX}

A ocupação do território brasileiro e a formação da rede de cidades têm seus fundamentos no sistema colonial e são consequência da maneira como se organizou a base produtiva regional nas suas vinculações com a economia nacional e internacional.

\footnotetext{
${ }^{17}$ As regiões metropolitanas de São Paulo, Rio de Janeiro e Belo Horizonte constituem, desde que foram criadas, na década de 1970-1980, as principais regiões metropolitanas brasileiras, posição que ocupam ainda hoje, quer pela concentração da capacidade produtiva em relação ao resto do País, quer pelo contingente populacional ali residente. No ano de 2010 residiam, apenas nessas três RMs, um total de 36.934 .384 habitantes, valor esse que corresponde a 41,6\% da população brasileira residente em áreas metropolitanas e a 19,3\% da população total brasileira, nesse período.

${ }^{18}$ No estudo desenvolvido pelo Instituto de Pesquisa Econômica Aplicada - IPEA, UNICAMP e IBGE (Caracterização e Tendências da Rede Urbana do Brasil, 2001), com relação às regiões metropolitanas brasileiras, foram identificados grupos de cidades que constituem o aglomerado metropolitano do país. No trabalho, foram empregados indicadores demográficos e econômicos, assim como dos fluxos de bens e serviços para definição do espaço urbano, de modo que realmente pudesse ser considerado um aglomerado metropolitano. O estudo, apesar de preciso e minucioso, foi elaborado no ano de 2001, razão por que a classificação adotada na tese será aquela definida pelo Observatório das Metrópoles, em 2010.
} 
A primeira fase da formação econômica do Brasil baseava-se em economias regionais, que se articulavam muito mais para fora do que para dentro do espaço nacional. A dinâmica regional ficava definida segundo o mercado externo e de acordo com a produção predominante de cada região. As ligações entre as regiões eram bem mais tênues do que as ligações de cada uma delas com o Exterior.

No Nordeste oriental, a rede de cidades foi decorrente da lavoura canavieira. O cultivo da cana-de-açúcar ensejou um sistema urbano na área correspondente à Zona da Mata, do Rio Grande do Norte até o sul da Bahia. No segundo momento, o território cearense (e o sertão do Nordeste, de modo geral) serve de apoio à lavoura da cana-de-açúcar, mediante a atividade da pecuária extensiva, marcada pela interiorização das fazendas de gado.

Algumas poucas aglomerações surgiam nos cruzamentos dos caminhos de penetração do gado, como pontos de pouso, e situavam-se próximas a fazendas, capelas e modestos entrepostos comerciais: "no entorno das fazendas de gado originou-se a maioria dos núcleos, onde mais tarde foi fundada a maioria das vilas de brancos na Capitania cearense, alterando, lentamente, durante todo o século XVIII e início do século XIX a dispersão reinante" (JUCÁ NETO, 2007, p.207).

A produção do charque, ocorrida posteriormente, propiciou o surgimento dos primeiros núcleos urbanos do interior do Ceará, dentre os quais se destacam o Icó, no sertão, e o Aracati, no litoral. Fortaleza figura neste cenário como coadjuvante, pois sua origem e formação estão relacionadas com sua função administrativa, primeiramente, mas também com seu papel de polo defensivo, desde o século XVII. Era então um povoado secundário, sem destaque regional ${ }^{19} \mathrm{e}$, isolada na zona costeira, não estabelecia vínculos com outros centros urbanos coloniais. A ocupação da Capitania ocorre, portanto, no sertão, ignorando o litoral.

Mas o século [XVIII] vê povoar-se, pouco a pouco, o Ceará. Praticamente do interior para o mar, no entanto. São imigrantes que procedem da Bahia e de Pernambuco. Descem os leitos dos rios secos, os chapadões e as caatingas, trazendo gado. A pecuária logo assume papel preponderante na economia e no sistema de povoamento da terra (CASTRO, 1977, p.25).

Os dois movimentos de ocupação, representativos do litoral e do sertão, caracterizam a organização espacial típica do Ceará colonial: o primeiro, fruto de lógica militar de defesa adotada pelos portugueses no litoral e o segundo, fruto da expansão das fazendas no sertão. No Ceará, o litoral não se instaura como ponto de penetração. Embora a ocupação inicial se realize a partir deste espaço, os aspectos tecnológicos, naturais e simbólicos apresentam quadro impróprio à penetração e justificador do fraco desenvolvimento desta zona em relação ao sertão (SILVA \& DANTAS, 2009, p.4).

O Nordeste oriental, com o declínio da produção canavieira no final do século XVIII, passou a assumir posição secundária no quadro econômico da Colônia, sobretudo depois da hegemonia do ciclo de mineração, na região das Minas e da mudança da capital do País para o Rio de Janeiro em 1763 e, posteriormente, com a ascensão e importância da cultura cafeeira.

\footnotetext{
19 "Recife e Salvador se constituíram, desde cedo, nos principais polos econômicos regionais, concentrando a riqueza colonial e comandando as trocas e povoamento para o interior" (COELHO, 1990, p.18).
} 
No Ceará, o ciclo do algodão substituiu a pecuária, depois da dizimação do rebanho, em decorrência das seguidas secas no final do século XVIII. O produto obteve valorização imediata e passou a ser comercializado diretamente com a Inglaterra. "Com a intensificação da demanda de algodão pelo mercado inglês, o Ceará passou a produzir um produto de exportação e a intensificar o povoamento do seu território e a abertura da sua economia" (ANDRADE, 1978, p.91).

Somente no final do século XVIII, portanto, com a criação da Capitania autônoma do Ceará, desligada da de Pernambuco, e com a mudança do sistema econômico, resultante da substituição da pecuária extensiva pelo cultivo do algodão, é que Fortaleza passou a ganhar importância, iniciando seu desenvolvimento como centro de coleta e exportação algodoeira para a Inglaterra, embora ainda fossem bastante limitadas as condições portuárias e a grande dificuldade dos transportes terrestres. Nesse período, a economia cearense começava a se inserir nas regras e nos interesses do capitalismo industrial, que então se consolidava.

Em 1823, Fortaleza é elevada à categoria de cidade, com o nome de Fortaleza de Nova Bragança e, durante todo o século XIX, assiste-se a um conjunto de mudanças de ordem político-administrativa e tecnológica, que contribuiu sobremaneira para a hegemonia da Capital no âmbito do Estado. Com a abertura dos portos às nações amigas, seu porto ganha importância e se reforça o fluxo de navegações com a Europa, confirmando seu papel no quadro urbano do Ceará. A produção do algodão se intensifica, com a construção da ferrovia em 1873, e Fortaleza transforma-se em importante entreposto comercial, expandindo sua zona de influência sobre o sertão.

"A partir dessa época, seja pelo declínio da influência de outras vilas, seja pelo aparecimento de novas funções urbanas, como a de centro exportador, Fortaleza, durante todo o século XIX, irá lentamente definindo sua posição nos quadros do estado" (CASTRO, 1977, p.27). Torna-se o principal centro coletor e distribuidor de produtos de exportação e importação, substituindo Aracati no comando das relações comerciais e ampliando sua influência político-econômica sobre todo o Ceará.

Apesar das consequências trágicas da grande seca ${ }^{20}$ ocorrida entre 1877 e 1879, repetida em 1888 e nos anos finais do século XIX, a Cidade conhece grande progresso material, com a inauguração dos serviços de bondes de tração animal, iluminação pública, calçamento nas ruas centrais, serviço de telefonia, rede de telégrafos para o País e para a Europa, a instalação de algumas poucas fábricas têxteis, além do surgimento das primeiras associações culturais e sociais. Todas essas transformações provocam expressivas mudanças socioespaciais e culminam com a definição de hegemonia da Capital em relação aos demais centros urbanos do Estado.

No final do século (1890), pois, consolida-se a emergência de Fortaleza, que contava então com 48.000 habitantes e assiste-se a um crescimento considerável de sua função comercial e de sua zona ocupada, mas, ainda assim, não passava de uma cidade muito pequena, sobretudo quando comparada com outras capitais brasileiras, como Rio de Janeiro (522.651 habitantes) e Salvador (174.412 habitantes), por exemplo.

\footnotetext{
${ }^{20}$ Uma das conseqüências da longa temporada de secas no Ceará nesse período foi o grande fluxo migratório do sertão para a Capital, ocasionando a formação das primeiras favelas da Cidade.
} 


\section{A cidade de Fortaleza no século XX, até meados da década de 1970}

Em meados do século XX, verifica-se uma mudança importante na vida do País. O Brasil supera a condição de exportador primário e torna-se um país de base industrial importante. O mercado interno passa a comandar a dinâmica econômica e as diversas "ilhas" "², antes existentes, começam a se articular e estabelecem relações cada vez mais intensas. Surge, então, a questão regional brasileira, na década de 1960-1970, quando se consolidam diferenciações regionais importantes.

Com o início da industrialização brasileira, se anuncia um esboço de integração nacional, viabilizada pela efetivação dos sistemas de transportes, inicialmente o ferroviário e o marítimo. Esta etapa caracteriza-se pelo início da formação de uma rede urbana nacional, a emergência de São Paulo como centro hegemônico do País e a supremacia regional do polo Centro-Sul (Rio de Janeiro, Minas Gerais e São Paulo). A construção de rodovias nas décadas de 1940-1960 teve como propósito incorporar o desenvolvimento do Sudeste às demais regiões.

Esse momento marca, em todo o País, como visto anteriormente, a consolidação do processo de urbanização, provocado principalmente pelo crescimento demográfico e pelos fluxos migratórios que acontecem, por um lado, na escala do território, representados principalmente pelos deslocamentos da população da Região Nordeste para as metrópoles da Região Sudeste (São Paulo, em primeiro lugar) e, por outro, na escala intrarregional, do campo em direção aos centros urbanos.

Nesse contexto, Fortaleza adquire domínio total sobre todo o território cearense e consolida cada vez mais sua hegemonia. As grandes secas de 1915 e 1932 provocam intenso fluxo migratório do interior. A população da Capital atinge 180.000 habitantes em 1940. A Cidade se organiza espacialmente, com base no Código Urbano proposto em 1931, que disciplinava o uso e a ocupação do solo. A zona comercial se amplia. Surgem as primeiras indústrias na zona oeste e bairros modestos nas vizinhanças, assim como se inicia a ocupação do leste, com o bairro da Aldeota, das classes mais abastadas.

Nessa época, se acentuaria espacialmente a divisão social e funcional da $\mathrm{Ci}$ dade, percebida em três grandes setores: o centro administrativo, comercial e financeiro; a zona oeste-industrial e popular e a zona leste - lugar de residência e do lazer das camadas mais favorecidas. Caracteriza-se, então, de maneira marcante a segregação espacial na cidade de Fortaleza (DIÓGENES, 2005, p.41).

Os dados censitários, a partir de 1940, demonstram o rápido crescimento da população de Fortaleza. De acordo com o recenseamento de 1950, o Município apresentou um acréscimo populacional de 49,9\% em relação à década anterior. E, nos decênios seguintes, 1950-1960 e 1960-1970, os índices foram respectivamente $90,5 \%$ e $66,6 \%$. Esses resultados posicionam Fortaleza entre as capitais do Nordeste que apresentavam os maiores índices de crescimento demográfico (ver tabela 3).

Apesar das elevadas taxas de crescimento, o aumento da população de Fortaleza resulta, em grande parte, das migrações internas. Os migrantes procedem, em sua maioria, do interior do Estado, e, como não dispõem nem de capital nem de qualificação, contribuem para a expansão das favelas. O rápido aumento da população traz implicações de ordem econômica e social, exigindo maiores investimentos em infraestrutura e maiores oportunidades de emprego.

\footnotetext{
${ }^{21}$ A noção de "arquipélagos" de regiões foi utilizada por Oliveira (1978, p.31) para ilustrar a situação econômica do País à época.
} 


\section{TABELA 3 - ÍNDICE DE CRESCIMENTO DEMOGRÁFICO} DA CIDADE DE FORTALEZA DE 1900 A 1970

\begin{tabular}{|c|c|c|}
\hline ANO & POPULAÇÃO & ÍNDICE DE CRESCIMENTO \\
\hline 1900 & 48.369 & 18,2 \\
\hline 1910 & 65.816 & 36,1 \\
\hline 1920 & 78.536 & 19,5 \\
\hline 1930 & 126.666 & 61,2 \\
\hline 1940 & 180.175 & 42,2 \\
\hline 1950 & 270.169 & 49,9 \\
\hline 1960 & 514.813 & 90,5 \\
\hline 1970 & 857.980 & 66,6 \\
\hline
\end{tabular}

O crescimento da Cidade é visualizado mediante a ampliação constante de seu espaço urbano, tanto na periferia como no núcleo central. Afora a foz do rio Ceará, no limite oeste do Município e a foz do rio Cocó, ao leste, a existência de poucos obstáculos físicos ${ }^{22}$ favoreceu a expansão no território, traduzida em baixas densidades urbanas.

Na segunda metade do século XX, quando a industrialização alcança grande incremento no Brasil, a urbanização de Fortaleza se relaciona com o processo, porém de modo indireto. Embora a Cidade não tenha conhecido, no período, uma industrialização efetiva, pode-se, entretanto, afirmar que houve reflexos no processo de urbanização, uma vez que o desenvolvimento industrial do Centro-sul contribuiu para a expansão do terciário em centros regionais, como a Capital cearense, transformando-os em polos de redistribuição.

A "industrialização pesada"23 ocorre na Região Sudeste, com base no capital internacional, incrementando a fabricação de bens de consumo e de produção, consolidando a posição de liderança de São Paulo mediante a concentração de capital e de atividades produtivas. Houve então uma expressiva ampliação da rede rodoviária nacional, com o objetivo de alcançar o mercado consumidor, interligando o polo industrial paulista aos demais estados brasileiros.

A crescente concentração urbana no território foi acompanhada, portanto, pela implementação de um sistema viário de grande porte, por meio de rodovias de ligações entre os estados do sul ao norte. A construção de Brasília destaca-se no centro desse sistema.

Evidenciaram-se, no País, à época, enormes desigualdades de renda. Como consequência da propalada "maturidade industrial", verificou-se o agravamento das disparidades regionais no território brasileiro. A percepção das desigualdades entre as regiões provocou o surgimento das chamadas agências de desenvolvimento regional, que propunham ações integradoras. Foi criado então o primeiro banco estatal de desenvolvimento regional do Brasil, o Banco do Nordeste do Brasil (BNB), em 1952, e a SUDENE - Superintendência

\footnotetext{
${ }^{22}$ A via férrea Parangaba-Mucuripe também constituiu, de certa forma, durante algum tempo, obstáculo para o crescimento da Cidade na direção leste.

${ }^{23}$ A chamada "industrialização pesada" - nova fase da industrialização brasileira, que ocorre no País entre os anos de 1956 e 1961 e se caracteriza por uma alteração radical na estrutura do sistema produtivo nacional - foi viabilizada pelo Plano de Metas do governo Juscelino, com base no capital estrangeiro. Na indústria pesada, distinguem-se como principais a metalurgia e a química.
} 
de Desenvolvimento do Nordeste, em 1959. Tais intervenções, no entanto, não tiveram o êxito pretendido ${ }^{24}$.

Entre as décadas de 1950 e 1960 verifica-se grande aumento de população em Fortaleza, que passa de 270.000 para 514.000 habitantes, evidenciando um processo mais efetivo de urbanização, com ocupação intensa, principalmente no sentido oeste e sudoeste, onde se concentra a camada da população de menor poder aquisitivo. As classes mais abastadas dirigem-se progressivamente para a zona leste, acentuando-se a segregação socioespacial25.

O estado conquista a posição de III Polo industrial do Nordeste, depois da Bahia e de Pernambuco. As indústrias (têxtil, calçados, e óleos vegetais) se fixam predominantemente na Capital (na zona oeste), intensificando-se a hegemonia de Fortaleza. Nesse período é iniciado o planejamento estatal, no governo de Virgílio Távora. O PLAMEG ${ }^{26}$ estabelece condições institucionais e de infraestrutura para a industrialização, que são materializadas na reforma do porto do Mucuripe, na pavimentação de rodovias e na implantação do Distrito Industrial de Maracanaú.

Dois planos urbanísticos foram propostos no período (Plano Helio Modesto - 1963 e PLANDIRF27, 1972), ambos aprovados, mas implementados apenas parcialmente, por mudança de administração e por contrariarem interesses dos proprietários de terra.

Segundo o diagnóstico do PLANDIRF, toda a zona leste foi considerada de alto nível econômico, portanto, tida como o eixo mais dinâmico de valorização e renovação da Cidade, ao contrário do que ocorria do lado oposto (oeste e sudoeste), onde se concentravam as indústrias e as residências de baixo padrão. O crescimento da mancha urbana também se dava ao longo dos principais eixos viários, principalmente nos sentidos sul, oeste e sudoeste, enquanto havia ainda grandes glebas vazias $^{28}$ ou subocupadas, em particular, entre esses eixos. O Plano oferecia uma clara idéia de como se desenvolvia a Cidade em termos de organização espacial.

O quadro nacional, nessa ocasião, durante os governos militares, caracterizou-se pelo "milagre brasileiro", quando, com a política de substituição de importações, o País apresentou elevadas taxas $^{29}$ de crescimento dos principais indicadores econômicos. Esse período foi logo seguido pela crise advinda do choque do petróleo, em 1973, que iniciou uma fase de crescimento com endividamento externo.

\footnotetext{
${ }^{24}$ A Região Nordeste, mesmo após a criação da Superintendência do Desenvolvimento do Nordeste (SUDENE) em 1959, cujos planos de desenvolvimento para a região elegeram primordialmente a industrialização como fator indutor capaz de minimizar as 'desigualdades regionais', não conheceu desenvolvimento desejável. Os incentivos fiscais foram os principais instrumentos para atração de investimentos no setor industrial do Nordeste, conduzindo uma política de desenvolvimento econômico industrial dependente, marcada pela criação de empresas filiais, com matriz no Centro-Sul, concentrando o centro de decisões e o excedente. Por outro lado, o problema da estiagem, além de não ser resolvido, continuou a manter a chamada "indústria da seca", favorecendo grupos políticos regionais e criando um círculo vicioso de assistencialismo do Estado.

${ }^{25}$ A segregação socioespacial, de acordo com Villaça (1998, p.142), "é um processo segundo o qual diferentes classes ou camadas sociais tendem a se concentrar cada vez mais em diferentes regiões gerais ou conjuntos de bairros da metrópole".

${ }^{26}$ PLAMEG I Plano de Metas Governamentais (1963-1966) do Governo Virgílio Távora.

${ }^{27}$ O PLANDIRF - Plano de Desenvolvimento Integrado da RMF, elaborado em 1972 por um consórcio de empresas de São Paulo, coordenado pelo arquiteto Jorge Wilheim, surgiu no contexto das discussões sobre o conceito de "região metropolitana" das cidades brasileiras e, assim, já evidenciava preocupação com a composição da Região Metropolitana de Fortaleza, que viria a ser institucionalizada posteriormente. (Ver item 2.3).

${ }^{28}$ Grande parte dessas terras era intencionalmente estocada, aguardando valorização posterior.

${ }^{29}$ Houve aumento no PIB: 11,3\% a.a; na indústria: 12,7\% a.a; nos serviços: 9,8\% a.a. e nas exportações: 24,00\% a.a.
} 
Na época, as áreas centrais das regiões metropolitanas, de modo geral, receberam significativos investimentos em termos viários, sanitários, de comunicação, transporte, etc. As periferias, ao contrário, foram contempladas estritamente segundo suas necessidades, ou seja, realizaram-se apenas os investimentos indispensáveis à viabilização de determinados projetos de desenvolvimento, como o saneamento. Os problemas foram tratados no limite de suas necessidades mínimas.

De modo idêntico, na Capital cearense, as questões urbanas agravavam-se, evidenciando-se expressivo déficit de infraestrutura urbana, equipamentos e serviços nos setores de saneamento básico, habitação, saúde e educação, revelando diferenças estruturais que só aumentaram o quadro de desigualdades.

No inicio da década de 1970-1980, com uma população em torno de 800.00 habitantes, a Cidade ainda mantinha estrutura monocêntrica, iniciando-se nessa época as primeiras manifestações de descentralização.

Com relação às grandes obras realizadas no período, destacam-se a abertura da av. Beira Mar (1963), que favoreceu a ocupação e utilização da orla marítima da Capital, a construção do Palácio da Abolição (1970), do Centro de Convenções (1974), a reforma do Aeroporto (1975), a construção do Terminal Rodoviário (1976), além da modernização do Porto do Mucuripe e da pavimentação das rodovias BR 116 e BR 020. Esse conjunto de obras teve forte impacto na paisagem urbana fortalezense e marcou o início das transformações da Cidade, evidenciando indícios de metropolização, que então se anunciava (ver figuras 2.1 a 2.3).

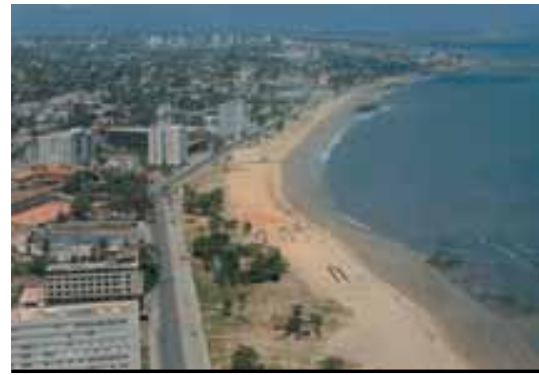

Fig. 2.1 Av. Beira Mar (década de 1960)

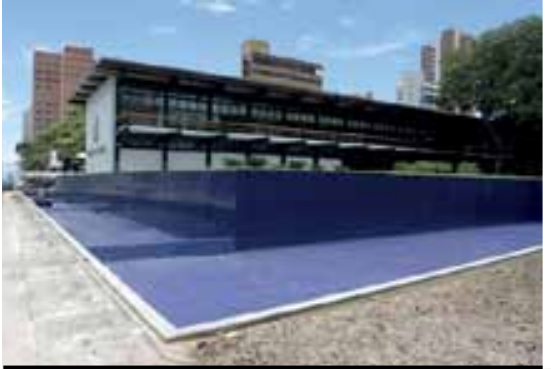

Fig. 2.2 Palácio da Abolição Fonte: rwarquitetura.blogspot.com

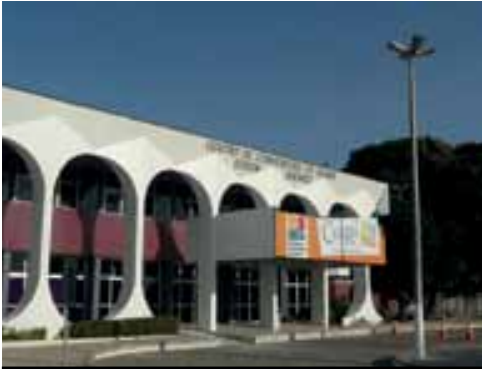

Fig. 2.3 Centro de Convenções Fonte: Panoramio

\subsubsection{A metropolização de Fortaleza}

O crescimento da cidade de Fortaleza, no que se refere à expansão da malha urbana e ao início da verticalização, tornou-se evidente durante os anos 1970-1980, quando a Região Metropolitana de Fortaleza (RMF) foi constituída oficialmente ${ }^{30}$. Já se percebia, então, um claro desequilíbrio na distribuição da população no território cearense, conferindo à Capital uma primazia absoluta, pelo acelerado crescimento e pela concentração demográfica.

A criação da RMF é questionada por alguns estudiosos da Cidade, quando se argumenta que não estaria ainda plenamente constituída uma Região Metropolitana ${ }^{31}$, portanto, não justificava a força de um decreto nesse sentido. De acordo com Amora (1999, p.35), "Fortaleza não se enquadrava

\footnotetext{
$\overline{{ }^{30} \mathrm{Em}} 1973$ é criada, pela Lei Complementar Federal n 14 a Região Metropolitana de Fortaleza, inicialmente com cinco municípios.

${ }^{31}$ Segundo relatório da AUMEF (1976), o objetivo do Governo federal com a criação das regiões metropolitanas foi antecipar a implantação de um sistema de Planejamento Metropolitano de modo a exercer uma ação preventiva e orientadora na região e minimizar os efeitos negativos de um processo acelerado de ocupação do território.
} 
rigorosamente na definição de metrópole, nem se constituía uma área metropolitana no sentido genérico desse conceito".

Silva e Dantas, em documento produzido pelo Observatório das Metrópoles também assinalam que

A oficialização da Região Metropolitana de Fortaleza foi do tipo compulsório, instituída e definida por força legal (Lei Complementar $n^{\circ}$ 14/73). No que tange à realidade socioespacial, sua institucionalização deu-se antes da manifestação do processo de metropolização (SILVA \& DANTAS, 2009, p.21).

Embora não se constatasse, de fato, uma realidade socioespacial metropolitana e apenas se esboçassem tendências de expansão do tecido urbano ultrapassando o município de Fortaleza ${ }^{32}$, já era reconhecida, entretanto, naquele momento, a existência de uma aglomeração urbana expressiva, que revelava sua grande área de influência, determinada principalmente pelo intenso fluxo migratório do interior para a Capital.

\section{O panorama nacional e o contexto local nas décadas de 1970 e 1980}

No plano nacional, a década de 1970-1980 conhece uma fase de desaceleração da economia, em conseqüência da chamada crise do petróleo, iniciada em 197333, que reduziu a capacidade de importação dos países desenvolvidos. O Brasil teve afetado o desempenho de seu desenvolvimento econômico, embora se registrasse crescimento em vários setores. Isso foi possível graças à implantação parcial do II PND, durante o Governo Geisel, que permitiu a implementação de alguns dos "grandes projetos", tais como o Projeto Carajás, a Usina de Tucuruí, no Pará, a Ferrovia do Aço e os Corredores de Exportação. Inicia-se a desconcentração industrial, que objetivava fortalecer o mercado unificado e descentralizar as atividades produtivas de São Paulo para o interior e para outros estados. A estratégia buscava alcançar a integração nacional e superar os desequilíbrios regionais.

A descentralização foi efetivada em diversas escalas, mas a hegemonia do capital paulista se manteve. Paralelamente, as desigualdades regionais se acentuaram, assim como ocorreu aumento na concentração de renda. Em conseqüência, desencadeou-se a chamada "crise dos anos $80^{\prime \prime}$, durante os governos Sarney e Collor, que resultou em recessão e no aumento da dívida externa.

O Ceará, em não promovendo uma política industrial significativa ${ }^{34}$, ficou à margem dos planos nacionais de desenvolvimento, embora apresentasse o mesmo quadro ${ }^{35}$ verificado no País no período, com crescente concentração de renda e marcado por desigualdades sociais.

\footnotetext{
${ }_{32}$ Essa expansão era materializada, sobretudo, pela instalação do Distrito Industrial de Maracanaú e os conjuntos habitacionais construídos nas vizinhanças e pela ocupação de trechos da faixa de praia nos municípios litorâneos, como segundas residências.

${ }^{33}$ Essa época assistiu ao fim do "milagre brasileiro".

${ }^{34} \mathrm{O}$ crescimento industrial ocorrido no Nordeste seria em decorrência primordialmente do Polo Petroquímico de Camaçari, na Bahia. No Ceará, houve um relativo desenvolvimento da indústria têxtil e de confecções (com base nos recursos do FINOR - Fundo de Investimentos do Nordeste) e a instalação de indústrias pioneiras, como a Companhia Siderúrgica Cearense, do Grupo Gerdau.

35 "A recessão dos anos 1980 e a crise fiscal do estado brasileiro tinham deixado marcas profundas na capacidade de investimento dos estados do Nordeste. A SUDENE já se encontrava bastante debilitada, com parcos recursos e sofrendo denúncias de corrupção" (BERNAL, 2006, p.307).
} 
Na ocasião, no Estado, prevaleceram por quase vinte anos (1963 a 1982) os chamados Governos "dos coronéis ${ }^{36 "}$, apoiados pelo regime militar vigente e caracterizado pela prática do clientelismo, que se baseava na "união da cúpula e na divisão das bases" (PARENTE, 2002, p.403). Durante os governos "dos coronéis", no entanto, há que salientar, foi implantada uma ampla infraestrutura", "a fim de dar suporte à industrialização incentivada pelo FINOR ${ }^{38}$ e pela SUDENE" (BERNAL, 2004, p.65).

Na conjuntura nacional, enquanto o país passava por uma recessão e apresentava inflação elevada, o Estado enfrentava secas e enchentes. Em 1980, o PIB cearense reduz-se a 1,55\% do PIB brasileiro e, em 1983, o setor agropecuário encolhe a renda interna do Estado de 18,9\% para 7,6\%. Assim, tal como no Brasil, torna-se baixo o crescimento econômico estadual. São propostos o PLAMEG II ${ }^{39} \mathrm{e}$ o PLANED ${ }^{40}$, no governo Gonzaga Mota (governador civil que sucedeu os coronéis), que tinham como objetivo reduzir as disparidades estaduais e elevar os níveis de renda.

\section{A fase inicial da metropolização de Fortaleza}

É durante a década de 1980-1990 que o Município de Fortaleza atinge níveis de urbanização bastante acentuados:

[...] a mancha urbana expande-se para o setor sudoeste em regiões limítrofes do perímetro urbano, iniciando-se o processo de fragmentação metropolitana associado a uma descentralização das indústrias, com um novo papel assumido pelo setor terciário que estimula os investimentos nas cidades de médio porte. Uma Fortaleza de contrastes e desigualdades, com uma intensa dinâmica econômica oriunda do mercado de imóveis e os maiores índices de exclusão social (PREFEITURA MUNICIPAL DE FORTALEZA. Plano Diretor de Desenvolvimento Urbano e Ambiental, 2008, p.90).

Por conseguinte, em meio a um fraco crescimento econômico, surge no $\mathrm{ClC}$ - Centro Industrial do Ceará - um movimento liderado por um grupo de jovens empresários, que passam a promover discussões em torno de um novo projeto político e econômico para o Estado. Esse grupo criou o Pacto de Cooperação Cearense ${ }^{41}$ e lançou as bases para o surgimento da candidatura ao governo de Tasso Jereissati, empresário e integrante do CIC.

No que se refere à expansão urbana, a Cidade começa a assumir ares de metrópole, com o surgimento de vários novos bairros, com a emergência da centralidade da Aldeota e dos subcentros nos bairros Montese, Seis Bocas, Parangaba e Alagadiço (Bezerra de Menezes), ao mesmo tempo em que se verifica o declínio do centro principal, com a perda de sua qualidade espacial e de sua memória, fenômeno que ocorre também em outras capitais brasileiras.

\footnotetext{
${ }^{36} \mathrm{O}$ "Governo dos Coronéis" caracterizou o quadro político cearense do período pós-64, quando o governo do Estado esteve predominantemente nas mãos de ex-militares, os coronéis Virgilio Távora, Adauto Bezerra e Cesar Cals, entre os anos de 1963 e 1982.

${ }^{37}$ A instalação do Distrito Industrial de Maracanaú, a energia trazida de Paulo Afonso e a ampliação da rede rodoviária constituíram os principais investimentos em infraestrutura no estado, nesse período. Em Maracanaú, junto ao Distrito Industrial, foram construídos grandes conjuntos habitacionais, que seguiam uma tendência iniciada em 1964, decorrente da política do BNH e que perdurou até o final dos anos 1980-1990.

${ }^{38}$ FINOR - Fundo de Investimentos do Nordeste.

${ }^{39}$ PLAMEG II: II Plano de Metas Governamentais 1979-1983, do segundo Governo Virgilio Távora.

${ }^{40}$ PLANED - Plano Estadual de Desenvolvimento (1983-1987), do Governo Gonzaga Mota.

${ }^{41}$ Segundo Philip Gunn (1994, p.3), o Pacto funcionou como uma instância de mediação entre o governo e a sociedade civil, e entre os distintos níveis de governo. Neste contexto, atuou como "um dos diversos mecanismos de articulação territorial de interesses, visando à problemática do desenvolvimento cearense".
} 
A legislação urbana aprovada na ocasião teve grande peso nas mudanças. As leis nº 4486 (1975) e $n^{\circ} 5122 A^{42}$ (1979), baseadas nas propostas do PLANDIRF, desempenharam importante papel ao permitirem a introdução de novos usos no espaço urbano (corredores de uso misto) e a verticalização, iniciada no final da década, que mudaram a fisionomia da Cidade. O prolongamento da av. Santos Dumont, regulamentado na lei de 1979, induziu o crescimento da Cidade para o leste, que se confirmava como espaço privilegiado das classes mais abastadas. A zona oeste ampliou-se como reduto da população de renda mais baixa, enquanto o processo de favelização mantinha curso.

Iniciava-se, também, nesse período o fenômeno da construção das residências de veraneio (ou segundas residências), que propiciou a ocupação de parte do litoral cearense, formando núcleos litorâneos ${ }^{43}$, sobretudo nos municípios vizinhos. A construção do $4^{\circ}$ Anel Viário $^{44}$, via que interliga as BRs 116, 020 e 222, foi uma realização importante na época, concebida com o propósito de disciplinar a expansão da Metrópole em direção aos municípios que compõem a RMF e facilitar a ligação entre as vias radiais, sem passar pela área central de Fortaleza.

Essas dinâmicas, verificadas nas décadas de 1970-1980 e 1980-1990, tiveram grande impacto na configuração metropolitana de Fortaleza.

\subsubsection{A Metrópole contemporânea}

\section{O Ceará do "Governo das Mudanças" e a consolidação da Metrópole}

O período transcorrido entre 1987 e 2002 tem particular significado para o Estado do Ceará, porque corresponde à vigência do chamado "Governo das Mudanças"4", quando a direção do Executivo fica a cargo do empresário Tasso Jereissati, oriundo do Grupo do CIC, citado anteriormente. A dinâmica do desenvolvimento do Estado nos últimos 20 anos deve-se, entre outras razões, ao fato de ter o Ceará desenvolvido uma política relativamente estável, comandada por um grupo integrante do empresariado local.

O Governo das Mudanças, com seu projeto de modernização e construção de uma "nova imagem" do Ceará, inaugura um novo modelo de administração ${ }^{46}$, caracterizado pela erradicação da prática política "coronelista", considerada conservadora e retrógrada, pela contenção dos gastos e correção do aparelho fiscal. Trata-se, sem dúvida, de um marco importante para o entendimento

\footnotetext{
42 "A lei 5.122-A, de 1979, inaugurou o novo "zoning" na cidade de Fortaleza. Definiu os Corredores de Atividades e de Adensamento, contribuindo para o processo de descentralização da cidade. Incentivou a verticalização e definiu o centro histórico como ZC-1 com a intenção de agregar uso residencial à área, o que não aconteceu. Nos Polos e Corredores de Adensamento (ZC-2) seriam permitidos índices de concentração maiores" (Síntese Diagnóstica do Município, 1992).

${ }^{43}$ Na década de 1970-1980 e na seguinte, surgiram vários loteamentos que se prestavam à construção de residências de veraneio nos núcleos litorâneos do Icaraí, Pacheco e Cumbuco (no Município de Caucaia, litoral oeste) e Prainha, Iguape, Presídio e Barro Preto (no Município de Aquiraz, litoral leste), induzindo a ocupação da orla marítima e ampliando o espaço urbanizado da Metrópole.

${ }^{44}$ A concepção do $4^{\circ}$ Anel Viário já havia sido prevista pelo PLANFIRF, em 1972, como forma de melhor integrar os diversos municípios da RMF.

45 "Governo das Mudanças": nome que o Poder Executivo local se conferiu, no período de 1987 a 2002. Tasso Jereissati elegeu seu sucessor, Ciro Gomes, em 1991 e reelegeu-se por duas vezes, em 1994 e 1998.

${ }^{46}$ Tasso Jereissati, eleito pelo PMDB em 1987, foi um dos fundadores do PSDB, em 1988. Utilizou a "cartilha" do novo partido em seus governos, denominada por uns de "neoliberal" e por outros de "social-democrata", confirmada no governo seguinte por seu aliado Ciro Gomes. A intenção era transferir para a administração pública o modelo de eficiência empresarial.
} 
do processo de mudanças que se estabeleceu desde então, para impulsionar o crescimento econômico do Estado.

No plano político nacional, esse período corresponde aos governos Sarney, Collor, Itamar e Fernando Henrique, quando ocorre a transição para a abertura política e redemocratização do País, assim também como o alcance da estabilização econômica, depois da crise dos anos 1980 e de quatro planos econômicos ${ }^{47}$.

Vivencia-se a chamada "globalização", manifestada na reestruturação produtiva, na abertura de mercado e liberalismo econômico, na informacionalização da sociedade e em mudanças culturais significativas. Por esse tempo, evidencia-se a penetração da ideologia do neoliberalismo no Brasil, que favorece a atuação da iniciativa privada, também em escala internacional, de acordo com as necessidades de reprodução do modo de produção capitalista e a superação da crise no processo de acumulação.

No Ceará, os dirigentes objetivaram repensar e reestruturar a economia local ${ }^{48}$, a fim de que pudessem ajustá-la, com êxito, ao novo cenário mundial e atender às novas exigências do desenvolvimento internacional. Alinhado ao Governo federal (FHC), e em consonância com o projeto neoliberal, tornam-se comuns as práticas das privatizações, diminuição do papel do Estado, regularização das finanças públicas, parcerias público-privadas e busca de investimentos estrangeiros.

As estratégias políticas do Governo local priorizaram as políticas que elegeram a indústria e o turismo como indutores do crescimento econômico ${ }^{49}$. Essas ações provocaram um forte incremento do fluxo turístico dirigido para o Estado e para a Capital, convertendo o Ceará, nos últimos anos, em polo receptor de grande fluxo turístico (ver item 2.4.3). Essa atividade assumiu papel de destaque na economia cearense e prospera como grande fonte de geração de emprego e renda para a região.

No que se refere ao desenvolvimento industrial do Estado, o Governo cearense oferece incentivos fiscais $^{50} \mathrm{e}$ financeiros para atrair indústrias de outros estados. Foram criados os polos industriais de Horizonte e Pacajus, que passaram, a partir de 1999, a integrar a RMF. A expansão metropolitana é visível ao longo da BR 116, junto às indústrias aí localizadas, que atraem grande parte da população.

A política de expansão da indústria e do turismo cearenses se ampara então em investimentos importantes em infraestrutura e grandes obras, como é o caso do Metrofor - metrô de Fortaleza (com investimento de 290 milhões de dólares e ainda não concluído), a construção da usina eólica em Aquiraz (1999), do Açude do Castanhão e do Canal do Trabalhador (1993), do novo aeroporto, inaugurado em 1998, do Complexo Industrial-Portuário do Pecém (2001), no Município de S.

\footnotetext{
${ }^{47}$ Plano Bresser (1987), Plano Verão (1989), Plano Collor (1990) e Plano Real (1994).

${ }^{48}$ As metas dos "governos das mudanças" estão contidas nos seguintes planos: Plano de Mudanças (1987-1991), $1^{\circ}$ Plano Plurianual 1992-1995, do Governo Ciro Gomes, e os dois Planos de Desenvolvimento Sustentável (1995-1998 e 1999-2002).

49 "A dinamização das atividades turísticas, da indústria da construção civil e das atividades especulativas, propiciada pela nova modalidade de gestão pública, introduziu elementos modernos, alterando o conteúdo da urbanização" (ACCIOLY, 2008, p.3).

${ }^{50}$ Os incentivos fiscais e financeiros, que constituem algumas das "facilidades" fornecidas pelo Estado, ao lado da oferta de infraestrutura e mão de obra barata, são conhecidos por "guerra fiscal", tida como estratégia de atração de capitais privados.
} 
Gonçalo do Amarante, e da ampliação do sistema viário da Região Metropolitana, principalmente os grandes corredores de acesso às zonas de praia ${ }^{51}$.

Houve intervenções significativas também no âmbito da Capital, como foi o caso da construção do Centro Cultural Dragão do Mar² (1999), da abertura da av. Sebastião de Abreu e duplicação da avenida/rodovia Washington Soares/CE 040 (1999). Verifica-se que os maiores investimentos ${ }^{53}$ do Estado se concentraram na Região Metropolitana de Fortaleza, provocando uma reestruturação espacial em seu território, ampliando a zona urbanizada e colocando a Cidade em destaque com relação às demais capitais nordestinas (ver figuras 2.4 a 2.6).

a reestruturação espacial que vem se processando no território cearense pode ser interpretada como fruto da liberalização dos fluxos de capital e comércio, que são, em última análise, fruto da reestruturação produtiva no nível nacional e da globalização financeira" (BERNAL, 2004, p.52).

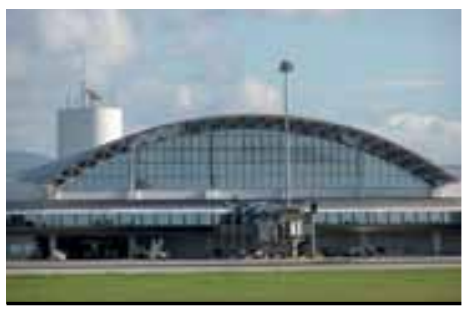

Fig. 2.4 Novo aeroporto Fonte: www.skyscrapercity.com

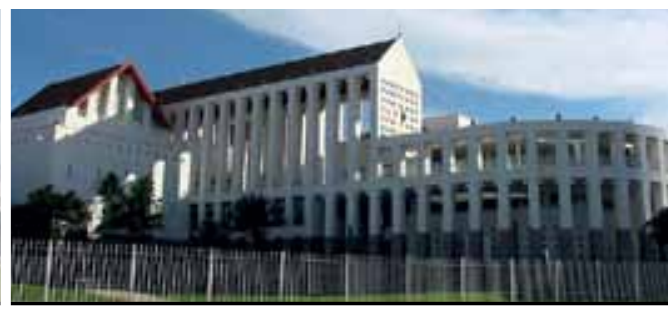

Fig. 2.5 Centro Dragão do Mar Fonte: www.dragaodomar.org.br/index.php

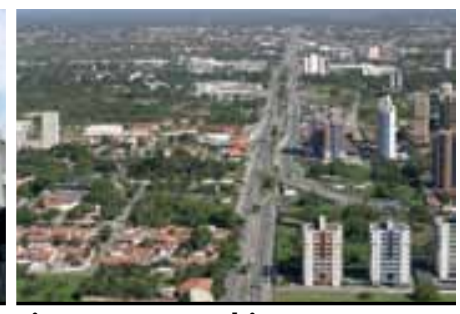

Fig. 2.6 Av. Washington Soares Fonte: www.skyscrapercity.com

Em 1992, foi aprovado o PDDU-FOR - Plano Diretor de Desenvolvimento Urbano de Fortaleza cujas propostas refletiram-se na Cidade, redundando no incremento da densidade demográfica e na verticalização acentuada. A aprovação da lei contribuiu para acelerar o processo de mudanças que já ocorria, modificando bastante a paisagem urbana de determinados bairros, particularmente no Meireles, Aldeota e Papicu.

Em suma, pode-se afirmar que, no período do "Governo das Mudanças", no Ceará, sem dúvida, houve avanços e a economia cresceu ${ }^{54}$, embora a participação no PIB nacional não tenha se alterado tanto, ficando em torno de 1,9\%, chegando a atingir 2,4\% em 1990. O Ceará cresceu em termos absolutos, mas continuou um dos estados mais pobres do Brasil. Houve mudanças, embora se constate a persistência de desigualdades sociais e regionais, pois acentuou-se a concentração de renda e os avanços nas áreas de educação e saúde ainda estão longe dos desejáveis.

\footnotetext{
${ }^{51}$ A ampliação do sistema viário e consequente melhoria na acessibilidade à orla marítima dos municípios litorâneos da RMF provocaram um incremento da atividade turística, o que influenciou sobremaneira na estruturação e expansão metropolitana.

${ }^{52}$ O Centro Dragão do Mar "inseriu-se nos fluxos turísticos da capital, mantendo uma atratividade cultural e de lazer indiscutível, (...) entretanto, há quase um consenso que foi uma estratégia política para incrementar a atividade turística em Fortaleza e reforçar não somente a imagem turística da cidade, mas a imagem do Governo das Mudanças" (PAIVA, 2011, p.251).

${ }^{53}$ Os investimentos em infraestrutura são em sua maioria financiados pelo BID (Banco Interamericano de Desenvolvimento) e através de parcerias formadas com o Governo federal, por meio de empréstimos do BNDES (Banco Nacional de Desenvolvimento Econômico e Social).

${ }^{54}$ Desde a segunda metade dos anos 1980-1990, o Ceará apresenta elevadas taxas de crescimento econômico, com taxas maiores do que as da Região Nordeste em seu conjunto e a do Brasil. Segundo dados do BNB/SUDENE, o PIB do Ceará cresceu a taxas mais elevadas do que as do PIB do Brasil (3,55\% contra 1,18\% respectivamente, no período de 1985-1990); entretanto, de acordo com Gondim (2002, p.424), "apesar do expressivo crescimento da economia cearense e da modernização dos métodos de gestão pública, permanece longínqua a meta de 'acabar com a miséria absoluta' no Ceará".
} 
Alguns indicadores selecionados do Atlas do Desenvolvimento Humano no Brasil, à época (PNUD, 2000), ilustram a realidade do Ceará, com relação aos 26 estados brasileiros:

- $8^{\circ}$ em população (7.444.000) - 4,4\% do contingente demográfico do país

- $12^{\circ}$ PIB (R\$20,8 bilhões) ou 1,9\% do PIB do Brasil

- $22^{\circ}$ em renda per capita (R\$2.794,00) ou 43,2\% do PIB per capita do Brasil

- $2^{\circ}$ maior desigualdade de renda: os $10 \%$ mais ricos ficam com $56,97 \%$ da renda

- $68 \%$ da população auferem menos de 1 salário mínimo

- $23^{\circ}$ taxa de alfabetização $(73,46 \%)$ - $5^{\circ}$ lugar no percentual de anafalbetos

- $23^{\circ}$ no índice de IDH

- $4^{\circ}$ lugar em pobreza $(56,80 \%)$

\section{A metrópole cearense atual}

No inicio do século XXI, Fortaleza consolida-se como metrópole nacional ${ }^{55}$, exercendo influência em espaço significativo do Nordeste. A Capital torna-se a quinta maior concentração urbana do País e vem mantendo a posição de líder no crescimento demográfico do conjunto metropolitano nordestino. A

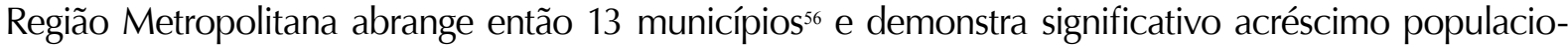
nal, contando com aproximadamente 3.500.000 habitantes. A metrópole expressa, "em sua estrutura, forma e movimento, a dinâmica da sociedade nacional, estando consoante com as transformações decorrentes das medidas políticas, econômicas e sociais adotadas no país nos últimos anos" (SILVA, 2002, p.216).

Concomitante ao primeiro governo do Presidente Lula, iniciado em 2003, o Ceará foi governado por Lúcio Alcântara, oriundo do PSDB, indicado por Tasso Jereissati, com quem rompeu posteriormente, durante o processo de reeleição, perdendo assim apoio fundamental, tendo em vista o papel do então senador, responsável em parte pela visibilidade que o Ceará adquiriu no âmbito nacional.

No plano federal, o governo Lula é marcado pela estabilidade econômica e pelo superavit da balança comercial. A dívida externa diminuiu, mas, por outro lado, cresceu o endividamento interno. Ao mesmo tempo em que o País se insere cada vez mais nas novas tendências da economia mundial, as políticas de distribuição de renda caracterizam a administração e elevaram a popularidade do Presidente, apesar das contínuas crises ligadas à corrupção no governo.

No Ceará, a ênfase é conferida à atividade turística, que se consolida como um novo fator econômico na viabilização do processo de desenvolvimento ${ }^{57}$ do Estado, amparado em investimentos estrangeiros. Intensifica-se o fluxo turístico, que passa de 200 mil visitantes em 1995 para 2,5 milhões em $2005^{58}$. É marcante a presença de investimentos estrangeiros, sobretudo espanhóis e portugueses, na construção de resorts e equipamentos de lazer.

\footnotetext{
${ }_{55}^{55}$ Segundo classificação do estudo produzido pelo IPEA/IBGE/UNICAMP, "Caracterização e tendências da rede urbana do Brasil".

${ }^{56}$ Os municípios de Cascavel e Pindoretama só foram incorporados à RMF no ano de 2009.

57 "As metrópoles nordestinas têm experimentado um notável dinamismo na última década, em razão dos financiamentos recebidos pelo BID destinados às grande obras de infraestrutura voltadas para o turismo e aos investimentos industriais realizados nos últimos anos. Porém, este crescimento tem tido pouco impacto nos segmentos mais pobres da população" (BERNAL, 2006, p.320).

${ }_{58}$ Atualmente (2012), registra-se um índice de 2,98 milhões de visitantes/ano. Conforme levantamento da Infraero, o número de desembarques no Aeroporto Internacional Pinto Martins aumentou 12,4\% em 2011. O crescimento foi o maior da região Nordeste, à frente de Rio Grande do Norte (6\%), Bahia $(7,6 \%)$ e Pernambuco $(8 \%)$. Em 2010, foram 2.658.315 desembarques entre domésticos e internacionais, enquanto em 2011 foram 2.989.218;
} 
Durante a administração do governador Lúcio Alcântara, foi proposta a construção do Centro de Eventos do Cearás9, projeto de grande porte que, depois de pronto, deverá proporcionar maior visibilidade à Capital cearense, nacional e internacionalmente, uma vez que incidirá em mais negócios para o Estado. Persiste o impasse com relação à propalada instalação de uma refinaria de petróleo e de uma siderúrgica no Porto do Pecém, obras prometidas pelo Governo federal desde a implantação do Complexo Portuário, ainda não concretizadas. A Siderúrgica, assim como outros grandes empreendimentos, se insere no projeto de desenvolvimento previsto para a região.

No ano de 2007, Cid Ferreira Gomes ascende ao poder estadual, rompendo posteriormente com o grupo do "Governo das Mudanças". Reeleito em 2010, conserva, entretanto, as mesmas políticas de promoção e desenvolvimento do Ceará, com base, sobretudo, na indústria e no turismo.

A escolha de Fortaleza, no ano de 2010, como uma das sedes da Copa do Mundo de Futebol de 2014 tem sido pretexto para uma agenda de modificações que devem ser efetuadas na Cidade, com obras de infraestrutura de grande porte, como reforma de estádios e construção de centros de treinamento, reforma e ampliação do aeroporto ${ }^{60}$, projetos de incentivo ao turismo, saneamento básico, energia, saúde e segurança, além de projetos de mobilidade urbana: trânsito, transporte e circulação. Segundo o plano de investimentos divulgado pelo Governo do Estado, as ações, no total, envolverão recursos ${ }^{61}$ da ordem de R\$ 9,4 bilhões.

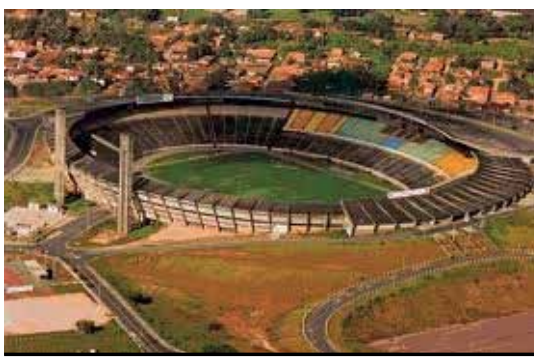

Fig. 2.7 Castelão

Fonte: http://colunas.imirante.com

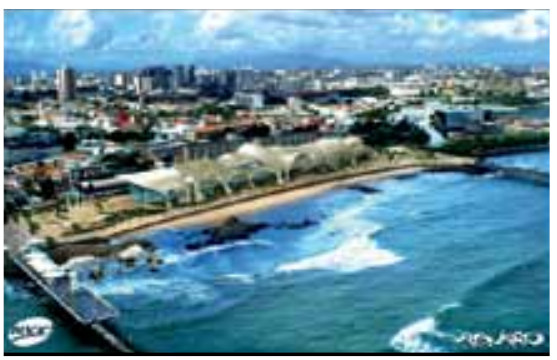

Fig. 2.8 Acquário

Fonte: www.skyscrapercity.com

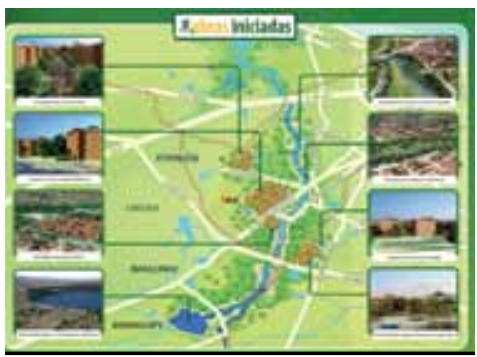

Fig. 2.9 Projeto Maranguapinho Fonte: Secretaria das Cidades - CE

Outras obras estão atualmente em andamento na Capital e na RMF, como a ampliação do porto do Mucuripe, a construção do Centro de Eventos e do Acquario ${ }^{62}$, a urbanização da av. Beira Mar, o Projeto Maranguapinho ${ }^{63}$, a construção do VLT - veículo leve sobre trilhos, a duplicação da CE 025 e do $4^{\circ}$ Anel Viário (ver figuras 2.7 a 2.9) Com a concretização de todas as obras

\footnotetext{
${ }^{59}$ O Centro de Eventos do Ceará encontra-se em fase de construção, devendo ser concluído em meados de 2012.

${ }^{60}$ A reforma do aeroporto, a ser concluída até o final de 2013, prevê a ampliação da sua capacidade para 9 milhões de passageiros por ano (atualmente recebe 6,2 milhões). A área do terminal passará de $38,5 \mathrm{mil} \mathrm{m}^{2}$ para $117,6 \mathrm{mil} \mathrm{m}^{2}$ (Dados da Infraero).

${ }^{61}$ Total de investimentos por área: Transporte e trânsito - R\$ 5,985 bilhões (63,3\%); Segurança - R\$ 114,702 milhões (1,2\%); Saúde - R\$248,68 milhões (2,6\%); Energia/telecomunicações - R\$ 42,689 milhões (0,5\%); Turismo - R\$ 851,208 milhões (9\%); Estádios - R\$ 451,961 milhões (4,8\%); Meio ambiente/saneamento - R\$ 1,764 bilhão (18,7\%); Total Geral - $\mathrm{R} \$ 9,4$ bilhões.

${ }^{62}$ A construção do Acquário (ainda não iniciada) faz parte do Projeto de Revitalização da Praia de Iracema. Trata-se de um projeto polêmico, por seu alto custo, seu aspecto formal e dimensões gigantescas, concebido por iniciativa do Governo do estado, com o propósito de constituir um equipamento com fins educacionais e científicos, e com objetivos turísticos.

${ }^{63}$ Segundo informações disponíveis no site da Secretaria das Cidades, "o Projeto Rio Maranguapinho é a maior intervenção urbana do Ceará e irá beneficiar cerca de 350 mil pessoas de Fortaleza e Região Metropolitana, em especial Maracanaú, Maranguape e Caucaia. Estão sendo executadas obras de dragagem, construção de conjuntos habitacionais, urbanização das margens do rio e barragem de contenção de cheias para evitar alagamentos. Ao todo, estão sendo investidos R\$ 497.548.859,29, do Governo Federal, com recursos do Programa de Aceleração do Crescimento (PAC), e do Governo do Estado". (http://www.cidades.ce.gov.br/cidades/categoria2/projeto-maranguapinho)
} 
previstas ${ }^{64}$, a Metrópole deverá ganhar, em determinados aspectos, uma nova feição e mudanças significativas na sua forma e estrutura urbana.

Em distintos pontos da área metropolitana, atualmente, percebe-se um expressivo incremento do setor imobiliário, de que participam investidores da região Sudeste na construção civil. A verticalização se acentua e a Cidade se expande na direção sudeste ${ }^{65}$, por força do surgimento de inúmeros condomínios fechados junto à CE 040, via que dá acesso ao litoral leste, onde se concentra a maioria dos equipamentos turísticos. Em conseqüência desse processo, surgem novas áreas de centralidade. Por outro lado, a periferização se expande com habitações precárias e muitas vezes localizadas em zonas de risco.

O quadro urbano atual revelado pela Metrópole cearense aponta para um centro urbano em expansão, extremamente dinâmico, que se consolida como polo nacional, porém evidenciando aspectos bastante contraditórios em seu conjunto ${ }^{66}$. Ao mesmo tempo em que apresenta uma "face" moderna, capaz de atrair os capitais privados, agravam-se os problemas, dentre os quais se sobressai a segregação socioespacial (as áreas valorizadas se expandem enquanto cresce em proporção maior o número de favelas e ocupações em áreas precárias).

\subsection{A ESTRUTURAÇÃO DO TERRITÓRIO METROPOLITANO - A RMF}

Neste item, serão abordados aspectos relativos à configuração física da Região Metropolitana de Fortaleza, além da caracterização dos diversos municípios que a compõem e o modo como interagem, bem como o papel polarizador da Capital no contexto metropolitano.

Conforme mencionado anteriormente, em 1973 foi criada a Região Metropolitana de Fortaleza - RMF, com a promulgação da Lei Complementar Federal $n^{\circ} 14$, a qual instituiu as nove regiões metropolitanas, localizadas em torno das principais capitais dos estados brasileiros.

A constituição da RMF já estava prevista pelo PLANDIRF - Plano de Desenvolvimento Integrado da Região Metropolitana de Fortaleza - elaborado em 1972, na gestão do Prefeito José Walter Cavalcante, pelo consórcio formado pela SERETE S/A, S.D. Consultoria de Planejamento e Jorge Wilheim Arquitetos Associados, com o apoio técnico e financeiro da SERPHAU.

Esse plano caracterizou-se, metodologicamente, como um diagnóstico do processo de expansão urbana de Fortaleza e pela análise integrada da Cidade no espaço regional, enfatizando a complementaridade intermunicipal, com vistas à problemática de sua área metropolitana. Entre os objetivos do PLANDIRF, com base no censo de 1970, estava o de identificar a Região Metropolitana de Fortaleza,

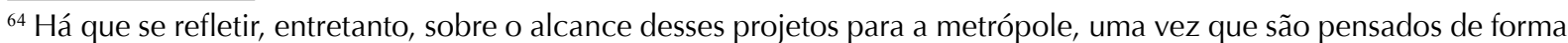
pontual, sem estarem inseridos em um processo mais amplo de planejamento. Sem isso, Fortaleza "continuará a acirrar suas contradições decorrentes da polarização da pobreza e das deficiências de sua infraestrutura" (FARIAS FILHO, Jornal O Povo, 19-02-2012).

${ }^{65} \mathrm{O}$ desenvolvimento e expansão recentes no setor sudeste da metrópole serão tratados com detalhes no capítulo 4.

${ }^{66}$ Com relação ao PIB do Estado, em 2010 houve um crescimento de 7,5\% em relação ao ano anterior. No que se refere à participação do PIB do Ceará no PIB nacional, em 2000, era de apenas 1,9\%. "Em 2009, um feito: o Ceará ultrapassou a faixa dos 2\% alcançando uma participação de 2,03\%. Em 2010, o Ceará andou mais um pouco chegando a 2,04\% da participação nacional. Mesmo positivo, o resultado mostra o grau de nossa pobreza. Afinal, temos uma população que ultrapassa os $4 \%$ da população nacional. A meta é igualar essa relação. Ou seja, mais que dobrar o atual PIB. Tarefa dificílima. Detalhe: em 1965, o Ceará obteve o melhor resultado na participação do PIB brasileiro, alcançando 2,23\%" (Coluna Política, Jornal O Povo, 17-03-2011).
} 
"caracterizando seus problemas básicos de sentido metropolitano, além de focalizar, em profundidade, os problemas locais do município, que são, em grande parte, de interesse metropolitano" (PLANDIRF, 1972).

A finalidade principal do plano, porém, era a integração regional, com o propósito de solucionar as diferenças entre os núcleos urbanos componentes da futura Região Metropolitana. Com efeito, as ligações viárias constituíram fator primordial para integrar a Capital aos demais municípios da RMF, papel exercido principalmente pelas rodovias BR 116 e BR 222. Da mesma forma, foi prevista também a construção de um anel rodoviário (o $4^{\circ}$ Anel Viário) para interligar esses municípios. Outra proposta relacionava-se à construção de conjuntos habitacionais, os quais serviriam para abrigar a população de mais baixa renda. Foi então indicada a instalação de grandes conjuntos na periferia de Fortaleza, nas proximidades das ligações viárias de cunho regional, principalmente ao longo da via férrea Caucaia-Pacatuba.

O PLANDIRF propôs uma abordagem da problemática metropolitana mais abrangente, envolvendo simultaneamente os diversos aspectos do processo de urbanização - físico, econômico, social e interinstitucional - sem perder de vista a dependência de diretrizes regionais, estaduais, federais e privadas, que interferem no processo de desenvolvimento urbano (MARQUES, 1986, p.119).

No plano, foram definidos os municípios que iriam compor a Região Metropolitana de Fortaleza: além da Capital, Caucaia, Aquiraz, Pacatuba e Maranguape. Foi então elaborado um diagnóstico da nova região, enfocando as relações econômicas intermunicipais da Capital com os demais municípios da RMF. O PLANDIRF ${ }^{67}$, sem dúvida, serviu de subsídio para a implementação da Região Metropolitana de Fortaleza, embora, em termos metropolitanos, suas propostas não tenham obtido os resultados esperados. Recomendações deixaram de ser atendidas e obras importantes propostas não foram executadas, o que impediu a solução de graves problemas. Persistem até hoje descontinuidades no sistema viário e congestionamentos na área central da Metrópole.

A institucionalização da RMF, na década de 1970-1980, coincide com um período de grande expansão da malha urbana de Fortaleza, que ultrapassou, posteriormente, os limites municipais, impondo novos desafios à gestão de um território expandido e fortemente dependente do núcleo principal.

Na ocasião, Fortaleza não se comparava, em termos econômicos, a metrópoles nacionais, como São Paulo e Rio de Janeiro, porém apresentava um patamar médio da realidade regional e, em escala local e microrregional, achava-se em estágio superior, acima de várias outras cidades e núcleos urbanos.

Atualmente, a RMF possui uma área de $5.794,7 \mathrm{~km}^{2}$ e é formada por 15 municípios (ver figura 2.10), com uma população de 3.615.767 (Censo IBGE, 2010) ${ }^{68}$, concentrando aproximadamente $42,78 \%$ da população do Estado ${ }^{69}$ (ver tabelas 4 e 5). A Região Metropolitana foi progressivamente ampliada, com a anexação de municípios, desde a sua criação, em 1973 (ver figuras 2.11 a 2.14).

\footnotetext{
${ }^{67}$ Embora boa parte de suas propostas não tenham sido implementadas, o PLANDIRF pode ser considerado como o plano que consolidou a estrutura urbana de Fortaleza, uma vez que o Plano Diretor Físico de 1975 e sua revisão, em 1979, se basearam em suas recomendações e foram, de uma forma ou de outra, adaptações dele.

${ }^{68}$ Segundo recente análise realizada pelo Instituto de Pesquisa Econômica Aplicada (Ipea), sobre o aumento populacional das nove maiores regiões metropolitanas do País e os problemas de mobilidade urbana nelas existentes, a população da Região Metropolitana de Fortaleza foi a que mais cresceu no Brasil na última década. A RM fortalezense passou de uma população de 3.056.769, em 2000, para 3.615.767 habitantes, segundo o Censo de 2010, ocupando a sexta posição nacional. Em uma década, a RMF registrou um crescimento significativo: 18,2\% ou mais de 553 mil novos habitantes.

${ }^{69}$ No Ceará, a população aumentou de 7.418 .476 em 2000, para 8.452.381 de pessoas em 2010, um aumento de 13,94\% (Censo IBGE 2010). Fortaleza se consolidou como a $5^{\text {a }}$ cidade mais populosa do Brasil e continua sendo a mais populosa do Ceará, agora com 2.452.185 habitantes, contra os 2.141.402 registrados em 2000.
} 
Fortaleza: a configuração socioespacial da Metrópole cearense

TABELA 4 - REGIÃO METROPOLITANA DE FORTALEZA: MUNICÍPIOS E POPULAÇÃO

\begin{tabular}{|c|c|c|c|c|c|}
\hline MUNICÍPIO & ANEXADO EM & LEGISLAÇÃO & ÁREA (km²) & $\begin{array}{l}\text { POPULAÇÃO } \\
(\mathbf{2 0 0 0 )}\end{array}$ & $\begin{array}{l}\text { POPULAÇÃO } \\
(\mathbf{2 0 1 0 )}\end{array}$ \\
\hline Fortaleza & Jun 1973 & LCF $14 / 73$ & 313,14 & 2.141 .402 & 2.452 .185 \\
\hline Caucaia & Jun 1973 & LCF $14 / 73$ & $1.227,89$ & 250.479 & 325.441 \\
\hline Aquiraz & Jun 1973 & LCF $14 / 73$ & 480,97 & 60.469 & 72.628 \\
\hline Pacatuba & Jun 1973 & LCF $14 / 73$ & 132,42 & 51.696 & 72.299 \\
\hline Maranguape & Jun 1973 & LCF $14 / 73$ & 590,82 & 88.135 & 113.561 \\
\hline Maracanaú & Abr 1986 & LCF 52/86 & 105,69 & 179.732 & 209.057 \\
\hline Eusébio & Abr 1991 & LE 11.845 & 78,65 & 31.500 & 46.033 \\
\hline Guaiuba & Abr 1991 & LE 11.845 & 267,20 & 19.884 & 24.091 \\
\hline Itaitinga & Dez 1999 & LE 18/99 & 150,78 & 29.217 & 35.817 \\
\hline Chorozinho & Dez 1999 & LE 18/99 & 278,40 & 18.707 & 18.915 \\
\hline Pacajus & Dez 1999 & LE 18/99 & 254,43 & 44.070 & 61.838 \\
\hline Horizonte & Dez 1999 & LE 18/99 & 159,97 & 33.790 & 55.187 \\
\hline S. Gonçalo & Dez 1999 & LE 18/99 & 834,39 & 35.608 & 43.890 \\
\hline Cascavel & Jun 2009 & LCE 78/09 & 837,96 & 57.129 & 66.142 \\
\hline Pindoretama & Jun 2009 & LCE 78/09 & 72,85 & 14.951 & 18.683 \\
\hline TOTAL & - & - & $5.785,82$ & 3.056 .769 & 3.615 .767 \\
\hline
\end{tabular}

Fonte: IBGE

TABELA 5 - REGIÃO METROPOLITANA DE FORTALEZA: DENSIDADE E TAXA DE URBANIZAÇÃO

\begin{tabular}{|c|c|c|c|c|c|}
\hline MUNICÍPIO & $\begin{array}{c}\text { DENSIDADE } \\
\left(\mathbf{h a b} / \mathbf{k m}^{2}\right)\end{array}$ & $\begin{array}{c}\text { TAXA DE } \\
\text { URBANIZAÇÃO } \\
(\%)\end{array}$ & $\begin{array}{l}\text { IDH } \\
(\mathbf{2 0 0 0 )}\end{array}$ & $\begin{array}{c}\text { PIB (R\$MIL) } \\
(\mathbf{2 0 0 8 )}\end{array}$ & $\begin{array}{c}\text { PIB PER CAPITA } \\
(\mathbf{R} \$) \\
(\mathbf{2 0 0 8 )}\end{array}$ \\
\hline Fortaleza & $7.786,52$ & 100,0 & 0,786 & 28.350 .622 & $11.461,22$ \\
\hline Caucaia & 265,93 & 89,2 & 0,721 & 1.952 .311 & $5.973,82$ \\
\hline Aquiraz & 150,50 & 92,4 & 0,670 & 496.794 & $7.052,83$ \\
\hline Pacatuba & 498,35 & 85,9 & 0,717 & 456.327 & $6.517,29$ \\
\hline Maranguape & 192,19 & 76,0 & 0,691 & 645.435 & $5.947,34$ \\
\hline Maracanaú & $1.877,75$ & 99,3 & 0,736 & 3.121 .055 & $15.620,27$ \\
\hline Eusébio & $58.264,00$ & 100,0 & 0,684 & 938.076 & $23.204,78$ \\
\hline Guaiuba & 94,83 & 78,4 & 0,652 & 73.580 & $3.130,79$ \\
\hline Itaitinga & 236,52 & 99,3 & 0,680 & 134.578 & $4.155,96$ \\
\hline Chorozinho & 67,94 & 60,4 & 0,633 & 71.220 & $3.794,36$ \\
\hline Pacajus & 243,00 & 81,9 & 0,678 & 414.878 & $7.118,57$ \\
\hline Horizonte & 344,96 & 92,5 & 0,679 & 837.005 & $15.946,59$ \\
\hline S. Gonçalo & 52,34 & 65,0 & 0,639 & 610.967 & $14.439,92$ \\
\hline Cascavel & 78,99 & 84,9 & 0,673 & 370.996 & $5.537,09$ \\
\hline Pindoretama & 256,06 & 60,4 & 0,657 & 57.876 & $3.211,43$ \\
\hline TOTAL & 623,97 & 96,1 & 0,767 & 38.531 .720 & $10.656,58$ \\
\hline
\end{tabular}

Fonte: IBGE e IPECE 
Segundo dados do IBGE, no período intercensitário 2000/2010, o crescimento geométrico anual da Região Metropolitana de Fortaleza foi da ordem de 1,9\% ao ano. No Município de Fortaleza, considerado 100\% urbano, a taxa de crescimento apresentou queda no período 2000/2010 em relação à década anterior, passando de 2,1\% para 1,3\% ao ano, ficando, portanto, abaixo da média da RMF.

Superaram Fortaleza quase todos os municípios da RMF, conforme o IBGE (2010): Horizonte (5,0\%), Eusébio (3,9\%), Pacajus (3,4\%), Pacatuba (3,4\%), Caucaia (2,6\%), Maranguape (2,5\%) Pindoretama (2,3\%), São Gonçalo (2,1\%), Itaitinga (2,1\%), Aquiraz (1,9\%) e Guiaiuba (1,9\%). Maracanaú e Cascavel registraram crescimento aproximado ao da Capital, de 1,6\% e 1,5\%, respectivamente. Apenas Chorozinho registrou crescimento inferior, de $0,1 \%$.

Ainda de acordo com os dados do Censo 2010, constata-se que a taxa de urbanização da RMF (96,2\%) é superior à do Estado do Ceará (75,1\%). Há municípios com população exclusivamente urbana, como Fortaleza e Eusébio, e municípios com população urbana abaixo da média do Ceará como São Gonçalo do Amarante (65,0\%), Chorozinho (60,4\%) e Pindoretama (60,4\%).

Com relação a esses dados e às taxas de crescimento diferenciadas entre os municípios, algumas considerações podem ser feitas. Na opinião de Dantas \& Pereira (2009, p.44),

A redução do ritmo de crescimento da Capital pode refletir, entre outros motivos, a valorização do solo urbano e a especulação imobiliária que afastam para os limites dos municípios vizinhos as populações de baixa renda; as políticas públicas habitacionais que geram a multiplicação de conjuntos habitacionais populares nas zonas periféricas à capital e a relocalização das indústrias na RMF que, estimuladas pelos benefícios fiscais e pela implantação de equipamentos urbanos, transferiram-se ou situaram-se em municípios vizinhos a Fortaleza.

Nos municípios litorâneos, a valorização dos terrenos propiciou a urbanização relacionada ao turismo, e, ultimamente, a transformação de residências de veraneio em residências permanentes, o que tem ocorrido em Aquiraz e Caucaia.

A população do Município de Fortaleza que, em 2000, totalizou 2.141.402 habitantes, no ano de 2010 registrou 2.452.185, o que perfaz 67,8\% da população da RMF $(3.615 .767)^{70}$.

Há de se ressaltar os índices apresentados pelos municípios de Caucaia (325.441 habitantes), Maracanaú (209.057 habitantes) e Maranguape (113.561 habitantes), que correspondem, respectivamente a 9,0\%, 5,8\% e 3,1\% da população da RMF. Esses municípios, juntamente com Fortaleza, concentram $85,7 \%$ da população metropolitana ${ }^{71}$ (ver tabela 4).

\subsubsection{A composição da RMF: caracterização e integração entre os municípios}

O processo de metropolização de Fortaleza revela a conformação de um território constituído de espaços variados. Momentos distintos se caracterizam por diferentes formas de ocupação, de políticas de uso do solo e de suas funções, resultando num espaço heterogêneo. Tal diversidade adquire, na totalidade da Metrópole, significados sociais (econômicos, políticos e culturais) que se articulam com o todo de maneiras também diferenciadas.

\footnotetext{
${ }^{70}$ Conforme dados divulgados pelo Censo 2010, a Região Metropolitana de Fortaleza registrou um crescimento significativo na última década: 18,5\% ou mais de 537 mil novos habitantes no período.

${ }^{71}$ Os índices são obtidos a partir do Censo de 2010.
} 
A formação da RMF, na sua composição político-administrativa, como visto, foi lenta, resultado da sucessiva incorporação de novos municípios, tanto pela fragmentação dos municípios originais, via emancipação de distritos, como pela inserção de novos municípios (ver tabela 6).

\section{TABELA 6 - EVOLUÇÃO POLÍTICO-ADMINISTRATIVA: RMF 1973/2009}

\begin{tabular}{|ccc|}
\hline ANO & No $^{*}$ DE MUNICÍPIOS & No DE DISTRITOS $^{1973}$ \\
1986 & 5 & 32 \\
1991 & 6 & 34 \\
1999 & 8 & 64 \\
\hline 2009 & 13 & 73 \\
\hline
\end{tabular}

Fonte: IBGE e IPECE

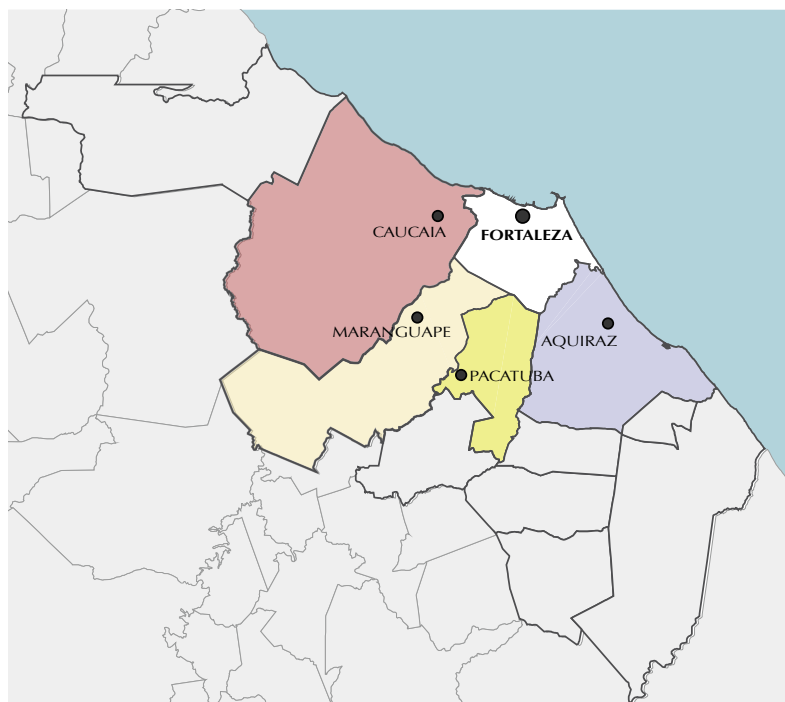

Fig. 2.11 Mapa RMF (1973)

Fonte: IPECE - elaborado pela autora

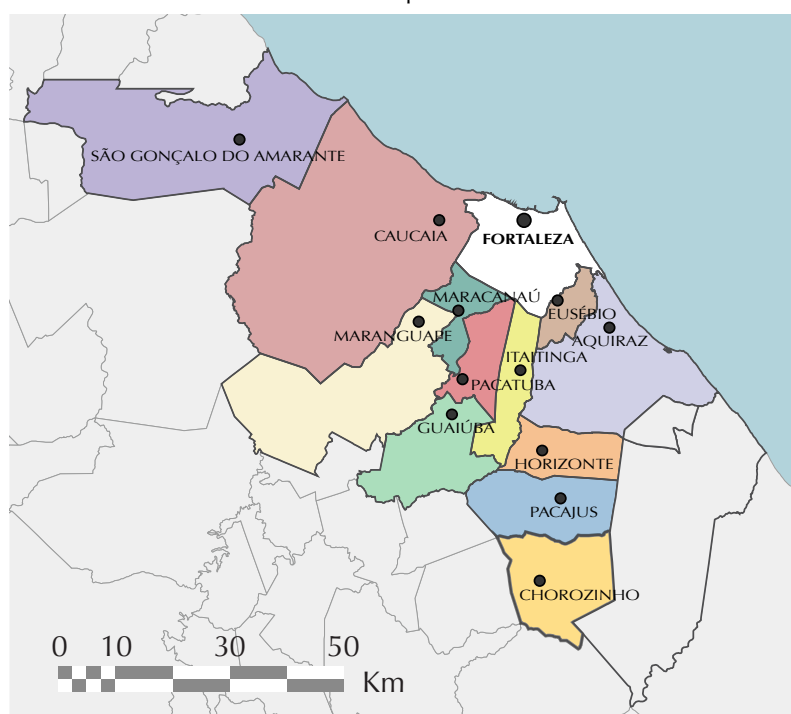

Fig. 2.13 Mapa RMF (1999)

Fonte: IPECE - elaborado pela autora

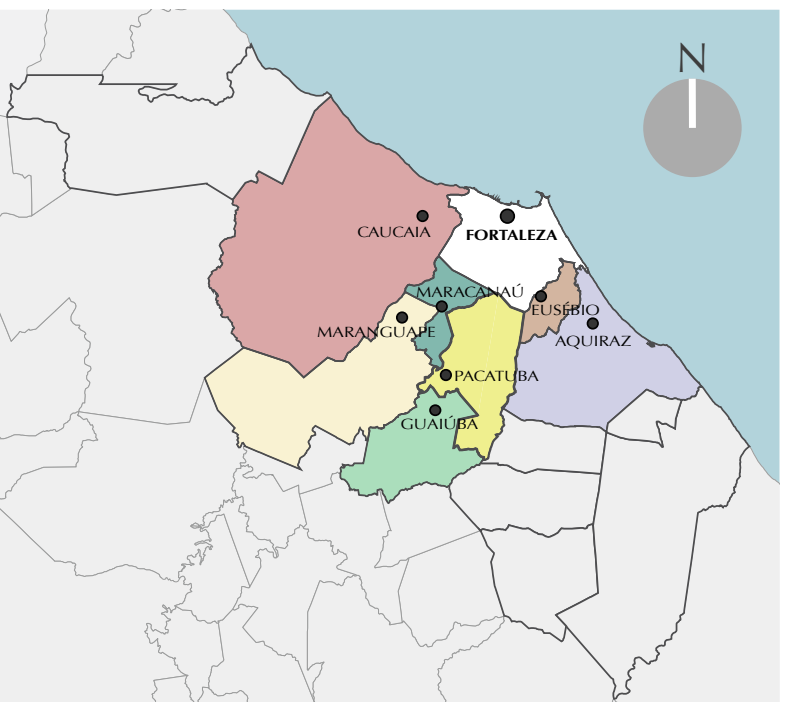

Fig. 2.12 Mapa RMF (1986)

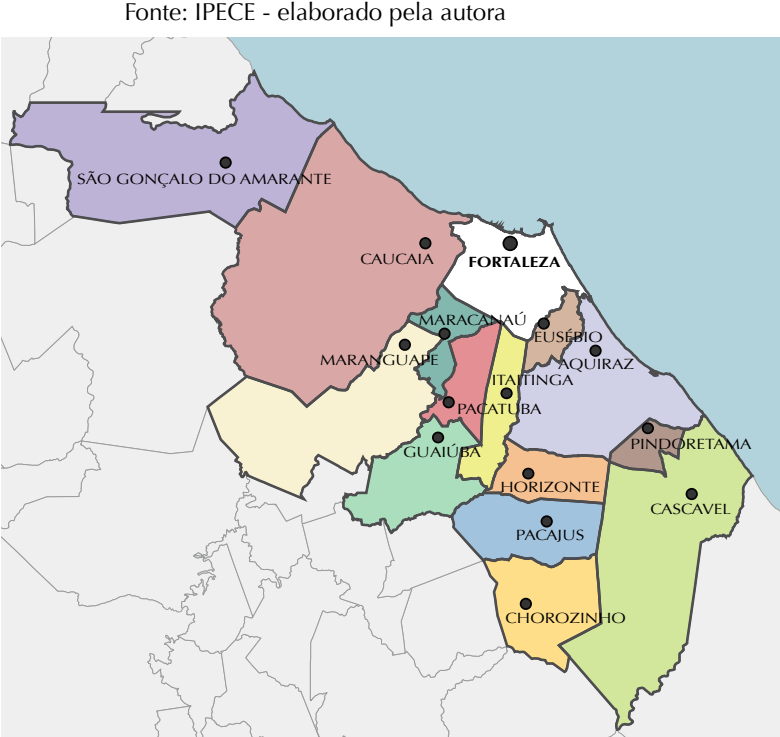

Fig. 2.14 Mapa RMF (2009)

Fonte: IPECE - elaborado pela autora 
A RMF foi ampliada quatro vezes; uma por designação federal e as três últimas por decisão estadual. Em 1986 é incorporado Maracanaú (figura 2.12), distrito emancipado de Maranguape, onde foi instalado o I Distrito Industrial do Ceará; em 1991, passaram a integrar a RMF Eusébio e Guaiúba, ambos emancipados respectivamente de Aquiraz e de Pacatuba. Em 1999, foram incorporados os municípios de Chorozinho, Horizonte, Pacajus, Itaitinga e São Gonçalo do Amarante (figura 2.13). A justificativa da inclusão dos municipios de Guaiúba, Eusébio e Itaitinga foi a emancipação dos antigos municípios dos quais eram distritos, como também por conseqüência da dinâmica industrial e, no caso de São Gonçalo do Amarante, pela instalação do Porto do Pecém.

O último arranjo se verificou no ano de 2009, com a incorporação de mais dois novos municípios, Cascavel e Pindoretama (figura 2.14).

Caucaia, município mais populoso depois de Fortaleza, destaca-se como área-dormitório, pelo grande número de pessoas que se desloca diariamente para trabalhar em Fortaleza, enquanto Maracanaú se sobressai pelas funções econômicas, ligadas a atividades industriais e de serviços.

A construção de conjuntos habitacionais ${ }^{72}$ nas imediações do Distrito Industrial, em Maracanaú, em meados da década de 1970-1980, contribuiu para o crescimento populacional do Município e para a reprodução do padrão periférico de urbanização. O surgimento desses grandes conjuntos propiciou nova dinâmica no territorio metropolitano e ampliou as relações entre o núcleo central e as periferias metropolitanas.

Estratégia semelhante foi adotada com relação a Caucaia, onde também foram implementados diversos conjuntos habitacionais e loteamentos populares, sem condições mínimas de infraestrutura. Atualmente, Caucaia e Maracanaú representam as principais concentrações populacionais da RMF, depois de Fortaleza.

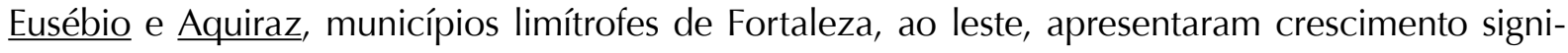
ficativo desde as últimas décadas, resultado dos investimentos em infraestruturas vinculadas às políticas de desenvolvimento turístico, entre as quais se destaca a duplicação da rodovia CE-040, corredor de deslocamento para o litoral leste.

Pacatuba, vizinho a Maracanaú, embora possua 26 indústrias, ainda tem sua economia baseada na agricultura (algodão, banana, caju, cana-de-açúcar, mandioca e feijão) e pecuária (bovino, suíno e avícola). E Guiauba, antigo distrito de Pacatuba, é o Municipio da RMF que mais apresenta caracteristicas rurais, com área considerada urbanizada ${ }^{73}$ de $78,35 \%$.

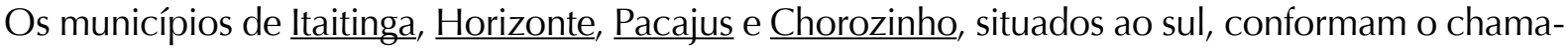
do "corredor industrial" da BR 116 e, inseridos na atual dinâmica industrial do Estado, vêm redefinindo importantes elementos em sua organização socioespacial; entretanto, apesar da crescente implantação de indústrias em seus domínios, ainda conservam grande parte de sua população vinculada às atividades agrícolas.

\footnotetext{
${ }^{72}$ Foi construído nesse período um total de dez conjuntos habitacionais, que representavam mais de 30.000 unidades habitacionais.

${ }^{73}$ Os municípios de Chorozinho e Pindoretama são os que apresentam menor taxa de urbanização na RMF, ambos com $60,4 \%$, menor que a do estado do Ceará.
} 
Vale chamar a atenção para o processo de incorporação de municípios à RMF, o que na maioria das vezes resulta de decisões meramente políticas, sem obedecer a critérios outros, que justifiquem a sua inclusão.

A lógica de identificação dos municípios que compõem a RMF segue critérios marcadamente institucionais, sendo os municípios integrantes da metrópole indicados por legislação própria, sem considerar a existência ou não de indicativos da coesão metropolitana (SILVA \& DANTAS, 2009, p.29).

A progressiva ampliação da RMF, se, por um lado acarreta a ampliação da área urbana, leva também à reflexão quanto à legitimidade de tais ações, ao serem incorporados municípios sem qualquer expressividade, pouco populosos, com baixíssima densidade demográfica e economia predominantemente rural. Assim, pode-se questionar em que medida a dimensão institucional se distancia de um processo efetivo de metropolização.

A anexação de novos municípios à RMF propicia também a alteração das legislações municipais, com ampliação das zonas urbanas, a despeito de suas características marcadamente rurais. Além disso, há de se ressaltar a precariedade de marcos regulatórios urbanos. Com exceção de Fortaleza, os demais municípios da RMF só vieram a ter Planos Diretores Urbanos a partir do ano de 2000.

Assim sendo, há que se questionar acerca do sentido de se expandir a RMF, abarcando cada vez maior número de municípios. O que justifica, por exemplo, a recente inclusão de Pindoretama e Cascavel, inseridos no ano de 2009? É inegável que a referida ampliação da área metropolitana apresenta forte efeito político-administrativo, sem, entretanto, provocar grandes alterações quanto à expressão da RMF sobre o total do Estado do Ceará ou outros impactos mais significativos.

\section{A integração entre os municípios na dinâmica metropolitana}

Os quase 40 anos que se passaram entre o desenho metropolitano proposto desde a criação da RMF, em 1973, até a configuração atual, evidenciam, por um lado, mudanças de escala, com a ampliação do território metropolitano e o grande crescimento populacional e, por outro, a mudança nas relações de integração e complementaridade entre os municípios. Estas relações constituem espacialidades diversas, que enfatizam o caráter heterogêneo da Região Metropolitana de Fortaleza.

Os vínculos metropolitanos estabelecidos entre Fortaleza e o espaço à sua volta eram, até bem pouco tempo, bastante tênues, haja vista a grande supremacia da Capital. Na fase inicial, quando da instituição da RMF, além da proximidade física, não se percebiam claramente maiores inter-relações dos cinco municípios que deram origem ao espaço metropolitano. Aos poucos, esses vínculos foram se formando e atualmente já se verifica maior nível de integração ${ }^{74}$ entre os vários municípios que compõem a RMF.

Desses, alguns possuem elevado grau de interação na dinâmica da aglomeração, principalmente aqueles situados junto ao núcleo principal; outros possuem nível médio e outros ainda apresentam índices muito baixos.

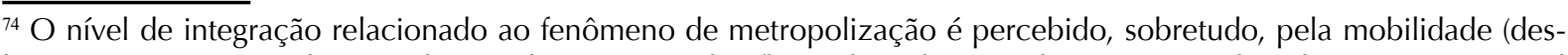
locamentos intrametrolitanos) da população, "a qual reflete, além do grau de integração da aglomeração, o papel desempenhado, as funções e a complementaridade entre os municípios integrantes da RMF" (ACCIOLY, 2009, p.152).
} 
Nesse tocante, Silva \& Dantas assinalam que:

[...] os níveis de integração maiores no aglomerado são percebidos nos municípios vizinhos, com histórico de integração antigo com o polo, Maracanaú e Caucaia;(...) os municípios classificados como de níveis baixos de integração representam, sobremaneira, municípios com forte participação da atividade rural, diferenciando-se os com indicadores alterados em virtude da inserção a longo tempo, no caso de Maranguape, e associado, também, à racionalidade de incorporação dos espaços litorâneos pelo empreendedores do turismo e imobiliário, no tocante a Aquiraz (2009, p.34).

Os municípios com baixo índice de integração nesse conjunto são os de Guaiuba, Pindoretama e Cascavel, primeiramente pela distância maior do Município-Sede; depois por apresentarem características ainda nitidamente rurais. A população dessas áreas mais afastadas do núcleo central distribui-se de forma dispersa pelo território, com grande carência de serviços básicos, como saúde e transportes coletivos.

O Município de Eusébio insere-se num nível de integração alto, pela proximidade de Fortaleza e pela progressiva localização da função residencial direcionada a segmentos das classes mais abastadas. São Gonçalo do Amarante se encontra numa fase de transição, tendo em vista a localização do Porto do Pecém em seu território, que propicia fluxo cada vez mais intenso em direção à Capital e vice-versa.

No que se refere ao conjunto dos municípios, Pacatuba recebe forte influência de Maracanaú, que abriga o Distrito Industrial e concentra inúmeros conjuntos habitacionais construídos com recursos públicos, além de dispor de loteamentos destinados aos segmentos populares. Itaitinga mantém complementaridade de atividades com Pacatuba, seu município de origem, do qual foi desmembrado. Guaiuba, também antigo distrito de Pacatuba, ainda conserva com este fortes vínculos e apresenta expressiva participação da atividade agrícola.

Maranguape, vizinho a Pacatuba, abrigava anteriormente sítios e chácaras de famílias tradicionais. Diferencia-se dos demais municípios por concentrar maior número de distritos ligados às atividades rurais. Atualmente é alvo de investimentos industriais.

Eusébio, desmembrado de Aquiraz, apresentou expressivo crescimento nos últimos anos, sobretudo desde a instalação em seu território da Fábrica Fortaleza, do Grupo M. Dias Branco. Atualmente, é escolhido como local preferencial para a instalação de condomínios residenciais. Aquiraz demonstra pouca alteração em sua fisionomia urbana, no que se refere à sua sede. Manifesta, entretanto, crescimento significativo em seu litoral, considerado o principal polo turístico do Estado, depois de Fortaleza, com investimentos crescentes em equipamentos de turismo e lazer, aliado à expansão e melhoramento da malha viária.

Como se pode observar, de maneira geral, os municípios que possuem atributos ou funções econômicas, industriais ou turísticas passaram por transformações significativas, enquanto, outros, como Chorozinho, Guaiuba e Pindoretama pouco se modificaram.

Percebe-se, por conseguinte, que a expansão da Região Metropolitana é pautada muito mais na dimensão econômica do que na espacial, porquanto os investimentos públicos se direcionam essencialmente para viabilizar a produção econômica. 
No que se refere aos municípios litorâneos, constata-se que

[...] além das políticas econômicas, fiscais, habitacionais e a própria lógica da dinâmica metropolitana, os investimentos nos eixos viários estruturantes, avenida Leste-Oeste/ Rodovia Sol Poente e Avenida Washington Soares/ Rodovia Sol Nascente foram elementos determinantes de integração e coesão (ACCIOLY, 2009, p.139).

Também se percebe, no território metropolitano, a existência de alguns processos de conurbação entre os diversos municípios, processos estes que, do ponto de vista territorial, viabilizam o surgimento e consolidam aglomerados urbanos de maior porte. Podem ser destacados, por exemplo, modelos desse tipo em alguns trechos da faixa litorânea oeste, pela sua linearidade e densidade orientadas pelos investimentos em infraestrutura e pelos empreendimentos do setor imobiliário e, mais ainda, nas franjas periféricas, ao oeste e ao sul, principalmente nos limites entre Fortaleza e Caucaia e Fortaleza e Maracanaú, onde predomina uma expansão diversificada, associada às camadas mais populares, resultado de programas habitacionais públicos e de invasões ou ocupações espontâneas.

Outro aspecto a assinalar diz respeito à precariedade da mobilidade da população no âmbito do território metropolitano, em decorrência da falta de um sistema eficiente de transporte público. Apenas os Municípios de Caucaia, Maracanaú, Eusébio e Aquiraz são mais bem servidos pelo transporte de massa. São, portanto, grandes as dificuldades de mobilidade da população, provocando maior descontinuidade urbana e maior tempo de percurso até o centro de Fortaleza, além de dificultar a integração dos municípios ${ }^{75}$.

Os 15 Municípios que compõem a RMF apresentam, portanto, realidades socioeconômicas e espaciais diversificadas e desiguais, manifestando diferentes níveis de integração e coesão metropolitana. A inexistência de políticas públicas de caráter metropolitano e de redistribuição de investimentos, associadas às precárias condições econômicas e financeiras dos diversos municípios, impediram a descentralização das atividades e da população. Desta forma, a repartição dos benefícios da metropolização atinge diferencialmente cada um deles, concentrando-se em áreas menos vulneráveis e, consequentemente, aumentando a desigualdade socioespacial.

Por outro lado, a Capital, além de polo de decisão e controle, continua a concentrar as principais funções econômicas, educacionais e culturais, mantendo relações assimétricas com os demais municípios, dificultando a integração metropolitana.

\subsubsection{O papel polarizador Fortaleza e a questão da macrocefalia urbana}

A presença marcante de Fortaleza no contexto metropolitano cearense e em todo o Estado atesta a sua condição de macrocefalia urbana, bastante expressiva quando comparada ao resto das metrópoles brasileiras. "É, sem dúvida, significativa a diferença de tamanho urbano, de qualidade de vida e possibilidades de emprego e renda quando se compara a capital com as demais cidades do interior" (PEQUENO, 2009, p.225).

\footnotetext{
${ }^{75} \mathrm{O}$ sistema viário metropolitano é estruturado e direcionado para o núcleo (Capital).
} 
A macrocefalia ${ }^{76}$ urbana pode ser entendida como o resultado da grande concentração de atividades econômicas, principalmente de serviços, e, portanto, de população, em algumas cidades, que acabam se tornando muito grandes, relativamente, e se tornam dominantes em relação a outras, ocasionando um desequilíbrio na rede urbana.

Embora esse fenômeno ocorra também em países desenvolvidos, ele assume proporções maiores nos países periféricos. Nesse caso, caracteriza-se pelo crescimento acelerado dos centros urbanos, principalmente nas metrópoles, acompanhado de um processo de marginalização da população, resultando em processos de exclusão socioespacial.

O Município de Fortaleza, com 2.452.185 habitantes, conforme o último censo do IBGE (2010), é atualmente a quinta cidade do País em população e a que possui a maior densidade demográfica ${ }^{77}$. A Cidade incorpora diretamente as atividades da população de vários municípios vizinhos, que compõem a Região Metropolitana. Sua predominância no Estado ${ }^{78}$ é marcante, e revela uma situação histórica de desequilíbrio regional.

A Capital cearense mantém, no âmbito estadual, primazia absoluta sobre os demais centros urbanos, concentrando-se nela quase 29,0\% da população do Ceará e 67,8\% da Região Metropolitana. Cabe ressaltar que a segunda cidade mais populosa do Estado, Caucaia ${ }^{79}$, tem 325.441 habitantes, ou seja, apenas 13,3\% da população da Capital, enquanto a segunda, Juazeiro do Norte, possui 249.939 e Sobral, ao norte, conta com 188.233 habitantes (Censo 2010). Essa realidade confirma a importância de Fortaleza e seu poder de concentração na RMF.

Atualmente, dos 184 municípios cearenses, apenas sete registram população superior a 100 mil habitantes, dos quais, quatro se encontram na Região Metropolitana: Fortaleza, Caucaia, Maranguape e Maracanaú.

A importância de Fortaleza não se reflete só no incremento populacional, mas também numa cidade que adquiriu nas últimas décadas especial destaque na região Nordeste, em termos econômicos e políticos. Com o segundo maior PIB (28,4 bilhões de reais) entre as capitais da região ${ }^{80}$, constitui importante centro comercial e industrial do País. No turismo, a Cidade alcançou a marca de destino mais procurado entre as capitais do Nordeste.

Fortaleza, por sua posição de importante entreposto comercial, associada à sua condição de sede político-administrativa do Estado, assume papel hegemônico na rede urbana cearense, exercendo forte atração com relação aos demais municípios da Região Metropolitana e do estado como um todo. Situa-se, portanto, como centro de referência, comando e controle político, econômico e cultural, coordenando e polarizando as atividades produtivas, de comércio e serviços e, consequentemente, de mercado de trabalho.

\footnotetext{
${ }^{76}$ A macrocefalia, segundo o Novo Dicionário da Língua Portuguesa (FERREIRA, A.B.H.), é definida como "a qualidade de quem tem a cabeça, ou parte dela, desenvolvida anormalmente."

77 Numa área de 315,00 km² habitam 2.452 .185 moradores, o que resulta numa densidade de 7.785 pessoas por km². Essa alta concentração da população em Fortaleza se explica não só pelo crescimento vegetativo, mas também por ser o município do Estado que oferece as maiores facilidades, oportunidades e investimentos em infraestrutura e, portanto, atrai população de outros municípios.

${ }^{78}$ Diferentemente de outros estados do Nordeste, como Bahia, Paraíba e Rio Grande do Norte, que possuem cidades relativamente importantes no interior, o Ceará apresenta uma configuração espacial altamente concentrada.

${ }^{79} \mathrm{O}$ município de Caucaia possui área quase quatro vezes maior que Fortaleza (ver tabela 3).

${ }^{80}$ A capital do Nordeste que tem o maior PIB é Salvador (29,7 bilhões).
} 
Silva (2002) destaca o papel preponderante de Fortaleza no contexto cearense e metropolitano:

A lenta consolidação do sistema urbano cearense ocorre tardiamente e, na verdade, até hoje, a rede de cidades no estado apresenta-se frágil, sob o comando intenso de Fortaleza, exemplo acabado do fenômeno da macrocefalia urbana, que explica o crescimento desmesurado da capital, em detrimento das cidades do interior (SILVA, 2002, p.217). (...) Fortaleza firma-se fortemente no cenário metropolitano, ampliando seu raio de influência direta e incorporando novas funções. Seu crescimento acelerado interfere sobremaneira no território da Região Metropolitana, facilitando a expansão da malha viária, de redes e sistemas cada vez mais integrados (IDEM, p.231).

No ano de 1972, conforme estudo elaborado pela geógrafa Salete de Souza, Fortaleza já teria "uma área de influência que abrangia 52 centros regionais, perfazendo um raio de ação de 400 mil $\mathrm{km}^{2}$ de área e uma cobertura populacional para quase 7 milhões de pessoas residentes no Ceará, Maranhão e Piauí" (SOUZA, 1978, p.74).

Essa influência se mantém até hoje, quando a Cidade desempenha um papel de capital regional que comanda amplo espaço, chegando a ultrapassar os limites do Estado. Esse papel polarizador é confirmado pelo estudo do IBGE - Regiões de Influência de Cidades ${ }^{81}, 2007$ - que identifica no País 12 grandes redes de influência, as quais interligam até mesmo municípios situados em diferentes estados (ver figura 2.16). Segundo o estudo, "na rede de Fortaleza, a terceira maior em população do País, apenas 15,8\% da população total encontram-se na metrópole. Abrange o Ceará, Piauí e Maranhão e compartilha a área do Rio Grande do Norte com Recife."

A capital do Ceará só perde para São Paulo e Rio de Janeiro como centro de influência urbana, servindo de principal referência para uma população de mais de 20 milhões de pessoas, distribuídas nos estados do Ceará, Piauí, Maranhão e parte do Rio Grande do Norte e Paraíba.

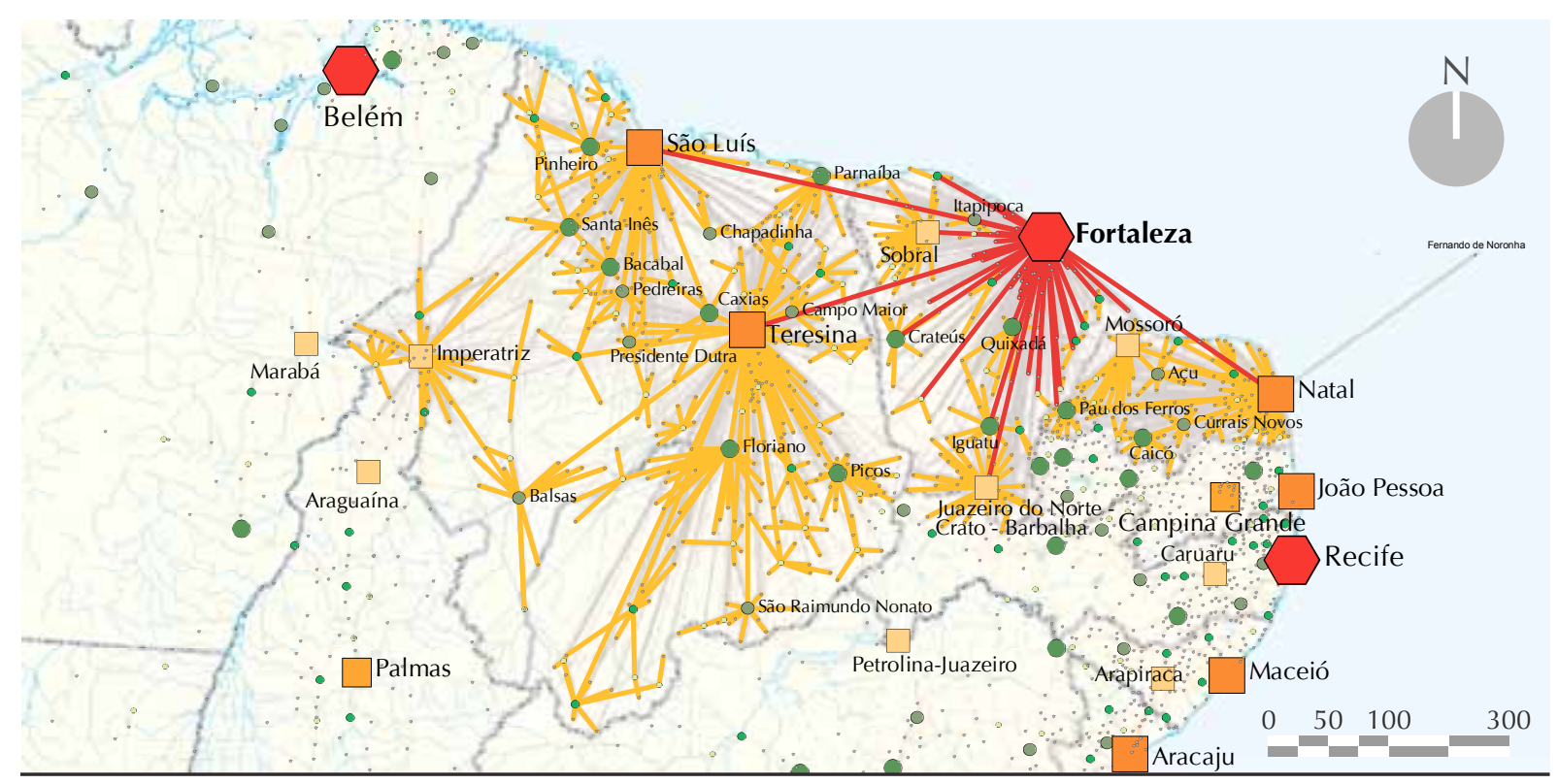

Fig. 2.16 Mapa Regiões de Influência IBGE (Fortaleza) Fonte: IBGE

${ }^{81}$ O estudo Regiões de Influência das Cidades mostra as redes formadas pelos principais centros urbanos do país, baseadas na presença de órgãos do Executivo, do Judiciário, de grandes empresas e na oferta de ensino superior, serviços de saúde e domínios de internet. Tais redes, às vezes, se sobrepõem à divisão territorial oficial, estabelecendo forte influência até mesmo entre cidades situadas em diferentes unidades da Federação. 
Esta situação de desequilíbrio na rede urbana cearense, herança também da migração provocada pelo fenômeno das secas, demonstra sua capacidade de atração e concentração, visíveis nas estatísticas de população, na taxa de urbanização, na concentração de renda, nos níveis de produção (ver tabela 8) e nos índices de geração de empregos ${ }^{82}$ (tabela 7). Estas disparidades quantitativas e qualitativas são visíveis na dimensão metropolitana, configurando um quadro de diferenciação relativamente aos demais municípios da RMF.

TABELA 7 - EMPREGOS FORMAIS POR MUNICÍPIO: RMF 2007-2010

\begin{tabular}{l|rrrr} 
MUNICÍPIOS & \multicolumn{1}{|c}{$\mathbf{2 0 0 7}$} & $\mathbf{2 0 0 8}$ & $\mathbf{2 0 0 9}$ & \multicolumn{1}{c}{$\mathbf{2 0 1 0}$} \\
\hline Total do Estado & 1.059 .392 & 1.129 .999 & 1.236 .261 & 1.325 .792 \\
RMF & 709.239 & 775.606 & 842.784 & 922.316 \\
\hline Aquiraz & 11.848 & 11.905 & 12.668 & 11.759 \\
Cascavel & 6.424 & 5.849 & 6.617 & 5.698 \\
Caucaia & 18.103 & 20.861 & 25.905 & 28.156 \\
\hline Chorozinho & 1.770 & 1.978 & 2.193 & 1.959 \\
\hline Eusébio & 25.891 & 28.296 & 31.274 & 34.212 \\
\hline Fortaleza & 560.475 & 614.690 & 660.745 & 725.525 \\
\hline Guaiúba & 1.702 & 1.951 & 2.229 & 2.857 \\
Horizonte & 14.829 & 15.812 & 18.240 & 21.240 \\
\hline Itaitinga & 2.367 & 2.237 & 2.814 & 3.119 \\
Maracanaú & 35.951 & 40.104 & 45.215 & 49.169 \\
\hline Maranguape & 12.316 & 12.522 & 13.285 & 14.305 \\
\hline Pacajus & 6.461 & 6.980 & 7.982 & 8.312 \\
\hline Pacatuba & 6.089 & 6.414 & 6.612 & 6.515 \\
\hline Pindoretama & 1.338 & 2.010 & 1.815 & 1.669 \\
\hline São Gonçalo do Amarante & 3.675 & 3.997 & 5.190 & 7.821 \\
\hline Fonte: RAIS/MTE & & & &
\end{tabular}

Fonte: RAIS/MTE

Nos últimos anos, as políticas de industrialização e de desenvolvimento das atividades turísticas, marcadas pelas obras de infraestrutura, principalmente viárias, aumentaram a atração de Fortaleza e reforçaram ainda mais os contrastes entre o núcleo central e os demais municípios da RMF.

A acentuada centralidade exercida por Fortaleza sobre toda a área metropolitana se evidencia também com clareza pela forma de ligações rodoviárias. A radioconcentricidade de seu sistema viário original mantém forte influência na distribuição da população e dos principais núcleos de prestação de serviços (ver figura 2.17). A magnitude desse processo provocou a duplicação das rodovias que partem da Capital em direção ao restante do Estado. A melhoria da qualidade da circulação nesses corredores de atividade e de adensamento amplia a ação do Município-polo e reforça sua centralidade.

\footnotetext{
82 Do total de empregos gerados no Estado do Ceará em 2010, 55\% ficaram em Fortaleza. E do total da RMF, 80\% foram para Fortaleza.
} 


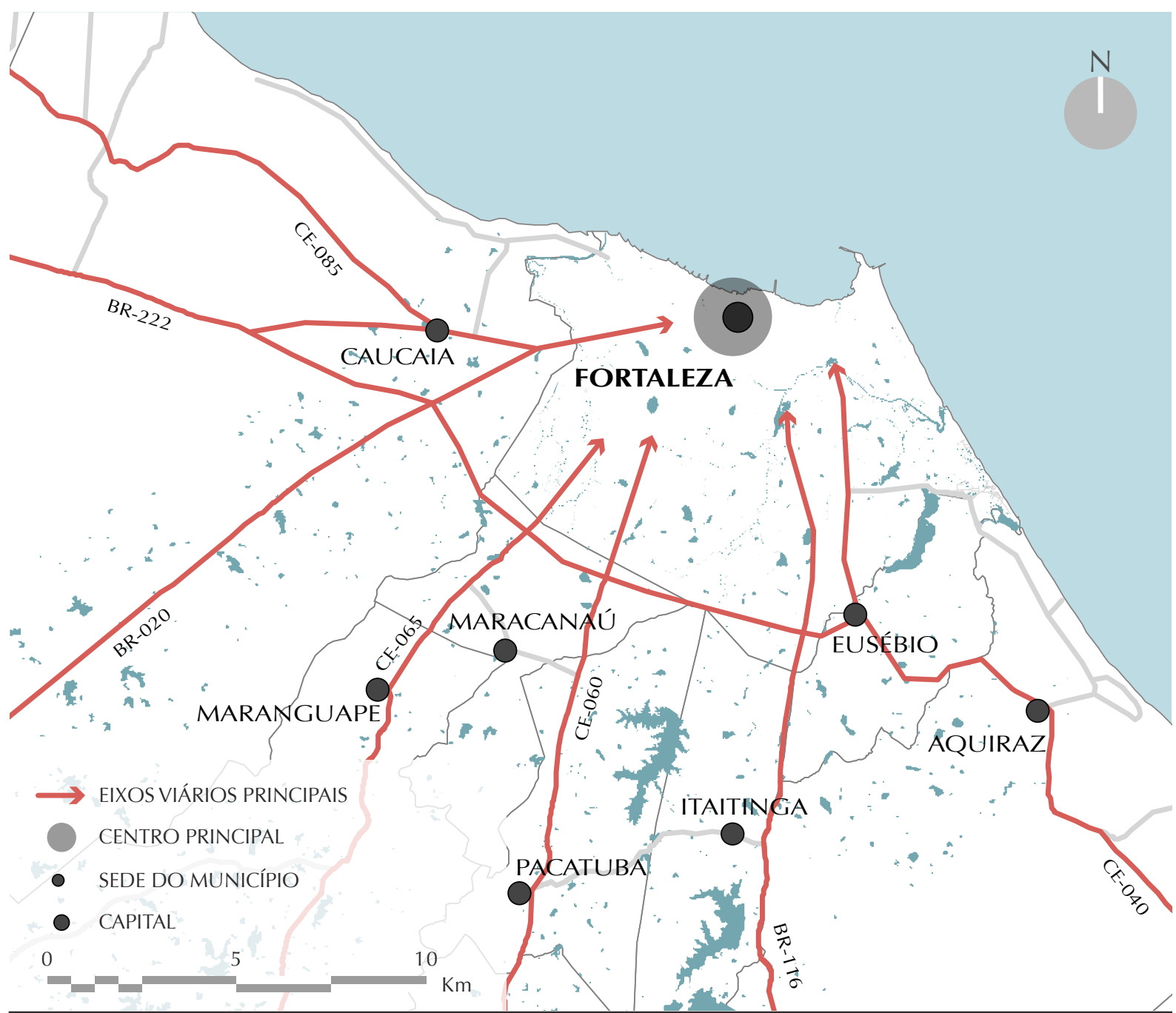

Fig. 2.17 Mapa RMF: ligações viárias

Fonte: elaborado pela autora

O papel preponderante que Fortaleza exerce, com sua força metropolitana, no âmbito do Estado, é considerado como inibidor no processo de inversão de capitais no interior. Desde as ultimas décadas, têm sido realizadas várias ações com vistas a viabilizar a interiorização de alguns setores da economia, objetivando a geração de uma situação de desenvolvimento do Estado como um todo.

No âmbito regional, programas governamentais buscaram garantir condições mínimas para a interiorização dos investimentos industriais a serem atraídos, aproveitando-se da conjuntura favorável em que se processava a reestruturação econômica no país. (...) Da mesma forma, foram elaborados programas de desenvolvimento urbano do Estado, tendo como principais ações estratégicas a realização de processos de planejamento na escala local, os quais buscavam promover o ordenamento territorial. Destaca-se também como objetivo deste programa a identificação de projetos estruturantes, os quais deveriam ser capazes de garantir às cidades do Ceará condições adequadas para atender às necessidades trazidas com as novas atividades. Com isso pretendia-se consolidar uma rede urbana estruturada por cidades consideradas "estratégicas", a qual viria a se contrapor ao histórico crescimento macrocefálico que prevalece no Estado, tendo a capital Fortaleza como ponto de convergência dos vários fluxos provenientes das diversas regiões em que o Ceará se subdivide (PEQUENO, 2011) ${ }^{83}$.

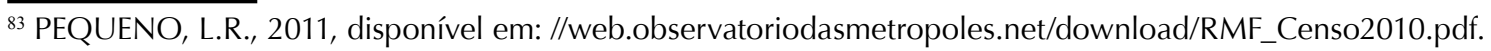


O que se observou, entretanto, foi que essa política de desenvolvimento estadual não teve impactos significativos além da fronteira da Região Metropolitana e, o que houve, de fato, foi o acirramento das desigualdades socioespaciais nas suas diferentes escalas.

O caráter hegemônico de Fortaleza é, sem dúvida, marcante no contexto estadual, o que reafirma a sua condição de macrocefalia urbana. Significativa é a diferença de dimensão urbana, de qualidade de vida e oportunidades de emprego ${ }^{84}$ e renda, quando se compara a Capital com as demais cidades do Estado. A RMF retrata, pois, uma situação de desequilíbrio, que historicamente atinge o Ceará, conforme demonstram os índices abaixo.

\section{QUADRO - DESEQUILÍBRIO DEMOGRÁFICO-ECONÔMICO}

\begin{tabular}{l|l}
\multicolumn{1}{c|}{ CEARÁ E RMF } & \multicolumn{1}{c}{ RMF E FORTALEZA } \\
\hline A RMF: & $\begin{array}{l}\text { Fortaleza } \\
\text { - ocupa 3,9\% do espaço estadual }\end{array}$ \\
- abriga 42,8\% da população cearense & - abriga cerca de $67,8 \%$ da população metropolitana \\
- apresenta uma densidade de 10,6 vezes a do estado & - apresenta uma densidade de 12,5 vezes a da RMF \\
- concentra $64,3 \%$ do PIB & - concentra $73,6 \%$ do PIB, $88 \%$ da arrecadação de tributos \\
- absorve $69,0 \%$ dos empregos & - absorve $80,0 \%$ dos empregos \\
\hline
\end{tabular}

Fonte: IBGE, IPECE e SINE-CE

Os números bem demonstram a importância da Capital no contexto metropolitano e, ao mesmo tempo, da Região Metropolitana de Fortaleza no âmbito estadual. A RMF continua concentrando serviços, indústrias e capital produtivo, constituindo de forma inequívoca um centro primaz e estratégico, que comanda o desenvolvimento econômico não somente do Ceará, mas também de parte do Nordeste brasileiro.

Na RMF - Região Metropolitana de Fortaleza - verifica-se claramente esta dinâmica conflituosa, na qual Fortaleza aparece como o município que concentra grande parte dos investimentos e infraestrutura de todo o estado, enquanto muitos outros municípios não contam, ao menos, com transporte público. Desta maneira, não existe uma relação equilibrada entre os municípios integrantes da Região Metropolitana, que não possuem, ainda, suas próprias funções e características dentro da dinâmica regional (FARIAS FILHO, 2005) ${ }^{85}$.

\subsection{A DINÂMICA ECONÔMICA CEARENSE E A CONFIGURAÇÃO METROPOLITANA}

\section{A atividade econômica e as transformações espaciais}

Este item pretende analisar alguns dos fatores econômicos relacionados à Metrópole cearense, os quais, de certa forma, estão associados ao seu processo de crescimento urbano, caracterizado pela rápida expansão nas últimas décadas.

\footnotetext{
${ }^{84}$ De acordo com dados do IPECE, são os seguintes os índices relativos à geração de emprego por municípios no primeiro semestre/2010: Fortaleza (20.710 postos); Horizonte (2.690 postos); Maracanaú (1.553 postos); São Gonçalo do Amarante (1.515 postos); Eusébio (1.508 postos); Maranguape (1.344 postos); para citar apenas os seis municípios que criaram empregos for mais acima de mil vagas.

${ }^{85}$ Região Metropolitana de Fortaleza - notas de aula da disciplina "Planejamento Urbano II" do Curso de Arquitetura e Urbanismo da UNIFOR - Universidade de Fortaleza.
} 
Sabe-se que a redistribuição espacial da atividade econômica e os movimentos populacionais delineiam, continuamente, reconfigurações no padrão de organização das cidades. Segundo o estudo coordenado pelo IPEA (Caracterização e tendências da rede urbana do Brasil, 2001), "a dinâmica e as alternativas de localização da atividade econômica têm importante papel indutor no processo de urbanização e de mudança territorial do país". O trabalho assinala ainda que "as tendências da urbanização brasileira e o próprio desenho do sistema urbano do país incorporaram as transformações espaciais da economia" (IPEA, 2001, p.35).

Embora se reconheça que a análise do desenvolvimento econômico é de fundamental importância, na medida em que propicia alterações substanciais no espaço urbano, não se pretende proceder a investigações aprofundadas acerca do assunto, que extrapolariam os objetivos da tese. Com efeito, o exame propõe-se tratar das tendências locacionais da atividade econômica na Metrópole cearense, com abrangência dos fenômenos de concentração e desconcentração da atividade produtiva, da diversificação do setor de serviços, das mudanças na estrutura ocupacional da população, na medida em que esses fatores induzem à conformação de novas espacialidades ou à reestruturação de áreas já existentes.

No Brasil, esses fenômenos revelam claras diferenças com relação àqueles que tradicionalmente se observavam até meados da década de 1970-1980. Resultam, sem dúvida, das novas dinâmicas em curso no contexto contemporâneo (o aumento das economias regionais, a desconcentração industrial, o incremento das exportações, o melhor desempenho da agricultura, etc.).

Ocorreram, em consequência, impactos no território, que passam a gerar novas áreas de dinamismo econômico, evidenciando novos arranjos espaciais, diferentes daqueles verificados anteriormente, com modificações relevantes na urbanização.

A Região Metropolitana de Fortaleza vivenciou de maneira própria os processos urbanos relacionados às transformações de ordem econômica. Convém investigar, portanto, as mudanças ocorridas na economia no contexto metropolitano e como elas influenciaram seu desenvolvimento e expansão urbana.

\subsubsection{As transformações econômicas no Ceará e na Metrópole}

Desde o final da década 1970-1980 até os dias atuais, o Ceará vem apresentando elevadas taxas de crescimento econômico e, a partir da segunda metade dos anos 1980-1990, tem registrado um crescimento maior do que o da região Nordeste em seu conjunto. A RMF, por sua vez, desponta como um polo regional significativo na atração de investimentos industriais e turísticos, colocando-se em destaque com relação às outras capitais nordestinas.

Entre os anos de 1985 e 1997, segundo dados do IPECE, o PIB do Ceará cresceu 55,90\% em termos reais, contra um crescimento de apenas 36,80\% do Nordeste e 36,50\% do Brasil. Nesse período, a participação do Ceará na economia nordestina ${ }^{86}$ cresceu de 12,20\% para 15,40\%. A indústria de

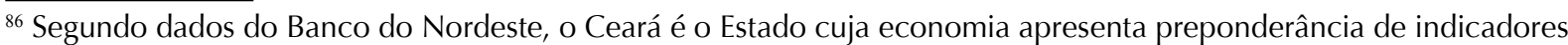
com variações acima da média regional. O crescimento da indústria e o aumento do volume de vendas do comércio varejista são alguns destes indicadores. No ano de 2010, respectivamente, cresceram 12,9\% e 16,9\% no Ceará, contra $11 \%$ e 12,6\% na região Nordeste. Fonte: http://www.brasil.gov.br/noticias/ arquivos/2010/12/23/banco-do-nordeste-aponta-crescimento-de-8-3-para-pib-nordestino-em-2010.
} 
transformação foi o principal setor responsável pelo crescimento do PIB, acumulando um crescimento de 49,60\% no período. Os empregos gerados, contudo, são, em sua maioria, precários e de baixa remuneração.

Já no período de 2002 a 2009, também conforme dados do IPECE (INFORME 20-12-2011), o PIB cearense cresceu 32,90\%, superando também os crescimentos acumulados do Nordeste ${ }^{87}(32,80 \%)$ e do Brasil (27,52\%). A participação do Estado na economia nordestina manteve-se entre 14,47\% em 2007 e 15,12\% em 2008, registrando 15,01\% em 2009. E, entre 2002 e 2010, o principal setor responsável pelo aumento do PIB, foi o de serviços, apresentando um crescimento acumulado de 50,64\% (IPECE, INFORME 25-04-2011).

Como a maioria das grandes cidades do Nordeste, Fortaleza se caracteriza principalmente pela atividade comercial e de serviços ${ }^{88}$, que representa $79,57 \%$ do $\mathrm{PIB}^{89}$, enquanto a indústria representa 20,26\% e a agropecuária 0,18\%. Os empreendimentos industriais do Ceará e da região Nordeste, com menor expressão, em geral, são voltados para o atendimento das demandas nacionais de bens intermediários e os centros urbanos permanecem fortemente integrados ao núcleo mais expressivo da economia do País, ou seja, São Paulo.

Assim sendo, a dinâmica econômica da RMF, como um todo, se caracteriza pela predominância do terciário. A atividade industrial se descentraliza em direção a outros municípios além da Capital, principalmente Maracanaú, Caucaia e Eusébio e, mais recentemente, o corredor industrial da BR 116, entre os municípios de Pacajus, Horizonte e Chorozinho. O Complexo Industrial e Portuário do Pecém ainda está em fase de consolidação, mas apresenta perspectivas concretas para um futuro próximo.

Esses municípios, embora demonstrem crescimento significativo da atividade industrial, ainda mantêm uma relação de dependência com a Capital, no que se refere ao abastecimento, tratamento de saúde e suprimento de serviços em geral e especializados.

O setor do turismo, nas últimas décadas, exibe índices de crescimento consideráveis e Fortaleza desponta como um dos principais destinos turísticos do País, conforme dados da SETUR-CE.

O turismo e a indústria, como se percebe, cresceram de maneira expressiva desde os últimos anos, apresentando importante incremento no âmbito das atividades econômicas do Estado e na participação do PIB. Com relação à Região Metropolitana de Fortaleza, vale ressaltar que a dinâmica econômica, sobretudo aquela ligada a estes setores, acarretou transformações espaciais importantes, alterando a relação entre áreas rurais e urbanizadas.

Nos itens seguintes, serão enfocadas, de forma sucinta, as transformações mais significativas que ocorrem, em particular aquelas relacionadas às atividades industriais e turísticas no âmbito da Região Metropolitana de Fortaleza, as quais tiveram desempenho expressivo no contexto econômico da Metrópole cearense nas últimas décadas. Algumas considerações serão feitas também com relação à predominância do setor terciário e à dinâmica imobiliária. No que se refere às manifestações espaciais e às mudanças na configuração

\footnotetext{
${ }_{87}^{87}$ No entanto, entre os nove estados nordestinos, o Ceará ficou na quarta colocação, perdendo para o Piauí (46,4\%), Maranhão (43,43\%) e Sergipe (37,07\%) (IPECE, INFORME 20-12-2011).

${ }^{88}$ No setor de serviços, prevalecem as atividades ligadas a hospedagem e alimentação, o que evidencia o desempenho da atividade turística.

${ }^{89}$ Segundo dados do Anuário do Ceará 2011/2012.
} 
metropolitana decorrentes dessas transformações, merecerão exame mais detalhados nos capítulos 3 e 4, pertinentes ao estudo dos processos de crescimento e expansão urbana verificados na Metrópole cearense.

\subsubsection{A atividade industrial}

A industrialização no Ceará, de acordo com Amora (2005), pode ser entendida mediante uma periodização que identifica três fases distintas, relacionadas à divisão internacional e nacional do trabalho. O primeiro período tem inicio ainda no final do século XIX e estende-se até a década de 1950-1960; o segundo abrange os anos 1960-1970 até meados de 1980-1990, quando começa o terceiro período, ainda em curso.

\section{A primeira fase}

Desde o final do século XIX, já havia em algumas cidades ${ }^{90}$ do Estado um precário parque industrial pertencente a um poder oligárquico familiar. A produção era restrita a charutos e cigarros, chapéus, carroças, couros e peles e materiais de construção, mas o maior destaque foi obtido mais tarde, pelas indústrias açucareira, têxtil e de óleos vegetais.

Entre os anos 1930-1960, em Fortaleza, começou a se formar uma zona industrial de maior expressão, nas imediações da av. Francisco Sá, na zona oeste, viabilizada pela presença do transporte ferroviário e pelo aumento da concentração de fluxos (de pessoas, de mercadorias, de informações, etc.) na Capital. A atividade industrial de então era associada aos ramos tradicionais de beneficiamento de produtos do setor primário (extrativismo, agricultura e produtos alimentares), além de couros e peles e, posteriormente, de confecções e calçados. A matéria-prima de origem agrícola e pecuária, principalmente o algodão, constituía, portanto, a base dos produtos manufaturados.

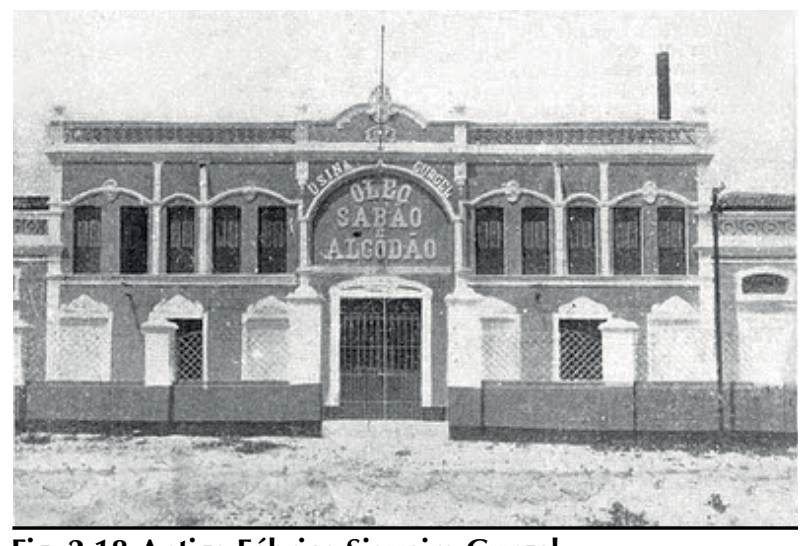

Fig. 2.18 Antiga Fábrica Siqueira Gurgel

Fonte: http://fortalezaemfotos.blogspot.com

A concentração de indústrias neste setor da Cidade atraiu um tipo de ocupação popular para a área, convergindo para os arredores das fábricas (e acompanhando a via férrea) considerável contingente de trabalhadores.

Na Capital cearense, a concentração fortalece a zona industrial da av. Francisco Sá, que se beneficia do Porto do Mucuripe, construído no final dos anos 1940, onde, nas proximidades, se instalam a Fábrica de Asfalto de Fortaleza, o Terminal de Gás Butano e os Moinhos de Trigo, caracterizando tal área como industrial portuária, de peso significativo na economia do Estado (ver figura 2.19).

\footnotetext{
${ }^{90}$ Essas cidades eram principalmente aquelas coletoras dos produtos agrícolas (Sobral e Aracati), além de Fortaleza, principal ponto de escoamento da produção cearense.
} 


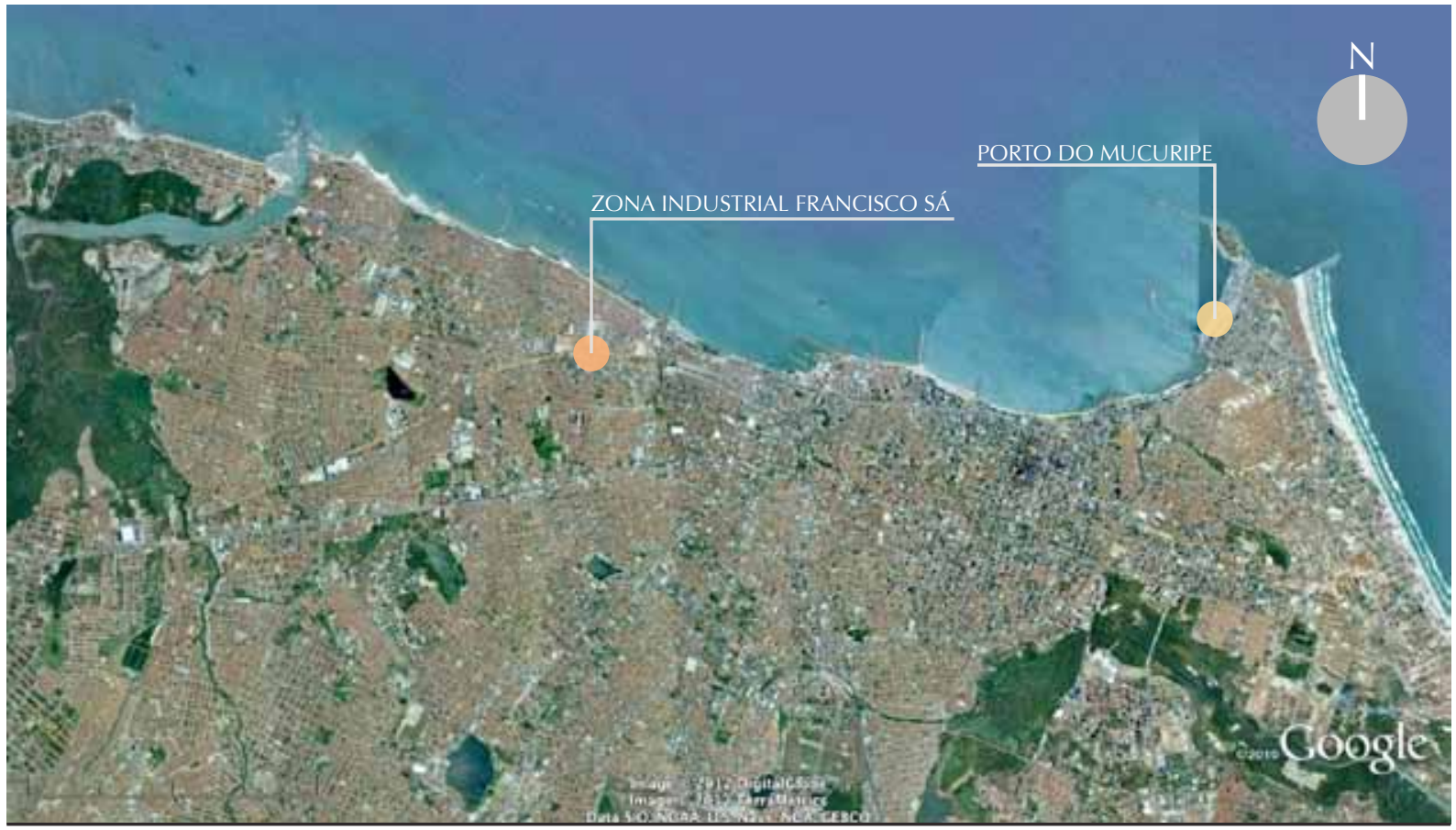

Fig. 2.19 Localização Zona Industrial Francisco Sá e Porto do Mucuripe Fonte: Google Earth - elaborado pela autora

\section{A segunda fase: a SUDENE e o desenvolvimento industrial do Ceará}

No final da década de 1950-1960, coincidindo com o incremento da industrialização no País, notadamente na região Sudeste, como visto anteriormente, foi criada a Superintendência de Desenvolvimento do Nordeste (SUDENE), com o objetivo de reduzir as disparidades regionais. A política de industrialização implementada pela SUDENE evidencia, no Nordeste, uma nova fase de industrialização, baseada nos incentivos fiscais e financeiros. Quanto à localização, segue uma lógica de concentração prioritária nos maiores núcleos urbanos da região, como Salvador, Recife e Fortaleza.

Nesse contexto, é instalado, no então distrito de Maracanaú ${ }^{91}$, por via de incentivos fiscais da SUDENE, o I Distrito Industrial de Fortaleza, proporcionando ao Estado maior dinamismo da produção. Implantado ainda nos anos 1960-197092, atrai o antigo setor industrial da Capital, que se moderniza sob os auspícios do FINOR ${ }^{93}$, ficando a zona oeste de Fortaleza, antigo reduto industrial, esvaziada e empobrecida. A instalação do Distrito Industrial em Maracanaú ocorreu em função das facilidades ${ }^{94}$ encontradas no que se refere a serviços e infraestrutura, além de situar-se junto à ferrovia e à CE 060, com fácil acesso ao porto do Mucuripe. A proposta do novo parque industrial

\footnotetext{
${ }^{91}$ Maracanaú era então distrito de Maranguape, só sendo emancipado em 1986.

${ }^{92} \mathrm{Na}$ fase inicial, o Distrito Industrial atravessou um período de sérias dificuldades para se consolidar. O quadro infraestrutural incompleto, como abastecimento irregular de água, retardou o seu funcionamento e o adensamento populacional na região. Somente foi superado pelo Governo estadual em meados da década de 1970-1980 (depois da institucionalização da RMF), com a construção do complexo hídrico Pacoti-Riachão-Gavião.

${ }^{93}$ O Fundo de Investimentos do Nordeste - FINOR é um benefício fiscal concedido pelo Governo Federal, criado pelo Decreto-Lei $n^{\circ}$ 1.376, de 12.12.1974, constituído de recursos aplicados em ações e debêntures, destinado a apoiar financeiramente empreendimentos instalados ou que venham a se instalar na área de atuação do Departamento de Gestão dos Fundos de Investimentos - DGFI. O objetivo é contribuir para o desenvolvimento econômico da Região Nordeste e partes dos Estados de Minas Gerais e Espírito Santo, além de ser um investimento atrativo para as empresas contribuintes do imposto de renda de todo o País.

${ }^{94}$ As "facilidades" se traduzem em incentivos fiscais, apoio financeiro, fornecimento de mão de obra barata e implantação de uma infraestrutura de funcionamento.
} 
visava a aplicar novas tecnologias às indústrias tradicionais (têxtil, calçados e alimentícia) e implantar setores mais modernos, como a metalurgia, material elétrico e materiais de embalagem.

Em síntese, a indústria que se desenvolve no Ceará a partir desse período, sob a égide da SUDENE, especializa-se no geral em dois setores produtivos: os produtos manufaturados que têm como destino o mercado nacional e os produtos beneficiados destinados à exportação (AMORA, 2005, p.375).

A atuação da SUDENE, se por um lado incrementou o desenvolvimento industrial na região e propiciou a modernização de alguns setores, por outro, não foi capaz de reduzir as desigualdades regionais e sociais, como era o objetivo inicial.

De fato, no final da década de 1970-1980, a economia cearense assistiu à passagem de um sistema produtivo agrário-exportador para outro, centralizado principalmente na indústria e no terciário. $\mathrm{O}$ que se constatou, desde então, foi a superação do tradicional sistema econômico, no qual a antiga predominância das atividades agropecuárias cederam lugar a uma economia moderna, dominada por relações eminentemente capitalistas.

No que se refere à espacialização da atividade industrial nesse período, a instalação do I Distrito Industrial de Fortaleza, no Município de Maracanaú, contribuiu para um aumento expressivo da densidade populacional, por exigir a implantação de inúmeros conjuntos habitacionais construídos nos anos 1970-1980 pelo Sistema Financeiro da Habitação (ver fguras 2.20 e 2.21).

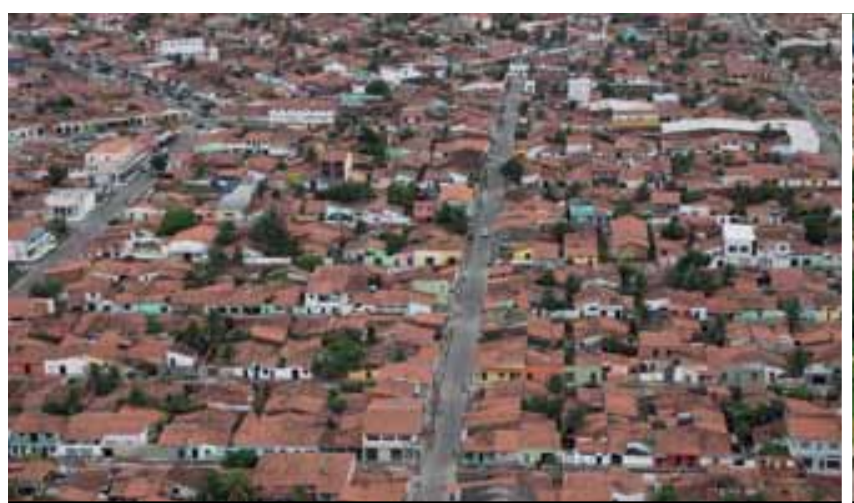

Fig. 2.20 Conjunto Habitacional no Município de Maracanaú Fig. 2.21 Indústrias no Distrito Industrial de Maracanaú Fonte: http://4.bp.blogspot.com

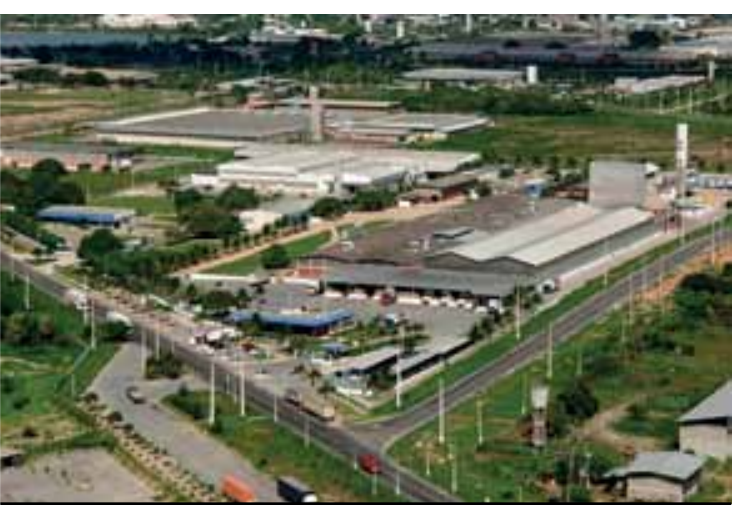

Fonte: http://www.maracanau.ce.gov.br/index.php

Apesar do incremento verificado na industrialização, a oferta de emprego no setor permaneceu insuficiente para absorver o extraordinário aumento da força de trabalho gerado pelo processo de urbanização. A ampliação da migração interestadual, fortalecida a partir de meados da década de 1970-1980, favoreceu então a expansão do setor informal na Capital (BERNAL, 2004).

\section{A terceira fase: a industrialização do Ceará no contexto da reestruturação produtiva}

A terceira fase de implantação industrial no Ceará, que tem início nos anos 1980-1990, intensifica-se na década seguinte, inserindo-se no contexto de reestruturação produtiva da economia mundial.

Nesse período, observa-se um movimento distinto, no que se refere ao desenvolvimento da atividade industrial no Estado. O esquema da substituição das importações no Sudeste é redimensionado de acordo com a indicação de novas variáveis de desenvolvimento, que definem novos níveis de integração da metrópole. 
A metrópole de Fortaleza experimentou, desde a segunda metade dos anos 80 , um processo de industrialização induzido pela guerra fiscal e pela precarização do trabalho, fenômeno que tem contribuído para um dinamismo econômico, embora não se tenham observado mudanças significativas na sua estrutura produtiva e no padrão do emprego. A evolução da ocupação em Fortaleza, no período 1981 a 1999, aponta para uma permanência da participação do emprego industrial, ao mesmo tempo em que decresce o emprego rural e cresce o emprego no setor de serviços, em todos os ramos (BERNAL, 2009, p.57).

Esse período coincide com a ascensão ao poder estadual de representantes de uma elite empresarial ligados ao CIC - Centro Industrial do Ceará, sob a liderança de Tasso Jereissati, que assumiu o governo em 1987. Iniciou-se então um novo modelo de gestão, conhecido como "Governo das Mudanças", conforme já mencionado, promovendo uma nova fase na organização política e econômica no Ceará.

Essas ações se traduziram no fortalecimento da industrialização, na ampliação da infraestrutura cearense, na atração de investimentos externos e na reestruturação do Estado baseada numa política de "privatização". Operaram-se, então, intensas ações político-econômicas, nas quais se verificava a intervenção do Governo estadual, associada a parcerias com o capital privado.

O Executivo estadual mantinha como principal objetivo a rentabilidade do capital, além de formular uma ideologia que colocava a indústria como elemento capaz de promover a transformação da economia, geradora de emprego e renda.

Com o intuito de consolidar a posição do Estado como III Polo Industrial do Nordeste, foram criados mecanismos para a liberação de recursos, como, por exemplo, o Fundo de Desenvolvimento Industrial do Ceará - FDI. Além disso, importantes obras de infraestrutura foram realizadas, como o Aeroporto Pinto Martins (R\$ 65 milhões) e o Porto do Pecém (R\$ 135 milhões), no sentido de oferecer vantagens para as empresas do Sul e Sudeste, que também exportam para a Europa e a América do Norte.

De acordo com Pereira Júnior (2005, p.53),

[...] desde a emergência do 'Governo das Mudanças', a industrialização é abertamente um dos maiores interesses dos programas econômicos adotados pelo Ceará (...) A ação do Estado objetiva desenvolver mecanismos para a atração e consolidação de investimentos industriais, sendo os incentivos fiscais, o apoio financeiro e a implantação de uma infraestrutura básica de funcionamento suas principais preocupações.

Com efeito, a nova lógica da industrialização toma como base a chamada "guerra fiscal"s", configurada como incentivo para a instalação de indústrias no território cearense. O Estado recebeu então inúmeras indústrias ${ }^{96}$ do Sul e Sudeste, atraídas pelos incentivos governamentais.

A industrialização do Ceará, um exemplo claro da deflagrada guerra fiscal assumida pelos estados brasileiros na década de 1990, se evidencia materializando investimentos que migram do sul do País em busca de novos lugares de reprodução e acumulação do capital. Esses investimentos, que definitivamente não correspondem aos investimentos de maior envergadura no País,

\footnotetext{
${ }_{95}$ A "guerra fiscal", como ficou conhecida, é a estratégia utilizada pelos estados, de modo a oferecer "facilidades", como incentivos fiscais, financiamento e mão de obra barata, com o intuito de atrair capitais privados.

${ }^{96}$ Matéria divulgada pelo jornal Diário do Nordeste em março de 1999 afirma terem sido atraídas para o Estado do Ceará aproximadamente 432 indústrias no período de 1994-99, representando 4,7 bilhões de dólares. São, em sua maioria, indústrias têxteis, de calçados, alimentos e embalagens.
} 
procuram vantagens comparativas que Ihes concedam maior competitividade diante de seus concorrentes externos. Aqui, acabam encontrando uma super-oferta de mão-de-obra e baixos salários, além da maior possibilidade de implantar racionalidades flexíveis nas relações de trabalho (PEREIRA JR, 2003, p.74).

A indústria tem apresentado, de fato, relevante contribuição para a economia cearense. De acordo com relatório do INDI (Instituto de Desenvolvimento Industrial do Ceará) ${ }^{97}$, o setor emprega 20,70\% do total da mão-de-obra formal e é responsável pelo consumo de $27,32 \%$ da energia elétrica e $66,71 \%$ das exportações, além de representar 49,52\% das fontes de arrecadação do ICMS. A participação da indústria alcança $24,51 \%$ da economia cearense. Ainda conforme o mencionado relatório, no período compreendido entre 1985 e 2008, segundo dados do IBGE e IPECE 98 , o PIB industrial cearense cresceu 153,6\%.

É reconhecido, portanto, o fato de que as novas estratégias político-econômicas do "Governo das Mudanças" foram eficientes no sentido de integrar o Ceará numa nova economia de trocas nacionais e globais. No que se refere à intensificação do processo de industrialização do Estado, pode-se constatar que as metas adotadas pela organização política no Ceará desde 1986 tiveram papel fundamental, conforme assinala Pereira Jr. (2003, p.73):

\begin{abstract}
Reagindo de maneira eficaz diante da gradativa falência dos programas regionais de apoio à industrialização, o estado (e até mesmo alguns municípios) se impôs solidamente na conquista de investimentos industriais externos, desenvolvendo estratégias de financiamento e de benefícios fiscais. Com efeito, grupos empresariais já consolidados nacionalmente, sobretudo nos ramos têxtil e de calçados, optaram por abrir (ou transferir) grandes fábricas no território cearense (é o caso do Grupo Vicunha e Grendene). Além disso, projetos de expressiva dimensão foram desenhados no intuito de aparelhar a infraestrutura do Estado e reestruturar a natureza da sua produção industrial.
\end{abstract}

\title{
A desconcentração industrial e a expansão metropolitana
}

Essa fase é caracterizada também pela política de desconcentração industrial, que incentivou a descentralização dos empreendimentos industriais, transferindo-os para outros municípios. Esse movimento ocorreu em duas escalas. Primeiramente, a vinda de indústrias do Sul e Sudeste do País, como forma de desconcentração do parque industrial daquelas regiões, sobretudo de São Paulo, enquanto no âmbito local, efetuou-se a tentativa de descentralização da Capital, direcionada a outros municípios do Estado e da RMF.

Desde os anos 1990, verifica-se, portanto, a expansão do setor em eixos e mini-distritos na RMF, ao longo das rodovias federais e estaduais, nos municípios de Horizonte, Pacajus, Pacatuba, Eusébio, Maranguape e Caucaia, vinculada à política estadual de atração de indústrias.

A implantação de indústrias em outros municípios ${ }^{99}$ diversifica o quadro de distribuição do setor industrial no Ceará, embora ainda permaneça importante concentração em Fortaleza, que abriga praticamente metade do total das indústrias do Estado, conforme mostram os dados da tabela 9. No que se refere à problemática da descentralização do setor industrial no Ceará, Silva \& Dantas (2009, p.17) comentam que:

\footnotetext{
${ }_{97}$ Disponível em: http://www.fiec.org.br/portalv2/sites/indi/

${ }_{98}^{98}$ De acordo com o INDI, disponível em: http://www.fiec.org.br/portalv2/sites/indi/

${ }^{99}$ Outro aspecto relativo à política de interiorização da indústria diz respeito à possibilidade de reduzir os custos da produção e, consequentemente, propiciar maior lucratividade. Além disso, também apresenta vantagens substanciais para os empresários, no sentido de favorecer maior distanciamento das lutas sindicais, presentes nos grandes centros.
} 
No concernente à RMF, tem-se um redimensionamento de lógica de urbanização na escala da metrópole, o que implica na relocalização da indústria em municípios que a compõem, adquirindo Fortaleza papel preponderante, em função do sistema de vias pautado no transporte rodoviário e convergindo para a zona portuária do Mucuripe e, atualmente, do recém-construído Porto do Pecém, em São Gonçalo do Amarante.

Apesar da política de descentralização efetivada, a predominância da Capital é visível e Fortaleza permanece como a cidade com maior capacidade financeira dentro da Região Metropolitana. Ao se analisar a renda per capita dos municípios da RMF (ver tabela 8), constata-se que a maior parte deles apresentou apreciável crescimento entre 1991 e 2000 e entre 2000 e 2010, notadamente Fortaleza, Aquiraz, Caucaia, Horizonte, Pacajus e Maracanaú. A Capital teve um incremento de $180 \%$ na renda per capita durante a última década.

TABELA 8 - RENDA PER CAPITA RMF (R\$)

\begin{tabular}{l|ccc} 
MUNICÍPIO & $\mathbf{1 9 9 1}$ & $\mathbf{2 0 0 0}$ & $\mathbf{2 0 1 0}$ \\
\hline Fortaleza & 235,77 & 306,70 & 857,54 \\
Caucaia & 102,71 & 129,23 & 405,51 \\
\hline Aquiraz & 76,76 & 123,29 & 381,97 \\
Pacatuba & 79,93 & 100,16 & 330,56 \\
\hline Maranguape & 76,42 & 105,09 & 324,19 \\
Maracanaú & 91,17 & 129,76 & 384,95 \\
Eusébio & 104,68 & 107,13 & 663,17 \\
Guaiuba & 60,72 & 71,39 & 260,40 \\
Itaitinga & 73,72 & 96,53 & 311,92 \\
Chorozinho & 64,32 & 82,49 & 296,74 \\
Pacajus & 93,36 & 105,87 & 366,19 \\
Horizonte & 74,96 & 126,68 & 351,17 \\
S. Gonçalo & 62,37 & 81,06 & 326,72 \\
Cascavel & - & - & 341,98 \\
Pindoretama & - & - & 351,66 \\
MÉDIA & 92,1 & 120,3 & 396,98 \\
\hline
\end{tabular}

Fonte: IBGE

Quanto ao PIB per capita ${ }^{100}$, os municípios de vocação industrial, como Eusébio, Horizonte e Maracanaú, sobressaem-se com os mais elevados valores (R\$23.204,78; $R \$ 15.946,59$ e $R$ \$15.620,27 respectivamente), conforme indica a tabela 5, enquanto Fortaleza registra $\mathrm{R} \$ 11.461,22$.

Na tabela 9, verifica-se que, das 15.431 empresas industriais ativas no Ceará, 9.946 encontram-se no âmbito da Região Metropolitana de Fortaleza, o que corresponde a 61\%. Os dados também evidenciam a preponderância de Fortaleza em relação aos demais municípios da RMF, ao concentrar 49,4\% das empresas industriais do Estado e 77,6\% da RMF. Na Capital, as indústrias situam-se preferencialmente nos bairros do Montese, Parangaba ${ }^{101}$ e Mucuripe ${ }^{102}$.

\footnotetext{
${ }^{100}$ Valores registrados pelo Censo 2010.

${ }^{101}$ Os bairros do Montese e da Parangaba, em Fortaleza, concentram a maior parte das indústrias da RMF, em número de estabelecimentos e oferta de empregos; entretanto, são, em sua maioria, empresas de pequeno e médio porte, relacionadas aos ramos de vestuário, calçados, alimentos e minerais não metálicos.

${ }^{102}$ A zona industrial do Mucuripe mantém ainda dinamismo expressivo em razão dapresença do porto, dos diversos moinhos de trigo e da fábrica de lubrificantes da Petrobrás.
} 
TABELA 9 - EMPRESAS INDUSTRIAIS ATIVAS POR TIPO, SEGUNDO OS MUNICÍPIOS DA RMF (2009)

\begin{tabular}{|c|c|c|c|c|c|}
\hline MUNICÍPIOS & TOTAL & $\begin{array}{l}\text { EXTRATIVA } \\
\text { MINERAL }\end{array}$ & $\begin{array}{c}\text { CONSTRUÇÃO } \\
\text { CIVIL }\end{array}$ & $\begin{array}{l}\text { UTILIDADE } \\
\text { PÚBLICA }\end{array}$ & TRANSFORMAÇÃO \\
\hline Ceará & 15.431 & 222 & 2.439 & 111 & 12.659 \\
\hline RMF & 9.946 & 58 & 1.742 & 62 & 8.072 \\
\hline Aquiraz & 189 & 12 & 28 & 3 & 146 \\
\hline Cascavel & 98 & - & 5 & 1 & 92 \\
\hline Caucaia & 506 & 13 & 43 & 5 & 445 \\
\hline Chorozinho & 22 & 1 & 1 & - & 20 \\
\hline Eusébio & 341 & 1 & 65 & 2 & 273 \\
\hline Fortaleza & 7.624 & 21 & 1.521 & 41 & 6.041 \\
\hline Guaiúba & 16 & - & 2 & - & 14 \\
\hline Horizonte & 105 & 4 & 10 & 1 & 90 \\
\hline Itaitinga & 63 & 3 & 6 & - & 54 \\
\hline Maracanaú & 559 & 3 & 41 & 2 & 513 \\
\hline Maranguape & 168 & - & 7 & 1 & 160 \\
\hline Pacajus & 91 & - & 3 & - & 88 \\
\hline Pacatuba & 82 & - & 12 & 2 & 68 \\
\hline Pindoretama & 29 & - & 2 & - & 27 \\
\hline São Gonçalo & 53 & 2 & 6 & 4 & 41 \\
\hline
\end{tabular}

Fonte: IPECE - Anuário Estatístico do Ceará, 2010

A localização da indústria no território cearense revela, por outro lado, um nível de integração na metrópole mediante um sistema de vias, que corresponde principalmente aos eixos viários de penetração para o interior - os vetores de expansão urbana (nas BR 116 e BR 222, e nas CE 085, CE 040 e CE 060), alterando o antigo modelo de concentração, visto no início do processo de industrialização, no período pré-SUDENE, restrito ao setor oeste de Fortaleza.

Na BR 116, foi previsto o corredor industrial Horizonte-Pacajus, de mais de dez quilômetros de extensão, ao longo da rodovia, provocando atração sobre a população da zona rural e de cidades próximas. A BR 222 e a CE 085 correspondem aos investimentos do Governo do Estado com a implantação do Complexo Industrial e Portuário do Pecém, o qual atrai progressivamente novos empreendimentos industriais. A CE 040, principalmente nas proximidades do Eusébio, recebeu algumas sedes de indústrias nos últimos anos e, na CE 060, encontra-se o já consolidado complexo industrial de Maracanaú.

Todas essas transformações apontam para alterações substanciais no arranjo do território, modificando a fisionomia da Região Metropolitana de Fortaleza, a qual adquire formas e intensidade variadas. A instalação do Distrito Industrial de Maracanaú, por exemplo, de acordo com as regras do planejamento econômico vigente na época, contrapõe-se visivelmente ao antigo Setor Industrial da av. Francisco Sá, inserido de forma conflituosa na malha urbana de Fortaleza, na zona oeste. 
A implantação do corredor industrial ao longo da BR 116, por outro lado, interferiu sobremaneira na modificação dessa área, passando a atrair maior número de pessoas ${ }^{103}$ para as proximidades, tendo em vista as oportunidades de emprego, contribuindo assim para o processo de expansão metropolitana.

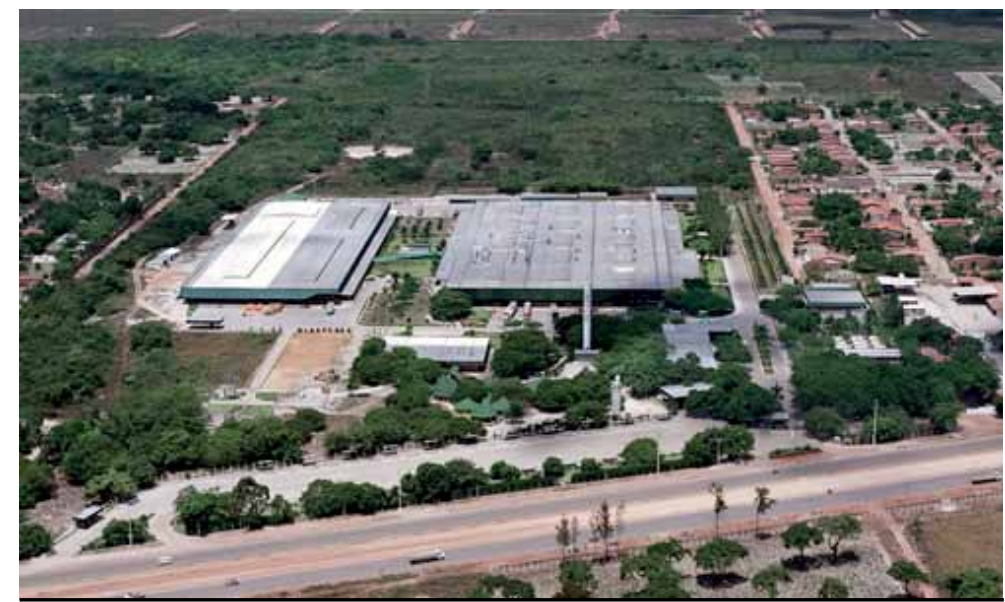

Fig. 2.22 Indústria Vulcabrás, na BR 116, no município de Horizonte Fonte: http://www.vulcabras.com.br

Neste sentido, Silva (2005, p.111) assinala que

O processo de industrialização modificou as estruturas internas do Ceará, no que se refere à sua realidade espacial. A partir dos anos 80 , o processo de fragmentação metropolitana, associado a uma descentralização e desconcentração da indústria, resultou na escolha de cidades menores, para receber novos investimentos. O grande atrativo repousava nos incentivos fiscais, fundado o pressuposto do maior distanciamento da capital, locus preferencial dos investimentos.

De fato, a desconcentração industrial no Ceará, com a implantação de indústrias fora do Município-Sede, acarreta uma série de investimentos e intervenções que proporcionam aos novos lugares mudanças significativas na sua estrutura produtiva e setorial.

A dinâmica de ampliação e descentralização da atividade industrial segue, portanto, uma trajetória de afastamento da Capital, seu principal núcleo urbano. Esta expansão é em parte responsável pela ocupação do espaço urbano da Região Metropolitana, sendo viabilizada também pela sua maior abrangência institucional, ao se incorporarem à região os municípios de Horizonte, Pacajus e São Gonçalo do Amarante.

O período mais recente do desenvolvimento industrial no Estado relaciona-se com a criação do Complexo Industrial Portuário do Pecém, o CIPP, entre os municípios de Caucaia e São Gonçalo do Amarante, decorrente de projetos governamentais seguindo a lógica do desenvolvimento exógeno $^{104}$ (ver figura 2.23).

\footnotetext{
${ }^{103}$ De acordo com dados do Censo 2010, o Município de Horizonte foi o que mais cresceu em população no Ceará nos últimos dez anos (63,3\%). O chefe da unidade estadual do IBGE, Francisco José Moreira Lopes, explica que o crescimento populacional de Horizonte e outras cidades da Região Metropolitana, como Eusébio, Pacajus e Caucaia, deve-se à maior oferta de empregos em indústrias que se instalaram nesses municípios.

${ }^{104} \mathrm{O}$ desenvolvimento exógeno é aquele realizado com investimentos (materiais e serviços) oriundos de fora da região. Ocorre principalmente mediante a instalação de empresas cuja matriz não é da região. São geralmente empresas de médio e grande porte que se instalam em função de algum atrativo que a região oferece, seja por motivos logísticos ou pela disponibilidade de recursos humanos habilitados.
} 


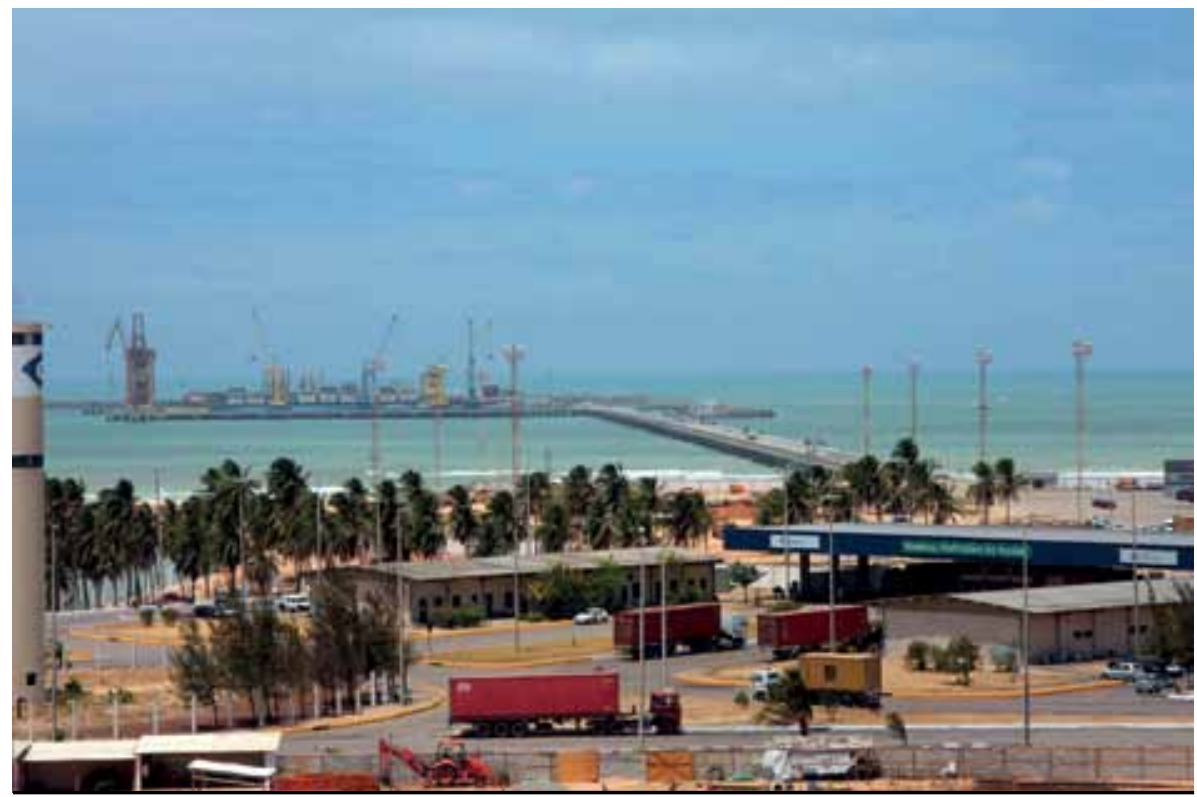

Fig. 2.23 Complexo Industrial e Portuário do Pecém

Fonte: http://www.maxpressnet.com.br

O CIPP, que abrange investimentos de peso (como a futura siderúrgica e a refinaria), ao se consolidar, deverá causar impactos significativos ${ }^{105}$ na estrutura econômica da Região Metropolitana de Fortaleza e, por extensão, no perfil ocupacional de sua população.

No que concerne ao desenvolvimento do setor industrial e ao crescimento econômico do Ceará, de modo geral, alguns aspectos devem ser destacados. Em primeiro lugar, a participação do Poder Público - o Estado - como agente do processo de acumulação de capital, atuando como propulsor e incentivador da implantação industrial, mediante programas de incentivos fiscais, bem como a instalação de infraestrutura, como atrativo e suporte para a instalação de indústrias.

Em segundo lugar, cabe ressaltar a questão da localização da atividade industrial em território cearense, quando se verifica uma concentração acentuada na RMF, espaço escolhido pela maioria das indústrias, seguindo a lógica capitalista da concentração espacial, apesar das políticas recentes preconizadas pelo Governo estadual relativas à interiorização do setor industrial. A localização das indústrias, portanto, constitui fator essencial para o processo de metropolização em curso.

105 “Em processo de implantação no Ceará, a usina da Companhia Siderúrgica do Pecém vai causar um impacto espetacular no cenário sócio-econômico do Estado, principalmente na geografia do município de São Gonçalo do Amarante, onde ela se localiza. Por exemplo: o Produto Interno Bruto (PIB) de S. Gonçalo crescerá $1.970 \%$ durante o período de construção da usina, mas será incrementado em 3.940\% quando ela estiver operando a pleno, ou seja, produzindo 3 milhões de toneladas/ano de placas de aço. Por sua vez, o PIB de Caucaia aumentará 206\% na construção da usina e 412\% na operação dela" (Jornal Diário do Nordeste, 01-06-2011). 
OCEANO ATLÂNTICO
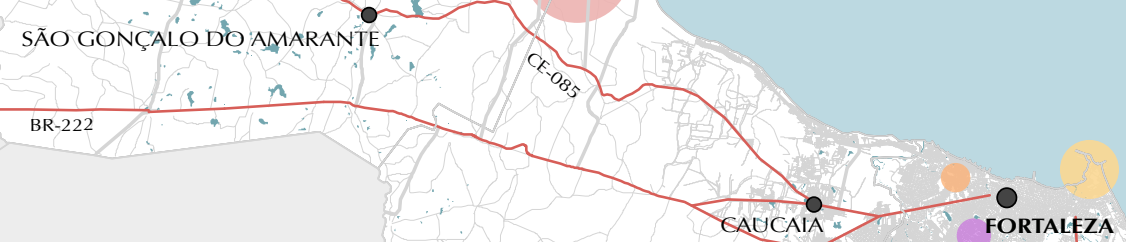

(1)
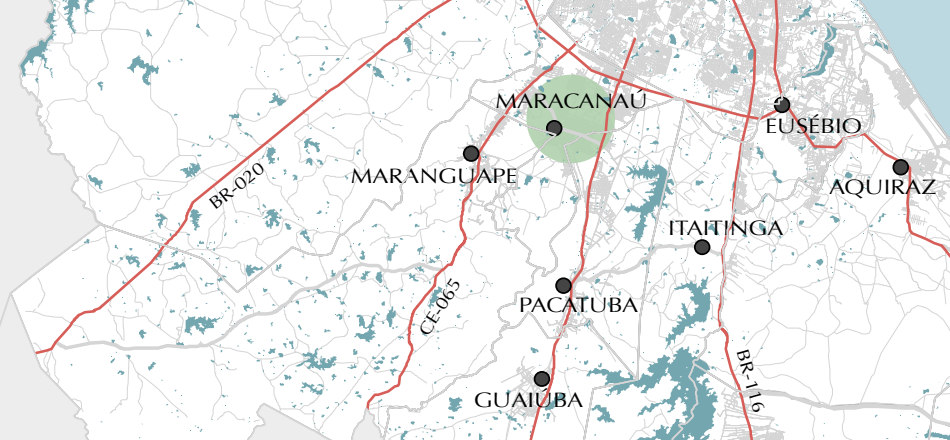

$\therefore \quad$ GUAIUB
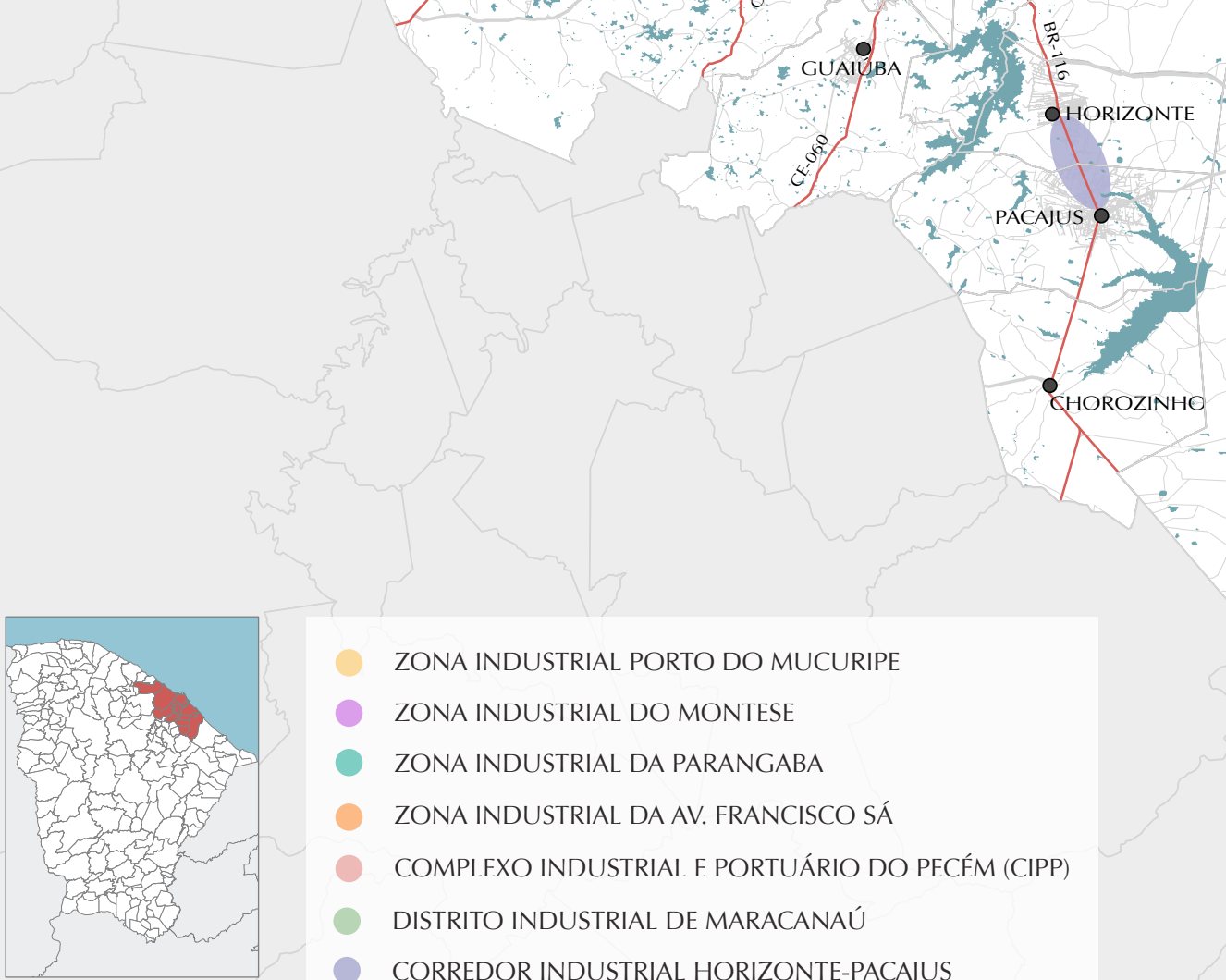

ZONA INDUSTRIAL PORTO DO MUCURIPE

- ZONA INDUSTRIAL DO MONTESE

ZONA INDUSTRIAL DA PARANGABA

ZONA INDUSTRIAL DA AV. FRANCISCO SÁ

- COMPLEXO INDUSTRIAL E PORTUÁRIO DO PECÉM (CIPP)

- Distrito indUSTRIAL DE MARACANAú

CORREDOR INDUSTRIAL HORIZONTE-PACAJUS

- SEDE DO MUNICÍPIO

- CAPITAL

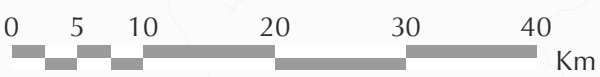




\subsubsection{A atividade turística}

Paralelamente ao desenvolvimento industrial, desde as últimas décadas, verifica-se a inserção cada vez maior do setor turístico como propulsor do desenvolvimento material do Nordeste, inserido nos planos governamentais como prioritário, em face da realidade da região. O turismo surge, assim, como alternativa econômica para os estados, tomando como base os elementos naturais, sobretudo a paisagem litorânea e o clima tropical.

O setor do turismo, pois, se desenvolveu intensamente nos últimos anos na região Nordeste e particularmente no Ceará, despontando, ao lado da indústria, como uma das principais estratégias de desenvolvimento ${ }^{106}$. É sabido que a região, por suas qualidades naturais, possui grande potencial para o turismo, que é incentivado e incrementado desde as últimas décadas.

Constata-se, portanto, que a atividade turística - principalmente no que se refere ao turismo de "sol e mar ${ }^{107 "}$ - ocupa atualmente importante papel no conjunto das relações políticas e econômicas do Estado. A Capital cearense e os municípios do litoral reúnem condições naturais favoráveis para o incremento dessa atividade, por seu clima ameno o ano todo e por sua localização estratégica, que possibilita situar o Estado nas rotas turísticas internacionais ${ }^{108}$.

Essa importância é evidenciada ainda, segundo Coriolano (2005, p.383) na medida em que,

[...] como atividade terciária da economia, reorganiza espaços geográficos, produz territorialidades em diferentes escalas espaciais e movimenta economias. (...) Como vetor do planejamento territorial tem ajudado a fortalecer e dinamizar alguns lugares, oferecendo oportunidades de organização de territórios, além de colaborar para a inserção do local nas escalas nacional e global.

O fluxo turístico internacional aumentou consideravelmente desde meados da década de 1990-2000 (ver tabela 10), com voos fretados que chegam semanalmente durante a alta estação, oriundos principalmente da Itália, França, Espanha, Argentina e Portugal, país este que se destaca como maior emissor de visitantes para o Estado. Com relação ao turismo doméstico, segundo dados da ABAV (Associação Brasileira de Agencias de Viagem), desde 2004, Fortaleza é um dos destinos mais vendidos para os turistas nacionais. Nesse processo, destaca-se a importância da Capital ${ }^{109}$ na concentração e distribuição dos fluxos turísticos, confirmando seu papel polarizador no contexto estadual e metropolitano.

\footnotetext{
106 "É importante demarcar que dentro dos planos de desenvolvimento regional, sejam os voltados para o Nordeste ou tendo como cenário o Brasil, o turismo como elemento gerador de riqueza era pouco percebido até a década de 1990, com exceção das políticas públicas de promoção ao turismo para o Rio de Janeiro e Salvador, cidades que serviam de "cartão postal" das belezas naturais brasileiras desde a década de 1970. (...) A partir de meados dos anos de 1990, entretanto, um novo cenário de competitividade global, marketing urbano e planos estratégicos, força uma redefinição do turismo que passa a ser tomado pelos gestores públicos no Brasil e, principalmente, no Nordeste como a "ponta de lança" do progresso e do desenvolvimento em escala internacional". (SILVA, 2008, disponível em http://www.ub.edu/ geocrit/-xcol/280.htm).

${ }^{107}$ A atividade turística no Ceará materializa-se predominantemente nos espaços litorâneos, correspondendo, conforme a SETUR (2008), a 80,8\% do fluxo turístico, seguido das regiões sertanejas e serranas com, respectivamente, 14,4\% e 4,8\%.

108 "Fatores geográficos e econômicos estratégicos são levados nas campanhas promocionais de turismo internacional, tais como a proximidade da cidade em relação aos mercados turísticos emissores da América do Norte e da Europa, o clima saudável, a temperatura estável e sol durante o ano todo, além da paisagem exuberante das praias cearenses como atributos naturais" (BERNAL, 2004, p.198).

${ }^{109}$ A Capital, Fortaleza, constitui o principal polo turístico do Estado, que atrai o concentra o maior número de visitantes, conforme atestam os dados da SETUR, assim também como é o local onde se localiza a maior quantidade de meios de hospedagem, equipamentos, comércio e serviços complementares ao turismo. Neste item, porém, serão tratadas com maior ênfase as atividades relacionadas ao turismo de "sol e mar" na faixa litorânea dos demais municípios da RMF, onde provoca mudanças expressivas na urbanização da orla marítima e contribui para a expansão metropolitana.
} 
TABELA 10 - FLUXO TURÍSTICO PARA FORTALEZA (NACIONAL E INTERNACIONAL)

\begin{tabular}{|c|rrrrrrr}
\multirow{2}{*}{ ANOS } & \multicolumn{2}{|c}{ TOTAL } & \multicolumn{2}{c}{ NACIONAL } & \multicolumn{2}{c}{ INTERNACIONAL } & PARTICIPAÇÃO \\
& TURISTAS & ÍNDICE & TURISTAS & ÍNDICE & TURISTAS & ÍNDICE & $(\%)$ \\
\hline 1995 & 761.777 & 100,0 & 723.688 & 100,0 & 38.089 & 100,0 & 5,0 \\
\hline 1996 & 773.247 & 101,5 & 733.038 & 101,3 & 40.209 & 105,6 & 5,2 \\
\hline 1997 & 970.000 & 127,3 & 914.710 & 126,4 & 55.290 & 145,2 & 5,7 \\
\hline 1998 & 1.297 .528 & 170,3 & 1.218 .379 & 168,4 & 79.149 & 207,8 & 6,1 \\
\hline 1999 & 1.388 .490 & 182,3 & 1.296 .850 & 179,2 & 91.640 & 240,6 & 6,6 \\
\hline 2000 & 1.507 .914 & 197,9 & 1.387 .281 & 191,7 & 120.633 & 316,7 & 8,0 \\
\hline 2001 & 1.631 .072 & 214,1 & 1.458 .178 & 201,5 & 172.894 & 453,9 & 10,6 \\
\hline 2002 & 1.629 .422 & 213,9 & 1.446 .927 & 199,9 & 182.495 & 479,1 & 11,2 \\
\hline 2003 & 1.550 .857 & 203,6 & 1.356 .539 & 187,4 & 194.318 & 510,2 & 12,5 \\
\hline 2004 & 1.784 .354 & 234,2 & 1.534 .544 & 212,0 & 249.810 & 655,9 & 14,0 \\
\hline 2005 & 1.968 .856 & 258,5 & 1.703 .060 & 235,3 & 265.796 & 697,8 & 13,5 \\
\hline 2006 & 2.062 .493 & 270,7 & 1.794 .369 & 247,9 & 268.124 & 703,9 & 13,0 \\
\hline 2007 & 2.079 .590 & 273,0 & 1.830 .039 & 252,9 & 249.551 & 655,2 & 12,0 \\
\hline 2008 & 2.178 .395 & 286,0 & 1.956 .285 & 270,3 & 222.110 & 583,1 & 10,2 \\
\hline 2009 & 2.466 .511 & 323,8 & 2.256 .858 & 311,9 & 209.653 & 550,4 & 8,5 \\
\hline 2010 & 2.691 .729 & 352,3 & 2.472 .299 & 341,6 & 219.430 & 576,1 & 8,2 \\
\hline
\end{tabular}

Fonte: SETUR

TABELA 11 - MOVIMENTAÇÃO TURÍSTICA EM FORTALEZA E PÓLOS TURÍSTICOS

\begin{tabular}{|c|c|c|c|c|c|c|c|c|}
\hline \multirow[b]{2}{*}{ PÓLOS } & \multicolumn{4}{|c|}{2008} & \multicolumn{4}{|c|}{2009} \\
\hline & TOTAL & $(\%)$ & $\begin{array}{c}\text { MEIOS DE } \\
\text { HOSPEDAGEM }\end{array}$ & $\begin{array}{c}\text { TX. DE } \\
\text { OCUPAÇÃO }\end{array}$ & TOTAL & $(\%)$ & $\begin{array}{c}\text { MEIOS DE } \\
\text { HOSPEDAGEM }\end{array}$ & $\begin{array}{c}\text { TX. DE } \\
\text { OCUPAÇÃO }\end{array}$ \\
\hline Total Geral & 10.188 .374 & 100,0 & 3.554 .735 & 56,8 & 11.446 .031 & 100,0 & 4.006 .597 & 57,8 \\
\hline Fortaleza & 2.178 .395 & 21,4 & 1.151 .741 & 57,3 & 2.466 .511 & 21,5 & 1.312 .741 & 62,8 \\
\hline Pólos Turíst. & 8.009 .979 & 78,6 & 2.402 .994 & 55,0 & 8.979 .520 & 78,5 & 2.693 .856 & 53,9 \\
\hline $\begin{array}{l}\text { Araripe/ } \\
\text { Cariri }\end{array}$ & 456.438 & 4,5 & 136.931 & 48,2 & 1.108 .637 & 9,7 & 332.591 & 50,0 \\
\hline Ibiapaba & 1.173 .342 & 11,5 & 352.003 & 55,4 & 533.330 & 4,7 & 159.999 & 50,3 \\
\hline Baturité & 544.377 & 5,3 & 163.313 & 57,3 & 557.823 & 4,9 & 167.347 & 56,7 \\
\hline Litoral Leste & 2.327 .271 & 22,8 & 698.181 & 58,3 & 2.928 .646 & 25,6 & 878.594 & 60,0 \\
\hline $\begin{array}{l}\text { Litoral } \\
\text { Oeste }\end{array}$ & 2.474 .233 & 24,3 & 742.270 & 61,7 & 2.792 .471 & 24,4 & 837.741 & 57,9 \\
\hline $\begin{array}{l}\text { Sertão } \\
\text { Central }\end{array}$ & 537.469 & 5,3 & 161.241 & 51,6 & 551.557 & 4,8 & 165.467 & 51,6 \\
\hline Outros & 496.849 & 4,9 & 149.055 & 52,5 & 507.056 & 4,4 & 152.117 & 51,1 \\
\hline
\end{tabular}

Fonte: SETUR 


\section{As ações e as políticas públicas ligadas ao turismo}

A atividade turística, como já mencionado, é integrada à política econômica do Estado como propulsora do desenvolvimento econômico. Assim, investe-se bastante no setor, que tende a crescer cada vez mais. As políticas públicas implementadas desde 1987 pelo "Governo das Mudanças" previram uma forte intervenção do Estado, dando prioridade, além da indústria, ao turismo, tendo esse último adquirido crescente importância na economia cearense.

Percebe-se um nítido esforço das gestões do Governo do Estado e dos municípios no sentido de desenvolver o interesse de diferentes agentes ligados à atividade turística, a fim de que seja reconhecida sua importância e dimensão para o desenvolvimento da região. Dessa forma, houve, nos últimos anos, uma ampliação na oferta de equipamentos e serviços e foram implementadas obras de infraestrutura de apoio, principalmente vias de acesso e transporte, comunicação e segurança, além de promover a capacitação de profissionais ligados à área, com o objetivo de qualificar o Estado para a atividade.

Efetivamente, é incentivada a construção e reforma de aeroportos ${ }^{10}$, assim como a previsão de outros $^{111}$, em municípios litorâneos, associada à melhoria da malha viária e construção de vias litorâneas (Estruturante/CE 085 e CE 025), a fim de favorecer a recepção e distribuição dos fluxos turísticos $^{112}$ no litoral cearense.

A implantação dessa política de incentivo ao turismo, sobretudo no litoral ${ }^{113}$, provoca alterações profundas nas funções sociais (políticas, econômicas e culturais) e urbanísticas da Metrópole.

De acordo com a lógica adotada de que o Nordeste possui imenso potencial para investimentos e geração de emprego e renda com o turismo, foi atribuída uma crescente prioridade ao setor. Em consequência, criaram-se programas de incentivo com o objetivo de atrair investimentos capazes de mudar o perfil da região e, desta forma, reduzir as disparidades sociais e econômicas de ordem regional, por meio do crescimento da oferta de emprego e melhor distribuição de renda.

O turismo consiste em elemento potencializador dos espaços litorâneos das metrópoles nordestinas, incorporando as zonas de praia de seus municípios à lógica de valorização turística alicerçada pelo PRODETUR-NE, a partir do final do século XX (anos 1990). A crença nos benefícios do turismo provoca no Nordeste um boom turístico, alicerçado por políticas públicas de valorização das zonas de praia e centrado nas capitais, transformadas em pontos de recepção e de distribuição do fluxo turístico. (SILVA \& DANTAS, 2009, p.20).

\footnotetext{
${ }^{110} \mathrm{O}$ aeroporto internacional de Fortaleza, inaugurado em 1999, mobilizou recursos da ordem de R\$ 65 milhões. O surgimento de novas rotas internacionais para a aviação consolida a tendência de investimentos nesta direção. Um novo projeto de reforma e ampliação já foi realizado, com previsão de conclusão das obras em 2013.

${ }^{111}$ Já estão em fase de aprovação os projetos dos aeroportos de Aracati e Jericoacoara, concebidos a fim de incrementar o turismo na região litorânea. "Com uma pista de pouso de 2.200 metros de comprimento por 45m de largura, com capacidade para receber aviões a jato de médio e grande portes (ex: Embraer 145, Air Bus 320, Boeing 737-300), o novo aeroporto de Jericoacoara começa a se tornar realidade. O terminal terá características regionais e será erguido num espaço de 3.517,45 m², abrigando os setores de embarque, desembarque, administração, manutenção, comercial e institucional" (Setur-Ce).

${ }^{112}$ A localização do novo aeroporto de Fortaleza, assim como as vias de acesso construídas facilitaram o fluxo de turistas para a orla marítima da Cidade, onde se localizam os hotéis.

${ }^{113}$ A SETUR definiu "roteiros turísticos temáticos" estaduais, dentre os quais se destaca o "Roteiro do Turismo de Sol e Praia".
} 
No âmbito regional, o programa de maior alcance é o PRODETUR-NE ${ }^{114}$ (Programa de Desenvolvimento do Turismo do Nordeste), criado com o intuito de desenvolver o turismo sustentável na região. As ações foram previstas em duas etapas, que correspondem ao PREDETUR-NE ${ }^{115} \mathrm{E}$ PRODETUR-NE II ${ }^{116}$ e são direcionadas, sobretudo, para a implantação da infraestrutura dos municípios contemplados pelo programa, a fim de fomentar a oferta turística, contribuindo para o desenvolvimento econômico do Estado. O programa foi concebido por iniciativa de governadores do Nordeste ${ }^{117}$, junto ao Banco do Nordeste, SUDENE, Instituto Brasileiro de Turismo e Comissão do Turismo Integrado do Nordeste.

As ações do PRODETUR-NE se fundamentam nas seguintes estratégias, segundo Dantas (2002, p.56):

Organização, desenvolvimento e promoção do turismo através de uma articulação entre governo e iniciativa privada; instalação de infraestrutura de base e de infraestrutura turística adaptadas às potencialidades regionais; formação profissional dos recursos humanos ligados ao setor (turismo); descentralização da gestão turística com o fortalecimento dos organismos estatais, a municipalização do turismo e a terceirização das atividades para o setor privado.

As obras de infraestrutura consistem na construção ou reestruturação de estradas e ações de saneamento básico nos municípios contemplados, bem como a implantação de equipamentos que contribuam para o desenvolvimento do turismo. O programa propõe também a recuperação e o controle ambiental das praias, mananciais e lagoas, assim como a urbanização dos arredores. $\mathrm{E}$ prevê ainda a elaboração de um plano de marketing e desenvolvimento turístico.

É inegável que o PRODETUR, de fato, oferece condições para a ocupação turística no Nordeste, preparando a infraestrutura, promovendo estratégias de mercado e atraindo empresas, principalmente a rede hoteleira, com destaque para os resorts. As políticas públicas desenvolvidas pelo Governo do Estado e os programas de incentivo ao turismo de fato surtiram efeito e o Ceará

\footnotetext{
114 “O PRODETUR-NE (Programa de Desenvolvimento do Turismo no Nordeste) é um programa de crédito para o setor público (Estados e Municípios) que foi criado com o objetivo de oferecer condições favoráveis à expansão e melhoria da qualidade da atividade turística na Região Nordeste, como também para melhorar a qualidade de vida das populações residentes nas áreas beneficiadas. O programa é financiado com recursos do BID e tem o Banco do Nordeste como Órgão Executor". (BANCO DO NORDESTE, disponível em: http://www.bnb.gov.br/ content/aplicacao/PRODETUR).

115 "O PRODETUR-NE I, implementado em dezembro de 1994, constituiu um marco na atividade turística do Nordeste. O Programa tinha como finalidade promover o desenvolvimento socioeconômico da região Nordeste através da dinamização da atividade turística. Os objetivos específicos do Programa compreendiam: atração das atividades turísticas privadas adicionais e de melhor padrão; geração de oportunidades de emprego; Melhoria dos níveis de renda; aumento das receitas públicas". (BANCO DO NORDESTE, 2005). Nessa primeira etapa (1995 a 2005), o PRODETUR investiu US\$ 166,13 milhões no estado. Além de obras para melhoria das estradas (Costa do Sol Poente e Costa do Sol Nascente), e da construção do Aeroporto Internacional Pinto Martins em Fortaleza e respectivas vias de acesso, foram construídos sistemas de abastecimentos d'água e esgotamento sanitário nos municípios beneficiados pelo programa. 116 O PRODETEUR-NE II, implementado em 2005, complementa ações da primeira fase e contempla mais dez municípios cearenses, dentre os quais Aquiraz. O programa, nessa etapa, "se vale de novos conceitos e mecanismos, como a prioridade em relação à criação e intervenção dos polos de turismo, incorporando a questão da sustentabilidade, a participação e o fortalecimento da capacitação dos recursos humanos, consolidando e complementando as ações propostas na primeira fase do programa." (PAIVA, 2011, p.145).

117 "A ênfase no turismo como vetor de desenvolvimento regional representa, neste contexto, um novo momento do planejamento governamental para o Nordeste, calcado, sobretudo, na chamada 'potencialidade natural' da região para a atividade, considerando-se, fundamentalmente, a extensão de sua costa (3.300 km aproximadamente) e o clima quente predominante. Dessa forma, é a natureza que se coloca, mais uma vez, no centro das políticas de desenvolvimento para a Região, embora, neste momento, com um significado oposto àquele que lhe era atribuído no passado. Na verdade, não se está tratando, agora da 'natureza adversa' do sertão, mas da 'natureza prodigiosa' do litoral'. (CORIOLANO, 1998, p.30).
} 
converteu-se num dos principais destinos turísticos do País e mesmo internacional. Observa-se, no entanto, que, se por um lado, houve um inegável incremento da atividade turística e melhorias podem ser constatadas no que se refere à infraestrutura, ainda se verifica um forte contraste relativamente ao desempenho social, cultural e ambiental. Pode-se afirmar que as maiores transformações ocorreram no âmbito espacial, com impactos importantes na faixa litorânea.

Constata-se, enfim, que toda essa conjunção de fatores, resultado da política de incentivo ao turismo e da "construção" de uma nova "imagem"18" da Cidade e do Estado, provocou uma reorganização na configuração espacial da Metrópole fortalezense, com modificações substanciais em toda a extensão da orla marítima.

\section{Fluxos globais: investimentos estrangeiros}

Consequência da política agressiva de marketing de turismo no Nordeste e no Ceará (propagandas em feiras, folhetos ${ }^{119}$ distribuídos em aviões, etc.), é grande o afluxo de turistas estrangeiros nos últimos anos, principalmente europeus. Atraídos pela paisagem natural, clima e com o câmbio favorável, viram no Estado também boas perspectivas de investimento e oportunidades de negócio.

O conjunto de investimentos do Estado revelou as potencialidades de um Nordeste turístico, altamente competitivo e atrativo ao capital estrangeiro que passou, desde 2003, a investir fortemente na região. É o que consideramos uma "nova fase" do turismo regional, onde o mercado - entendido como os aportes financeiros pulverizados em diversos agentes econômicos - passa a redefinir o Nordeste turístico (SILVA, 2008) ${ }^{120}$.

Nos últimos anos, houve expressivos investimentos em euros na Cidade, no setor imobiliário, principalmente em áreas relacionadas ao turismo. Com a vantagem da diferença do câmbio da União Europeia e o favorecimento de empréstimos a juros baixos em seus países de origem, até o ano de 2010, foi grande o número de investidores ${ }^{121}$ a fazer negócios no Estado ${ }^{122}$. Os projetos, alguns deles ainda em andamento, são geralmente executados em parceria com fortes grupos empresariais locais.

Segundo pesquisa realizada por Silva (2008), no ano de 2007 o Ceará foi o estado do Nordeste que mais recebeu investimentos estrangeiros:

\footnotetext{
118 “No processo de transformação de Fortaleza (e do Ceará) em 'centro turístico', há que se considerar a busca da construção de uma 'imagem turística' da Cidade, a partir da adoção de uma política de marketing divulgada insistentemente na mídia e baseada, sobretudo, em seus atributos e qualidades climáticas, a fim de desempenhar o seu papel na economia globalizada. As políticas de planejamento e marketing reforçam o papel de Fortaleza na valorização de suas zonas de praia, vista agora como a 'cidade do sol'. O objetivo é reverter a idéia negativa dos imperativos do meio (o sol ligado às adversidades da seca), em contraposição a uma imagem positiva, relacionada agora à natureza pródiga da região e vinculado à prática do turismo de sol e mar. Essa estratégia é utilizada pela elite política local, no poder desde os anos 1980, que tenciona desde então modificar e modernizar a imagem do Ceará, passando assim a inserir-se de forma positiva no cenário nacional e atuando, por outro lado, como reflexo do novo governo, autêntica propaganda política" (DIÓGENES, 2010, p.220).

${ }^{119}$ Os anúncios se reportam, sobretudo, "ao clima fantástico, aos preços baixos, à cultura exótica e ao povo", referindo-se ao turismo litorâneo no Nordeste brasileiro.

${ }^{120}$ Disponível em http://www.ub.edu/geocrit/-xcol/280.htm).

${ }^{121}$ Grupos espanhóis e principalmente portugueses como Pestana, Dorisol, Oásis e João Rendeiro investem no Estado, como atestam alguns dos empreendimentos atualmente em fase de execução no Ceará.

${ }^{122}$ Com a crise européia em curso, já se começa a sentir os efeitos da recessão, com os recuos dos investimentos imobiliários. O maior volume de vendas atualmente se deve a investidores locais, conforme informações do SECOVI-CE.
} 


\section{TABELA 12 - VALORES (EM US\$) DE ENTRADA DE CAPITAL ESTRANGEIRO PARA O SETOR IMOBILIÁRIO -TURÍSTICO EM ESTADOS NORDESTINOS (2001-2007)}

\begin{tabular}{|c|crrrrrr|}
\hline ESTADOS & $\mathbf{2 0 0 1}$ & $\mathbf{2 0 0 2}$ & $\mathbf{2 0 0 3}$ & $\mathbf{2 0 0 4}$ & $\mathbf{2 0 0 5}$ & $\mathbf{2 0 0 6}$ & \multicolumn{1}{c}{2007} \\
\hline RN & 10.355 .947 & 2.214 .459 & 8.153 .610 & 24.477 .033 & 37.188 .720 & 61.683 .547 & 96.718 .864 \\
\hline CE & $\mathbf{1 0 . 3 5 6 . 0 0 0}$ & $\mathbf{1 8 . 4 8 1 . 1 5 7}$ & $\mathbf{2 0 . 9 6 0 . 5 2 4}$ & $\mathbf{1 5 . 5 8 8 . 4 3 1}$ & $\mathbf{2 9 . 8 2 2 . 4 8 6}$ & $\mathbf{3 7 . 6 1 9 . 1 7 5}$ & $\mathbf{1 5 3 . 8 0 0 . 7 9 8}$ \\
\hline BA & 11.797 .575 & 23.311 .979 & 42.284 .139 & 16.147 .789 & 89.964 .095 & 243.743 .934 & 49.699 .086 \\
\hline PE & - & 2.350 .000 & 2.849 .500 & 959.205 & 1.252 .800 & 24.323 .904 & 4.798 .787 \\
\hline TOTAL & 32.509 .522 & 46.357 .595 & 74.247 .773 & 57.172 .460 & 158.228 .101 & 367.370 .561305 .017 .536 \\
\hline
\end{tabular}

Fonte: SILVA, 2008

Conforme análise de Bernal (2008),

para os estrangeiros que chegam a Fortaleza com moeda forte (euro ou dólar), os preços dos imóveis, mesmo já aquecidos pela especulação do mercado imobiliário parecem atrativos para a realização de investimentos (...) Informações do SINDUSCON-CE revelam que 30\% das compras de imóveis na Aldeota, Varjota, Beira-Mar e Meireles são concretizadas por clientes de fora do país, representando este segmento cerca de $10 \%$ de todo o mercado imobiliário da Grande Fortaleza. Estes mesmos estrangeiros vêm comprando flats, terrenos de praia, lotes urbanizados e casas de praia. ${ }^{123}$

Se o turismo consiste em importante fator de desenvolvimento da região, por outro lado, são constantemente mencionados outros impactos ${ }^{124}$ que a atividade produz:

O turismo é um vetor importante na estruturação do espaço, apresentando considerável crescimento na ultima década, porém carrega consigo uma perigosa simbiose. Ao mesmo tempo que agrega valor à renda, contribui para o avanço da economia subterrânea [de difícil mensuração e que qualifica mal a metrópole] e gera graves problemas sociais, desigualdades e segregação (BERNAL, 2004, p.196).

\section{O turismo no litoral da RMF}

A maior atração para o turismo do Ceará é sem dúvida o seu litoral, com seus 573 km de extensão e suas praias, clima ensolarado, comunidades nativas, polos de lazer, hotéis e residências de veraneio que oferece. O litoral é a região mais procurada pelos visitantes e a área com maior oferta de serviços turísticos, fortalecida com a construção crescente de hotéis, resorts ${ }^{125}$, pousadas e parques temáticos, implantados em toda a extensão da orla.

\footnotetext{
${ }^{123}$ Disponível em: http://googlegroups.com/a/metrowiki.net/observatoriodasmetrpoles-workshop-fortaleza.

${ }^{124}$ Os impactos negativos mencionados referem-se principalmente à prática do "turismo sexual", realizada por muitos dos turistas estrangeiros em terras cearenses e nordestinas, além do tráfico de drogas e "lavagem" de dinheiro. Essa análise, entretanto, foge aos objetivos da tese, que se relacionam principalmente aos efeitos do turismo no processo de urbanização e expansão metropolitana.

${ }^{125}$ Para a Associação Brasileira dos Resorts, enquadra-se nessa qualificação "o estabelecimento que for destino exclusivo e diferenciado, dotado de excelente infraestrutura e situado em local paradisíaco. É onde se pode ter contato com a natureza e desfrutar de várias opções de lazer". Os resorts são, de fato, meios de hospedagens com configurações espaciais elitizadas, localizadas preferencialmente em áreas naturais preservadas e, muitas vezes, distantes de áreas urbanizadas. São verdadeiros enclaves nas comunidades onde se instalam; formam um mundo isolado e utilizam uma variedade de estratégias para reter o turista, sem dar-lhes chances de sair desses ambientes, para divertimentos e consumos fora das dependências. Têm, como frequentadores, clientes de alto poder aquisitivo, que podem pagar pelo lazer de luxo.
} 
Embora a atividade turística se estenda por toda a costa cearense, sobretudo de Jericoacoara, ao oeste, a Canoa Quebrada, ao leste, determinados trechos do litoral se transformam mais intensamente, convertendo-se em espaços voltados quase que exclusivamente para fins turísticos. Essas transformações são mais visíveis na zona litorânea da Região Metropolitana de Fortaleza (ver figura 2.25).

O litoral leste da RMF compreende as praias dos municípios de Aquiraz (Porto das Dunas, Prainha, Presídio, Iguape e Barro Preto) e Cascavel (Caponga e Águas Belas).

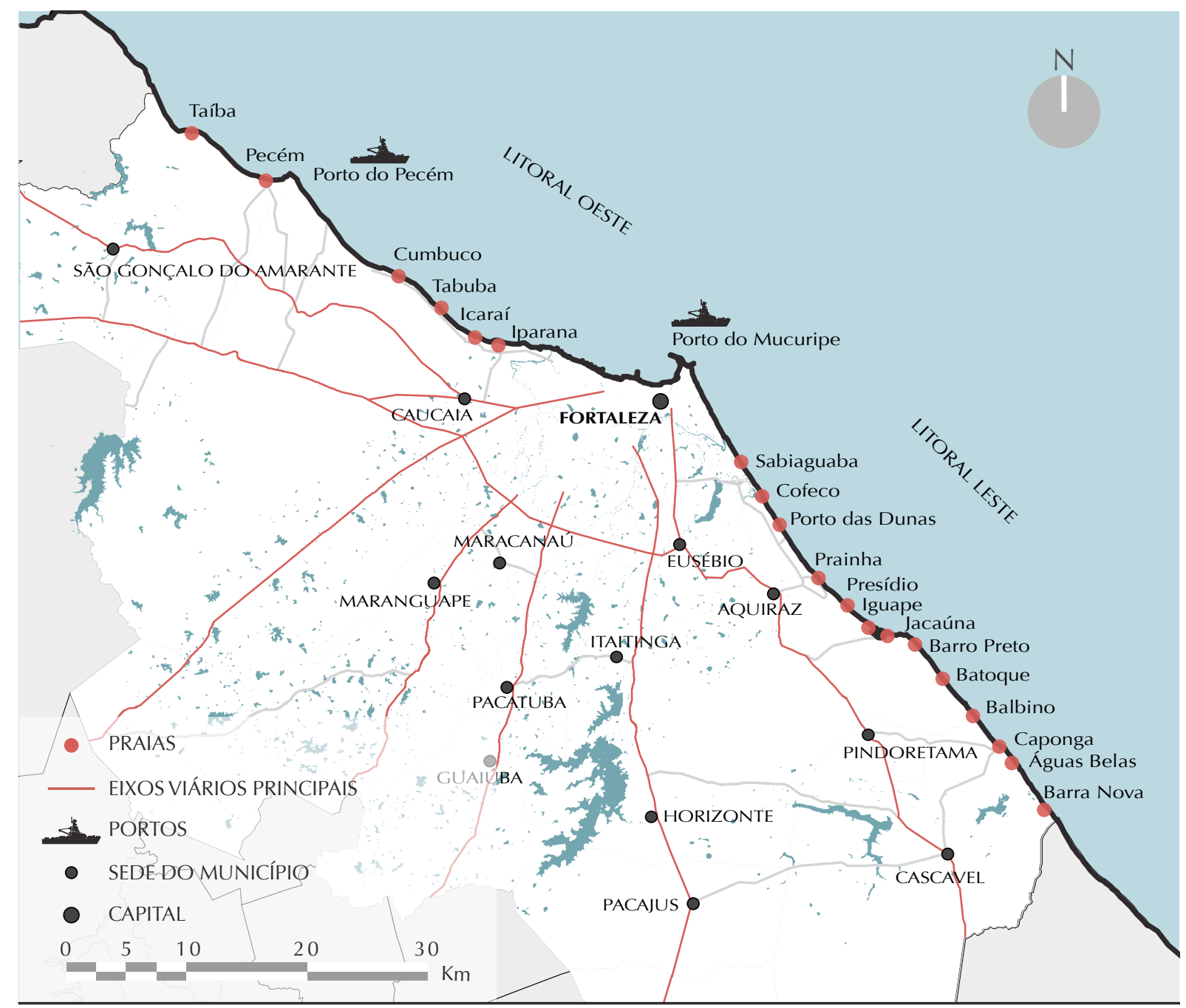

Fig. 2.25 Mapa RMF: litoral com praias Fonte: elaborado pela autora

A orla marítima do Município de Aquiraz tornou-se o principal polo turístico do Estado, depois de Fortaleza, concentrando a maior parte dos equipamentos de lazer e turismo, abrangendo o Complexo Beach Park, diversos resorts, hotéis e condomínios de lazer (ver figura 2.26). As transformações ocorridas neste trecho da faixa litorânea cearense adquirem uma conformação específica e diferenciada, as quais serão analisadas com maior profundidade e detalhes no capítulo 4, uma vez que esta área integra o chamado setor sudeste da Metrópole, assunto do referido capítulo. 


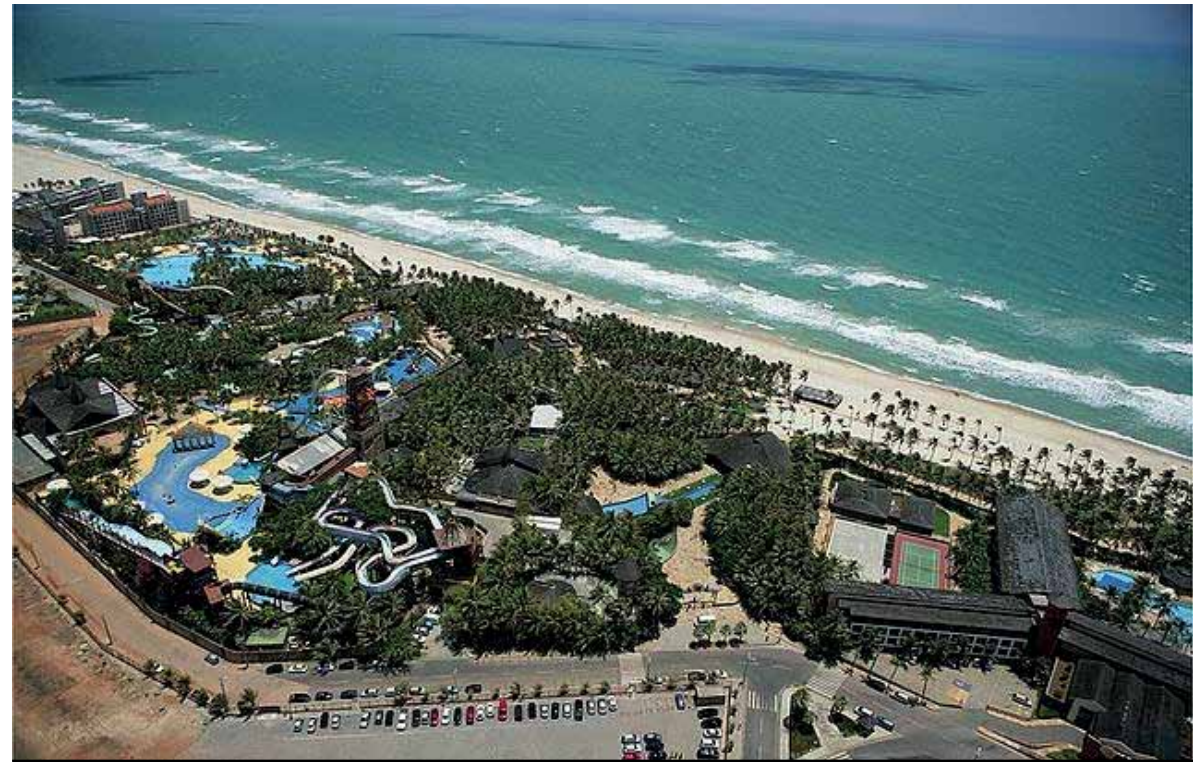

Fig. 2.26 Complexo Beach Park

Fonte: http://www.feriasbrasil.com.br/ce/fortaleza/beachpark

Também na direção leste, na faixa litorânea de Cascavel - município que só recentemente passou a integrar a RMF - as mudanças estão ocorrendo em ritmo acelerado, apesar de haver ainda grandes extensões de áreas desocupadas. A praia da Caponga, principal núcleo litorâneo, abriga antiga comunidade de pescadores e residências de veraneio construídas nas décadas de 1970-1990. Nas vizinhanças (praia de Águas Belas), porém, grandes empreendimentos de turismo e lazer de luxo começam a ser implantados, como o Águas Belas Golf Resort \& Spa ${ }^{126}$, um dos denominados "resorts integrados ${ }^{127 "}$ que, em área de 77,8 ha compreende dois hotéis, 1.200 unidades imobiliárias (casas e apartamentos), além de restaurantes e campo de golfe (ver figura 2.27).

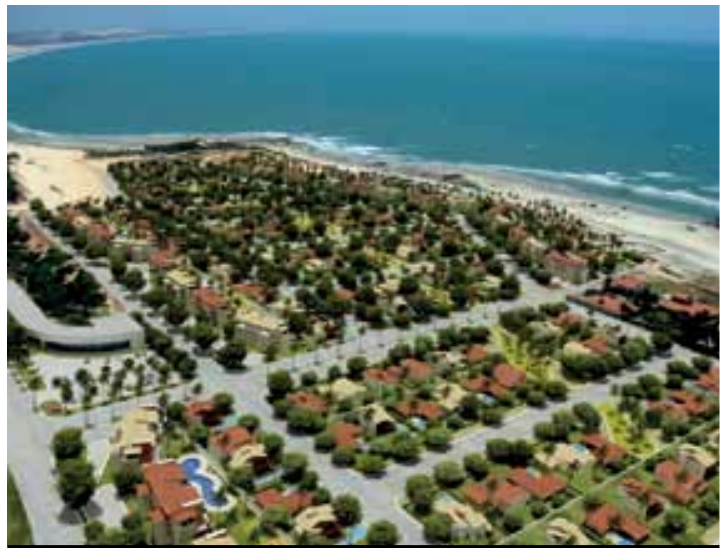

Fig. 2.27 Águas Belas Golf Resort \& Spa Fonte: http://www.bldbrasil.com/site

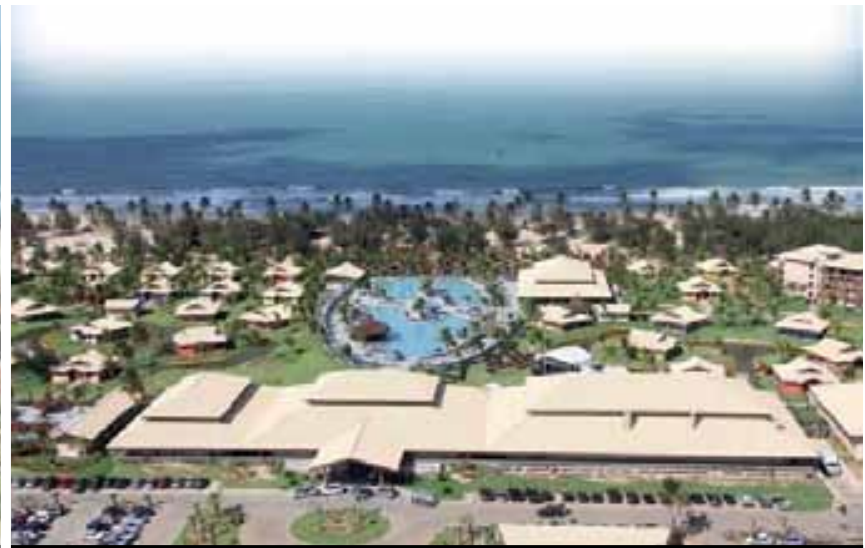

Fig. 2.28 Resort Vila Galé Cumbuco

Fonte: http://www.revistahoteis.com.br

${ }^{126}$ Com investimento de $\mathrm{R} \$ 600$ milhões por parte de empresas cearenses, associadas à portuguesa Mikatys Empreendimentos Imobiliários, o complexo deverá ficar completamente pronto até o ano de 2014, mas a primeira fase, que compreende um hotel, o campo de golfe e um condomínio com 280 unidades, já foi concluída.

${ }^{127}$ Os chamados resorts integrados constituem uma tendência recente do mercado imobiliário, e traduzem-se em mega-empreendimentos, os quais abrangem, além do equipamento hoteleiro, centros de comércio e serviços, loteamentos diversos, segundas residências (casas e/ou apartamentos), campos de golfe, restaurantes, etc. 
O litoral oeste da RMF é formado pela zona costeira dos municípios de Caucaia e São Gonçalo do Amarante. A orla de Caucaia possui 44 km de extensão e abrange as praias Pacheco, Iparana, Icaraí, Tabuba e Cumbuco. Antes comunidades de pescadores, a ocupação com fins de veraneio nesses núcleos ocorreu entre as décadas de 1960-1990, com a oferta de loteamentos para a construção de residências secundárias, principalmente em Iparana, Pacheco e Icaraí128, que constitui atualmente o núcleo mais urbanizado do litoral oeste, com inúmeras residências de veraneio transformadas em residências permanentes. Nos anos 1990-2000, com o incremento do turismo, verificou-se uma transformação significativa na ocupação dessa orla, com a construção de hotéis, pousadas, restaurantes, condomínios de lazer, etc.

A praia do Cumbuco é a que possui maiores atrativos turísticos, com paisagem natural privilegiada e a que abriga a maior concentração de hotéis. Recentemente, foi inaugurada a primeira etapa do Cumbuco Golf Resort, do grupo português Vila Galé, um empreendimento de grande porte, também considerado um resort integrado, com investimento da ordem de R $\$ 470$ milhões e que deverá abrigar, quando concluído, 1,5 mil unidades hoteleiras, cinco condomínios residenciais e um campo de golfe (ver figura 2.28).

O litoral de São Gonçalo do Amarante apresenta uma ocupação bem mais rarefeita, com poucos núcleos turísticos (a praia da Taíba ${ }^{129}$, situada a $65 \mathrm{~km}$ de Fortaleza, é o principal) e abriga o Complexo Industrial Portuário do Pecém ${ }^{130}$, situado na divisa com o Município de Caucaia, o qual tem provocado impactos significativos na região onde foi instalado.

A construção da ponte sobre o rio Ceará, concluída em 1997, facilitou sobremaneira o acesso aos núcleos litorâneos da chamada Costa do Sol Poente, favorecendo a expansão metropolitana via litoral oeste ${ }^{131}$. Na direção oposta, ao leste, a ponte sobre o rio Pacoti, construída em 1981, permitiu a integração viária direta entre Fortaleza e o litoral de Aquiraz, antes feita apenas pela CE 040. E, mais recentemente, em 2010, foi concluída a construção da ponte sobre o rio Cocó ${ }^{132}$, entre as praias do Futuro e Sabiaguaba, embora o acesso viário (a pavimentação das vias) ainda não esteja plenamente efetivado.

\footnotetext{
${ }^{128}$ A praia do Icaraí passou por um processo de desvalorização de seus terrenos e hoje é utilizada preferencialmente pela população de classe média baixa. Constitui um núcleo urbano em desenvolvimento, crescendo em continuidade espacial com relação à Sede do Município de Caucaia e atraindo comércio e serviços complementares. A proximidade de Fortaleza e facilidade de acessos transformam-no quase num bairro residencial da Metrópole, dado o número de residências de veraneio transformadas em permanentes.

${ }^{129}$ Também aí são previstos empreendimentos turísticos de porte, como o Taíba Beach Resort, de um grupo norueguês, ocupando parte significativa da faixa de praia.

${ }^{130} \mathrm{O}$ CIPP, já citado, será descrito e analisado com detalhes no capítulo 3.

${ }^{131}$ A construção das rodovias CE 090, situada bem próximo à orla e, posteriormente, da CE 085 (Via Estruturante), foi determinante para o acesso às praias do litoral oeste e para incrementar a ocupação deste trecho da RMF.

${ }^{132}$ A ponte sobre o rio Cocó tem 325 m de extensão e demorou oito anos para ser concluída.
} 
CAPÍTULO 2

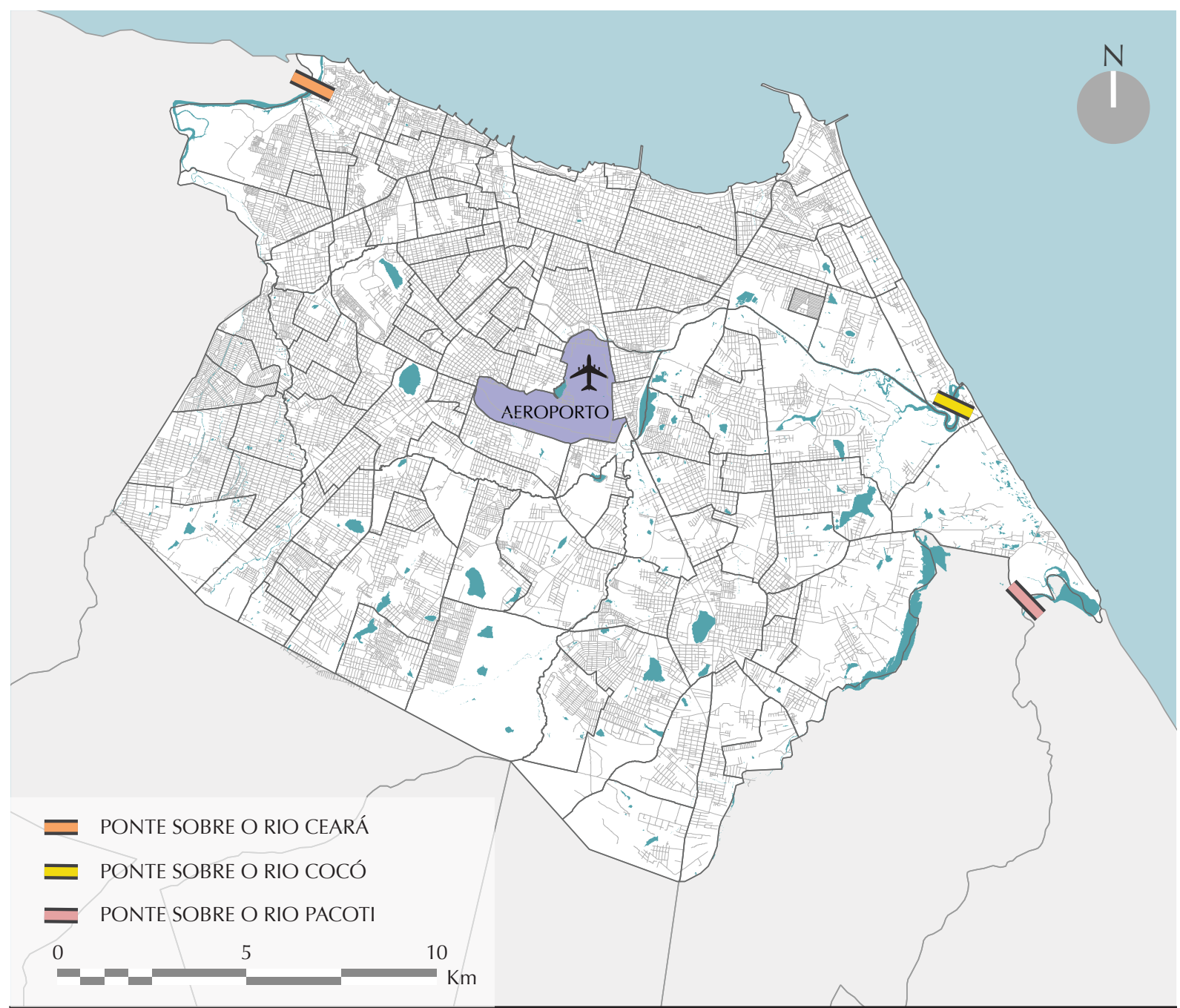

Fig. 2.29 Mapa Fortaleza: aeroporto e pontes

Fonte: elaborado pela autora

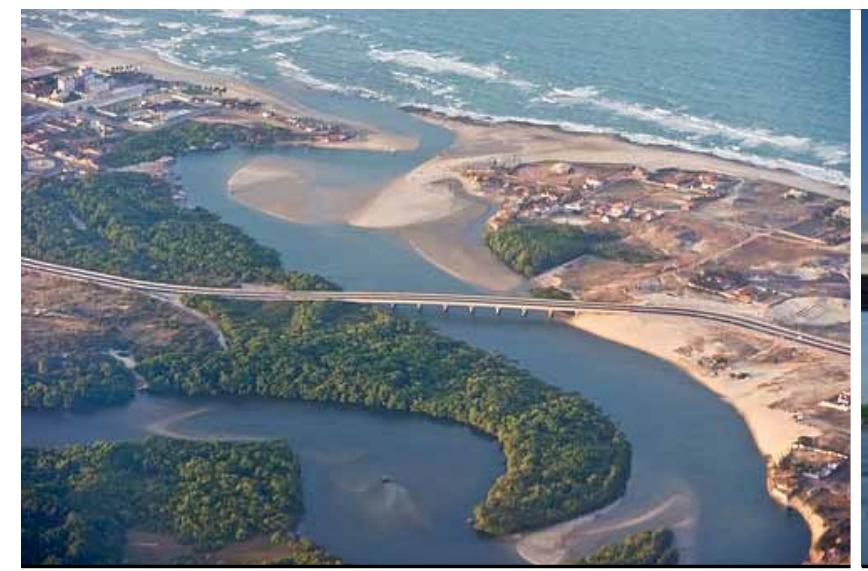

Fig. 2.30 Ponte sobre o rio Cocó

Fonte: http://www.jangadeiroonline.com.br/fortaleza/

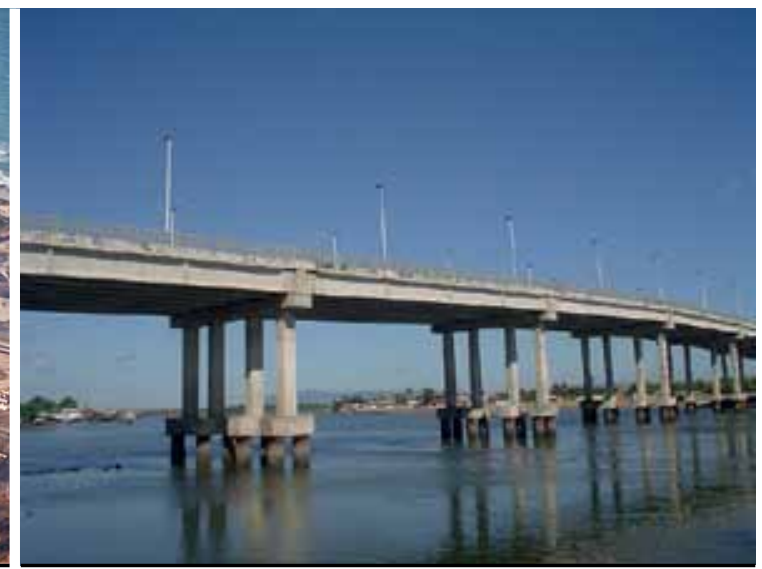

Fig. 2.31 Ponte sobre o rio Ceará

Fonte: http://liecejajwp1.blogspot.com.br 
Vale ressaltar que o processo de urbanização verificado na faixa litorânea da RMF não se expande de forma contínua com relação ao Município de Fortaleza. Primeiramente, devido à existência de barreiras naturais e à dificuldade de acessos ${ }^{133}$ e depois, por conta da própria forma de urbanização, que se caracteriza pela implantação de núcleos descontínuos e presença de grandes áreas sem qualquer ocupação. Por outro lado, os acessos viários entre Fortaleza e os núcleos litorâneos de Aquiraz e Caucaia se fizeram relativamente distantes da orla marítima, dificultando a continuidade da área urbanizada.

\section{A manifestação espacial da atividade turística e a urbanização da faixa litorânea}

Ante o incremento da atividade turística no Ceará nos últimos anos ${ }^{134}$, verifica-se que há progressiva ocupação de trechos não urbanizados no litoral, alterando o espaço e produzindo novas configurações territoriais. Surgem aos poucos, e em escala crescente, inúmeros hotéis, residências e condomínios de férias, parques temáticos, restaurantes e outros equipamentos ligados a turismo e lazer, além de loteamentos e condomínios dirigidos para as classes de maior poder aquisitivo, nas regiões litorâneas. Grandes empreendimentos têm sido implantados e muitos outros são previstos, provocando mudanças cada vez mais significativas no espaço, agindo também na remodelação da paisagem.

Conforme ressalta a geógrafa Rita Cruz (1999, p.174),

[...] outro aspecto da modernização de territórios litorâneos nordestinos é dado pelos mega-projetos turísticos em implantação. Esses mega-projetos modernizam, "instantaneamente", as porções de território sobre as quais se assentam. Estradas pavimentadas, energia elétrica, telefonia, hotéis de luxo, heliportos, campos de golfe e inúmeros outros objetos são introduzidos, de uma só vez, nesses territórios, trazendo consigo novos fluxos (de pessoas, de informações, de capitais, etc.). É o turismo impondo seu tempo, criando seu espaço.

Constata-se, portanto, que a expansão urbana da RMF é condicionada em grande parte pelos efeitos das manifestações espaciais do turismo, principalmente na faixa litorânea, a qual apresenta características específicas, marcada pela dinâmica imobiliária que extrapola a escala urbana, pela implantação de grandes empreendimentos, como os resorts integrados e hotéis diversos; e pela instalação de equipamentos turísticos e de lazer, como restaurantes, parques temáticos e aquáticos.

\footnotetext{
${ }^{133}$ Antes da construção das pontes sobre os rios Ceará, Pacoti e Cocó, os acessos aos municípios litorâneos eram feitos via av. Bezerra de Menezes/BR 222 ao oeste e av. Washington Soares/CE 040, ao leste, distantes da orla. A construção das pontes permitiu maior articulação metropolitana entre os municípios, propiciando melhor integração viária entre a Capital e os núcleos do litoral da RMF e, consequentemente, a expansão da aérea urbanizada.

${ }^{134}$ Segundo informações da Secretaria de Turismo do Estado (SETUR), a demanda turística, via Fortaleza, cresceu 13,5\%, janeiro a abril/2010 sobre janeiro a abril/2009, correspondendo a 912,18 mil visitantes. A demanda hoteleira, também (13,6\%). A taxa média de ocupação hoteleira ficou em 66,6\%. Foi significativo o número de passageiros desembarcados, de janeiro a abril/2010, totalizando 700,32 mil pessoas, $26,4 \%$ a mais do que o registrado no mesmo período de 2009, 554,01 mil passageiros.
} 
Entre os efeitos do turismo no processo de urbanização no litoral da RMF, pode-se relacionar: a ampliação da rede viária, facilitando o acesso aos núcleos litorâneos ${ }^{135}$; a ocupação rarefeita e descontínua, com baixa densidade demográfica; a ocupação progressiva de áreas desocupadas, com privatização da faixa de praia, provocando alterações entre o espaço público e o privado; a inexistência de núcleos urbanos significativos; a paulatina expulsão das comunidades de nativos (pescadores); o surgimento de novas tipologias ligadas ao turismo, além de impactos sobre o meio ambiente, ensejando quase sempre conflitos entre o meio natural e o construído.

Outro aspecto relacionado à chamada "urbanização turística ${ }^{136 ", ~ v e r i f i c a d a ~ n o ~ l i t o r a l ~ d a ~}$ RMF, consiste no fato de que esse processo, além de transformações substantivas no espaço da orla marítima, "produz grande afluxo de pessoas, mercadorias e atividades, mas não promove necessariamente a fixação de pessoas no território por ele apropriado" (PAIVA, 2011, p.178).

Sendo assim, a produção e o consumo do espaço voltados para o turismo não geram necessariamente o crescimento da população nas áreas apropriadas pelos turistas (espaços litorâneos) uma vez que, estatisticamente, nem o turista nem mesmo os veranistas (proprietários de residências secundárias) são considerados como população residente, muito embora os espaços apropriados pelos visitantes sejam amplamente transformados, constituindo uma espécie de "urbanização vazia", ou seja, há um aumento da área urbanizada e construída, mas que são utilizadas em períodos específicos (fins de semana, feriados, férias) por uma população flutuante (IDEM).

As manifestações espaciais da urbanização relacionadas à atividade turística serão mais bem apreciadas no capítulo 4, quando for analisada a área do litoral de Aquiraz e suas respectivas especificidades.

\footnotetext{
${ }^{135}$ As diversas articulações viárias entre Fortaleza e os espaços litorâneos da RMF contribuem para a expansão do tecido metropolitano, além de propiciar dinâmicas imobiliárias, com o surgimento de vários loteamentos nas imediações das vias.

${ }^{136}$ Segundo conceito formulado por Patrick Mullins (1991) a "urbanização turística" consiste basicamente na constatação da existência de formas específicas de produção do espaço urbano concebidas com base na atividade turística, sobretudo quando esta se impõe como dominante na economia local. Trata-se, em suma, de uma modalidade particular de produzir e estruturar o espaço urbano.
} 


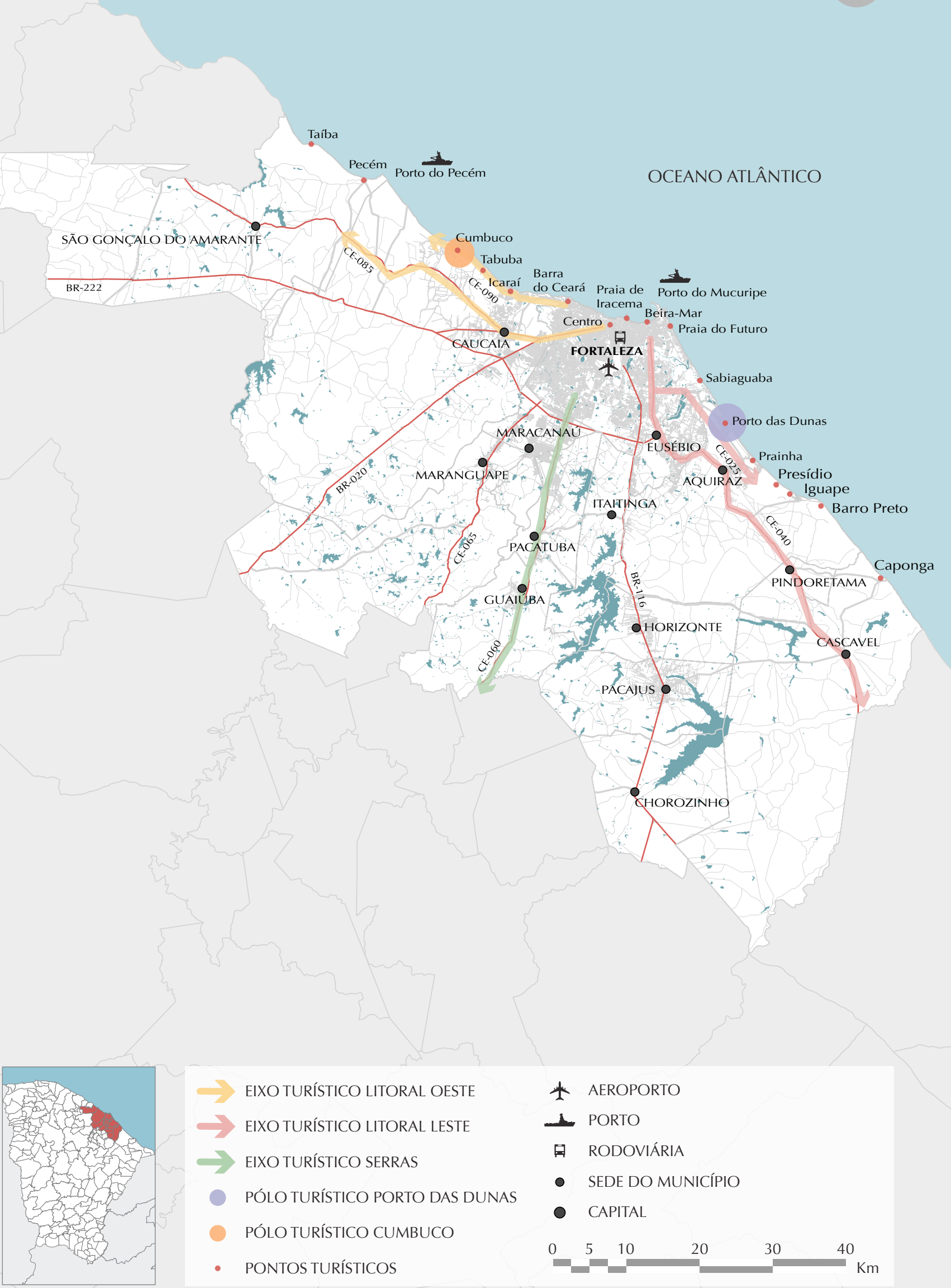

Fig. 2.32 Mapa RMF: dinâmica do turismo

Fonte: elaborado pela autora 


\subsubsection{Considerações acerca da dimensão econômica atual da Metrópole: o predomínio do setor terciário, a dinâmica imobiliária e o papel do Estado}

A economia cearense ${ }^{137}$, principalmente na RMF, mesmo diante do dinamismo e do avanço crescente da atividade industrial, mantém a sua característica terciário-comercial, baseada nas atividades de prestação de serviço e comércio de mercadorias, com presença marcante do setor informal. A atividade terciária' ${ }^{138}$, pois, continua comandando a economia do Estado, da Região Metropolitana e da Capital.

Apesar do aumento significativo do PIB industrial, de acordo com as pesquisas recentes (tabela 13), a maior participação na esfera econômica do Estado ainda decorre do setor de serviços, situação que vem se mantendo, conforme assinala Amora (2005, p.378): "a dinâmica industrial registrada nas ultimas décadas não foi suficiente para superar setores tradicionais da economia cearense".

De acordo com o Boletim de Conjuntura Econômica do IPECE (2010), o setor de serviços ${ }^{139}$ foi o principal responsável pelo crescimento da economia cearense $(5,6 \%)$, seguido da indústria, com um aumento de 1,1\%. A agropecuária fechou o ano de 2009 com queda de 9,0\% sobre o resultado de 2008, como mostra a tabela 12. Para o Brasil, o setor de serviços também foi o único com resultado positivo (2,6\%), haja vista que a agropecuária e a indústria registraram taxas negativas de, respectivamente, -5,2\% e -5,5\%.

TABELA 13 - TAXA DE CRESCIMENTO DO PIB 2010 (\%)

\begin{tabular}{lcc} 
ATIVIDADE & CEARÁ & BRASIL \\
\hline Agropecuária & $-8,1$ & 6,5 \\
Indústria & 9,7 & 10,1 \\
Serviços & 7,5 & 5,4 \\
TOTAL & 7,9 & 7,5
\end{tabular}

Fonte: IPECE (Informe março/2011)

O setor terciário ${ }^{140}$ representa, pois, no contexto da economia da RMF, a maior participação no PIB (79,57\% - IPECE - Instituto de Pesquisa e Estratégia Econômica do Ceará) e na taxa de população empregada (74\% - SINE/CE - Sistema Nacional de Empregos), principalmente no Município de Fortaleza. Estes percentuais, que vêm sendo mantidos, evidenciam a hegemonia da atividade terciária, independentemente do avanço da industrialização recente.

\footnotetext{
${ }^{137}$ Segundo relatório do IPECE (2010), “o ano de 2009, que poderia ser um dos mais pessimistas para a economia cearense entra para história econômica do Ceará, por ter superado os obstáculos dos efeitos de uma das maiores crises ocorridas em décadas. O Produto Interno Bruto (PIB), que mede a riqueza gerada pelos setores econômicos, fechou o ano com um crescimento de 3,1\% superior ao resultado da economia brasileira, que recuou $0,2 \%$. Estes resultados positivos da economia estadual foram reflexos do desempenho do setor de Serviços, 5,5\%, e da Indústria, 1,0\%". Neste ano, o Ceará gerou 64.436 empregos formais, figurando como o segundo Estado que mais gerou empregos no Nordeste, antecedido pela Bahia, com 71.170 vagas ( $6^{\mathrm{a}}$ posição nacional). Também no ano de 2009, no que se refere à geração de empregos, a Região Metropolitana de Fortaleza (RMF) obteve a terceira colocação entre as metrópoles brasileiras que mais geraram empregos formais (46.733 vagas), antecedida pelas regiões metropolitanas de São Paulo (159.670 vagas) e do Rio de Janeiro (74.224 vagas).

${ }^{138}$ Conforme classificação do IPECE, o setor terciário compreende as atividades de comércio e prestação de serviços (públicos e privados), a qual envolve as seguintes categorias: transporte e armazenamento, comunicação, alojamento e alimentação, intermediação financeira, atividades imobiliárias, administração pública, educação, saúde e serviços sociais. O turismo, portanto, faz parte da atividade terciária.

${ }^{139}$ Segundo dados do IPECE (2010), o setor de serviços foi o que mais criou emprego formal no Ceará no ano de 2009, com um saldo de 21.439 vagas, seguida da indústria de transformação, com 21.130 vagas. O comércio vem a seguir, com a geração de 12.559 postos de trabalho e a construção civil ocupou a quarta posição, com um saldo de 9.816 vagas.

140 "O crescimento mais notável do setor terciário acontece nos serviços de comércio ambulante, hospedagem e alimentação, serviços de administração, limpeza e vigilância e serviços técnico-profissionais e de incorporação de imóveis. Isto denota um crescimento da estrutura do emprego no que diz respeito às atividades ligadas ao turismo, aos negócios imobiliários e ao chamado setor informal, onde cresce a participação de vendedores ambulantes e biscateiros" (BERNAL, 2009, p, 57).
} 


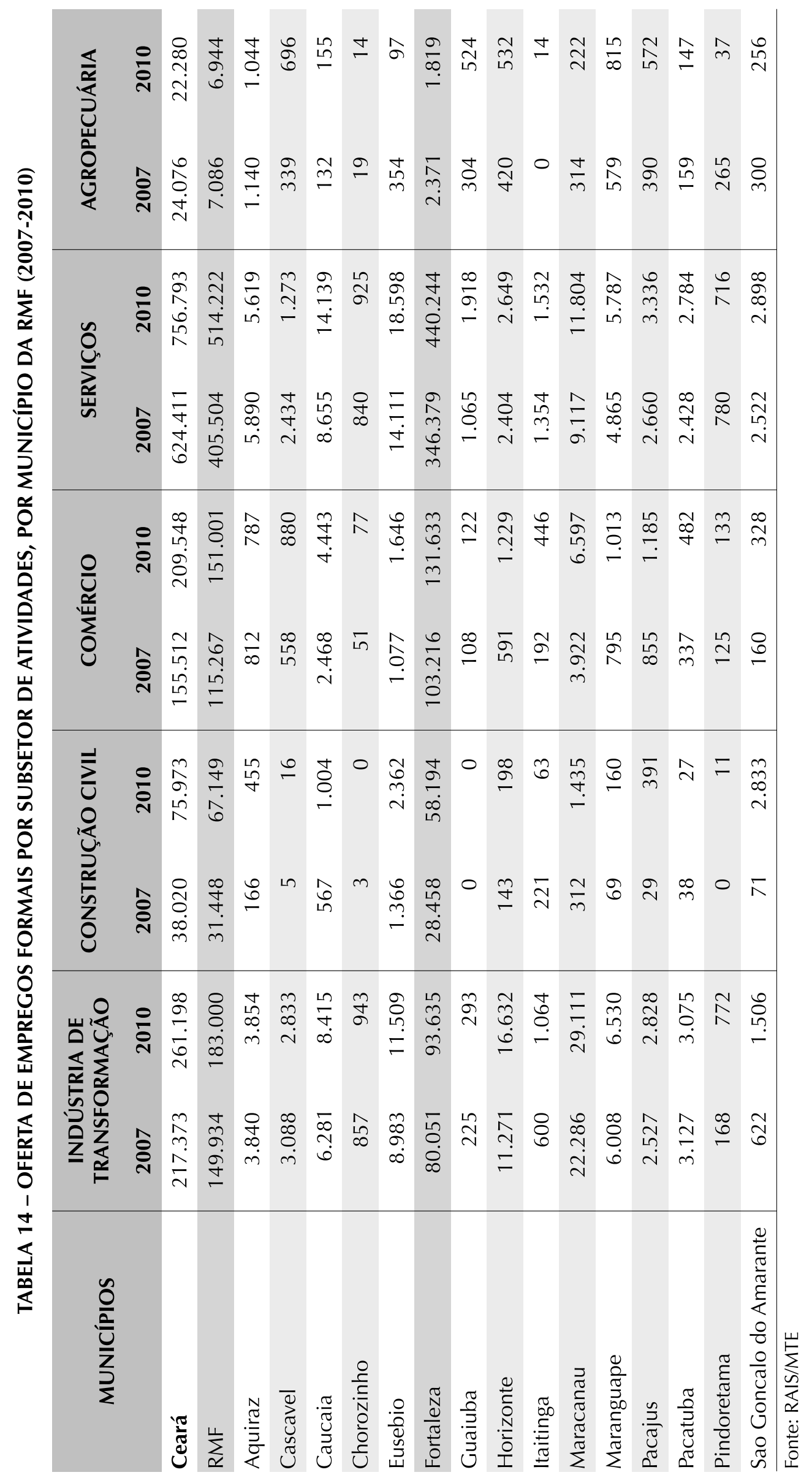




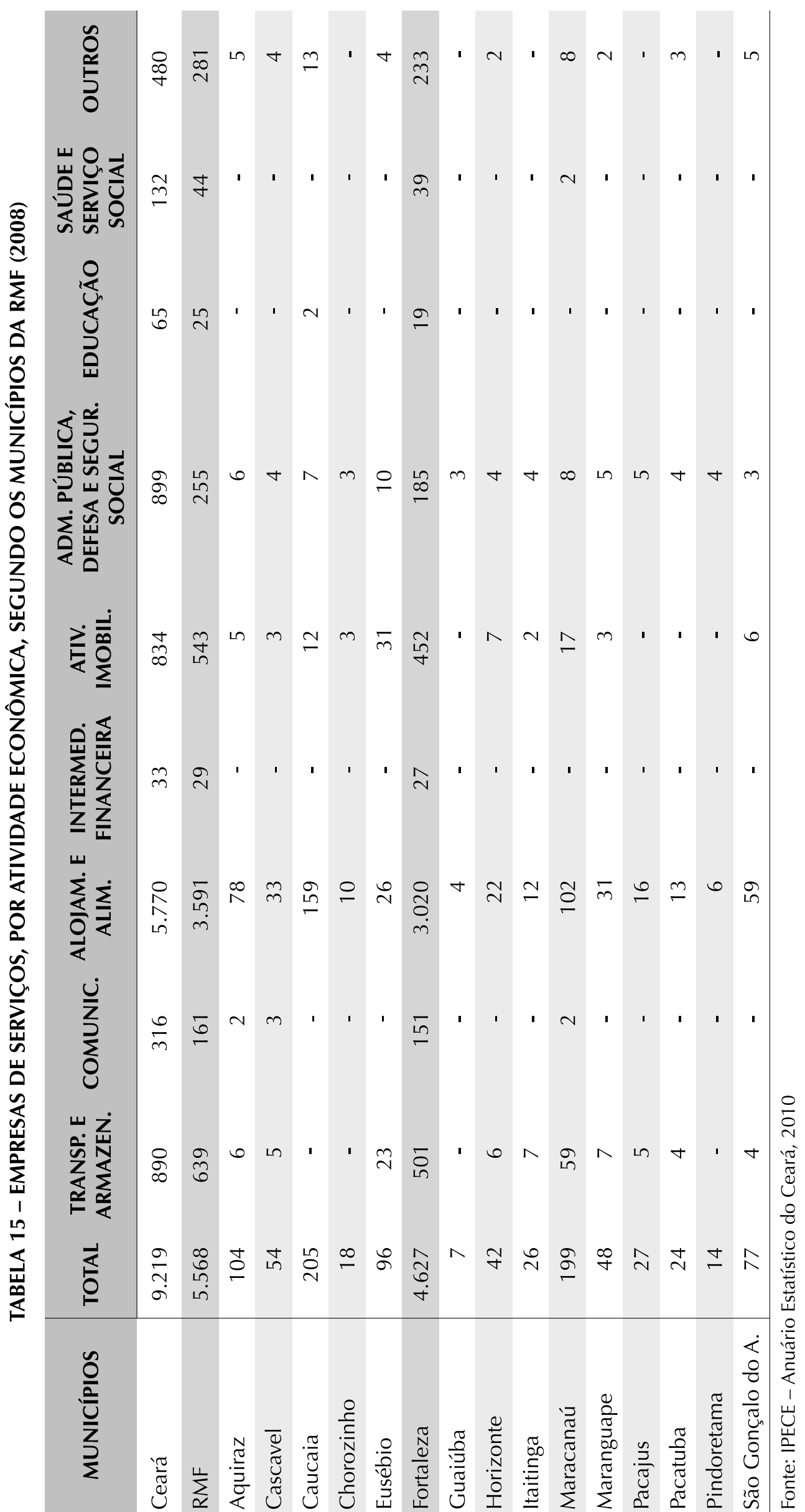


A tabela 14 indica a oferta de empregos em diversos setores, revelando, por um lado, o dinamismo do terciário e, por outro, a posição de destaque de Fortaleza em relação aos outros municípios da RMF.

Conforme se observa, também consoante os dados da tabela 15, que registra o número de empresas de prestação de serviços estabelecidas nos municípios da RMF, o setor de serviços foi novamente preponderante na economia cearense, com destaque para o comércio e alojamento e alimentação, categorias essas que explicam a tendência de desempenho da atividade turística ${ }^{141}$, sobretudo na Capital - a qual confirma a sua primazia - e nos municípios litorâneos de Aquiraz e Caucaia.

No que se refere à espacialização das atividades de comércio e serviço na Metrópole, verifica-se que elas se concentram preferencialmente na Capital ${ }^{142}$ e se desenvolvem principalmente nos corredores viários, ao longo das vias de maior fluxo, nos shoppings centers, que surgem com frequência ${ }^{143}$, e em centralidades que despontam em áreas de maior crescimento urbano (ver figuras 2.33 a 2.35).

Além da centralidade da Aldeota ${ }^{144}$ e daquela que se forma ao longo da av. Washington Soares, no bairro Edson Queiroz, com atividades de comércio e serviços voltadas para uma população de maior poder aquisitivo, outras áreas, de comércio mais popular, se destacam na Cidade, nos bairros do Montese, Parangaba e Antônio Bezerra, ao longo das avenidas Gomes de Matos, João Pessoa e Bezerra de Menezes/Mister Hull, respectivamente.

O centro tradicional, apesar da perda de status desde a década de 1970-1980 ${ }^{145}$, quando surgiram novas áreas de centralidade, permanece bastante dinâmico ${ }^{146}$ e atende toda a área metropolitana, embora seja voltado para uma população de menor poder aquisitivo, pois abriga um comércio mais popular.

O fenômeno é observado na maioria das grandes cidades brasileiras, onde os centros tradicionais atualmente não correspondem mais às áreas de maior prestígio e, portanto, de maior valor imobiliário. Os maiores valores passaram se verificar nas novas áreas de centralidade. O comércio de luxo e os serviços modernos abandonaram o Centro quase completamente, embora este continue muito ativo, pois é o local de concentração de um comércio popu-

\footnotetext{
${ }^{141}$ A atividade turística foi responsável pela ampliação de empregos formais no ano de 2009, segundo dados do IPECE (2010), registrando um dos maiores saldos dentre as principais atividades econômicas, com 7.498 postos de trabalho. ${ }_{142}$ É muito pouco expressiva a incidência da atividade comercial nos demais municípios da Região Metropolitana de Fortaleza. Apenas em Maracanaú existe uma concentração mais significativa, sobretudo depois da instalação do North Shopping Maracanaú, em 2003. ${ }^{143}$ Mais cinco grandes shoppings serão inaugurados em Fortaleza nos próximos dois anos (até 2013). Dois na zona sul, no bairro de Parangaba: o Parangaba Shopping, com um investimento de R\$180 milhões, e o North Shopping Parangaba (R\$ 150 milhões). Dois na zona leste/sudeste: o RioMar Shopping (R\$ 600 milhões), do grupo pernambucano JCPM, no bairro do Papicu, e o Reserva Open Mall, no bairro Edson Queiroz. E um na zona oeste, o Boulevard Shopping, no bairro Jacarecanga, com investimento de R\$ 250 milhões. Esses equipamentos são sempre responsáveis por mudanças significativas na estruturação da Metrópole, como já ocorreu nas décadas de 1970-1980 com a inauguração do Center Um, que mudou a fisionomia do bairro da Aldeota, transformando-o em uma nova área de centralidade, e na de 1980-1990, com a instalação do Shopping Iguatemi, que incentivou a formação do polo de comércio e serviços que se desenvolve na av. Washington Soares e induziu a expansão da Cidade na direção sudeste. ${ }^{144} \mathrm{O}$ bairro da Aldeota concentra um grande número de shoppings centers, em uma área relativamente pequena, num raio de 600,00 m² (Center Um, Shopping Avenida, Shopping Aldeota, Shopping Del Paseo e Pátio D. Luís).

${ }^{145}$ Conforme análise de Villaça (1998), "por volta da década de 70 - variando um pouco conforme a metrópole - os centros já estavam bastante abandonados, principalmente como local de compras, diversões e escritórios de profissionais liberais da burguesia. Abandonados pelas elites, eles sofrem uma desvalorização imobiliária acentuada e os grandes investimentos imobiliários, os grandes edifícios de escritórios típicos dos anos 60 não são mais construídos no centro. Não ocorre nenhum investimento imobiliário de porte. Na década de 80, os centros principais já estavam quase totalmente tomados pelas camadas populares. Aquilo que se chama ideologicamente de "decadência" do centro é tão somente a sua tomada pelas camadas populares, justamente sua tomada pela maioria da população". (VILLAÇA, 1998, p.283).

${ }^{146}$ Os dados da pesquisa realizada pelo SEBRAE-CE em 2005 apontam um fluxo de 215 mil pessoas/dia no centro de Fortaleza, aumentando consideravelmente aos sábados. Na realidade, houve perdas no que se refere às atividades de lazer, culturais e administrativas, bem como de quase todos os marcos simbólicos do poder (à exceção de alguns poucos, como a praça do Ferreira e o Passeio Público, por exemplo), acarretando na degradação de certos trechos. O processo também se agravou com a transferência, para o bairro da Aldeota, dos serviços de profissionais liberais, em busca de vantagens na nova localização.
} 
lar, de parte dos serviços públicos e culturais e das atividades financeiras. É o local, também, da concentração do comércio de rua, dos vendedores ambulantes que vendem produtos populares àqueles de renda mais baixa. $\mathrm{O}$ centro principal, abandonado pelas camadas de alta renda, torna-se então acessível às camadas populares que dele se apropriam (DIÓGENES, 2005, p.64).

Ainda com relação ao setor de serviços, vale ressaltar o papel da atividade imobiliária, que constitui importante agente na apropriação, produção e uso do espaço, direcionando o crescimento da Metrópole e induzindo, de certa forma, a distribuição da população no território, notadamente quando se defronta com a fragilidade dos instrumentos de planejamento e gestão.

O mercado imobiliário, em plena expansão nos últimos anos ${ }^{147}$, constitui, assim, um vetor importante na estruturação socioespacial da Metrópole. Em Fortaleza, concentra-se preferencialmente em determinados bairros, atendendo à população de maior poder aquisitivo, que se apropria de áreas mais qualificadas, bem atendidas pelas redes de infraestrutura e serviços urbanos (ver figura 2.36).

Inicialmente, nas décadas de 1980-2000, verificou-se na Cidade o fenômeno da substituição de residências por condomínios verticais, concentrados principalmente nos bairros do Meireles e da Aldeota $^{148}$, modificando completamente a fisionomia desses bairros, onde ocorreu intensa verticalização. Atualmente, o setor sudeste é o principal foco de interesse, onde se disseminam os condomínios horizontais destinados à classe média alta, extrapolando muitas vezes os limites do Município de Fortaleza ${ }^{149}$.

Estas áreas passam a redefinir a distribuição dos grupos sociais de maior poder aquisitivo na RMF e, em consequência, observa-se uma tendência de valorização crescente dos terrenos nos municípios de Aquiraz e Eusébio. O primeiro, em razão da faixa litorânea, propícia para a implantação de empreendimentos ligados ao turismo, e o segundo, por se tratar, desde a última década, da área preferencial para instalação dos condomínios fechados de luxo ${ }^{150}$.

Por outro lado, o mercado imobiliário também oferta loteamentos em outros bairros menos privilegiados e mais afastados do centro, como Itaperi, Maraponga e Messejana, e mesmo em municípios vizinhos $^{151}$ a Fortaleza, dirigidos a populações de menor renda, que não dispõem de recursos para adquirir terrenos na Capital.

Dessa forma, observam-se dois padrões de periferização, em face do surgimento dos loteamentos populares, concentrados em um lado da Metrópole (sul e oeste) e da expansão dos loteamentos das classes mais abastadas, nos condomínios fechados e nas residências de veraneio, nas áreas litorâneas, principalmente na direção sudeste. A oferta de moradias em outros municípios da RMF

\footnotetext{
${ }_{147}$ Segundo dados do Sindicato das Indústrias da Construção Civil do Ceará (Sinduscon-CE), no último ano, houve um aquecimento expressivo do mercado imobiliário na RMF. Foi registrado um crescimento superior a 100\% em junho de 2011 quando comparado a junho de 2010, no que se refere ao volume total de imóveis residenciais comercializados na Região Metropolitana de Fortaleza. Em 2010, o mercado imobiliário faturou R\$ 2,5 bilhões com a venda de imóveis novos em Fortaleza e Região Metropolitana. A média foi de R\$209,99 milhões vendidos por mês. (Jornal O Povo, 24-08-2011).

${ }^{148}$ Os bairros da Aldeota e do Meireles são considerados os mais privilegiados da Cidade, reduto das classes mais abastadas como local de habitação, comércio e serviços de luxo. O valor do metro quadrado da Meireles alcança hoje R\$ 8.000,00, na Avenida Beira Mar, segundo o presidente do Conselho Regional de Corretores de Imóveis do Ceará, Armando Cavalcante. ${ }^{149}$ A questão da legislação favorece a implantação de condomínios horizontais fora do Município de Fortaleza, principalmente o Município do Eusébio, uma vez que legislação urbana da Capital possui regras mais rígidas quanto à tipologia dos condomínios. O assunto será enfocado com detalhes no capítulo 4.

${ }^{150}$ Os dois condomínios Alphaville implantados em solo cearense estão localizados no Município do Eusébio.

${ }^{151}$ Esses loteamentos concentram-se principalmente nos municípios de Caucaia, Maracanaú e Maranguape, situados ao oeste e ao sul da Capital.
} 
é também motivada pela escassez de terrenos dentro dos limites do Município de Fortaleza, contribuindo dessa forma para a expansão metropolitana.

Há que se destacar ainda a estreita articulação que se verifica entre a atividade turística e o mercado imobiliário, por meio da produção de imóveis, inovando as formas de comercialização e diversificação do setor (hospedagem, lazer, serviços de gastronomia, "segundas residências", etc.). Esse conjunto de atividades relacionadas com o setor do turismo traduz-se em um capital "imobiliário-turístico" e sustenta uma modalidade que está sendo nomeada, e divulgada pelos meios de comunicação, de "turismo imobiliário"152". (SILVA \& FERREIRA, 2008).

A presença marcante deste capital (nacional e internacional) é evidenciada nas atividades imobiliárias e turísticas, dinamizando intensamente a indústria da construção civil e alterando a configuração urbana da Metrópole, ao incorporar novas áreas e implantar novas estruturas de habitação e consumo, como condomínios fechados, flats, apart-hotéis, condomínios, shoppings centers, etc.

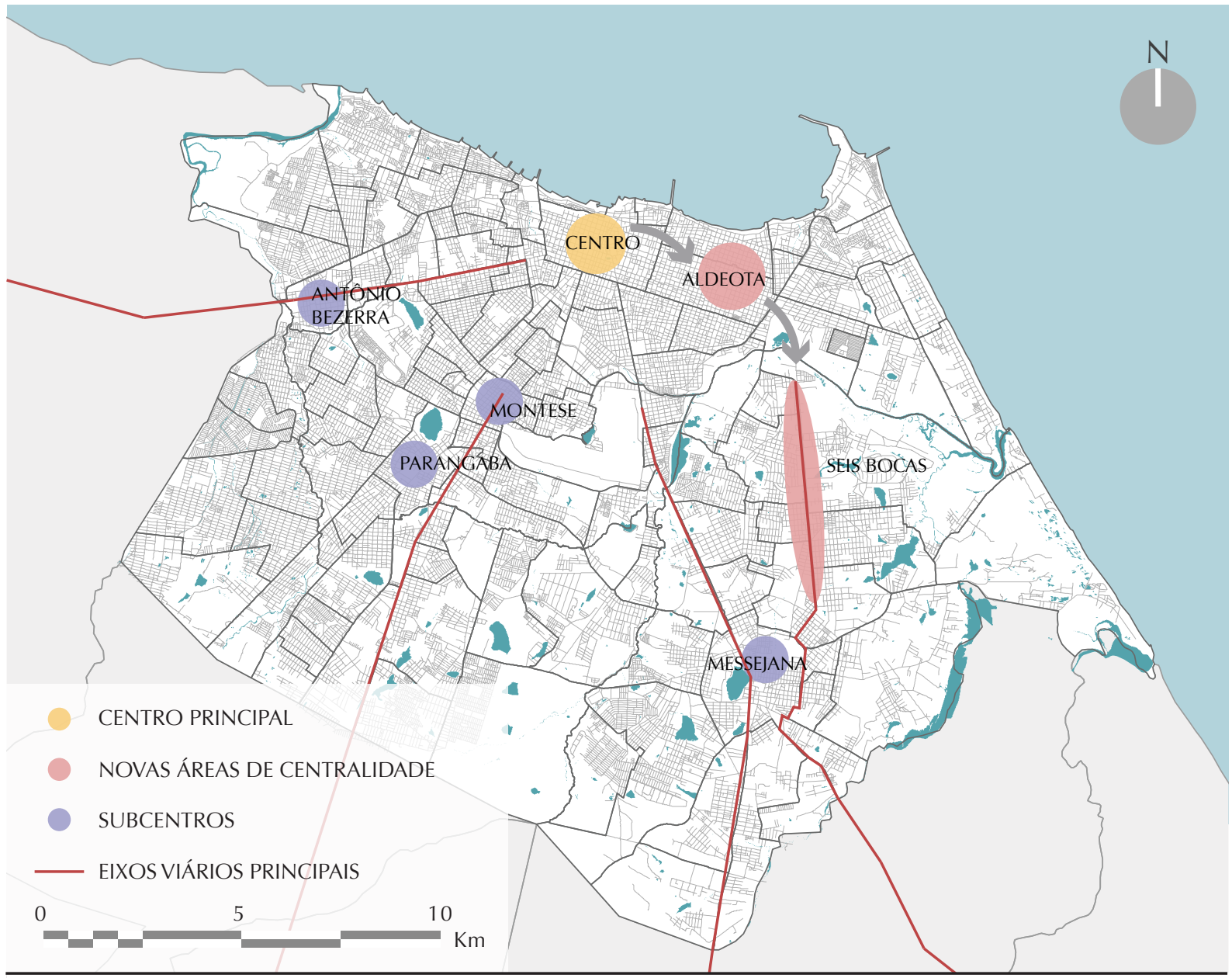

Fig. 2.33 Mapa Fortaleza: centralidades

Fonte: elaborado pela autora

\footnotetext{
${ }^{152}$ Em relação ao capital imobiliário, pode-se perceber a formação e consolidação de uma nova modalidade de produção espacial, destinada a uma modalidade de consumo que está sendo chamada, pelo mercado, de "turismo imobiliário". Tal modalidade parece se ajustar a um padrão inter-relacional de tradicionais empreendimentos imobiliários (residencial) e novos equipamentos (hotéis, flats, shoppings, restaurantes) localizados não apenas no polo principal da área metropolitana, mas em diversos pontos estratégicos na zona litorânea da Região Metropolitana. Um dos fatores que parece assumir certa relevância nesse processo é a hipótese, que aqui se pode formular, da modificação do capital imobiliário em face das transformações econômicas não apenas locais, mas, sobretudo internacionais. (OBSERVATÓRIO DAS METROPOLES, disponível em http://web.observatoriodasmetropoles.net/index.php?option=com_content\&view=article\&id=\&ltemid=62\#2)
} 


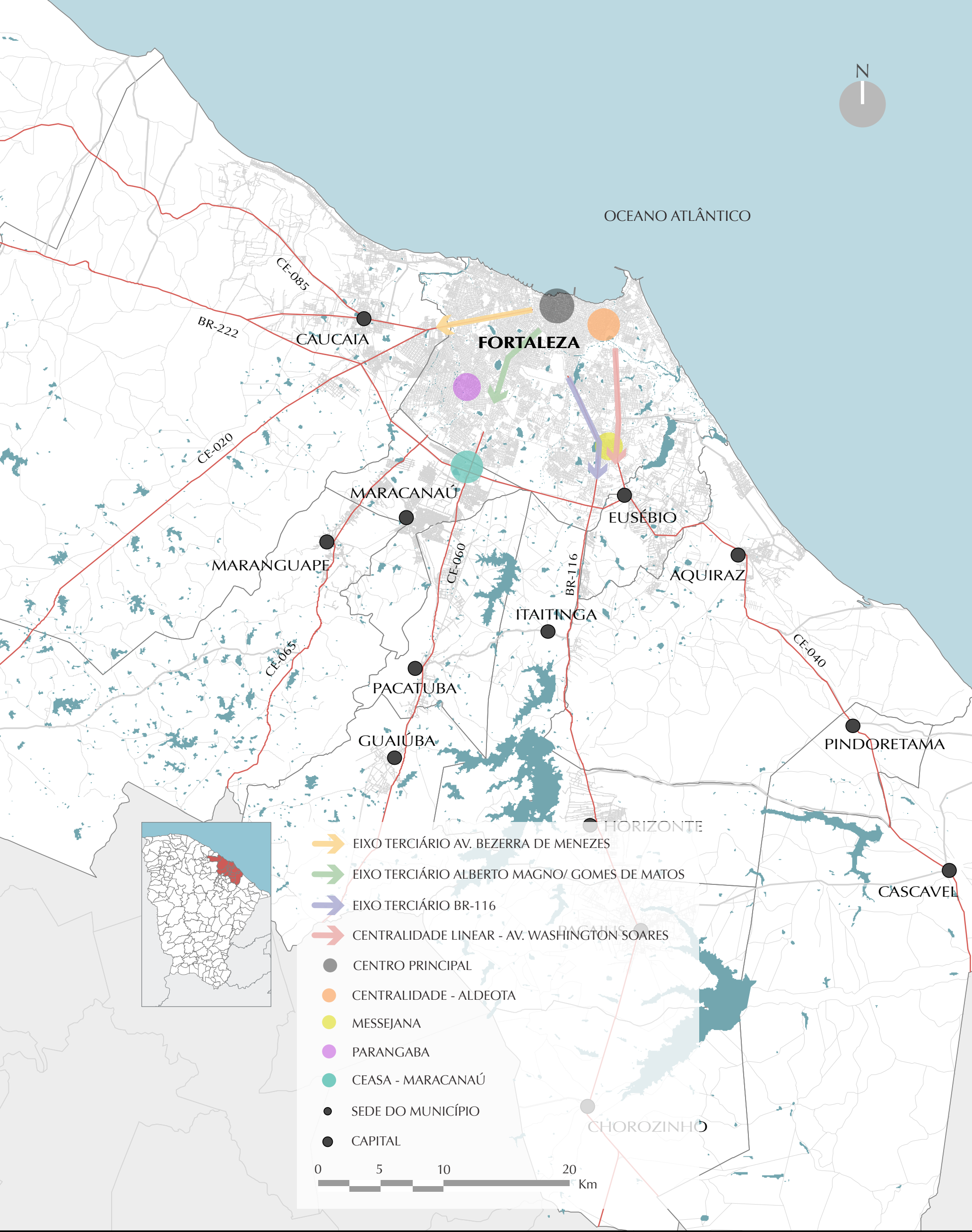




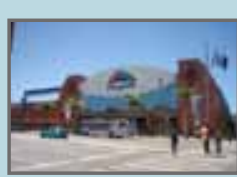

Shopping Benfica

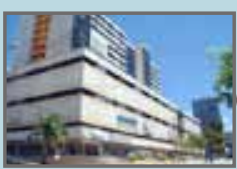

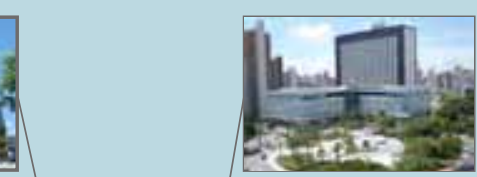

Shopping Aldeota

Pátio Dom Luís

RioMar Shopping

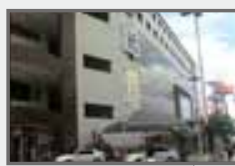

North Shopping

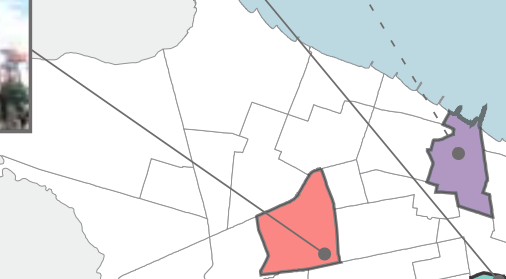

North Shopping Parangaba
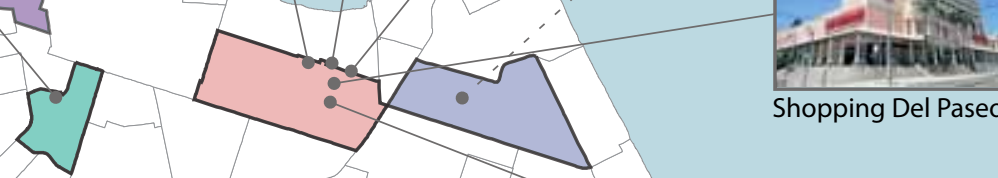

Shopping Del Paseo
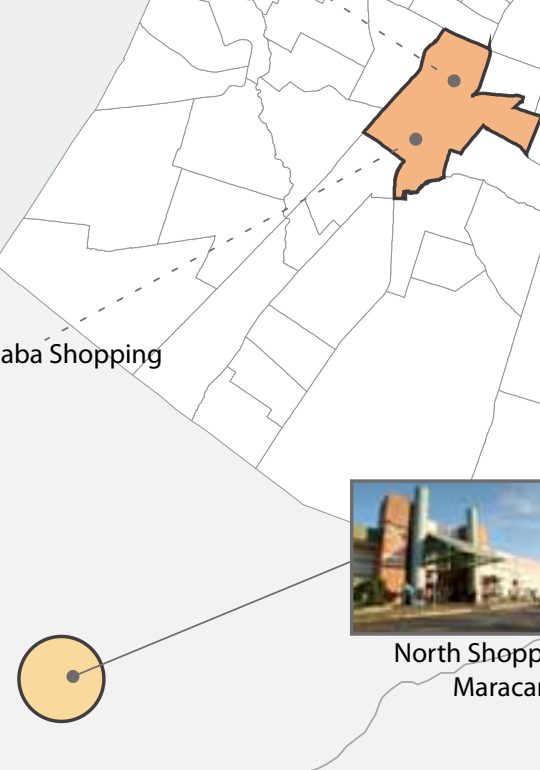
Maracanaú

BAIRROS
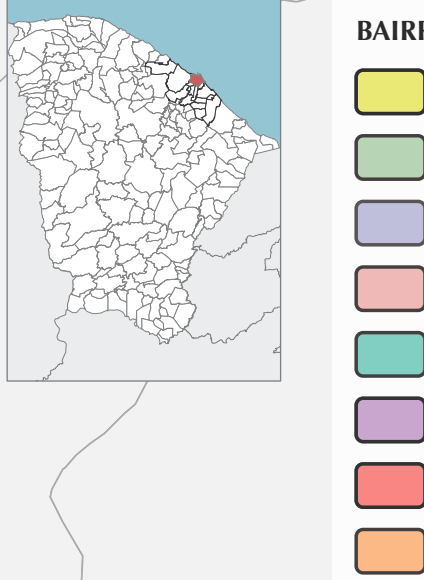

LAGOA DA SAPIRANGA

EDSON QUEIROZ

PAPICU

ALDEOTA

BENFICA

JACARECANGA
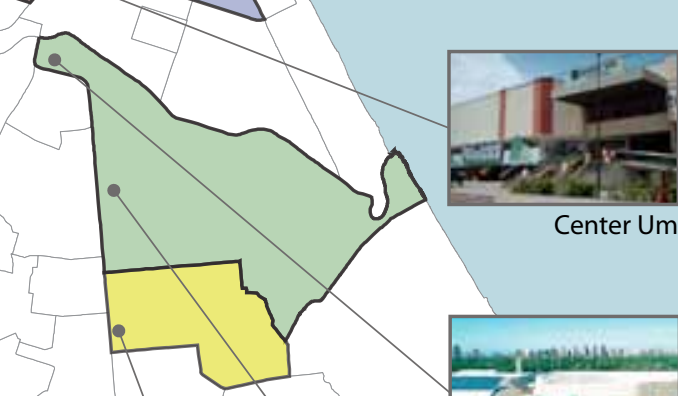

Center Um

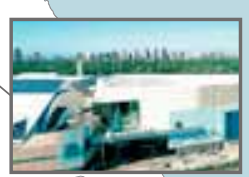

Shopping Iguatemi
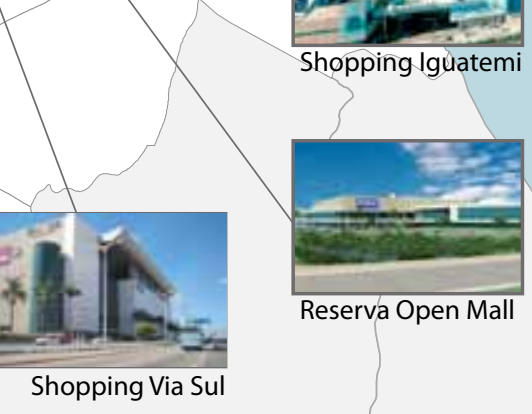

Reserva Open Mall

PRESIDENTE KENNEDY

PARANGABA 


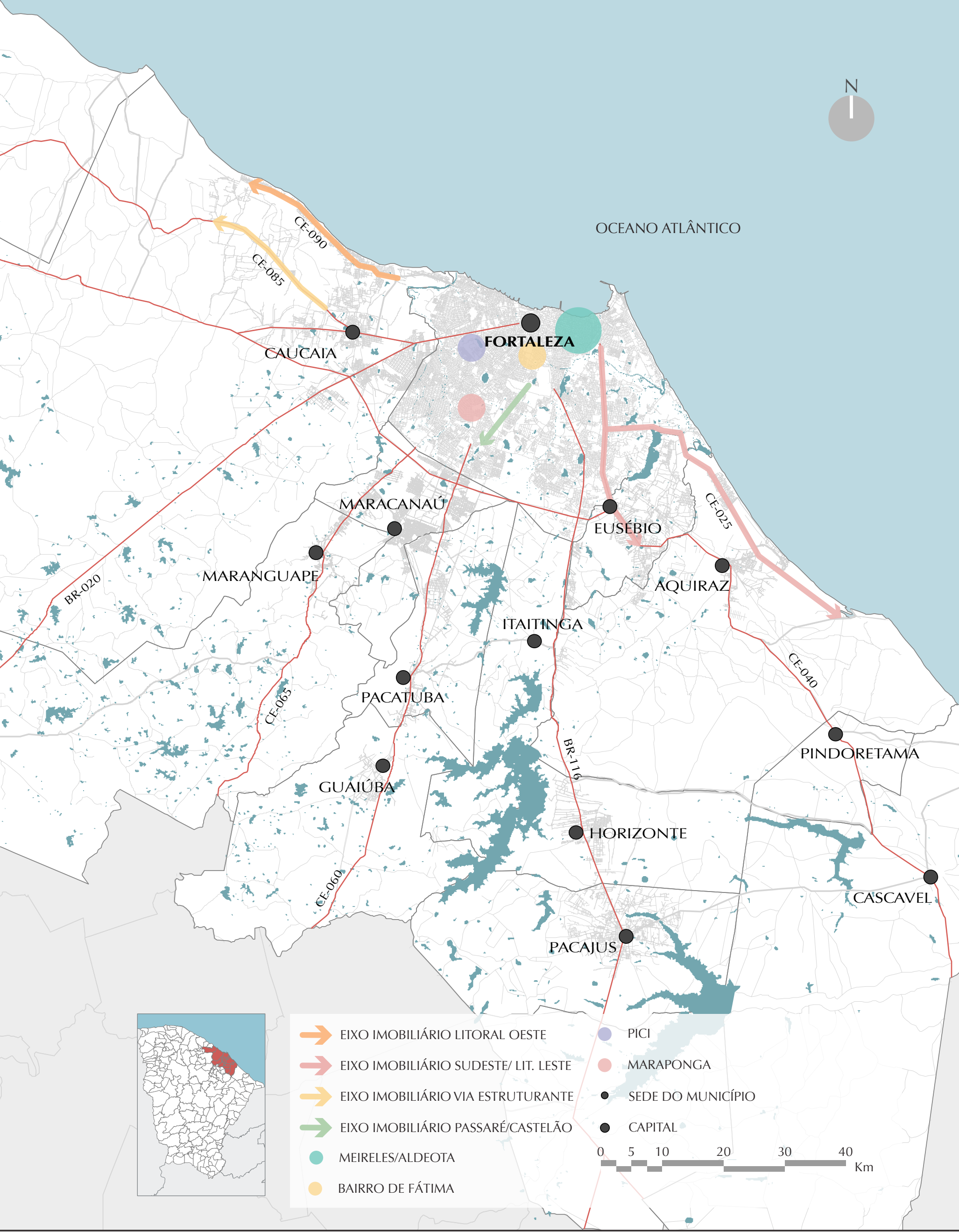




\section{A atuação do Poder Público na expansão metropolitana}

Em síntese, o que se pode concluir desta análise, com relação às dinâmicas relacionadas há pouco, é que elas desempenham importante papel na estruturação e expansão da RMF. A atividade industrial, a atividade turística e os diversos segmentos do setor terciário-comercial, em suas diferentes manifestações, condicionam direta ou indiretamente os caminhos da urbanização.

Aliado a isso, vale mencionar a atuação do Estado nesse processo, uma vez que se constitui um dos principais agentes ${ }^{153}$ da produção do espaço, responsável que é pelo fornecimento de infraestrutura e bens de consumo coletivo, além da elaboração das leis de uso e ocupação do solo, direcionando os investimentos públicos, interferindo no espaço e no crescimento urbano. São consideráveis os impactos das ações institucionais e políticas do governo no processo de expansão da Metrópole.

O poder estadual (e o municipal) estabeleceu, desde os últimos governos, estratégias políticas dirigidas, sobretudo, para as atividades turísticas e industriais, evidenciadas em obras de infraestrutura, equipamentos de grande porte e renovação de bairros tradicionais, o que sem dúvida fortalece o mercado imobiliário e a construção civil.

Alguns exemplos podem ser citados nesse sentido, conforme já mencionado. No caso da indústria, a decisão da instalação do Complexo Industrial e Portuário do Pecém e a criação do corredor industrial na BR 116 determinaram direções de crescimento na Metrópole diferentes do que ocorria até então. No que se refere à atividade turística, a oferta de infraestrutura, com abertura e melhoria da malha viária, a construção do aeroporto e a política agressiva de marketing ${ }^{154}$ do Estado também conferem um incremento significativo ao setor, favorecendo o surgimento de núcleos urbanos ligados ao turismo e lazer, ampliando o espaço metropolitano, sobretudo na faixa litorânea.

No âmbito intraurbano, a recente expansão da Cidade na direção sudeste desde a década 19801990 foi viabilizada em grande parte pela parceria entre o Poder Público e a iniciativa privada ${ }^{155}$, com o alargamento da av. Washington Soares e a instalação de equipamentos importantes na área, como o Centro de Convenções, o Fórum, a Imprensa Oficial, o Centro Administrativo, a sede do Governo Estadual ${ }^{156} \mathrm{e}$ o novo Centro de Eventos, situados em terrenos estratégicos que influenciaram sobremaneira na valorização daquela zona, a qual se transforma num dos eixos mais valorizados e dinâmicos da Cidade ${ }^{157}$.

\footnotetext{
${ }^{153}$ A produção do espaço urbano resulta da ação de um conjunto de agentes: os próprios habitantes, que consomem o espaço (e que pertencem a diferentes classes sociais); o setor imobiliário (proprietários de terra) e empresários da construção civil e o Estado, direcionando o crescimento da Cidade mediante a legislação urbana, fornecimento de infraestrutura e bens de consumo coletivo.

154 "O slogan 'Ceará, Terra da Luz' faz parte da constituição de uma imagem positiva ligada à ideologia neoliberalista de gestão urbana, produzida pelo marketing, em substituição à velha idéia de 'Cidade da Seca', personificação negativa associada aos preceitos do funcionalismo. A imagem de cidade-vítima, alimentada pela 'indústria da seca', ideologia compartilhada pelas políticas desenvolvimentistas, é substituída pelo imaginário da cidade-civilizada. Nesta ideologia, a cidade torna-se um novo produto cultural, competente, com fins de atrair investimentos e tecnologias, e, portanto, empresas multinacionais e turistas". (ACCIOLY, 2009, disponível em: http://egal2009.easyplanners.info/area05/5837_ Vera_Mamede_Accioly.pdf).

${ }^{155}$ Os proprietários de terras ofereceram terrenos a preços baixos para a instalação de tais equipamentos, com o objetivo de auferir lucros futuros, com a valorização da área. Deste modo, grandes vazios urbanos ficaram estocados, permanecendo nas mãos de especuladores, aguardando oportunidades lucrativas de venda.

${ }^{156}$ A sede do Poder estadual foi transferida para o bairro do Cambeba em 1987, por ocasião do governo Tasso Jereissati e posteriormente para o bairro Edson Queiroz, durante os governos Lúcio Alcântara e Cid Gomes, onde permaneceu até o ano de 2011, quando voltou a ocupar o Palácio da Abolição, no bairro Meireles. A localização da sede do Executivo Estadual na zona sudeste também contribuiu para a valorização da área.

${ }^{157}$ A análise do desenvolvimento dessa área da Metrópole será tratada com detalhes no capítulo 4.
} 
O processo de modernização do Ceará, no contexto recente de desenvolvimento, desde o "Governo das Mudanças", instaurou transformações econômicas e estruturais relevantes, que tiveram repercussões importantes no espaço. Se, no entanto, por um lado, contribuíram para uma elevação satisfatória dos indicadores econômicos e para o crescimento das cidades, de outra parte, não trouxeram soluções para o problema da pobreza e das desigualdades socioespaciais.

Esse aspecto se rebate também na Metrópole, que revela elevado crescimento demográfico ${ }^{158}$, alta concentração de renda ${ }^{159}$, elevados índices de pobreza ${ }^{160}$ e grande segregação socioespacial, ao se proporem intervenções urbanas que privilegiam determinadas áreas e atingindo de forma diferenciada as diversas camadas sociais. Essa situação é destacada pela arquiteta Vera Mamede Accioly (2009), em seu artigo ${ }^{161}$ A metrópole e o impacto das políticas públicas na expansão urbana: Fortaleza entre 1980 e 2008.

Como as demais metrópoles periféricas, a cidade apresenta dupla face, revelada pela sua configuração complexa e contraditória, marcada pela convivência entre a cidade competitiva, moderna, incluída no circuito da economia nacional e mundial, espacializada nos condomínios fechados, flats, hotéis de luxo, shoppings centers, torres empresariais, e a cidade informal, ligada à economia local e de sobrevivência, com tipologias tradicionais e populares, disseminadas nos interstícios do urbano, nos espaços periféricos e nas áreas de risco.

Os investimentos públicos e privados concentrados na Capital e nos demais municípios da RMF, associados à ausência de políticas públicas e alternativas econômicas voltadas para o meio rural, continuam atraindo a população em busca de emprego e de outras oportunidades, favorecendo um crescimento deveras desequilibrado entre as diversas regiões do Estado.

É perceptível, atualmente, na Metrópole, uma concentração de investimentos em infraestrutura e equipamentos urbanos, atraindo cada vez mais grandes empreendimentos imobiliários, comerciais e serviços privados. Essa dinâmica, entretanto, ocorre desvinculada das políticas de desenvolvimento e gestão metropolitana, as quais não são executadas de forma a "espacializar os benefícios da urbanização e criar condições básicas que atendam as necessidades e aspirações do conjunto da população" (ACCIOLY, 2009, p.144).

\footnotetext{
${ }^{158}$ Dentre as nove maiores regiões metropolitanas do País, a RMF foi a que apresentou a maior taxa de crescimento $(18,1 \%)$ entre os anos 2000 e 2010. Passou de uma população de 3.056.769 para 3.610.379, o que representa uma variação de 1,68\% ao ano, ou seja, maior que São Paulo (0,96\%), Rio de Janeiro (0,67\%) e Salvador (1,37\%). Os dados são do Comunicado $N^{\circ}$ 102, do Instituto de Pesquisa Econômica Aplicada (Ipea), que realiza uma reflexão sobre o crescimento populacional nas regiões metropolitanas brasileiras e a mobilidade urbana.

${ }^{159}$ A concentração de renda na Região Metropolitana de Fortaleza tem crescido, de acordo com os dados da Pesquisa Nacional por Amostras de Domicílios (PNAD, 2008): os 20\% mais pobres da população contam com apenas 1,9\% da renda per capita; em contrapartida, os $20 \%$ mais ricos detêm $71 \%$ da riqueza produzida.

${ }^{160}$ De acordo com a pesquisa "Indicadores Fortaleza e Região Metropolitana" do Laboratório de Estudos da Pobreza (LEP), ligado ao Centro de Pós-Graduação em Economia da Universidade Federal do Ceará (Caen/UFC), 40,11\% da população da sua Região Metropolitana vive em situação de pobreza, com renda per capita de meio salário mínimo. Este percentual coloca a RMF em penúltimo lugar entre as dez maiores regiões metropolitanas do País, com situação melhor apenas que a registrada na Região Metropolitana do Recife. O estudo toma como base os dados de 2007 da Pesquisa Nacional de Amostra Domiciliar (PNAD) do Instituto Brasileiro de Geografia e Estatística (IBGE), fazendo um comparativo com o ano de 1995. No que se refere ao IDH, o índice é de 0,767, segundo o Censo 2000.

${ }^{161}$ Disponível em http://egal2009.easyplanners.info/area05/5837_Vera_Mamede_Accioly.pdf
} 


\subsection{A GESTÃO E O PLANEJAMENTO METROPOLITANO NA RMF}

\subsubsection{A questão da gestão metropolitana no contexto atual}

A administração do espaço metropolitano, de maneira geral, é fundamental na organização do território. As grandes aglomerações demográficas e suas respectivas atividades exercem forte influência nas áreas do entorno, exigindo, por sua vez, um aparelho administrativo capaz de extrapolar os limites políticos do Município.

Para Reis (1996, p.10),

[...] as áreas de maior concentração populacional e industrial devem ser objeto de formas especiais de planejamento, cuja execução deve caber a órgãos também especiais, mais amplos que os municípios e mais restritos que o estado, cujo âmbito pode ser definido como a região ou área metropolitana, mas sua estrutura e competência podem assumir aspectos variados.

As diversas questões que se sobrepõem, relacionadas aos espaços metropolitanos, representam desafios constantes às politicas públicas, uma vez que já não podem ser tratadas de forma setorial. O enfrentamento dos problemas urbanos exige novos arranjos institucionais, no sentido de conjugar os diversos órgãos governamentais e os diferentes níveis de governo e da sociedade.

Os projetos desenvolvidos, que ocorrem na maioria das vezes de maneira contingencial, ao privilegiarem uma abordagem estritamente local, deixam de levar em consideração questões mais amplas, de escala metropolitana. Como resultado, verifica-se uma sucessão de projetos ora não implementados, ora realizados apenas parcialmente, sem capacidade de reverter o quadro de problemas da região como um todo. As experiências demonstam que essas ações são ineficientes, do ponto de vista de uma necessária abordagem abrangente e integrada da questão metropolitana.

As metrópoles e as grandes cidades, ante a intensidade das mudanças registradas no mundo contemporâneo, se configuram como "espaços contraditórios de concentração de poder e riqueza e de crescimento econômico, emergindo como lugares onde se agravam as desigualdades sociais, que provocam dentre outros problemas, crises de governabilidade pelo processo" (BARCELLOS, apud COSTA, C., 2009, p.180).

O novo contexto de transformações por que passam as metrópoles atualmente demanda, pois, novas atitudes do Poder Público, mediante um planejamento metropolitano, com vistas a agilizar e diversificar sua atuação, como formulador de normas, adequando-as aos processos recentes de transformação funcional da cidade, no correto ordenamento de uso e ocupação do solo. Torna-se indispensável ainda a implementação de ações decisivas, a fim de orientar a reorganização das dinâmicas urbanas, visando a atender ao novo papel econômico que essas metrópoles desempenham, por meio de programas e projetos específicos e criteriosos - em alguns casos, em parceria com a iniciativa privada - na busca de um desenvolvimento coerente, que contemple a diversidade de seus espaços.

Segundo Meyer, Grostein \& Biderman, (2004, p.221), o grande desafio da gestão urbana contemporânea é "assimilar a lógica imposta pela nova regulação de construção da cidade e pelos pressupostos do Plano Diretor, na busca de um desenvolvimento urbano harmônico, equilibrado, socialmente justo e comprometido com um ambiente urbano saudável." 
Percebe-se, porém, nas metrópoles do País, de maneira geral, haver um grande distanciamento entre o crescimento urbano e as atividades de planejamento, de que resultam processos extremamente deficientes e frustrantes, assunto debatido e enfatizado por inúmeros estudiosos.

A gestão de uma região metropolitana extrapola o bom desempenho de cada um dos munícipios que a compõem, uma vez que existe um conjunto de atividades distribuídas em todo o seu território que define um espaço bem maior, de alcance metropolitano.

Nesse sentido, ainda de acordo com Meyer, Grostein \& Biderman (2004, p.221),

O plano e a agenda de projetos voltada para o desenvolvimento metropolitano devem se basear em propostas de articulação de projetos de infraestrutura de âmbito metropolitano e na presença de equipamentos e serviços - estações intermodais, hospitais, universidades, escolas, aeroportos, portos, parques, complexos de esporte e lazer e outros - cuja escala de atendimento é a metrópole e a macrometrópole.

Para que obtenha eficácia, a gestão metropolitana deve se basear em diretrizes gerais, abrangentes e integradas ao processo de metropolização, o que só pode ocorrer por meio do planejamento. Acerca da problemática, o pesquisador Luiz Cesar Queiroz Ribeiro, coordenador do Observatório das Metrópoles, argumenta:

A despeito da multiplicação de instituições metropolitanas, observamos a inexistência de efetivas políticas públicas voltadas especificamente para o desenvolvimento dessas áreas. As políticas urbanas são hoje fortemente intra-urbanas, setoriais ou locais. Os organismos metropolitanos, onde existem, têm à sua disposição frágeis mecanismos para empreender ações cooperativas de planejamento e gestão (RIBEIRO, 2004, p.11).

\subsubsection{A gestão metropolitana da RMF}

Diante do que foi exposto, a Região Metropolitana de Fortaleza constitui importante aglomerado urbano, de grande expressão política e econômica, que registrou, nos últimos anos, um crescente processo de ocupação e expansão de seu território, apresentando mudanças substanciais em sua estrutura urbana.

Dessa forma, faz-se necessária a formulação de políticas públicas capazes de debater e propor programas e projetos de interesse da região metropolitana, objetivando, sempre que possível, a unificação quanto aos serviços comuns.

Seis meses depois de sua institucionalização, em 1973, a RMF já contava com o apoio de um órgão estadual criado especificamente para a sua gestão e planejamento: a Autarquia da Região Metropolitana de Fortaleza - AUMEF, que operou durante 18 anos, tendo sido extinta em 1991.

A AUMEF foi criada num contexto que corresponde, na classificação de Azevedo \& Mares Guia (2004), à primeira etapa da metropolização das cidades brasileiras:

Nessa primeira fase, respaldadas pelo forte componente autoritário do modelo de planejamento e gestão, as regiões metropolitanas contavam com uma estrutura institucional e uma disponibilidade de recursos financeiros oriundos da União que permitiram a implementação de vários projetos, especialmente na área de saneamento básico, transporte e trafego urbano. Com a crise financeira que se abate sobre o país nos anos 1980 e o início do processo de mobilização contra a ordem vigente e em favor da redemocratização, as brechas 
institucionais e as fragilidades do sistema de planejamento metropolitano são explicitadas. A escassez de recursos públicos tem como conseqüência imediata o estancamento dos investimentos federais nas grandes metrópoles, culminando com o desmonte do aparato de organismos metropolitanos que atuavam na promoção do desenvolvimento urbano (AZEVEDO \& MARES GUIA, 2004, p.100).

A AUMEF era uma agência especial - uma autarquia - criada pelo Governo estadual, dirigida por um superintendente que exercia um poder supramunicipal, embora o cargo não fosse eletivo. Tinha por objetivo desenvolver e integrar os municípios de acordo com os planos da lei federal que criou as oito primeiras regiões metropolitanas no Brasil. Em face das contradições, resultavam muitas vezes conflitos e choques entre as diferentes esferas de governo e autoridades.

Durante os primeiros anos, a AUMEF foi responsável pela elaboração dos planos diretores dos municípios da RMF, realizando, de início, um plano geral de desenvolvimento urbano integrado de toda a área metropolitana. As principais obras realizadas pelo órgão foram a construção de um anel viário ( $4^{\circ}$ Anel Viário), interligando todas a estradas de acesso aos municípios periférios, e o alargamento das rodovias de acesso a Fortaleza (BR 116 e BR 222). Os primeiros planos do metrô para Fortaleza surgiram ainda durante a vigência da autarquia.

A extinção do órgão, em 1991, foi seguida de um vazio administrativo no contexto do panorama socioespacial da RMF. Na realidade, a extinção ocorreu de forma gradual, desde o início dos anos 1980-1990, como conseqüência do processo de abandono do planejamento em todas as escalas da gestão. Após a Constituição de 1988, como o planejamento e desenvolvimento metropolitano ficaram a cargo dos estados, autarquias do tipo AUMEF deixaram de fazer parte de uma lógica de desenvolvimento nacional.

O desmonte do sistema de planejamento urbano no País promoveu significativo retrocesso na questão urbana, de maneira geral, à falta de instrumentos suficientes e adequados para enfrentar os problemas advindos da metropolização.

Durante os anos 1990-2000, não houve praticamente ações políticas voltadas para a integração dos municipios da Região Metropolitana de Fortaleza. Somente em 1997 ocorreu um debate em torno do assunto, com a criação da ONG Planefor ${ }^{162}$, apoiada pelo CIC - Centro Industrial do Ceará, com o intuito de realizar ações de planejamento na Metrópole. Mesmo assim, sem força política e com fraca exposição na mídia local, o Planefor não se mostrou satisfatório para o desenvolvimento da região e dos municípios envolvidos.

Após a dissolução da AUMEF, suas atribuições foram repassadas para as secretarias de governo, criadas e renomeadas diversas vezes. O conceito então defendido pelos técnicos do Governo estadual propunha diretrizes não apenas para a Região Metropolitana, mas também para todo o contexto urbano estadual. As intervenções e os planos permaneceram, todavia, bastante restritos.

Atualmente, há vários órgãos e empresas atuantes no território da RMF, sem, contudo, solucionar seus problemas mais agudos, que exigem ações de planejamento e de políticas públicas em condições de conhecer a realidade, atender a demandas e projetar o futuro.

162 PLANEFOR - Plano estratégico de Fortaleza e sua Região Metropolitana. Tratava-se de um "plano conjunto envolvendo comunidades, governo e iniciativa privada, nas soluções dos problemas dos municípios, em Fortaleza" (http:// cidadesdobrasil.com.br/cgi-cn/news.cgi?cl=099105100097100101098114\&arecod=17\&newcod=408) 
Por tal razão, as estratégias implementadas desde as últimas décadas, que coincidem com o crescimento acelerado da Metrópole, são incapazes de promover ações integradoras entre os diversos municípios, à parte de se mostrarem ineficazes na formulação e implementação de políticas necessárias ao enfrentamento de seus problemas comuns.

Além do mais, a estrutura atual da Região Metropolitana enseja conflitos políticos, nascidos dos choques de correntes políticas com interesses antagônicos. Verifica-se, pois, a premência do estabelecimento de mecanismos de cooperação intermunicipal, de modo a amenizar impactos e ampliar os níveis de integração institucional entre os municípios da RMF.

A estruturação da aglomeração metropolitana cearense, na sua configuração atual, abrange questões amplas e complexas que só encontrarão respostas técnicas e políticas consistentes quando tratadas em escala adequada, o que talvez implique a criação de uma nova entidade de planejamento, projeto e gestão urbana.

No entendimento de Meyer \& Grostein (2010, p.295), o correto planejamento das regiões metropolitanas há de se amparar no pressuposto de que

[...] um plano metropolitano deverá conter um projeto global para o conjunto dos municípios, entendido como unidades territoriais, funcionais, sociais, culturais e ambientais, porém, compostos de subsistemas e de lugares cuja especificidade é evidenteecujaconsideraçãonomomentoemquesepropõeoplanoéindispensavel.

Na perspectiva da gestão do território, devem ser consideradas as devidas particularidades de cada espaço metropolitano, o que envolve a determinação de seus atributos físicos e seu desenvolvimento específico. Com efeito, faz-se indispensável buscar caracterizar as formas de apropriação e uso do território, assim como a nova disposição e organização dos espaços urbanos, além de observar e analisar as suas formas próprias de crescimento e a configuração espacial gerada pela fragmentação e dispersão funcional das atividades.

Enfim, é recomendável a definição criteriosa dos elementos que comandam a atual dinâmica urbana, como os grandes equipamentos metropolitanos, as redes de infraestrutura e acessibilidade e as áreas de atividade logística.

No caso de Fortaleza, é fundamental a compreensão do quadro metropolitano atual, tomando como base as alterações que começaram a se verificar desde a década de 1980-1990. A omissão do Poder Público e a ausência de ações decisivas, sobretudo no que concerne ao planejamento urbano, propiciaram intervenções do setor privado da economia, as quais, de uma forma ou de outra, direcionaram a expansão da Metrópole segundo seus interesses.

Além disso, de modo paralelo, questões diversas se impõem, como a precariedade da infraestrutura, a falta de saneamento básico, a poluição das praias e dos rios, rodovias mal conservadas, problemas que provocam dificuldades e variáveis a serem consideradas.

Essa conjunção de problemas origina-se tanto da insuficiência de uma legislação que regule o uso e ocupação do espaço metropolitano de forma adequada, abrangente e integrada, como também procede da ausência de instrumentos de controle com relação à forma do crescimento urbano em curso. 
Por outro lado, faz-se premente a aplicação de um sistema de acompanhamento de todo o processo, de novas diretrizes que possam não só oferecer melhor infraestrutura, mas também orientar investimentos privados e estabelecer critérios de integração para os novos empreendimentos que surgem, a fim de oferecer condições melhores para a população, ou seja, um tipo de planejamento que atenda de forma satisfatória a essas demandas.

De acordo com Silva (2009a),

A questão da gestão metropolitana está posta. A discussão em torno de temas que envolvem a preservação, conservação e manejo dos recursos naturais, a gestão de bacias hidrográficas, a estruturação de um sistema viário e de transporte, a distribuição e manutenção de equipamentos e serviços de educação e saúde, entre tantos problemas prementes, inerentes à aglomeração metropolitana, na perspectiva da melhoria da qualidade de vida da população, fazem da RMF um espaço preferencial de políticas públicas (SILVA, 2009a, p.226).

Sabe-se que o planejamento, o controle e a gestão metropolitana são partes de um processo que se traduz como fundamental no conjunto do desenvolvimento da Metrópole, como forma de propiciar o correto atendimento de suas demandas e contribuir com melhores resultados.

No contexto atual da RMF, percebe-se, entretanto, um quadro de intenso crescimento e transformações recentes e diferenciadas, a par de uma dificuldade muito grande no enfrentamento dessas questões. A realidade se mostra deveras complexa e é visível a defasagem verificada entre a intensidade do fenômeno e as ações decisivas por parte das instituições, no sentido de oferecer respostas satisfatórias. A falta de instrumentos adequados de controle, associada a interesses políticos, dificulta sobremaneira a condução do processo.

A dinâmica urbana atual da RMF, resultado de transformações físicas, espaciais, funcionais e sociais verificadas nas últimas décadas, adquire formas e intensidades variadas que evidenciam a complexidade da realidade metropolitana em seus múltiplos aspectos e apontam a necessidade de estudos em diversas escalas de influência e abrangência.

É essencial, portanto, antes de tudo, o conhecimento aprofundado e integrado da dinâmica própria da Metrópole cearense, bem como a elaboração de análises detalhadas que permitam o completo entendimento da configuração do espaço metropolitano, com seus problemas e potencialidades. De modo paralelo, torna-se imprescindível a busca de novos caminhos para a gestão metropolitana, envolvendo, de forma integrada, o Governo Federal, o Governo do Estado, prefeituras municipais e representantes da sociedade civil.

Somente assim haverá condições que possam propiciar a formulação de normas para o controle e planejamento do território atual, bem como subsidiar a realização de projetos urbanísticos articuladores, que considerem essa complexidade e sejam capazes de organizar e reordenar esse espaço.

As análises elaboradas ao longo deste capítulo, acerca da dinâmica socioespacial da área metropolitana de Fortaleza, tiveram como objetivo fornecer um panorama geral da Metrópole, de modo a caracterizar sua configuração física, bem como os aspectos socieconômicos que interferem na sua estruturação, a fim de melhor se compreender o objeto de estudo da tese, qual seja, o espaço da região metropolitana Fortaleza. 
Como resumo dos fatos, ficaram evidenciados, por um lado, a questão da macrocefalia de Fortaleza no âmbito da RMF - e do Estado - e o papel polarizador da Capital, que influencia sobremaneira no processo de expansão metropolitana. E, por outro lado, a dinâmica econômica, sobretudo as atividades relacionadas à indústria e ao turismo, responsáveis por alterações substantivas no espaço, induzindo formas diferenciadas de crescimento e ampliando as áreas urbanizadas. Também foi destacada a importância da gestão metropolitana eficaz, que pressupõe o conhecimento e a compreensão do espaço e da problemática metropolitanos.

O capítulo seguinte abordará as formas de expansão urbana verificadas nas últimas décadas na Metrópole cearense, com base na leitura do espaço urbano - e metropolitano - dos eixos viários, os quais constituem os principais vetores de crescimento. Por fim, no capítulo final, será analisado com maior ênfase o eixo mais recente de expansão, que corresponde ao setor sudeste da Metrópole. 
$\mathrm{E}$ fetuada a caracterização da Metrópole cearense, em seus distintos aspectos, o objetivo deste capítulo é discorrer sobre a forma de expansão metropolitana de Fortaleza verificada nas últimas décadas, tomando como base a análise dos diferentes vetores ${ }^{1}$ de crescimento urbano. Esses vetores podem ser identificados já nos primórdios do desenvolvimento da Cidade, desde o início do século XIX, porque procedem de superposições às primitivas estradas de acesso e saída da Capital.

Cada um dos quatro vetores apontados - que correspondem às diferentes direções de crescimento - constituiu objeto de descrição e análise neste capítulo, na busca de se compreenderem as diversas dinâmicas em curso no processo de crescimento da Metrópole fortalezense.

Com base na pesquisa empírica efetuada - com observações in loco e amplo registro fotográfico bem como com o posterior exame de imagens de satélite associadas às diferentes áreas de estudo, os vetores foram analisados, com vistas a verificar suas especificidades, tipos de uso e ocupação, bem como as formas urbanas resultantes. Do mesmo modo, foi elaborado o estudo das vias que constituem os anéis viários, ou seja, aquelas que fazem as ligações entre os diversos eixos, examinando os respectivos papéis exercidos na estruturação urbana da Metrópole.

A análise empreendida buscou investigar em que medida a expansão da Metrópole obedece ao modelo tradicional centro-periferia, se acompanha preferencialmente as vias/vetores ou se ocorre de maneira diferenciada, produzindo espaços mais fragmentados e dispersos, marcados por novas polaridades e por configurações espaciais diversas, em consonância com as novas formas de organização do território.

\subsection{O CRESCIMENTO DAS CIDADES E OS VETORES DE EXPANSÃO URBANA}

"Do caminho, a cidade", diz Henri Lefèbvre (1969), explicando poeticamente o estreito vínculo entre a estrada e a urbanização. Fruto do percurso dos animais, dos homens, de suas caravanas, o caminho organiza o território desde os tempos imemoriais. (PANERAI, 2006)

No crescimento físico de uma cidade, o sistema viário desempenha importante papel e estrutura caminhos e direções que comandam a expansão urbana. Esse padrão de crescimento é verificado em muitas das Metrópoles brasileiras, na maioria das vezes obedecendo ao modelo radial-concêntrico.

Segundo Panerai (2006, p.18), “a força da relação caminho/cidade é de tal ordem que certas cidades parecem ser tão somente uma sucessão de estradas em torno das quais se organiza o tecido urbano".

A presença dessas vias/rodovias, que favorecem os fluxos de pessoas e mercadorias, induz a expansão e articulação espacial dos aglomerados urbanos, "contribuindo para afirmar uma morfologia do tipo tentacular na maioria dessas cidades e para fortalecer a tendência a uma metropolização expandida ou dilatada" (DE MATTOS, 2004, p.170).

\footnotetext{
${ }^{1}$ Vector. [do latim vectore] s.m.: segmento de reta orientado. (FERREIRA, A.B.H, s.d., p.1445). O termo vetor está sendo usado neste capítulo - e na tese como um todo - como sinônimo de "eixo", ao referir-se aos eixos viários que correspondem às diferentes direções de crescimento urbano e metropolitano de Fortaleza. Como na Física, o termo vetor está associado à ideia de direção, dinâmica, movimento.
} 
De acordo com Villaça (1998, p.69 e 70), a expansão das Metrópoles "é fortemente influenciada pela vias - rodovias e ferrovias - regionais". Para o autor, é significativo o efeito das vias de transporte sobre a estruturação urbana: "parece haver íntima relação entre as vias regionais de transporte e o crescimento físico das cidades".

Ao se observar a atual organização de algumas cidades brasileiras, percebem-se claramente as marcas deixadas pelos caminhos primitivos. Trata-se, portanto, de um modelo de crescimento bastante comum.

No caso de Belo Horizonte, por exemplo, a expansão urbana da Metrópole - segundo análise de Brito \& Sousa (2006, p.84) - apresenta diferentes direções de crescimento que obedecem às mesmas direções espaciais da expansão da capital e "que seguiram, regra geral, o seu rígido sistema viário. Historicamente, foram se formando seis grandes vetores de expansão urbana: oeste, norte, norte central, leste, sul e sudoeste."

Ainda sobre Belo Horizonte e seu entorno metropolitano, de acordo com Monte-Mór et al (2006, p.402), "podem ser identificados diversos 'vetores' de expansão conformados a partir dos principais eixos viários que estruturam as redes de centros urbanos que se articulam ao centro metropolitano".

Em São Paulo,

[...] apesar de o ritmo da área urbanizada não ser uniforme e nem tão pouco unidirecional, a expansão radioconcêntrica do município-sede se reproduz na escala regional e segue freqüentemente a direção dos investimentos públicos em infra-estrutura rodoviária. Em determinados casos consolidam vetores de expansão urbana que acompanham o dinamismo econômico dos municípios predominantemente industriais, em outros reforçam e definem o destino de municípios que adquirem a função estrita de "municípios-dormitório", ocupados pela população de baixa renda, ou ainda se transformam em vetores que atendem à desconcentração de atividades que, até então, estavam localizadas exclusivamente no município-sede (MEYER, GROSTEIN \& BIDERMAN, 2004, p.41).

A pesquisadora Juliana Cipolletta também realizou estudo acerca dos vetores de expansão da Metrópole paulista, associando o fenômeno do crescimento urbano aos sistemas de circulação e transporte. Segundo a autora, "o sistema viário norteia o alargamento da malha urbana desde os primórdios da ocupação do território"².

A cidade de Salvador demonstra padrão similar, assunto abordado pelo geógrafo Itamar Rangel Vieira Jr., em trabalho sobre a expansão urbana da Metrópole baiana, onde identifica quatro principais vetores de expansão: o Vetor Orla de Salvador - ao longo da Avenida Otávio Mangabeira, nas margens do Oceano Atlântico; o Vetor BR 324 - que se estende até o Município de Simões Filho, derivando para o chamado "Miolo" e o Subúrbio Ferroviário; o Vetor Ilha de Itaparica / BA 001 - que deriva para os povoados de Vera Cruz e finalmente, o mais recente e mais dinâmico, o Vetor av. Paralela/ Estrada do Coco/ Linha Verde - que apresenta ramificações para o "Miolo", Itinga, Villas do Atlântico, Lauro de Freitas e os povoados de Camaçari, ao longo da Estrada do Coco. Esses vetores, conforme o autor, "representam as tendências de desenvolvimento espacial metropolitano" (2005, p.31).

\footnotetext{
${ }^{2}$ Vetores de expansão urbana e metropolitana, uma abordagem histórica - Juliana Cipolletta - disponível em: http:// www.usp.br/siicusp/Resumos/17Siicusp/resumos/2685.pdf.
} 
O crescimento urbano da cidade de João Pessoa foi analisado por Silveira (2004) e manifesta padrão semelhante:

As transformações do espaço construído foram, em grande medida, orientadas e calibradas pelos percursos que, ao longo do tempo, transformaram-se em linhas de força da paisagem e do processo de expansão da cidade. (...) o traçado resultante dos principais percursos radiais em João Pessoa é um dos elementos claramente identificadores tanto da forma quanto das possibilidades e intenções de ocupação, planejamento e expansão da cidade³.

Em cada cidade, porém, a expansão urbana, mesmo obedecendo aos chamados "vetores" de crescimento urbano, adquire formas diferenciadas e específicas, de acordo com o sítio e o modo particular de desenvolvimento.

\subsubsection{O caso de Fortaleza}

Tal como outras Metrópoles brasileiras, Fortaleza manifesta também forma de crescimento segundo determinados vetores que direcionam sua expansão urbana e metropolitana. Trata-se de eixos viários que compõem um sistema radioconcêntrico e desempenham importante papel na estruturação urbana.

Nas diversas análises de estudiosos acerca da configuração metropolitana de Fortaleza, é recorrente a identificação de quatro vetores de expansão, os quais correspondem ao sistema de vias radiais que partem da Capital e que, desde os primórdios ${ }^{4}$, marcaram de forma decisiva a expansão da Cidade, constituindo verdadeiros vetores de crescimento.

De acordo com a Síntese Diagnóstica do Município ${ }^{5}$, que efetuou a revisão do PDDU-FOR ${ }^{6}$, em 2003, "a expansão da RMF obedece a um modelo radial, que confirma os antigos caminhos - e posteriormente vias e eixos viários - que se dirigiam para o interior e zonas leste e oeste da faixa litorânea, a partir da Capital."

Outros pesquisadores confirmam esse modelo:

O processo de expansão da RMF obedece a uma estruturação que reafirma os eixos viários que se dirigem para o interior e áreas leste e oeste da faixa litorânea, a partir da capital. Esta forma de ocupação territorial é responsável pela formação de imensos vazios inter-radiais ou áreas de baixa densidade populacional, inclusive no município de Fortaleza, ao mesmo tempo em que apresenta baixa capilaridade, em termos de acessibilidade entre os eixos (BERNAL, 2004, p.118).

O atual território metropolitano teve como um dos principais elementos estruturantes as preexistências espaciais historicamente construídas, sobretudo as vias que compõem o traçado radioconcêntrico de Fortaleza. Este traçado de origem remota constituiu o lastro que definiu os eixos de expansão não somente de Fortaleza, mas de todo território metropolitano. Os eixos estruturantes correspondem às estradas que comunicavam o sertão à capital, responsáveis pelo fluxo de mercadorias, iniciado a partir do ciclo do algodão, e de pessoas, representado principalmente pelo processo migratório campo-cidade induzido pelas consequências das calamidades provocadas pela seca (PAIVA, 2011, p.60).

\footnotetext{
${ }_{3}^{3}$ Disponível em: http://www.vitruvius.com.br/revistas/read/arquitextos/08.090/191

${ }^{4}$ Esse sistema de vias corresponde às antigas estradas que comunicavam o sertão ao litoral, responsáveis pelo fluxo de pessoas e mercadorias.

${ }^{5}$ Síntese Diagnóstica do Município: PREFEITURA MUNICIPAL DE FORTALEZA (PMF). Lei de Uso e Ocupação do Solo

- Lei no 7.987/1996; Plano Diretor de Desenvolvimento Urbano.

${ }^{6}$ Plano Diretor de Desenvolvimento Urbano de Fortaleza - 1992.
} 
A geógrafa Clélia Lustosa da Costa também assinala que "Fortaleza cresceu de forma radiocêntrica, acompanhando os grandes eixos viários, em torno dos quais se formaram os bairros mais antigos" (2001, p.52).

A Síntese Diagnóstica do Plano Diretor (2003) baseou-se num texto elaborado pelo economista Roberto Smith, em 2001, segundo o qual "o processo de expansão da RMF obedece a uma estruturação radial, que reafirma os antigos caminhos e, posteriormente, os eixos viários que se dirigiam para o interior e porções leste e oeste da faixa litorânea, a partir da Capital" (2001, p.06).

De fato, é claramente perceptível essa forma de expansão da Metrópole cearense, já evidenciada desde a planta da cidade elaborada em 1817 (ver figura 3.1), pelo engenheiro Antonio José da Silva Paulet ${ }^{7}$, ainda na época do Brasil-colônia. Na planta, conforme destaca o arquiteto José Liberal de Castro (1982, p.47),

[...] eram vários os caminhos que do interior demandavam à vila, alguns dos quais de certa forma hoje transformados nas radiais do conjunto urbano contemporâneo. A "planta" de Paulet indica-os contornando de leste para oeste: Picada d'Mucuripe, Estrada da Crusinha, Estrada do Lagamar do Cocó, Estrada d'Messejana (duas saídas), Estrada do Tauape, Estrada d'Montemor, Estrada d'Arronches eEstrada d'Soure.

No desenho, "já estão presentes os caminhos que orientaram o crescimento de Fortaleza, na forma radiocêntrica: estrada de Jacarecanga, de Soure, de Arronches, do Aquiraz, de Precabura e a Picada do Mucuripe" (COSTA, C., 2001, p.55).

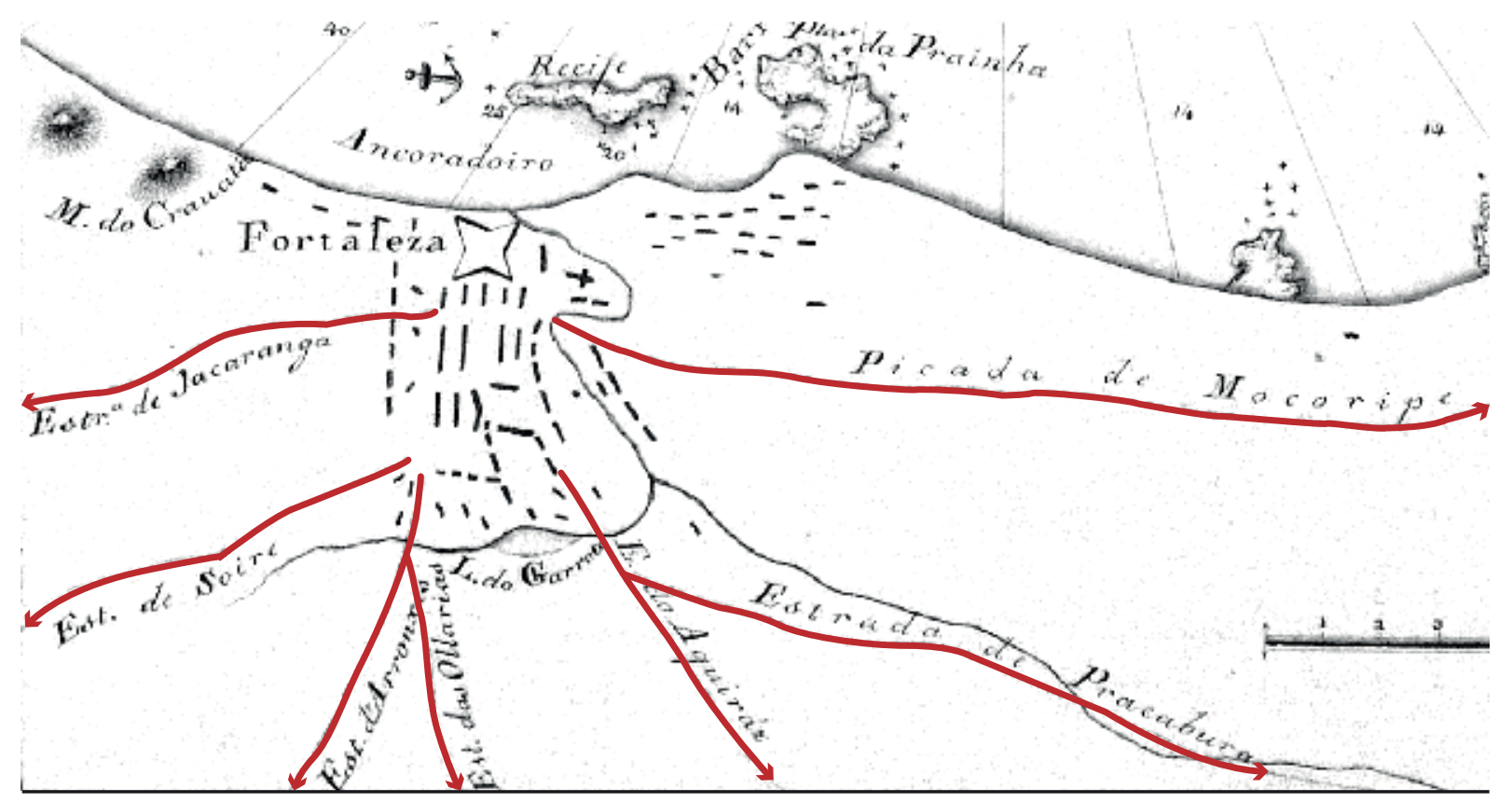

Fig. 3.1 Planta do Porto e Villa da Fortaleza, 1817 - Silva Paulet Fonte: CODEF/PMF

\footnotetext{
${ }^{7}$ Paulet elaborou a primeira planta de expansão da vila, inspirada num desenho em xadrez, permanecendo até hoje como a matriz básica da cidade de Fortaleza.
} 
Na Planta Exacta de Fortaleza, elaborada pelo engenheiro Adolfo Herbster em 1859 (ver figura 3.2), essas antigas "saídas" da Cidade, denominadas de "estradas" no mapa, todas convergentes para o centro da Cidade, estavam demarcadas, "e já antecipavam o plano radial que iria caracterizar a Metrópole do futuro. Por certo não passavam de meros caminhos, ainda praticamente os mesmos assinalados na planta de Silva Paulet, das primeiras décadas do século" (CASTRO, 1982, p.61).

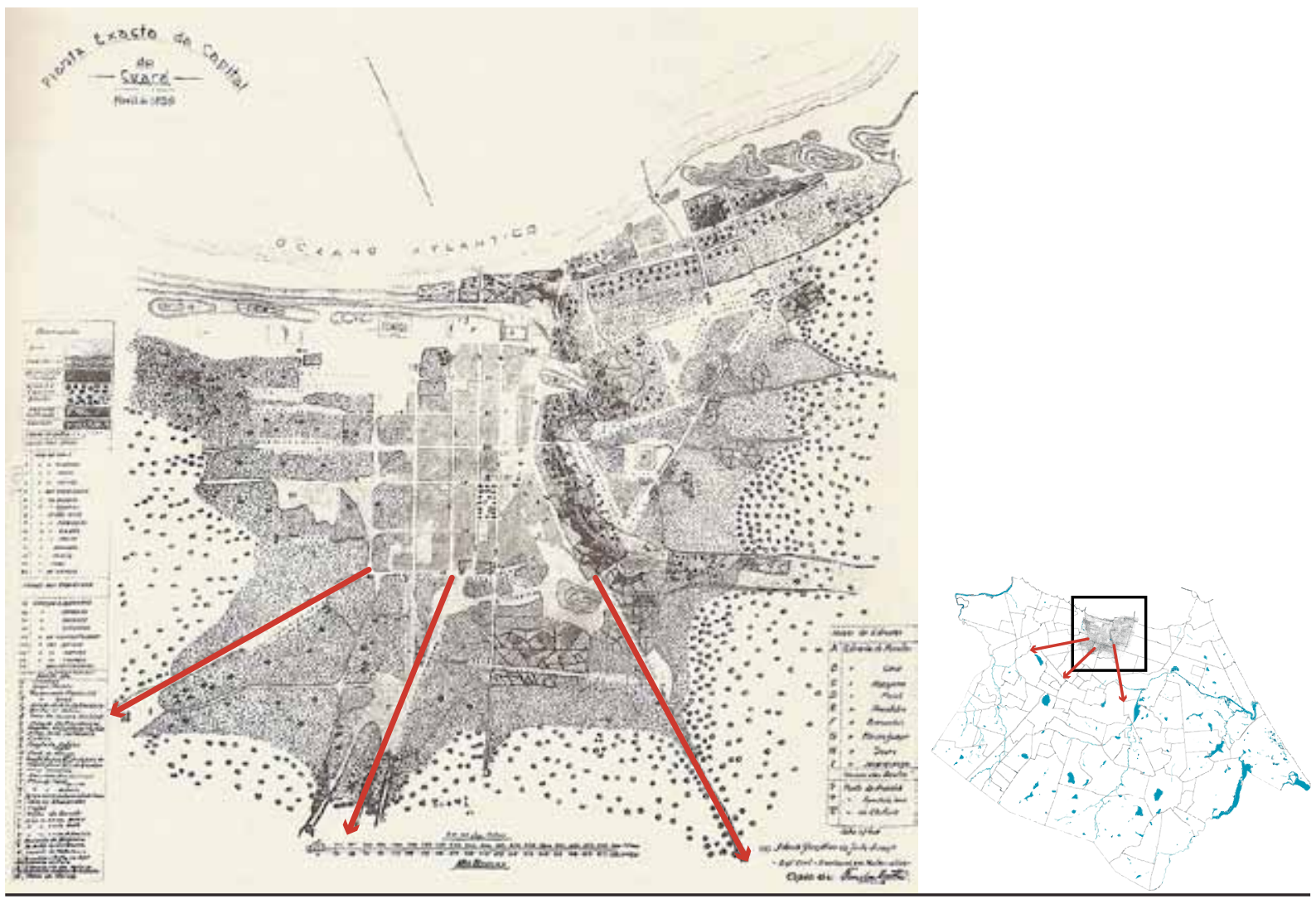

Fig. 3.2 Planta Exacta de Fortaleza, 1859 - Adolfo Herbster Fonte: CODEF/PMF

Na planta elaborada por Herbster anos depois, em 1875 (ver figura 3.3), o engenheiro já não retrata apenas o que era a Cidade de então, mas prevê como viria a ser, conforme mostra a ampla área de expansão pontilhada. É visível a intenção de Herbster em fazer diluir na malha urbana as antigas estradas de penetração. Isso se comprova, por exemplo, com a saída para Messejana, que aparece na planta inteiramente recoberta pelo traçado em xadrez.

Certo da impossibilidade de mudar as saídas para o sul, isto é, Pacatuba (atual rua Mal. Deodoro), Arronches (Parangaba) e Maranguape (atual Av. da Universidade), bem como sem conseguir alterar a Estrada do Soure (saída para Caucaia), Herbster tratou de dar a esses logradouros um desenvolvimento retilíneo, admitindo mesmo a viabilidade do nascimento de novas malhas referidas ortogonalmente a essas saídas (CASTRO, 1982, p.64). 
CAPÍTULO 3

A expansão territorial da Metrópole cearense e os vetores de crescimento urbano e metropolitano

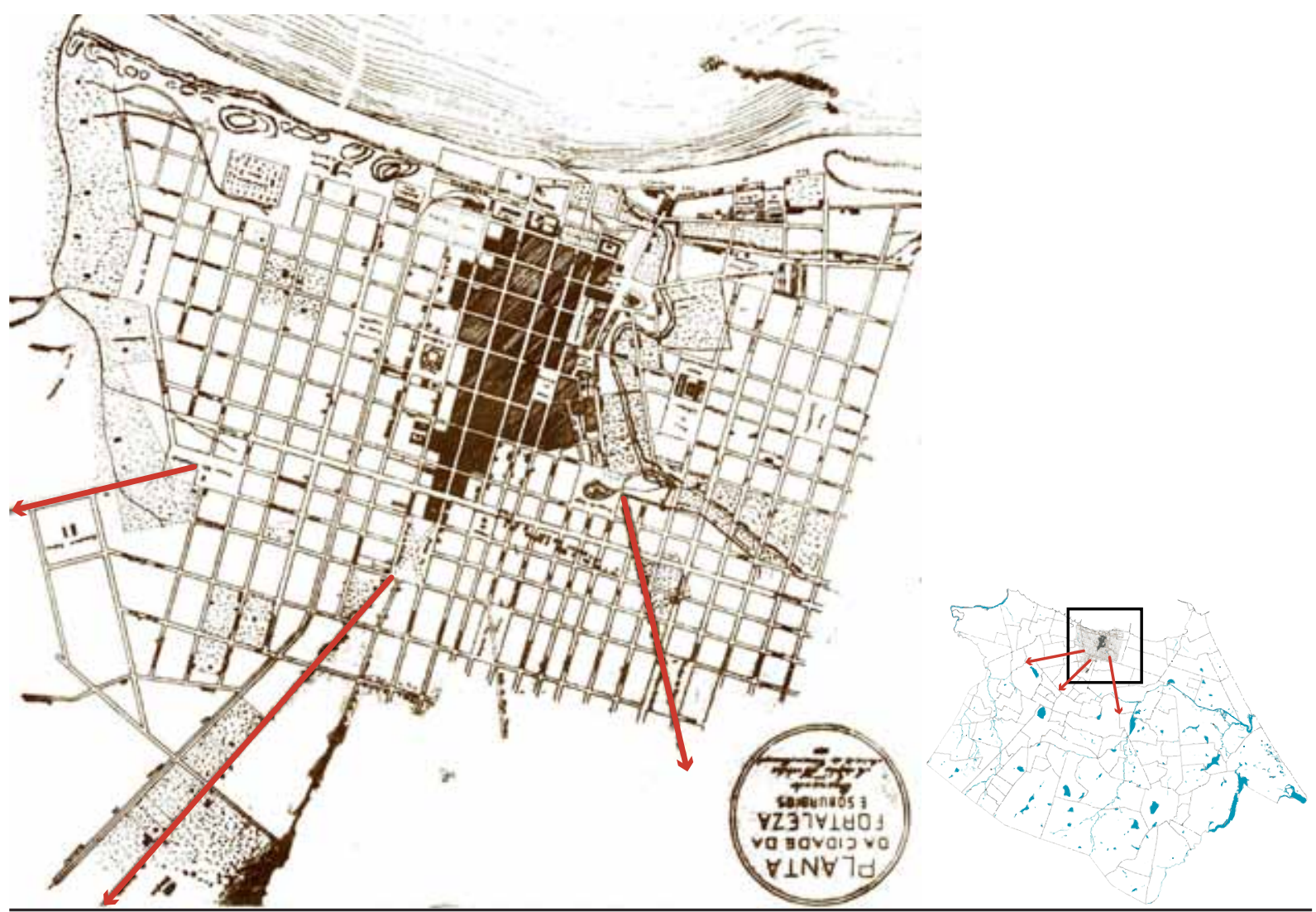

Fig. 3.3 Planta da cidade de Fortaleza e subúrbios, 1875 - Adolfo Herbster Fonte: CODEF/PMF

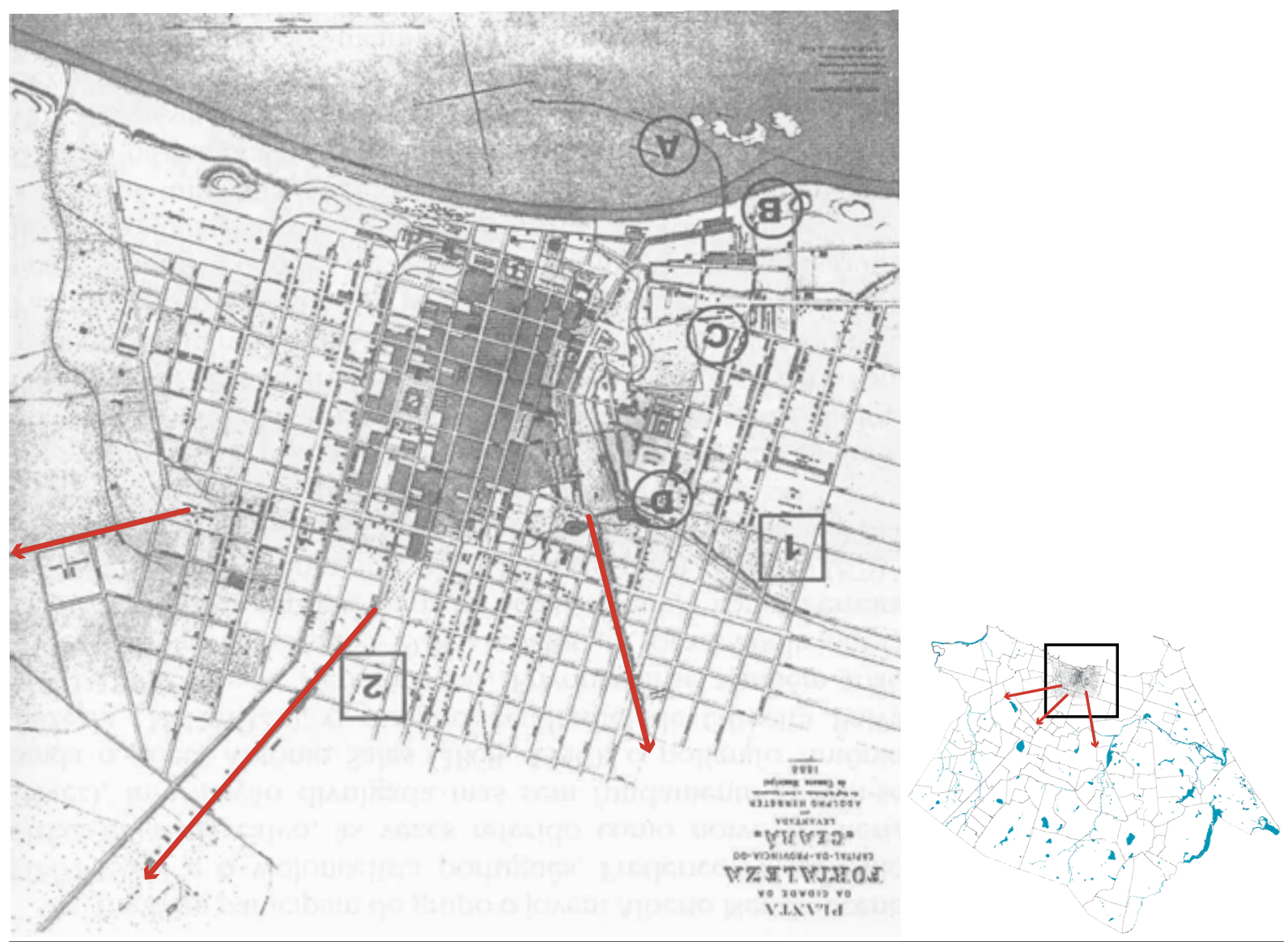

Fig. 3.4 Planta da cidade de Fortaleza, 1888 - Adolfo Herbster Fonte: CODEF/PMF 
Em 1888, Herbster decidiu atualizar a planta de 1875 e elaborou nova carta (ver figura 3.4), a chamada Planta da cidade de Fortaleza, capital da província do Ceará, levantada por Adolfo Herbster, ex-eng ${ }^{\circ}$ da Província e aposentado da Câmara Municipal.

A planta mostra algumas novidades com relação à de 1875, quando a Cidade começava a se espalhar, "lançando tentáculos pelas estradas de saída para o interior, agora praticamente reduzida a três: Messejana, Arronches (Parangaba) e Soure (Caucaia)" (CASTRO, 1982, p.64). Não se percebia ainda a expansão para leste e oeste, mas já havia indícios de uma progressiva descentralização.

Na virada do século XIX para o XX, Fortaleza cresce acompanhando as antigas estradas de Jacarecanga, Soure, Arronches e Aquiraz.

Na zona oeste da cidade, surge o bairro Jacareacanga, onde se aglutinam em sobrados representantes da elite comercial e agrária. (...) Casas vão se aglomerando ao longo da estrada de Arronches (Parangaba) (...) Mais para o interior, começa a se desenhar, ao final do século XIX, o Benfica, com sobrados, bangalôs, chácaras e casas recuadas, com jardins. (...) Na estrada do Soure (Caucaia), a oeste, vai se formar o bairro Farias Brito, em torno do matadouro público. Posteriormente, nesta área, foram construídas a estação de trem Otávio Bonfim, a Igreja N. Sra. das Dores, o convento dos frades franciscanos e o Cine Familiar. Para o sudeste, no boulevard Visconde do rio Branco (estrada de Aquiraz), são construídos na área da Lagoa do Garrote, o Largo do Garrote e o Parque da Liberdade. Acompanhando esta estrada, forma-se o bairro de Joaquim Távora (COSTA, C., 2001, p.67 e68).

Essa configuração é também enfatizada por Accioly (2009, p.134):

Os eixos viários estruturantes da Região Metropolitana são formados por um conjunto de rodovias e estrada de ferro, cuja configuração radial concêntrica superposta à malha em xadrez, tem raízes históricas no século XIX. Os antigos caminhos de escoamento da produção agro-exportadora e dos fluxos migratórios transformaram-se nos principais eixos de circulação e integração metropolitana, reforçando a centralidade da cidade-núcleo.

Nas sucessivas plantas e levantamentos da Cidade, na malha urbana destacam-se as vias radiais, convergentes para o núcleo central, como é perceptível ainda hoje (ver figuras 3.5 a 3.11).

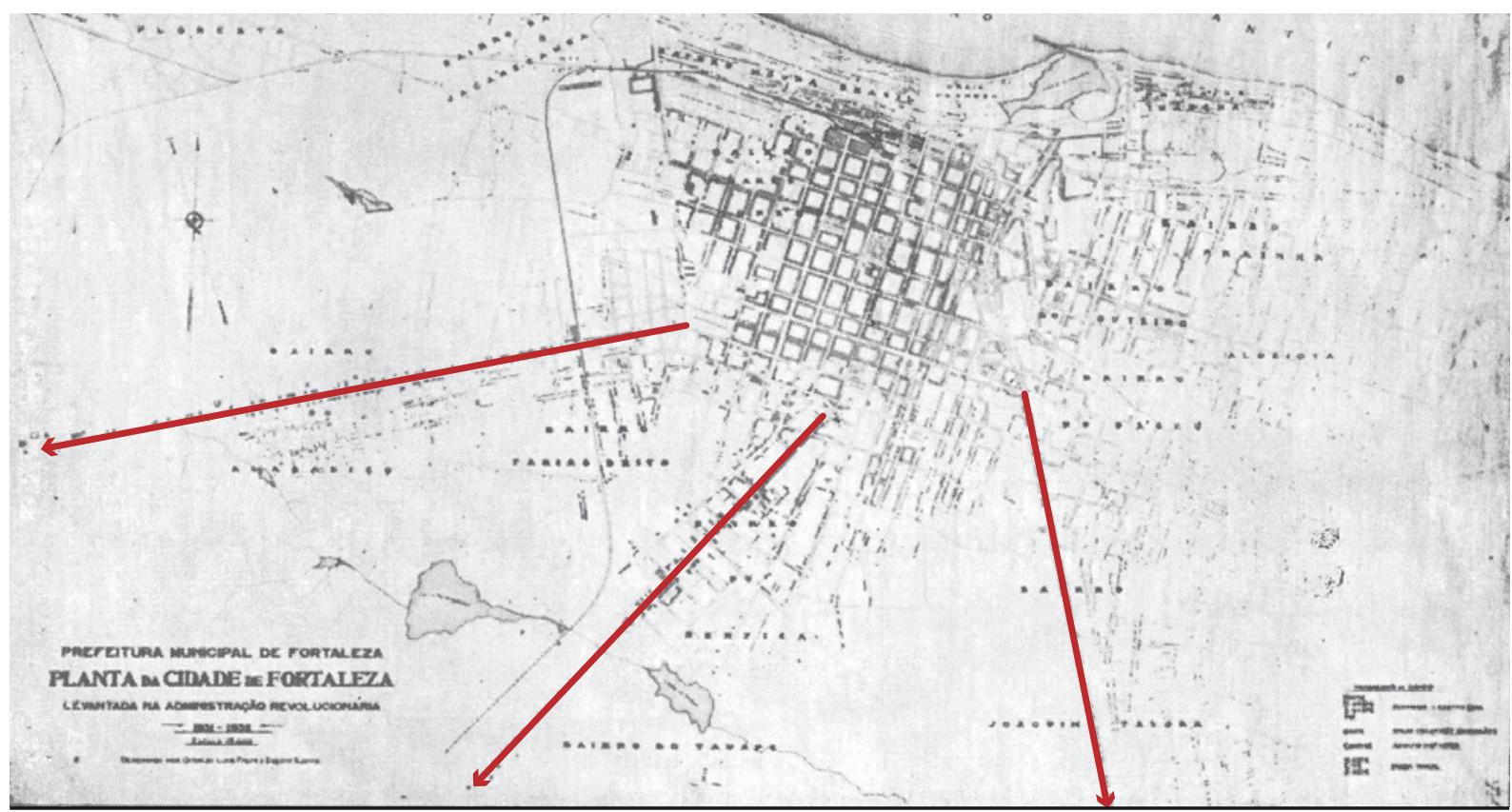

Fig. 3.5 Planta cadastral da cidade de Fortaleza, 1932 
CAPÍTULO 3

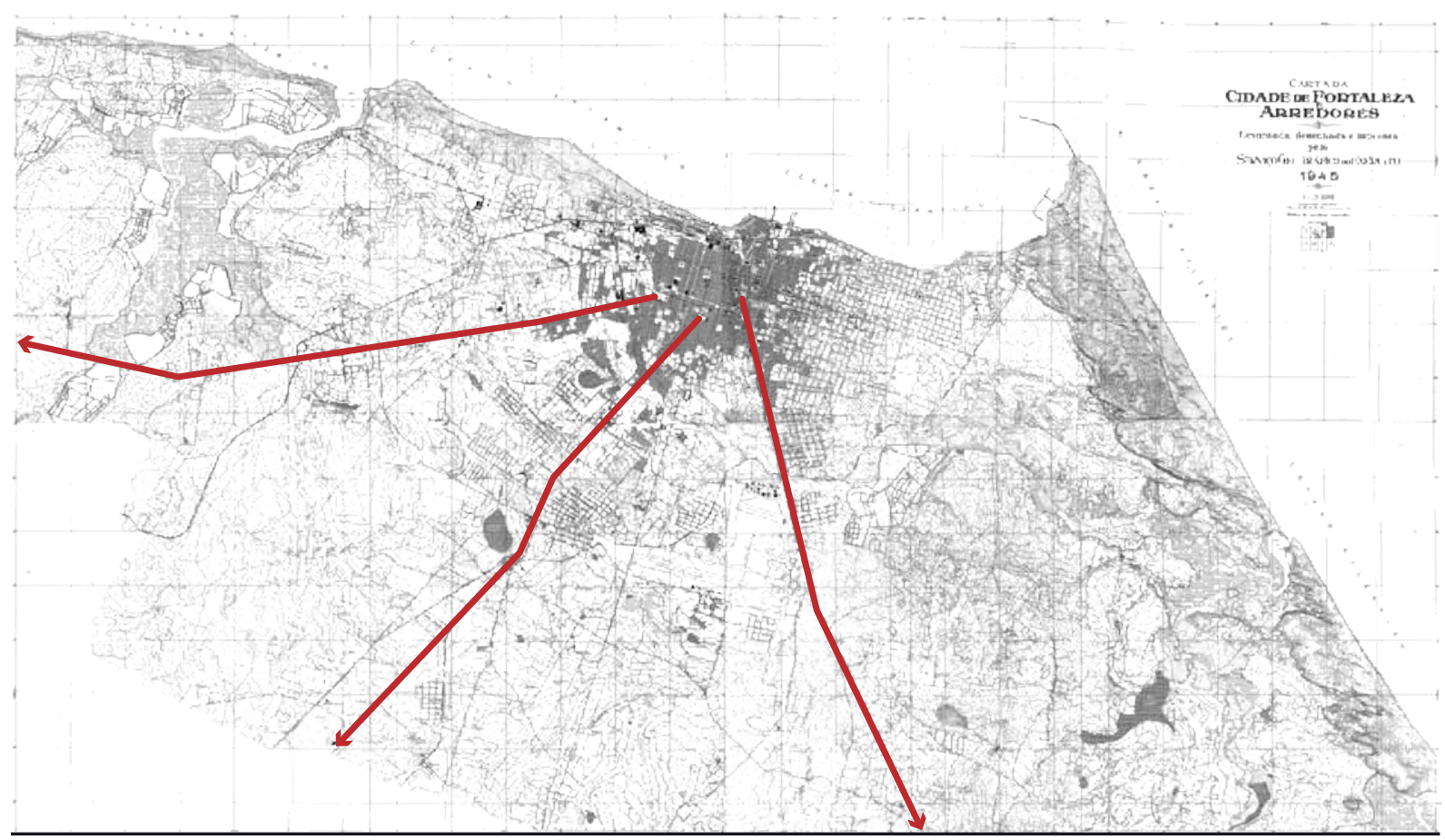

Fig. 3.6 Levantamento aerofotogramétrico do Exército, 1945

Fonte: reconstituição - Margarida Andrade

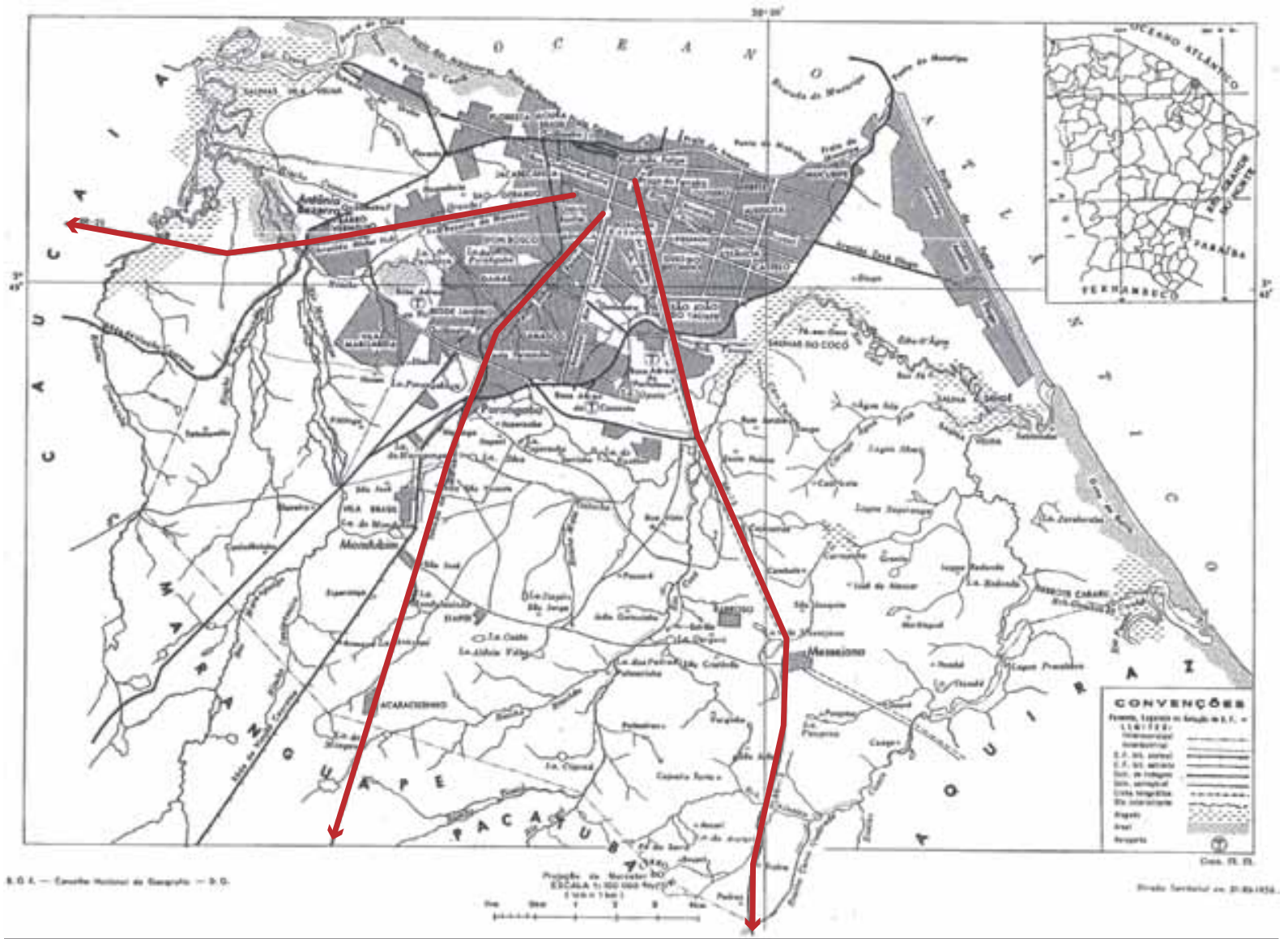

Fig. 3.7 Planta IBGE, 1956

Fonte: IBGE 


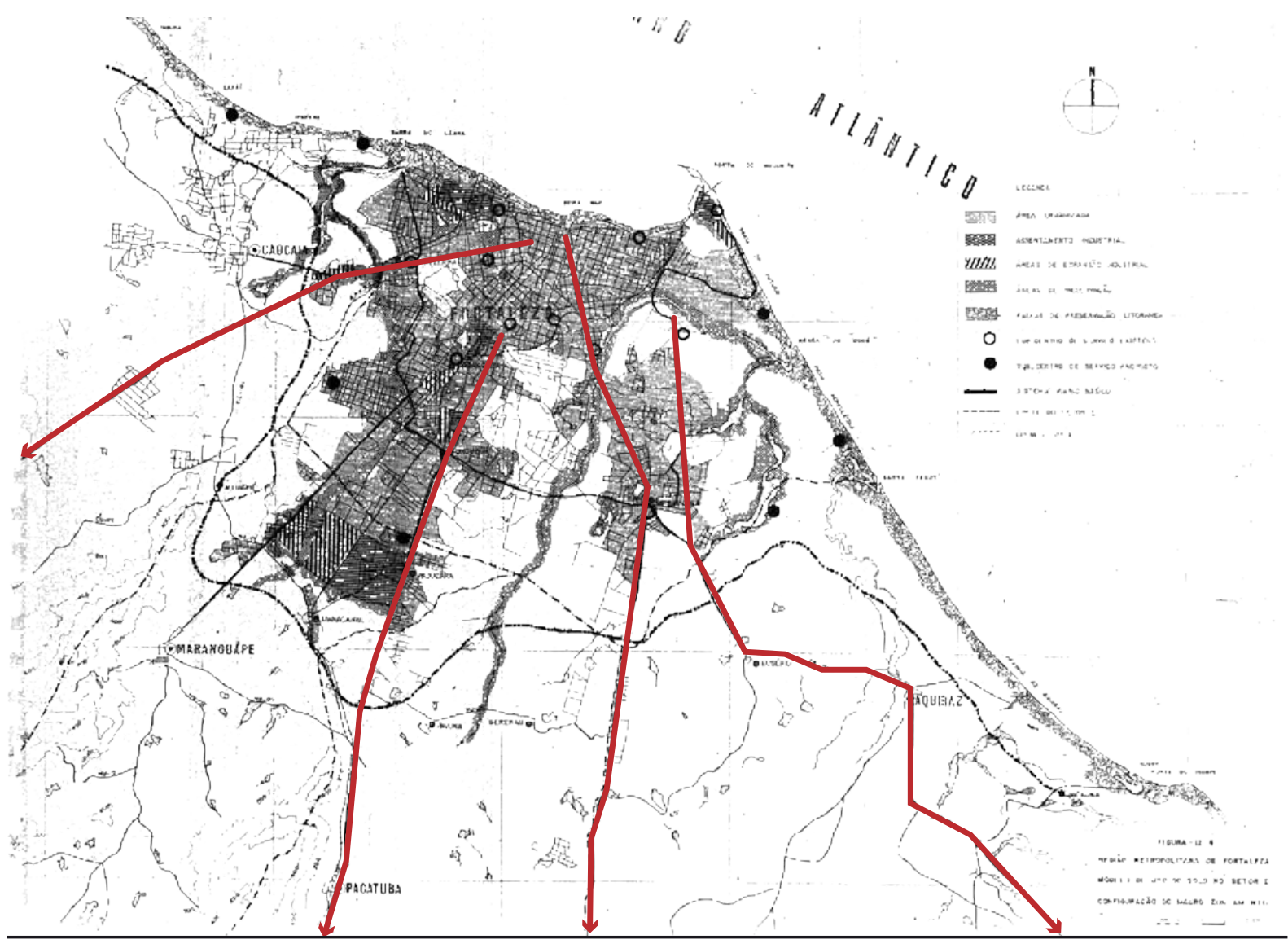

Fig. 3.8 Região Metropolitana de Fortaleza - AUMEF, 1977

Fonte: AUMEF

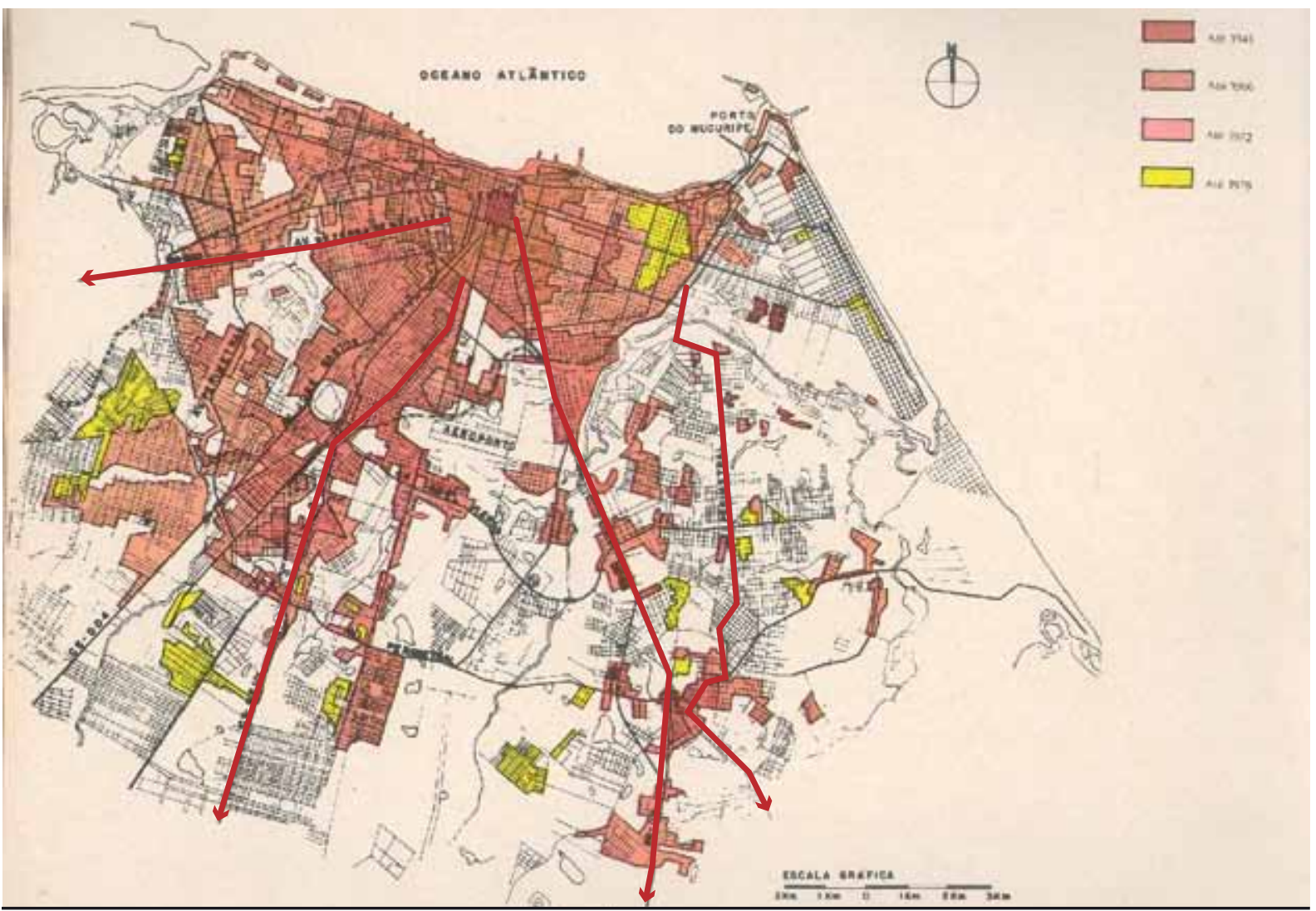

Fig. 3.9 Evolução urbana de Fortaleza, 1982

Fonte: PMF 


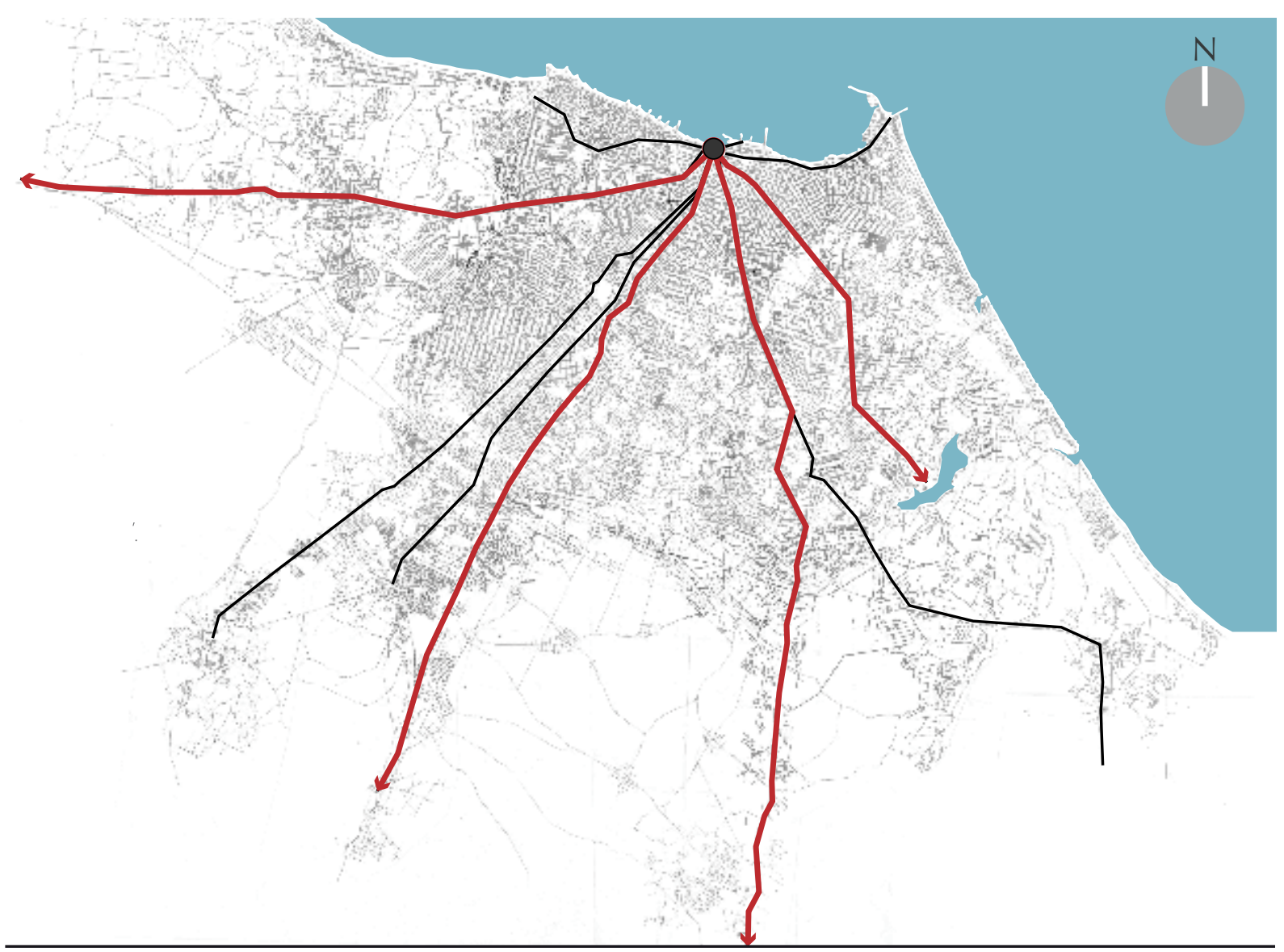

Fig. 3.10 Região Metropolitana de Fortaleza - expansão urbana, 2000 Fonte: org. José Liberal de Castro

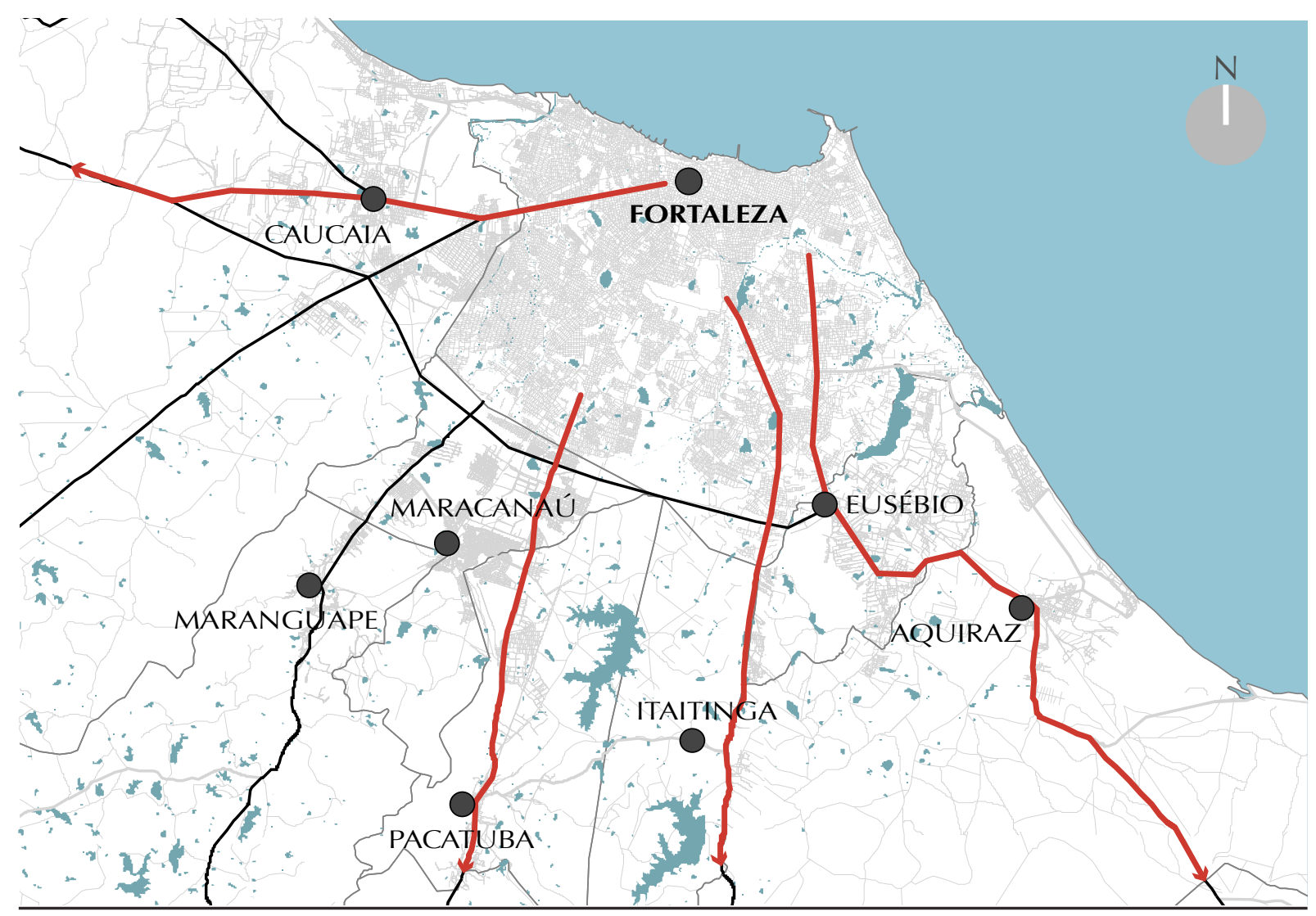

Fig. 3.11 Região Metropolitana de Fortaleza, 2011

Fonte: IPECE - elaborado pela autora 
A consolidação da mancha adensada obedece, pois, ao desenho dos eixos estruturantes formados pelas vias e ferrovias ${ }^{8}$. O esquema radioconcêntrico, partindo do centro da Capital resultou num modelo semiestelar, como afirmam alguns, do tipo "pé-de-galinha", um padrão comum às metrópoles que se desenvolvem junto ao litoral, em território sem grandes obstáculos físicos.

Vale salientar que esta forma de ocupação tem como consequência a formação de grandes vazios ou áreas de baixa densidade populacional entre as vias radiais, à medida que se afasta do centro, ao mesmo tempo em que apresenta baixa capilaridade, devido à precariedade de ligações entre os diversos eixos.

A rede viária hoje existente estimula a ocupação ao longo das vias radiais e esse desenho tem se mantido ao longo do tempo. Isso resulta numa afluência forçosa para Fortaleza, que dificulta e desestimula ligações diretas entre pontos situados nos diferentes eixos.

O desenho dos eixos viários, portanto, em convergência para o núcleo central, reforça ainda mais a questão da macrocefalia urbana da Capital, que concentra a maioria dos investimentos industriais, serviços e empregos, conforme destacado no capítulo anterior, contribuindo para o desequilíbrio verificado entre o Município de Fortaleza e as demais cidades cearenses.

A excessiva centralidade exercida por Fortaleza sobre o conjunto metropolitano se expressa com maior nitidez a partir das ligações rodoviárias. A radioconcentridade de seu sistema viário original mantém forte influência na distribuição da população e dos principais núcleos de prestação de serviços (SILVA, 2009, p.16).

A identificação dos vetores como determinantes da configuração e expansão metropolitana reforça, sem dúvida, o papel dos eixos viários de herança histórica na estruturação espacial da Metrópole. Faz-se necessária, entretanto, uma análise mais aprofundada, a fim de se averiguar a dinâmica socioespacial contemporânea, investigando em que medida essa expansão se faz de modo unicamente linear, ao longo dos eixos, se se verifica a existência de polos ou núcleos mais dinâmicos em toda sua extensão e quais as dinâmicas econômicas que incidem em cada um dos vetores, determinando processos urbanos diferenciados.

O estudo dos vetores, pois, servirá de base para se compreender o crescimento e expansão da Metrópole cearense e, assim, apreendê-la em sua totalidade.

\subsection{OS VETORES DE CRESCIMENTO URBANO E METROPOLITANO}

São quatro os vetores identificados, segundo a Síntese Diagnóstica do Plano Diretor de Fortaleza (2003). Os três primeiros relacionam-se com as zonas sul e oeste da Metrópole, historicamente ligadas às áreas industriais e de habitação popular; o vetor 1 corresponde ao eixo onde se localizam o Distrito Industrial de Maracanaú e conjuntos habitacionais surgidos nas vizinhanças. O vetor 2 configura-se ao longo da BR 116, concentrando as indústrias situadas nos Municípios de Eusébio, Horizonte e Pacajus. O vetor 3 se desenvolve em direção ao Município de Caucaia e ao longo da faixa litorânea oeste, abrangendo o Complexo Industrial Portuário do Pecém. O vetor 4 situa-se no quadrante sudeste da Metrópole, em direção aos Municípios de Eusébio e Aquiraz. Constitui o eixo imobiliário mais valorizado da Metrópole e abrange também equipamentos de lazer e turismo (ver figura 3.12).

\footnotetext{
${ }^{8}$ A presença da via férrea também foi determinante na futura estruturação metropolitana, ao definir, de início, a localização das primeiras indústrias; ao favorecer o fluxo de pessoas e cargas entre a Capital e o restante do Estado, principalmente nas direções sul e oeste e, mais recentemente, ao promover a mobilidade metropolitana, com o transporte de passageiros residentes nos municípios vizinhos.

${ }^{9}$ De acordo com Panerai (2006, p.43), "em geral estabelecidos antes da urbanização e herdados dos caminhos antigos e estradas importantes, os eixos rodoviários são responsáveis pela estruturação das periferias".
} 


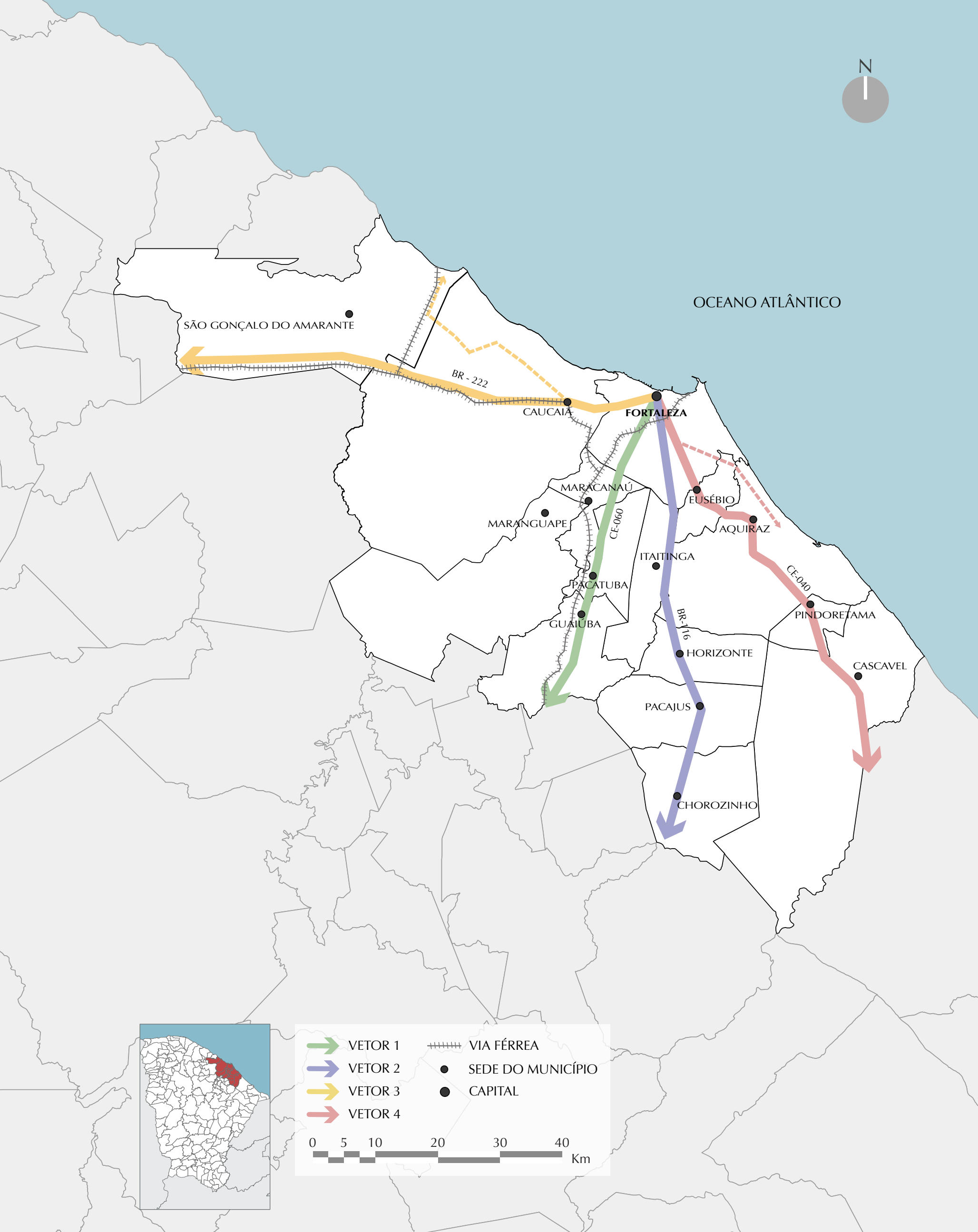

Fig. 3.12 Mapa RMF: os Vetores de expansão urbana

Fonte: elaborado pela autora 
Cada vetor possui características próprias e distintas, as quais conferem ao espaço urbano e metropolitano configurações específicas e determinam tipos de ocupação e crescimento diferenciados. Por tais razões, merecem ser analisados separadamente.

Tem-se, pois, a seguir, o exame de cada um dos vetores (divididos em trechos, para melhor análise), elaborado, sobretudo, a partir de observação empírica ${ }^{10}$, com o intuito de verificar sua forma particular de expansão.

Cabe ressaltar que a análise e a leitura da paisagem foram empreendidas com base na situação atual, buscando identificar e destacar: os principais usos, tipos de ocupação, marcos simbólicos, recursos naturais mais significativos, atividade econômica predominante, investimentos mais importantes, principais concentrações de atividades e as intervenções mais recentes.

\subsubsection{Vetor 1 - O Distrito Industrial de Maracanaú}

O Vetor 1 corresponde ao eixo mais antigo de ocupação, onde se localiza o Distrito Industrial de Maracanaú, instalado em meados da década de 1960-1970, segundo as regras do planejamento econômico vigente à época - promovido pela SUDENE e pelo Governo do estado - em cujas vizinhanças surgiram conjuntos habitacionais, ao longo da ferrovia, na década de 19701980.

Esta fase de investimentos industriais efetuados no Ceará, naquele período, privilegiou principalmente, os setores têxtil, confecções, alimentos e metal-mecânico, com indústrias implantadas no Município de Maracanaú. Do ponto de vista da moradia, a presença do eixo ferroviário sul e a política do $\mathrm{BNH}$, de atendimento a déficits habitacionais, fizeram surgir, na área, inúmeros conjuntos habitacionais, que visavam a desafogar a Capital.

O vetor se inicia ainda no Município de Fortaleza, no bairro do Montese, e se estende na direção sul até o Município de Guaiuba, integrante da Região Metropolitana. A análise do referido vetor, assim como a dos outros que se seguem, será feita a partir dos diferentes trechos que o compõem, os quais possuem, quase sempre, características diferenciadas (ver figuras 3.13 e 3.14).

\footnotetext{
${ }_{10}$ Para o exame e análise da paisagem urbana dos diversos vetores, foi empreendida ampla pesquisa de campo, identificando-se os elementos que constituem a paisagem por meio de uma análise direta, realizada in situ, associada à fotografia, à imagem de satélite e à análise cartográfica.
} 


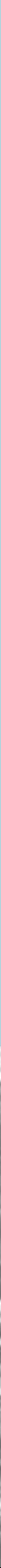


CAPÍTULO 3

A expansão territorial da Metrópole cearense e os vetores de crescimento urbano e metropolitano

\section{TRECHO 1 - O subcentro do Montese}

O Vetor 1 tem início na av. Borges de Melo, no bairro do Montese, definido pelo binário formado pela rua Alberto Magno e pela av. Gomes de Matos, em sentido inverso. O bairro do Montese constitui importante subcentro na cidade de Fortaleza, com estabelecimentos de comércio e serviços voltados para a população de renda média e média baixa, concentrados principalmente nas duas vias citadas, que se transformaram em dinâmicos corredores comerciais.

O comércio é formado principalmente por autopeças, confecções e varejo em geral, além de várias agências bancárias. A ocupação é densa, mas predominantemente horizontal, com a maioria das antigas residências transformadas em lojas e praticamente não há terrenos desocupados. Há intensa poluição visual, com uma infinidade de placas indicativas, instaladas sem qualquer ordenamento. Como se trata de um eixo de ligação com a zona sul da Cidade (e do Estado), a via tem fluxo contínuo e é bastante movimentada"1.

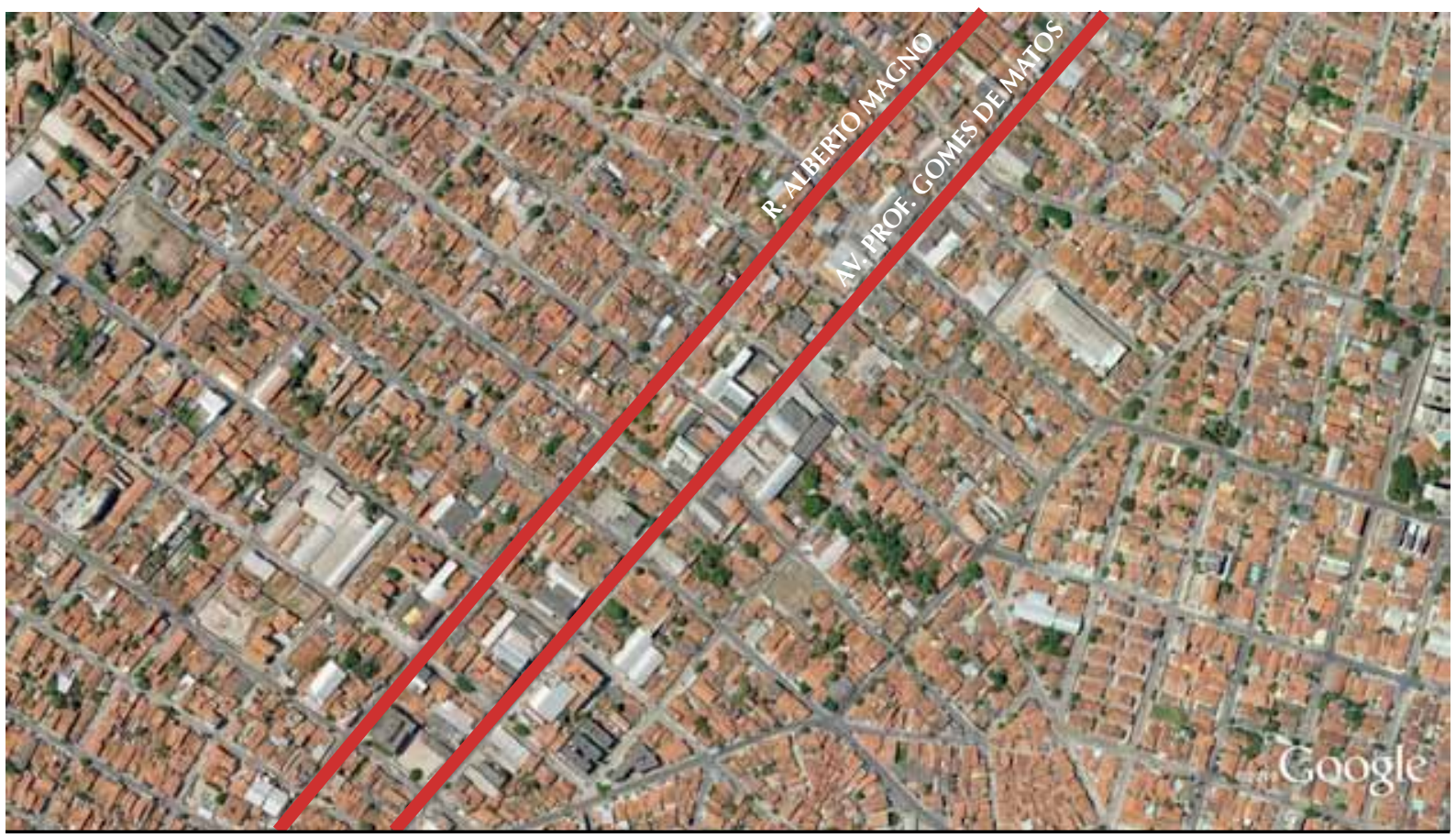

Fig. 3.15 Vetor 1: Trecho 1 (r. Alberto Magno e av. Prof. Gomes de Matos)

Fonte: Google Earth - elaborado pela autora

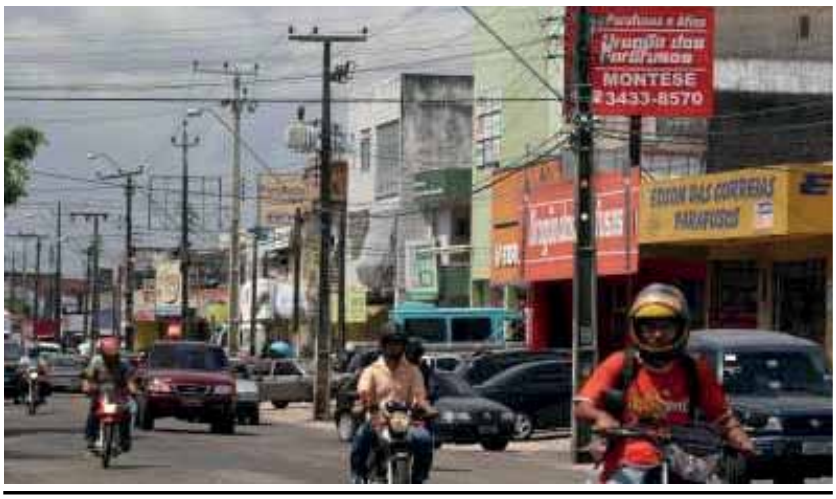

Fig. 3.16 Trecho 1 - Bairro Montese

Fonte: http://fortalezaacademica.blogspot.com.br

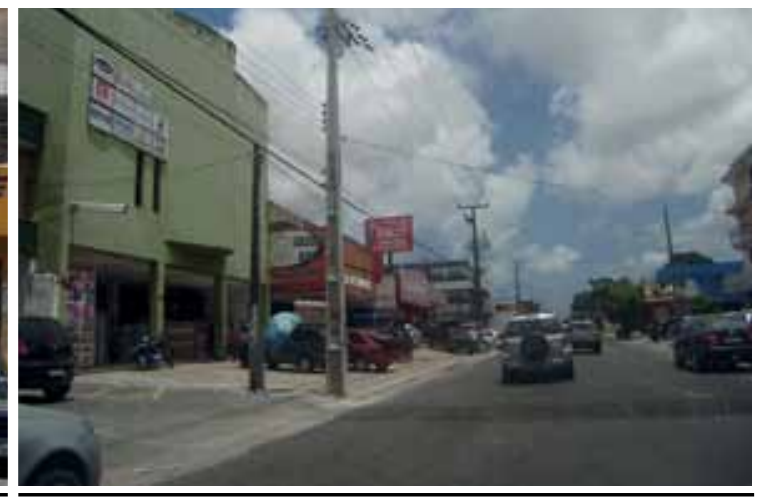

Fig. 3.17 Trecho 1 - Bairro Montese Fonte: acervo autora

${ }^{11}$ A r. Alberto Magno (assim como a av. Gomes de Matos) possui a configuração de uma via local, com dimensões reduzidas e desenho incompatível com sua função viária, de vetor de expansão urbana. Como via de entrada e saída da Cidade, deveria obrigatoriamente ser redesenhada e ampliada, sem, contudo, deixar de manter as identidades dos bairros que percorre. 


\section{TRECHO 2 - A expansão residencial da classe média-baixa no bairro da Maraponga}

Saindo do bairro do Montese, a via transforma-se na av. Godofredo Maciel, já de mão dupla. Atravessa o bairro da Parangaba (antigo distrito de Fortaleza) e margeia a lagoa da Maraponga, onde há presença de vegetação e algumas habitações situadas em áreas alagadas, consideradas de risco. O trecho se diferencia do anterior, com lotes maiores e ocupação um pouco menos densa, com predominância da função habitacional (ver figuras 3.18 a 3.21).

Abrange ainda o bairro da Maraponga, que atualmente passa por alterações significativas, em decorrência da construção progressiva de edifícios multifamiliares, de 5 a 14 pavimentos. O bairro tem conhecido valorização recente e vem se transformando em zona residencial preferencial da classe média-baixa, com intensa atuação da atividade imobiliária. Em consequência dos vários empreendimentos em construção, há visível melhoria na tipologia das edificações, com restaurantes e lanchonetes que exploram as fachadas a fim de atrair a nova clientela. Percebe-se um substancial aumento da oferta de moradias nessa área.

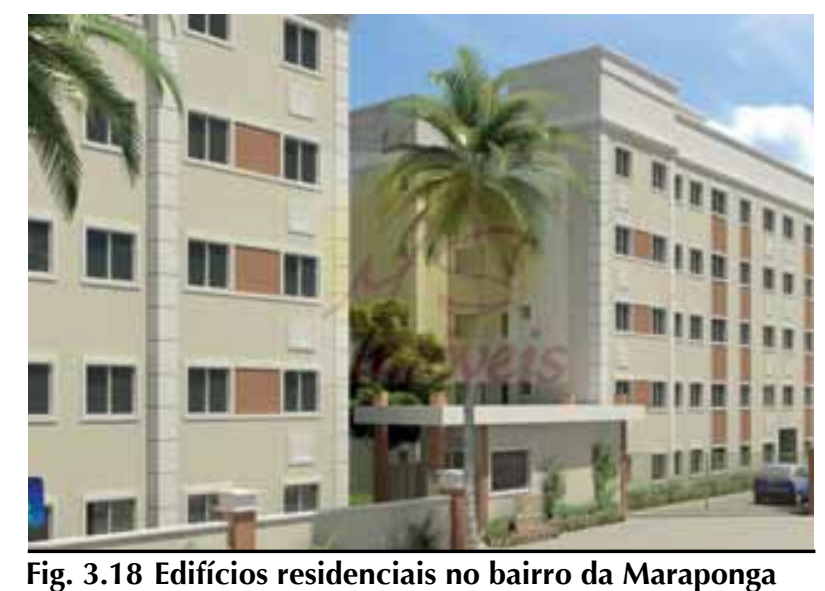

Fonte: http://fortaleza.olx.com.br

Segundo matéria veiculada no jornal O Povo,

Empreendedores avaliam que a região é uma das que mais avança, entre os bairros de Fortaleza, apresentando uma valorização de $20 \%$ ao ano. A demanda, que já é maior que a oferta, deve seguir crescente com o aumento no valor limite do programa Minha Casa Minha Vida. Os imóveis são destinados à cada vez mais participativa classe C. E esse público é significativo, com tendência de crescimento. O valor do metro quadrado no bairro da Maraponga é de R\$ $2.350,00$. As construtoras e imobiliárias já perceberam o nicho de mercado há algum tempo e continuam investindo na região (Jornal O Povo, 09-02-2011).

O DETRAN (Departamento Estadual de Trânsito) localiza-se nas imediações, ocupando lote considerável, constituindo polo gerador de tráfego e atraindo grande fluxo de pessoas e veículos em determinadas horas do dia. Ao lado, foi implantado equipamento de grande porte, o supermercado Carrefour, também responsável por um fluxo mais intenso na área. Há uma concentração de comércio e serviços complementares, que se compõe de lojas de materiais de construção, borracharias, postos de gasolina, churrascaria e motéis. É visível a incidência de moradias instaladas em área de risco, junto à lagoa da Maraponga. 


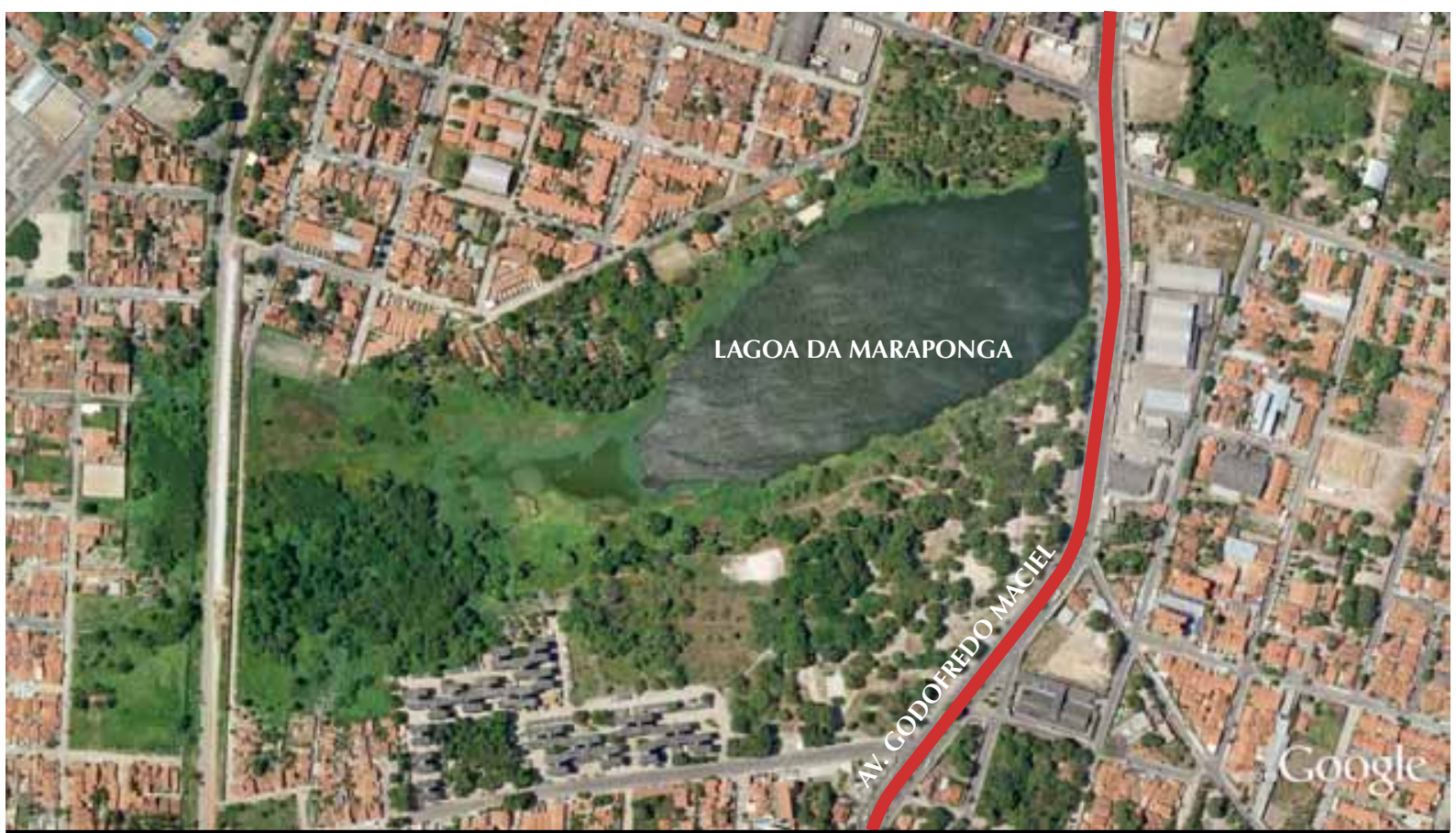

Fig. 3.19 Vetor 1: Trecho 2 (bairro Maraponga)

Fonte: Google Earth - elaborado pela autora
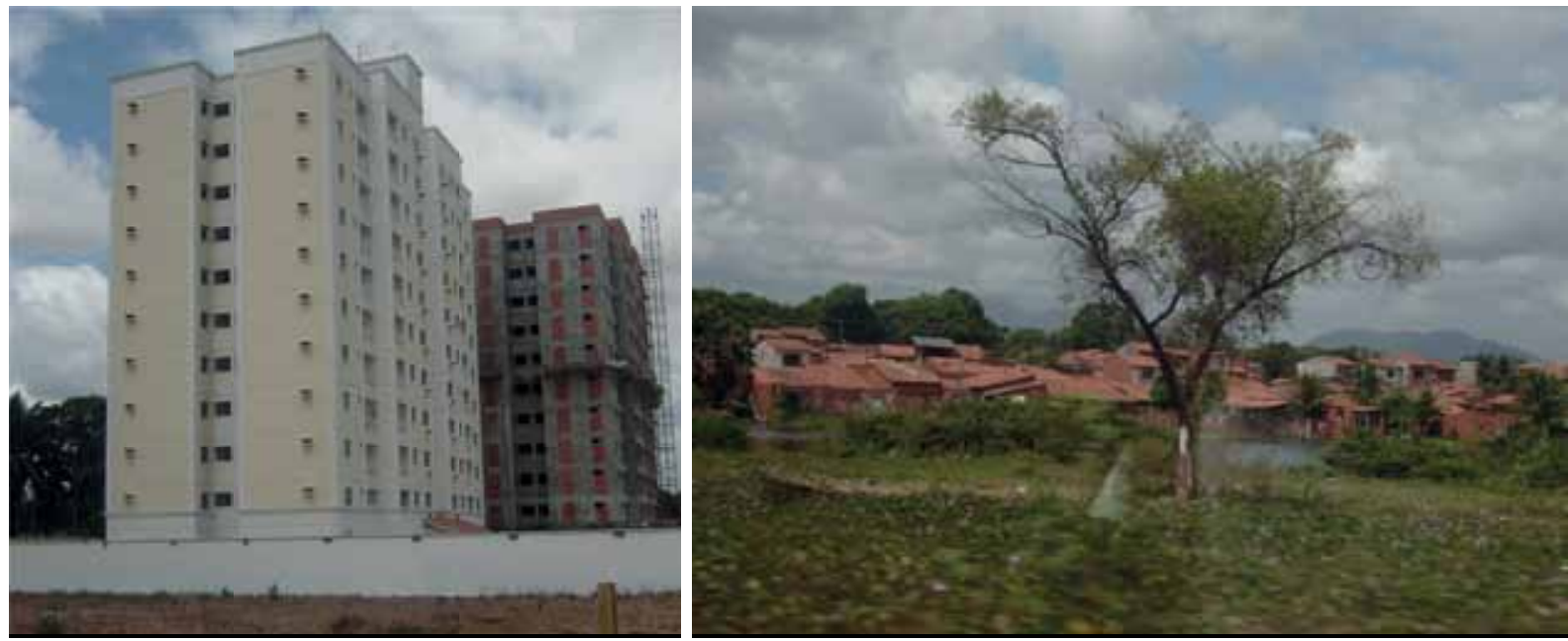

Fig. 3.20 Trecho 2 - Edifícios no bairro da Maaponga Fig. 3.21 Trecho 2 - Favelas em áreas de risco

Fonte: acervo autora

Fonte: acervo autora

\section{TRECHO 3 - A CEASA e o cruzamento com o $4^{\circ}$ Anel Viário}

Em seu prosseguimento, a via/vetor atinge o Município de Maracanaú ${ }^{12}$, onde, na entrada para a Sede, se localiza a CEASA - Central de Abastecimento de Fortaleza S/A. Este trecho conforma um corredor comercial bem definido, onde se localizam frigoríficos, supermercados e diversas agências bancárias, as quais operam com atividades relacionadas ao Município de Maracanaú. Há também edificações voltadas para o comércio atacadista (ver figuras 3.22 a 3.24).

A CEASA situa-se no cruzamento da via com o $4^{\circ}$ Anel Viário, o qual faz a ligação entre os diversos vetores citados. Pelo Anel Viário, tem-se acesso, à esquerda, aos vários conjuntos habitacionais localizados nas imediações e, à direita, há indicação para o conjunto José Walter,

\footnotetext{
${ }^{12}$ Maracanaú, antes distrito de Maranguape, passou à condição de em 4 de julho de 1983, pela Lei Estadual n 10.811, publicada no Diário Oficial em 5 de julho de 1983.
} 
um dos primeiros a ser implantado no Município de Fortaleza, cujo projeto inicial previa 5.500 unidades residenciais. A partir deste cruzamento, a via transforma-se em rodovia (CE 060), sob o nome de Av. Dr. Mendel Steinbruch. Passa ao leste da Sede do Município de Maracanaú e possui pista dupla com canteiro central e ciclovia.

Até esse trecho, percebe-se uma ocupação concentrada e conurbada, em continuidade com o tecido urbano do Município de Fortaleza.

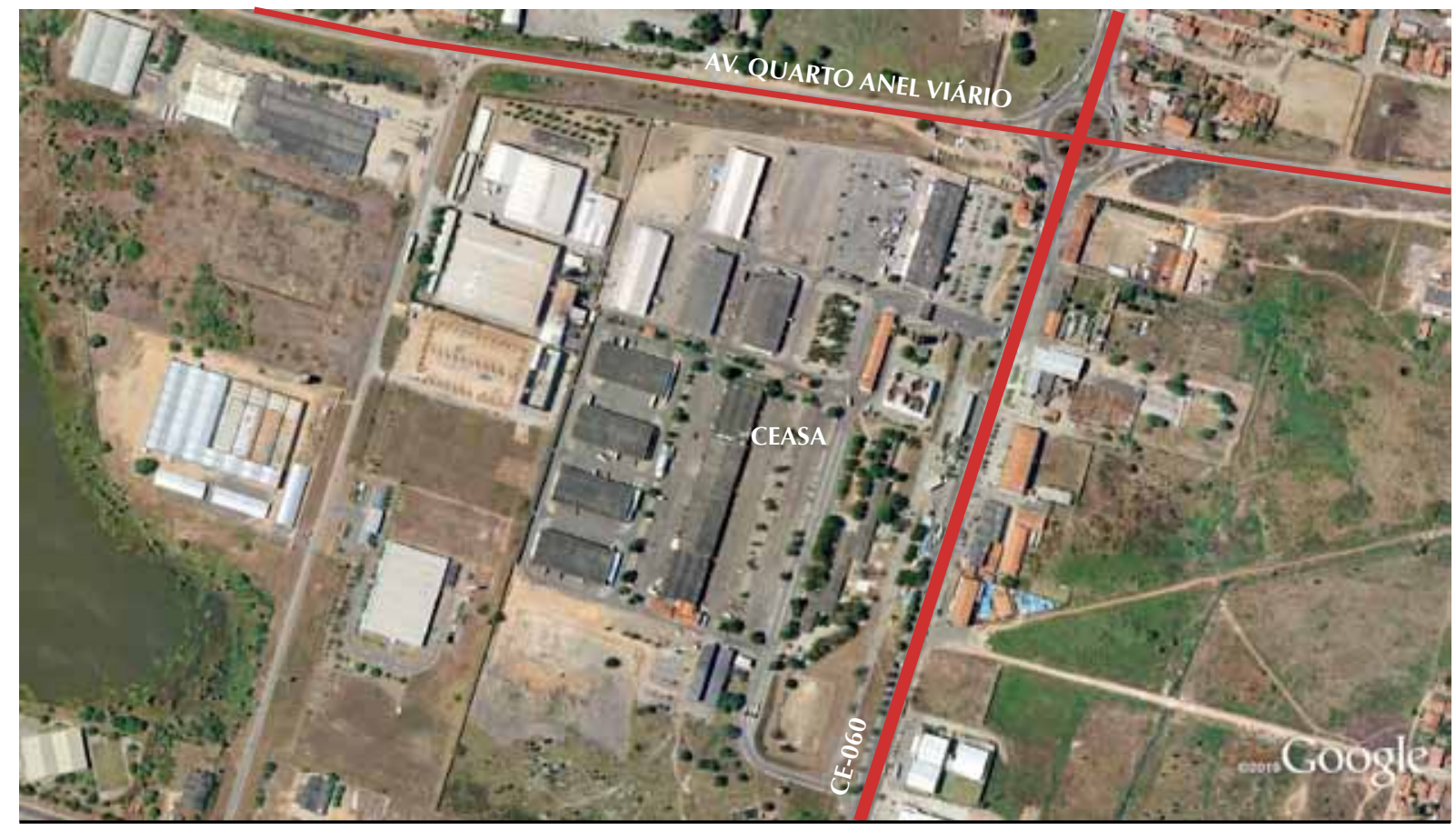

Fig. 3.22 Vetor 1: Trecho 3 (CEASA)

Fonte: Google Earth - elaborado pela autora

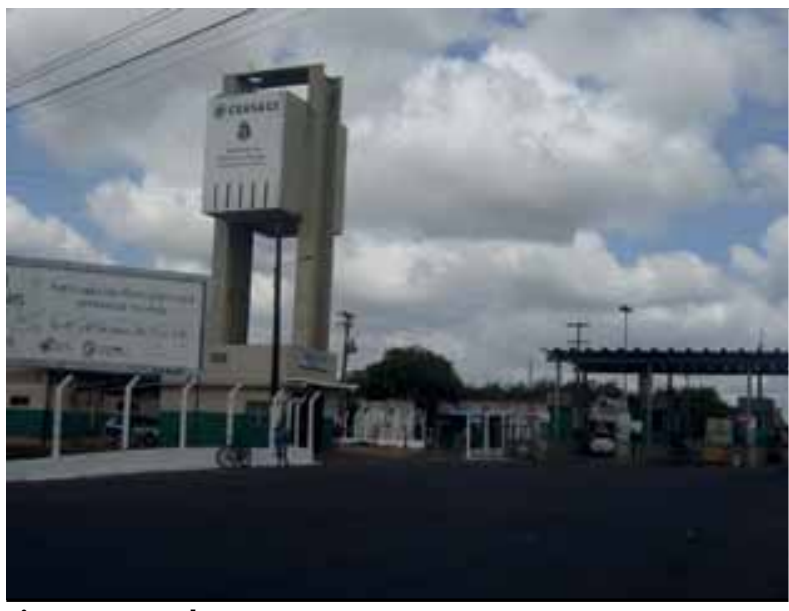

Fig. 3.23 Trecho 3 - Ceasa

Fonte: acervo autora

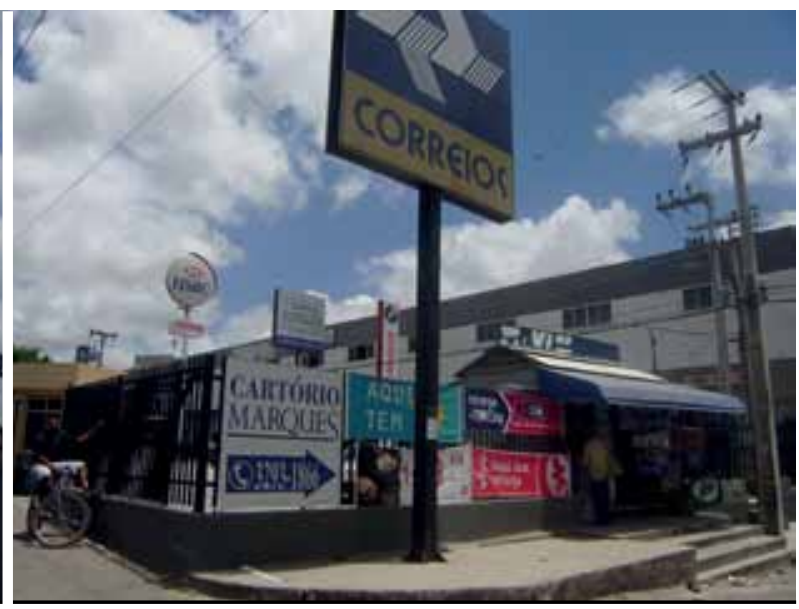

Fig. 3.24 Trecho 3 - comercio próximo à Ceasa

Fonte: acervo autora 


\section{TRECHO 4 - O Distrito Industrial de Maracanaú e os conjuntos habitacionais}

A via dá acesso, neste trecho, ao Distrito Industrial de Maracanaú13, implantado no Município ${ }^{14}$ de mesmo nome, onde foram instaladas diversas indústrias desde quando foi criado, em 1964.

As indústrias ocupam grandes lotes dentro da área determinada e o Distrito é circundado por conjuntos habitacionais ${ }^{15}$, construídos ao longo da via férrea ${ }^{16}$ durante a década de 1970-1980. As construções que compõem os conjuntos são habitações populares, todas de volumetria horizontal, além de pontos comerciais, a maioria de tipologia bastante simples (ver figuras 3.25 a 3.27).

A dinâmica social do Município foi fortemente impulsionada pela implantação de
grandes conjuntos habitacionais populares, deslanchando uma dinâmica popula-
cional inusitada no Município. Porém, é necessário ressalvar que a construção des-
ses conjuntos habitacionais teve como principal objetivo a descompressão popu-
lacional de Fortaleza e, em menor escala, atender alguns municípios da região me-
tropolitana. Valea pena ressaltar que a implantação dos conjuntos habitacionais em
Maracanaú obedeceu à idéia de que eles, ao se localizarem nas proximidades do
distrito industrial, se constituiriam em fornecedores naturais da força de trabalho ${ }^{17}$.

Maracanaú teve expressivo crescimento populacional ${ }^{18}$, motivado principalmente pela construção dos vários conjuntos habitacionais na década de 1970-1980, os quais exerceram forte atração junto à classe trabalhadora de Fortaleza. A ocupação é feita de maneira contínua com relação à Capital, e vários desses conjuntos, além dos bairros do Novo Mondubim, Alto Alegre e Siqueira localizamse parte em Fortaleza e outra em Maracanaú, registrando-se aí o fenômeno da conurbação ${ }^{19}$.

Esses conjuntos, localizados em áreas distantes, foram fatores fundamentais para a expansão da cidade. Os moradores organizados exigiam do Poder Público infra-estrutura e serviços, os quais favoreciam a valorização de vazios urbanos (...) Nos anos 80, os conjuntos habitacionais ultrapassaram a fronteira dos espaço fortalezense e foram implantados em municípios da região metropolitana (Timbó e Jereissati, em Maracanaú). A extinção do BNH levou à redução do ritmo das construções populares (COSTA, C., 2001, p.84).

A transferência maciça da população para os municípios integrantes do espaço metropolitano teve seu processo iniciado com a construção de grandes conjuntos habitacionais ao longo das linhas troncos norte e sul da antiga RFFSA e em torno do distrito industrial de Maracanaú (SILVA, 2002, p.104).

De acordo com as diretrizes da Política Habitacional, mediada no Ceará pela $\mathrm{COHAB}$, visando à erradicação das favelas dos espaços intra-urbanos, os conjuntos habitacionais localizaram-se ao longo dos eixos viários regionais, em direção a Caucaia e Maracanaú. As diretrizes básicas para escolha das áreas

\footnotetext{
${ }^{13}$ Tem-se acesso também ao Distrito Industrial (em seu lado oeste) por meio de outra rodovia estadual, a CE 065, a qual interliga Fortaleza a Maranguape. A CE 065 constitui, portanto, outro eixo rodoviário que liga a Capital ao interior do Estado. ${ }^{14}$ Com 112 unidades industriais implantadas, o Município de Maracanaú tem a segunda maior arrecadação de ICMS do Ceará, sendo superado apenas pelo Município de Fortaleza. O DI é responsável por 10\% do Imposto Sobre Circulação de Mercadorias e Serviços (ICMS) arrecadado no Estado do Ceará.

${ }^{15}$ São esses os conjuntos habitacionais instalados nas redondezas do Distrito Industrial: Conjunto Industrial, Aracapé, Cidade Nova, Acaracuzinho, Alto Alegre I, Alto Alegre II, Alto Alegre III, Alto da Mangueira, Timbó, Santo Sátiro, Piratininga, Mucunã, Pitaguary, Novo Oriente, Jereissati I e Jereissati II.

${ }^{16}$ Para Fortaleza, existe a ligação ferroviária, através da linha Tronco Sul, com frequência de trens de passageiros a cada 30 minutos.

${ }^{17} \mathrm{http}: / /$ www.portalmaracanau.com.br/maracanau/contextoregional02.htm

${ }^{18}$ Maracanaú possui a $4^{a}$ maior população entre os municípios do Estado (209.057 hab. em 2010), em uma área bastante reduzida $\left(105,69 \mathrm{~km}^{2}\right)$, o que representa uma densidade de $1.984 \mathrm{hab} / \mathrm{km}^{2}$.

${ }^{19}$ Conurbação (de con+urbe+ação) é a unificação da malha urbana de duas ou mais cidades, em consequência de seu crescimento geográfico. (Grande Enciclopédia Larousse Cultural; São Paulo: Nova Cultural, 1998, v. 7, p. 1601.) Trata-se de um fenômeno urbano que ocorre com a união de duas ou mais cidades, formando uma malha urbana contínua.
} 
A expansão territorial da Metrópole cearense e os vetores de crescimento urbano e metropolitano

eram as condições de acessibilidade financeira e física da população. Assim, os terrenos deveriam ter preços baixos e serem beneficiados pelo sistema viário e de transportes coletivos, portanto, apresentando melhores facilidades para os fluxos cotidianos intra-metropolitanos (ACCIOLY, 2009, p.140).

Tal ocupação induziu a expansão metropolitana e o adensamento populacional, sobretudo nas faixas adjacentes à rodovia. A localização dos conjuntos integrados à via férrea foi recomendada pelo PLANDIRF, por conta da maior acessibilidade e também da futura melhoria do transporte ferroviário ${ }^{20}$, que não se viabilizou.

Houve enorme incremento populacional, em decorrência dos conjuntos aí localizados, mas não se pode afirmar que tenha havido qualquer planejamento ou organização territorial ${ }^{21}$. Permanecem bastante precários os serviços urbanos diversos e outros equipamentos qualificadores, como serviços de saúde, educação, áreas de lazer e cultura, além de comércio e centros de bairro para atender a essa população.

A atividade industrial é determinante na dinâmica econômica de Maracanaú (com 57,9\% de participação no PIB) ${ }^{22}$. Vale ressaltar, por outro lado, que a proximidade física de Fortaleza e a facilidade de transportes rodoviários dificultam, de certo modo, o incremento de atividades comerciais em Maracanaú, o que tem sido objeto de preocupação por parte da Administração municipal, que pretende transformar o Município num polo comercial alternativo ${ }^{23}$ na Região Metropolitana, exercendo também atração de demanda de municípios vizinhos.

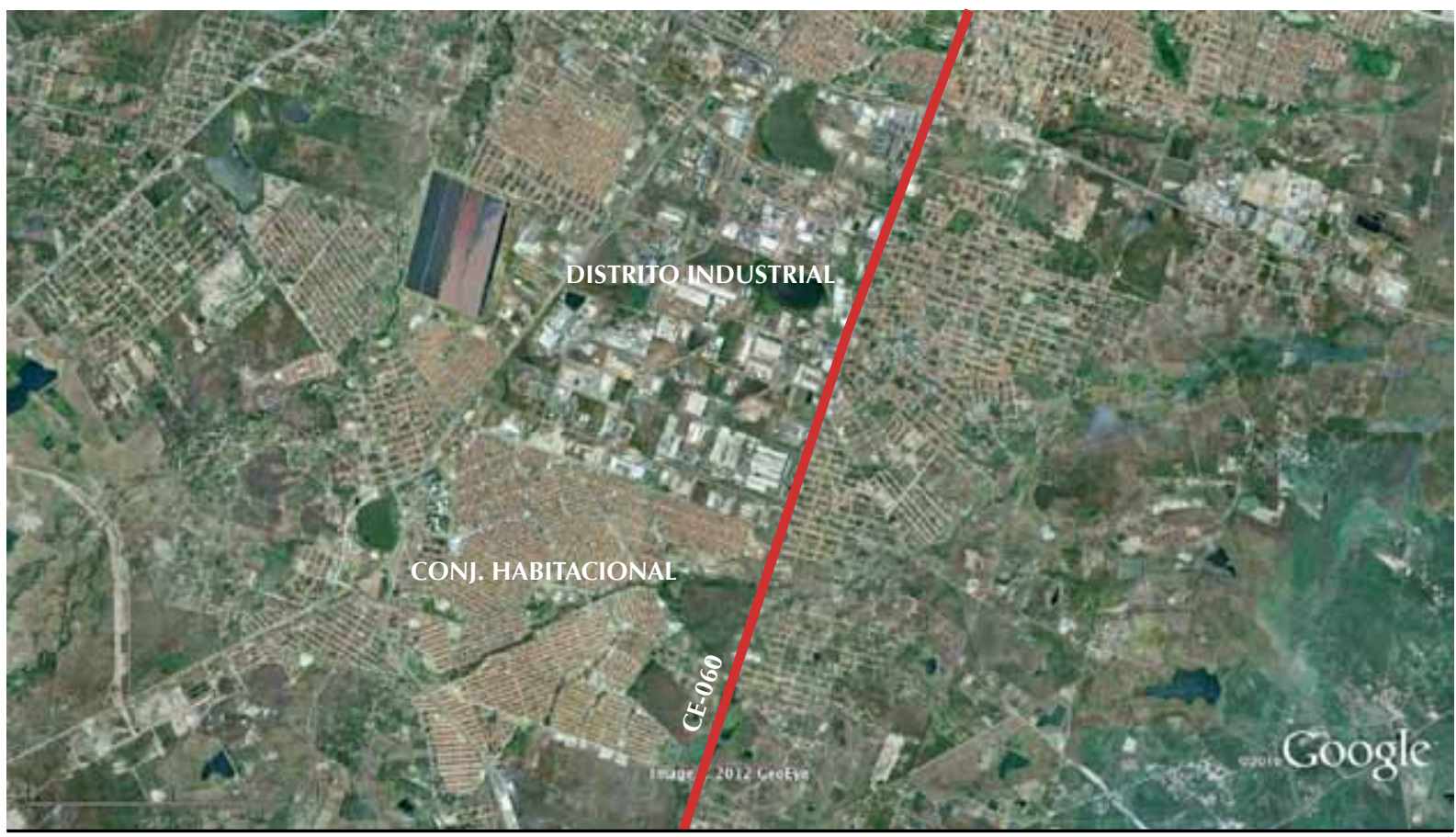

Fig. 3.25 Vetor 1: Trecho 4 (Distrito Industrial de Maracanaú e conjuntos habitacionais) Fonte: Google Earth - elaborado pela autora

\footnotetext{
${ }^{20} \mathrm{O}$ sistema ferroviário, obsoleto e sucateado, sem investimentos modernizadores, permanece à espera da integração com o Metrofor (Trem Metropolitano de Fortaleza), a fim de viabilizar o transporte de passageiros adequado em direção à Capital. ${ }^{21}$ A construção dos conjuntos habitacionais nessa região correspondeu à política habitacional da época, implementada pelo $\mathrm{BNH}$, em atendimento ao déficit habitacional; entretanto, essas iniciativas foram "circunscritas a soluções improvisadas, de baixa qualificação urbanística e construtiva, com implicações negativas, tanto em termos sociais quanto na perspectiva de uma progressiva valorização imobiliária, ao longo do tempo, nessas bases territoriais. O processo foi irradiado numa linha de expansão e atendimento habitacional também no de Caucaia, no eixo que acompanha a BR-020" (PDDUA FOR, 2004). ${ }^{22}$ Dados do Anuário do Ceará 2011-2012.

${ }^{23} \mathrm{Em} 2003$, foi inaugurado o North Shopping (filial de em empreendimento existente em Fortaleza) na Cidade, com área total de 18.943 m², o primeiro da RMF fora da Capital, que atende aos Municípios de Maracanaú, Pacatuba e Guaiuba.
} 


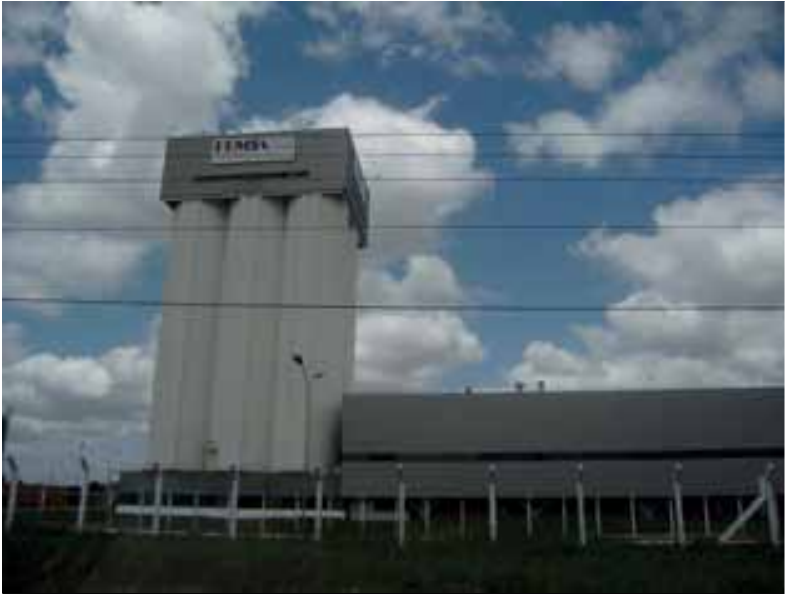

Fig. 3.26 Trecho 4 - indústrias DI Maracanaú Fonte: acervo autora

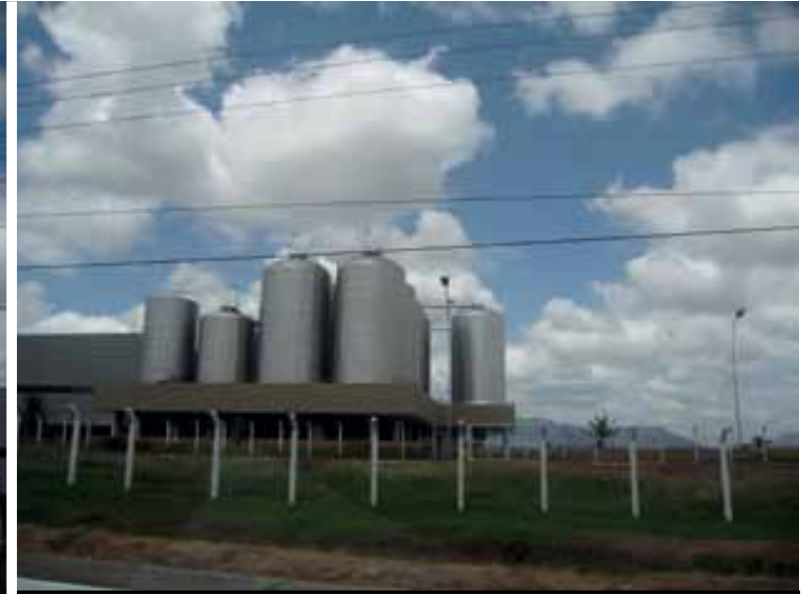

Fig. 3.27 Trecho 4 - indústrias DI Maracanaú Fonte: acervo autora

\section{O Distrito Industrial de Maracanaú}

O Plano Diretor do Primeiro Distrito Industrial de Fortaleza (DI de Maracanaú) data de 1964, elaborado durante o primeiro mandato do Governador Virgílio Távora (1963-1966), tendo sua implantação sido iniciada em março de 1966. A área de abrangência totaliza 1.100 hectares, divididos entre a zona industrial, áreas verdes e circulação, o que corresponde a $12,35 \%$ da área do Município.

A primeira indústria a se instalar no Distrito Industrial de Maracanaú, com o projeto da SUDENE - Superintendência de Desenvolvimento do Nordeste, foi a Ceará Laminado e Compensados S.A (Celaco), no início de 1967, já com a energia de Paulo Afonso. A segunda empresa a montar suas bases no DI foi a Iplac, inaugurada em fins de 1968.

As indústrias que compõem o DI de Maracanaú são predominantemente de preparação de britamento e outros trabalhos em pedras; produtos de laticínios; artefatos têxteis de tecidos; artigos para cama e mesa; biscoitos e bolachas; calçados de couro, plástico, tecidos, fibras, madeira ou borracha; fungicidas; herbicidas; defensivos agrícolas; massas alimentícias; material elétrico para veículos e medicamentos.

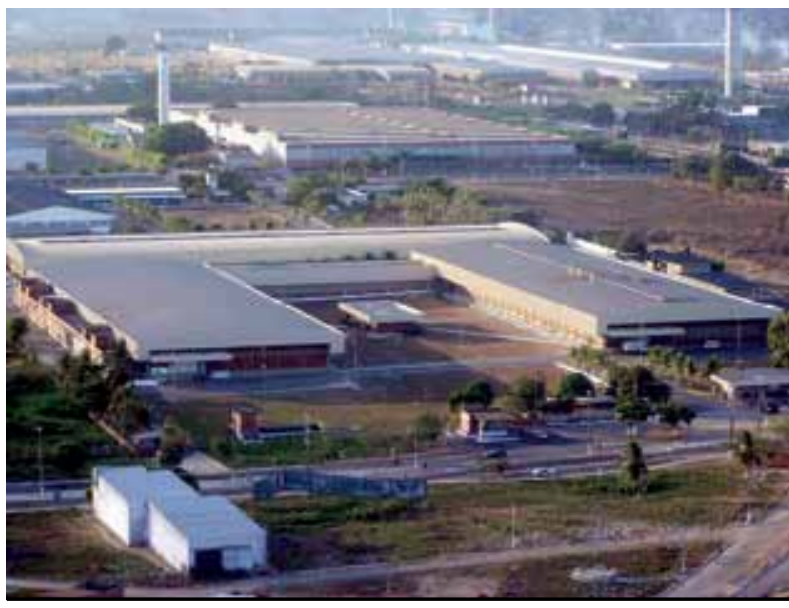

Fig. 3.28 Indústrias Distrito Industrial Maracanaú Fonte: http://www.maracanau.ce.gov.br/empresas.html

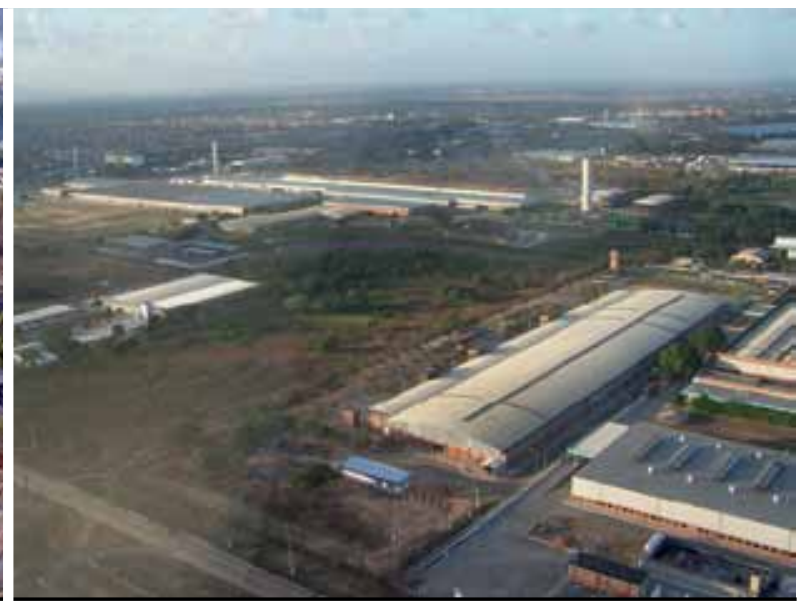

Fig. 3.29 Indústrias Distrito Industrial Maracanaú 
Atualmente, segundo dados da Prefeitura Municipal de Maracanaú ${ }^{24}$, 16,5 mil pessoas trabalham diretamente nas 112 empresas instaladas nos três distritos industriais de Maracanaú (DIF I, DIF III e DI 2000), sendo que 15 mil estão alocadas nas 75 indústrias do primeiro polo implantado no Ceará. Dessa mão de obra, 50\% moram em Maracanaú ou nos conjuntos habitacionais que circundam a zona industrial.

O DI de Maracanaú fica a $18 \mathrm{~km}$ do centro de Fortaleza e a $12 \mathrm{~km}$ do Aeroporto Internacional Pinto Martins. A distância para o Porto do Mucuripe é de $26 \mathrm{~km}$ e o acesso pode ser feito pela CE-060 (interligada pelo Anel Viário às BRs 116, 020 e 222 e CE 065). Para o Porto do Pecém, a distância é de $61 \mathrm{~km}$. O acesso ferroviário é feito pela linha tronco sul da antiga RFFSA, atual Companhia Ferroviária do Nordeste.

O Distrito Industrial possui situação privilegiada dentro da Região Metropolitana, pela proximidade da confluência de importantes eixos rodoviários, pela posição equilibrada entre os portos do Mucuripe e do Pecém, pela presença da via férrea e pela futura implantação do metrô, que ligará o Município a Fortaleza.

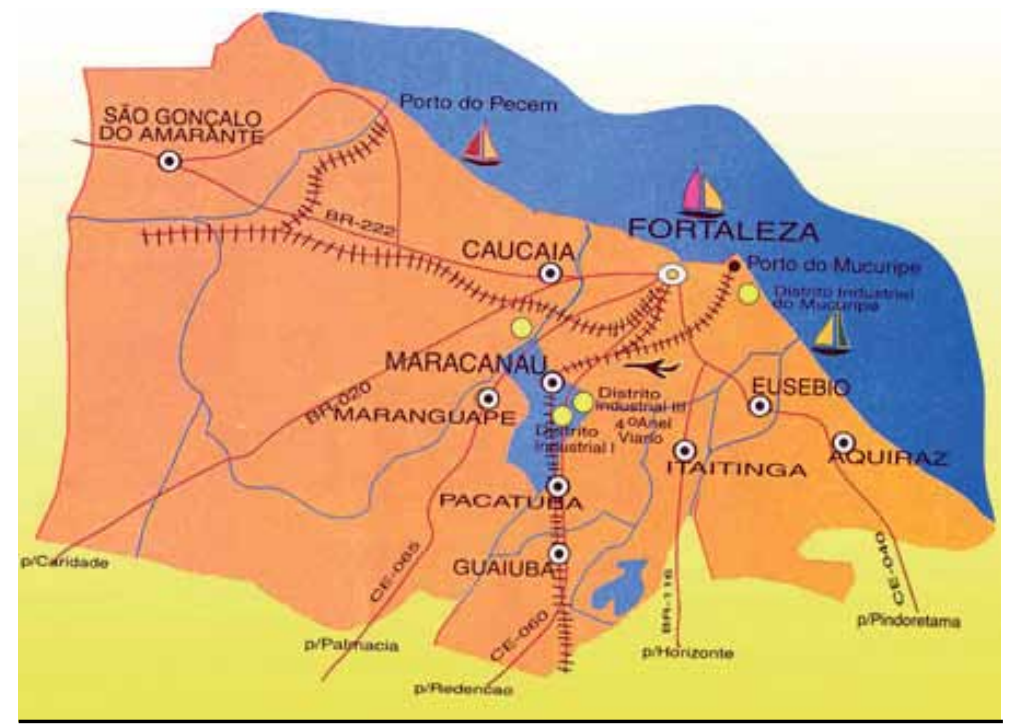

Fig. 3.30 Distrito Industrial de Maracanaú na RMF

Fonte: http://www.achetudoeregiao.com.br/CE/maracanau/geografia.htm

O incremento industrial no Estado do Ceará no período 1960-1975, mediante incentivos fiscais da SUDENE, certamente alterou a fisionomia da futura Região Metropolitana de Fortaleza. A instalação de um distrito industrial segundo as regras do planejamento econômico vigente à época veio contrapor-se ao então Setor Industrial localizado na av. Francisco Sá, inserido na malha da Cidade, na zona oeste.

A instalação e transferência de indústrias mais poluidoras induziram o crescimento do novo Distrito Industrial, garantindo a dinâmica e expansão da economia cearense, além de promover grandes alterações no arranjo socioespacial metropolitano, estimulando o crescimento urbano naquela direção.

Neste trecho, portanto, percebe-se a formação de um polo expressivo junto ao vetor, formado pelo Distrito Industrial, pelos conjuntos habitacionais e pela Sede do Município, contrariando a ocupação linear ao longo da via.

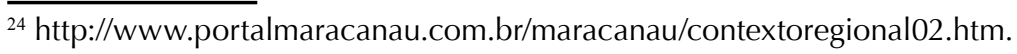




\section{TRECHO 5 - Em direção à zona rural}

A paisagem muda consideravelmente a partir do cruzamento viário que dá acesso ao Distrito Industrial de Maracanaú. Trata-se então de zona predominantemente rural, com presença de algumas habitações de pequeno porte às margens da via (ver figuras 3.31 a 3.33). Veem-se grandes glebas desocupadas e algumas indústrias situadas à margem da via: Marisol, EMSA (fabricante de cerveja), Mecesa e Killing.

Por localizar-se em espaço contíguo a Maracanaú, o Município de Pacatuba ${ }^{25}$ se beneficia da expansão das indústrias e dos conjuntos habitacionais lá concentrados. O núcleo urbano, situado próximo à rodovia, mantém suas características originais e não registrou crescimento significativo nos últimos anos, apesar do desenvolvimento recente da atividade industrial. O Município possui 26 fábricas, mas sua economia ainda é baseada na cultura de algodão, banana, caju, cana-deaçúcar, mandioca e feijão, além da pecuária.

A via de acesso conta com pistas duplas até a entrada para a sede de Pacatuba e o cruzamento com a CE 021, continuando com pista simples e características de zona rural até o Município de Guaiuba $^{26}$ - o último integrado à RMF no vetor - e cuja sede se localiza às margens da estrada. Merece destaque a grande quantidade de galpões destinados à avicultura nas imediações, sendo comum a presença de gado pastando nas redondezas. A rodovia, acompanhada pela via férrea em grande parte deste trecho, segue em direção ao interior do estado e dá acesso aos Municípios de Redenção, Baturité e Guaramiranga, este último localizado no alto da serra e considerado importante polo turístico do Estado.

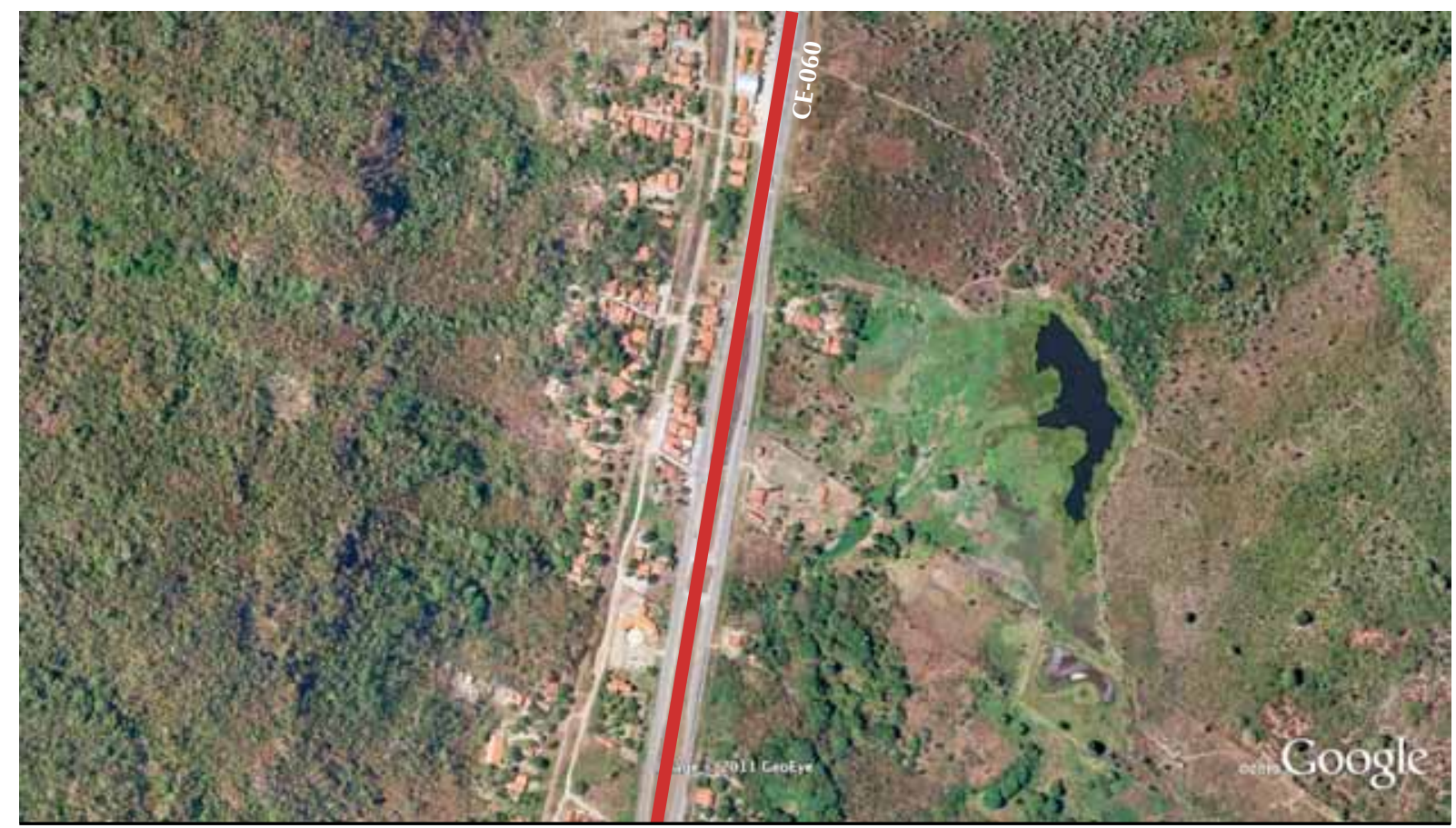

Fig. 3.31 Vetor 1: Trecho 5 (CE-060 zona rural)

Fonte: Google Earth - elaborado pela autora

\footnotetext{
${ }^{25}$ O Município de Pacatuba possui população de 72.999 hab (2010), área de 132.427 km² e densidade de 0,55 hab/km². ${ }^{26}$ O Município de Guaiuba foi incorporado à RMF em 1999, em razão do seu desmembramento do Município de Pacatuba. Possui população de 24.091 hab (2010), área de 267,203 km² e densidade de 90,16 hab/km².
} 


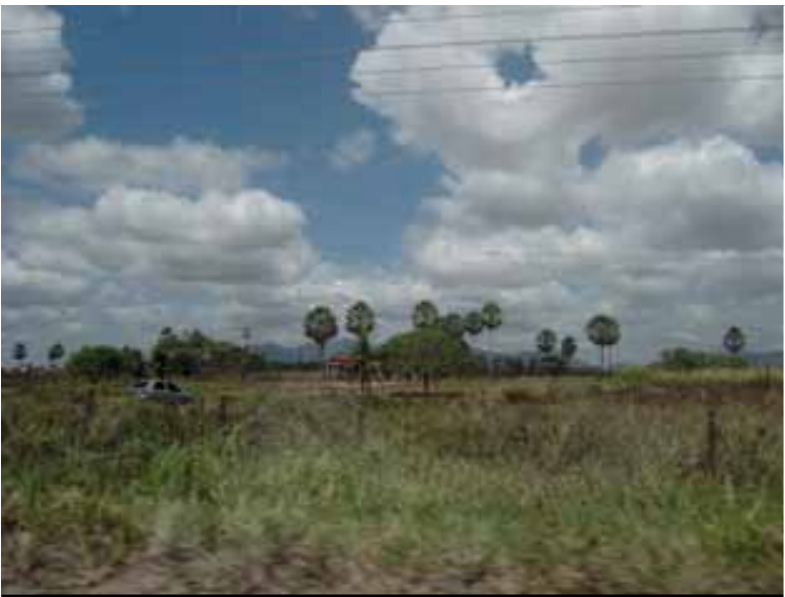

Fig. 3.32 Trecho 5 - rodovia/zona rural Fonte: acervo autora

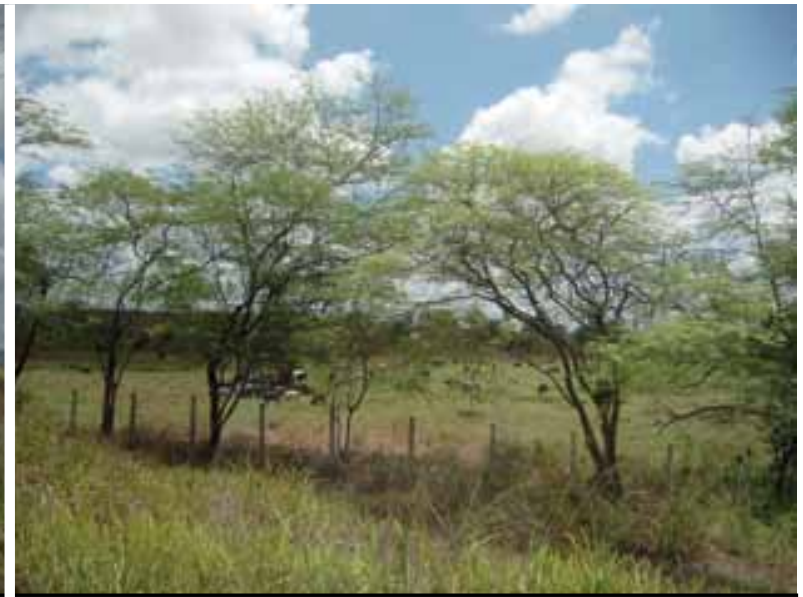

Fig. 3.33 Trecho 5 - rodovia/zona rural Fonte: acervo autora

\section{Sobre a forma de ocupação do Vetor 1}

De maneira geral, com relação à forma de ocupação nesse vetor, observa-se que nos trechos iniciais, até a entrada da Sede de Maracanaú, a malha urbana expande-se de maneira bem mais concentrada, em continuidade com o tecido urbano existente, apresentando-se como um prolongamento da ocupação do Município de Fortaleza, com o que chega a formar uma conurbação. Em seguida a esse ponto, a via, que corresponde à rodovia CE 060, transforma-se numa estrada para o interior do Estado, com predomínio de área rural.

A ocupação deste eixo remete à fase inicial da metropolização cearense, associada à implantação das indústrias e dos grandes conjuntos habitacionais construídos nas vizinhanças, que resultou num crescimento contínuo da malha urbana com relação à Capital. Esse processo se deu em consonância com o modelo "centro-periferia", comum às Metrópoles brasileiras de maneira geral. De acordo com Zancheti, Lacerda \& Diniz (2000, p.78), esse padrão de organização do espaço, que predominou até a década de 1970-1980,

[...] baseava-se na existência de um centro e uma periferia, definindo uma forma específica de apropriação social, econômica e política do território. O centro concentrava as principais atividades econômicas, públicas ou privadas, as infra-estruturas urbanas e as áreas habitacionais de mais alto nível de renda. A periferia servia para abrigar a massa da população migrante, de baixa renda. Era formada por meio de invasões, loteamentos populares e/ou clandestinos, conjuntos habitacionais e outras formas típicas de ocupação das grandes cidades dos países periféricos.

O polo formado pelo Distrito Industrial de Maracanaú, aliado à implantação dos conjuntos habitacionais, foi responsável, de fato, pela ocupação e pelo adensamento desse eixo, com ponderável peso na expansão metropolitana. O desenvolvimento dessa área, portanto, está ligado principalmente à dinâmica industrial ali instalada.

No crescimento urbano e metropolitano verificado a partir desse eixo, há que se destacar, por outro lado, a importância do papel da estrutura viária (ferroviária e rodoviária). Além da rodovia, que concentra às suas margens a ocupação mais efetiva, a presença da via férrea contribuiu para dinamizar o fluxo de pessoas entre a Capital e os demais municípios, favorecendo a conurbação, verificada principalmente entre os Municípios de Fortaleza e de Maracanaú, onde se localiza a maioria dos grandes conjuntos habitacionais. 


\subsubsection{Vetor 2 - $\mathrm{O}$ corredor industrial da BR 116}

O Vetor 2 expande-se ao longo da BR 116, formando um corredor industrial, com fábricas instaladas nos últimos 20 anos, entre os Municípios de Eusébio, Horizonte e Pacajus (ver figuras 3.34 e 3.35).

A BR 116 é uma das principais rodovias que ligam o Nordeste ao Sul do País. Tem seu início na cidade de Fortaleza (e chega até a Cidade de Jaguarão, no Rio Grande do Sul) e, no trecho em estudo, passa pelos Municípios de Eusébio, Itaitinga, Horizonte, Pacajus e Chorozinho, que compõem a RMF. Todo esse trecho da via é duplicado ${ }^{27}$, com acostamento dos dois lados e ciclovia na parte central.

Os fatores de desenvolvimento industrial que distinguem este vetor apresentam características históricas e econômicas diversas daqueles anteriormente abordados, expressos no Vetor 1. Inserem-se no processo de reestruturação produtiva, conforme destacado no capítulo precedente, que se manifestou desde o final da década de 1980-1990, e que iria impor novos padrões competitivos, acompanhados de uma crescente abertura internacional das economias.

A implantação de indústrias nessa região faz parte ainda do processo de desconcentração industrial de São Paulo, evidenciado desde então, motivado pelas crescentes deseconomias de escala ${ }^{28}$ e estimulado pelo incentivo de políticas fiscais e de infra-estrutura em outras regiões, além da melhoria do sistema de transportes e telecomunicações. Esse processo fez com que Metrópoles regionais, como Fortaleza, ganhassem importância como alternativa para a localização das atividades econômicas.

Em conseqüência, a BR 116 se impôs como o novo espaço destinado a receber empreendimentos industriais diversificados, sendo escolhida pelo Governo do Estado ${ }^{29}$ como o novo "corredor" de industrialização da Metrópole, sobretudo pela oferta de grandes glebas de terreno a preços reduzidos e facilidade de acesso entre os centros industriais do Sudeste e a Capital cearense.

Por outro lado, manifesta-se nesse período uma orientação generalizada, no sentido de remoção dos vestígios de uma política industrial e urbana, planejada e implementada por meio da forte presença estatal e regional conduzida pela SUDENE e BNH. Essas instituições perdem espaço e função, uma vez que a gestão de setores como o industrial e o urbanístico passa a ser exercida pelos próprios estados, de modo mais autônomo e distinto, sendo caracterizada, sobretudo, pela intensa competição em busca de recursos e pelo expressivo teor de renúncia fiscal para a geração de atratividades (Síntese Diagnóstica do Município, 2003).

O Governo do Ceará começa então a concentrar suas atenções com vistas a gerar infra-estrutura destinada a atender às condições dos investimentos industriais, como fator de atratividade, aliado aos subsídios decorrentes dos incentivos fiscais. Ampara-se no pressuposto do favorecimento do maior distanciamento da Capital, até então locus preferencial das novas instalações industriais.

Dos anos 1980-1990 em diante, portanto, o processo de descentralização e desconcentração da

\footnotetext{
${ }_{27}^{27}$ A duplicação do trecho entre Fortaleza e Pacajus foi concluída no ano de 2010.

${ }^{28}$ A deseconomia de escala ocorre quando o aumento dos custos é maior do que o aumento de produção, de modo que o custo médio por produção aumenta. São consideradas fontes de deseconomias de escala: os custos de transporte, as imperfeições no mercado de trabalho (programas de treinamento e recrutamento de mão de obra), o inadequado fluxo de materiais, perda de materiais, fatores organizacionais, etc. (MAGLIORINI \& TAVARES, 2005 - A importância das economias e deseconomias de escala nas análises de custo para decisão. Disponível em: http://www.uninove.br/PDFs/Publicacoes/caderno) ${ }^{29}$ A decisão da criação do corredor industrial da BR 116 foi tomada durante o primeiro governo Tasso Jereissati (19871991).
} 
indústria resultou na escolha de cidades menores para receber os novos empreendimentos.

O saneamento financeiro do estado, procedido às vésperas da Constituição Federal de 1988, gera uma capacidade de endividamento em bases sadias, que serão atendidas pelas agências nacionais e internacionais de financiamento. Isso, conjuntamente com investimentos privados, alavancará o estado do Ceará a uma condição de segundo estado da federação, após São Paulo, em volume de formação bruta de capital fixo em 1997. Esse processo de impulso industrializante produz um certo grau de desconcentração, tanto na RMF quanto em outros s, como Sobral e Juazeiro do Norte, mas concentra-se sobretudo em Horizonte, orientando-se também para Caucaia, onde desenvolve-se o terceiro vetor de expansão (SÍNTESE DIAGNÓSTICA DO PLANO DIRETOR DE FORTALEZA, 2003).

Desde meados dos anos 1980-1990, portanto, "o processo de fragmentação metropolitana, associado a uma descentralização e desconcentração da indústria, resultou na escolha de cidades menores, para receber novos investimentos" (SILVA, 2005, p.111). A implantação de um eixo industrial ao longo da BR 116 levou à incorporação de novos municípios à Região Metropolitana de Fortaleza, como Horizonte, Pacajus e Chorozinho, que são cortados pela rodovia. Em consequência, esses municípios vêm redefinindo, nos últimos anos, importantes elementos na sua organização socioespacial.

A dinâmica de expansão da atividade industrial seguiu então uma trajetória de afastamento do seu principal núcleo urbano, ou seja, a Capital. Esta expansão foi, e continua sendo, um dos principais fatores que contribuíram para a ocupação do espaço urbano da Região Metropolitana. De acordo com o geógrafo Edilson Pereira Jr., que estuda a expansão industrial cearense nessa região,

A nova organização do espaço industrial no Brasil se apresenta como manifestação bem definida dessa expansão capitalista pelo território. Viabilizados pelos capitais privados nacionais e multinacionais, que contam muitas vezes com o suporte do Estado, através de financiamentos diversos, novas regiões anteriormente desprovidas de infra-estrutura acabam se inserindo numa renovada ciranda de produção, circulação e consumo de riquezas, afetando a economia e a sociedade, cada vez mais abertas às imposições da racionalidade produtiva moderna (PEREIRA JR., 2005, p.1).

O número de empresas do Sul e Sudeste que procuraram se instalar no Ceará aumentou consideravelmente a partir da década de 1990-2000, correlacionado à política de benefícios e facilitações tributárias e à oferta de força de trabalho a um custo bem mais rentável para os investidores do setor, se comparado a estados do Sul e Sudeste do Brasil.

Além da mão de obra mais barata, o preço dos terrenos nessa região oferecia como vantagem um custo bem mais reduzido. A oferta de grandes glebas na BR 116 a preços atrativos e a garantia da acessibilidade ${ }^{30}$ contribuíram para a implantação do "corredor industrial" nas suas margens, confirmando assim a tendência de localização das fábricas longe dos centros urbanos e junto às rodovias, conforme assinala Reis (2006, p.120):

a configuração formal das unidades industriais era, portanto, ao longo dos eixos. As unidades deixavam de ser polarizadas pelas ferrovias dentro das cidades e passavam a ser polarizadas ao longo das rodovias, fora das cidades, dando origem a novos polos e a novas centralidades.

\footnotetext{
${ }_{30} \mathrm{~A}$ instalação das indústrias às margens da rodovia favorece o transporte rodoviário de cargas - para o recebimento de matérias-primas e distribuição dos produtos - como também facilita a circulação dos trabalhadores, geralmente recrutados de locais próximos à localização das fábricas.
} 


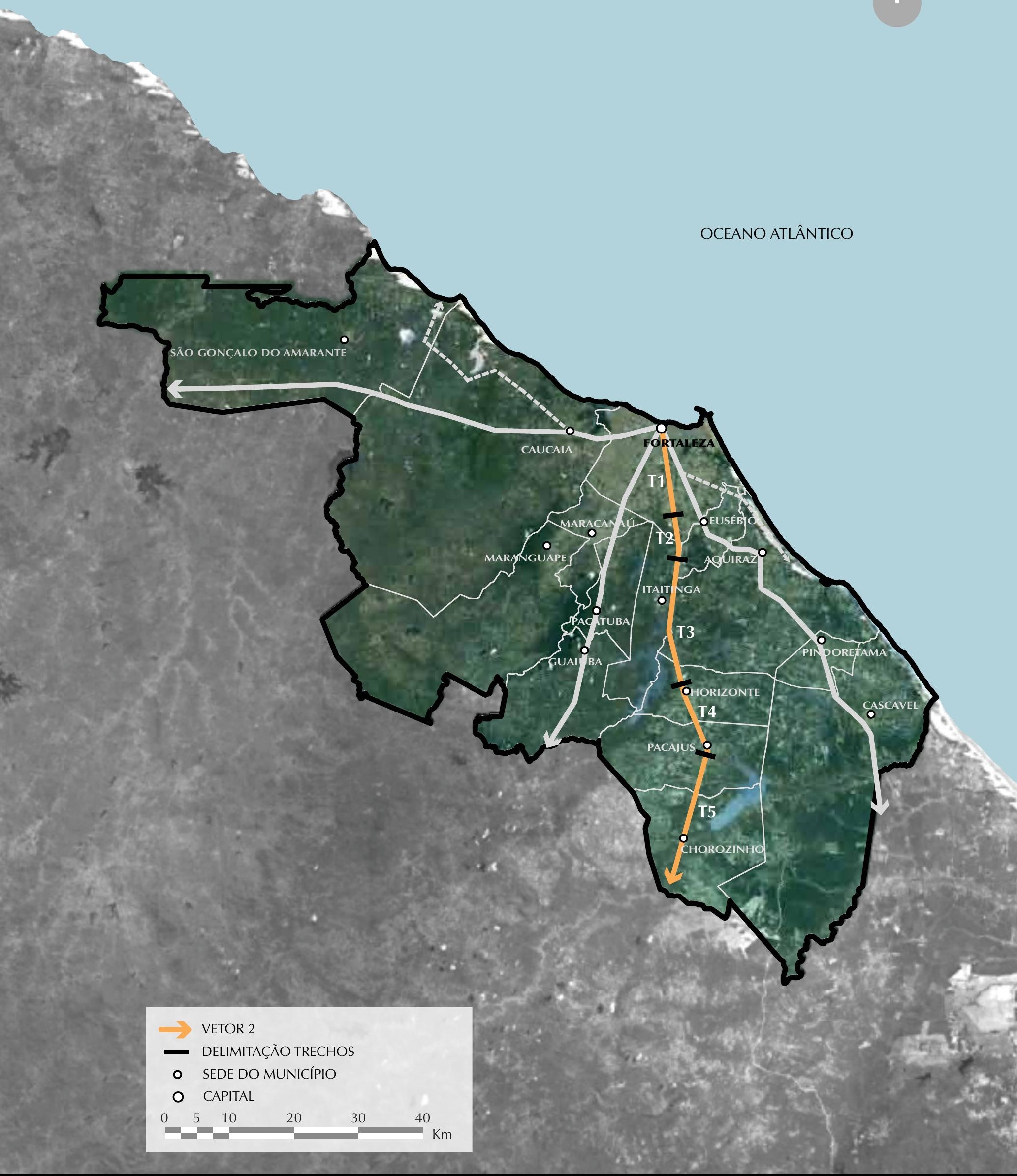

Fig. 3.35 Vetor 2: marcação dos trechos

Fonte: Google Earth - elaborado pela autora 


\section{TRECHO 1 - A saída de Fortaleza}

O vetor 1 tem início em Fortaleza, no final da av. Aguanambi, bairro de Fátima. Todo o primeiro trecho, que segue até o bairro de Messejana, é densamente ocupado ao longo da via, com volumetria predominante horizontal e de tipologia bastante simples.

A parte inicial tem ocupação mais antiga, relacionada com a instalação da Base Aérea de Fortaleza, já presente na planta da cidade de 1945.

Como se trata de via de acesso (e saída) da Cidade, o uso predominante é de comércio e serviços relacionados a esse percurso: sedes de transportadoras, empresas de logística, borracharias, lojas de peças, postos de gasolina, equipamentos e máquinas (tratores), além de pequenas pousadas. Um depósito da Fábrica Perdigão se localiza nas imediações, destacando-se, por sua implantação, das demais edificações.

A via é de alta velocidade e fluxo intenso, com a ocorrência de algumas passarelas para pedestres em intervalos regulares. Neste trecho, tem-se acesso, por meio de trevos e viadutos, aos bairros de Messejana, Cambeba, Castelão e Passaré.

Há que se discutir a presença de uma rodovia como esta cruzando uma área urbana já consolidada, como ocorre aí. O seu desenho, se por um lado facilita o acesso à Cidade, por outro impede o livre trânsito pelas áreas urbanas que atravessa, principalmente ao se levar em conta o fluxo de pedestres. As passarelas, em número reduzido e muito distante uma das outras, não atendem à demanda das comunidades, expondo os moradores a situações de risco.

Neste trecho, nas vizinhanças, existem equipamentos importantes da Cidade, como a rodoviária, o aeroporto e o estádio Castelão, que, embora não estejam situados propriamente na via, se utilizam dela para seus acessos, concorrendo para aumentar consideravelmente o fluxo de veículos (ver figuras 3.37 a 3.39).

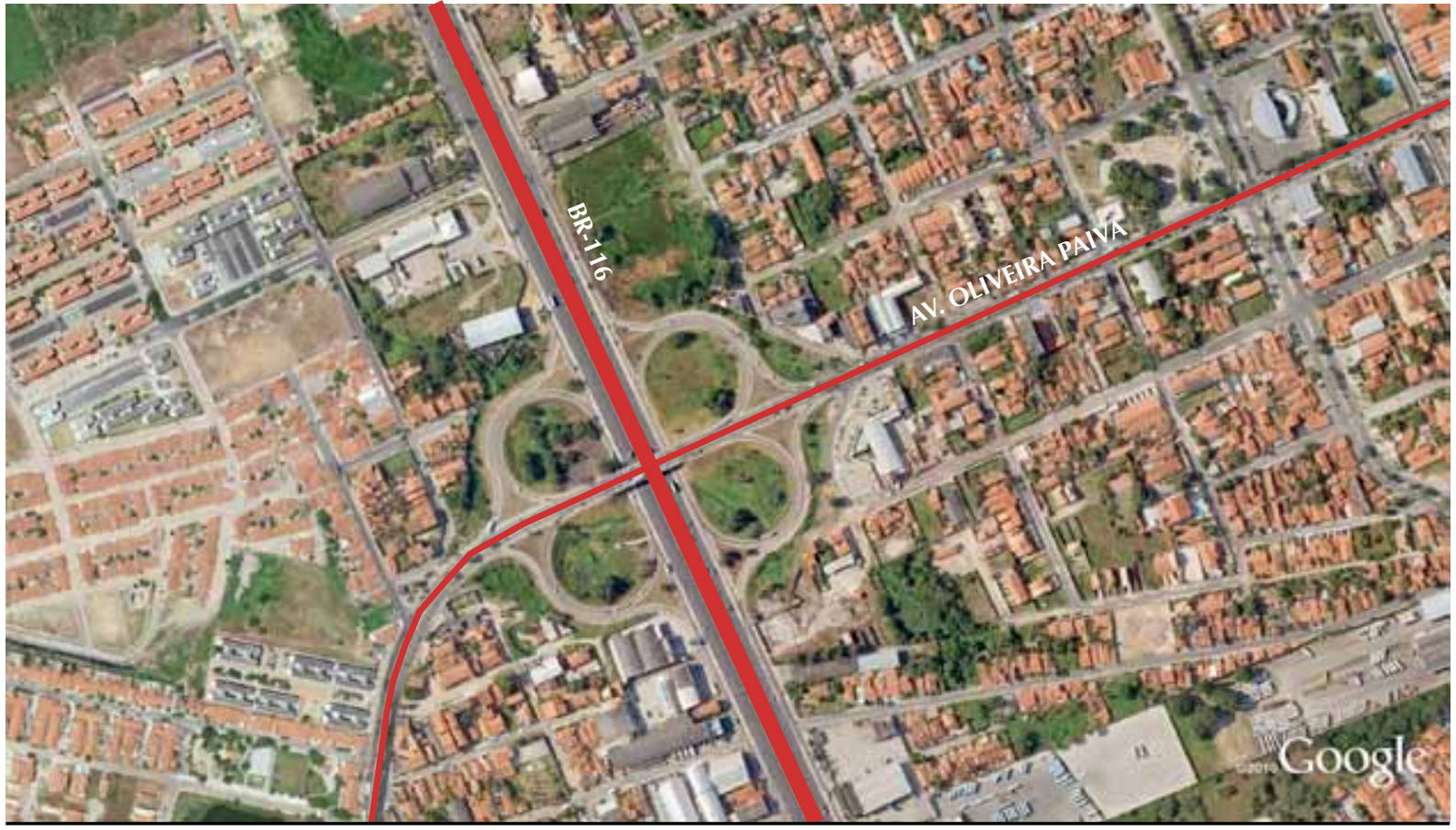

Fig. 3.36 Vetor 2: Trecho 1 (BR-116 trecho inicial)

Fonte: Google Earth - elaborado pela autora 


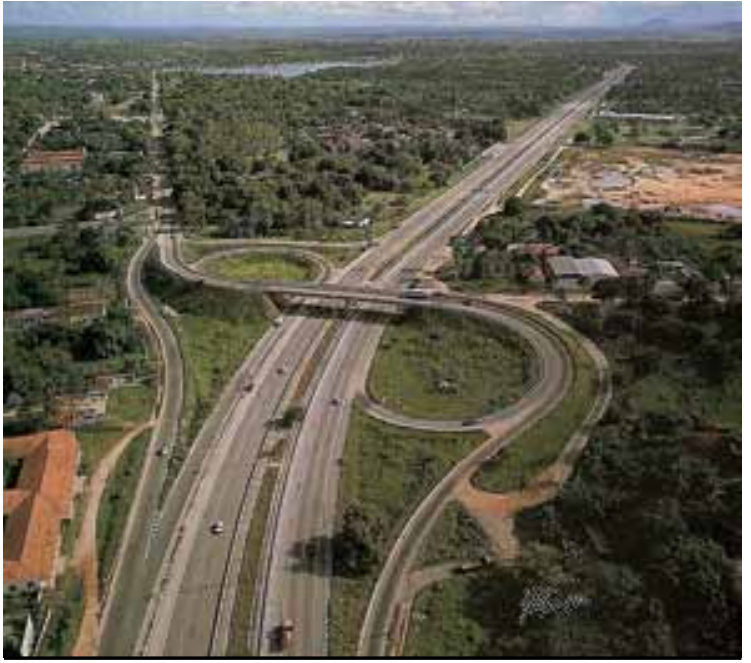

Fig. 3.37 BR 116

Fonte: http://pt.wikipedia.org/wiki/

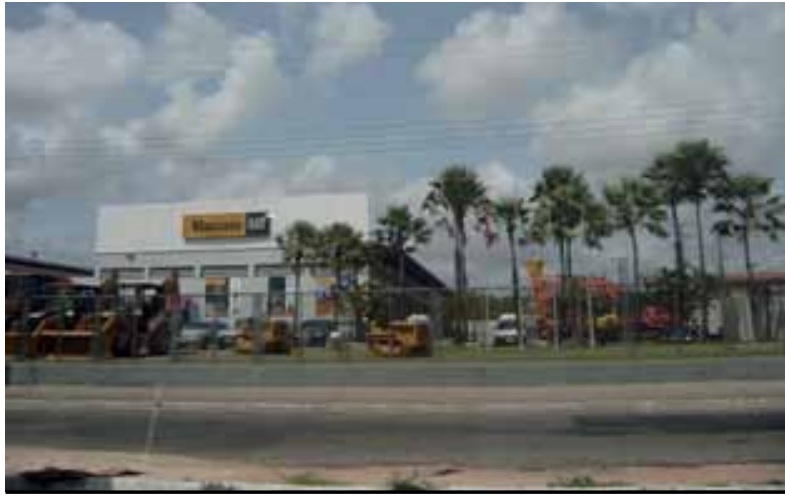

Fig. 3.38 Trecho 1 - inicio BR 116

Fonte: acervo autora

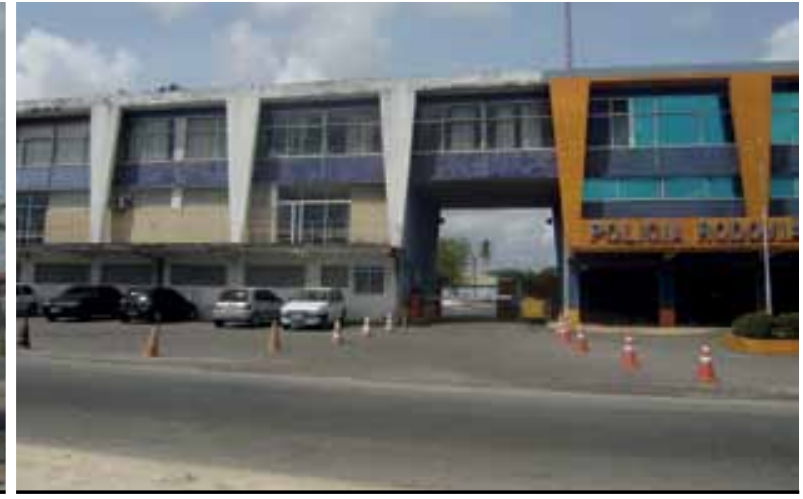

Fig. 3.39 Trecho 1 - inicio BR 116

Fonte: acervo autora

\section{TRECHO 2 - O bairro de Messejana e a Fábrica Fortaleza}

Da entrada para Messejana até o cruzamento com o $4^{\circ}$ Anel Viário, o tipo de ocupação é praticamente o mesmo do trecho anterior, uma vez que abrange área ainda densamente habitada, nas cercanias da rodovia. A partir daí, a ocupação torna-se mais rarefeita e a via adquire o aspecto de estrada, com grandes vazios em seu entorno. As edificações e equipamentos ali situados relacionam-se com o comércio ligado ao transporte e à logística, como revendedoras de pneus, transportadoras, postos de gasolina, etc. Registra-se, também, a existência de ocupações irregulares às margens da rodovia.

Nas proximidades, situa-se o bairro de Messejana, antigo distrito de Fortaleza, de ocupação mais antiga e alta densidade populacional. O bairro articula-se com a rodovia apenas no que se refere aos acessos, feitos mediante trevos e viadutos.

Constata-se, a partir daí, a presença de um tráfego mais pesado, sobretudo de caminhões que efetuam o transporte de cargas. É frequente também o fluxo de ônibus que fazem percursos interestaduais, uma vez que a BR liga Fortaleza a diversas cidades do Nordeste, Sudeste e Sul.

No quilômetro 18 da rodovia está localizada a Fábrica Fortaleza, do Grupo M. Dias Branco 31, implantada no local no ano de 1980. Considerada a maior indústria de biscoitos e massas alimentícias

\footnotetext{
${ }^{31}$ O Grupo Empresarial M. Dias Branco, um dos maiores do estado, possui considerável quantidade de terras no Município do Eusébio (cerca de $26.000 \mathrm{~km}^{2}$, praticamente $1 / 3$ do Município), adquiridas a preços baixos desde a década de 1970-1980. Especula-se que vai implantar em breve no Município um mega-projeto imobiliário, com área total de 2 mil hectares, o que deverá alterar toda a ocupação dessa área.
} 
A expansão territorial da Metrópole cearense e os vetores de crescimento urbano e metropolitano

da América Latina, a Fábrica Fortaleza ${ }^{32}$ está sediada no Município do Eusébio, em um terreno de $600.000 \mathrm{~m}^{2}$, com $120.000 \mathrm{~m}^{2}$ de área construída.

A edificação constitui um marco na paisagem, por sua volumetria e forma de ocupação, e transformou grande parte da área nas proximidades, fazendo surgir uma concentração de comércio e serviços em sua vizinhança. Trata-se, entretanto, de um núcleo praticamente isolado, sem continuidade com a paisagem que se segue, onde predominam áreas sem qualquer ocupação, caracterizadas pelo aspecto rural, apesar de situar-se cerca de $18 \mathrm{~km}$ da Capital.

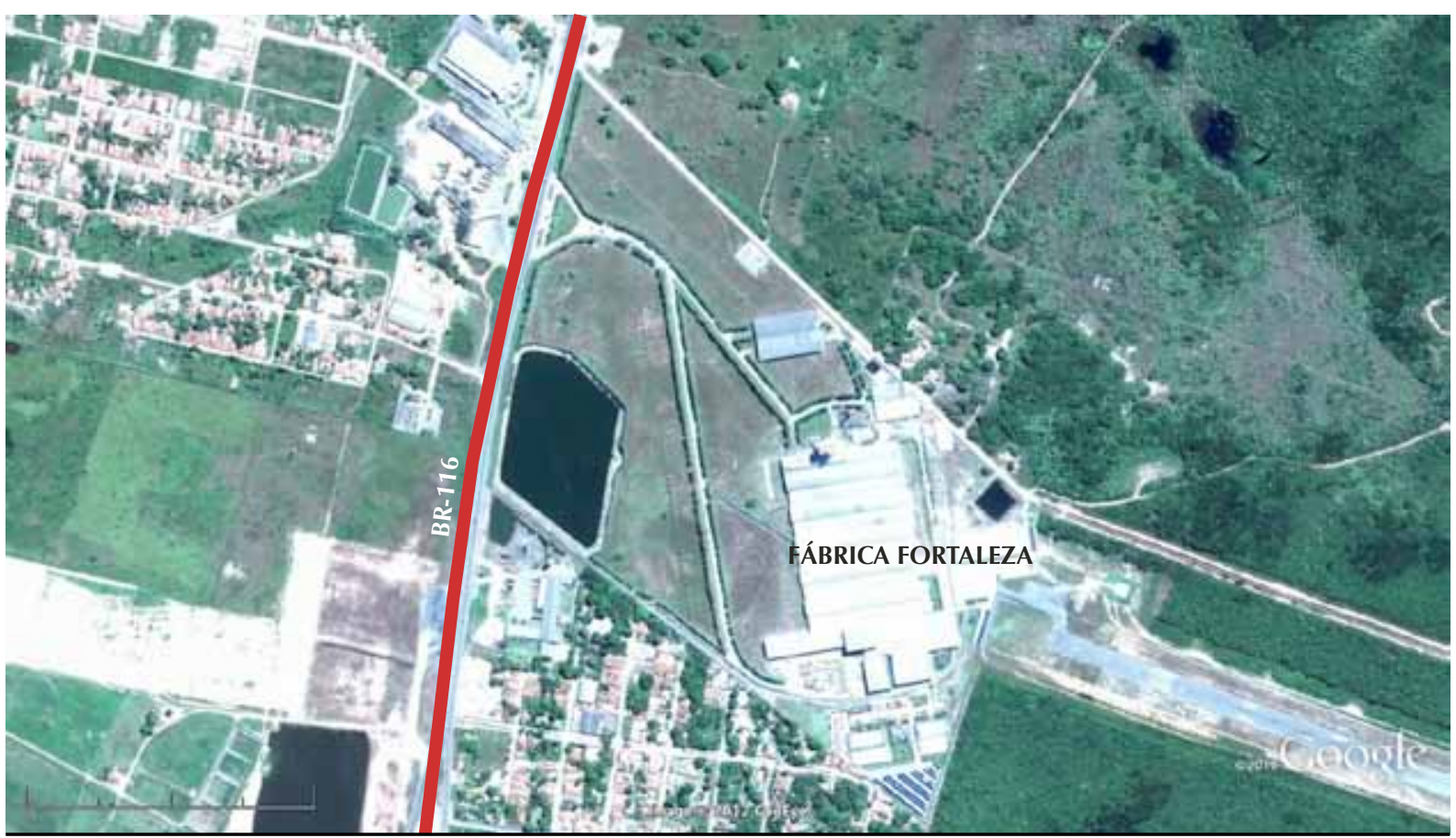

Fig. 3.40 Vetor 2: Trecho 2 (Fábrica Fortaleza)

Fonte: Google Earth - elaborado pela autora

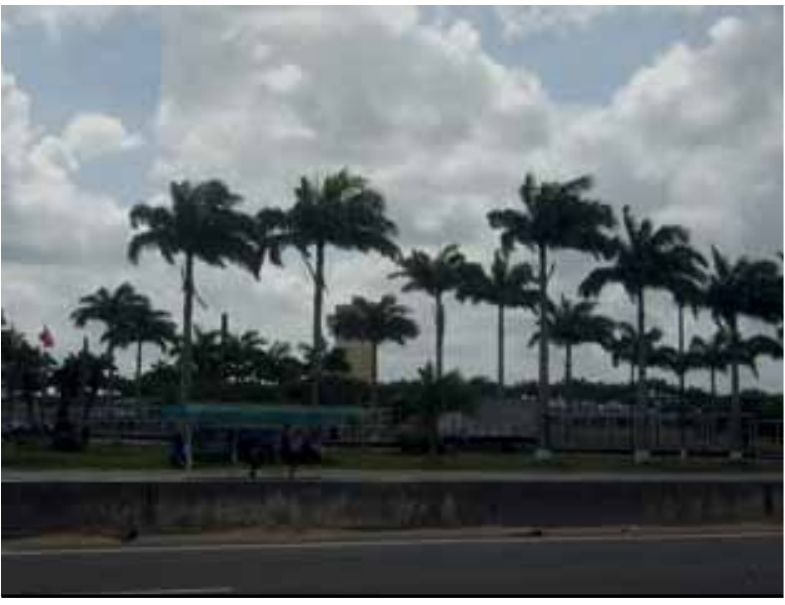

Fig. 3.41 Trecho 2 - Fábrica Fortaleza

Fonte: acervo autora

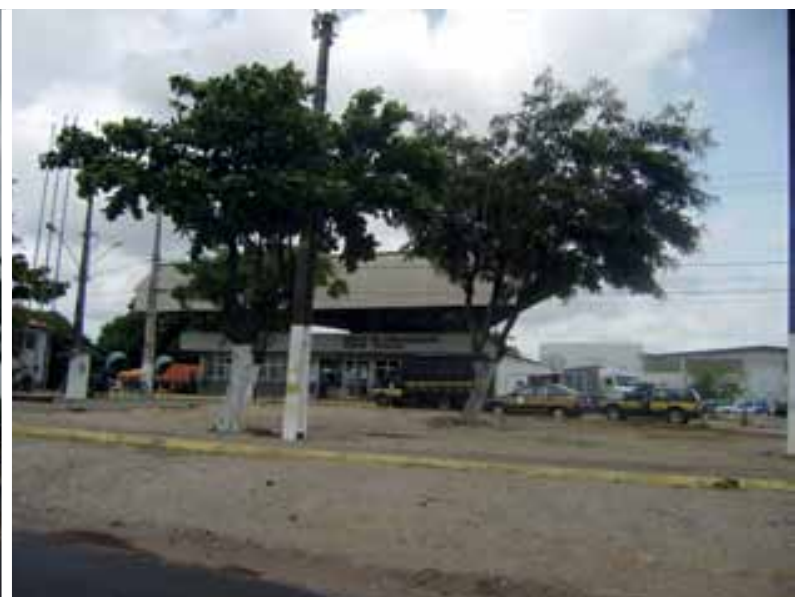

Fig. 3.42 Trecho 2 - Posto de fiscalização

Fonte: acervo autora

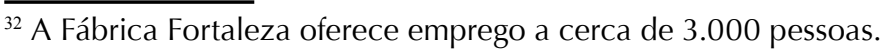




\section{TRECHO 3 - O início do Corredor Industrial}

A via prossegue com as mesmas características, de grande rodovia, onde predomina o tráfego pesado, de caminhões de carga. No quilômetro 26, situa-se a entrada para a Sede do Município de Itaitinga, que também compõe a RMF.

Algumas olarias são vistas nas margens da estrada, entre os grandes vazios, assim também como algumas poucas residências. Localiza-se neste trecho a fábrica da AMBEV, já no Município de Horizonte, que também se destaca na paisagem, sobretudo por suas dimensões. Nessa área, podem ser identificados terrenos destinados a futuras instalações de indústrias que devem se instalar aí, conforme anunciam algumas placas junto à rodovia.

Diversos estabelecimentos ligados à avicultura também se localizam neste trecho, como se observa pela presença de grandes galpões destinados à criação de aves. Os Municípios de Horizonte e Pacajus estão entre os maiores produtores avícolas do Estado. A avicultura, assim como a cajucultura, consistiam nas principais atividades econômicas desses dois municípios, até a década de 1990-2000, antes da implantação das indústrias.

Com os investimentos no setor industrial e a progressiva instalação de fábricas na região a partir de então, a indústria passou a liderar a economia local, aumentando o emprego no setor secundário e inserindo novas relações de trabalho nesses municípios, além de propiciar mudanças nos equipamentos e fluxos urbanos, que resultaram em novas formas de apreensão e consumo do espaço.

Ao romper com as relações mais tradicionais de conexão espacial, as recentes empresas criam laços de integração e dependência com os diversos centros de produção e consumo do mundo, (...) além de imprimir relações bem mais intensas dos municípios com diversos pontos do país, o que pode ser confirmado através dos fluxos realizados com a Região Metropolitana de Fortaleza e com outras regiões fora do estado (PEREIRA JR., 2003, p.95).

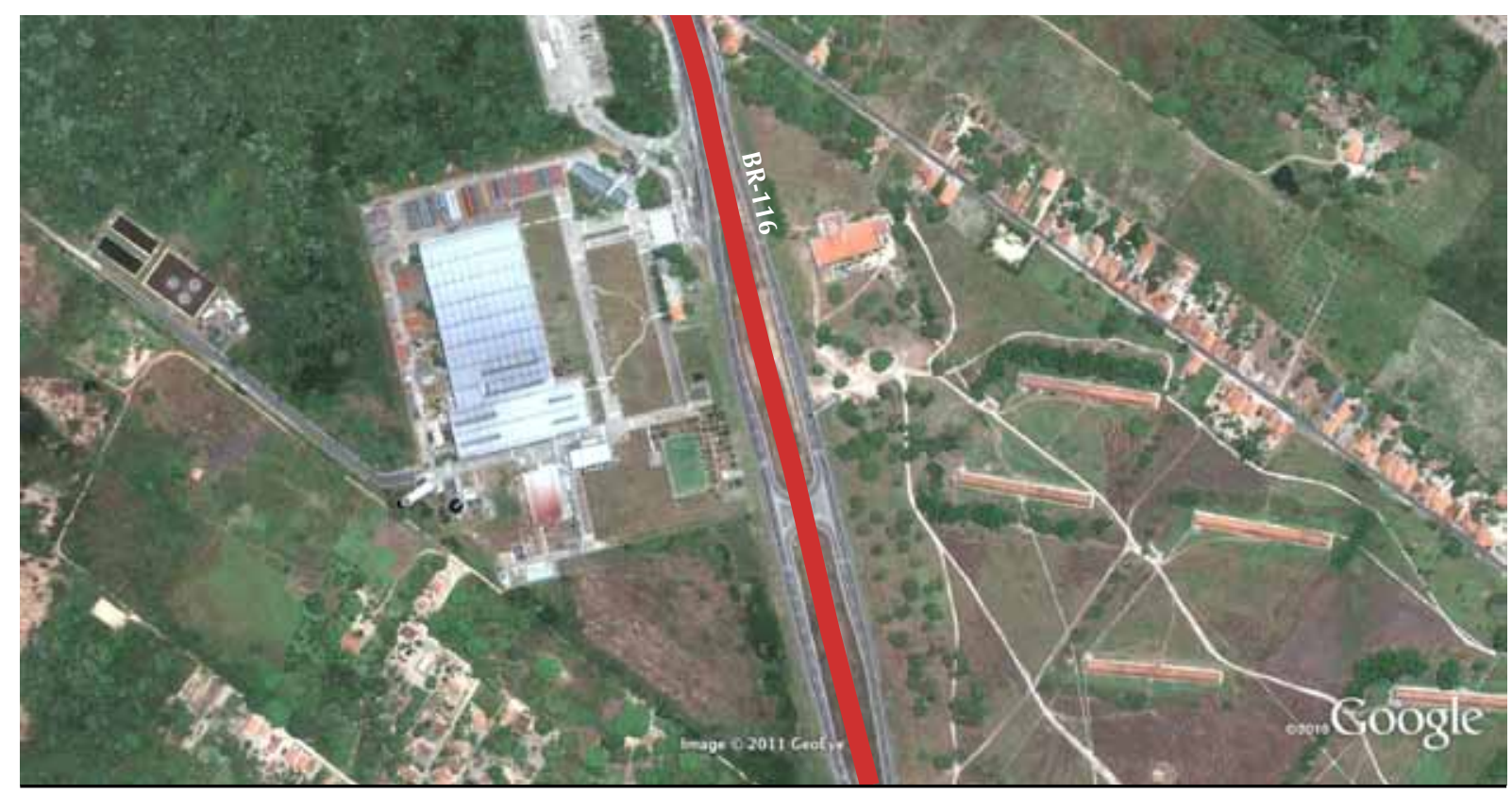

Fig. 3.43 Vetor 2: Trecho 3 (Indústria na BR-116) Fonte: Google Earth - elaborado pela autora 


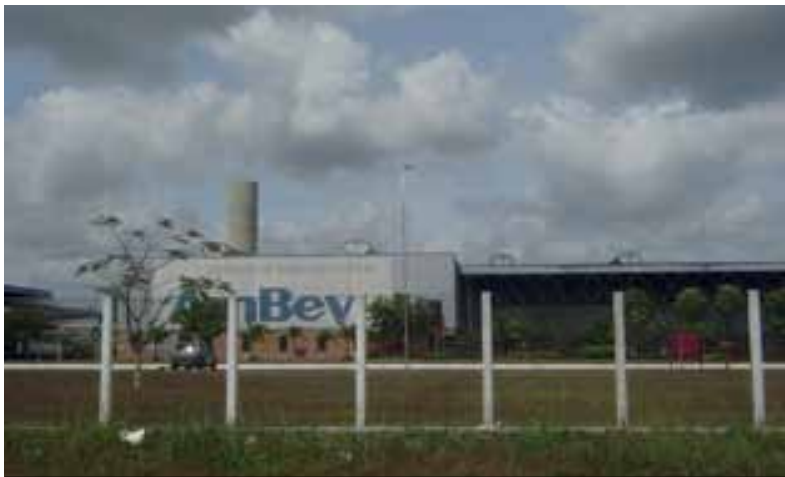

Fig. 3.44 Trecho 3 - Fábrica AMBEV Fonte: acervo autora

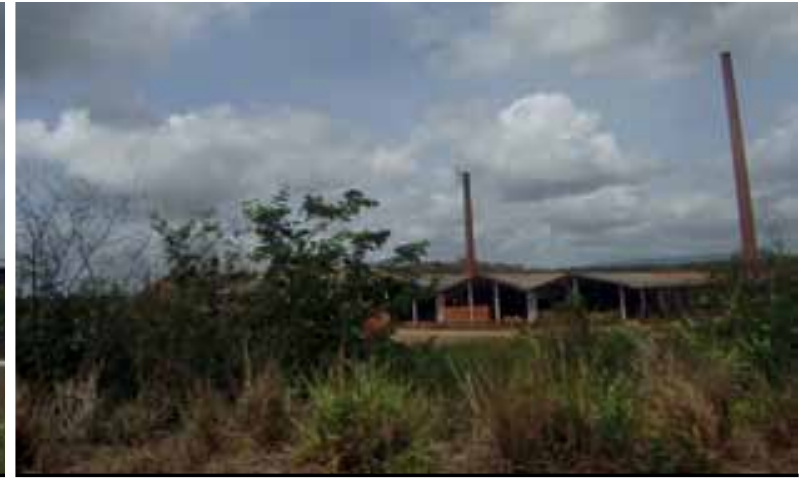

Fig. 3.45 Trecho 3 - olarias Fonte: acervo autora

Por outro lado, esses municípios atualmente apresentam acentuado crescimento demográfico, resultado do incremento da atividade industrial. O número e o porte das indústrias instaladas atraem trabalhadores de várias regiões do Estado em busca de novas oportunidades de emprego e renda.

\section{TRECHO 4 - O Corredor Industrial Horizonte-Pacajus}

Nas proximidades da entrada da sede do Município de Horizonte, surge uma concentração maior de indústrias, todas instaladas recentemente. Esse trecho corresponde ao Corredor Industrial Horizonte-Pacajus, que abrange aproximadamente dez quilômetros e que responde pela principal dinâmica que caracteriza esse vetor de expansão. Observa-se que a ocupação se faz diferenciada, com tendência à formação de núcleos urbanos próximos às edificações industriais. A implantação das indústrias nessa área ${ }^{33}$ tem como objetivo, entre outros, atrair a população da zona rural e de cidades próximas, como força de trabalho da nova atividade.

Estão aí (entre os quilômetros 35 a 45 da rodovia) localizadas as indústrias Santana Têxtil (confecções), Troller (automóveis), Schincariol (cerveja), Vicunha, Vulcabrás, Nordeste Industrial, Rigesa, etc., as quais formam o polo/corredor industrial de Horizonte (ver figuras 3.47 a 3.50).

A concentração industrial no eixo Horizonte-Pacajus se impõe como mancha expressiva no traçado urbano descontínuo nesse eixo comandado pela BR 116, de expansão metropolitana. Os lotes destinados às indústrias são todos de grandes dimensões e, apesar do porte das edificações, ainda há grandes extensões de terrenos para futuras expansões.

Vale destacar que a industrialização verificada nesse trecho da BR, embora situado no território dos Municípios de Horizonte e Pacajus, não constitui absolutamente uma iniciativa desses municípios, conforme já salientado. Trata-se de um movimento, conforme ressalta Pereira Jr. (2003, p.95), que "está intimamente ligado ao atual quadro de mudanças pelo qual vem passando o 'capitalismo tardio' e os seus reflexos no Brasil e no Ceará." Esse processo, já disseminado há algumas décadas nos países de capitalismo periférico, "agora se apresenta consumindo novos lugares e impondo os ditames da produção industrial"' (IDEM).

Esse espaço torna-se, assim, objeto de decisões tomadas por articuladores que estão bem distante destes lugares, juntamente com ações promovidas pelo Poder Estadual, e reflete todas

\footnotetext{
${ }^{33}$ A determinação de localização de unidades industriais nessa região justificou a incorporação dos Municípios de Horizonte e Pacajus à RMF, por lei complementar de 29 de dezembro de 1999.
} 
essas mudanças, redefinindo sua estruturação. Como consequência, intensificam-se as relações que esses municípios estabelecem com a Capital e com outros estados.

Apesar do avanço da atividade industrial em Horizonte e Pacajus, ainda é relevante a participação do setor agrícola na economia, principalmente a tradicional cajucultura e uma fruticultura diversificada, com produção industrial recente.

A entrada para a Sede de Horizonte (situada a $42 \mathrm{~km}$ da Capital) é marcada pela presença de iluminação pública na rodovia e pela concentração urbana nas imediações. Observa-se também a ocorrência de habitações construídas recentemente, já reflexo da dinâmica industrial instalada na região desde as últimas duas décadas.

Apesar da evidência de núcleos urbanos que se formam nas imediações, predomina grande extensão de área rural, que margeia a rodovia.

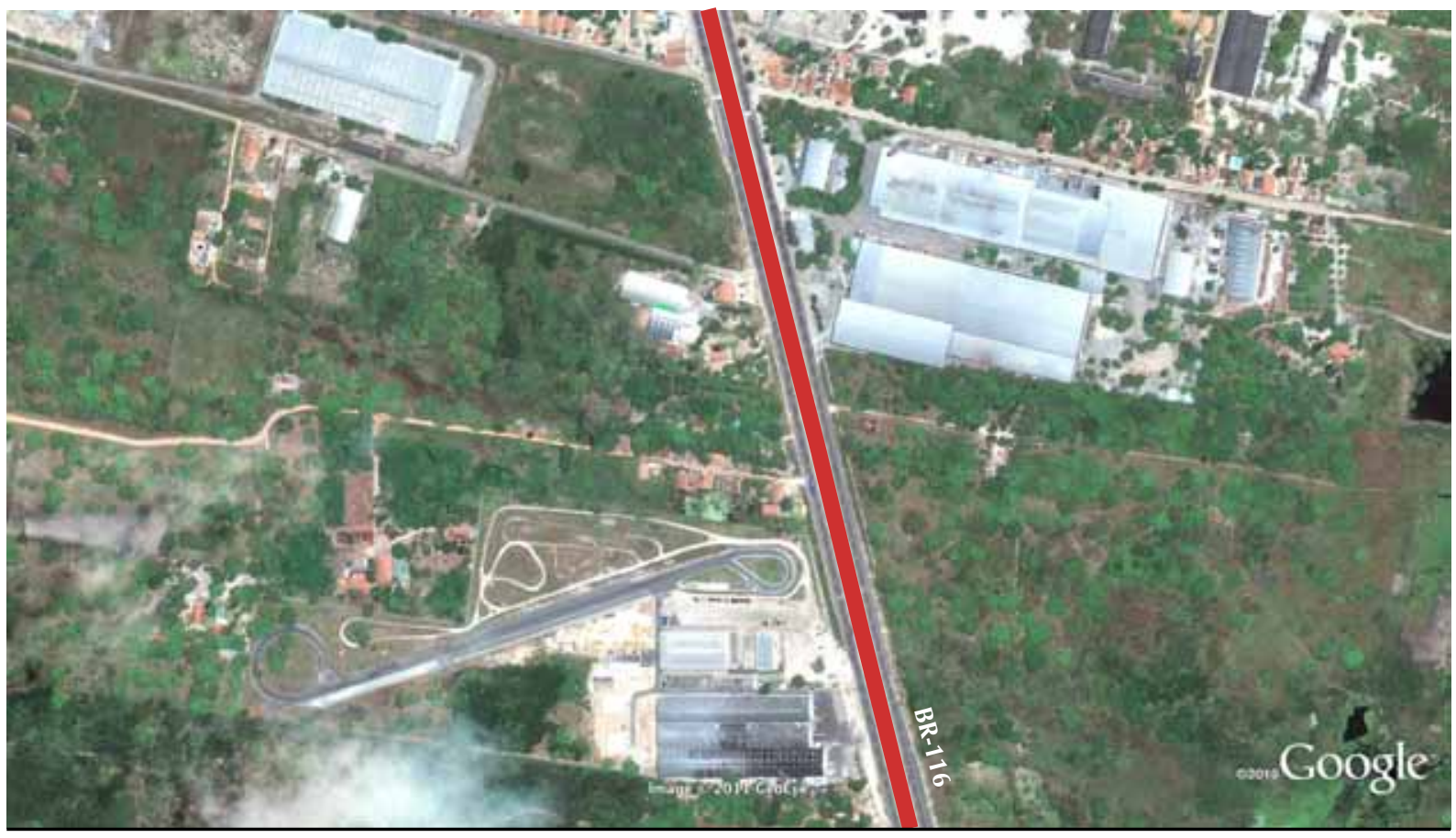

Fig. 3.46 Vetor 2: Trecho 4 (Corredor industrial BR-116) Fonte: Google Earth - elaborado pela autora

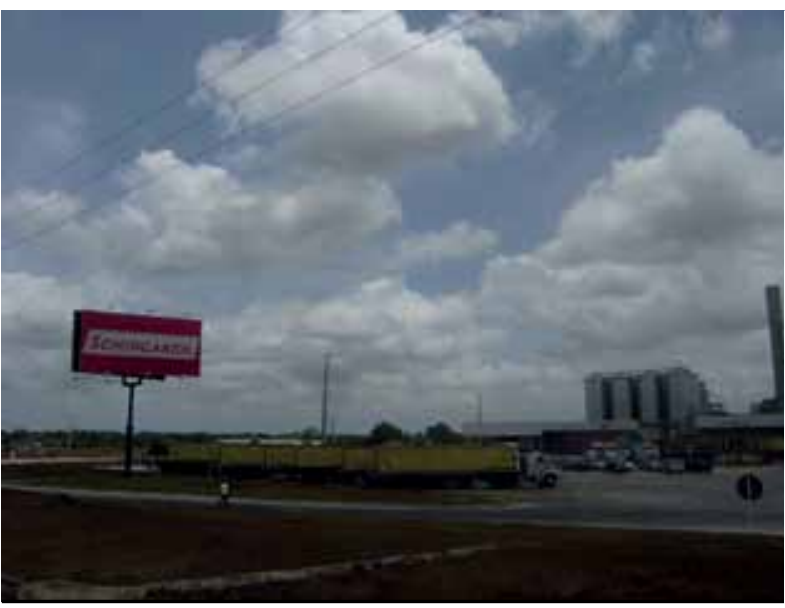

Fig. 3.47 Trecho 4 - indústrias ao longo da rodovia Fonte: acervo autora

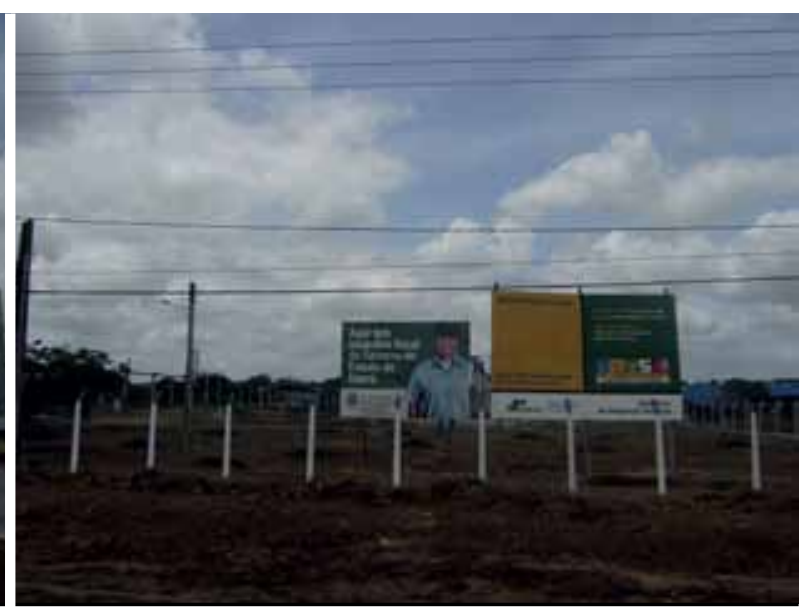

Fig. 3.48 Trecho 4 - terrenos para indústrias na rodovia Fonte: acervo autora 


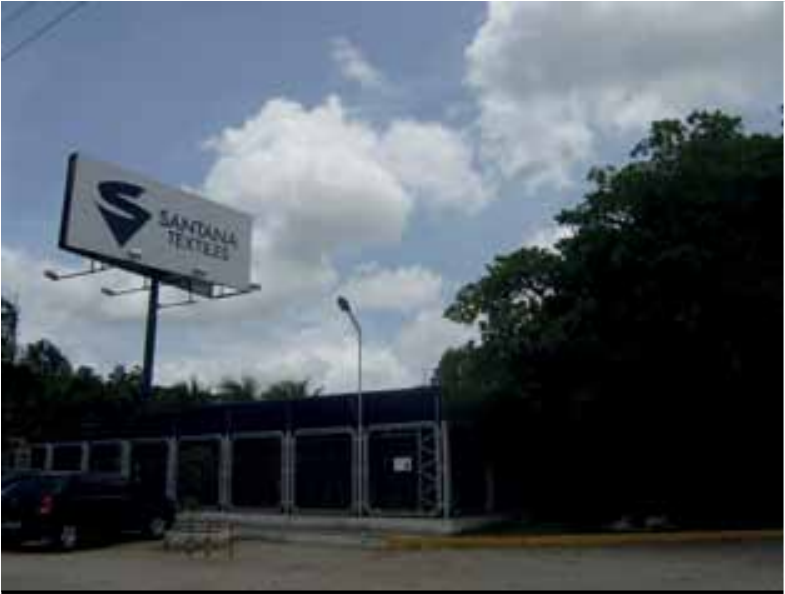

Fig. 3.49 Trecho 4 - indústrias ao longo da rodovia Fonte: acervo autora

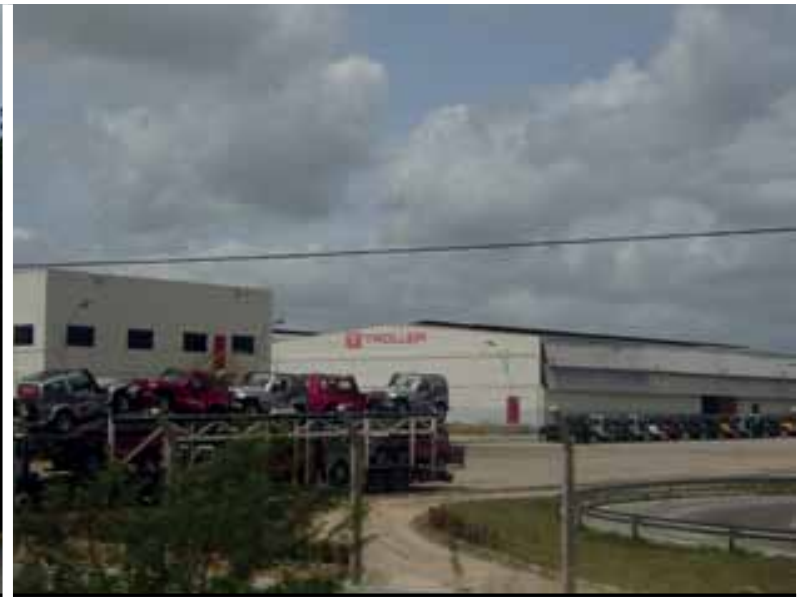

Fig. 3.50 Trecho 4 - indústrias ao longo da rodovia Fonte: acervo autora

\section{TRECHO 5 - Pacajus - Chorozinho}

O trecho final desse vetor, que corresponde à BR 116, liga a cidade de Horizonte a Chorozinho, passando por Pacajus. A rodovia teve seu trajeto original desviado para passar ao largo das cidades, evitando assim o fluxo intenso e o tráfego pesado por dentro da zona urbana.

A partir da entrada para a Sede do Município de Chorozinho ${ }^{34}$, a via deixa de ser duplicada, e segue em direção ao interior do Ceará e demais estados, até o extremo sul do País.

Poucas indústrias ainda são vistas nesse trecho, como a BR Juice e a Flamingo Sucos do Brasil, cuja implantação fez surgir, nas proximidades, pequenas aglomerações urbanas, com residências, igrejas, lojas, restaurantes e até clubes ligados às indústrias; entretanto, prevalecem grandes vazios, evidenciando o predomínio de área rural.

Próximo aos ramais que dão acesso às diferentes cidades, também começam a surgir concentrações de comércio e serviços ${ }^{35}$ de apoio aos transportes que utilizam a rodovia, como hotéis, restaurantes, postos de gasolina, lojas de conveniência, etc., que podem vir a constituir embriões de novas localidades.

Percebe-se que o desenvolvimento desses municípios está intimamente ligado ao sistema rodoviário, como já atestava o documento produzido pela AUMEF, em 1977: "essas rodovias, de certa forma, estimularam o desenvolvimento dessas cidades, alimentadas pelo grande volume de tráfego, que favorece o dinamismo das funções urbanas municipais" (AUMEF, 1977, p.152).

Com a recente duplicação da rodovia e a crescente implantação de indústrias em sua extensão, vê-se, aliás, o progressivo surgimento de determinadas atividades complementares, como lanchonetes, restaurantes, padarias, farmácias, etc., as quais estão, em grande parte, associadas ao atendimento da mão de obra industrial.

\footnotetext{
${ }^{34}$ Chorozinho, o último dos municípios que integram a RMF ao sul, situado a $64 \mathrm{~km}$ da Capital, possui evidenciadas características do mundo rural (ver figuras 3.51 a 3.53).

${ }^{35}$ Esses equipamentos funcionam quase que exclusivamente como apoio aos transportes que circulam pela rodovia. Nesse sentido, um aspecto a considerar é que, apesar dos investimentos na indústria nessa região, verifica-se que os municípios citados ainda mantêm uma relação de grande dependência com a Capital, no que se refere à atividade terciária, uma vez que os equipamentos de comércio e os serviços existentes ainda são insuficientes e manifestam um padrão bastante precário.
} 
É sabido que a localização de atividades produtivas estratégicas, tanto a indústria, como equipamentos e serviços instalados fora dos limites municipais, provoca o surgimento de aglomerações urbanas, pois, de acordo com Lefebvre (1991, p.09), "a industrialização não produz apenas empresas (operários e chefes de empresas), mas sim estabelecimentos diversos, centros bancários e financeiros, técnicos e políticos".

Nesse sentido, Santos também ressalta que, por meio da produção, o homem transforma a natureza em segunda natureza, ou seja, "as novas atividades exigem um lugar no espaço e impõem uma nova arrumação para as coisas, uma disposição diferente para os objetos geográficos, uma organização do espaço diferente" (SANTOS, 2002, p.172).

A implantação das indústrias nesse trecho, portanto, da mesma forma como ocorreu em outras regiões do País que experimentam processos semelhantes, propicia o surgimento de núcleos urbanos, que abrangem zona residencial e atividades complementares.

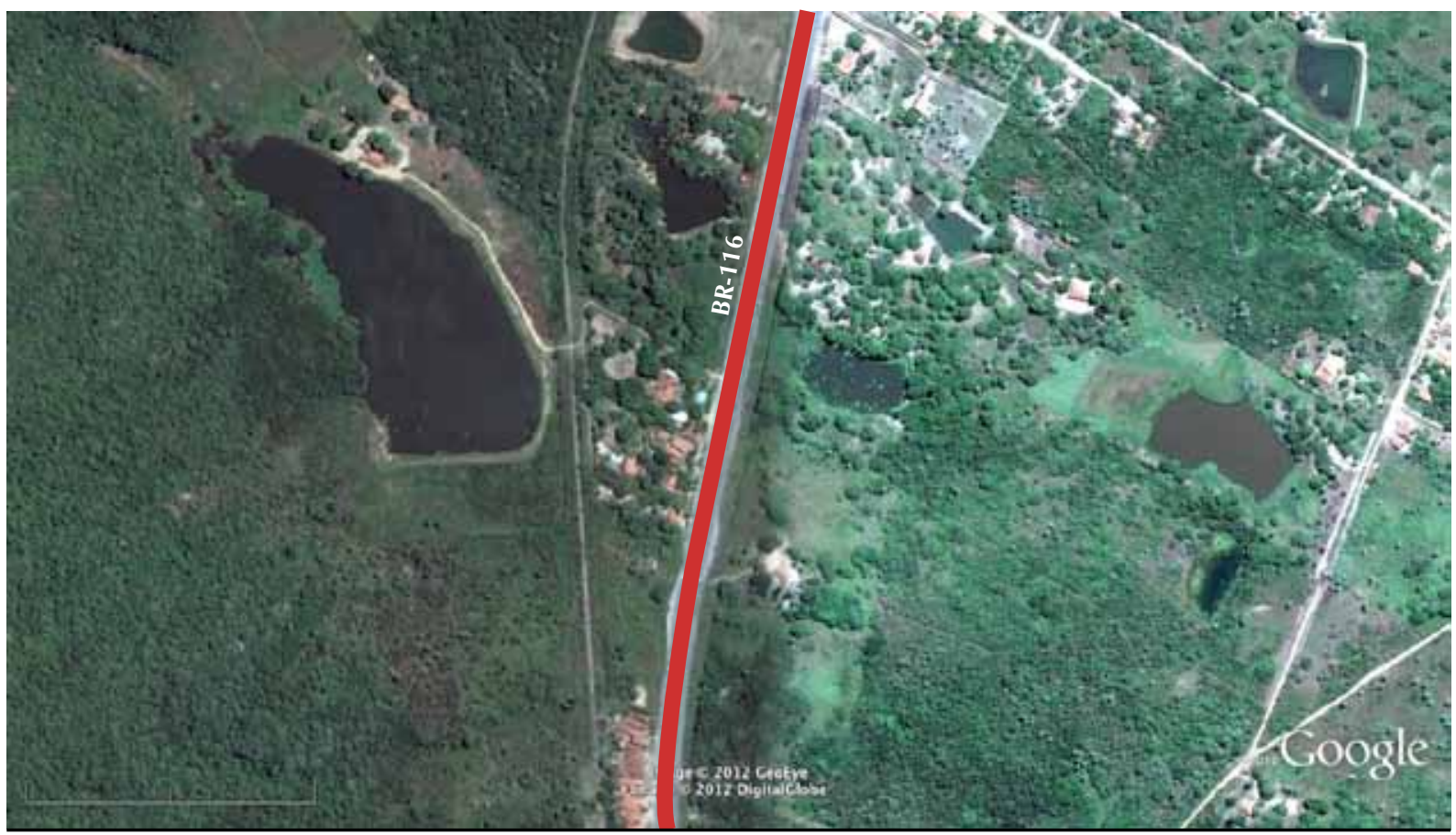

Fig. 3.51 Vetor 2: Trecho 5 (BR-116 zona rural) Fonte: Google Earth - elaborado pela autora

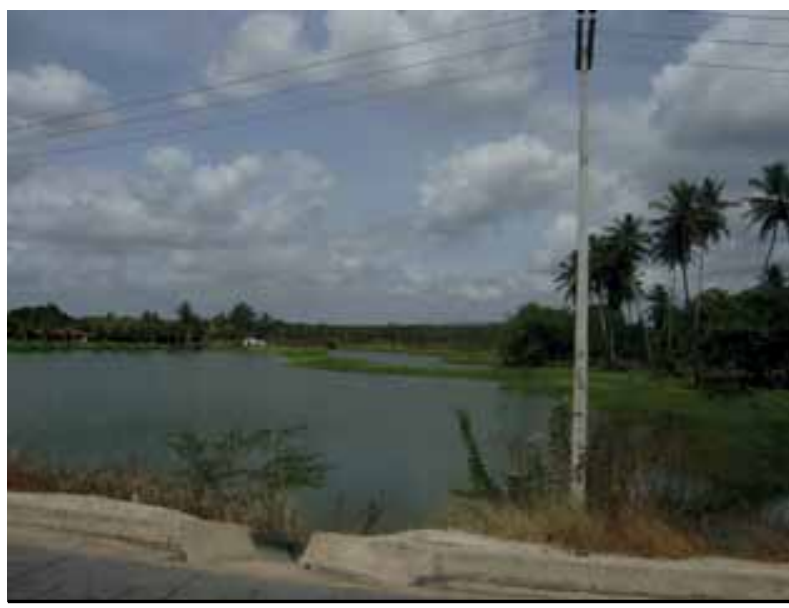

Fig. 3.52 Trecho 5 - rodovia/zona rural Fonte: acervo autora

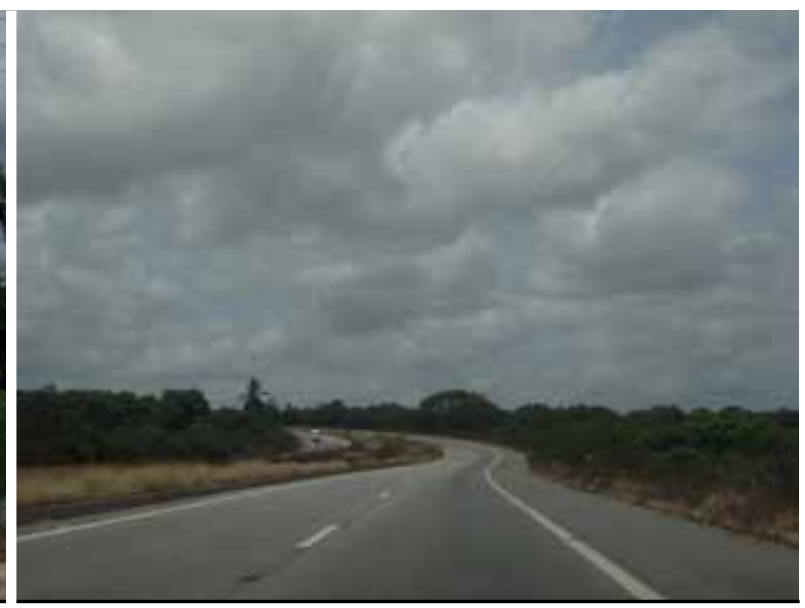

Fig. 3.53 Trecho 5 - rodovia/zona rural Fonte: acervo autora 


\section{Sobre a forma de ocupação do Vetor 2}

Como visto, com relação à ocupação desse vetor, pode-se enfim constatar que a implantação de indústrias nas margens da BR 116 propiciou o surgimento de alguns poucos núcleos urbanos de pequenas dimensões, distanciados entre si e separados por extensas áreas rurais, configurando uma zona de baixa densidade, com características de urbanização dispersa. Da mesma forma como ocorreu em outras metrópoles brasileiras, conforme destaca Reis (2006, p.118) ao referirse à localização das fábricas nas margens dos grandes eixos rodoviários, "as grandes rodovias transformaram-se em eixos de metropolização dispersa".

Desde a instalação das indústrias, a partir do final da década de 1990-2000, essa área vem experimentando transformações que estão alterando suas características originais, de área rural. A forma de ocupação dos empreendimentos industriais e dos núcleos urbanos que surgem nas vizinhanças insere-se nos conceitos de urbanização dispersa, definidos em Reis (2006) e igualmente citados por Monclús (1998, p.7), quando afirma que o fenômeno da dispersão urbana está associado ao predomínio das baixas densidades e "também à descentralização e ao caráter cada vez mais extensivo das novas instalações industriais".

A ocupação registrada, entretanto, ocorre preferencialmente ao longo da rodovia, não se estendendo para áreas vizinhas, o que reforça a função da via, de ligação entre os estados do Nordeste e o Sul do país.

O eixo viário desempenha, de fato, papel preponderante, ao atravessar os diversos municípios onde se localizam as indústrias, garantindo a comunicação ativa com a Capital e com outros pontos do País, conforme se observa pelo intenso fluxo de pessoas e mercadorias realizado diariamente nesse trecho da BR. Esse fato confirma a assertiva de Villaça (1998) acerca da importância das redes viárias no cotidiano regional, as quais possuem um "poder estruturador" significativo nos deslocamentos de materiais e da população.

No entanto, se por um lado, a via constitui elemento essencial de integração e estabelece uma relação metropolitana e regional extremamente importante, no nível local produz uma grande descontinuidade no tecido urbano. Assim, conforme assinalam Meyer \& Grostein,

[...] a avaliação desses impasses viários deve ser objeto de projetos de reorganização viária em escala local que contemplem as possibilidades de circulação de pedestres e de veículos, de forma a restabelecer a coesão entre os vários trechos isolados pela passagem de grandes sistemas (MEYER \& GROSTEIN, 2010, p.270).

Constata-se, portanto, que há uma imperiosa necessidade de se planejar o desenvolvimento desses núcleos urbanos ao longo da rodovia, de modo a disciplinar e adequar o solo aos novos usos e ocupação. 


\subsubsection{Vetor 3 - o eixo litorâneo oeste e o CIPP}

O Vetor 3 se desenvolve em direção à zona oeste, estabelecendo a ligação com Caucaia, abrangendo a faixa litorânea e o Complexo Industrial Portuário do Pecém, situado no Município de São Gonçalo do Amarante (ver figura 3.55). Tem início na av. Bezerra de Menezes, a antiga Estrada do Soure, ainda na zona central de Fortaleza, e que dá acesso aos municípios da zona norte do Estado. Continua pela av. Mr. Hull até o ponto em que, já denominada BR 020, tem inicio a BR 222. Daí, dirige-se para Brasília, enquanto a BR 222 segue em direção aos Estados do Piauí e Maranhão.

O vetor oeste é complementado pela linha norte do trem metropolitano, responsável pelo fluxo diário de grande parte da população que se desloca para o Centro e para a zona leste; e pela Via Estruturante (CE 085), que constitui um verdadeiro subvetor de crescimento metropolitano.

Nesse sistema de vias, componentes do vetor, vale destacar também o eixo formado pela av. LesteOeste, junto à orla marítima, que se prolonga pela ponte sobre o rio Ceará até o Icaraí e praias adjacentes, no Município de Caucaia, aí já transformado na rodovia CE 090.

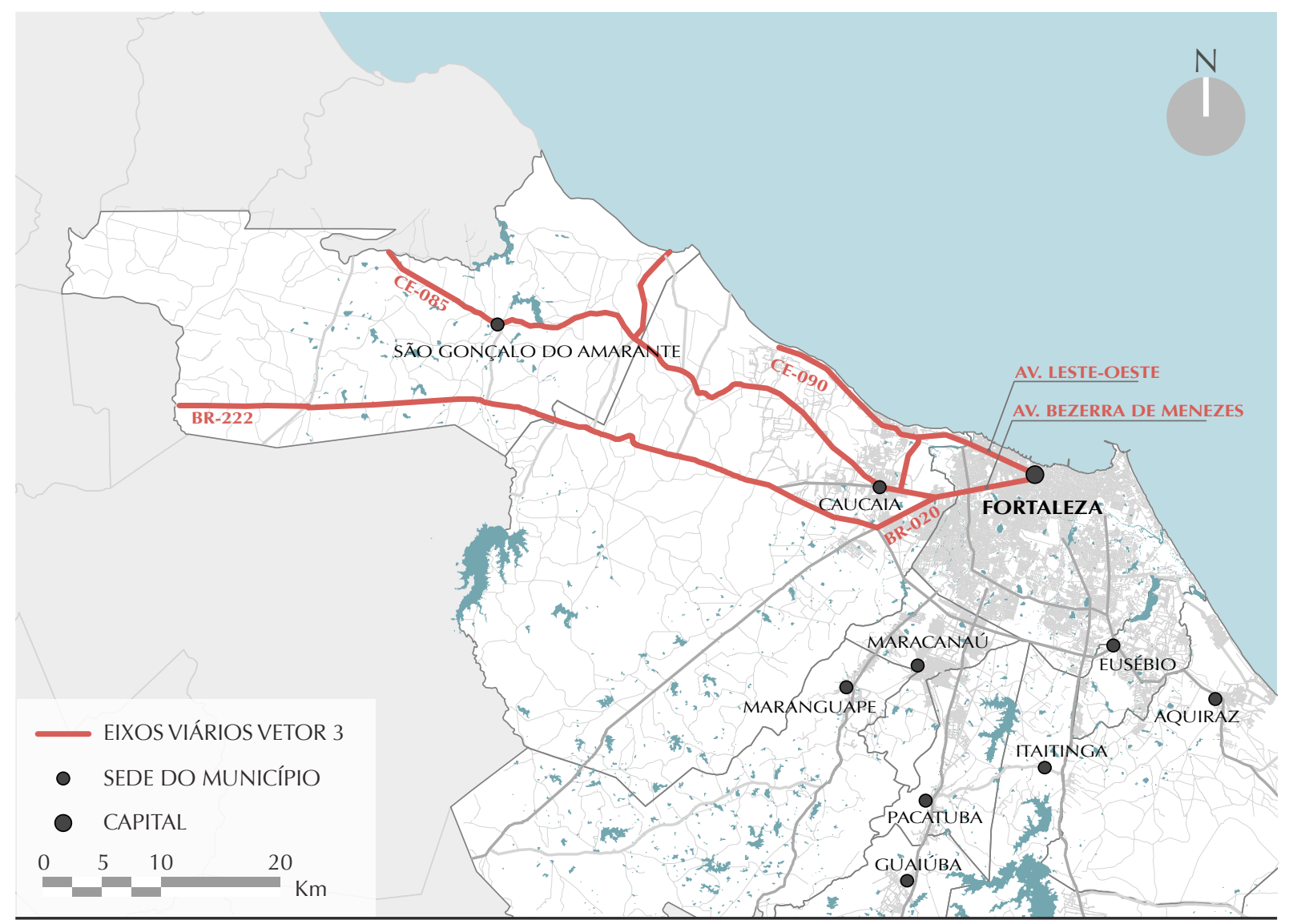

Fig. 3.54 Mapa RMF: vetor 3 com indicação das principais vias/eixos viários

Fonte: elaborado pela autora 


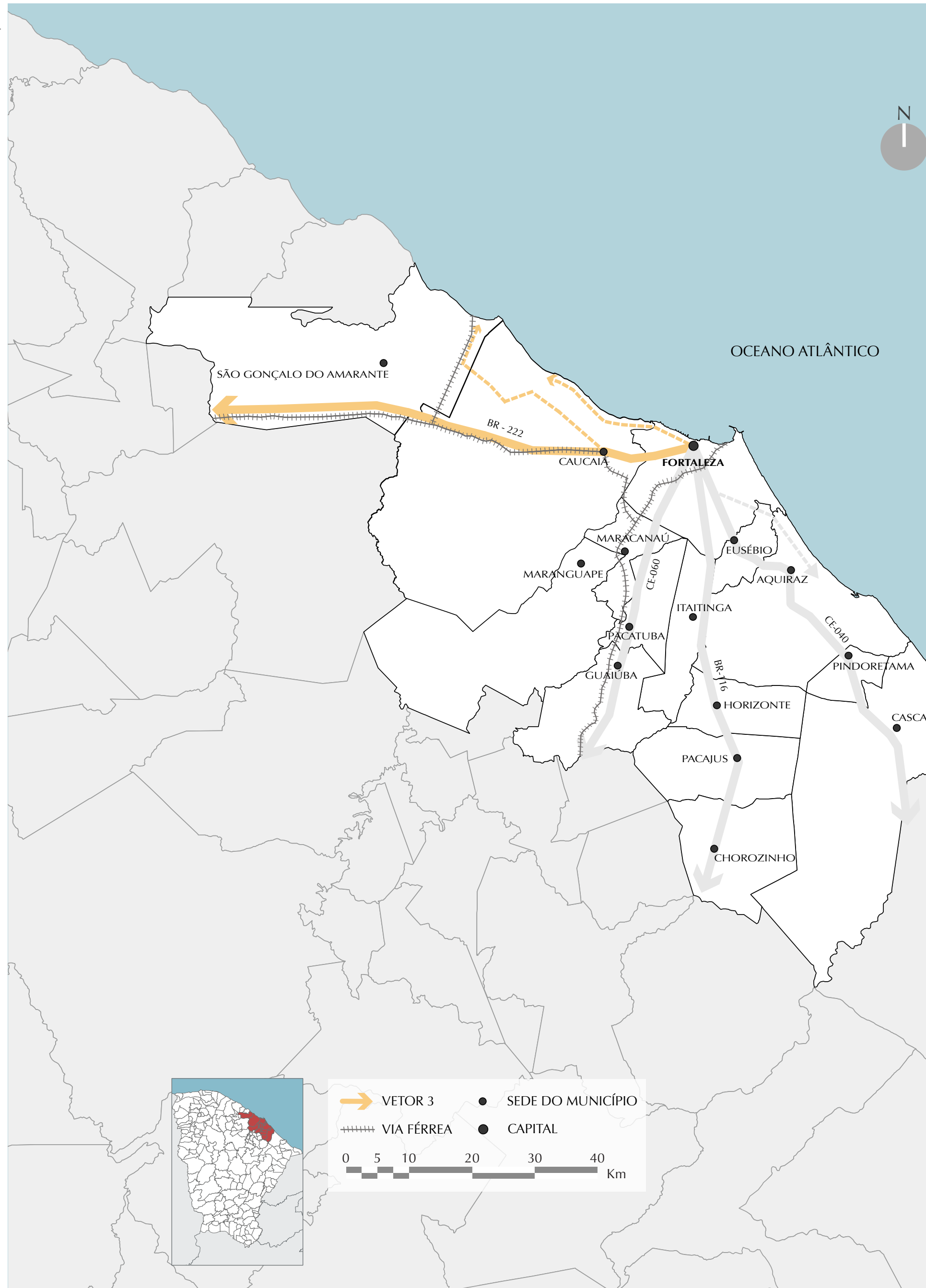

Fig. 3.55 Mapa RMF: vetor 3 
Toda a zona oeste de Fortaleza é caracterizada historicamente, conforme destacado no capítulo anterior, pela presença da via férrea e da zona industrial (em Jacarecanga ${ }^{36} \mathrm{e}$ na av. Francisco Sá), implantada na década de 1930-1940 ${ }^{37}$, na parte mais próxima ao Centro. Também conta com inúmeros conjuntos habitacionais, construídos junto à ferrovia e à BR 020, nas décadas de 1960-1980. Trata-se de área densamente povoada, ocupada por setores de renda baixa e média-baixa, como também por favelas e autoconstrução.

A concentração de indústrias na zona oeste, ainda nas primeiras décadas do século XX, como também foi assinalado no capítulo 2, resultou num tipo de ocupação popular dessa área, na vizinhança das fábricas e acompanhando a via férrea, fator importante para os trabalhadores.

A posterior criação do Distrito Industrial de Maracanaú - considerado o primeiro distrito industrial moderno - na década de 1970-1980, quando foram transferidas para lá as indústrias de maior porte e com maior grau de poluição, causou forte impacto nessa área da Cidade, deixando trechos da primeira periferia industrial parcialmente esvaziados e empobrecidos.

Esse fenômeno, comum a outras metrópoles brasileiras, ocorre em grande parte pela falta de políticas públicas, no sentido de propor novos usos (públicos ou privados) para os edifícios remanescentes, que mantenham a identidade do bairro e intensifiquem seu dinamismo ${ }^{38}$. Conforme assinalam Meyer \& Grostein (2010, p.177),

O processo de reestruturação produtiva e a saída das plantas industriais das áreas centrais das grandes cidades geraram impacto no tecido urbano, como zonas abandonadas e degradadas que contêm grandes terrenos em áreas dotadas de infraestrutura urbana. (...) A reutilização dessas áreas com novos programas urbanos apresenta-se como uma oportunidade de reestruturação de importantes setores da cidade.

Ainda no que se refere ao tipo de ocupação do Vetor 3, além dos diversos conjuntos habitacionais construídos pelo Sistema Financeiro da Habitação ${ }^{39}$ na zona oeste e sudoeste da Cidade, cabe ressaltar que houve também, desde os anos 1970-1980, uma explosão de loteamentos populares e irregulares, conformando grande parte dessa zona como uma imensa área urbana de infraestrutura deficiente, habitada por população de baixa renda, com fraco dinamismo econômico.

Tudo isso contribuiu significamente para o crescimento populacional da periferia oeste do $\mathrm{Mu}$ nicípio de Fortaleza, o que evidencia o padrão periférico de urbanização, marcando de forma expressiva o espaço metropolitano.

O Vetor 3 apresenta características bastante específicas. Vem se desenvolvendo em etapas, tendo iniciado com a construção dos conjuntos habitacionais de Araturi, Metrópole e Nova Metrópole, em área situada às margens da BR 020, entre os Municípios de Fortaleza e Caucaia. Diferentemente do Programa Habitacional de Maracanaú, que estava ligado às necessidades do Distrito

\footnotetext{
${ }^{36} \mathrm{O}$ bairro de Jacarecanga ainda manifesta marcas visíveis da atividade industrial e da vida urbana da classe operária, que predominavam no início do século XX: os galpões industriais, as antigas fábricas e sua maquinaria, as linhas de trem e a antiga estação, pátios de manobra e o próprio parcelamento do solo, com a presença de vilas operárias.

${ }^{37} \mathrm{O}$ deslocamento da ferrovia para o trecho em que corta a zona oeste da Cidade, em 1919, e a posterior instalação da oficina de manutenção e mecânica da RFFSA - Oficina do Urubu - em 1930, atraíram para as proximidades da via férrea as primeiras indústrias de beneficiamento de algodão e de tecidos e a mão de obra nelas empregada. Essa área, posteriormente, constituiu a primeira zona industrial de Fortaleza, com intensa atividade até a década de 1970-1980, quando foi instalado o Distrito Industrial de Maracanaú.

38 "Para a economia urbana contemporânea, a inclusão e o desenvolvimento de uma economia criativa nos antigos setores industriais situados nas grandes cidades têm sido apontados como fatores decisivos de renovação urbana" (MEYER \& GROSTEIN, 2010, p.148).

${ }^{39}$ Na década de 1970-1980, o Poder Público comprou estoque considerável de terras rurais, a preços reduzidos, para a construção dos conjuntos habitacionais.
} 
Industrial, a oferta habitacional gerada nessa região tinha como objetivo reduzir o déficit de moradias de Fortaleza e deslocar populações de baixa renda de áreas de valorização imobiliária em potencial, processo que se inicia com a construção da av. Leste-Oeste ${ }^{40}$.

A etapa seguinte da urbanização desse vetor é a ocupação da faixa litorânea de Caucaia, que se iniciou na praia do Icaraí, na década de 1970-1980, com finalidade de segunda moradia, de veraneio e lazer, e que vem se transformando progressivamente em local de moradia principal, determinando uma expansão urbana mais concentrada na zona litorânea compreendida entre as praias do Icaraí e do Cumbuco. A atividade turística, incrementada desde a década de 1990-2000, também provoca mudanças substantivas nessa área, sobretudo na praia do Cumbuco.

Tem-se verificado ainda, nos últimos anos, um processo de ocupação de terras e auto-construção precária nos aglomerados/conjuntos denominados Ciro Gomes e Patrícia Gomes, ao oeste da BR 020, na área próxima à BR 222.

A etapa mais recente de ocupação desse vetor é a que se refere à implantação do Complexo Industrial Portuário do Porto do Pecém - CIPP - instalado no Município de São Gonçalo do Amarantet. Segundo Smith (2001, p.9),

[...] a decisão do governo estadual em localizar a nova estrutura portuária do estado no município de São Gonçalo do Amarante, no distrito do Pecém, limite com o Município de Caucaia, e o esforço que vem sendo empreendido no sentido de dotar a área portuária como parte integrante de um Complexo Industrial a partir de duas indústrias-chave: a refinaria de Petróleo e a Siderúrgica, acompanhadas da imediata transferência do parque de tancagem e distribuição de combustíveis e gás da área contígua ao Porto do Mucuripe em Fortaleza, aponta para uma concentração maciça de investimentos do Estado nessa região.

A instalação do CIPP, com o porto e retroporto (siderúrgica e refinaria), demanda vultosos investimentos, assim como a previsão de maior concentração de pessoas em busca de trabalho, intensificando a expansão urbana nessa área e ampliando o espaço metropolitano.

A implantação do trem metropolitano de Fortaleza reforça essa concentração de investimentos, assim como a duplicação do $4^{\circ}$ Anel Viário, ligando os Municípios de Maracanaú, Fortaleza e Caucaia, além de uma linha de sete quilômetros da via férrea, que deverá reativar o ramal de Maranguape e a instalação, em Aracapé, de um pátio de cargas. Pretende-se que o sistema seja ainda integrado ao de ônibus urbanos e metropolitanos e também ao do trem diesel.

A Via Estruturante do Turismo (CE 085), que participa desse eixo, tende a se tornar o principal vetor de deslocamento rodoviário na área, e prevê-se, ainda segundo Smith (2001, p.9), um adensamento populacional "dentro de vários matizes qualitativos de ocupação, até a faixa destinada ao Complexo Industrial Portuário do Pecém - CIPP, com maiores concentrações urbanas na faixa litorânea a partir do Cumbuco e na área interna de Matões e outros sítios adjacentes".

Diferentemente dos anteriores, este vetor possui três ramificações distintas: a primeira prossegue pela BR 222, a segunda acompanha a Via Estruturante (ou CE 085), desde Caucaia até o Porto do Pecém, e a terceira corresponde à via que passa junto ao litoral (CE 090) (ver figura 3.54).

\footnotetext{
${ }^{40}$ A av. Leste Oeste foi construída no inicio da década de 1970-1980, na gestão do prefeito Vicente Fialho. Foi concebida a fim de propiciar uma ligação mais rápida entre o porto do Mucuripe e a zona industrial localizada a oeste. ${ }^{41}$ A instalação do CIPP no Município de S. Gonçalo do Amarante justificou sua inserção na RMF, em 1999.
} 


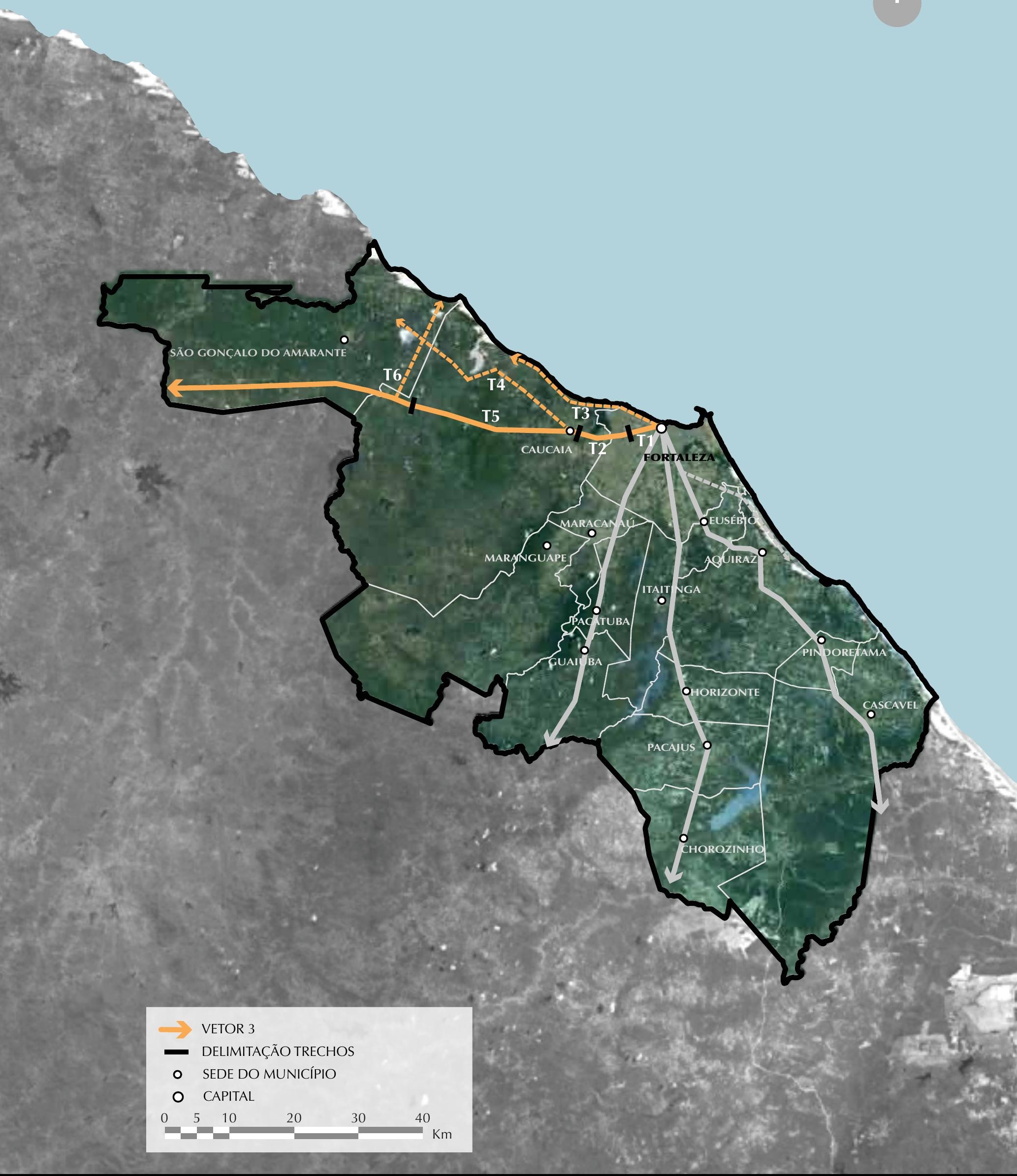

Fig. 3.56 Vetor 3: marcação dos trechos

Fonte: Google Earth - elaborado pela autora 


\section{TRECHO 1 - Av. Bezerra de Menezes e av. Mr. Hull}

O trecho inicial do Vetor 3 corresponde à av. Bezerra de Menezes, principal via de penetração no sentido oeste, e onde se desenvolve um subcentro expressivo da Cidade. Tradicional zona residencial de classe média, a via transformou-se desde os anos 1980-1990 em um centro dinâmico de comércio e serviços, com a concentração de lojas diversas, shoppings, restaurantes, casas de shows e edifícios de escritório. A avenida tem dimensões avantajadas e fluxo intenso nos dois sentidos. Registra-se nesse trecho a presença de grandes equipamentos, como o North Shopping, a Secretaria de Agricultura e o acesso ao Campus do Pici, da Universidade Federal do Ceará (ver figuras 3.57 e 3.58). Observa-se uma mudança na volumetria dessa área, que tem se verticalizado desde a década de 1990-2000, resultado da mudança da legislação².

Ao final da av. Bezerra de Menezes, o vetor continua em direção oeste pela av. Mr. Hull, no bairro Antônio Bezerra, antigo distrito de Fortaleza, onde a paisagem urbana já muda consideravelmente. Algumas indústrias estão instaladas às margens da via, ocupando lotes maiores, além de serviços diversos: postos de gasolina, borracharias, lojas de peças e supermercados. Merecem destaque a presença do Terminal de Passageiros de Antônio Bezerra e o Terminal Rodoviário Antônio Bezerra, conhecido como "Rodoviária dos Pobres"43. Este terminal possui intenso movimento, abrigando os ônibus que fazem o percurso para a zona norte do estado. No que se refere às habitações, são quase todas unifamiliares, de tipologia bastante simples (ver figura 3.59).

Nas imediações da av. Mr. Hull estão situados inúmeros conjuntos habitacionais, instalados desde a década de 1970-1980. A ocupação é bastante densa, com habitações muitas vezes precárias, algumas ocupando áreas de risco. Grande parte da população residente trabalha no centro da Cidade ou na zona leste - Aldeota e arredores - configurando essa região como área-dormitório.

Existe, portanto, um fluxo intenso de pessoas que se dirigem para aquelas áreas no início do dia e que retornam ao seu fim, sobrecarregando o sistema viário deste setor da Cidade. O sistema de transporte por ônibus é bastante precário, enquanto um sistema de transporte urbano de passageiros por trem suburbano, hoje completamente sucateado, mantém-se à espera de sua transição para o trem metropolitano de Fortaleza (metrô), aproveitando a via férrea. Esse melhoramento parece à população ser impossível de ocorrer, tal da demora em se concretizar. Já são passados mais de 20 anos desde o início do projeto Metrofor ${ }^{44}$.

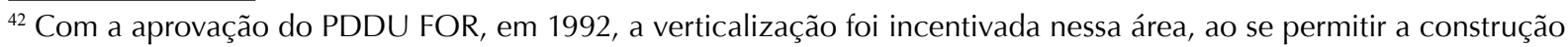
de edifícios de até 22 pavimentos, ou 72,00 m.

43 "O Terminal Rodoviário de Antônio Bezerra é conhecido pelos fortalezenses como Rodoviária dos Pobres. O nome indica a origem modesta do povoado de Antônio Bezerra, depois assimilado pela expansão urbana de Fortaleza. (Vasconcelos, R., in: http://fortalezanobre.blogspot.com/2010/09/de-rodoviaria-dos-pobres-terminal. html)

${ }^{44}$ O Consórcio do Trem Metropolitano de Fortaleza foi criado em 25 de setembro de 1987, com assinatura do Contrato de Constituição do Consórcio, pela RFFSA, CBTU e Governo do Estado do Ceará com interveniência da União, por meio do Ministério dos Transportes.
} 


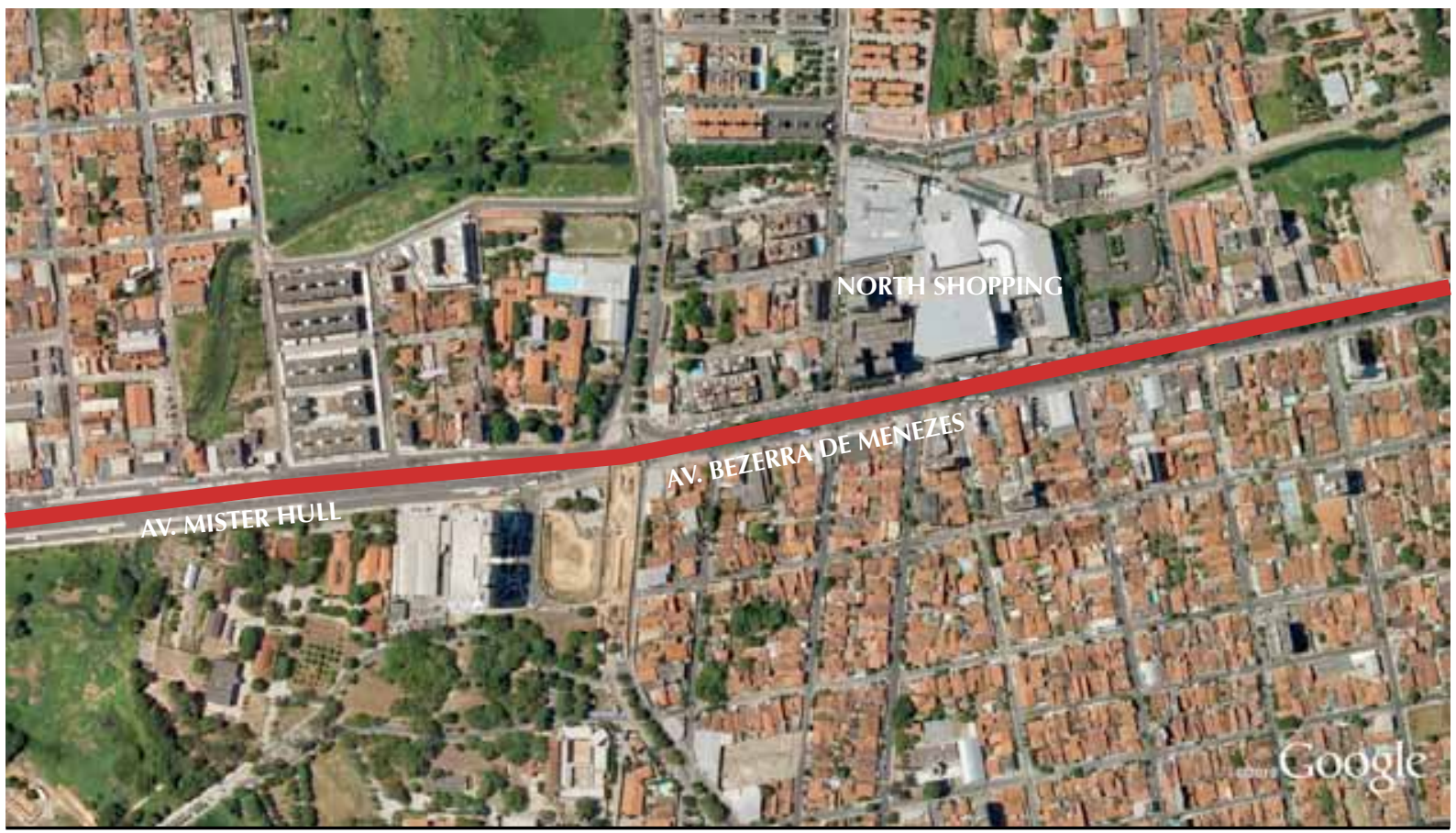

Fig. 3.57 Vetor 3: Trecho 1 (av. Bezerra de Menezes/Mister Hull)

Fonte: Google Earth - elaborado pela autora

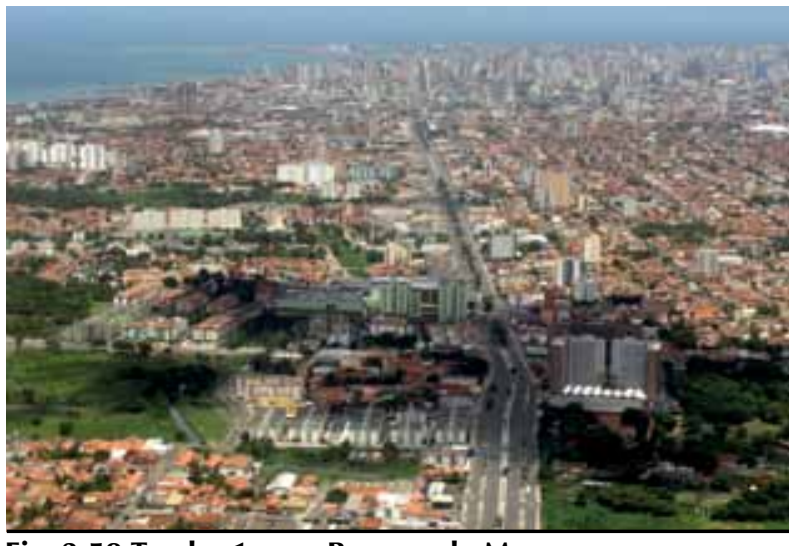

Fig. 3.58 Trecho 1 - av. Bezerra de Menezes

Fonte: http://www.skyscrapercity.com/showthread.php

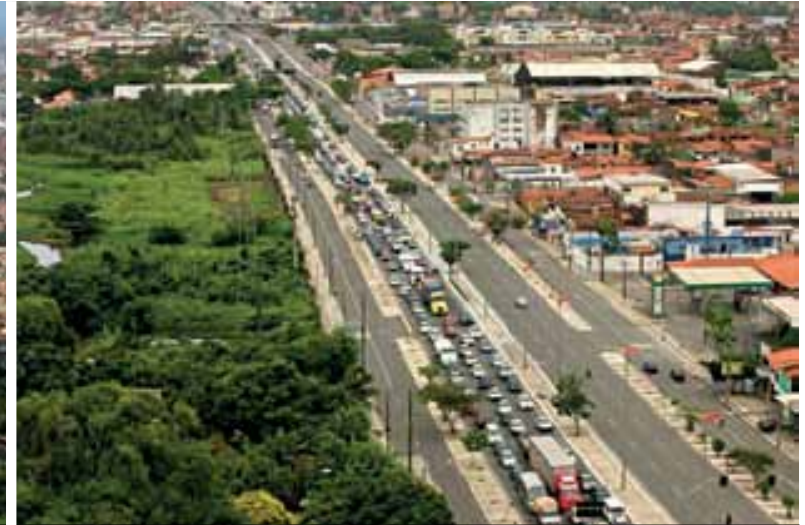

Fig. 3.59 Trecho 1 - av. Mister Hull

Fonte: http://diariodonordeste.globo.com/materia.asp

\section{TRECHO 2 - Os conjuntos habitacionais, as favelas e o manguezal}

O trecho seguinte continua pela av. Mr. Hull, e atinge a BR 020, rodovia que segue em direção à região Centro-oeste do País, até Brasília.

Na primeira parte desse trecho, as formas de uso e ocupação continuam as mesmas do anterior, com algumas indústrias e armazéns, além de comércio ligado à rodovia: postos de gasolina, borracharias, lojas de peças, supermercados, etc. A densidade populacional permanece alta, em virtude da implantação, também, nessa área, de vários conjuntos habitacionais ${ }^{45}$.

\footnotetext{
${ }^{45}$ Conjuntos habitacionais situados junto à av. Perimetral: Bancários, Planalto da Barra, Assunção, Alto Jerusalém, Beira-Rio, Vila Velha, Polar, etc.
} 
Vale salientar que a construção desses conjuntos contribuiu sobremaneira para a expansão ${ }^{46}$ de toda a zona oeste da Cidade. Em maioria, estão situados junto aos rios Ceará e Maranguapinho e acompanham a av. Perimetral, que cruza a av. Mr. Hull neste trecho. Essa expansão se estende ao sul da av. Mr. Hull até encontrar os bairros Bom Jardim, Granja Portugal e Conjunto Ceará e, embora extrapole os limites da Capital ${ }^{47}$, ela "independe em grande parte do dinamismo das sedes municipais. Na realidade, ela é decorrente da expansão de Fortaleza que se materializa nos inúmeros loteamentos que são implantados nesses municípios, nas zonas limítrofes à Metrópole" (AUMEF, 1977, p.153).

Os rios Ceará e Maranguapinho, em determinados trechos, constituem verdadeiros eixos de degradação socioambiental, promovendo o crescimento de um processo de favelização às suas margens, e que evidencia a ausência de qualquer controle urbano e ambiental com relação aos recursos hídricos (ver figuras 3.60 a 3.62).

Essas favelas, muitas delas situadas em "áreas de risco" e exclusão social para os municípios vizinhos ${ }^{49}$. Com o intuito de solucionar tal situação, conforme citado no capítulo anterior, está em vigência atualmente o "Projeto Maranguapinho", programa governamental ${ }^{50}$ que propõe a reabilitação desses espaços, com obras de esgotamento sanitário, dragagem e despoluição do rio e de seus afluentes, construção de equipamentos de lazer e de moradias.

Ainda nesse trecho, a implantação dos grandes conjuntos habitacionais nos espaços periféricos ao oeste e sudoeste e a ocorrência de inúmeras favelas e ocupações em "áreas de risco", induzem uma conurbação entre Fortaleza e Caucaia, formando um continuum urbano.

A BR 020 cruza, a partir daí, uma extensa área de mangue, que corresponde à foz do rio Ceará, onde se encontra uma comunidade indígena, dos índios Tapebas. Esse manguezal interrompe a ocupação densa verificada até aí.

Na rodovia, há uma bifurcação que dá acesso à cidade de Caucaia, Sede do Município do mesmo nome, local onde se origina a CE 090, denominação dada à via litorânea, que segue em direção às praias de Icaraí, Tabuba e Cumbuco.

\footnotetext{
${ }^{46}$ Os conjuntos habitacionais e loteamentos periféricos passaram a ser construídos em outros municípios, fora de Fortaleza, principalmente em locais acessíveis pelo transporte rodoviário.

${ }^{47}$ Nesse trecho, muitos dos conjuntos mencionados já ocupam terrenos do Município de Caucaia.

${ }^{48}$ Segundo dados do IPECE, Fortaleza possui atualmente 105 "áreas de risco", 51 das quais junto ao rio Maranguapinho.

49 "Na RMF, a formação de extensas periferias metropolitanas adquire muita evidência, especialmente em Fortaleza e seu entorno. Observa-se um acentuado processo de transferência da população pobre para os s localizados ao sul e sudoeste do pólo. Agravam a situação de pobreza, a precariedade e o déficit que atinge os setores de infra-estrutura, equipamentos e serviços nas áreas do saneamento básico, habitação, saúde e educação" (SILVA, 2009, p.17).

${ }^{50}$ De acordo com o site da Secretaria das Cidades, "o projeto Rio Maranguapinho é a maior intervenção urbana do País e irá beneficiar cerca de 350 mil pessoas de Fortaleza e Região Metropolitana, em especial, Maracanaú, Maranguape e Caucaia. Estão sendo executadas obras de dragagem, construção de conjuntos habitacionais, urbanização das margens do rio e barragem de contenção de cheias para evitar alagamentos. Ao todo, estão sendo investidos R\$ 497.548.859,29, do Governo Federal, com recursos do Programa de Aceleração do Crescimento (PAC), e do Governo do Estado" (disponível em: http://www.cidades.ce.gov.br/categoria2/projeto-maranguapinho).
} 


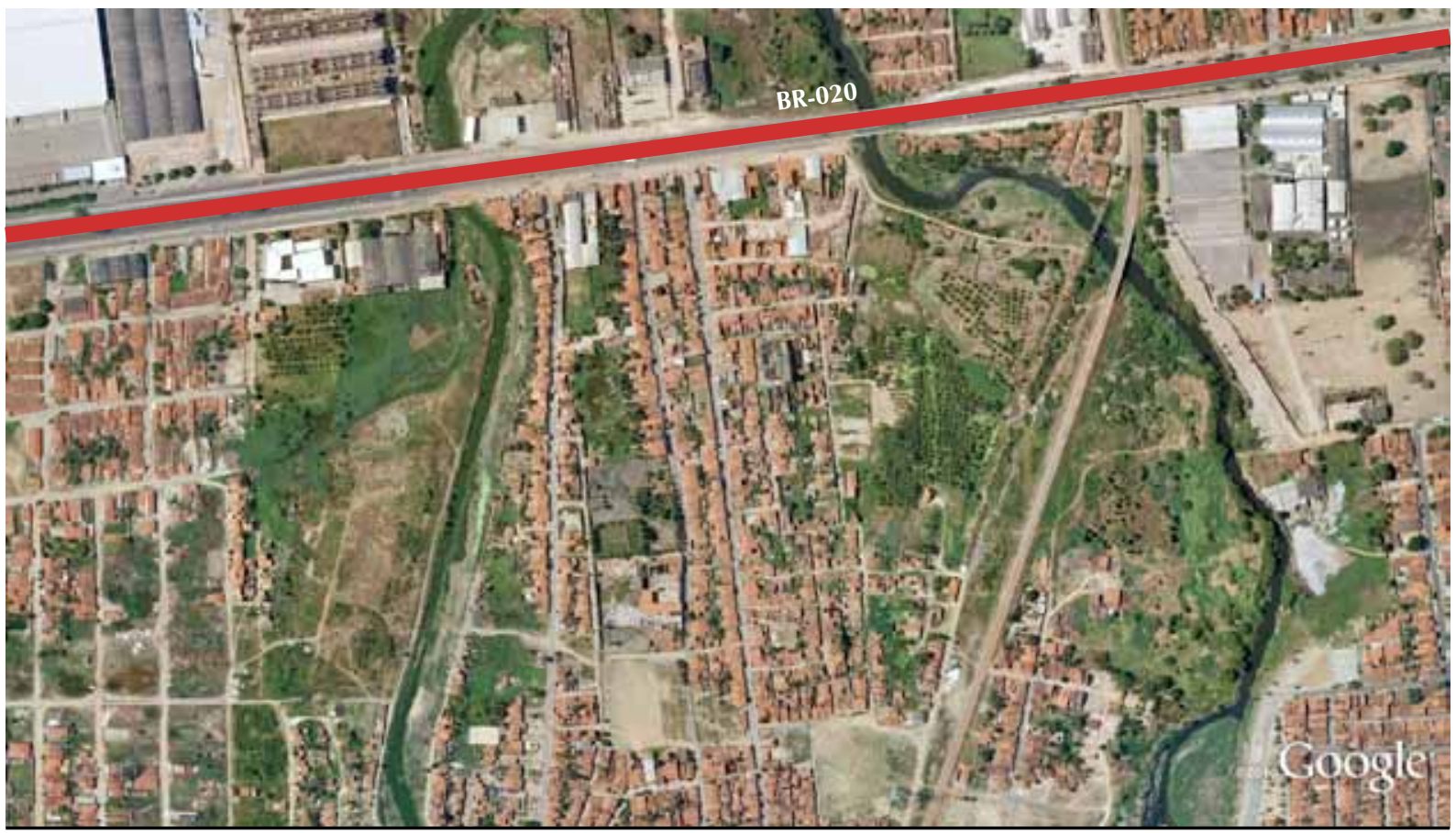

Fig. 3.60 Vetor 3: Trecho 2 (BR-020 - conjunto habitacional e moradias em área de risco) Fonte: Google Earth - elaborado pela autora

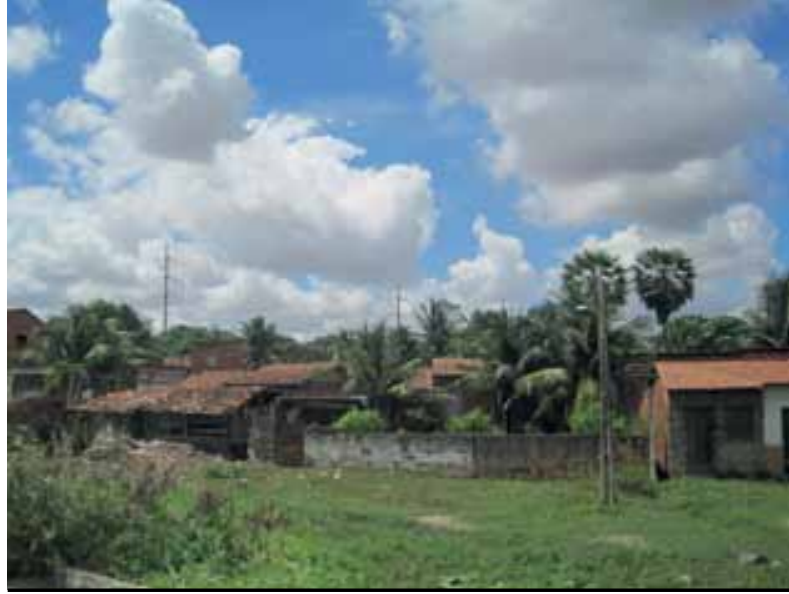

Fig. 3.61 Trecho 2 - Favelas junto à rodovia Fonte: acervo autora

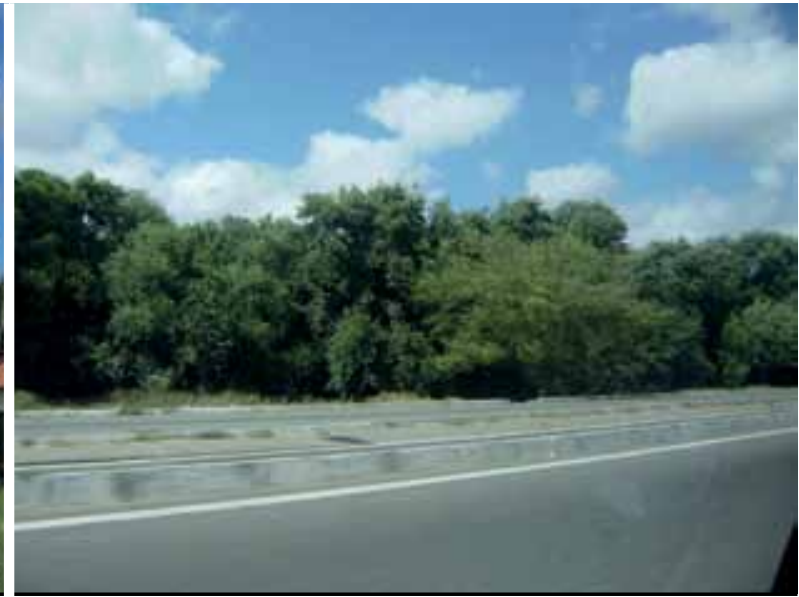

Fig. 3.62 Trecho 2 - área de Manguezal Fonte: acervo autora

\section{TRECHO 3 - Via litorânea - CE 090}

A CE 090, com início em Caucaia, atinge as praias de Icaraí, Tabuba e Cumbuco. Trata-se de uma via que foi construída para dar acesso à praia do Icaraí, tão logo se iniciaram as vendas de lotes para veraneio, na década de 1970-1980. Como ainda não havia a ponte sobre o rio Ceará, inaugurada em 1997, era a principal via de acesso à zona litorânea oeste.

No que se refere à estruturação espacial, vale salientar que esta região também constitui importante vetor de expansão urbana, uma vez que grande parte das residências de lazer e férias (segundas residências), construídas desde a década de 1970-198051, vem se transformando ultimamente em residência permanente. A alteração da forma de usar e ocupar o solo constitui assim expressivo

${ }^{51} \mathrm{O}$ veraneio marítimo, iniciado nessa época, "intensifica o processo de incorporação da zona de praia à tessitura urbana da Metrópole em constituição, extrapolando, a partir de então, os limites da cidade de Fortaleza" (DANTAS, 2009, p. 37). 
fator na urbanização da zona costeira metropolitana, que se transforma em um núcleo urbano em desenvolvimento, crescendo em continuidade espacial com relação à Sede do Município de Caucaia. Vários blocos de apartamentos de veraneio construídos na praia do Icaraí já abrigam população residente. Estabelecimentos de comércio e serviços de apoio surgem nas imediações, evidenciando uma área urbana em plena expansão.

Esse quadro demonstra o expressivo crescimento populacional do Município de Caucaia, que acusou acréscimo de 30\% no último censo (2010), em relação ao anterior ${ }^{22}$.

Além das habitações de veraneio instaladas, essa área também compreende atividades turísticas, intensas nessa parte da orla, sobretudo a partir dos anos 1990-2000, em vista da instalação progressiva de hotéis, resorts, pousadas e condomínios de lazer, principalmente na praia do Cumbuco, situada a $30 \mathrm{~km}$ da Capital e considerada aquela de maior atrativo, conforme ficou destacado no item 2.4.3 do capítulo anterior (ver figuras 3.63 a 3.65). Verifica-se, pois, uma expansão da dinâmica imobiliária, na oferta crescente desses empreendimentos, os quais muitas vezes se apropriam da faixa de praia, com ocupações irregulares, que privatizam espaços públicos.

É importante ressaltar, nesse sentido, que grande parte da área é formada por dunas, as quais vêm sendo progressivamente ocupadas por equipamentos hoteleiros, restaurantes e barracas de praia. Vale salientar que não tem sido dispensada a devida atenção à via, que deveria privilegiar a paisagem, como seria recomendado. Além do desmonte e ocupação indevida das dunas e da falta de arborização, não se vê o mar, e a implantação de edificações entre a via e a orla marítima também não favorece as vistas para a praia.

A CE 090 liga-se à Via Estruturante (ou CE 085) depois de passar pela Praia do Cumbuco. A continuação da via litorânea fica praticamente impedida pela incidência de dunas móveis.

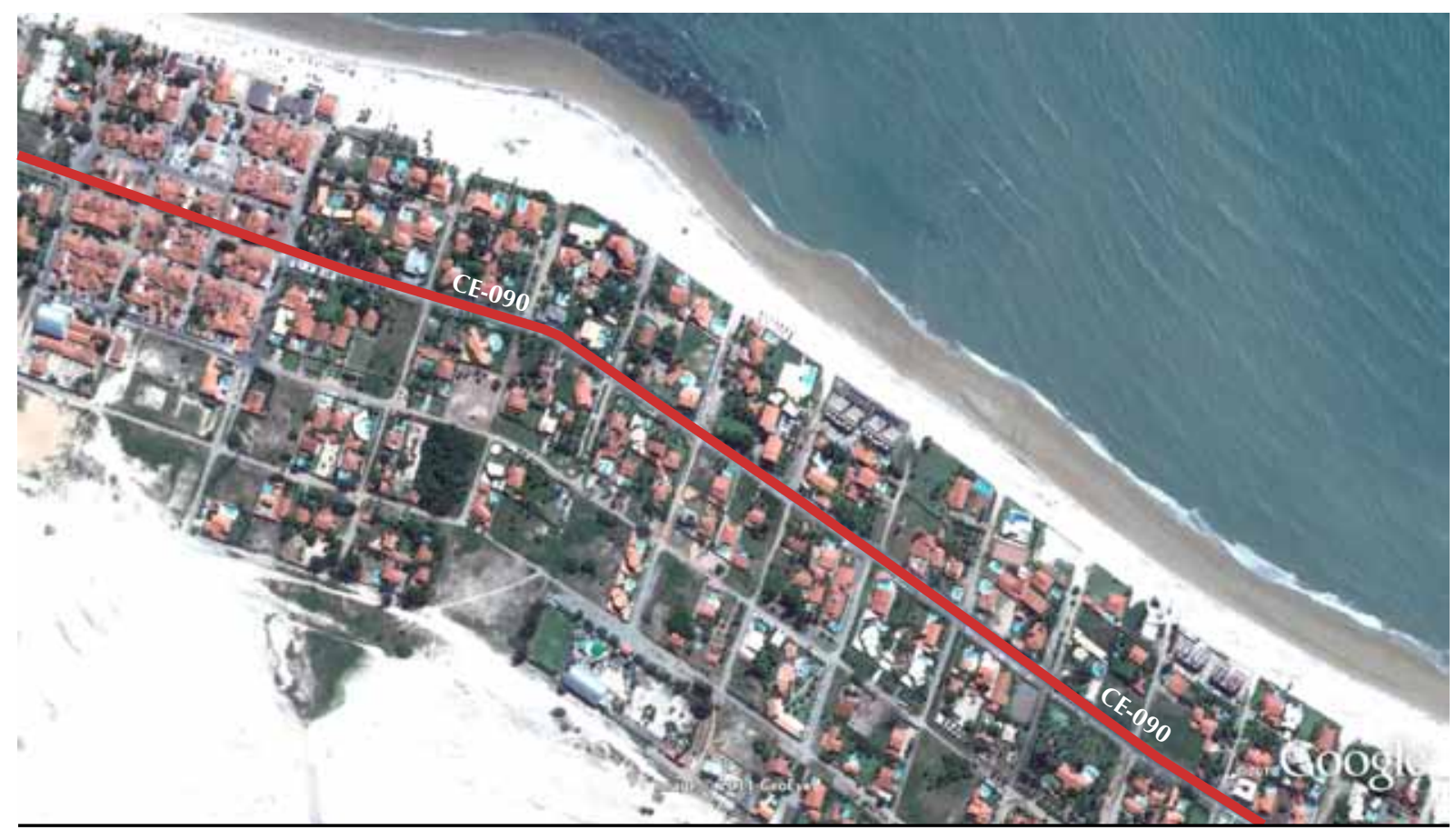

Fig. 3.63 Vetor 3: Trecho 3 (Praia do Cumbuco)

Fonte: Google Earth - elaborado pela autora

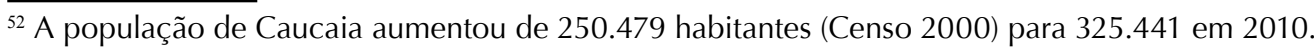




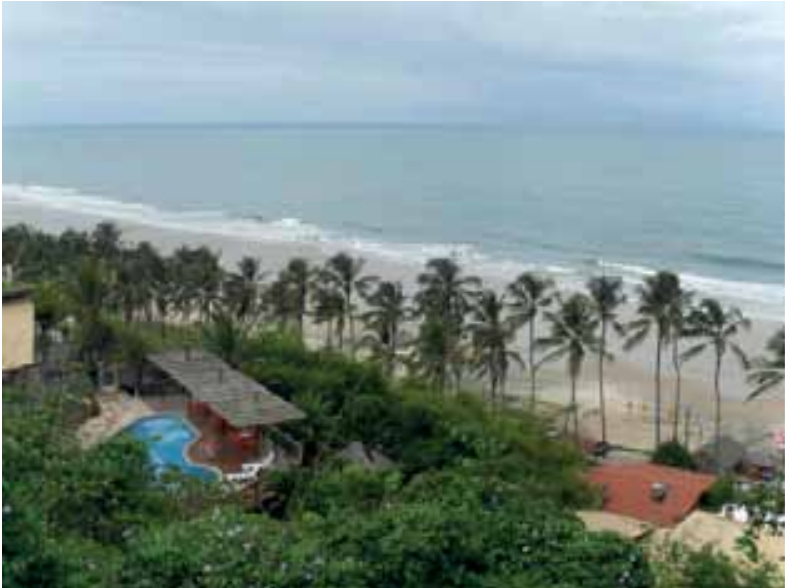

Fig. 3.64 Trecho 3 - Praia do Cumbuco Fonte: http://www.mundi.com.br

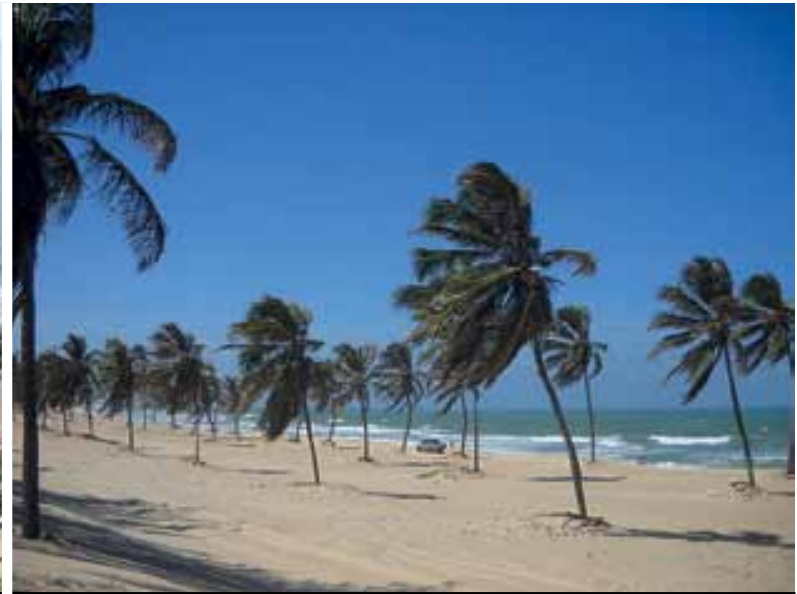

Fig. 3.65 Trecho 3 - Praia do Cumbuco

Fonte: viagem.uol.com.br/album/cumbuco_album.jhtm

A Via Estruturante (CE-085), na chamada Costa do Sol Poente, constitui um dos investimentos do Programa de Desenvolvimento do Turismo no Nordeste (PRODETUR-NE) no Estado do Ceará. Foi concebida para facilitar o acesso às praias do litoral oeste cearense, com o intuito, portanto, de incrementar o desenvolvimento turístico de vários municípios dessa região (ver figura 3.66).

A via tem início em Caucaia e segue na direção oeste, com várias entradas (vias secundárias transversais) que levam aos diferentes núcleos litorâneos, além de conduzir também a alguns sítios situados nas imediações. A Via Estruturante permite ainda o acesso ao Complexo Industrial Portuário do Pecém, passando por dentro do Distrito ${ }^{53}$ do mesmo nome, desempenhando assim papel importante também com relação ao incremento da atividade industrial, embora tenha sido construída com recursos do PRODETUR.

A primeira etapa da CE 085 - do Município de Caucaia até o Distrito de Barrento, no Município de Itapipoca, com os acessos às diversas praias - teve início em 1996 e foi concluída em 1999, quando completou 253 quilômetros. A segunda etapa da obra ${ }^{54}$ foi também concluída e segue em direção a Jijoca de Jericoacoara, importante destino turístico do Estado.

De maneira geral, a paisagem ao longo da rodovia é predominantemente rural, com abundante vegetação em ambos os lados (ver figuras 3.67 a 3.69); no entanto, observam-se indicações (e anúncios) de vários loteamentos à venda nas imediações, o que aponta, por um lado, a valorização da área, em consequência da abertura da via, e, por outro, uma tendência de futura ocupação, em virtude da facilidade de acesso e também da proximidade do CIPP, o qual deverá atrair grande contingente de trabalhadores.

Segundo a avaliação do PRODETUR-NE, a Via Estruturante (CE-085) permitiu melhor integração entre os municípios do litoral oeste, estimulou o desenvolvimento dos núcleos urbanos, possibilitou o acesso à infraestrutura, em geral, e ensejou negócios ao longo da rodovia, com investimentos privados e aumento na oferta turística.

\footnotetext{
${ }_{53}$ Apesar da recente instalação do porto no litoral, o Distrito de Pecém não registrou crescimento significativo desde então. ${ }^{54}$ A última etapa da Via Estruturante (ainda não concluída) deverá ligar os núcleos do litoral oeste à cidade de Viçosa do Ceará, na serra da Ibiapaba, situada a 365 km da Capital.
} 
CAPÍTULO 3

A expansão territorial da Metrópole cearense e os vetores de crescimento urbano e metropolitano

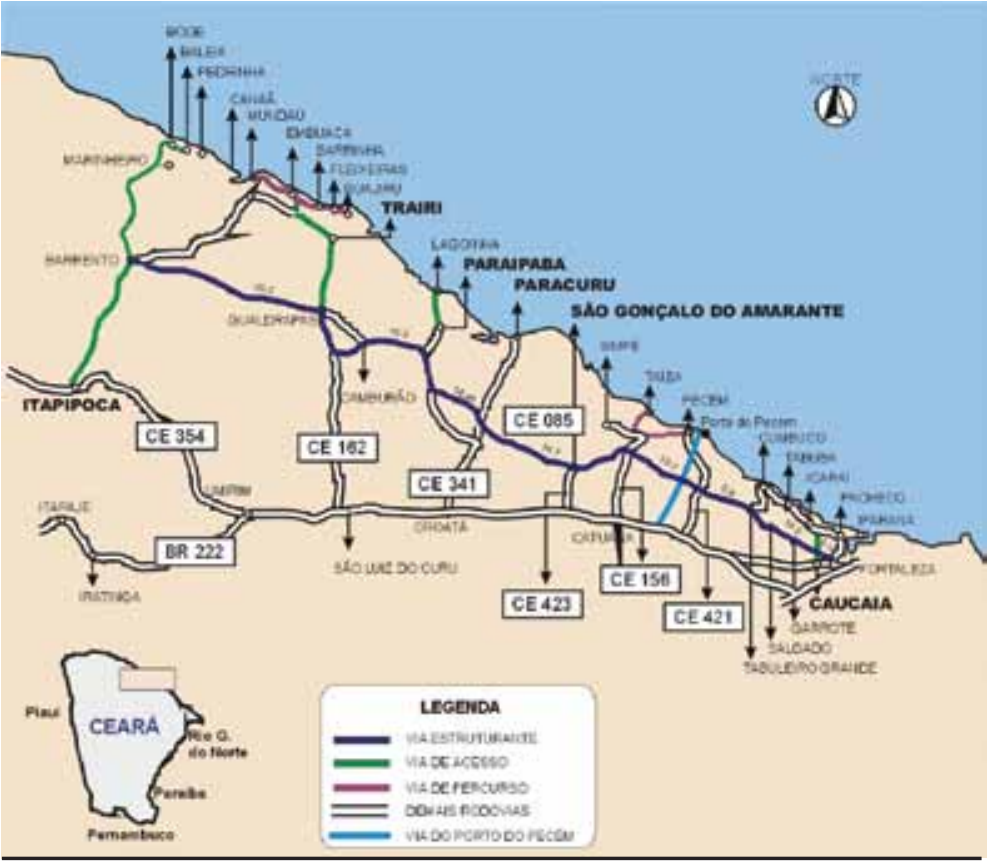

Fig. 3.66 Mapa via Estruturante Fonte: SETUR-CE

De fato, essa rodovia intensificou os eixos de comunicação entre a Capital e os acessos às diversas praias da zona oeste, ao mesmo tempo em que interferiu no processo de metropolização ligado à ocupação do litoral, constituindo verdadeiro subvetor de expansão, com impacto significativo nos municípios que atravessa.

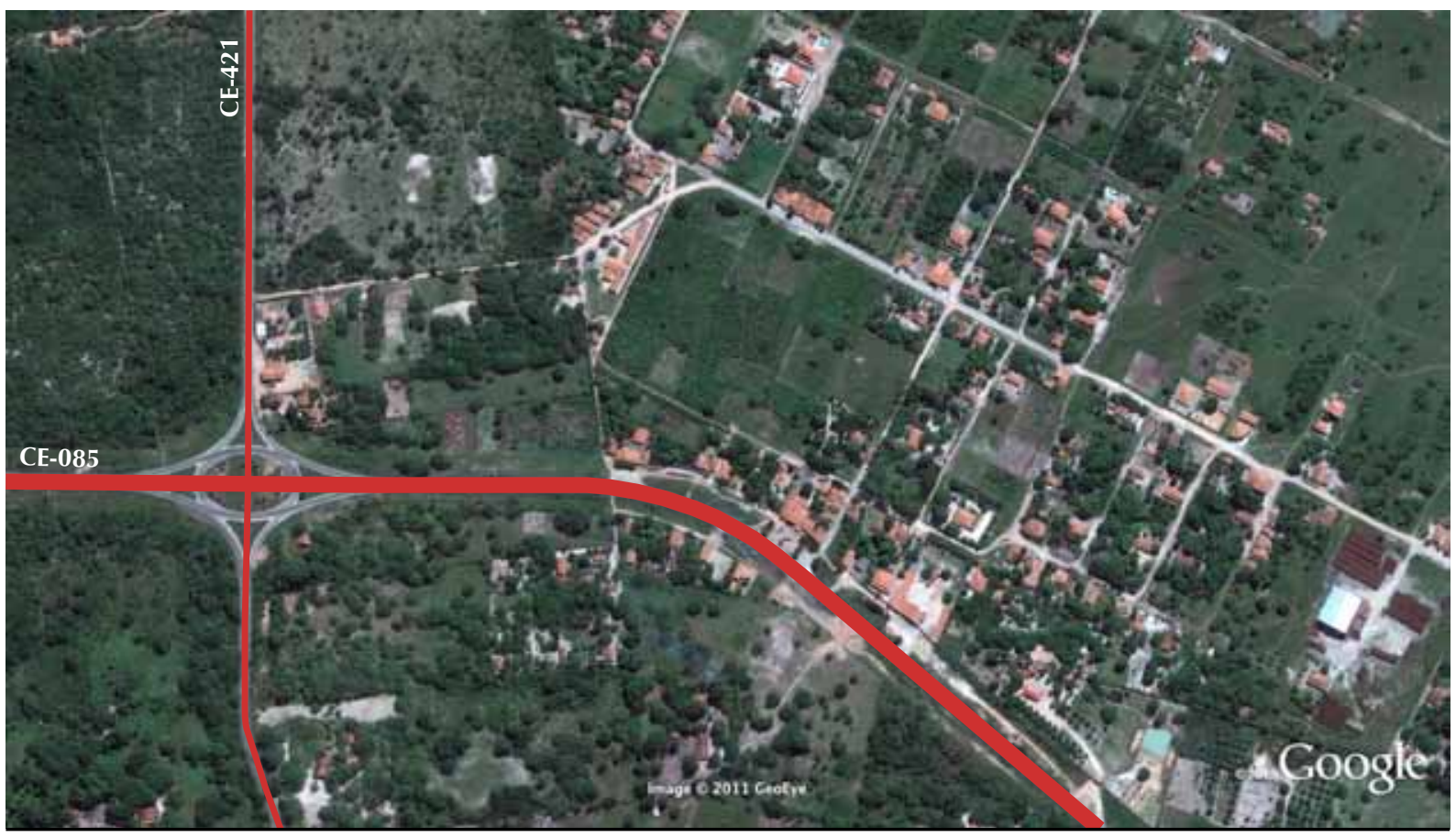

Fig. 3.67 Vetor 3: Trecho 4 (Via Estruturante/CE-085) Fonte: Google Earth - elaborado pela autora 


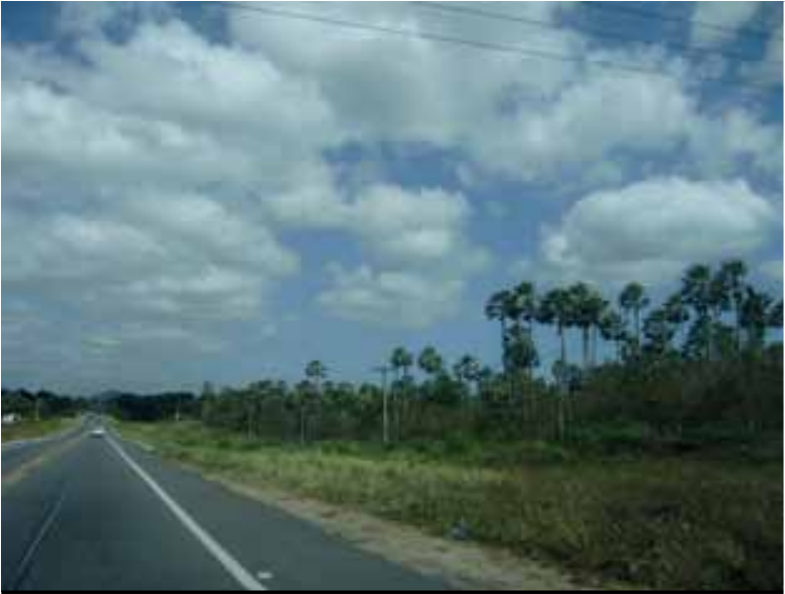

Fig. 3.68 Trecho 4 - via Estruturante Fonte: acervo autora

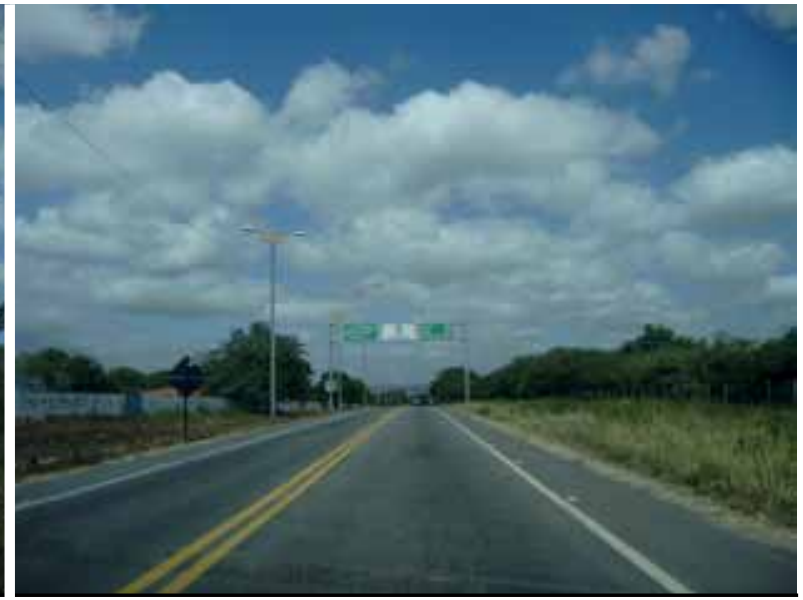

Fig. 3.69 Trecho 4 - via Estruturante Fonte: acervo autora

\section{TRECHO 5 - BR 222 - CE 421 (A futura Cidade do Atacado)}

A BR 020 cruza o $4^{\circ}$ Anel Viário, ainda no Município de Caucaia em ponto onde tem início a BR 222, que dá acesso aos municípios do norte do Estado e também ao Piauí e Maranhão.

Nesse trecho, a via percorre território com características predominantemente rurais, com vegetação abundante, formada principalmente por carnaubais e com poucas edificações nas imediações. É daí que parte a rodovia CE 421, que segue até o Porto do Pecém (ver figura 3.70).

No cruzamento da BR 222 com o $4^{\circ}$ Anel Viário, está prevista a construção de um grande equipamento, denominado "Cidade do Atacado". Trata-se de um polo atacadista de grandes dimensões, com uma área de 1,89 milhão de $\mathrm{m}^{2}$ (e previsão de construção $389 \mathrm{mil} \mathrm{m}^{2}$ de galpões e estruturas de armazenagem), investimentos de R 260 milhões, e que, segundo dados do Governo do Ceará, deverá proporcionar uma geração de 3.280 empregos diretos e de 11.400 indiretos.

Este equipamento ${ }^{55}$, que abrangerá grandes armazéns e pontos de venda para a comercialização de produtos em grande quantidade, deverá provocar transformação significativa nessa área, atraindo grande concentração de pessoas e o incremento do fluxo de veículos. O projeto prevê ainda área de lazer, escola, creche, hotel, centro de saúde, praça de alimentação, centro ecumênico, área de esportes, espaço do caminhoneiro, aluguel de empilhadeiras e heliporto.

Segundo pronunciamento do governador Cid Gomes, por ocasião do lançamento do empreendimento ${ }^{56}$, "com a proximidade do Porto do Pecém, poderemos investir em importações e exportações para o Brasil, criando um novo marco no ramo de atuação do setor atacadista e produtivo do Ceará".

A localização da Cidade do Atacado no Município de Caucaia, conforme o responsável pelo investimento ${ }^{57}$ Michel Amin Jereissati, é estratégica, uma vez que está próxima a Fortaleza e ao Porto do Pecém, além de situar-se na confluência de duas rodovias federais, o que facilita a operação de cargas e o escoamento (ver figuras 3.71 e 3.72 ).

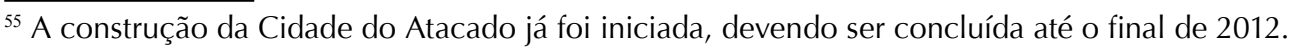

${ }^{56}$ O empreendimento "Cidade do Atacado" foi lançado no dia 27 de maio de 2010, em Caucaia.

${ }^{57}$ A empresa Varicred do Nordeste é a responsável pelo investimento, em parceria com a Associação Cearense dos Atacadistas e Distribuidores de Produtos Industrializados do Estado do Ceará - ACAD. O empreendimento conta com o apoio do Governo do Estado e da Prefeitura Municipal de Caucaia.
} 
A primeira etapa do projeto - que consiste na construção de 389 mil metros quadrados de galpões e estrutura de armazenagem completa - já foi iniciada e a obra final, de acordo com Eliseu Sousa dos Santos, secretário de Desenvolvimento Econômico de Caucaia, deverá ser entregue até o final de 2012.

A Cidade do Atacado, ao ser concluída, deverá provocar uma concentração significativa nessa área, conformando uma centralidade, atraindo também a função habitacional e contribuindo para o incremento da urbanização e expansão metropolitana neste trecho do Vetor 3.

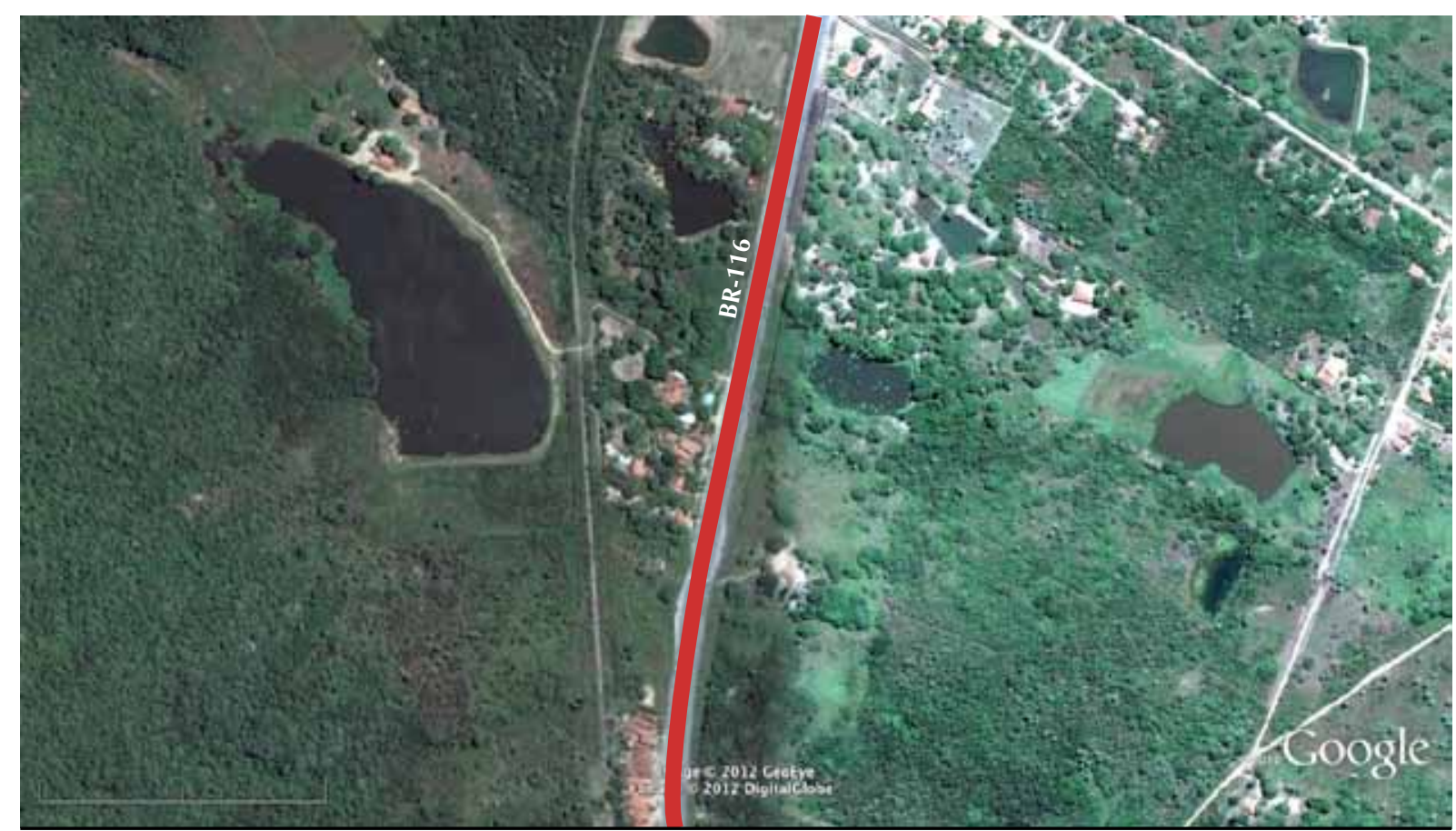

Fig. 3.51 Vetor 2: Trecho 5 (BR-116 zona rural)

Fonte: Google Earth - elaborado pela autora

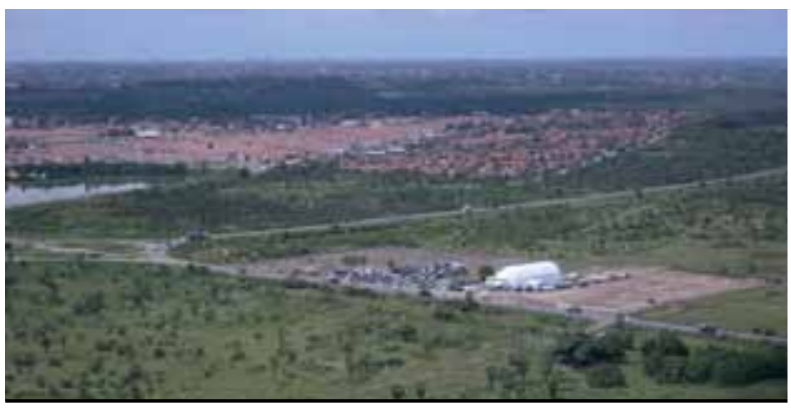

Fig. 3.71 Cidade do Atacado - localização Fonte: http://www.skyscrapercity.com

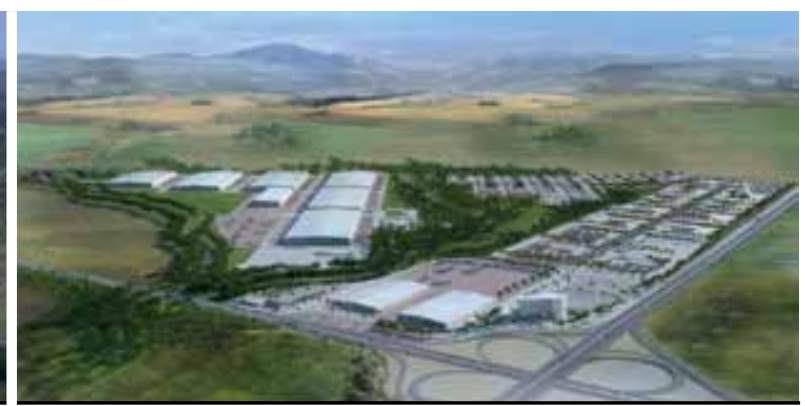

Fig. 3.72 Cidade do Atacado - maquete Fonte: http://www.skyscrapercity.com

\section{TRECHO 6 - A CE 421, a APA do Pecém e o CIPP}

A rodovia CE 421, que faz a ligação da BR 222 com o Porto do Pecém, conta com pavimentação reforçada, uma vez que é utilizada sobretudo por caminhões de carga que levam a produção para escoamento no Porto. Foi construída especialmente para permitir o acesso ao Porto, evitando o tráfego de veículos pesados nas demais rodovias. No projeto, foram previstas duas "faixas de servidão" de 100,0 m para cada lado da estrada, a partir de suas margens, por onde passam o gasoduto, as linhas da rede elétrica e telefônica e a rede ferroviária, que deverá abastecer as indústrias de insumos e servir para o escoamento dos produtos. A Via Estruturante, destinada principalmente ao fluxo de veículos e ônibus intermunicipais, também cruza a CE 421, já próximo ao Distrito do Pecém. 
Não há indícios de habitações ao longo da via, mas já existem empresas instaladas, de apoio ao porto, como a Votorantim Cimentos N/NE S/A.

Esse trecho passa próximo à APA - Área de Proteção Ambiental - do Pecém, que possui uma área de 122,79 hectares e foi criada pelo Decreto Estadual no 24.957, de 05 de junho de 1998. Trata-se de uma Unidade de Conservação de Uso Sustentável, dela fazendo parte comunidades nativas e de veranistas.

A APA foi criada a fim de minimizar os impactos decorrentes da implantação do CIPP nessa área, uma vez que o complexo deverá concentrar empreendimentos industriais de grande porte - siderúrgica, refinaria, complexo petroquímico, parque de estocagem de combustíveis e outras indústrias de transformação, tudo isso situado em área de grande fragilidade ambiental (a planície litorânea). A APA constitui um "cinturão verde" e deve, portanto, proteger os recursos naturais ${ }^{58}$ da região, com relação às situações de fragilidade do entorno e aos núcleos urbanos já consolidados, além de prevenir impactos sobre os equipamentos de turismo previstos para a área.

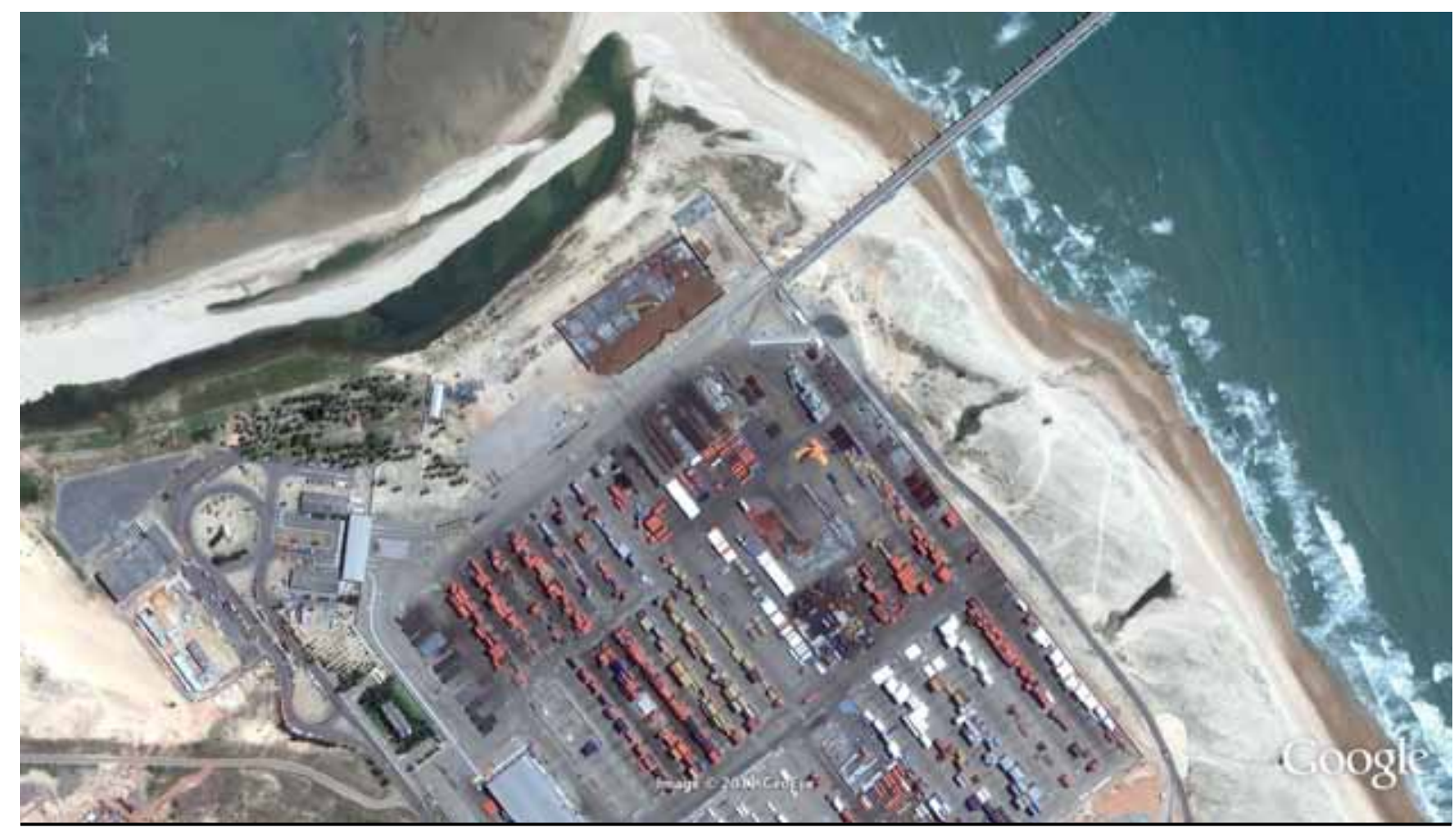

Fig. 3.73 Vetor 3: Trecho 6 (Porto do Pecém/CIPP)

Fonte: Google Earth

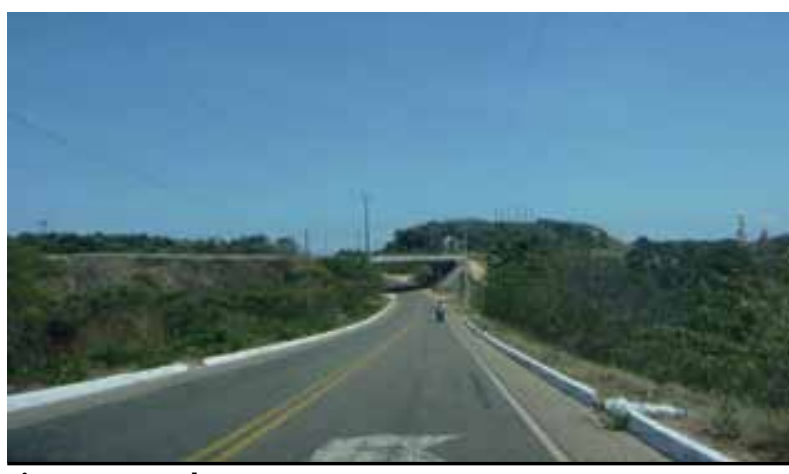

Fig. 3.74 Trecho 6 - CE 421

Fonte: acervo autora

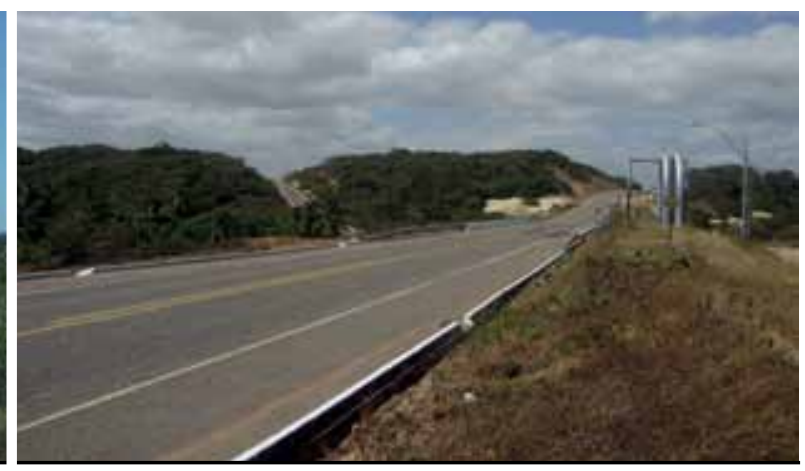

Fig. 3.75 Trecho 6 - CE 421

Fonte: acervo autora

${ }^{58}$ A APA integra ecossistemas da planície litorânea, dos tabuleiros pré-litorâneos e uma planície lacustre, na qual está localizada a lagoa do Pecém que abastece o Distrito do Pecém. A cobertura vegetal é composta por espécies características de áreas de dunas e tabuleiros pré-litorâneos, como cajueiros, coqueiros, além de murici e jatobá (frutas nativas). 


\section{O CIPP}

O Complexo Industrial Portuário do Pecém "Governador Mário Covas" foi inaugurado em março de 2002. Está situado ao noroeste da RMF, entre os Municípios de Caucaia e S. Gonçalo do Amarante, a cerca de $60 \mathrm{~km}$ da Capital (ver figuras 3.76 a 3.79).

A instalação do CIPP constitui um dos investimentos de maior impacto no território metropolitano, concebido pelo Governo Estadual como uma estratégia para incrementar diversos setores da economia do Ceará.

Foi idealizado para possibilitar o escoamento da produção, ampliar os mercados e diversificar a pauta de exportações, contribuindo assim para aumentar a participação do Estado no PIB brasileiro. Os desdobramentos positivos da instalação do CIPP na economia local estão relacionados com a geração de emprego e renda, bem como o aumento do comércio e infra-estrutura necessária para atrair outros investimentos.

O Complexo Industrial e Portuário do Pecém (CIPP) foi desde o início pensado como um dos instrumentos chave para dinamizar e desenvolver a economia cearense. Apoiado no porto do Pecém, o complexo desenhado ao seu redor deverá abrigar empreendimentos estruturantes capazes de redefinir os patamares de crescimento e os níveis de desenvolvimento econômico percebidos hoje no Estado. Refinaria, siderurgia e zona de processamento de exportação (ZPE) são alguns dos projetos já encaminhados para a área e trazem consigo oportunidades que demandam uma atuação ativa, coordenada e eficaz do governo estadual ${ }^{59}$.

Segundo Smith (2001, p.10),

Há um entendimento que o processo industrial que vem sendo desencadeado no CIPP não se enquadra na mesma lógica daquele ocorrido no vetor da BR 116/Horizonte. Trata-se de um conjunto de empreendimentos dotados de forte poder estratégico de encadeamentos econômicos para frente e para trás, de maior densidade de capital e requisitos de infra-estrutura energética, hídrica, ferroviária, urbana e de comunicações de grande porte.

Embora as ações industriais do complexo ainda não estejam inteiramente consolidadas, as atividades portuárias já estão em pleno funcionamento, assim como grande parte da infraestrutura de apoio, o que tende a transformar o CIPP num dos principais polos de desenvolvimento contemporâneo da RMF ${ }^{60}$. Atualmente, uma década depois de sua instalação, conta com oito empresas em operação e oito em fase de instalação (ver tabelas 16 e 17).

\footnotetext{
${ }^{59}$ PAIVA, Witalo de Lima, MEDEIROS, Cleyber \& CAVALCANTE, Alexsandre. Caracterização Socioeconômica e Geográfica dos municípios que compõem o Complexo Industrial e Portuário do Pecém (CIPP), disponível em http://www. ipece.ce.gov.br/publicacoes/textos_discussao/TD_65.pdf.

60 "Apesar da ainda diminuta ocupação dos seus 13.337 hectares, o Complexo do Pecém já respira a cifra de R\$ 34,2 bilhões em investimentos industriais até 2017. Desse total, 3\%, cerca de R\$1,04 bilhão, são das oito empresas instaladas e em funcionamento. Os 77\% restantes são de indústrias em instalação." (Jornal O Povo, 17-03-2012).
} 
TABELA 16 - RELAÇÃO DE INDÚSTRIAS INSTALADAS E EM FUNCIONAMENTO NO CIPP

\begin{tabular}{|c|c|c|c|c|}
\hline EMPRESAS & MUNICÍPIO & PRODUÇÃO & \begin{tabular}{|} 
INVESTIM. \\
(R\$MIL)
\end{tabular} & EMPREGOS \\
\hline $\begin{array}{l}\text { CGTF Central Geradora } \\
\text { Termoelétrica Fortaleza }\end{array}$ & Caucaia & $\begin{array}{l}\text { Usina termelétrica destinada } \\
\text { a geração de energia elétrica }\end{array}$ & 100.000 & 490 \\
\hline $\begin{array}{l}\text { Termoceará Ltda } \\
\text { (Petrobrás) }\end{array}$ & Caucaia & $\begin{array}{l}\text { Usina termelétrica destinada } \\
\text { a geração de energia elétrica }\end{array}$ & 250.000 & 20 \\
\hline $\begin{array}{l}\text { Wobben Windpower } \\
\text { Industria e Comércio } \\
\text { Ltda. }\end{array}$ & Caucaia & $\begin{array}{l}\text { Fábrica de aerogeradores } \\
\text { e seus componentes }\end{array}$ & 23.500 & 506 \\
\hline Jotadois NE Ltda. & S. Gonçalo & $\begin{array}{l}\text { Fábrica de pré-moldados } \\
\text { de concreto }\end{array}$ & 2.180 & 205 \\
\hline $\begin{array}{l}\text { Tortuga Cia Zootecnia } \\
\text { Agrária }\end{array}$ & S. Gonçalo & $\begin{array}{l}\text { Fábrica de complem. e } \\
\text { concentrados } \\
\text { minerais p/ nutrição animal }\end{array}$ & 100.000 & 490 \\
\hline $\begin{array}{l}\text { Votorantim Cimentos } \\
\text { N/NE S/A }\end{array}$ & S. Gonçalo & Fábrica de cimento e argamassa & 45.000 & 55 \\
\hline $\begin{array}{l}\text { Companhia Industria de } \\
\text { Cimento Apodi }\end{array}$ & S. Gonçalo & Fábrica de cimento & 55.000 & 160 \\
\hline $\begin{array}{l}\text { Hydrostec Tecnologia e } \\
\text { Equipamentos Ltda }\end{array}$ & S. Gonçalo & $\begin{array}{l}\text { Fabricação de tubos de aço, } \\
\text { carbono, } \\
\text { Equipamentos e peças mecânicas }\end{array}$ & 13.000 & 80 \\
\hline
\end{tabular}

Fonte: Jornal O Povo (18-03-2012)

TABELA 17 - RELAÇÃO DE INDÚSTRIAS EM INSTALAÇÃO NO CIPP

\begin{tabular}{|c|c|c|c|c|}
\hline EMPRESAS & MUNICÍPIO & PRODUÇÃO & \begin{tabular}{|l|} 
INVESTIM. \\
(R\$MIL)
\end{tabular} & EMPREGOS \\
\hline $\begin{array}{l}\text { MPX-Pecém Geração } \\
\text { De Energia S/A }\end{array}$ & S. Gonçalo & $\begin{array}{l}\text { Geração de energia elétrica } \\
\text { A base de carvão mineral }\end{array}$ & 2.400 .000 & $\begin{array}{c}120 \text { (dir) } \\
490 \text { (indir) }\end{array}$ \\
\hline $\begin{array}{l}\text { CSP Companhia } \\
\text { Siderúrgica do Pecém }\end{array}$ & S. Gonçalo & Siderurgia & 11.100 .000 & $\begin{array}{c}3.000 \text { (const) } \\
14.000 \text { (operação) }\end{array}$ \\
\hline $\begin{array}{l}\text { Petróleo Brasileiro S/A } \\
\text { - Petrobrás }\end{array}$ & S. Gonçalo & Indústria Química & 200.250 & $\begin{array}{c}192 \text { (dir) } \\
798 \text { (indir) }\end{array}$ \\
\hline $\begin{array}{l}\text { Fuhander Energia Brasil } \\
\text { Ltda }\end{array}$ & S. Gonçalo & Metalmecânica & 3.000 & $\begin{array}{c}35 \text { (dir) } \\
140 \text { (indir) }\end{array}$ \\
\hline $\begin{array}{l}\text { Agroenergia do Norte/ } \\
\text { Termelétrica José de } \\
\text { Alencar }\end{array}$ & Caucaia & $\begin{array}{l}\text { Geração de energia elétrica } \\
\text { A base de gás natural }\end{array}$ & 510.000 & $\begin{array}{c}30 \text { (dir) } \\
120 \text { (indir) }\end{array}$ \\
\hline Eternit S/A & Caucaia & Fábrica de material de construção & 117.000 & $\begin{array}{l}400 \text { (dir) } \\
1.600 \text { (ind) }\end{array}$ \\
\hline Aeris Energia S/A & S. Gonçalo & $\begin{array}{l}\text { Fábrica de pás de rotores } \\
\text { P/ turbinas de energia eólica }\end{array}$ & 80.000 & $\begin{array}{c}340 \text { (dir) } \\
1.360 \text { (ind) }\end{array}$ \\
\hline Refinaria Premium & Caucaia & Óleo refinado & 19.800 & $\begin{array}{c}90.000 \\
\text { (diretos e indiretos) }\end{array}$ \\
\hline
\end{tabular}

Fonte: Jornal O Povo (18-03-2012) 
Com a construção da Siderúrgica e da Refinaria, previstas para o Complexo (com investimentos estimados de 11 bilhões de reais e 19,8 bilhões de reais, respectivamente), estima-se que haverá

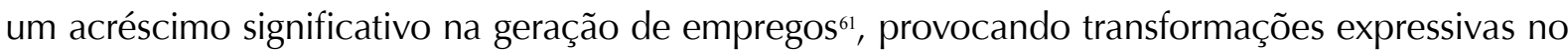
quadro urbano do Município e dos arredores ${ }^{62}$.

Grandes investimentos em infraestrutura vêm sendo realizados pelos Governos federal e estadual como apoio ao CIPP, como a Ferrovia Transnordestina ${ }^{63}$, a implantação do Terminal de Múltiplo $U_{s O^{64}}$ e outras obras relacionadas à logística, energia e desenvolvimento urbano.

Como se pôde constatar, conforme observação empírica, a instalação recente do CIPP e do próprio Porto do Pecém no Município de S. Gonçalo do Amarante não implicaram até agora a transformação substancial da área e o Município aparece caracterizado como rural, segundo a metodologia de classificação do Observatório das Metrópoles.

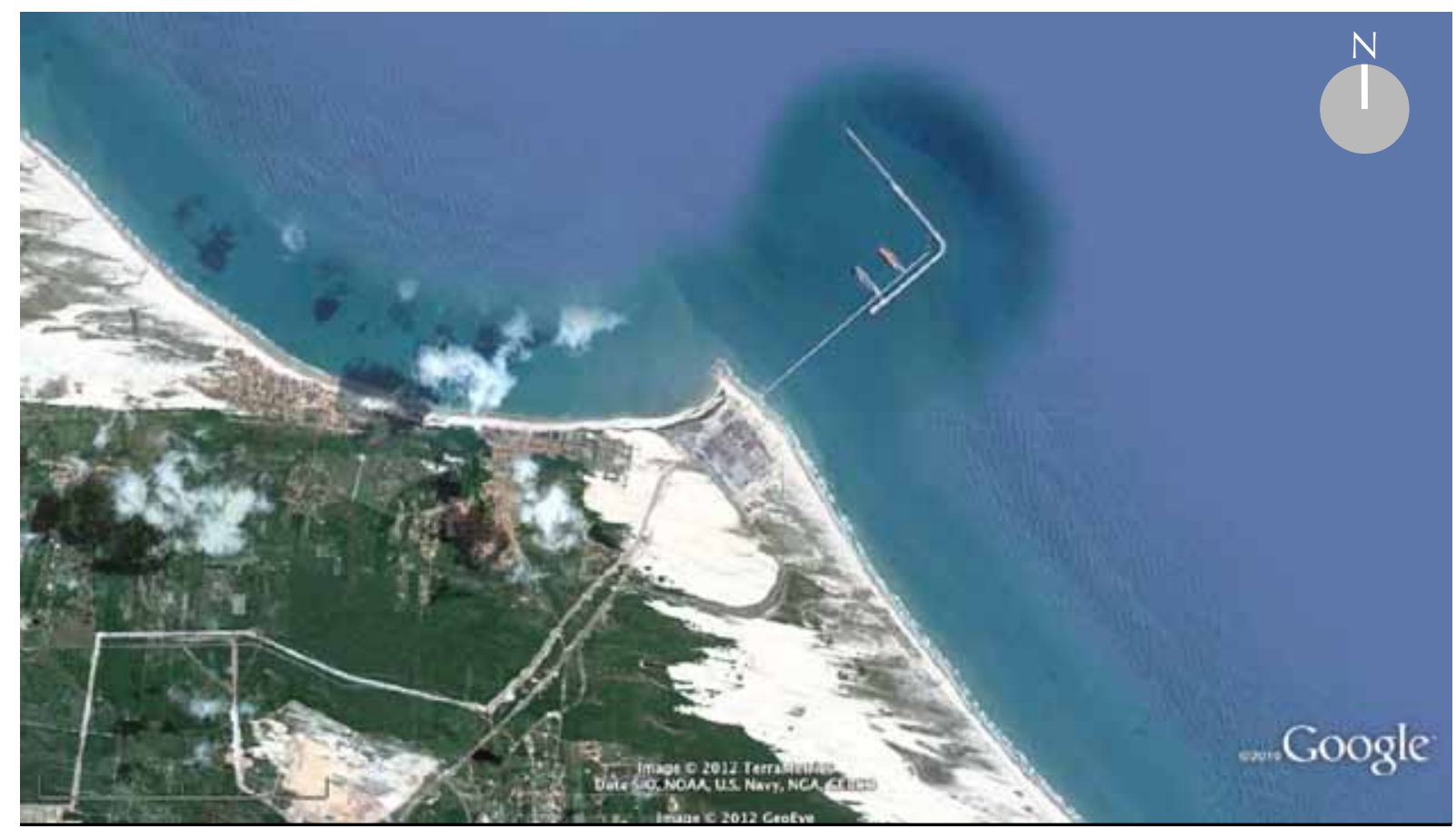

Fig. 3.76 CIPP

Fonte: Google Earth

\footnotetext{
${ }^{61}$ Segundo informações de técnicos do CIPP, deverão ser gerados cerca de cinco mil empregos, com a conclusão das obras previstas para o complexo.

${ }^{62}$ De acordo com a opinião do economista Roberto Smith, "a gestão do CIPP é muito complexa, porque mexe não só com o que está acontecendo, mas envolve uma visão prospectiva. Trata-se de uma área de intenso dinamismo. Vamos ter uma concentração populacional grande nos próximos dez anos e que, a meu ver, precisaria estar inserido num planejamento de uso e ocupação do solo" (Jornal O Povo, 18-03-2012).

${ }^{63}$ A ferrovia Transnordestina é uma das principais obras do Programa de Aceleração do Crescimento (PAC), que deverá interligar os polos de produção agrícola, mineral e industrial aos portos do Pecém (CE) e Suape (PE). A ferrovia, que envolve investimentos de R\$ 4,5 bilhões, possuirá $1.728 \mathrm{~km}$ de extensão, dos quais 527 no Ceará. A previsão de conclusão é o final de 2012.

${ }^{64}$ O Terminal de Múltiplo Uso - TMUT - do Porto do CIPP foi inaugurado em agosto de 2011, ampliando a movimentação de contêineres de 150 mil TEUs (contêineres de 20 pés) para 750 mil TEUs.
} 


\section{COMPLEXO INDUSTRIAL E PORTUĹaIO DO PESÉm PLANO DIRETOR}

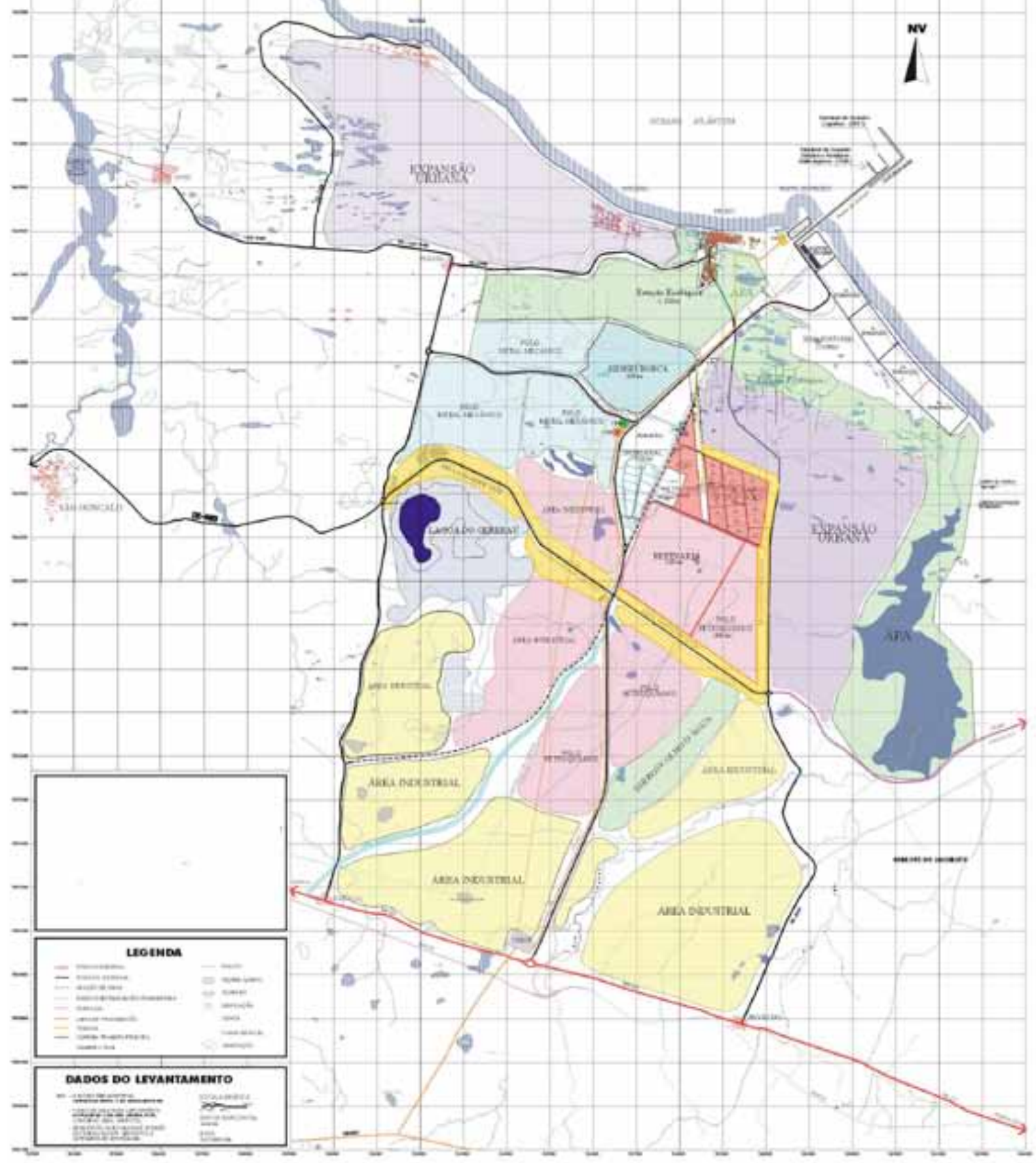

Fig. 3.77 Plano Diretor CIPP 


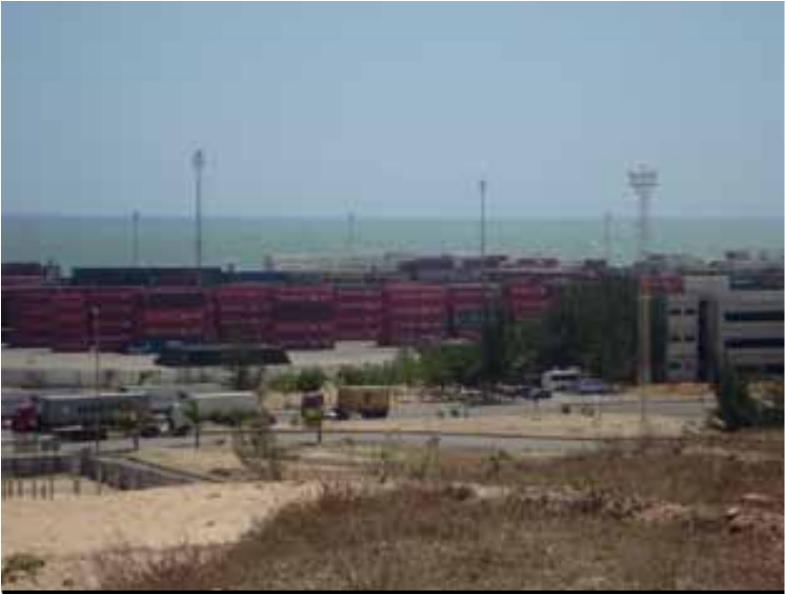

Fig. 3.78 CIPP/ Porto do Pecém

Fonte: acervo autora

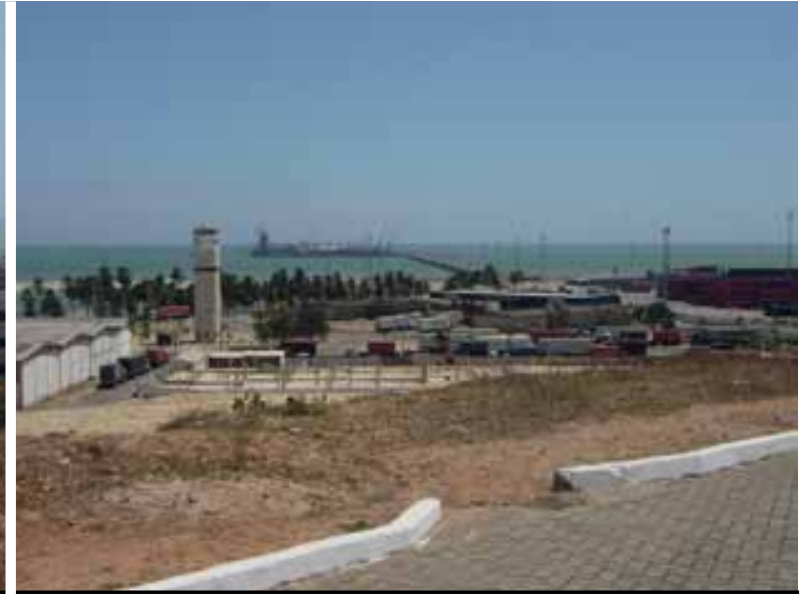

Fig. 3.79 CIPP/ Porto do Pecém Fonte: acervo autora

\section{O Porto do Pecém}

O terminal portuário do Pecém - Porto do Pecém - faz parte do CIPP e é administrado pela Ceará Portos, empresa do Governo do Estado. Foi concebido para propiciar operações portuárias mais eficientes e competitivas, com facilidade de acessos rodoviários e ferroviários e também para dar suporte à movimentação do Complexo Industrial do Pecém.

Possui uma área total de $75.000 \mathrm{~km}^{2}$, com área (atual) de armazenamento de $380.000 \mathrm{~m}^{2}$, a qual abriga 1.000 tomadas para refrigeração dos contêineres. O calado é de 16,00 m e o cais, com seu sistema de "piers", tem a extensão de 686,00 m. No ano de 2011, foi concluída uma expansão, com investimentos da ordem de 500 milhões de reais, aplicados na construção de mais dois "piers", cada qual com dois berços de atracação.

As principais cargas embarcadas são frutas ${ }^{65}$, calçados, pescados, couros e produtos têxteis e são importados insumos siderúrgicos, granéis líquidos e gás natural.

O porto é um terminal off shore ${ }^{66} \mathrm{e}$, segundo os técnicos do empreendimento, não carece de dragagem e possui custos operacionais baixos ${ }^{67}$, constituindo um diferencial entre os portos do Nordeste, além da vantagem de localização ${ }^{68}$ em relação aos portos da Europa e dos Estados Unidos.

A mão de obra portuária do Pecém é formada por aproximadamente 750 funcionários, divididos entre os quadros da Ceará Portos e de empresas terceirizadas. Esse operariado é em parte formado de operadores de empilhadeiras de contêineres, a maioria dos quais, segundo depoimento de técnicos do Porto, mora em Fortaleza e se desloca até o Pecém diariamente em ônibus fretados.

Desde a sua criação, o CIPP tem como objetivo criar um "retroporto" de amplo espectro (siderúrgica, refinaria e indústrias petroquímicas, etc.) de modo a consolidar um conglomerado industrial

\footnotetext{
${ }^{65}$ O Porto do Pecém ocupa o quarto lugar em exportação entre os portos brasileiros e o primeiro na exportação de frutas.

${ }^{66}$ Terminal off shore: porto em alto mar, longe da costa.

${ }^{67}$ Segundo o diretor do Porto do Pecém, Erasmo Pitombeira, o porto chega a exportar carga vinda até do Estado de Tocantins, em razão do baixo custo das operações.

${ }^{68}$ A condição geográfica do Pecém, com o menor tempo de trânsito entre o Brasil, os Estados Unidos e a Europa (com média de sete dias para alcançar o destino), funciona como um dos atrativos para conquistar os armadores e impulsionar as exportações brasileiras.
} 
que modifique a ocupação da área, transformando-a em zona urbanizada autônoma, definida pela concentração de pessoas, geração de empregos, etc. Por enquanto, porém, limita-se à polarização aos arredores do porto propriamente dito.

De fato, com o atraso da instalação da siderúrgica e da refinaria no CIPP, percebe-se que o desenvolvimento previsto para a região ainda não se efetivou. Não houve acréscimo significativo da área urbana, assim como as características do lugar não foram substancialmente modificadas. Considera-se, porém que, a médio ou longo prazo, com a consolidação do CIPP, deverá ocorrer significativa mudança em todo o setor, inclusive nas vias que dão acesso ao Complexo, quando os empreendimentos previstos estiverem efetivamente em funcionamento, atraindo população vultosa, pelas oportunidades de empregos gerados. E deverá provocar, por outro lado, um crescimento acentuado em direção ao Município de Fortaleza, ou seja, do CIPP para a Capital.

Na avaliação de Smith (2001, p.9), a área do CIPP "contingenciará a maior parte da ocupação no território de Caucaia, e a ocupação de São Gonçalo do Amarante, com exceção do Pecém, seguirá tendo um ritmo de ocupação e transformações mais lento".

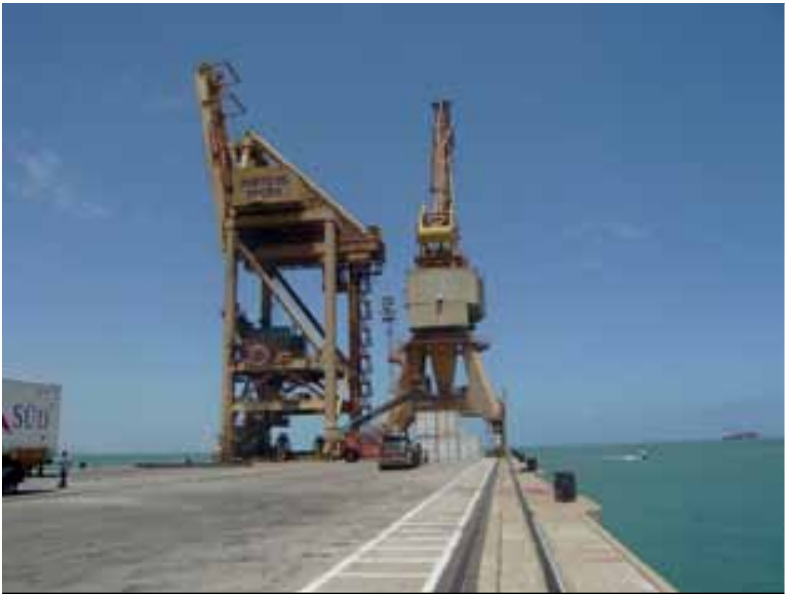

Fig. 3.80 Porto do Pecém Fonte: acervo autora

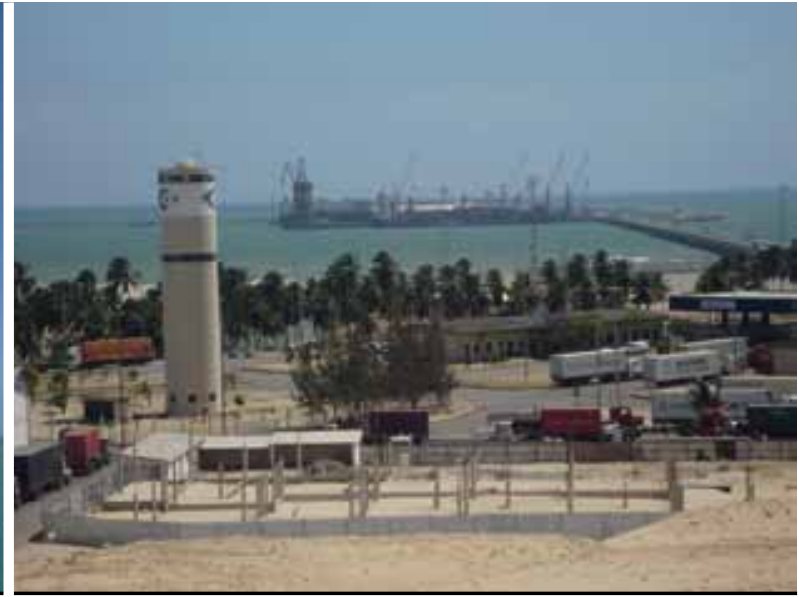

Fig. 3.81 Porto do Pecém Fonte: acervo autora

\section{Sobre a forma de ocupação do Vetor 3}

A ocupação do eixo oeste apresenta dinâmicas diferenciadas, quer dizer, relacionadas à função habitacional, à atividade turística e à implementação do CIPP, conforme foi explicitado há pouco. Cada uma dessas dinâmicas corresponde a épocas distintas e a processos urbanos diversos. No que se refere à função habitacional, é perceptível a conurbação entre os Municípios de Fortaleza e Caucaia, propiciada pela expansão da malha urbana formada pelos conjuntos habitacionais, por habitações populares e favelas situadas em áreas de risco, principalmente às margens dos rios Ceará e Maranguapinho. Esse tipo de assentamento residencial resulta numa periferia extensa e bastante densa, na porção oeste/sudoeste da Capital, que se relaciona com a fase inicial da metropolização cearense. 
Além da ocupação linear, verificada em determinados trechos ao longo do eixo viário e que vai se tornando rarefeita à medida que se afasta do Município de Fortaleza, observase a formação de dois polos expressivos: um turístico-residencial, concentrado no Icaraí e no Cumbuco ${ }^{69}$ e outro, mais recente, ainda em formação, junto ao CIPP (relacionado a atividades portuárias e industriais).

Diferentemente dos vetores descritos anteriormente, o Vetor 3, representado principalmente pelo eixo da BR 222, possui bifurcações que correspondem:

- à CE 091, via litorânea;

- à CE 085, Via Estruturante, de acesso a diferentes praias;

- à CE 421, via de transporte de cargas que dá acesso ao CIPP.

Esse sistema de vias compõe o vetor oeste, que comanda a expansão metropolitana nessa direção, a qual tende a se ampliar consideravelmente com a consolidação do CIPP, a médio e longo prazo. A CE 085 e a CE 421, construídas na última década e respectivamente ligadas às políticas do turismo e da indústria do Estado, tiveram impacto significativo na configuração metropolitana atual, conforme destacado.

\subsubsection{Vetor 4 - o setor sudeste}

O Vetor 4 situa-se no quadrante sudeste, em direção aos Municípios de Eusébio e Aquiraz e constitui o eixo imobiliário mais valorizado da Metrópole. Corresponde ao mais recente vetor de expansão e, diferentemente dos vetores anteriores, não está ligado à atividade industrial (ver figuras 3.82 e 3.83). É marcado, no trecho inicial, por uma área de centralidade em desenvolvimento, pela implantação de inúmeros condomínios residenciais horizontais no Município do Eusébio e pela construção de mega-empreendimentos de turismo na faixa litorânea, onde surgem núcleos voltados inteiramente para o turismo e lazer, gerando formas diferenciadas de tecido urbano.

Desde as últimas décadas do século passado, o Poder Público, juntamente com a iniciativa privada (proprietários de terras e empresários), começou a promover e dirigir o desenvolvimento da Cidade para a zona sudeste, implantando infraestrutura e serviços, construindo grandes obras e equipamentos públicos e abrindo ou duplicando grandes vias, como a av. Washington Soares.

A construção do Shopping Iguatemi (1982) e a localização de equipamentos como a Unifor - Universidade de Fortaleza (1973), o Centro de Convenções (1974), e posteriormente o Fórum Clóvis Bevilácqua (1997) e a FA7 - Faculdade 7 de Setembro (2000), ao longo da av. Washington Soares, fizeram dessa área um novo centro de interesses da Cidade.

\footnotetext{
${ }^{69}$ Este polo teve início com a construção das residências de veraneio, ainda na década de 1970-1980, as quais se transformaram, em grande parte, em residências permanentes e expandiu-se posteriormente, a partir da década de 1990-2000, com o incremento da atividade turística na "Costa do Sol Poente".
} 


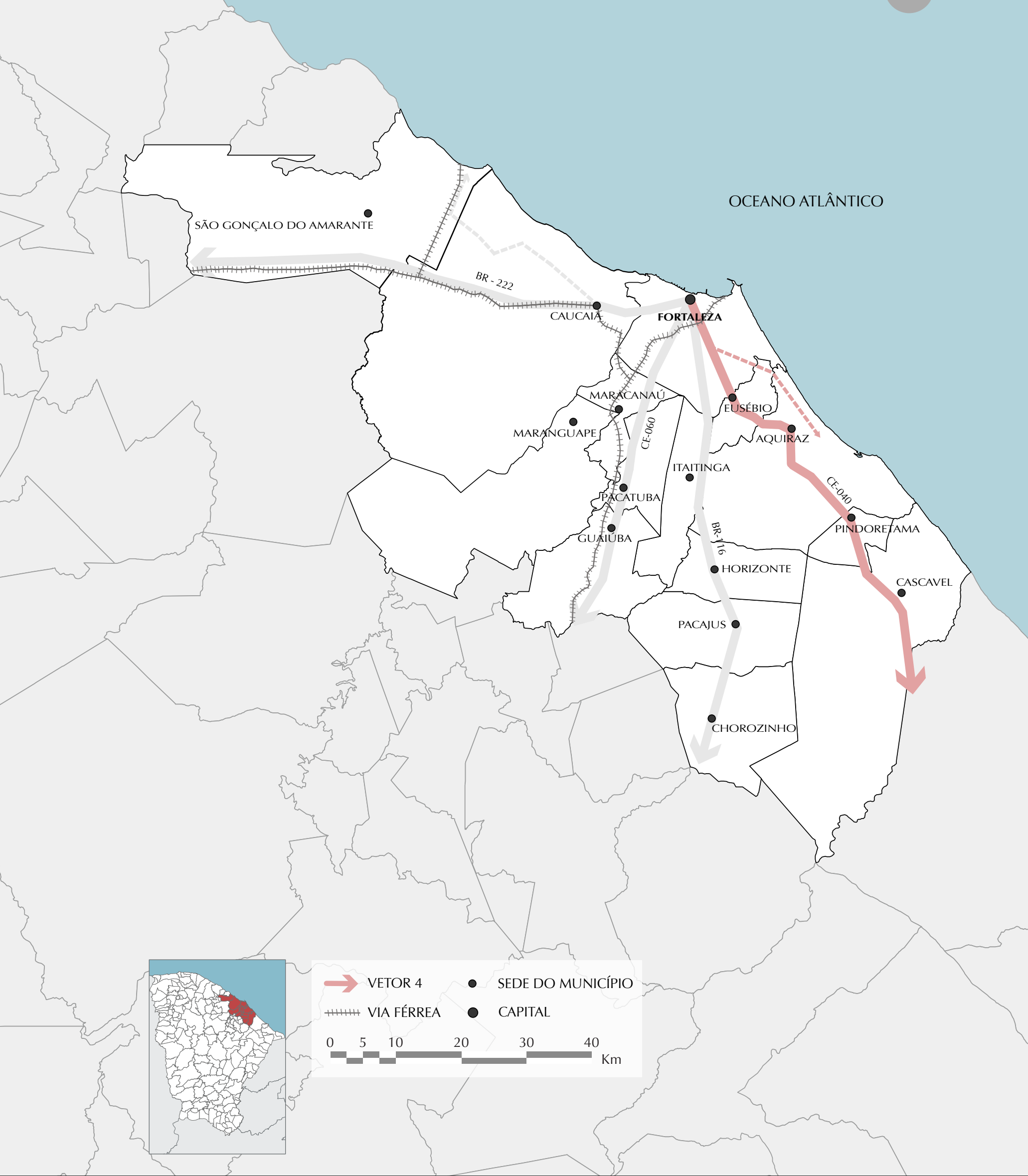




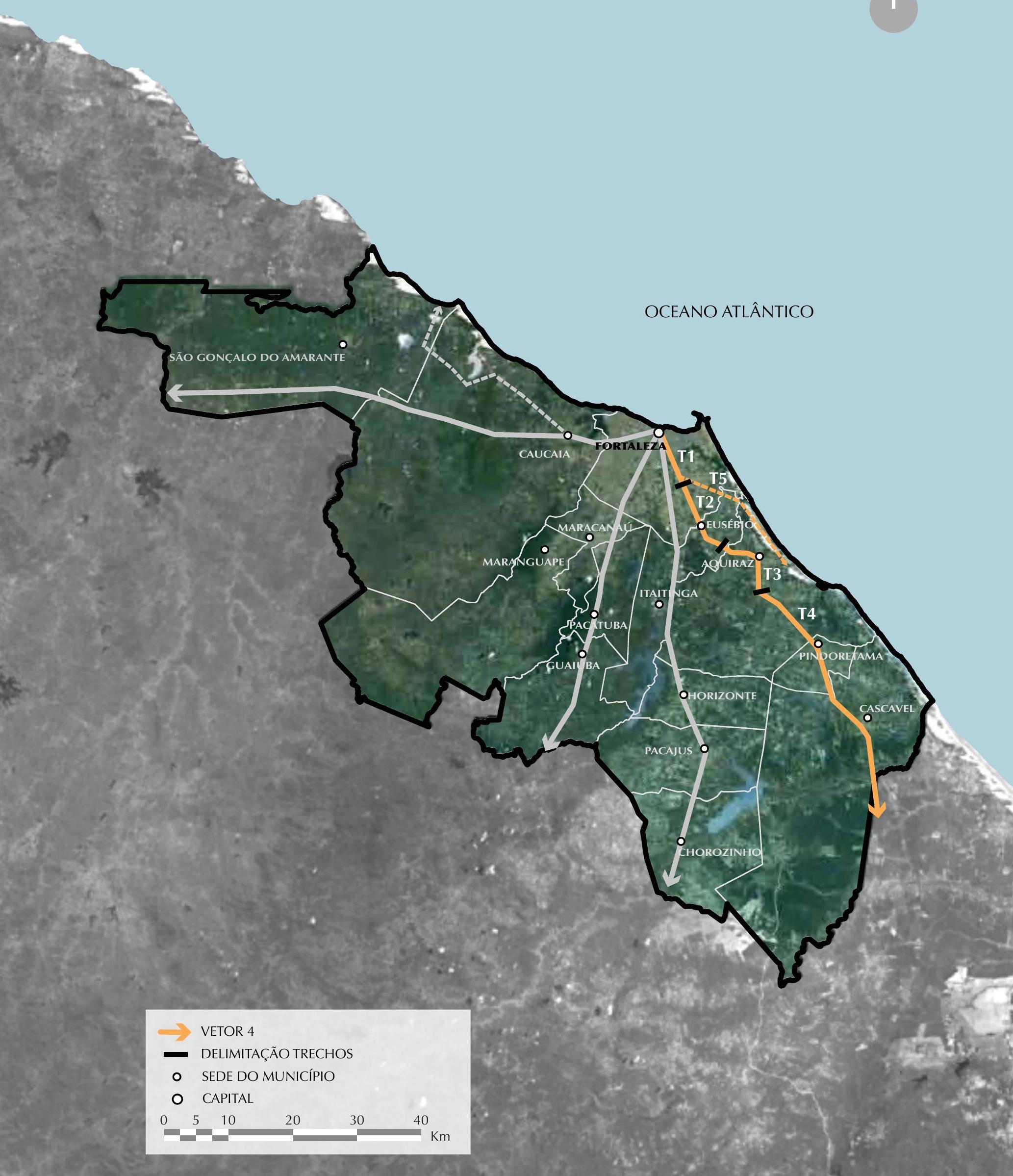


A transferência do Centro Administrativo do Estado, em 1980, para o bairro do Cambeba, assim como a sede do Poder Executivo estadual para o bairro Edson Queiroz ${ }^{70}$, também contribuíram para a valorização deste novo eixo. Com a ampliação da avenida, os terrenos lindeiros e próximos à via passaram a valorizar-se ainda mais. Outro fator importante no desenvolvimento dessa área foi a transferência do Fórum ${ }^{71}$, do Centro para esta avenida, com a decorrente mudança de profissionais e atividades ligadas ao setor judiciário.

Vale destacar, ainda, nessa região, no prolongamento da via, na direção do litoral leste do Estado e já nos Municípios de Aquiraz e Eusébio, o surgimento crescente de condomínios residenciais unifamiliares, revelando uma tendência de ocupação diferenciada.

Todo esse setor sudeste abrange rico patrimônio ambiental, sendo permeado por importantes recursos naturais, como o rio e o parque Cocó, que percorre grande extensão na área, vegetação diversificada e abundante, a lagoa da Sapiranga e a lagoa da Precabura, o rio Pacoti, além das dunas e toda a faixa litorânea leste.

A área configura-se também como de grande potencial turístico, sobretudo junto ao litoral, onde se têm implantado empreendimentos de vulto, o que lhe altera a fisionomia e atrai novos investimentos imobiliários.

A análise aprofundada desse vetor será objeto do capítulo 4, razão por que a descrição dos referidos trechos será feita de modo sucinto, apenas para caracterizar a área em foco.

\section{TRECHO 1 - A centralidade da av. Washington Soares}

O trecho inicial do vetor 4 corresponde à av. Washington Soares ${ }^{12}$, no bairro Edson Queiroz, nas proximidades do Shopping Iguatemi e parque do Cocó e prolonga-se até à Casa José de Alencar, da UFC, no bairro de Messejana.

Essa área, em parte zona residencial de alta renda - considerada a princípio como uma extensão do bairro da Aldeota, eleito bairro de elite da Cidade - desenvolveu-se, em certa medida, em razão do esgotamento de terrenos naquele bairro ${ }^{73}$. Muitos dos seus moradores são antigos habitantes da Aldeota, que passaram a procurar locais mais aprazíveis para morar, onde havia grande quantidade de terrenos disponíveis para construir suas mansões.

Essa forma de ocupação confirma a tendência apontada por Villaça (1998) de localização dos bairros residenciais de alta renda ${ }^{74}$, sempre na mesma direção, formando "setores de círculo"75. Ou

\footnotetext{
${ }^{70}$ A sede do Executivo Estadual funcionou no bairro Cambeba entre os anos 1987 e 2002, durante o Governo das Mudanças. Em seguida, transferiu-se para o Palácio de Iracema, no bairro Edson Queiroz, durante os governos Lúcio Alcântara e Cid Gomes, lá funcionando até o ano de 2011, quando voltou a ocupar o Palácio da Abolição, no bairro do Meireles.

${ }^{71}$ A transferência do Fórum Clóvis Bevilácqua para essa área da Cidade acarretou visível prejuízo para a população, em virtude de sua localização excêntrica.

${ }^{72}$ A Av. Washington Soares é a principal via de saída da Cidade em direção ao litoral leste.

${ }^{73}$ A transformação do bairro da Aldeota, desde a década de 1980, num dinâmico centro de comércio e negócios também provocou a procura, por parte de seus habitantes, por locais mais tranqüilos e aprazíveis para morar.

${ }^{74} \mathrm{~A}$ atração exercida pelos sítios naturais privilegiados e suas características paisagísticas constitui importante fator da expansão da zona residencial de mais alta renda da cidade.

75 "A organização social baseada na segregação ocorre nas metrópoles brasileiras, em primeiro lugar em uma única 'região geral' da cidade, e, em segundo lugar, formando 'setores de círculos', de acordo com o modelo de Hoyt (1939), citado por Villaça (1998). A forma de organização numa mesma radial, além de demonstrar a necessidade de manter o acesso ao Centro, permite também maior controle do espaço urbano, conforme teoria demonstrada pelo autor. O geógrafo Roberto Lobato Corrêa (1983, p.69) também comenta o modelo de Hoyt, o qual se baseia, segundo ele, 'na tendência auto-segregativa da população de alto status, que se expande ao longo de um eixo de circulação que corta as melhores áreas da cidade, de onde então pode exercer um efetivo controle de seu território. A partir de sua ação estabelecem-se os demais grupos sociais em outros setores'" (DIÓGENES, 2005, p.39).
} 
seja, a classe mais abastada "tende a se concentrar cada vez mais em regiões gerais ou conjunto de bairros da cidade". Em Fortaleza, a população de maior renda se deslocou progressivamente do Centro para o setor leste/sudeste; primeiramente, desde as primeiras décadas do século XX, ocupou os bairros da Aldeota e do Meireles e, posteriormente, os bairros do Papicu e Edson Queiroz, este último o maior e o mais dinâmico do setor sudeste (ver figura 3.84).

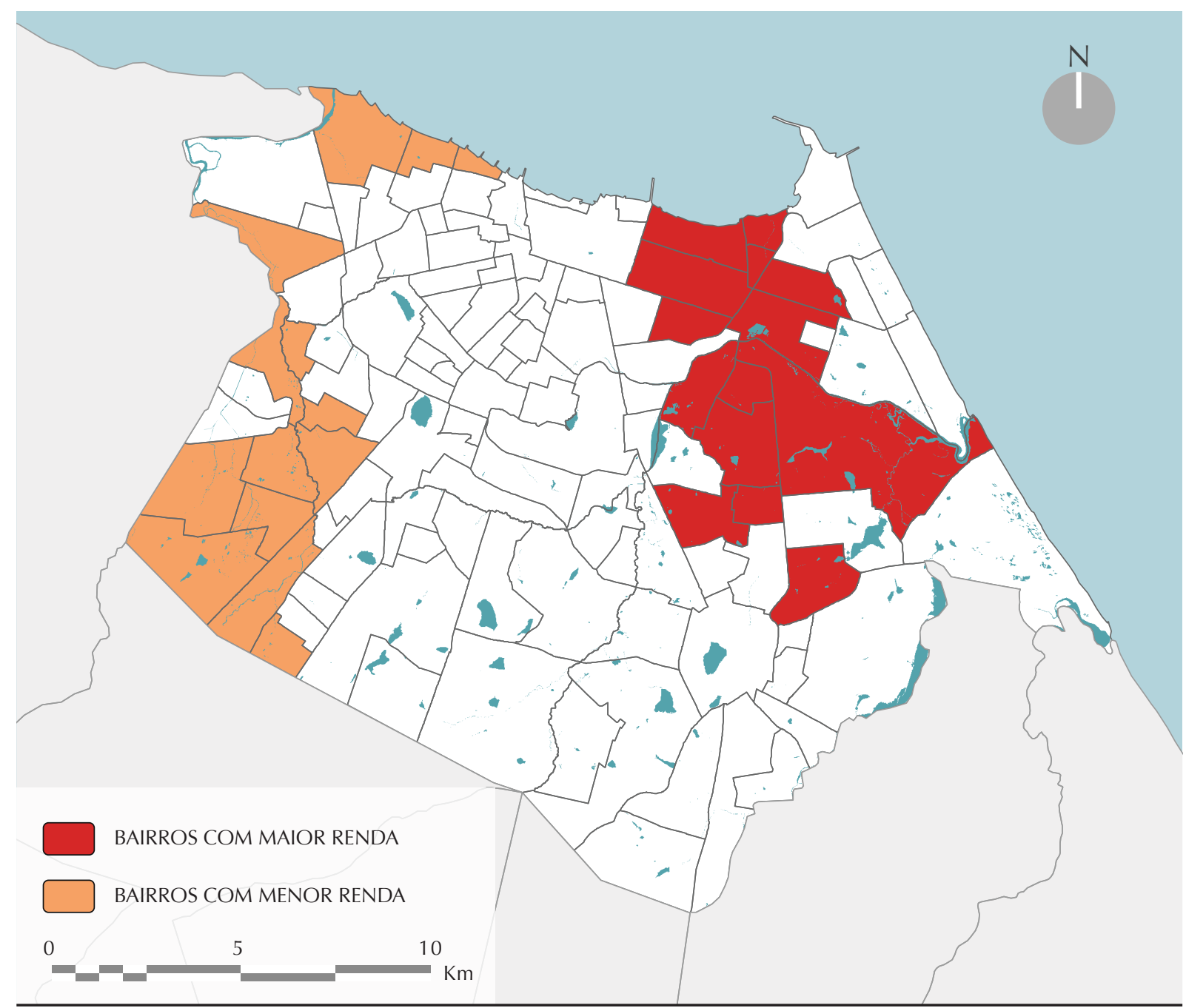

Fig. 3.84 Mapa Fortaleza: bairros residenciais de alta renda/baixa renda Fonte: IBGE (2010) - elaborado pela autora

Existe, entretanto, nesta região, uma espécie de bolsão formado por habitações precárias, resultado de invasões e ocupações irregulares, a chamada Comunidade do Dendê, situada junto a habitações de elevado padrão. Trata-se de uma área considerável, localizada por trás da Unifor, a cerca de 600,00 m da av. Washington Soares, onde habitam aproximadamente 3.400 famílias (ver figura 3.85). 


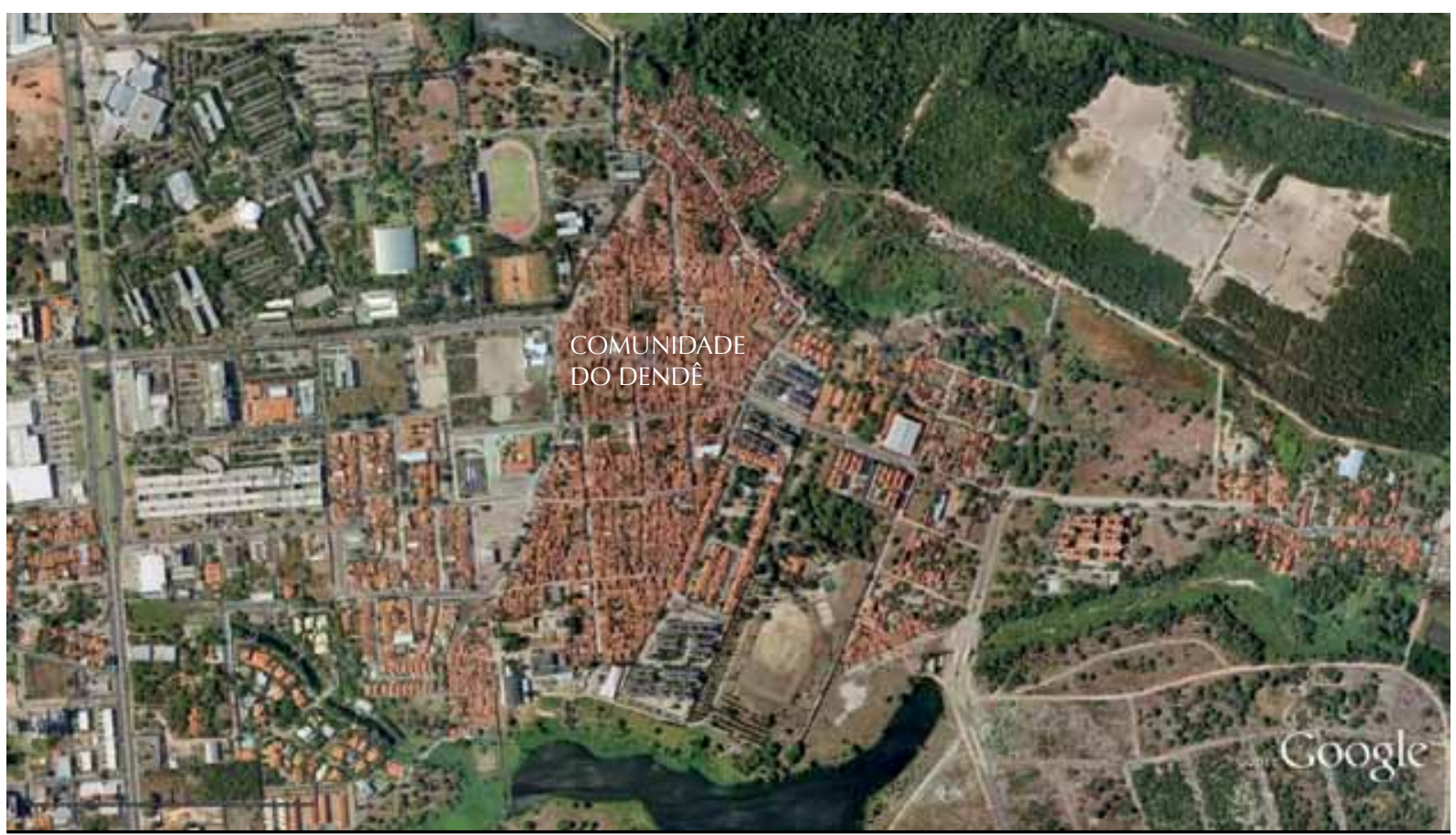

Fig. 3.85 Comunidade do Dendê

Fonte: Google Earth

Em meados dos anos 1970-1980, o Poder Público, juntamente com o setor privado, passou a implantar infraestrutura e construir grandes obras e equipamentos públicos nessa área, junto à av. Washington Soares, induzindo o crescimento da Cidade nessa direção.

A transformação desta avenida/rodovia' em corredor terciário de comércio e serviços traduz-se também como um impacto urbano resultante da tendência apontada desde a implantação de loteamentos de veraneio e condomínios residenciais de classe alta nas zonas de praia dos municípios vizinhos (Eusébio e Aquiraz), nas décadas de 1980-2000.

A inauguração do Shopping Iguatemi, em 1982 (e sua ampliação, em 1992) e o posterior alargamento da av. Washington Soares, em 1999, fez com que se iniciasse um intenso processo de uso e ocupação do solo em seu entorno, desencadeando um aumento acentuado da atividade terciária ao longo da via, atualmente o eixo imobiliário mais dinâmico da Cidade.

Novo impulso no movimento de descentralização das localizações residenciais das classes médias e altas se dá com a implantação do Shopping lguatemi, em 1982, nas margens do rio Cocó. A atração que este equipamento irá exercer sobre o mercado especulativo da terra irá apontar novo eixo de expansão urbana, reforçado pela existência, naquela região, de equipamentos como o campus da Unifor e o Centro de Convenções (FERNANDES, 2004, p.74).

Começou a formar-se desde então, nessa região, um polo terciário dinâmico, em conformidade com os processos atuais de produção do espaço, isto é, o surgimento de novas áreas de centralidade na Metrópole, ou a policentralidade. Essa centralidade se desenvolve de forma "linear" ${ }^{2}$, ao

\footnotetext{
${ }^{1}$ Uma ação estratégica do Governo estadual, em 1984, transformou a av. Washington Soares de via "municipal" (avenida) para "estadual" (rodovia).

${ }^{2}$ Essas novas áreas de centralidade que se desenvolvem ao longo de eixos viários (ruas, avenidas, vias expressas, etc.) surgem assim em virtude da maior mobilidade espacial, favorecida pela difusão do transporte individual, e situam-se quase sempre em zonas residenciais de alta renda, como é o caso da av. Santa Mônica, em Los Angeles e a área comercial linear da orla de Boa Viagem e Piedade, no Recife, e na Barra da Tijuca, no Rio de Janeiro.
} 
longo da av. Washington Soares, onde são instalados grandes equipamentos, ocupando terrenos livres, às margens da avenida, com amplas áreas de estacionamento ${ }^{3}$. São equipamentos quase sempre de grandes dimensões, como faculdades, Centro de Convenções, shoppings, Fórum, escolas, grandes lojas, etc (ver figuras 3.86 a 3.89).

A av. Washington Soares constitui assim a nova localização privilegiada de sedes de empresas, edifícios de escritórios, equipamentos culturais, instituições de ensino superior e serviços avançados. Esse trecho inicial do Vetor 4, portanto, configura-se como uma área de centralidade em expansão, que tende a ser reforçada com a construção do Centro de Eventos ${ }^{4}$, previsto para ser inaugurado até meados de 2012.

Observa-se, entretanto, que ainda restam grandes terrenos desocupados, sobretudo na vizinhança da via, nas ruas lindeiras, onde predominam habitações unifamiliares. Edifícios altos, de apartamentos e escritórios são localizados no trecho próximo ao Shopping Iguatemi e à Unifor.

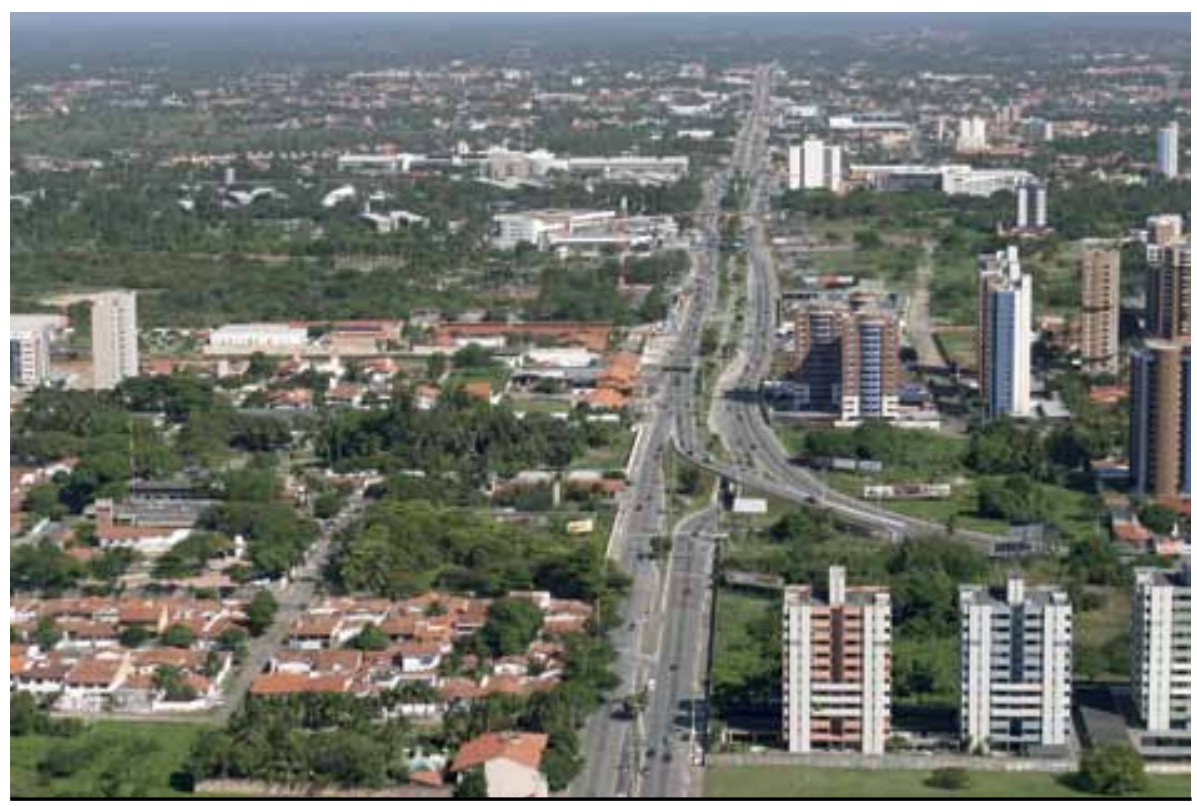

Fig. 3.86 Av. Washington Soares

Fonte: http://img324.imageshack.us/img324/4159/ave2jc.jpg

No final do trecho, próximo ao cruzamento com a av. Maestro Lisboa (CE 025), percebe-se outra concentração de edifícios residenciais, todos de 14 pavimentos $^{5}$, de construção bem recente, o que tem alterado bastante a ocupação e a densidade dessa área.

A av. Washington Soares é cortada por importantes vias que fazem a ligação da área com a BR 116 e outras partes da zona oeste da Cidade, como a av. Oliveira Paiva, nas "Seis Bocas", e a av. Ministro José Américo, que dá acesso ao Centro Administrativo do Cambeba.

\footnotetext{
${ }^{3}$ Apesar de amplas, algumas áreas de estacionamento já se mostram deficientes, como ocorre com a Unifor, o Fórum e o Centro de Convenções.

${ }^{4}$ A localização do Centro de Eventos nessa área abrange toda uma reformulação no sistema viário do entorno, com túneis e viadutos, operação que já se encontra em fase de execução.

${ }^{5} \mathrm{O}$ limite de altura deve-se às restrições impostas pela legislação urbana devido ao chamado "cone aéreo".
} 


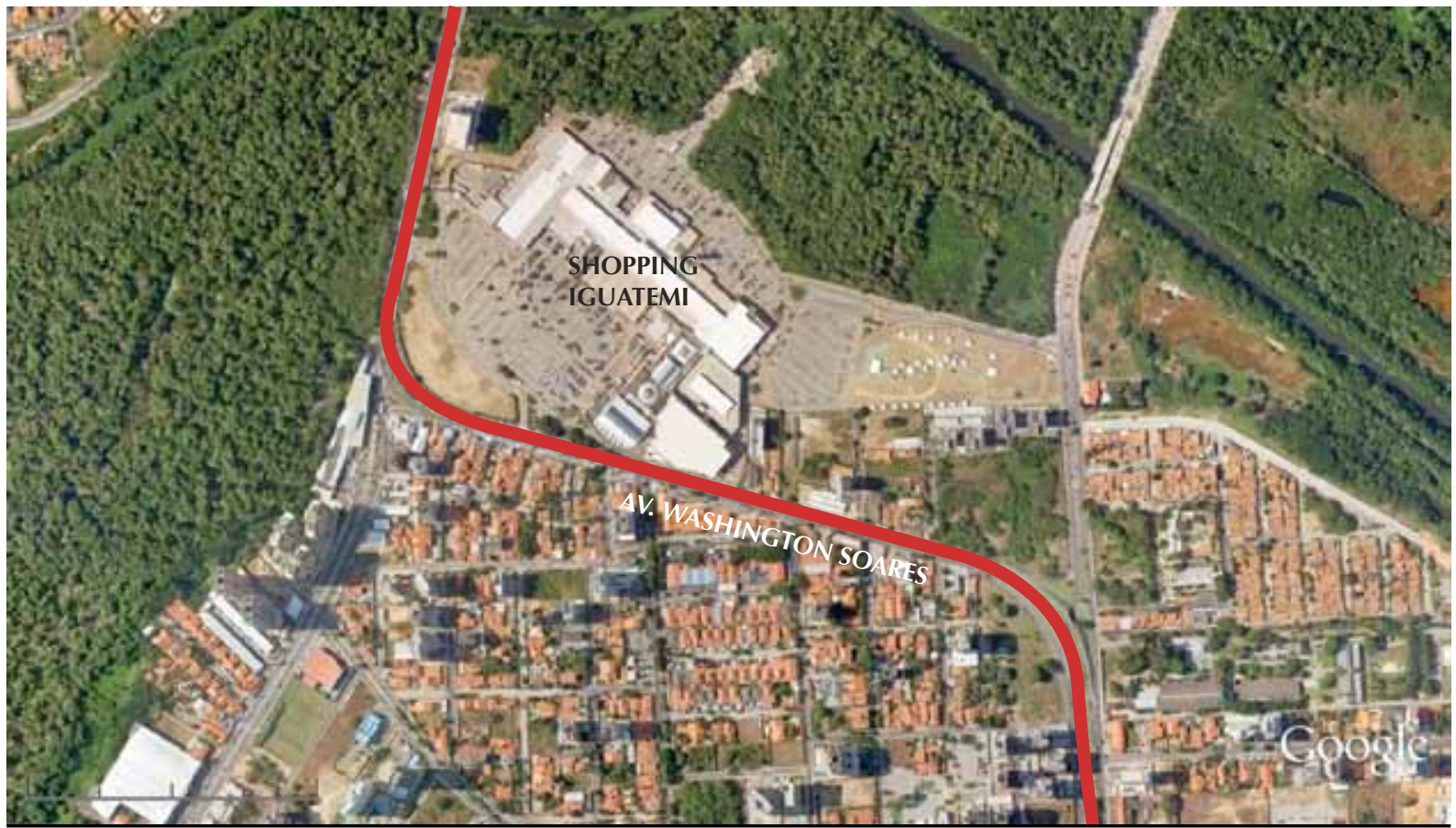

Fig. 3.87 Vetor 4: Trecho 1 (av. Washington Soares/ Shopping Iguatemi)

Fonte: Google Earth - elaborado pela autora

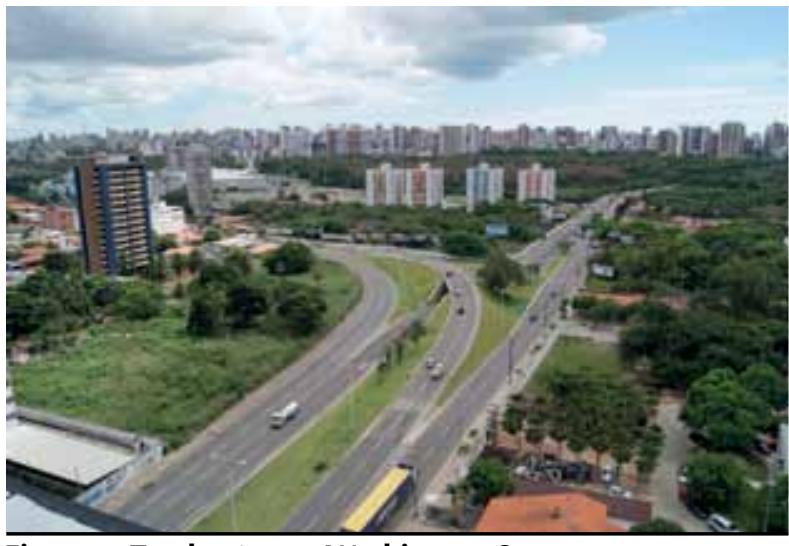

Fig. 3.88 Trecho 1 - av. Washington Soares

Fonte: acervo autora

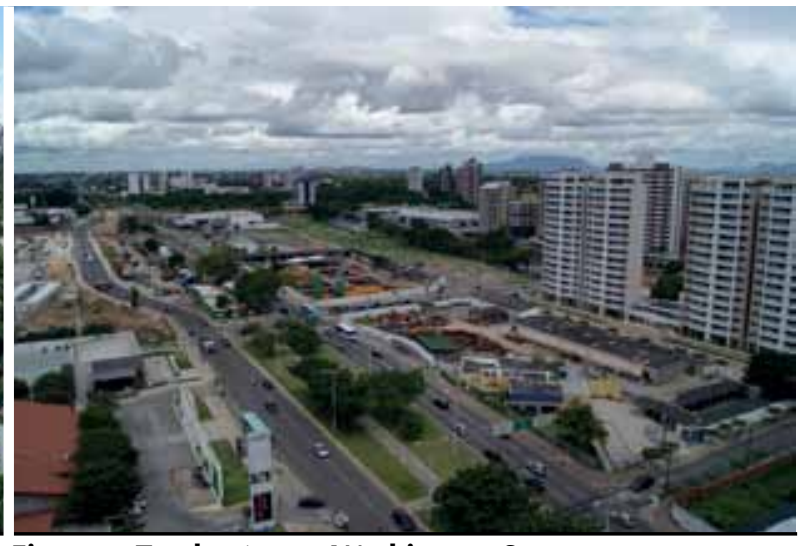

Fig. 3.89 Trecho 1 - av. Washington Soares

Fonte: acervo autora

\section{TRECHO 2 - O Município do Eusébio e os condomínios fechados}

O trecho seguinte do vetor já corresponde à CE 040, que segue em direção ao litoral leste do Estado. A via passa no limite leste do bairro de Messejana, de ocupação antiga, bastante adensado, e cruza uma região onde se concentram inúmeros condomínios horizontais. Observações de campo evidenciam a crescente implantação desses empreendimentos no eixo sudeste de expansão metropolitana.

Esses condomínios, de várias formas e dimensões, em maioria são destinados à classe média e média-alta. Revelam processos contemporâneos de produção do espaço da Metrópole, constituindo territórios fechados que se multiplicam rapidamente pelo tecido urbano (ver figuras 3.90 e 3.91). 
O Condomínio Alphaville - já presente em outras cidades do País - inaugurou um novo padrão de uso e ocupação do solo, que tem servido de modelo a outros empreeendimentos. São dois os condomínios Alphaville em Fortaleza, ambos situados nesse vetor sudeste.

Este setor configura-se, presentemente, como área preferencial de expansão habitacional da classe média alta fortalezense, a qual busca áreas mais afastadas (embora nas proximidades da Capital) e tranquilas, com segurança e maior "contato com a natureza", buscadas nesse tipo de moradia. O preço dos terrenos também atua como atrativo, já que são mais baixos do que aqueles praticados nas áreas mais urbanizadas da Capital. Cada vez maior número de pessoas elege o condomínio horizontal fechado como local preferido de moradia.

O cliente que compra casa hoje não compra mais a casa isolada. Ele quer comprar casa em condomínio. O que acontece é que essas casas precisam de mais terrenos e Fortaleza está muito adensada, tem pouco terreno, então esses condomínios tão se espalhando para a região metropolitana (Jornal O Povo, 13-04-2010).

A região do Eusébio ${ }^{7}$ é a preferida para a localização de condomínios de casas. São inúmeros os empreendimentos construídos em uma década" de expansão ininterrupta. "A população é constituída principalmente de casais jovens de classe média que procuram maior qualidade de vida, mais ar puro, menos poluição" (Jornal O Povo, 13-04-2010).

Os vários anúncios veiculados na internet sobre condomínios horizontais aí situados exploram sobretudo a segurança, o planejamento, o contato com a natureza e a área verde, a melhor qualidade de vida, o acesso a equipamentos coletivos de lazer e a infra-estrutura, atrativos proporcionados por este tipo de empreendimento.

A acessibilidade também é questão considerada e concorre para o incremento dos condomínios nessa região, sobretudo depois do alargamento da av. Washington Soares e da duplicação das pistas da CE 040, vias que oferecem fácil acesso a esses empreendimentos, apesar de estarem situados em áreas mais distantes da Capital.

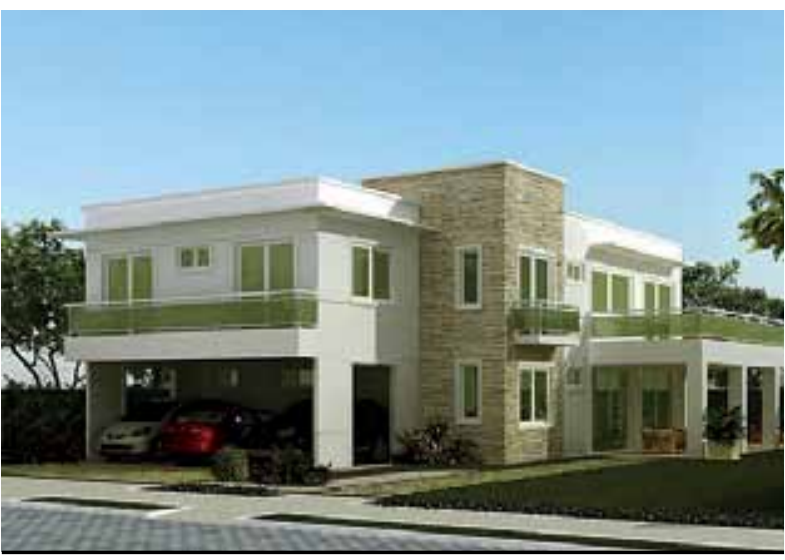

Fig. 3.90 Casa condomínio Quintas do Lago

Fonte: http://www.skyscrapercity.com/showthread.php

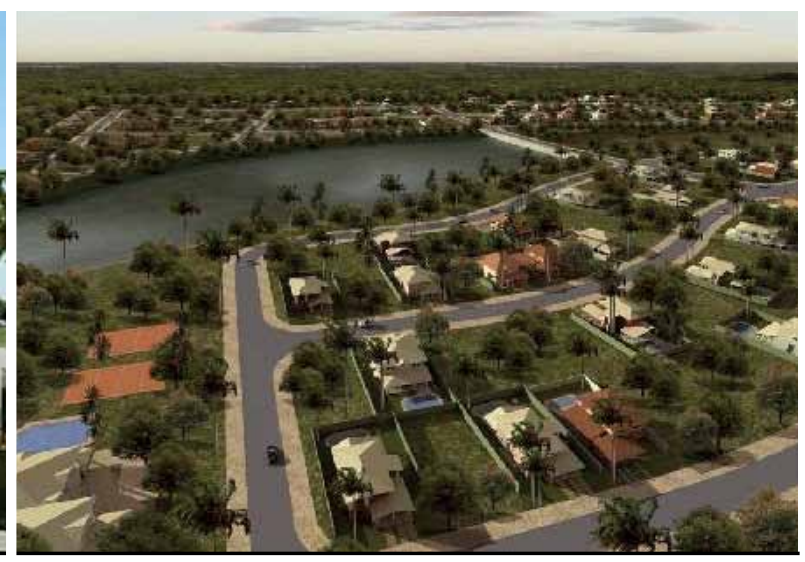

Fig. 3.91 Condomínio Alphaville Eusébio Fonte: http://investfortaleza.com/index.php

\footnotetext{
${ }^{6}$ Em São Paulo, a urbanização do Alphaville foi concebida a partir de "um projeto urbanístico cujo conceito se apoiou na idéia de 'cidades de contorno', semelhantes às edge-cities americanas. São espaços autônomos, situados nas bordas de eixos metropolitanos, onde projeto urbanístico e modo de vida formam um conjunto indissociável". (MEYER, GROSTEIN \& BIDERMAN, 2004, p.62).

${ }^{7}$ Outra razão determinante para a localização dos condomínios horizontais no Município do Eusébio recai na legislação, mais favorável e com menores restrições para este tipo de empreendimento, assunto que será desenvolvido com detalhes no próximo capítulo.

${ }^{8}$ O primeiro projeto de condomínio aprovado na região do Eusébio foi em 2002.
} 
A crescente implantação de condomínios e loteamentos fechados nessa região tem redefinido a dinâmica urbana do Município do Eusébio. Apesar de apresentar ainda grandes extensões de áreas desocupadas, todo o seu território $\left(76,5 \mathrm{~km}^{2}\right)$ já é considerado urbano, resultado do intenso processo de parcelamento do solo pela transformação de propriedades rurais em loteamentos para esses empreendimentos.

Os moradores desses condomínios mantêm total dependência da Capital, pois precisam se deslocar para suas atividades diárias - trabalho, escolas, lazer, comércio e serviços, atividades não exercidas ali, o que reforça a estreita dependência do automóvel particular.

Pode-se, enfim, afirmar que a construção de condomínios fechados, como núcleos autônomos nessa região, contribui para o espraiamento da área urbanizada metropolitana. O assunto será retomado com profundidade no capítulo 4.

Outras modalidades de serviços, como a corretagem de imóveis e empresas de segurança armada, foram identificados nesse trecho, ambos ligados a essa tipologia habitacional, que predomina na região.

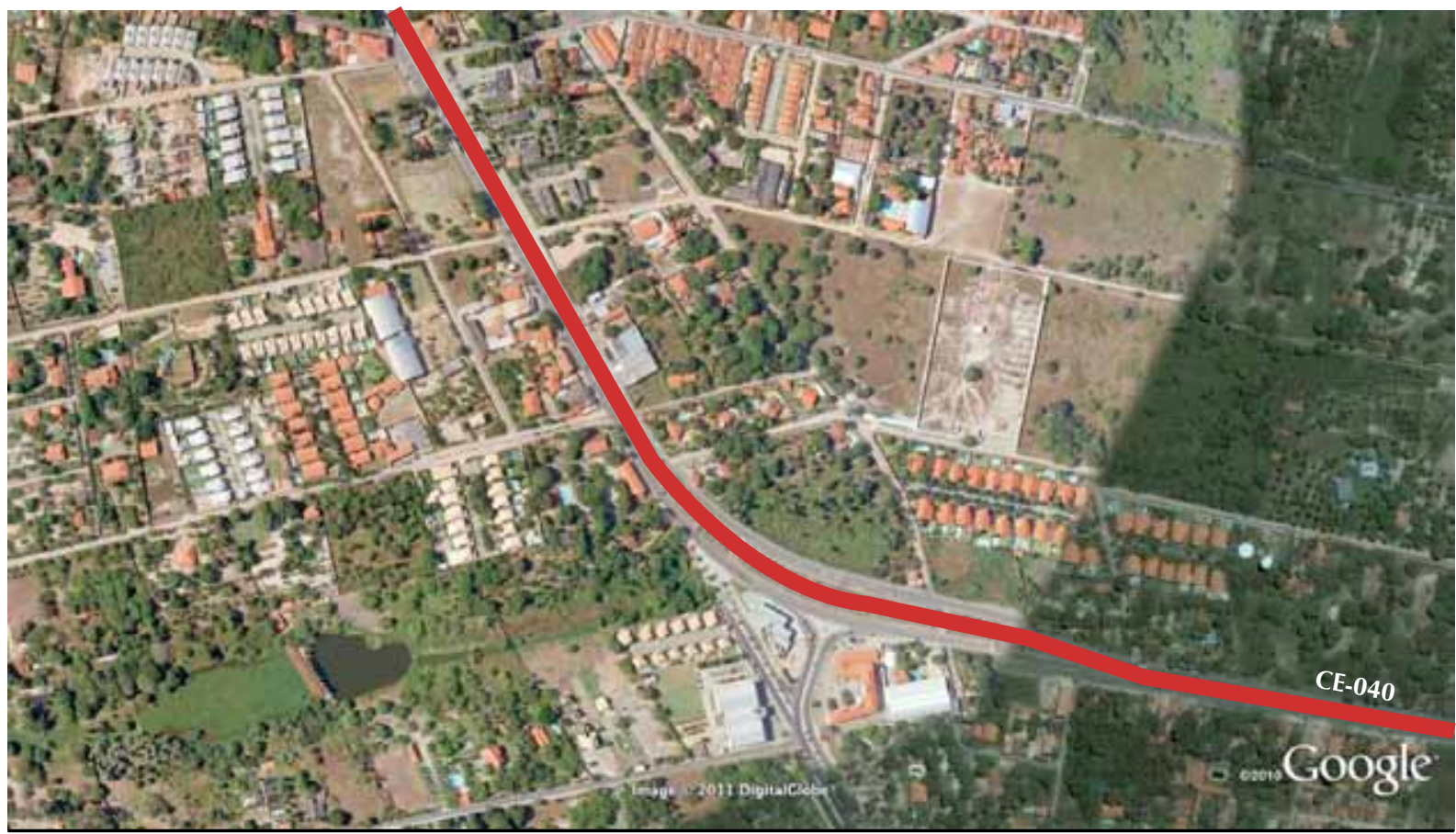

Fig. 3.92 Vetor 4: Trecho 2 (Condomínio fechados no Eusébio) Fonte: Google Earth - elaborado pela autora

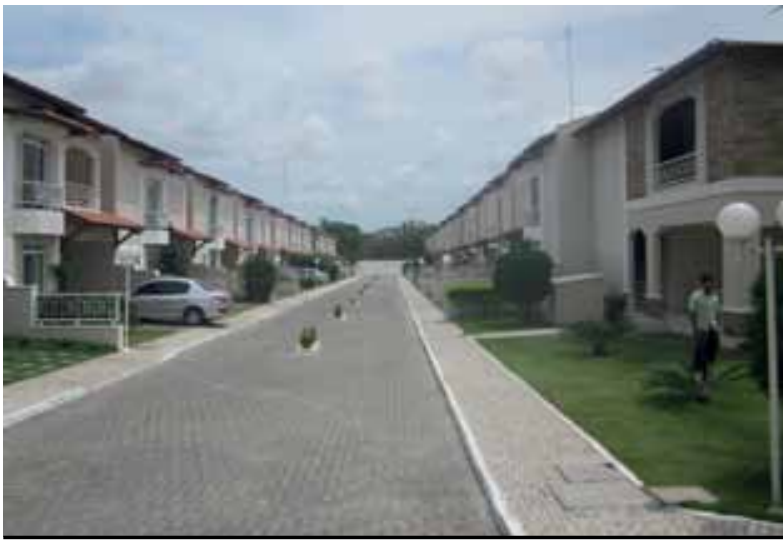

Fig. 3.93 Trecho 2 - cond
Fonte: acervo autora

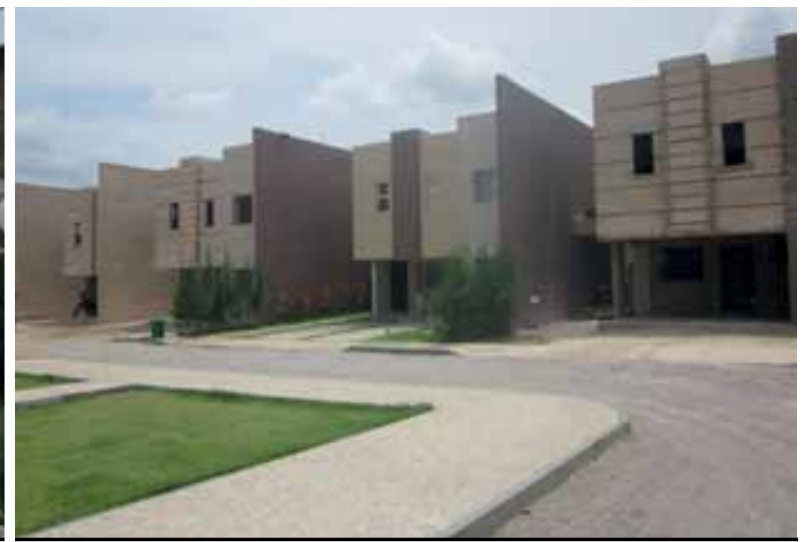

ig. 3.94 Trecho 2 - condomínios horizontais no Eusébio Fonte: acervo autora 


\section{TRECHO 3 - A CE 040}

O trecho seguinte da rodovia CE 040 segue em direção à Sede de Aquiraz e à Praia do Iguape. Após a duplicação da rodovia, o acesso à Sede foi desviado para uma via secundária. Algumas edificações, entretanto, são vistas nas margens da estrada, embora predominem áreas desocupadas (ver figuras 3.95 a 3.97).

É comum a incidência de sítios nessa área, com acessos feitos pela $\mathrm{CE}$, assim também como placas indicativas de loteamentos diversos, o que aponta para uma futura ocupação mais efetiva ao longo do vetor. Como se trata de uma via de acesso às praias do litoral leste, goza de crescente valorização imobiliária.

A CE 040 tangencia a lagoa do Catu, onde têm surgido empreendimentos ligados ao lazer e turismo, indicando um tipo de ocupação diferenciada, que se assemelha aos condomínios fechados implantados junto à orla marítima.

É nesse trecho que se alcança a via que leva à Praia do Iguape, de ocupação mais antiga, e à Praia da Marambaia, onde está localizado o Aquiraz Riviera, um resort integrado, de grandes dimensões, já parcialmente em funcionamento9. Toda uma infraestrutura - em grande parte financiada pelo Governo estadual - foi criada nessa área, de modo a viabilizar o empreendimento, como vias de acesso, energia elétrica, rede de água, de telecomunicações, estação de tratamento, etc.

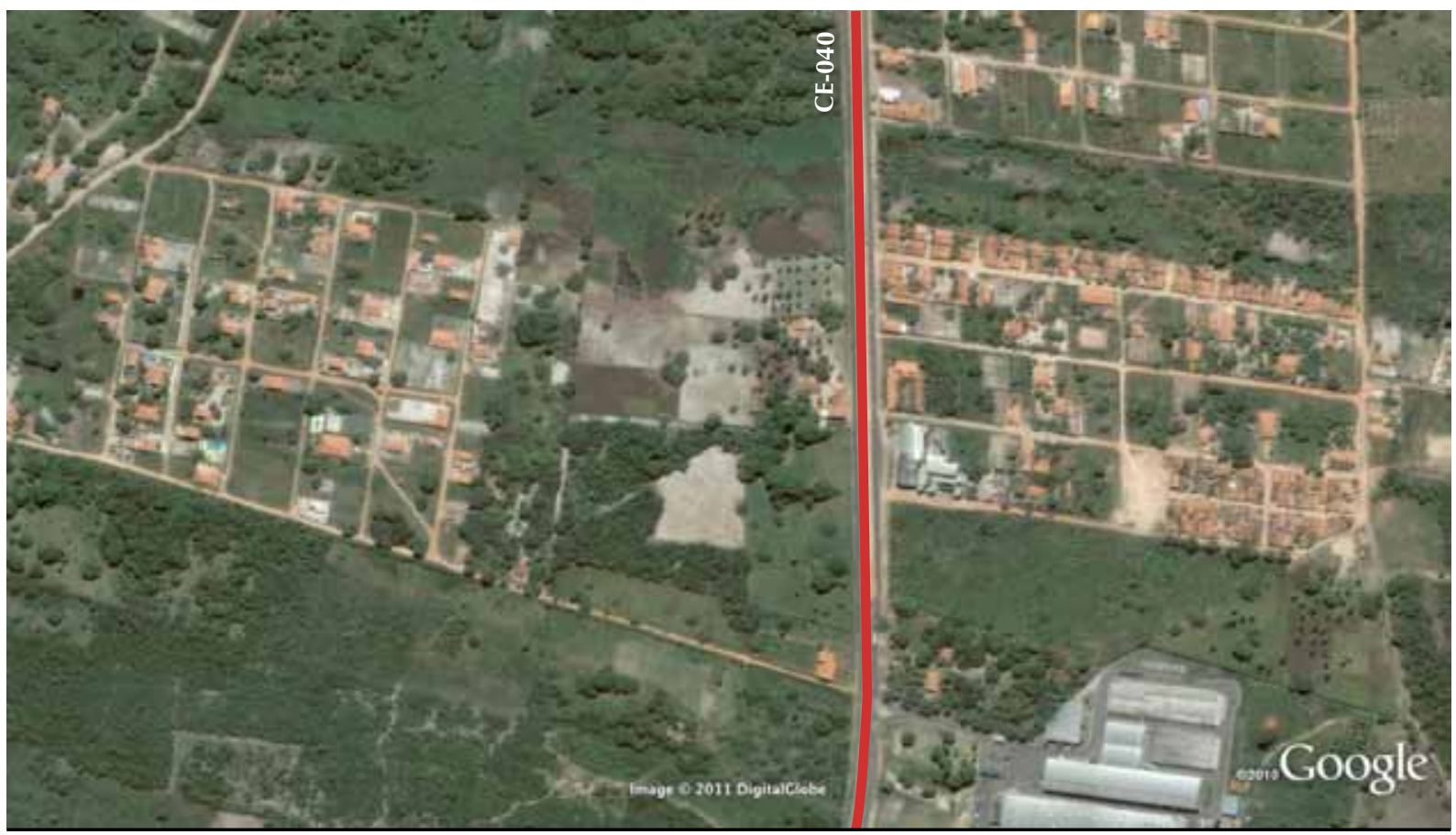

Fig. 3.95 Vetor 4: Trecho 3 (CE-040)

Fonte: Google Earth - elaborado pela autora

\footnotetext{
${ }_{9}^{9}$ O Hotel Dom Pedro Laguna foi inaugurado em 2010, assim como o campo de golfe, de 18 buracos. A segunda etapa do empreendimento, que abrange a construção de condomínios de lazer, centro comercial e demais hotéis, deverá ser concluída até o final de 2013.
} 


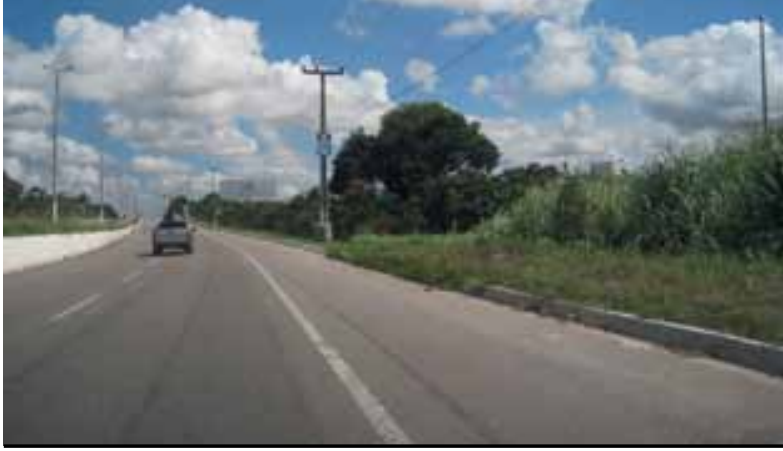

Fig. 3.96 Trecho 3 - rodovia CE 040

Fonte: acervo autora

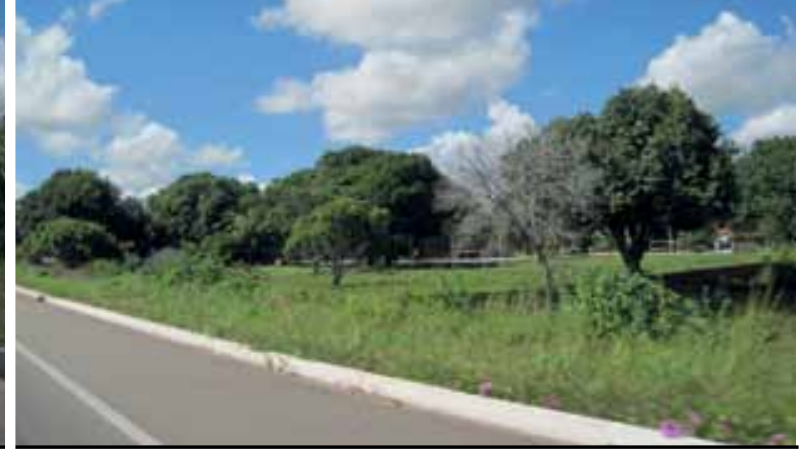

Fig. 3.97 Trecho 3 - rodovia CE 040

Fonte: acervo autora

\section{TRECHO 4 - a CE 040 e o acesso a Pindoretama e Cascavel}

O vetor mantém características semelhantes até o trecho final, que compreende os acessos às cidades de Pindoretama e Cascavel ${ }^{10} \mathrm{e}$ às praias da Caponga e Águas Belas.

Nessa área é grande a incidência de empreendimentos destinados à criação de aves, vistos ao longo da rodovia, aí localizados desde a década de 1970-1980, segundo relato de alguns proprietários. Loteamentos diversos também podem ser identificados, o que evidencia valorização dos terrenos e aponta para uma ocupação mais efetiva dessa região (ver figuras 3.98 a 3.100).

À medida que se afasta das sedes dos municípios situados próximos à via, a ocupação vai se tornando mais rarefeita. A rodovia continua com características semelhantes, de área rural, em direção aos municípios e praias do litoral leste do Estado, como Beberibe (Morro Branco e Praia das Fontes), Aracati (Canoa Quebrada e Majorlândia) e Icapuí (Redonda e Tremembé).

A rodovia passa, por vezes, a cerca de 500,00 m da orla marítima e, em grande parte do percurso, avistam-se variados recursos naturais, como rios, lagoas, dunas e abundante vegetação.

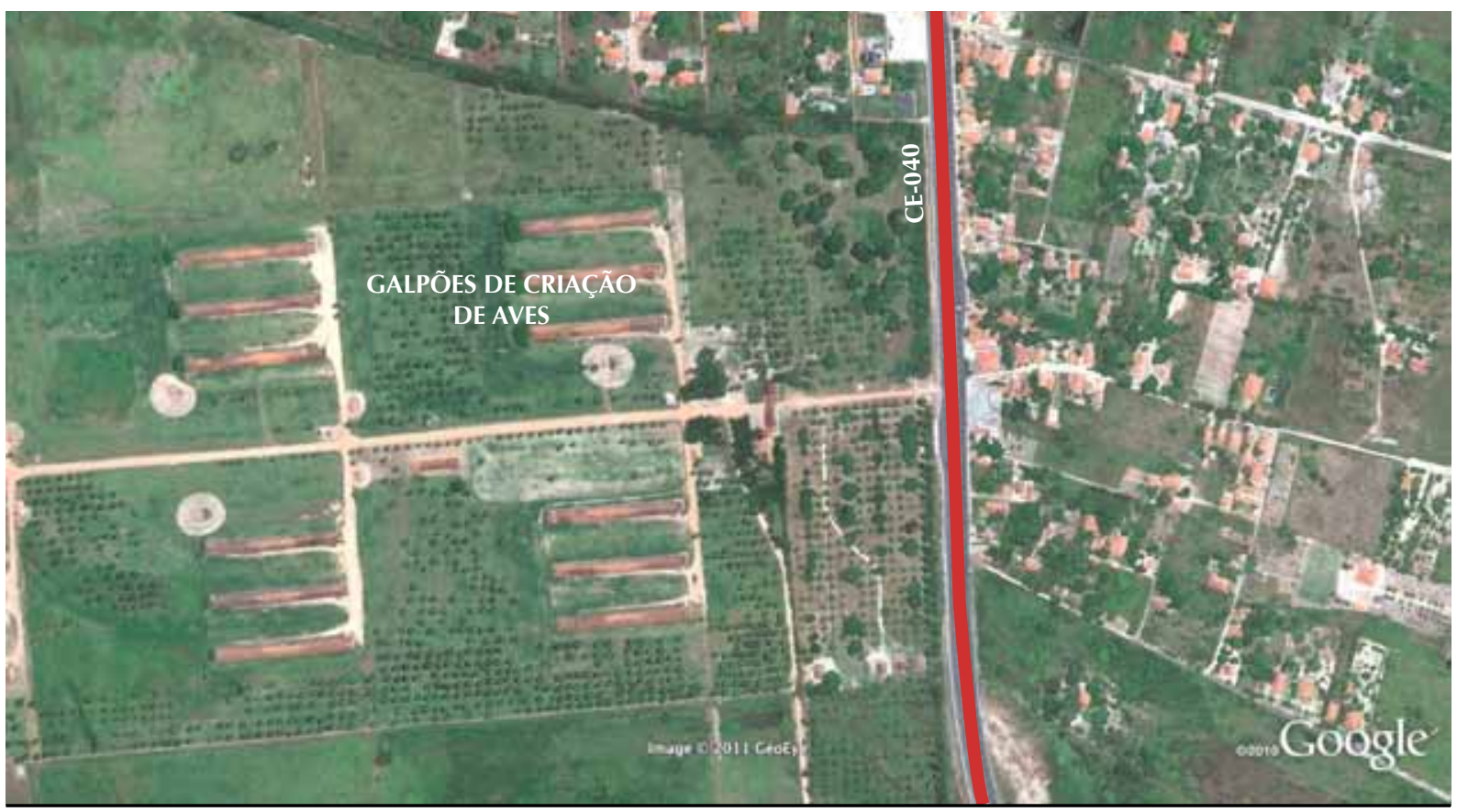

Fig. 3.98 Vetor 4: Trecho 4 (CE-040 - galpões de criação de aves) Fonte: Google Earth - elaborado pela autora

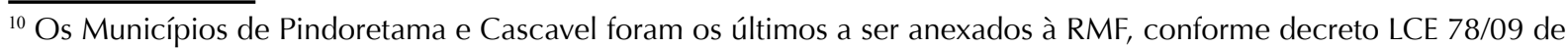
26 de junho de 2009. 


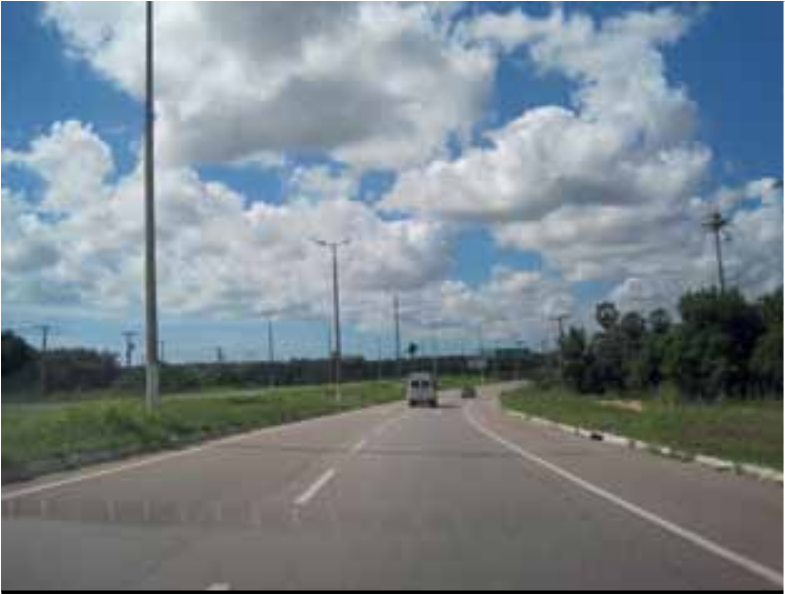

Fig. 3.99 Trecho 4 - rodovia CE 040 Fonte: acervo autora

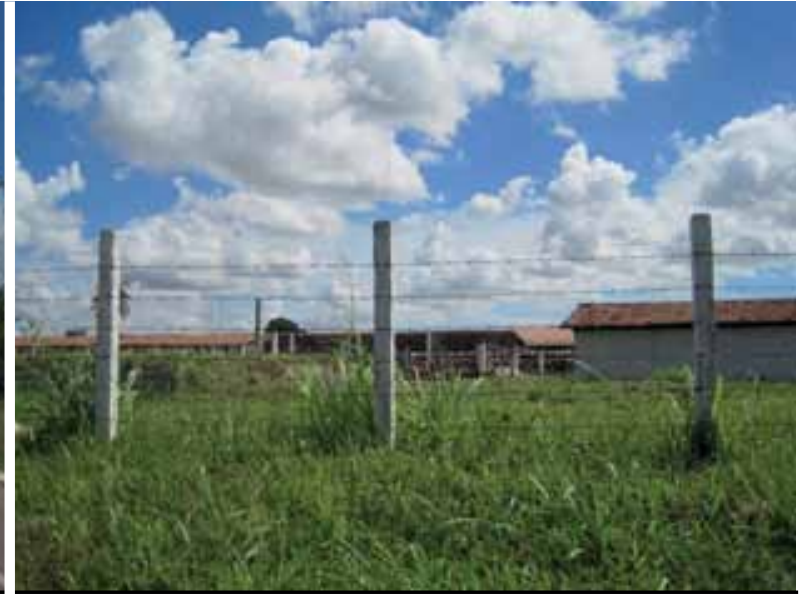

Fig. 3.100 Trecho 4 - aviários na rodovia CE 040 Fonte: acervo autora

\section{TRECHO 5 - A atividade turística na faixa litorânea}

O Vetor 4 apresenta uma ramificação, que acompanha parte da faixa litorânea leste do Estado, onde se observam sinais visíveis de expansão metropolitana, ligada à atividade turística. Da av. Washington Soares, segue-se pela av. Maestro Lisboa, espécie de ramal que se transforma, mais adiante, na rodovia CE 025.

Por meio dessa rodovia, se tem acesso às primeiras praias situadas ao leste de Fortaleza, uma vez que a ponte sobre o rio Cocó, que liga a Praia do Futuro à Praia da Sabiaguaba, somente agora foi concluída"1, o que dificultou, durante muito tempo, a ligação contínua entre as diversas praias, desde o Município de Fortaleza.

Essa via, originalmente bastante estreita' ${ }^{12}$, teve um aumento de fluxo expressivo desde a inauguração do Complexo Turístico Beach Park, em 1985, já que constitui o principal acesso a essa zona voltada para o turismo. Toda a área que margeia a av. Maestro Lisboa, anteriormente formada em grande parte por sítios, atualmente passa por um processo de alteração do seu espaço urbano, com o surgimento de condomínios horizontais, construções de grandes colégios e equipamentos comerciais e de serviço.

A CE 025, continuação da av. Maestro Lisboa, pode ser considerada via paisagística' ${ }^{13}$, uma vez que percorre uma zona com abundante vegetação (coqueiros, principalmente) e recursos naturais: mangue, rios, lagoas e dunas, a foz do rio Pacoti e grandes extensões de praia, que compõem a paisagem da região, fator bastante explorado pelo setor imobiliário quando da comercialização do loteamento Porto das Dunas, na década de 1980-1990. A atividade turística desde então aí desenvolvida tem como principais atrativos a valorização da paisagem e o lazer litorâneo.

Essa área é a que expressa, de modo mais explícito, o modelo de desenvolvimento turístico adotado pelo Estado e onde a atividade turística e a expansão imobiliária se manifestam com maior intensidade, sobretudo a região do Porto das Dunas. Inclui ainda as praias conhecidas por Prainha, Presídio, Marambaia, Iguape e Barro Preto.

\footnotetext{
${ }^{11}$ Iniciada há mais de cinco anos, a ponte foi concluída em junho de 2010, embora ainda com ligações rodoviárias precárias. Prevê-se que, com a conclusão da pavimentação da rodovia, será facilitado o acesso às praias da zona leste do Estado, localizadas além do rio Cocó.

${ }^{12}$ Já foram iniciadas as obras de alargamento da av. Maestro Lisboa, em conclusão até o final de 2012.

${ }^{13}$ Apesar de constituir via paisagística, pela ocorrência expressiva de recursos naturais, essa via não recebeu tratamento adequado, quando poderiam ter sido criados praças, largos e belvederes para fruição da paisagem.
} 
De acordo com o zoneamento previsto na lei de uso e ocupação do solo (PDDU-FOR ${ }^{14}$ 1996), a maior parte dessa área

[...] se encontra dentro da Zona de Uso Sustentável- ZUS definida pelo zoneamento da APA, onde se descortina uma das mais belas paisagens do lugar, entre os coqueirais, a barra do rio e o mar. Do Porto das Dunas, quando se cruza a ponte sobre o rio, observa-se a paisagem marcante em torno da APA que lhe atribui um significado, agregando valor mediante a imagem de preservação do meio ambiente, um recurso inestimável, cada vez mais valorizado nos países mais desenvolvidos. Hoje, corre o risco de ser reduzida e alterada (MONTENEGRO JR., 2006, p.143).

Alguns condomínios residenciais estão sendo construídos ao longo dessa via e outros já estão sendo habitados, como o Alphaville Fortaleza, em grande parte já ocupado.

Atravessada a ponte sobre o rio Pacoti, chega-se ao Porto das Dunas, região situada próxima à foz do rio, que abrange a faixa litorânea e cerca de $1 \mathrm{~km}$ ao sul, incluindo as dunas. Toda essa área passou a ser ocupada no início dos anos 1980-1990, quando foi criado um grande loteamento ${ }^{15}$ voltado para as classes média e alta, valorizado pelas qualidades paisagísticas de uma região de belezas naturais exuberantes, proporcionadas pelo mar, dunas e o conjunto de vegetação litorânea, às margens de um rio de águas limpas. A proximidade de Fortaleza (cerca de $15 \mathrm{~km}$ ) constituiu outro fator de atração, aliado à vantagem da ausência dos congestionamentos de tráfego da Capital.

O loteamento do Porto das Dunas foi rapidamente comercializado e logo foram construídas diversas residências de veraneio e outras permanentes, dada a proximidade de Fortaleza. Em 1985 foi inaugurado o complexo do Beach Park, considerado como a grande "âncora" da região, que se consolidou rapidamente como principal polo de lazer do Ceará, atraindo significativo fluxo turístico. O parque é responsável pela imagem turística do lugar e se impõe com a sua escala horizontal, permeada de vegetação (ver figura 3.108).

É expressiva a ocorrência de condomínios fechados, de lazer, construídos nas proximidades do empreendimento, junto à orla. Alguns fazem parte do próprio complexo e todos obedecem à mesma tipologia: edifícios residenciais de até quatro pavimentos em torno de ampla área de lazer, composta de quadras esportivas, clube, restaurante, piscinas, playground, etc. Observa-se que todos são cercados por muros e possuem controle rígido e acesso restrito, produzindo a noção de "enclausuramento", comum a esse tipo de equipamento, os quais exemplificam a emergência de um novo padrão de organização do espaço urbano (ver figuras 3.101 a 3.104).

Ainda com relação ao Porto das Dunas, constata-se que grande parte das residências de férias (segunda residência) tendem a tornar-se definitivas, configurando o local como um bairro residencial em desenvolvimento e atraindo, consequentemente, atividades de comércio e serviços complementares. Falta, entretanto, ao bairro, em contraste com sua vocação turística, infraestrutura (abastecimento de água, saneamento, drenagem, coleta de lixo, iluminação pública e pavimentação de vias), em condição de atender de modo satisfatório à população que tem se fixado no local de forma progressiva.

\footnotetext{
${ }^{14}$ PDDU-FOR - Plano Diretor de Desenvolvimento Urbano de Fortaleza.

${ }^{15}$ O loteamento Porto das Dunas foi idealizado e viabilizado pelo empresário João Gentil Jr., proprietário da "Sociedade Porto das Dunas Limitada", a qual financiou a construção da atual ponte sobre o rio Pacoti, que liga Fortaleza ao loteamento (via CE 025), proporcionando assim o acesso à área.
} 


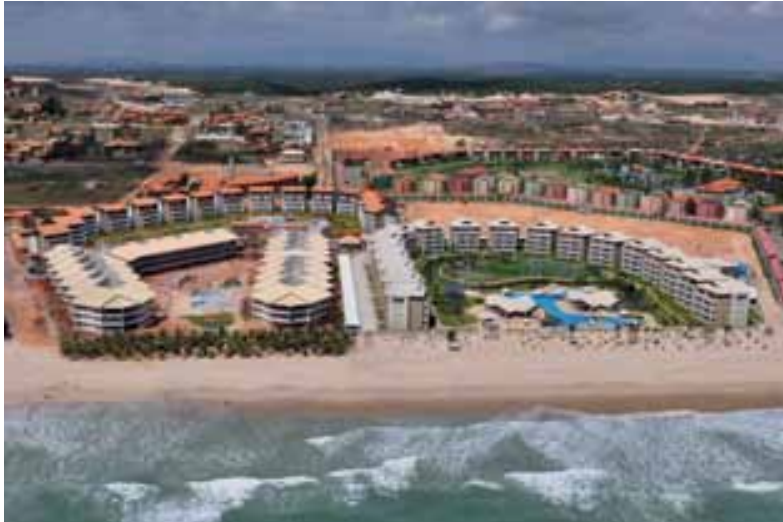

Fig. 3.101 Condomínio/ Porto das Dunas Fonte: http://www.skyscrapercity.com

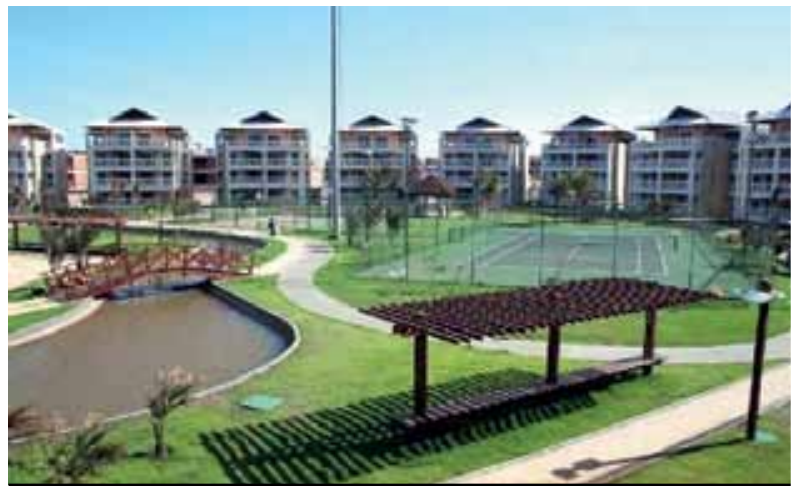

Fig. 3.103 Condomínio/ Porto das Dunas Fonte: http://aquiraz.olx.com.br/

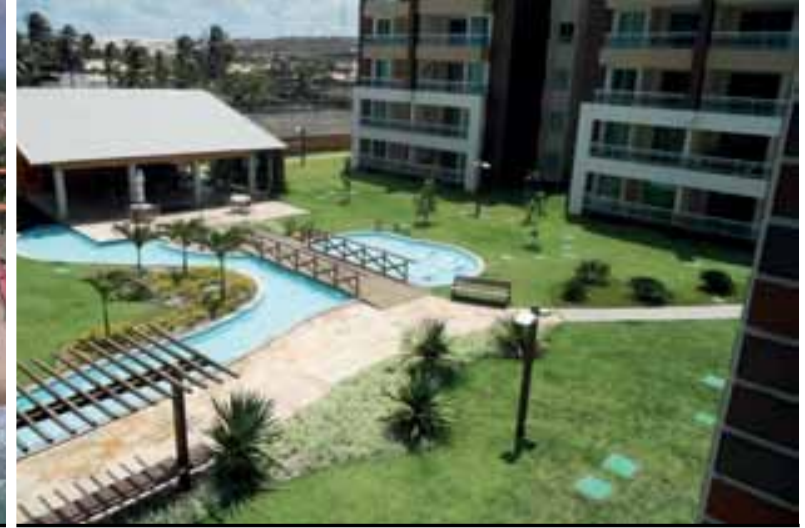

Fig. 3.102 Condomínio/ Porto das Dunas Fonte: http://aquiraz.olx.com.br/

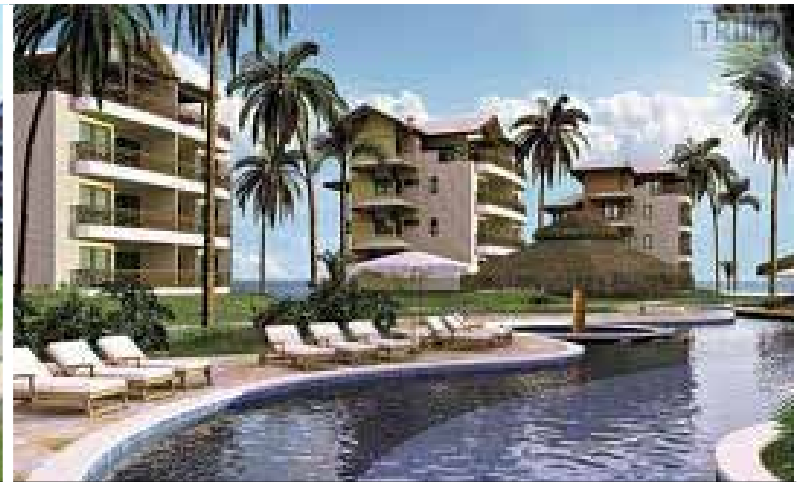

Fig. 3.104 Condomínio/ Porto das Dunas

Fonte: http://www.trioimobiliaria.com.br/

A ocupação é predominantemente horizontal, com residências implantadas de modo a se ajustar à topografia das dunas, mas já se percebe a introdução de alguns edifícios de até cinco pavimentos, que ameaçam a plena visibilidade do mar e das dunas.

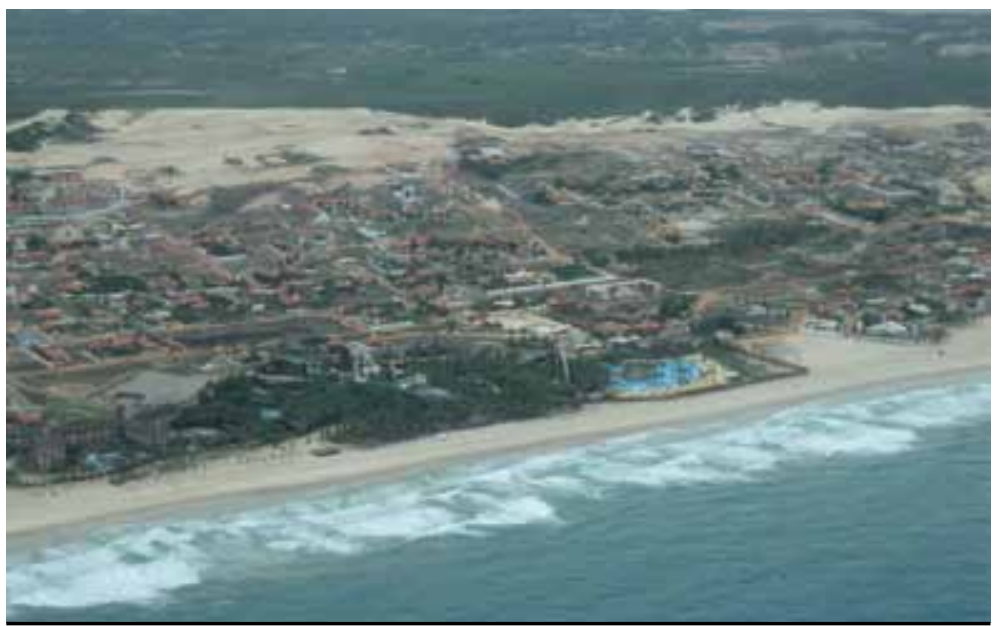

Fig. 3.105 Loteamento Porto das Dunas

Fonte: http://img293.imageshack.us/i/52454229tz4.jpg/

Outros núcleos são vistos ao longo do litoral, correspondentes às praias ditas da Prainha, Presídio, Iguape e Barro Preto, todos ainda no Município de Aquiraz. Essas aglomerações, formadas principalmente por casas de veraneio, pequenas pousadas e restaurantes, surgiram de modo espontâneo, ora onde havia colônia de pescadores, ora em loteamentos propostos desde a década de 1970-1980. Algumas delas demonstram atualmente sinais de decadência, com casas desocupadas e muitas delas postas à venda 
- consequência, provavelmente, do clima de insegurança reinante, como também das transformações verificadas nos últimos anos na região, onde prevalece a proposta dos grandes complexos turísticos. Esses núcleos, na realidade, são pequenas extensões de terras urbanizadas, dispostas ao longo do litoral, distanciadas entre si, constituindo assim uma forma de dispersão, evidenciada há algum tempo.

Convém ainda chamar atenção para a chamada Reserva Extrativista do Batoque, situada próxima à praia do Barro Preto, que possui belas e intocadas paisagens, sem qualquer ocupação. Constitui a maior área preservada do Município de Aquiraz, diferentemente do que acontece na região do Porto das Dunas, onde é intenso o processo de transformação espacial.

A Reserva, por sua dimensão e importância nesse trecho da orla, poderia ser inserida como tal num planejamento mais amplo de toda essa região, de forma a ser preservada e servir de contraposição à crescente ampliação da área edificada; entretanto, a área já começa a atrair a atenção dos investidores.

Empreendimentos de grande porte, ligados a turismo, hotelaria de lazer e férias, estão sendo implantados de forma progressiva junto à orla, no espaço metropolitano, como o Aquiraz Riviera (na praia de Marambaia, próximo à praia do Presídio), o Mandara Porto das Dunas e o Golf Ville (Porto das Dunas) e o Águas Belas Resort (próximo à praia da Caponga), interferindo sobremaneira na ocupação dessa área, desocupada há até pouco tempo.

A atividade turística, tal como se manifesta nessa região, resulta em transformações significativas no espaço, agindo também na modificação da paisagem. Esses empreendimentos, tais como outros previstos, são implantados na faixa litorânea, em áreas despovoadas, formando núcleos dispersos ao longo da orla marítima, alterando a paisagem e produzindo novas formas de tecido urbano. Caracterizam-se como unidades independentes, distantes dos núcleos urbanos préexistentes, produtos de intervenções pontuais. Obedecem, portanto, ao modelo de urbanização dispersa, comum a outras cidades litorâneas, sobretudo no Nordeste, porém marcado com suas especificidades.

Percebe-se, com efeito, que a configuração e visibilidade espacial do turismo conduzem à intensificação da dispersão urbana verificada atualmente, com tendência à descentralização e fragmentação, induzindo formas de urbanização diferenciadas, pois, como observa Reis (2006, p.135), "os padrões de urbanização dispersa e novas formas de tecido urbano difundem-se também com facilidade nas áreas turísticas do litoral e do planalto, ocupadas pelas faixas de renda média e alta".

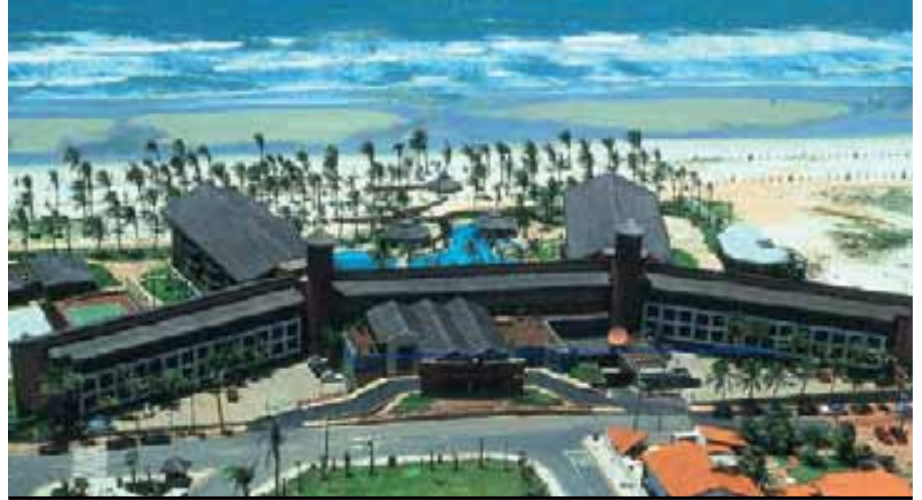

Fig. 3.106 Resort/ Porto das Dunas Fonte: http://www.reidaverdade.com/

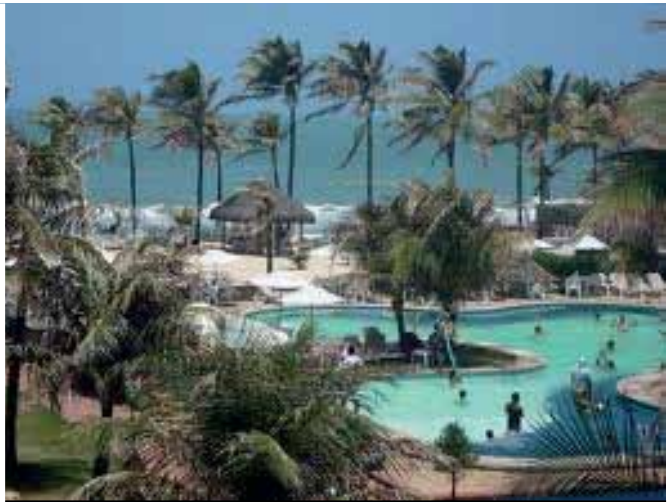

Fig. 3.107 Resort/ Porto das Dunas Fonte: http://www.e-destinos.com.ar/ 


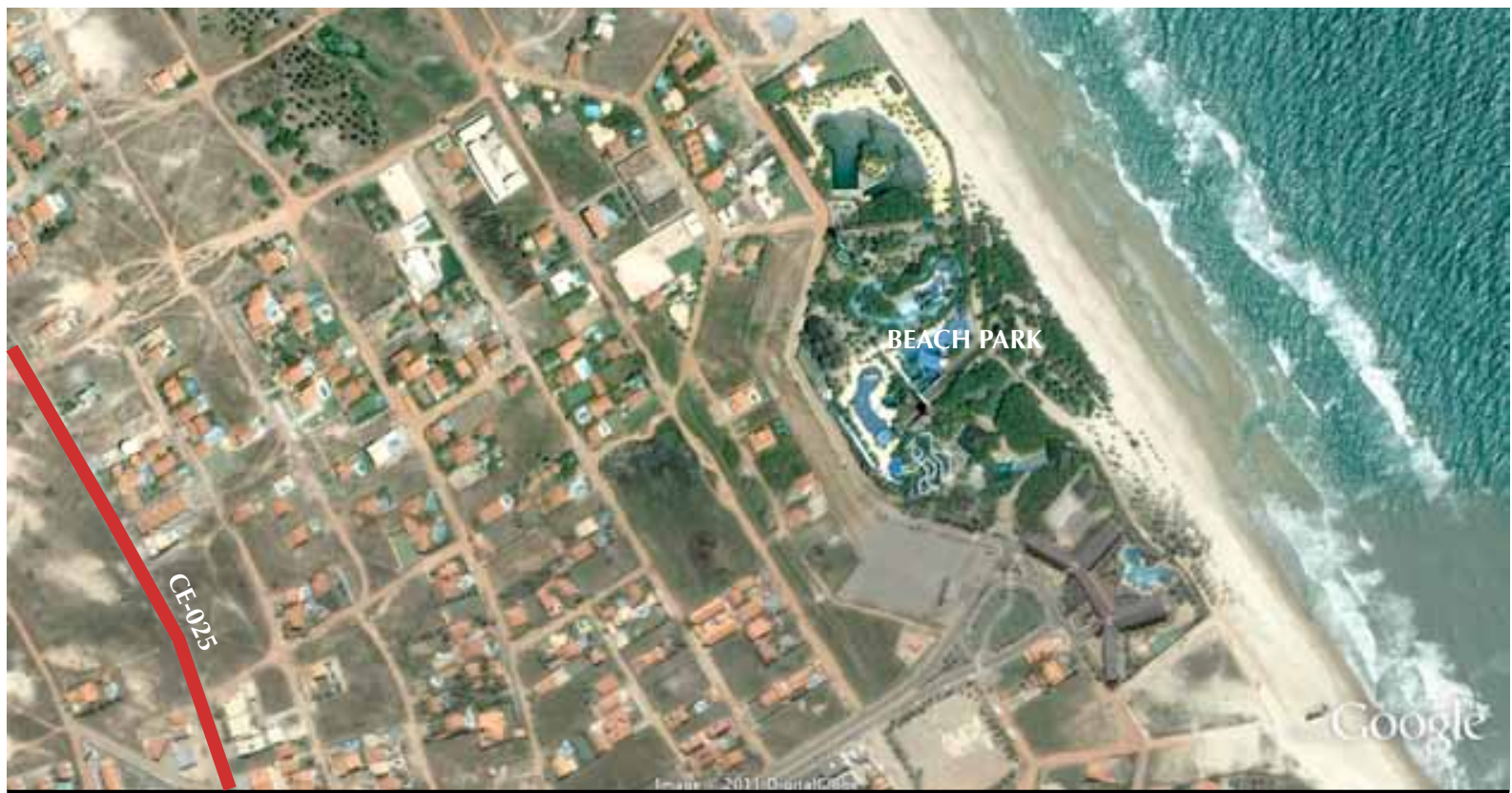

Fig. 3.108 Vetor 4: Trecho 5 (Porto das Dunas/Beach Park) Fonte: Google Earth - elaborado pela autora

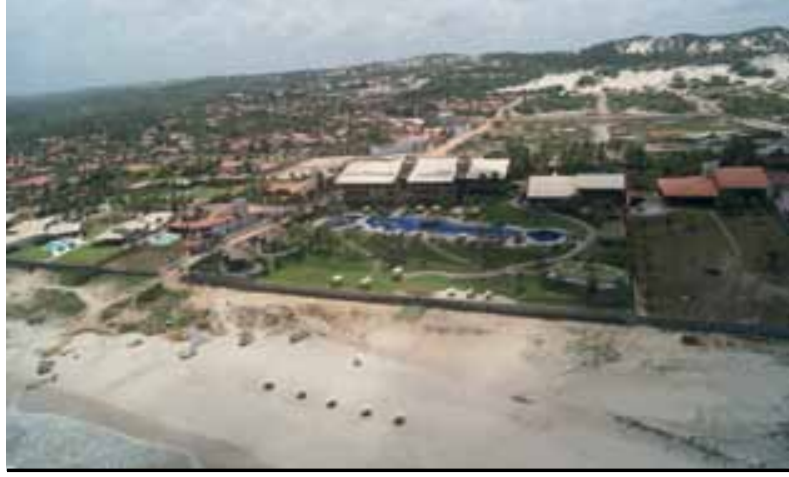

Fig. 3.109 Porto das Dunas - foto aérea Fonte: Rodrigo Ponce de Leon

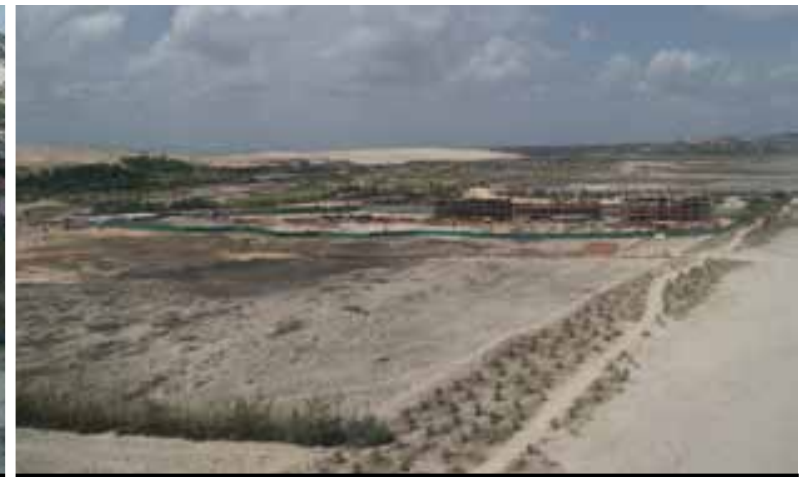

Fig. 3.110 Porto das Dunas - foto aérea Fonte: Rodrigo Ponce de Leon

\section{Sobre a forma de ocupação do vetor 4}

A expansão da urbanização de Fortaleza em direção ao sudeste, numa perspectiva metropolitana, verifica-se ao longo de dois eixos viários: av. Washington Soares/CE 040 e Av. Maestro Lisboa/CE 025, o qual constitui uma bifurcação do primeiro.

Com relação ao desenvolvimento desse setor, de maneira geral, observa-se que cresce e expandese de modo diverso do restante da área metropolitana. Em primeiro lugar, pelo dinamismo e rapidez com que se vêm processando as transformações no espaço urbano. Até pouco tempo despovoado em grande parte, atualmente destaca-se pela maior velocidade de mudanças. É também aquele que manifesta de maneira mais acentuada uma tendência à dispersão urbana, pela ocorrência de condomínios horizontais e núcleos voltados para o turismo e lazer, que configuram novas formas de tecido urbano, em consonância com os processos de urbanização contemporânea.

Formam-se, assim, periferias metropolitanas diferenciadas, ligadas à expansão da moradia da classe média alta e da atividade turística. Em razão disso, e por apresentar formas novas de produção do espaço, que resultam de processos urbanísticos mais complexos, esse vetor será objeto de investigação e análise mais pormenorizada, assunto a ser desenvolvido no próximo capítulo. 


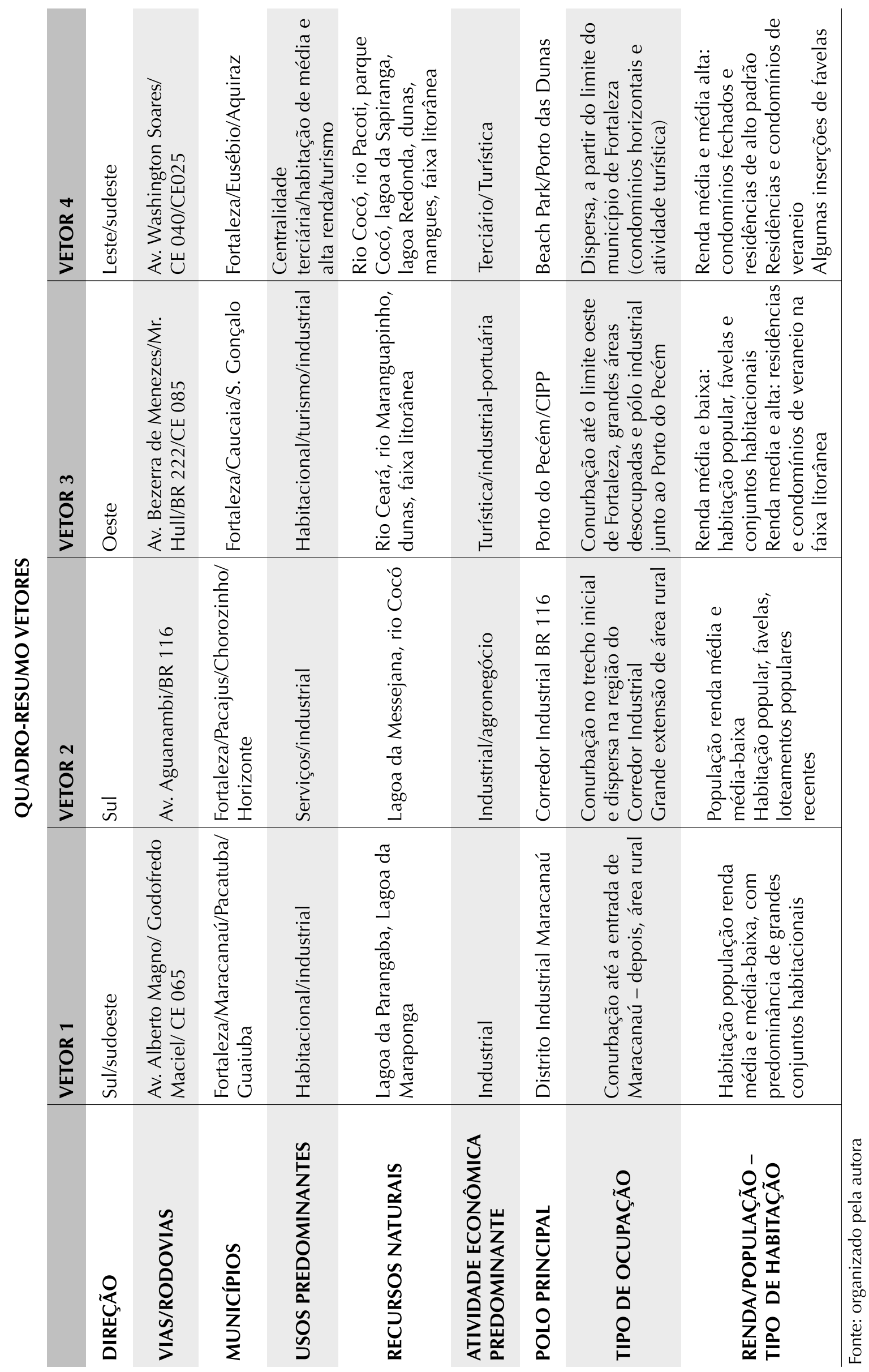




\subsection{OS ANÉIS VIÁRIOS}

Na estruturação da Metrópole, a fim de facilitar a comunicação entre os diferentes eixos e disciplinar a expansão da Cidade, foram introduzidos anéis viários sobre o desenho radioconcêntrico dominante, formado pelos principais eixos viários. A referência recai sobre dois principais anéis ${ }^{16}$, construídos em épocas distintas: a chamada avenida Perimetral, executada no início dos anos 1960-1970, na administração do Prefeito Cordeiro Neto (1959-1963) e o $4^{\circ}$ Anel Viário, construído em meados da década de 1980-1990, o qual constitui praticamente o limite sul de Fortaleza.

Esses anéis, desde que foram executados, alteraram a trama viária, modificaram e redefiniram os fluxos de circulação, criaram opções de locomoção mais rápida, interligaram bairros e requalificaram espaços.

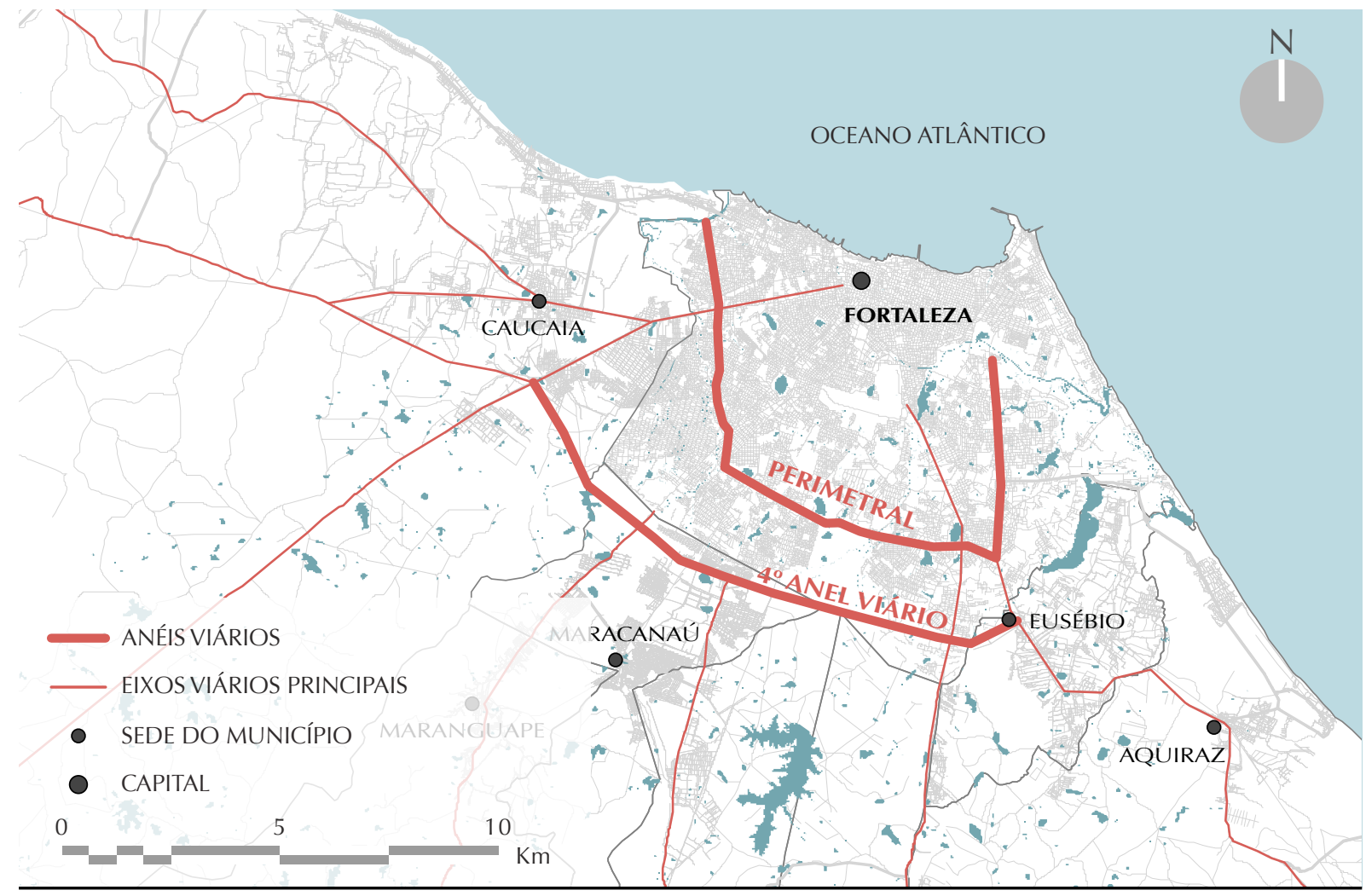

Fig. 3.111 Mapa RMF: av. Perimetral e $4^{\circ}$ Anel Viário Fonte: elaborado pela autora

\subsubsection{A av. Perimetral}

A av. Perimetral foi criada em 1960, com o propósito de contornar a Cidade, ligando os bairros da então periferia urbana, da Barra do Ceará ao Mucuripe. Deveria percorrer, ao todo, $42 \mathrm{~km}$. O objetivo era construir uma via que envolvesse toda a Cidade, em seu limite externo. Com o passar do tempo, a área edificada se expandiu até atingir a avenida, a qual passou a ser definida por vários topônimos.

A via foi concebida também para conduzir o tráfego pesado (de cargas) do setor industrial, então localizado ao oeste, para o porto do Mucuripe, ao leste, e vice-versa, sem que os veículos precisassem passar pelo centro de Fortaleza. Outra finalidade foi a de propiciar maior intercomunicação dos diversos bairros, para que as áreas mais afastadas se vissem beneficiadas, além da pretensão de disciplinar o crescimento da Cidade, conforme defendia o então prefeito Cordeiro Neto, idealizador e construtor da artéria.

\footnotetext{
16 Trata-se, na realidade, não de anéis completos, mas de vias em forma de semicírculo, que ligam os principais eixos viários que partem do núcleo central.
} 
A expansão territorial da Metrópole cearense e os vetores de crescimento urbano e metropolitano

A Perimetral se formou pela integração de vias e desapropriações de casas e terrenos. Especula-se que o trajeto proposto beneficiaria proprietários de terras inaproveitadas, ou aqueles que teriam adquirido terrenos antecipadamente, com vistas à futura valorização.

De acordo com a SEINF (Secretaria Municipal de Desenvolvimento Urbano e Infraestrutura), a avenida é composta por diversos trechos ${ }^{17}$ e acha-se, atualmente, bastante fragmentada, dividida em ruas sem destaque, quase todas com larguras bastante reduzidas.

A artéria constituiu, todavia, importante fator no processo de expansão da Cidade, uma vez que foi rapidamente ocupada em toda a sua extensão, como também propiciou a integração de bairros afastados. Seu desenho foi bastante alterado ao longo do tempo e atualmente, com o crescimento da Metrópole, acha-se completamente integrada à malha urbana (ver figura 3.112).

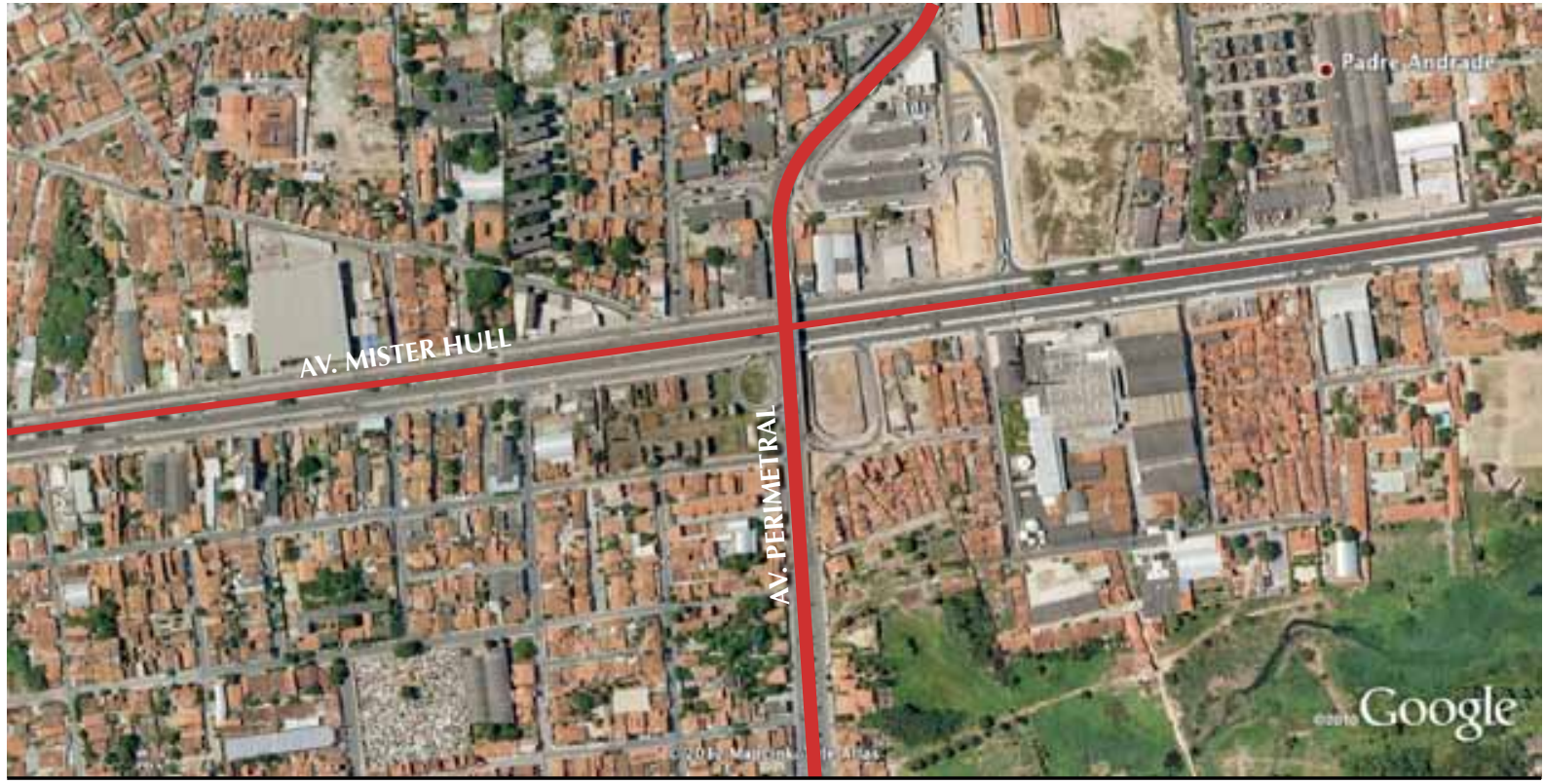

Fig. 3.112 Av. Perimetral

Fonte: Google Earth - elaborado pela autora

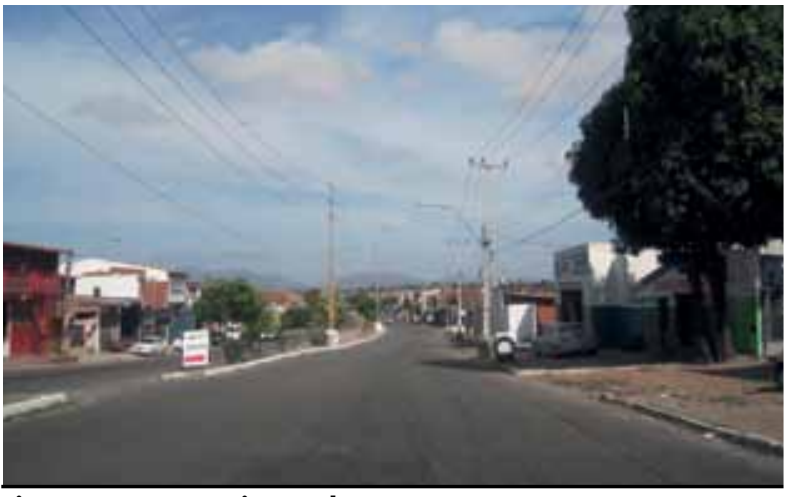

Fig. 3.113 Av. Perimetral

Fonte: acervo autora

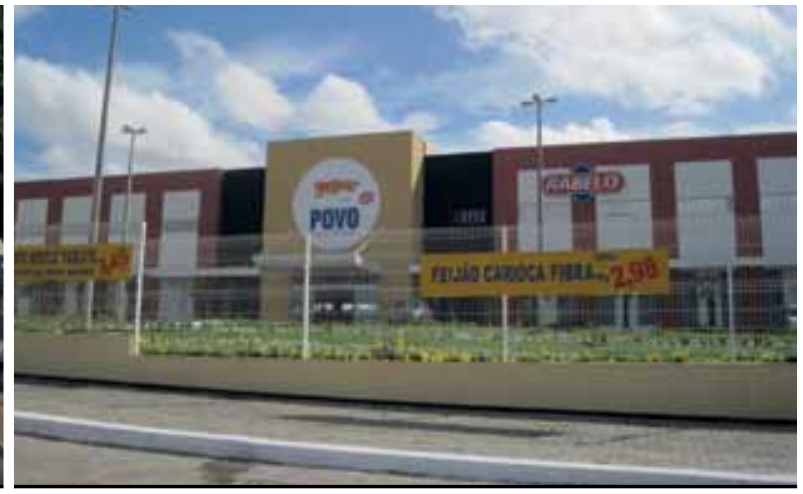

Fig. 3.114 Av. Perimetral

Fonte: acervo autora

\footnotetext{
${ }_{17}$ São esses os trechos que compõem atualmente a avenida Perimetral: av. Coronel Carvalho - 2.358,149 m (Antonio Bezerra), rua Joaquim Albano - 371,897 m, av. Mattos Dourado - 2.565,901 m, rua Vitória - 1.640,728 m, rua Cacilda Becker - 931,456 m, rua Astronauta (Verbena) - 1.171,826 m, rua Cônego de Castro - 370,321 m, rua Waldir Diogo - 1.273,826 m, av. Wenefrido Melo 550,281 m, av. Presidente Costa e Silva - 8.041,573 m (Parque dois Irmãos, Conjunto Prefeito José Walter e Passaré), av. Jornalista Thomaz Coelho (Messejana) - 766,687 m, rua Tenente Jurandir Alencar - 230,595 m, rua Coronel Dionísio Alencar - 722,736 m, rua Dr. Joaquim Bento - 1.003,636 m, av. Washington Soares - 478,245 m (Edson Queiroz e Cidade dos Funcionários), av. Engenheiro Santana Júnior - 2.674,278 m (Cocó), av. Engenheiro Alberto Sá - 3.097,347 m (Papicu), av. Engenheiro Luís Vieira - 236,436 m (Dunas), rua Hermínia Bonavides - 544,215 m (Praia do Futuro), rua Renato Braga - 662,437 m. A extensão total da avenida é 30,170 km.
} 


\subsection{2. $4^{\circ}$ Anel Viário}

O $4^{\circ}$ Anel Viário, já previsto pelo PLANDIRF, foi concebido pela AUMEF (Autarquia da Região Metropolitana de Fortaleza) em 1975, com o intuito de interligar todas as estradas de acesso aos municípios periféricos. Percorre 32 km e liga a CE 040 à BR 222, permitindo o tráfego entre os Municípios de Eusébio, Itaitinga, Maracanaú e Caucaia, sem que haja necessidade de passar por dentro do Município de Fortaleza. Tem início na CE 04018 e cruza a BR 116, a CE 060, a CE 065 e a BR 222.

A via constitui praticamente o limite do Município de Fortaleza, em sua porção sul e sudoeste e foi concebida também com o propósito de organizar a expansão da Metrópole em direção aos municípios que compõem a RMF e facilitar a ligação entre as vias radiais.

Trata-se de importante caminho de entrada e escoamento de mercadorias, pois liga grandes polos econômicos, como o Porto do Pecém e o Distrito Industrial de Maracanaú, sendo intenso o tráfego de caminhões pesados em toda a sua extensão, consideravelmente aumentado ${ }^{19}$ nos cruzamentos com a CE-060 e CE-065, causando grandes congestionamentos.

Desde o seu trecho inicial, é frequente a presença de armazéns, em forma de grandes galpões, como de distribuidoras de mercadorias, confirmando o papel de via de transporte de cargas entre os principais polos produtivos. Em alguns trechos, atravessa grande extensão de área rural (ver figuras 3.117 e 3.118).

A paisagem urbana verificada ao longo do $4^{\circ}$ Anel viário remete à citação de Philippe Panerai (2006) acerca das novas formas urbanas, próprias da cidade contemporânea, quando a aglomeração se estende muito além do núcleo compacto tradicional:

O espraiamento vem acompanhado de uma esgarçadura do tecido urbano. A evolução dos modos de vida engendra um consumo expressivo de espaços. E a cidade, outrora compacta, inclui hoje grandes zonas não construídas, áreas naturais, plataformas logísticas, setores de estocagem, terrenos baldios (2006, p.13).

O mercado imobiliário parece também estar iniciando ao longo da via um processo de vigorosa expansão. Devido à disponibilidade de terrenos mais baratos, à facilidade de acesso viário e às perspectivas de crescimento da região, alguns incorporadores já começam a propor condomínios fechados e loteamentos residenciais para a classe média e média-baixa, inseridos no Programa Minha Casa Minha Vida.

Como exemplo, está sendo comercializado atualmente um empreendimento habitacional de grandes dimensões - o Bairro Novo - da construtora Odebrecht, às margens da rodovia, entre a BR 116 e a CE 065, o que indica a futura ocupação residencial nessa área. O projeto prevê a construção de 2.846 casas e apartamentos (com preços a partir de $\mathrm{R} \$ 65.000,00$ ). Trata-se de "um condomínio fechado dentro de um bairro planejado", conforme anúncio veiculado na Internet pela própria construtora (ver figuras 3.115 e 3.116 ).

\footnotetext{
${ }^{18} \mathrm{O}$ desenho original do $4^{\circ}$ Anel Viário previa seu início no Porto do Mucuripe, o que não foi efetivado. Atualmente, a via tem origem junto à CE 040, no Município do Eusébio.

${ }^{19}$ Segundo dados do DNIT (Departamento Nacional de Infraestrutura e Transportes do Ceará), 14 mil veículos passam diariamente pela via. A previsão é de que, após a duplicação do anel viário, o fluxo diário aumente para 22 mil veículos.
} 


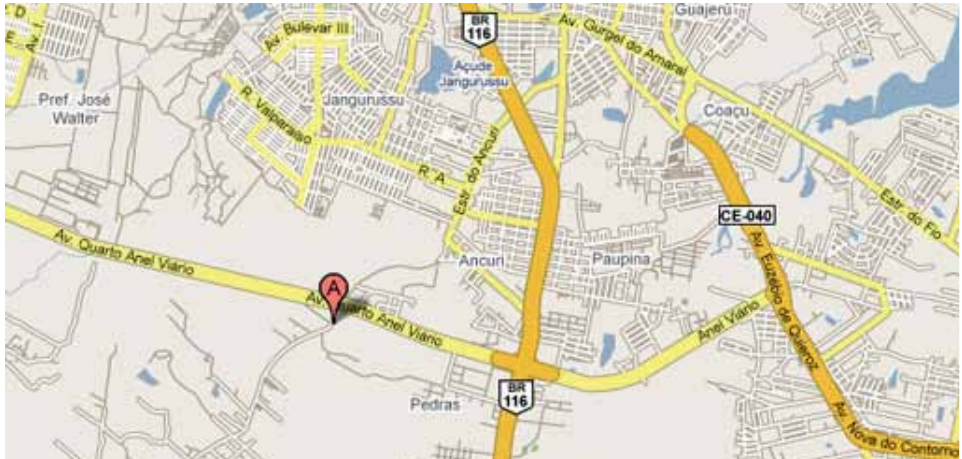

Fig. 3.115 Localização cond. residencial Bairro Novo, no $4^{\circ}$ anel Viário Fonte: http://www.bairronovo.com/empreendimentos/ce/fortaleza/

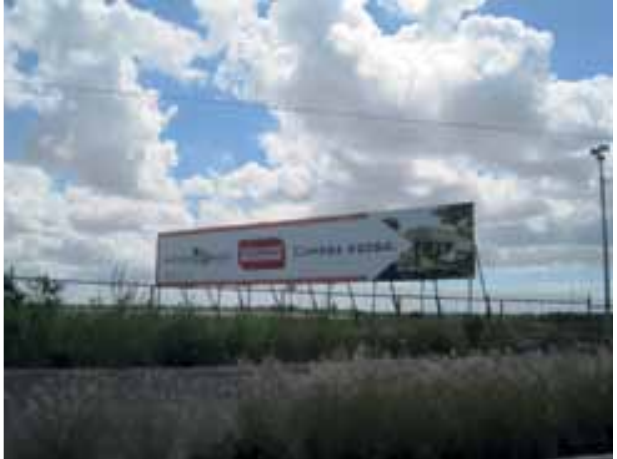

Fig. 3.116 $4^{\circ}$ Anel viário - anúncio Bairro Nvo Fonte: acervo autora

Contará também com um centro comercial, composto por farmácia, supermercado, locadora de vídeo, loja de material de construção e cinema, conforme consta do programa do empreendimento. A consolidação de um bairro residencial dessas proporções faz supor um adensamento considerável na área, onde hoje, praticamente, não se verifica a função moradia.

Esse fato reflete um fenômeno recente e um novo momento no processo atual de ocupação urbana, quando alguns setores da periferia se tornam objeto de interesse do mercado imobiliário formal para implantação de empreendimentos diversos, evidenciando novas formas de utilização do território.

Empreendimentos como esse têm ainda o potencial de desencadear transformações de porte nos padrões de uso e ocupação do solo onde são instalados, interferindo sobremaneira na dinâmica de mudanças do seu entorno.

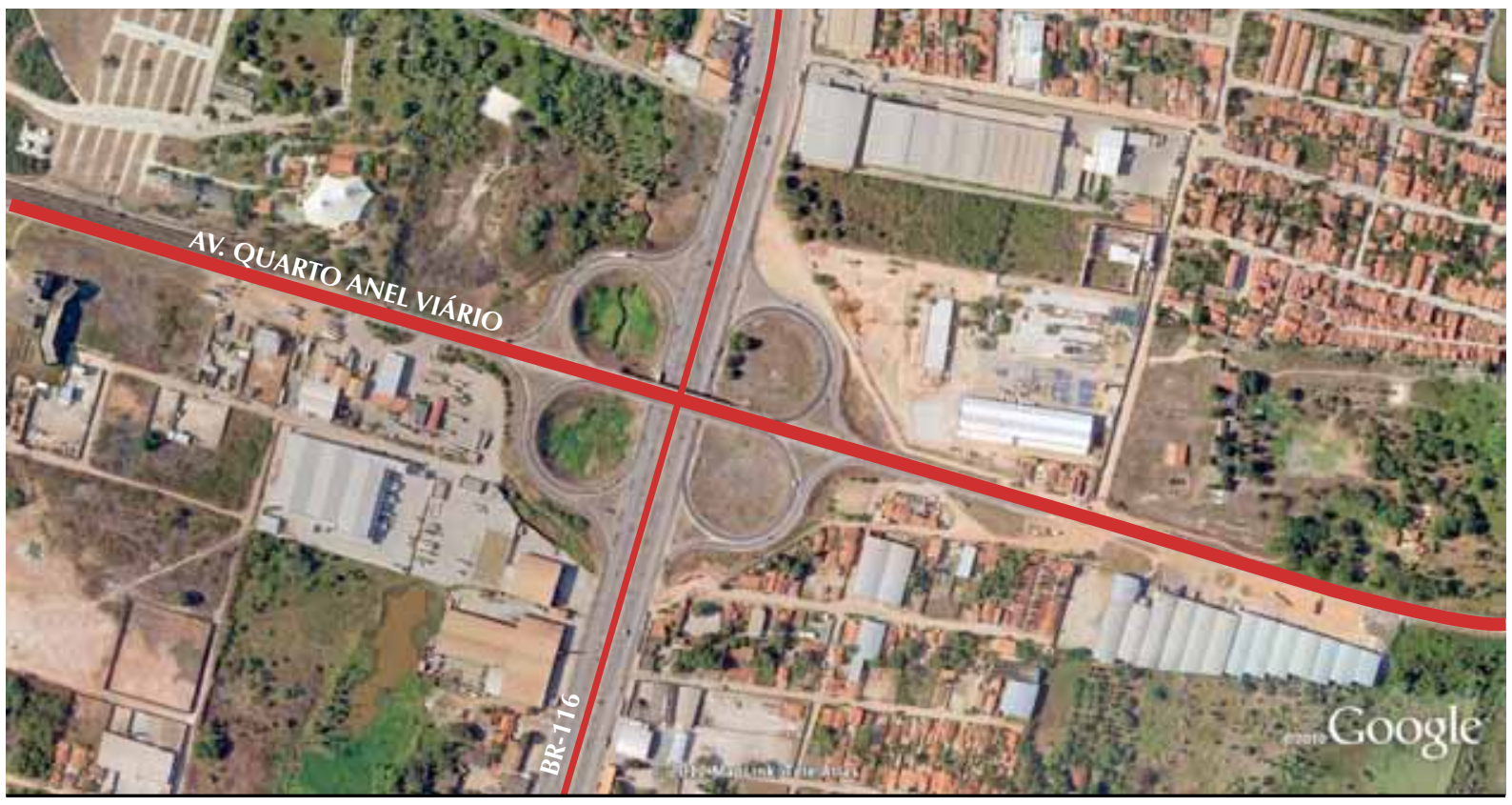

Fig. $3.1174^{\circ}$ Anel Viário

Fonte: Google Earth - elaborado pela autora 
Atualmente, encontram-se em andamento obras de duplicação do $4^{\circ}$ Anel Viário (a via é estreita, com apenas duas faixas, em sentidos opostos), proposto como forma de melhorar o fluxo de veículos na RMF, sobretudo no trecho compreendido entre a BR 116 e a BR 222, que absorve o tráfego de caminhões de carga para o porto do Pecém. O projeto prevê também a construção de sete viadutos, a fim de evitar os congestionamentos nos cruzamentos. Segundo o superintendente regional do DNIT, a obra será concluída no final de 2012.

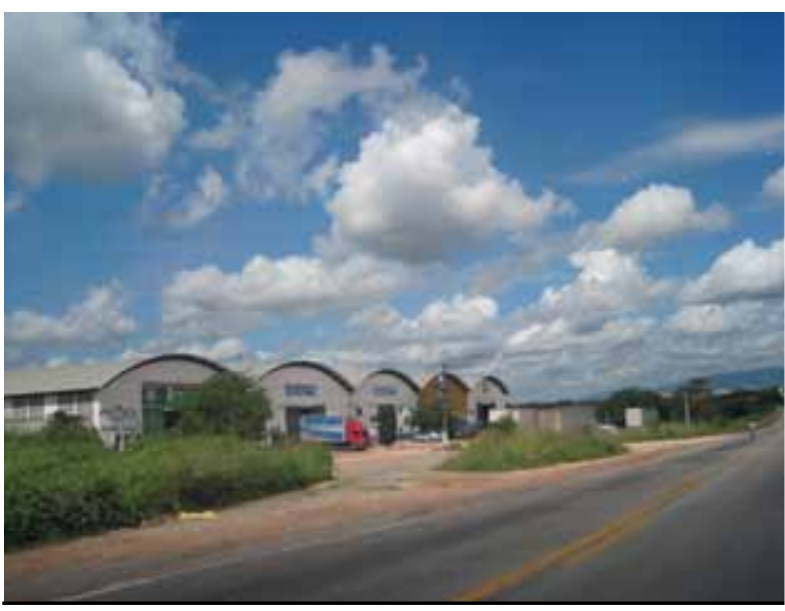

Fig. 3.118 $4^{\circ}$ Anel viário - armazéns Fonte: acervo autora

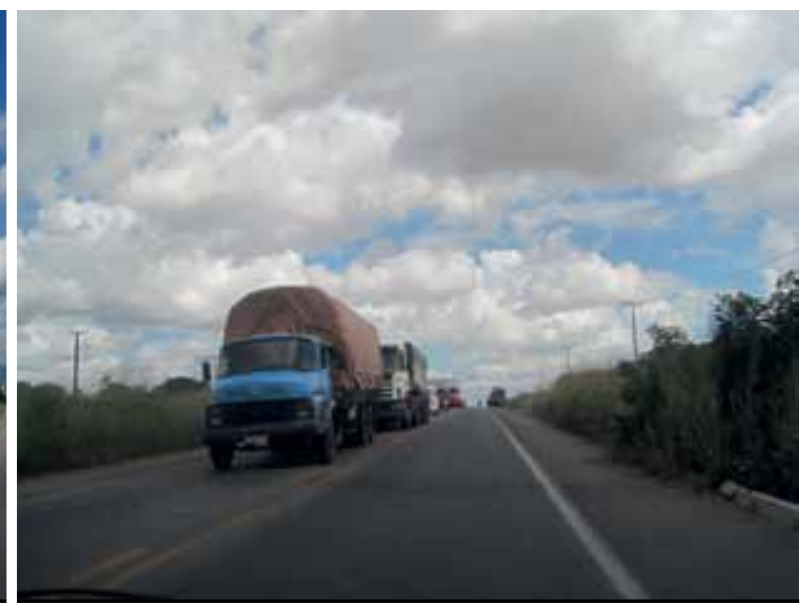

Fig. 3.119 $4^{\circ}$ Anel viário - tráfego de caminhões Fonte: acervo autora

\subsection{CONSIDERAÇÕES ACERCA DA EXPANSÃO METROPOLITANA DE FORTALEZA}

Efetuada a pesquisa empírica, com observações in loco e análises de imagens de satélite e mapas, e após a descrição da forma como vêm ocorrendo o uso e a ocupação do solo ao longo dos diversos vetores de crescimento urbano, algumas considerações podem ser feitas com relação à expansão da Metrópole cearense.

A área metropolitana apresenta, à primeira vista, um padrão de urbanização identificado por uma concentração mais compacta na área central, onde ocorre maior densidade demográfica, construtiva e de investimentos públicos, e que se torna mais rarefeita à medida que se distancia do núcleo central. Essa concentração se estende pela zona oeste/sudoeste, ligada historicamente ao desenvolvimento industrial e à habitação popular, que se apresenta bem mais densa do que as zonas leste ${ }^{20}$ e sudeste, de ocupação mais recente, e onde se verificam processos mais diferenciados de crescimento (ver figuras 3.120 e 3.123).

Os grandes eixos viários direcionam, de certa forma, a expansão urbana, a qual se relaciona diretamente com a concentração de infraestrutura econômica (industrial e turística), seguida de perto pela intensa dinâmica imobiliária e fundiária que sempre acompanha os investimentos públicos e privados, deles se beneficiando. A configuração metropolitana está, pois, inteiramente ligada à estrutura viária e aos fluxos decorrentes da dinâmica econômica e populacional, que redimensionam e interferem continuamente nos usos e funções associados à indústria, ao comércio, aos serviços e à habitação (ver figura 3.121).

\footnotetext{
${ }^{20}$ Apesar da verticalização verificada na zona leste, sobretudo nos bairros da Aldeota, Meireles e Papicu, os bairros da zona oeste apresentam maior densidade demográfica. Os bairros do Pirambu, Manuel Sátiro e Quintino Cunha, situados nas zonas oeste e sul, por exemplo, possuem densidade de $32.318 \mathrm{hab} / \mathrm{km}^{2}, 33.585 \mathrm{hab} / \mathrm{km}^{2}$ e $22.193 \mathrm{hab} /$ $\mathrm{km}^{2}$, respectivamente, enquanto Aldeota, Meireles e Papicu apresentam densidades de $10.917 \mathrm{hab} / \mathrm{km}^{2}, 14.334 \mathrm{hab} /$ $\mathrm{km}^{2}$ e $8.789 \mathrm{hab} / \mathrm{km}^{2}$ (Censo IBGE, 2010). (ver figura 3.120).
} 


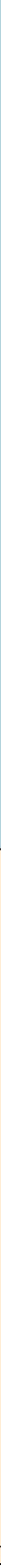




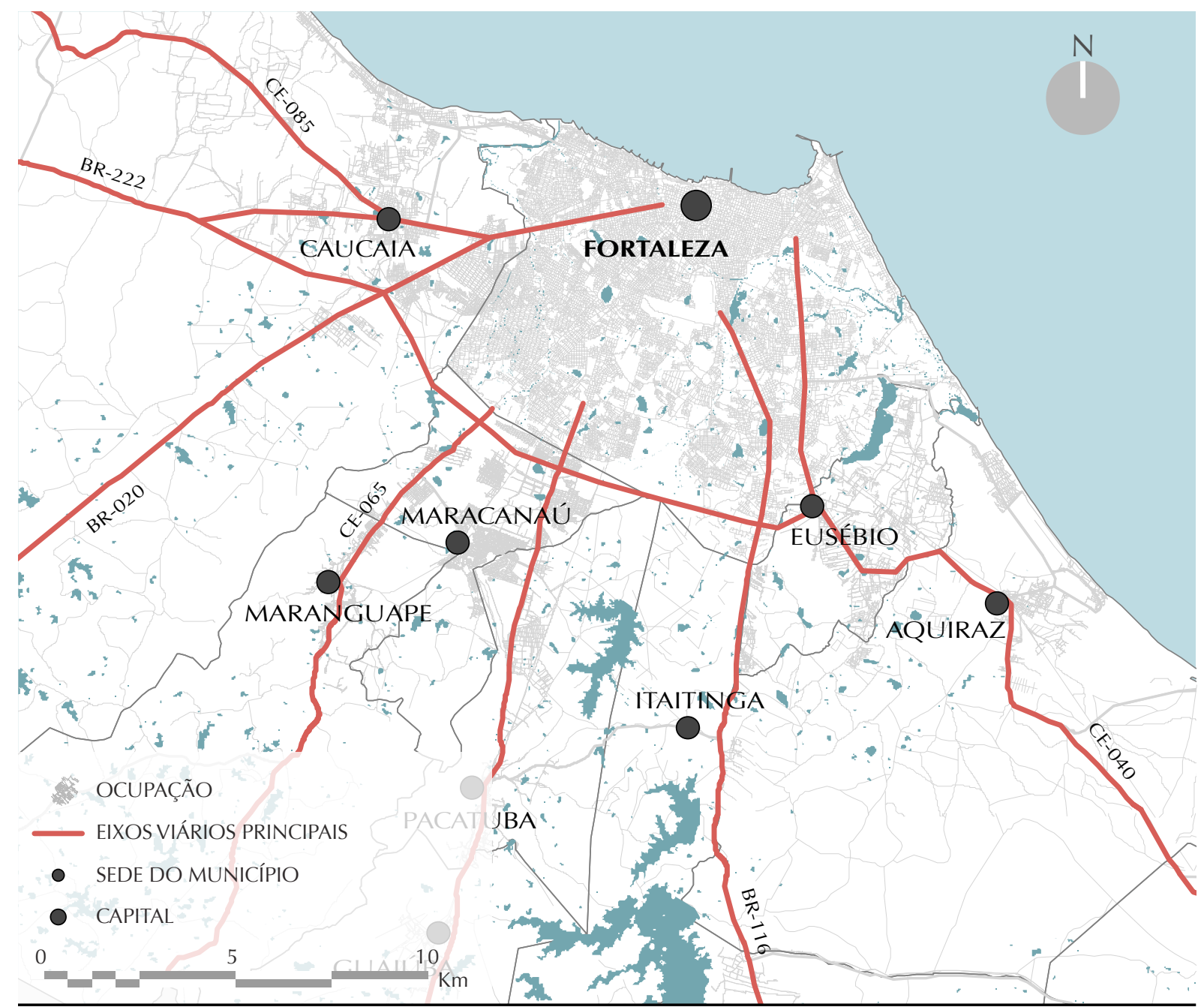

Fig. 3.121 Mapa RMF: eixos viários

Fonte: IPECE - elaborado pela autora

A área metropolitana por inteiro experimenta transformações significativas, com mudanças substanciais em sua estrutura e configuração espacial. A dinâmica dos processos socioeconômicos, sobretudo nos últimos 30 anos, resultou em sensíveis alterações. Com base no estudo realizado, algumas conclusões podem ser obtidas desse processo de crescimento e expansão, conforme delineado na sequência.

- Os eixos viários principais como vetores de crescimento urbano e metropolitano

O crescimento urbano e metropolitano de Fortaleza obedece predominantemente ao modelo radioconcêntrico, apoiado em quatro principais vetores de expansão, ao longo dos quais se expande a malha urbana, em direção ao interior do Estado. Essas vias assumem papel preponderante na configuração urbana da Metrópole, determinando a estruturação do território. Os quatro vetores analisados obedecem a lógicas distintas de formação e possuem características próprias e marcantes, evidenciadas em cada um deles.

Vetor 1 - de ocupação mais antiga, a malha urbana parece expandir-se em continuidade com o tecido urbano pré-existente, como um prolongamento da ocupação do Município de Fortaleza.

Vetor 2 - a implantação recente de indústrias nas margens da BR 116, nos Municípios do Eusébio, Horizonte e Pacajus, fez surgir núcleos urbanos ligados a elas, ao longo da rodovia, distanciados entre si e separados por extensas áreas rurais, manifestando características da urbanização dispersa. 
Vetor 3 - dinâmicas diversas caracterizam o vetor: 1) a expansão residencial da classe de mais baixa renda, conformando periferias densas no limite oeste e sudoeste de Fortaleza; 2) a atividade turística verificada na faixa litorânea; e 3) o Complexo Industrial Portuário do Pecém, situado na porção final desse vetor, que constitui área com tendência crescente de concentração urbana, reforçada com a implantação do trem metropolitano e a construção da Via Estruturante do Turismo.

Vetor 4 - situado no setor sudeste da Metrópole, corresponde ao mais recente vetor de expansão. É o que apresenta formas mais diferenciadas de tecido urbano, tais como a formação de uma área de centralidade de porte no trecho inicial e a inserção de inúmeros condomínios residenciais horizontais e equipamentos de turismo na faixa litorânea, onde surgem núcleos voltados inteiramente para o turismo e lazer. Pela maneira como se desenvolve e com base nas observações em campo, verifica-se que o crescimento desse setor ocorre de forma diversa do restante da área metropolitana.

O vetor 4 é também aquele que manifesta processos urbanos mais complexos, que constituem desafios de análise e interpretação, exigindo reflexões mais aprofundadas. Por essas razões, considera-se que esse vetor deve ser enfocado mais detalhadamente no decorrer do trabalho, buscando-se compreender como tem ocorrido sua forma específica de desenvolvimento, assunto que será tratado no capítulo 4.

\section{- As ramificações dos eixos/vetores}

A análise dos vetores revelou ainda, com relação aos eixos 3 e 4, que o desenvolvimento não ocorre de forma apenas linear, ao longo de uma única via, mas apresenta subdivisões, ou ramificações.

No caso do Vetor 3, por exemplo, percebe-se a formação de um eixo (a BR 020 e BR 222) com três subdivisões, que correspondem à faixa litorânea, à Via Estruturante, de acesso às diversas praias, e à CE 422, que leva ao Porto do Pecém.

Já o Vetor 4 apresenta duas vertentes; uma corresponde à av. Washington Soares/CE 040, que abrange uma área residencial em expansão, formada predominantemente por condomínios fechados voltados para a população de renda média e média-alta; e outra (av. Maestro Lisboa/CE 025), que acompanha a faixa litorânea, onde se localizam os equipamentos ligados ao turismo e lazer.

\section{- Os eixos mais dinâmicos}

Dos vetores analisados, constata-se que os dois últimos (3 e 4) revelam um ritmo de desenvolvimento diferenciado em relação aos outros, já que o Vetor 1 (Maracanaú) manifesta um crescimento mais concentrado, formando um continuum urbano com Fortaleza, enquanto o Vetor 2 (a BR 116) é, marcadamente, uma via de passagem, que percorre grande extensão de área rural, cumprindo seu papel de ligação entre a Capital e o interior e demais estados do Sudeste e Sul.

Assim sendo, os vetores 3 e 4, que se direcionam para os litorais oeste e leste, respectivamente, apresentam diversidade e dinamismo, com base, por um lado, em investimentos ligados ao turismo e, por outro, ao desenvolvimento do Complexo Portuário Porto do Pecém, no litoral oeste. Esses fatores atuam como catalisadores da expansão urbana e resultam em configurações espaciais diferenciadas.

Como a expansão determinada pelo Vetor 3, a oeste, está muito relacionada ao desenvolvimento do CIPP, o qual ainda não se acha consolidado, optou-se por analisar mais detalhadamente o 
Vetor 4, isto é, o setor sudeste, onde se observam novas dinâmicas urbanas e metropolitanas, as quais evidenciam novas formas de produção do espaço.

\section{- As ligações entre os vetores: os anéis viários}

A ligação entre os diversos vetores ainda não ocorre de modo satisfatório. A falta de eixos viários suficientes à integração apropriada reforça ainda mais a questão da macrocefalia urbana de Fortaleza. E, à medida que os vetores avançam em direção ao interior, as áreas intersticiais permanecem como grandes vazios urbanos.

O anel viário mais externo, embora em grande parte ainda pouco ocupado, já apresenta indícios de futuro adensamento, com a implantação de loteamentos residenciais.

Evidencia-se como essencial a abertura de vias que cumpram o papel de ligação entre os diversos eixos radiais, no sentido de facilitar a integração metropolitana.

\section{- O papel do sistema viário}

O sistema viário formado pelos vetores desempenha papel fundamental no processo de expansão urbana e metropolitana de Fortaleza, dilatando a malha urbana para o interior do estado em todas as direções, desde que constituíam, no passado, antigos caminhos de penetração para outros pontos da rede urbana cearense.

Posteriormente, adquiriram importância como integrantes do sistema rodoviário no contexto de unificação do mercado nacional, relacionado à industrialização, e transformaram-se nos principais corredores de circulação viária da Metrópole, promovendo intenso fluxo de pessoas e mercadorias no âmbito estadual e nacional, condição que mantêm ainda hoje. Atualmente, ao incorporarem as vias estruturantes leste e oeste (CE 085 e CE 021) do litoral21, ampliam os espaços metropolitanos nessas direções ${ }^{22}$, favorecendo novos fluxos e estimulando novas dinâmicas ${ }^{23}$, relacionadas ao turismo.

A intensidade desse processo, ou seja, a forte influência do sistema viário na distribuição da população e na expansão urbana e metropolitana é tal que provocou, desde as últimas décadas, a duplicação de todas as rodovias (BR 116, BR 222, CE 060, CE 065, CE 040 e CE 025) que partem da Capital, além do $4^{\circ}$ Anel Viário. São visíveis os sinais da melhoria da qualidade desses corredores viários, que, se por um lado expandem as áreas urbanas, por outro, ampliam a ação do Municípiopolo e reforçam sua centralidade. O Metrofor - metrô de Fortaleza - em fase de conclusão, reforçará ainda mais os vínculos entre Fortaleza e seu espaço metropolitano.

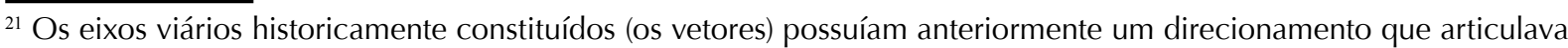
apenas o sertão à Capital, pois a dinâmica econômica verificada até as décadas de 1960-1980 não justificava a existência de caminhos paralelos à linha da costa e próximos ao litoral, uma vez que os usos litorâneos até então não tinham importância significativa e se restringiam à pesca e à atividade portuária. Com o advento do veraneio marítimo e do turismo, tornou-se necessária a construção de tais vias, a fim de favorecer a acessibilidade à zona litorânea.

${ }^{22}$ A construção das vias litorâneas (CE 085 e CE 025) concorreu para a expansão do espaço metropolitano ao longo da orla marítima, e não apenas em direção ao sertão, como ocorria anteriormente. Atualmente, com a facilidade de acessos, os núcleos litorâneos se acham devidamente incorporados à estrutura metropolitana e articulados com a Capital. O fato revela como a atividade turística tem influenciado na expansão da Metrópole.

${ }^{23}$ A dinâmica imobiliária está diretamente relacionada a esse processo, viabilizada pela facilidade de acessos e pela valorização dos espaços litorâneos.
} 



\section{- A questão da macrocefalia urbana de Fortaleza}

A forma de crescimento mencionada fortalece a questão da macrocefalia urbana do Município de Fortaleza, que concentra de modo dominante a maior parte da população, oportunidades de empregos e investimentos, resultando em distorções que interferem num desenvolvimento adequado da Metrópole.

A Capital, apesar de todo o esforço do Governo estadual para reverter esse quadro, continua exercendo forte poder de atração para a população como um todo, e comandando o processo de expansão metropolitana. De fato, algumas políticas públicas tentam minimizar o problema do desequilíbrio regional, incentivando a transferência de indústrias para fora da Cidade e investindo em infraestrutura em regiões mais distantes. Até o momento, entretanto, esta política de desenvolvimento regional não teve impactos significativos.

Nesse processo, o sistema viário formado pelos vetores de expansão urbana e metropolitana reforça o papel dominante e polarizador de Fortaleza, uma vez que convergem todos para a Capital.

\section{- Os investimentos em economia e infraestrutura}

O crescimento urbano da Metrópole está intimamente associado à expansão da economia cearense e os diferentes vetores analisados refletem essa realidade, cada qual relacionado a investimentos ligados, principalmente, à indústria e ao turismo, conforme enfocado.

O Distrito Industrial de Maracanaú, o Corredor Industrial da BR 116, o Complexo Industrial Portuário do Pecém, a atividade turística no litoral oeste e o polo de turismo e lazer no litoral leste constituem elementos decisivos na estruturação e expansão da Metrópole, como visto nos itens anteriores.

Todas as intervenções têm como fundamento o discurso ideológico "modernizante" do Governo estadual e de setores empresariais, no sentido de inserir Fortaleza nos circuitos da competitividade internacional do capital, atraindo assim investimentos produtivos.

Desde as últimas décadas, a área metropolitana de Fortaleza passou por transformações significativas em sua configuração socioespacial, transformações essas derivadas do processo de reestruturação econômica produzidas no contexto da globalização. Observa-se, pois, a estreita relação estabelecida entre as políticas socioeconômicas implementadas e suas consequências no nível do território.

A instalação de grandes equipamentos - como os citados há pouco - tem importância considerável na configuração urbana e metropolitana, alterando sobremaneira a relação entre espaços vazios e construídos. Desse modo, contribuem para a valorização e o parcelamento do solo, gerando novos fluxos no espaço onde se localizam, motivados pela transferência de capital, mercadorias, trabalho e também moradia.

Nesse processo de reestruturação econômica, associada à implementação (e previsão) de grandes obras públicas, faz-se necessária e urgente a formulação de processos de planejamento no âmbito metropolitano e estadual, a fim de que sejam delineadas políticas adequadas, que coordenem, articulem e integrem as ações ligadas ao desenvolvimento urbano e ao controle urbanístico. 


\section{- A segregação socioespacial e a questão ambiental}

Questões diversas transparecem no que se refere ao desenvolvimento urbano da Metrópole cearense. Algumas são relacionadas a aspectos já estabelecidos, como a imposição dos interesses do mercado imobiliário e a segregação socioespacial verificada. Constata-se, por exemplo, a predominância da população de baixa renda em todo o setor oeste, caracterizada pela pobreza e pela precariedade de meios, buscando na ocupação irregular de terras a solução para seus problemas de moradia, portanto, oposta aos espaços residenciais da população de alta e média renda na porção leste/sudeste da capital, que avançam em direção aos Municípios do Eusébio e Aquiraz.

Outras questões têm surgido nos últimos anos. Na expansão da Metrópole, a emergência de um novo padrão de habitação, relacionado aos condomínios fechados e o desenvolvimento da atividade turística ao longo do litoral, redundam na crescente privatização de áreas de preservação ambiental, o que revela um enorme descaso em relação ao patrimônio ambiental do Estado.

Persiste um quadro de degradação dos recursos naturais, sobretudo rios e lagoas, associado, por um lado, às "invasões" por parte da população de menor poder aquisitivo, e também à ocupação intensiva e predatória dos equipamentos turísticos junto à orla marítima.

Neste sentido, há que se refletir acerca dos reais impactos de tais ações num futuro próximo e na necessidade de políticas de controle urbano e ambiental com relação às margens dos recursos hídricos e outras áreas da RMF, como a APA do Pecém e a reserva Extrativista do Batoque, assim como a urgente necessidade de um planejamento ambiental que abranja todo o território metropolitano, preservando áreas ainda intocadas ou de possível recuperação do meio ambiente.

\section{- A configuração atual da Metrópole}

O processo de expansão da Metrópole cearense resulta, portanto, numa estrutura espacial onde são percebidos espaços de concentração e dispersão, que ocorrem no território, conformando padrões variados de urbanização; ou seja, ao mesmo tempo em que se evidencia uma expansão além das fronteiras do Município-Sede, que se estende de maneira descontínua pelo espaço metropolitano, também permanece uma expressiva concentração nas áreas centrais, fenômenos que resultam da própria dinâmica demográfica, característica de áreas mais urbanizadas, mas também de transformações relativas à moradia, ao mercado de trabalho e às condições de mobilidade urbana.

Efetuadas as análises, muitos indícios levam a crer que a estrutura socioespacial de Fortaleza esteja em pleno processo de redefinição e apresente padrões bem mais complexos do que o modelo centro-periferia, verificado no início da metropolização ${ }^{24}$, quando predominavam a concentração urbana e a monocentralidade.

\footnotetext{
${ }^{24}$ Essa fase inicial da metropolização manifestou-se, sobretudo, em virtude da extrapolação econômica (industrialização) e urbana de Fortaleza sobre os Municípios vizinhos (Maracanaú e Caucaia) e se traduziu principalmente na oferta de habitação para a população de mais baixa renda e na ocupação de extensas áreas por loteamentos, habitações precárias e favelas, na periferia da Capital e nas zonas limítrofes com esses municípios.
} 
Embora não se possa garantir que aquele modelo tradicional tenha desaparecido por completo, pois a periferização coexiste com as novas dinâmicas, as mudanças verificadas atualmente no padrão de localização da população e das atividades econômicas secundárias e terciárias começam a produzir um tecido urbano mais fragmentado, policêntrico e bem mais diversificado.

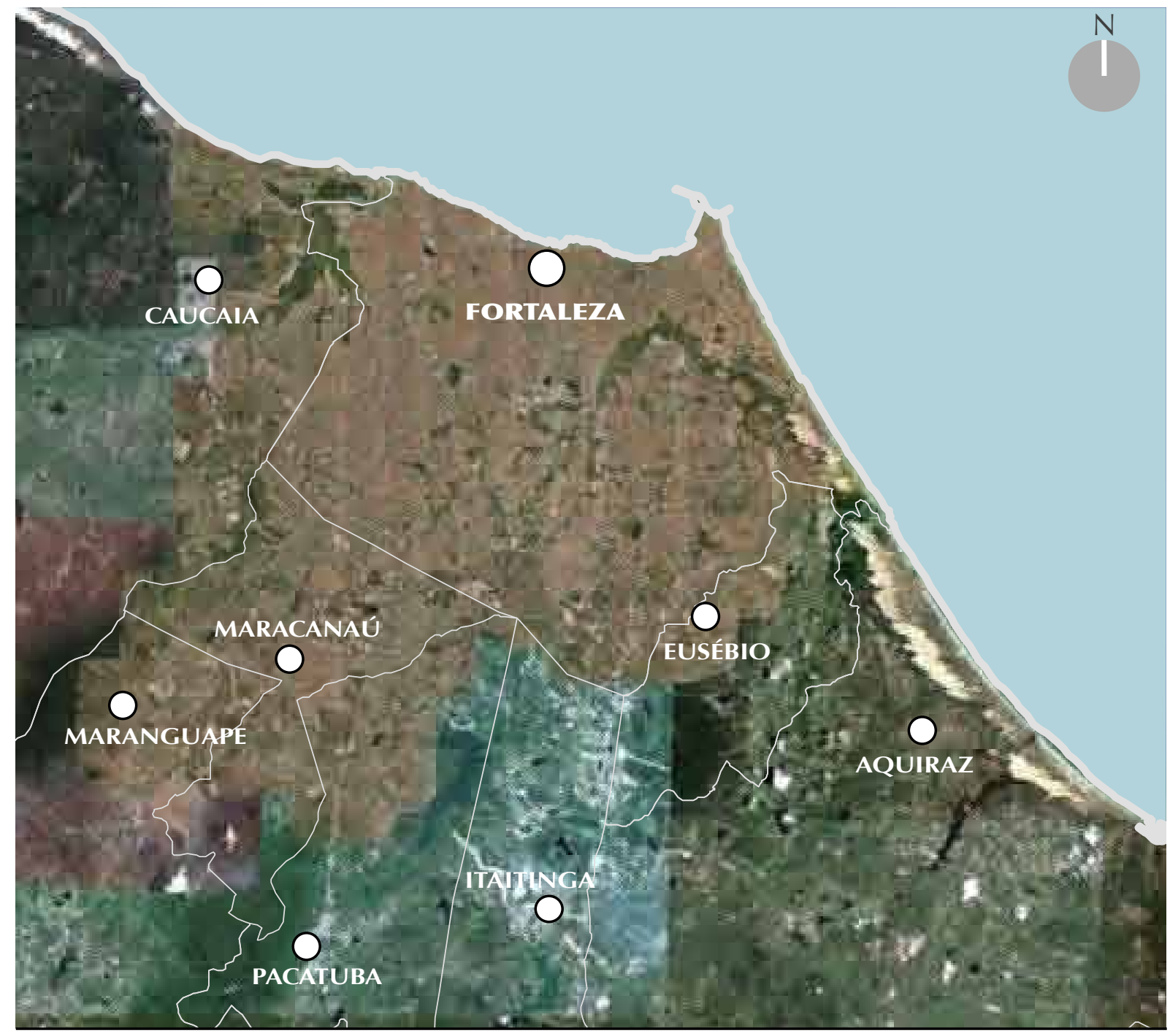

Fig. 3.123 Mapa RMF: ocupação

Fonte: Google Earth - elaborado pela autora

Pelo que se pôde observar, com relação à área metropolitana por inteiro, a ocupação ocorre de modo concentrado e contínuo em quase toda a extensão do Município de Fortaleza e nos limites sul e sudoeste (junto aos Municípios de Maracanaú e Caucaia), onde habita a população de mais baixa renda (ver figura 3.123). A expansão verifica-se também a partir da Capital, estendendo-se para o restante do Estado ${ }^{25}$, ao longo dos eixos viários principais, com o reforço das atividades de comércio e serviços. Na direção sudeste, são registrados tipos de crescimento que resultam em áreas mais dispersas e geram novas formas de tecido urbano, contrariando o "modelo periférico" de urbanização. Trata-se de uma tendência observada mais recentemente, relacionada à atividade turística e à habitação da população de maior renda, decorrente também em grande parte da

\footnotetext{
${ }^{25}$ As áreas da RMF mais distantes da Capital, com exceção das sedes dos municípios, ainda apresentam características predominantemente rurais.
} 
dinâmica imobiliária, que atua de maneira intensa nessa região. No processo de crescimento da Metrópole, observa-se ainda a formação de novas áreas de centralidade ligadas à atividade terciária, além de algumas concentrações em forma de polos, como o polo industrial do Pecém e o polo turístico de Aquiraz, nos litorais oeste e leste, respectivamente.

As transformações em curso registradas em determinadas áreas, marcadas pelo caráter mais fragmentado e descontínuo, estão associadas aos novos processos da urbanização contemporânea, abordados no primeiro capítulo. Fazem-se necessárias, portanto, a investigação e interpretação mais aprofundadas, no sentido de se buscarem explicações acerca dessa forma de crescimento metropolitano. O conhecimento do processo poderá vir a orientar ações de planejamento, com a correta definição de programas e diretrizes relacionadas a essa nova realidade.

Nesse sentido, foi escolhida uma área específica da Metrópole - o setor sudeste, aquela que apresenta padrões urbanos mais inovadores e que, portanto, exigem um desafio maior de compreensão, onde se pretende investigar as peculiaridades que o fenômeno está assumindo e proceder a uma análise mais minuciosa de como ocorre a expansão da área metropolitana de Fortaleza nesse setor, assunto que será desenvolvido no próximo capítulo. 


\section{CAPÍTULO 4}

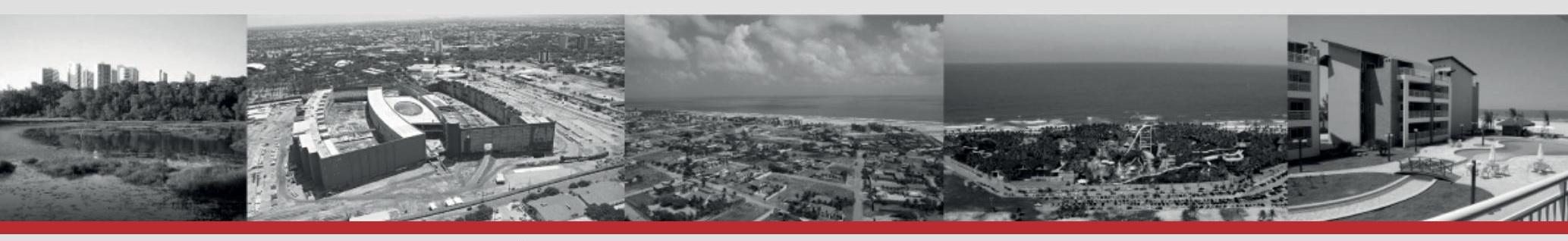

DINÂMICA E ESPECIFICIDADES DO SETOR SUDESTE 
$\mathrm{D}$ e acordo com os estudos realizados e expostos no capítulo anterior, acerca dos vetores de expansão da Metrópole cearense, ficou constatado que o Vetor 4, que corresponde ao setor sudeste, é aquele que manifesta uma tendência de crescimento mais diferenciado. Primeiramente, pelo dinamismo demonstrado desde as três últimas décadas e, depois, por ser aquele que apresenta padrões de crescimento mais complexos, diferentes do modelo centro-periferia de estruturação metropolitana, razão pela qual foi escolhido para ser objeto de estudo mais aprofundado.

Este capítulo pretende, pois, caracterizar esse espaço da Metrópole, buscando analisar sua dinâmica de expansão, enfocando aspectos de seu crescimento, seus atributos físicos, assim como os usos predominantes e a forma de ocupação, de que resultam espaços mais dispersos e fragmentados, de acordo com os processos mais recentes de urbanização.

O desenvolvimento dessa área está ligado, sobretudo, a mudanças nos padrões de habitação e aos equipamentos turísticos localizados no litoral leste, evidenciando novas formas de tecido urbano, diferentes dos assentamentos tradicionais verificados até a década de 1980-1990. Pretende-se, portanto, aprofundar a análise sobre algumas tendências e processos recentes que podem estar contribuindo para a reestruturação do espaço da Região Metropolitana de Fortaleza, particularmente no eixo de expansão sudeste.

Ao se estabelecerem as premissas para analisar o setor sudeste, procurou-se enfatizar as questões que melhor o identificam sob o ponto de vista da análise urbana. Deste modo, elegeram-se os seguintes aspectos: a caracterização geral da área, o processo inicial de formação, os componentes ambientais, os usos predominantes e o tipo de ocupação. Serão destacadas, posteriormente, as principais dinâmicas que predominam nesse setor, como a centralidade ali formada, a concentração dos condomínios horizontais fechados na região do Município Eusébio e a atividade turística desenvolvida no litoral leste da RMF, dinâmicas essas que serão analisadas de modo mais detalhado, no sentido de compreender a lógica de produção do espaço urbano e metropolitano.

\subsection{CARACTERIZAÇÃO DA ÁREA}

O setor sudeste, objeto de análise deste capítulo, é aquele situado junto aos eixos formados pelas avenidas Washington Soares/CE 040 e Maestro Lisboa/CE 025', que se dirigem rumo aos municípios do litoral leste do Estado. A expansão urbana se verifica basicamente em torno dessas duas importantes rodovias. Ambas funcionam como eixo de ligação entre os bairros típicos de residência da classe média alta na Capital e as novas áreas ocupadas pelos condomínios fechados no Eusébio e pela atividade turística no litoral de Aquiraz (ver figuras. 4.1 a 4.3).

A extensão da urbanização, na perspectiva metropolitana, ocorre, portanto, ao longo desses eixos viários e tem início junto ao Parque do Cocó e o Shopping Iguatemi, no bairro Edson Queiroz². Além deste, o setor compreende também os bairros da Lagoa da Sapiranga, Cambeba, Alagadiço Novo e Lagoa Redonda. Extrapola o Município de Fortaleza, abrangendo parte dos Municípios do Eusébio e de Aquiraz, integrantes da RMF.

\footnotetext{
${ }^{1}$ A av. Maestro Lisboa e sua continuação, a CE 025, constituem uma espécie de bifurcação do Vetor 4, que dá acesso às praias situadas no Município de Aquiraz, onde se concentram equipamentos ligados à atividade turística e de veraneio.

${ }^{2} \mathrm{O}$ bairro Edson Queiroz é um dos maiores da Cidade, com área de $14 \mathrm{~km}^{2}$ e população de 22.100 habitantes. Toda essa região formada pelos bairros Edson Queiroz, Guararapes e Luciano Cavalcante era historicamente denominada de Água Fria.
} 


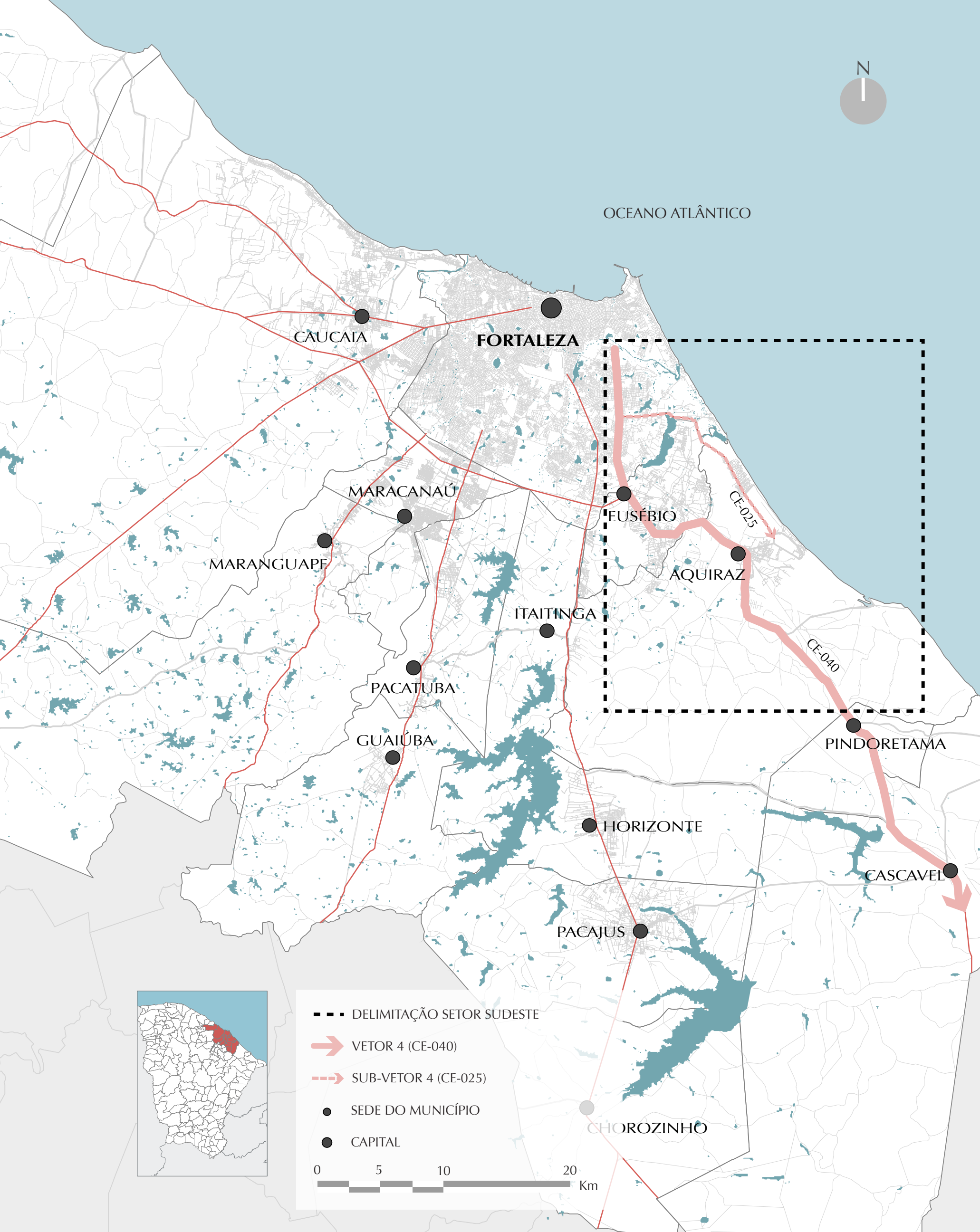

Fig. 4.1 Mapa RMF: delimitação do setor sudeste 


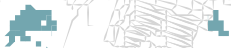

$-2--=---$

$2=-7$

-

내

\section{-20'RTALEZA}
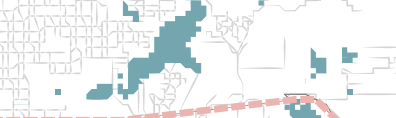

" +1

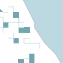

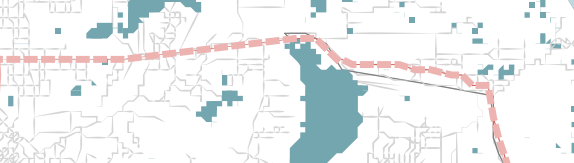
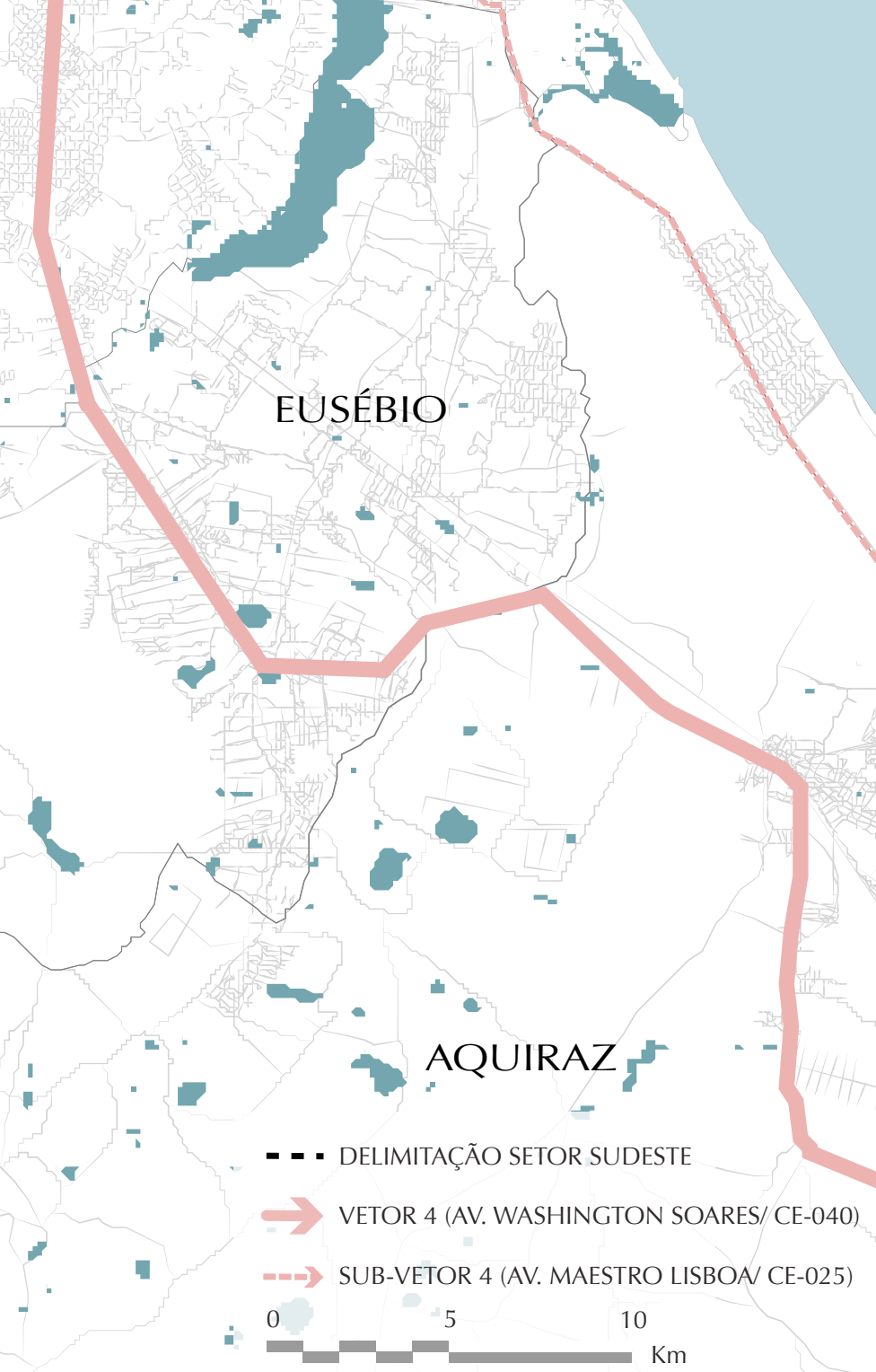

EUSSÉBIO
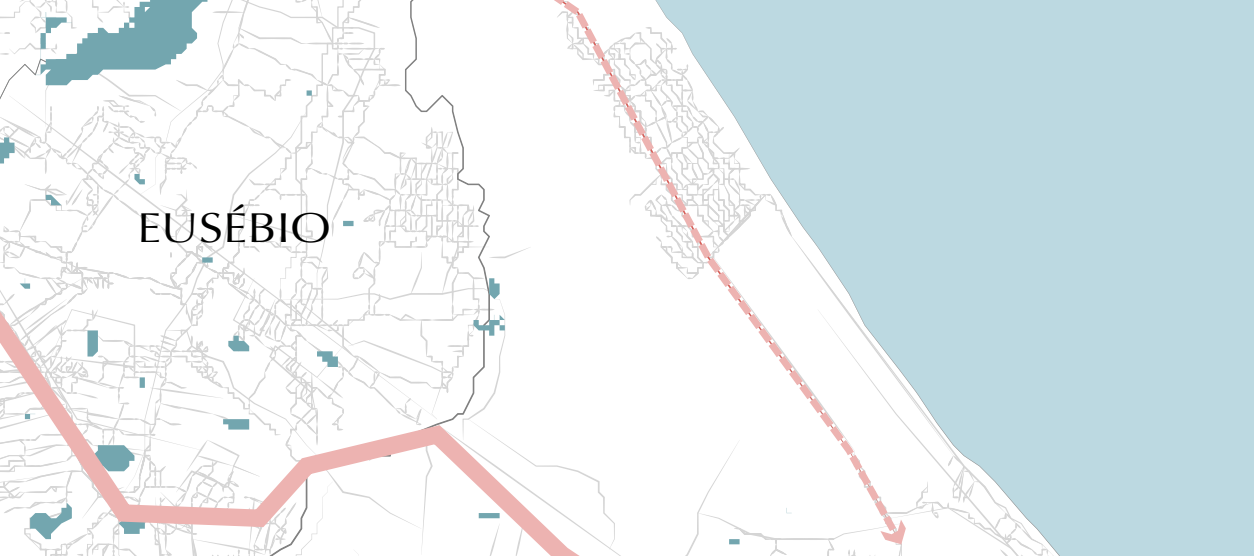


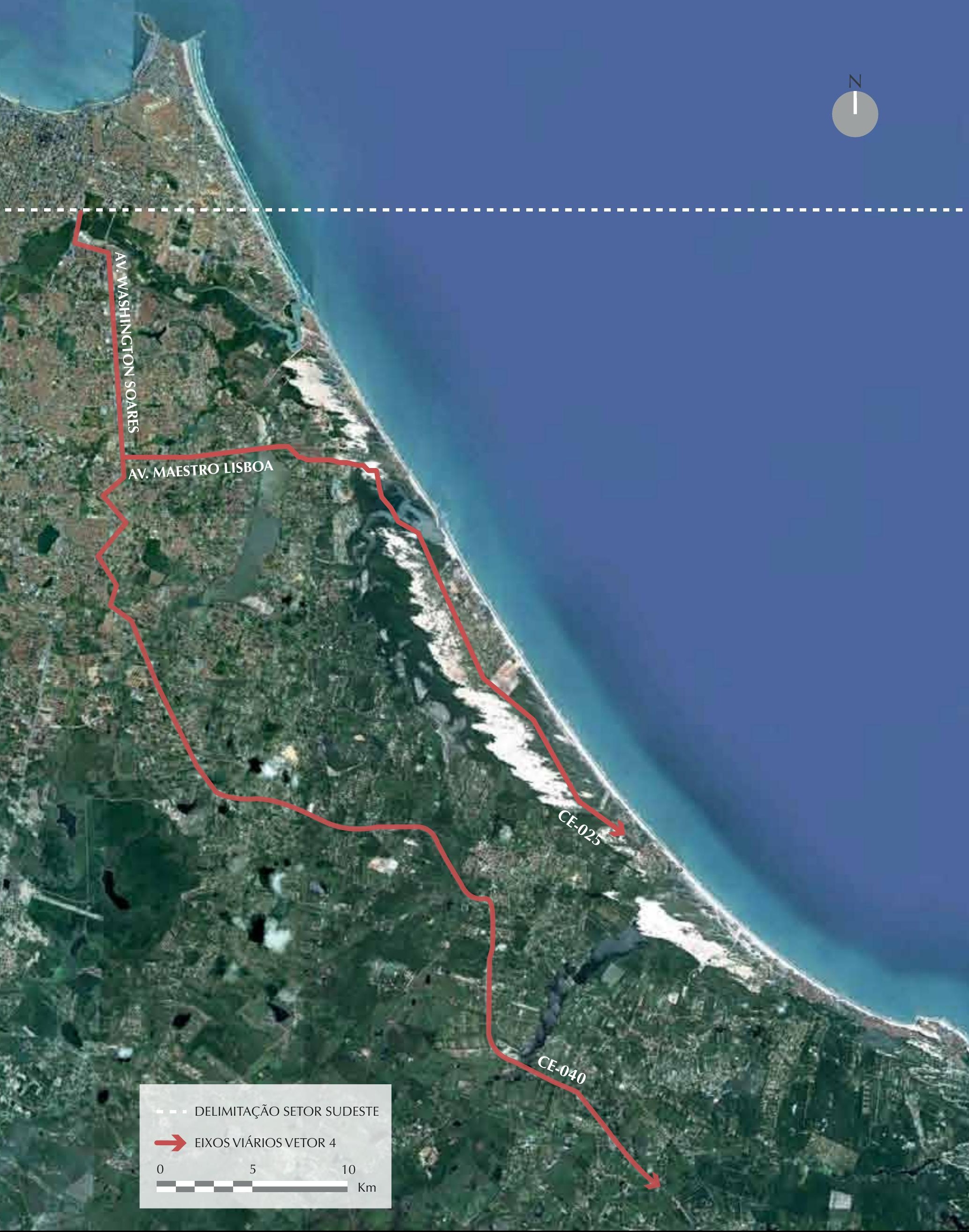

Fig. 4.3 Setor sudeste e principais vias

Fonte: Google Earth - elaborado pela autora 
Cabe esclarecer que o setor sudeste, examinado neste capítulo, compreende apenas parte da área percorrida pelo Vetor 4, ou seja, aquela ainda dentro do Município de Fortaleza e trechos dos Municípios de Eusébio e Aquiraz mais próximos da Capital, zona essa onde se processam as mudanças mais significativas, além de ser aquela que manifesta, desde a década de 1980-1990, dinâmicas diferenciadas de uso e ocupação do solo.

O setor é constituído predominantemente por bairros onde se localizam as camadas de renda média e alta da Metrópole 3 . Configuram o que é conhecido, simbolicamente, como a "zona nobre" nas cidades brasileiras, ou seja, abrange uma mistura de bairros residenciais, comércio e serviços elitizados, além de apresentar intensa valorização imobiliária, crescente verticalização e alguns bolsões de favelas, que resistem em determinados trechos. Desenvolve-se rumo ao Município do Eusébio (onde se verifica atualmente a expansão residencial em forma de condomínios horizontais fechados) e ao litoral do Município de Aquiraz, onde se concentram equipamentos ligados ao veraneio e à atividade turística.

De acordo com a Síntese Diagnóstica do Município (2003),

[...] esse é um eixo que, pelo fato de situar-se fora dos processos onde vêm se intensificando os investimentos industriais de maior envergadura, apresenta vantagens substanciais, tanto como eixo estruturante do turismo quanto pelo efeito de espraiamento da função moradia, dentro de melhores condições ambientais e paisagísticas da RMF. Esses aspectos oferecem perspectivas de atração mais voltadas para a classe média.

As transformações ocorridas nessa área tiveram origem, conforme destacado no capítulo anterior, em um conjunto de projetos e investimentos ${ }^{4}$ públicos e privados, iniciados na década de 1970-1980, quando alguns equipamentos foram instalados na porção inicial da av. Washington Soares, que, juntamente com outras dinâmicas, desencadearam um processo acelerado de mudanças nessa parte da Metrópole.

Até pouco tempo praticamente despovoada, tida como bairro distante e isolado de Fortaleza, a área em estudo tem conhecido ocupação intensa desde a década de 1980-1990, apresentando mudanças relevantes e transformando-se, desde então, no eixo de expansão mais dinâmico e valorizado de Fortaleza, com forte rebatimento do setor imobiliário.

\subsection{UM BREVE HISTÓRICO DA OCUPAÇÃO DA ÁREA}

Cabe fazer, de início, uma breve prospecção sobre as origens da formação do espaço urbano dessa área da Metrópole, no sentido de contribuir para o entendimento da estrutura urbana atual.

Não se afigura tarefa simples, entretanto, dada a carência de dados e documentos que comprovem a evolução da área. Além disso, até a década de 1960-1970, toda a zona sudeste não fazia parte do perímetro urbano da Capital. Não constava sequer nas diretrizes dos planos Saboya Ribeiro (Plano Diretor para Remodelação e Extensão da Cidade, de 1947) e Hélio Modesto (Plano Diretor da Cidade de Fortaleza, de 1962).

\footnotetext{
${ }^{3}$ Essa área constitui o caminho imobiliário traçado pelas classes mais abastadas de Fortaleza, que se deslocam no setor leste/sudeste da Capital e da Metrópole.

${ }^{4}$ O primeiro grande equipamento a se instalar na área foi a UNIFOR Universidade de Fortaleza, inaugurada em 1973. Depois da Unifor, seguiram-se o Centro de Convenções (1974) e a Imprensa Oficial (1978).
} 
Até os primeiros decênios do século XX, constituía uma zona quase completamente desabitada. Obstáculos físicos, como o rio Cocó, impediam a integração com o resto da Cidade.

A planta da Cidade de Fortaleza de 1945 evidencia a ocupação rarefeita dessa área, com pouquíssimas habitações e presença de propriedades semirrurais, destinadas à agricultura de subsistência e à criação de gado. A planta do IBGE, de 1956, traz poucas alterações com relação à anterior, apontando os sítios existentes à época. Havia nessa área, junto ao rio Cocó, conforme mostrado na planta, um conjunto de salinas (Salinas Diogo), que se mantiveram ativas até o início dos anos 1980-1990, quando foram desativadas, para dar lugar ao Parque do Cocó e à construção do Shopping Iguatemi (ver figuras 4.4 a 4.10).

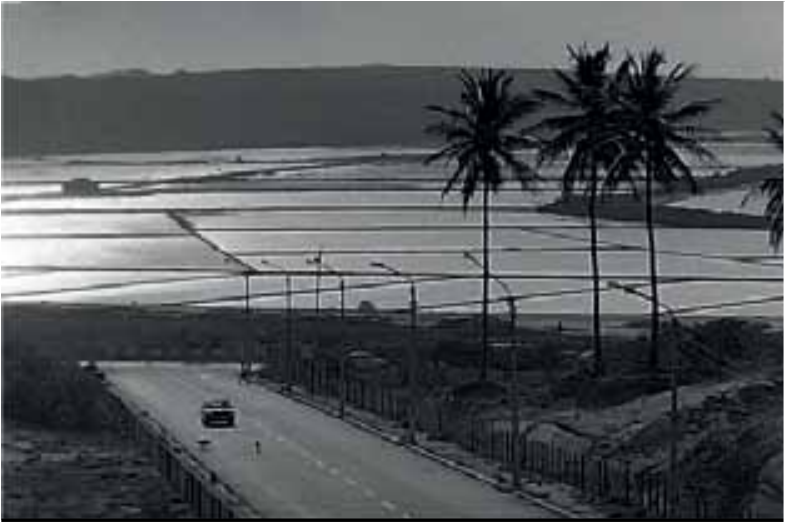

Fig. 4.4 Antigas salinas junto ao rio Cocó Fonte: http://blogdoguilhon.blogspot.com.br

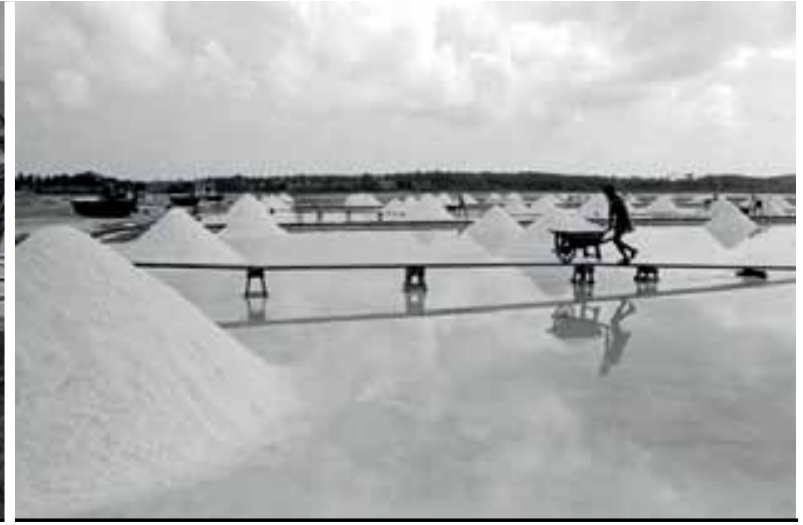

Fig. 4.5 Antigas salinas junto ao rio Cocó Fonte: http://blogdoguilhon.blogspot.com.br

Nos anos oitenta, há uma consolidação deste expansionismo urbano neste setor da cidade, envolvendo poderosos interesses comerciais, e, sobretudo, imobiliários. São implantados, contraditoriamente, o Parque do Cocó e o Shopping Center Iguatemi, em um mesmo espaço físico, redefinindo zonas residenciais, em áreas de manguezais, em torno de mananciais hídricos; expulsando antigos moradores, de baixa renda, que sobreviviam daquele ecossistema, e atraindo uma população de renda bem mais elevada, pela existência de infra-estrutura implantada pela administração pública (CARLEIAL, 2003).5

A construção da ponte sobre o rio Cocó ${ }^{,}$, nas proximidades da av. Antonio Sales, efetivada quando da abertura da av. Perimetral, na década de 1960-1970 pelo então prefeito Cordeiro Neto, permitiu a ocupação, que se deu muito lentamente, até a década de 1970-1980.

Vale destacar o fato de que o PLANDIRF (1972), que considerou o Município de Fortaleza totalmente urbano, reforçou o processo de ocupação dessa área da Cidade, por meio de diretrizes que incentivavam a instalação de infraestrutura e equipamentos na região. Com isso, vários sítios (Água Fria, Colosso, Carrapicho, Alagadiço Novo e Cambeba) e áreas não habitadas foram incorporados à malha urbana de Fortaleza.

\footnotetext{
${ }^{5}$ Disponível em: http://www.ub.edu/geocrit/sn/sn-146(030).htm

${ }^{6}$ A primeira ponte foi construída na década de 1940-1950. Era de madeira e o acesso se fazia de forma precária, com largura suficiente para a passagem de apenas um automóvel. A ponte foi concebida para viabilizar a ligação Mucuripe-Messejana.

${ }^{7}$ PLANDIRF - Plano de Desenvolvimento Integrado da Região Metropolitana de Fortaleza (1972).
} 
CAPÍTULO 4

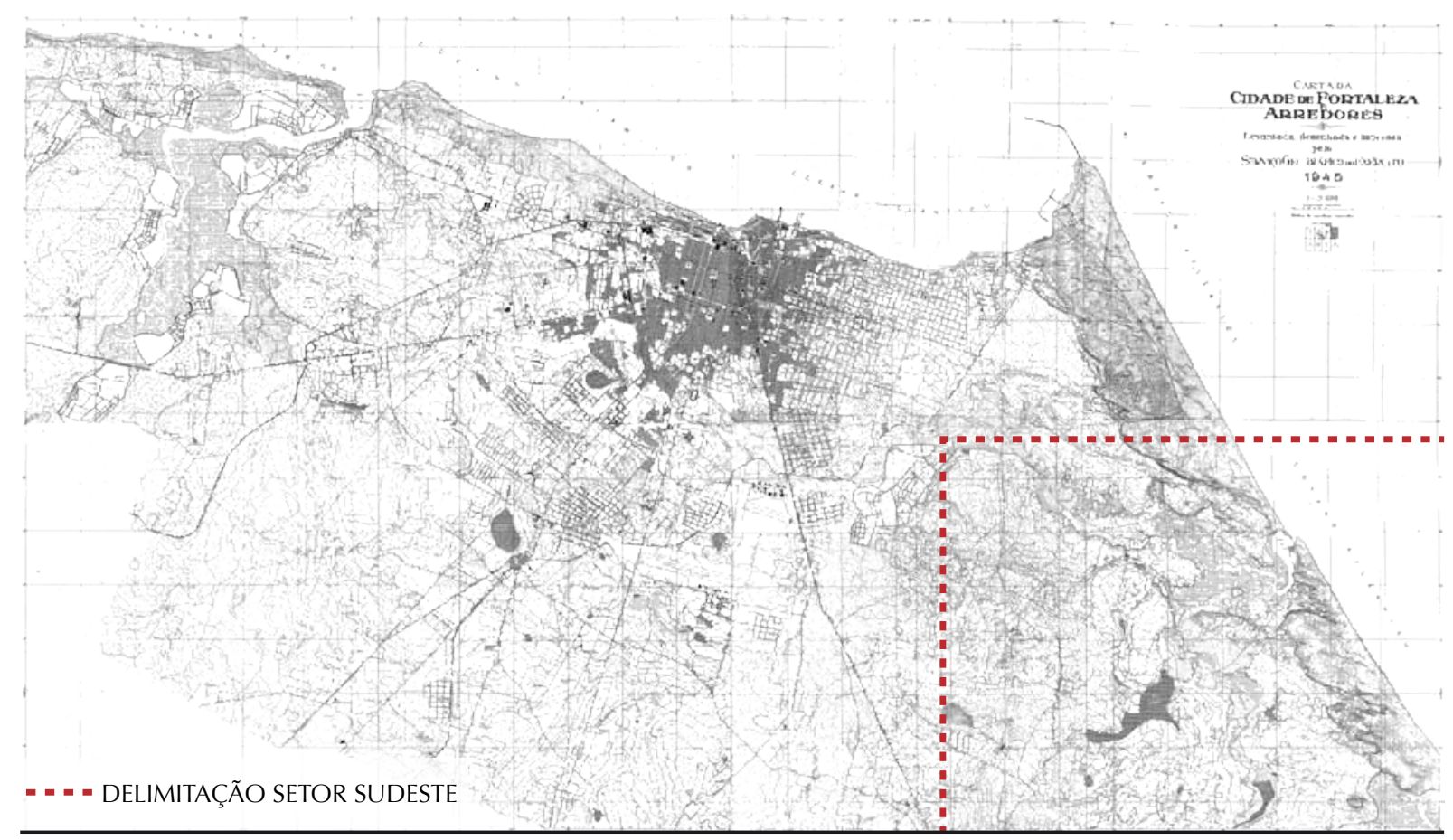

Fig. 4.6 Setor sudeste no Levantamento aerofotogramétrico de 1945 Fonte: reconstituição - Margarida Andrade

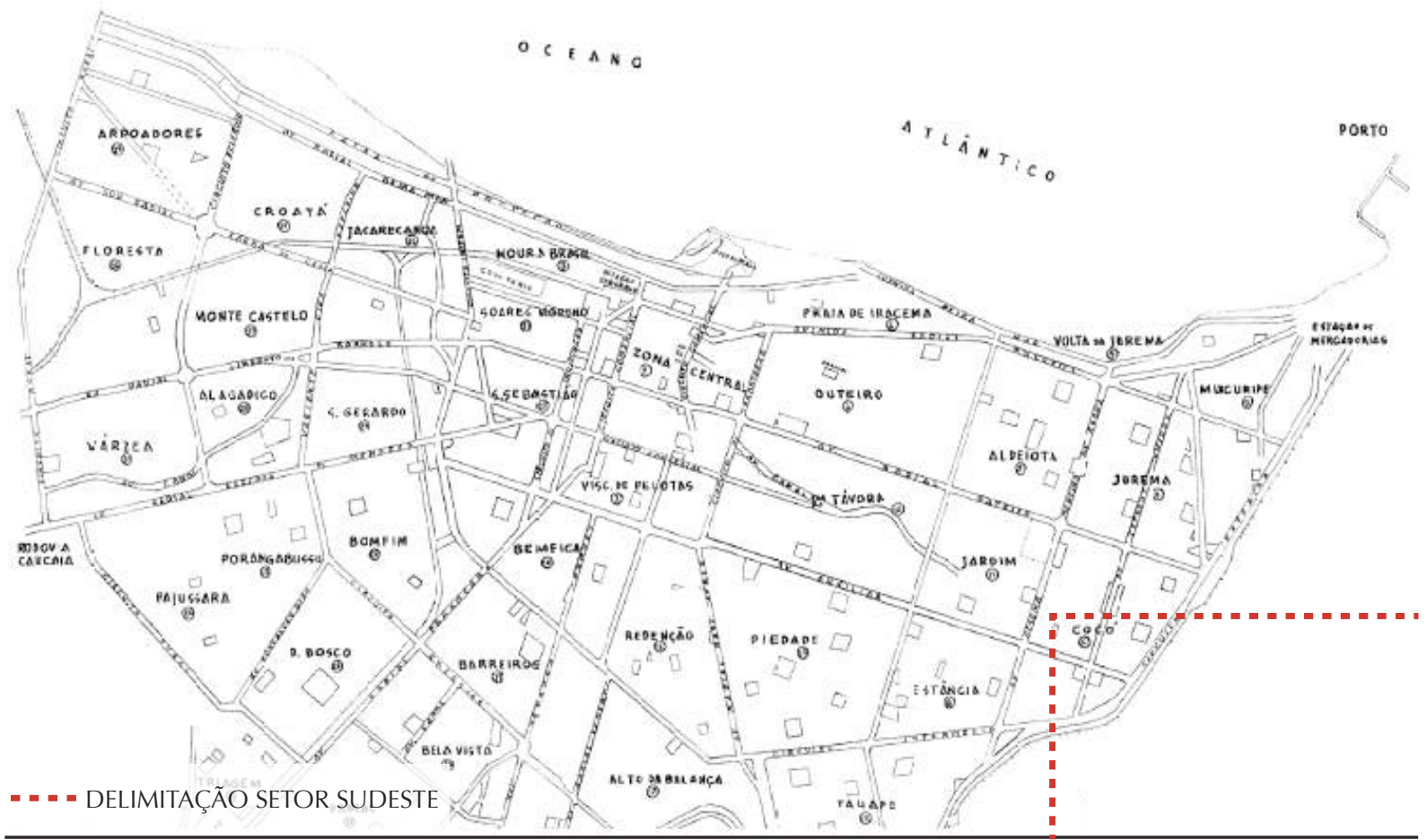

Fig. 4.7 Setor sudeste no Plano Diretor para Remodelação e Extensão da Cidade (1947) Fonte: CODEF/PMF 


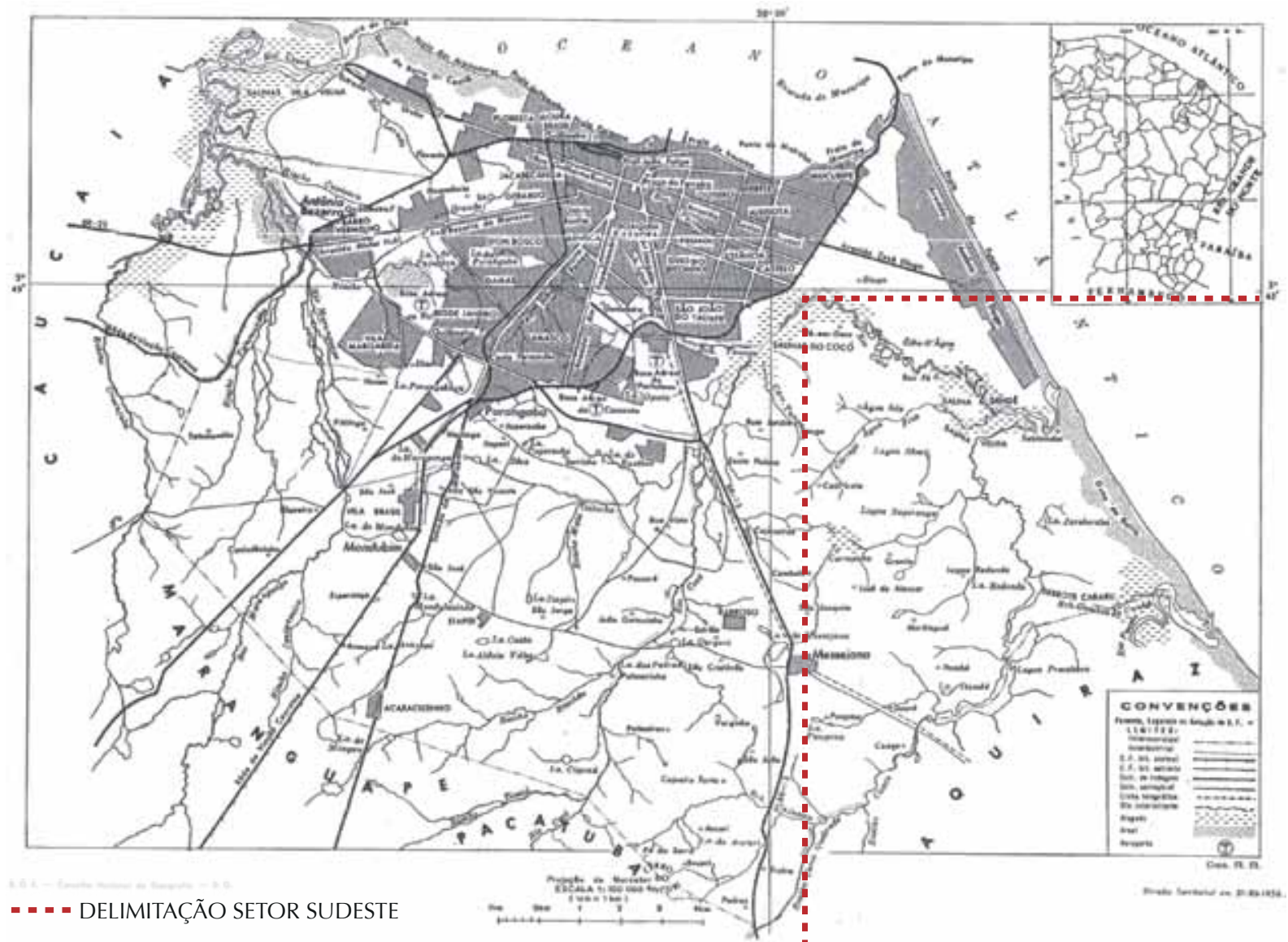

Fig. 4.8 Setor sudeste na planta do IBGE (1956)

Fonte: IBGE

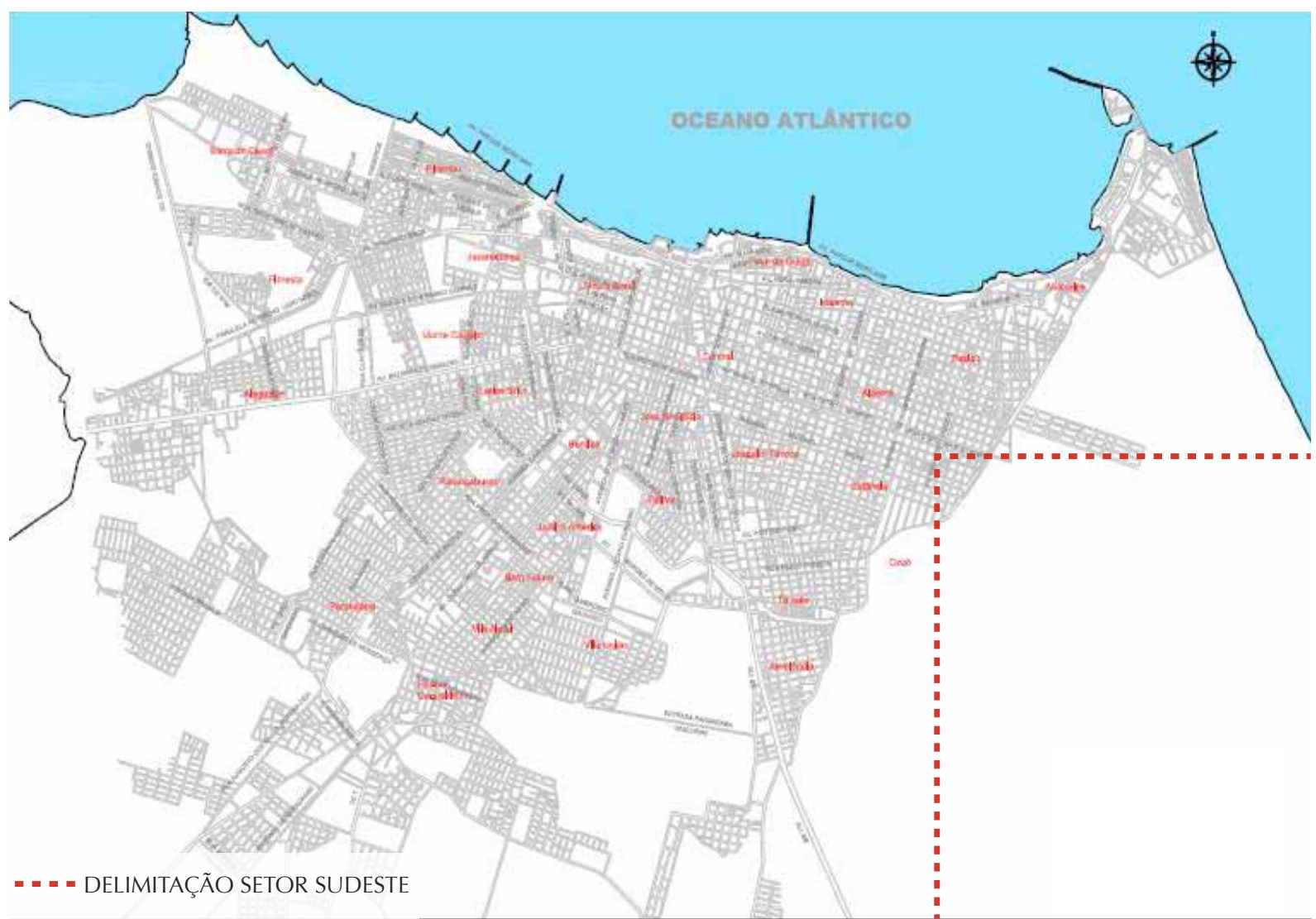

Fig. 4.9 Setor sudeste no Plano Diretor da Cidade de Fortaleza (1962) Fonte: PMF/Org. Vera M. Accioly 


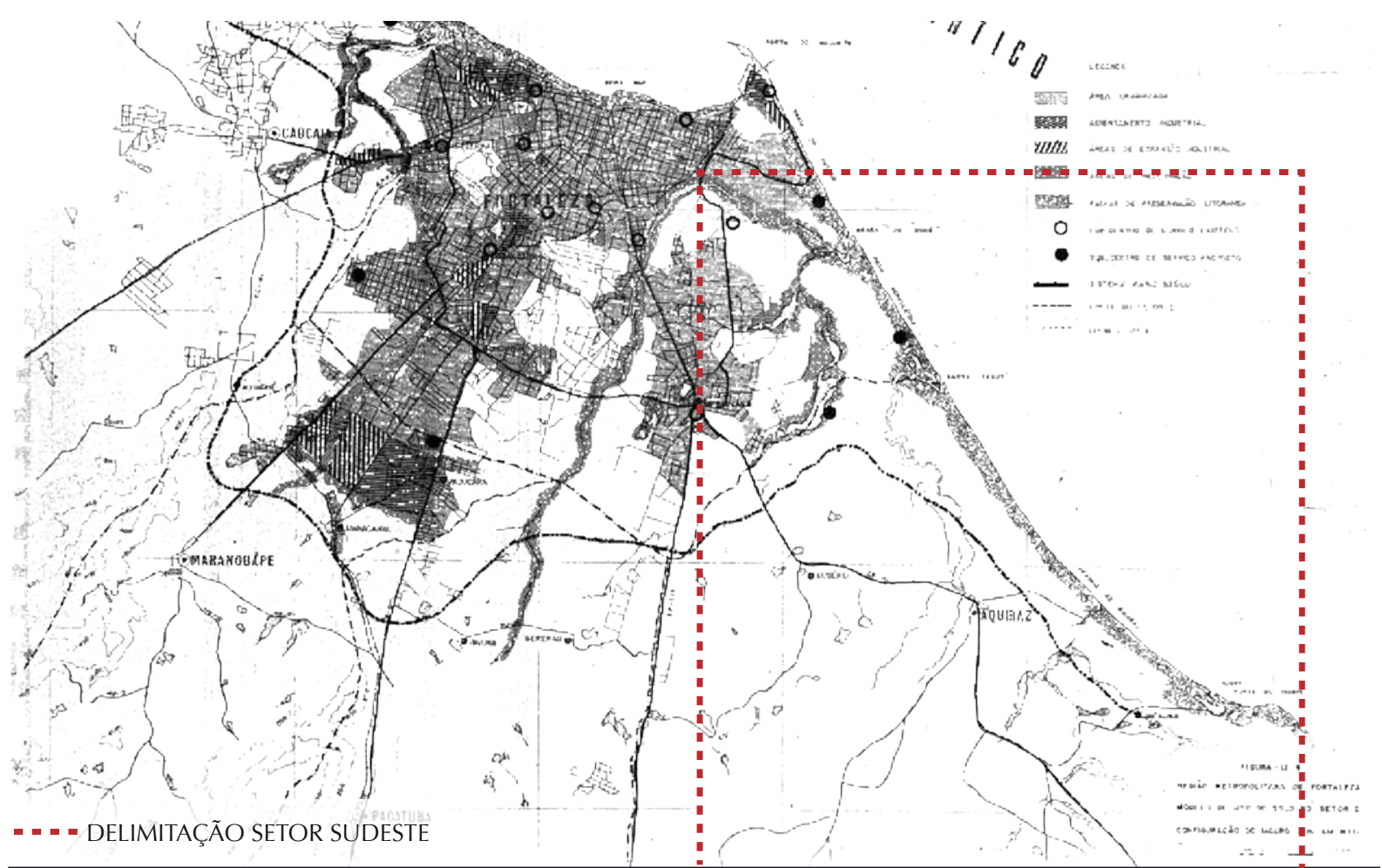

Fig. 4.10 Setor sudeste na planta da AUMEF (1977) Fonte: AUMEF

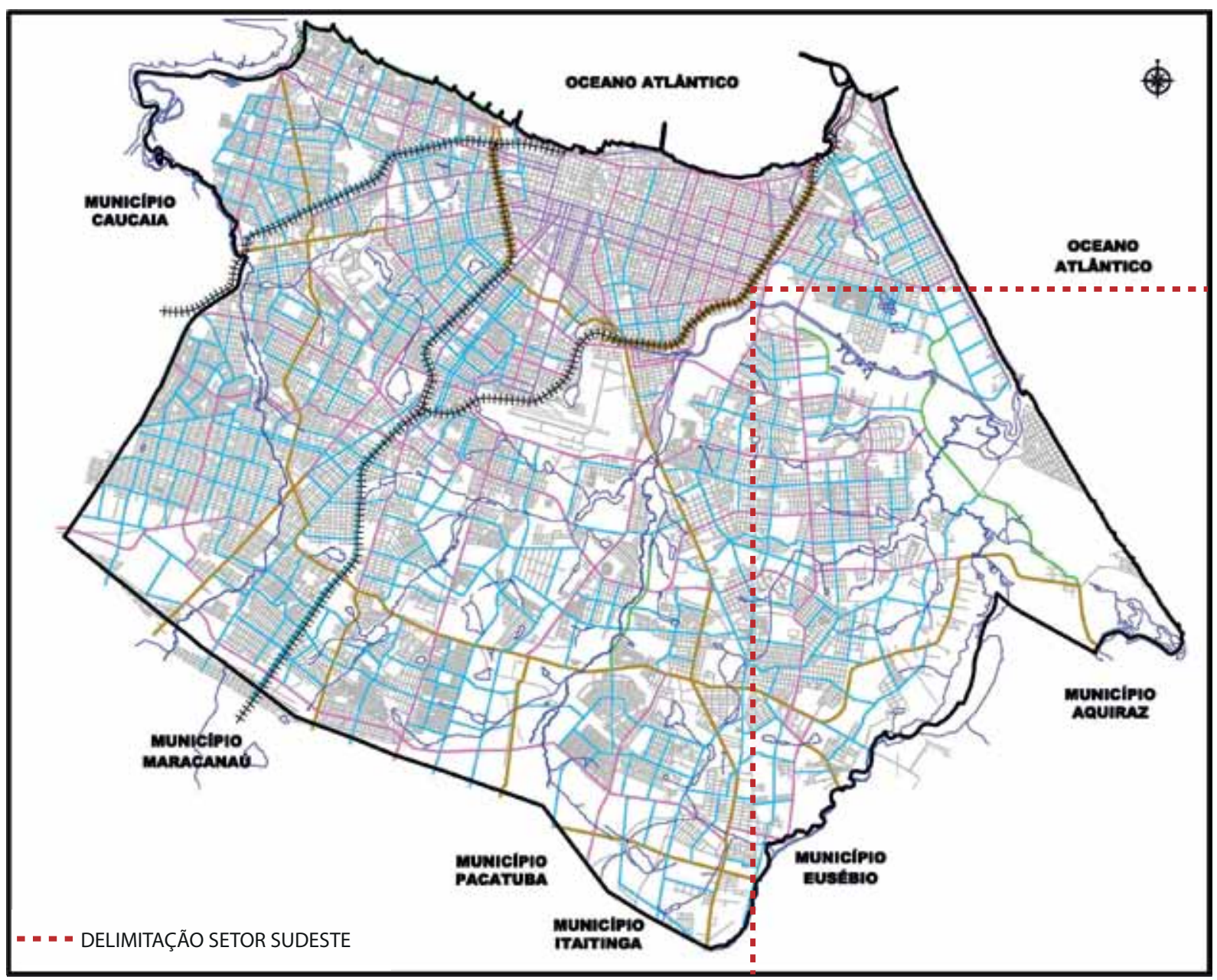

Fig. 4.11Setor sudeste no PDDU FOR (1992)

Fonte: PMF 


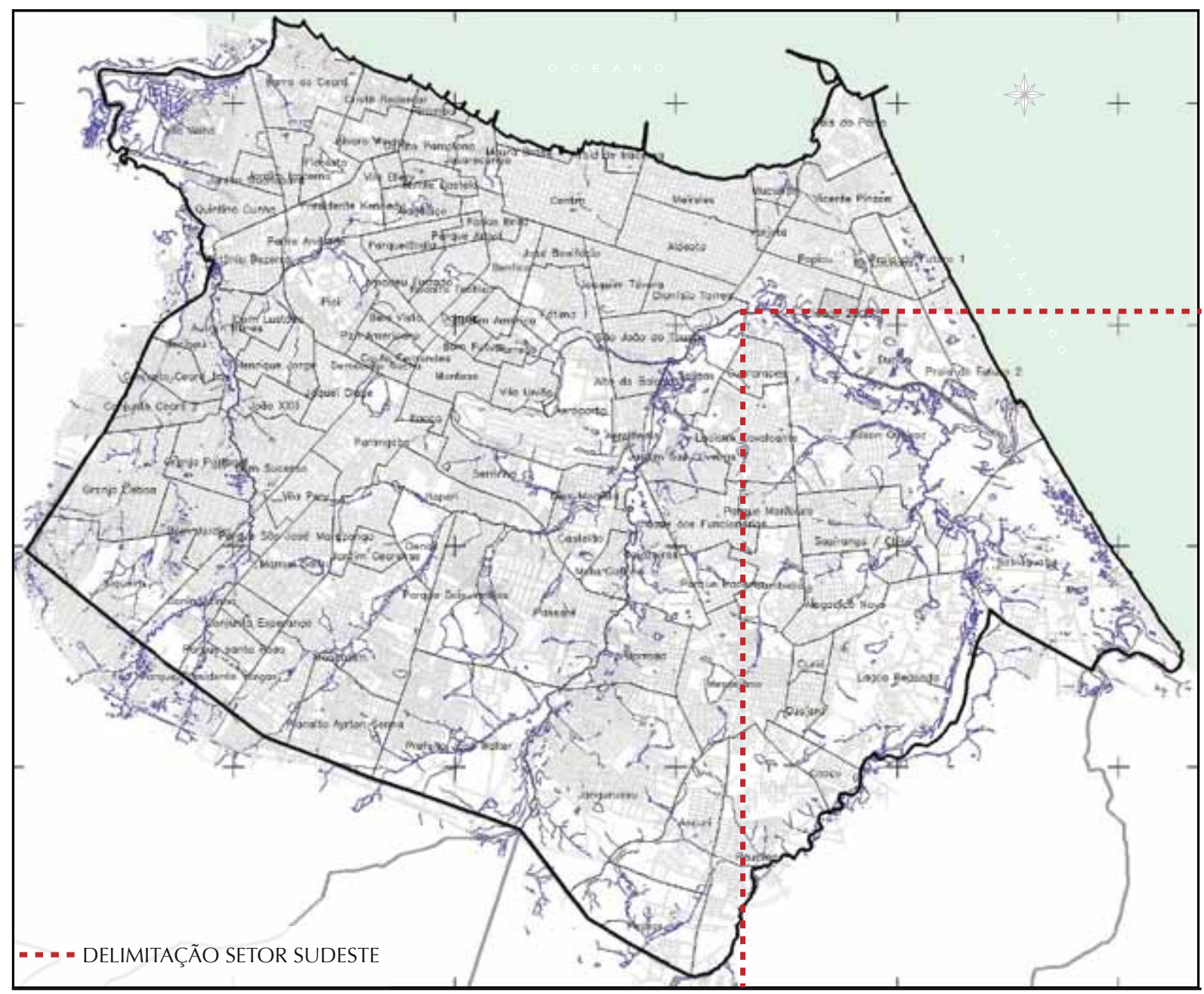

Fig. 4.12 Setor sudeste no PDDUA FOR (2004) Fonte: PMF

A parte inicial do setor sudeste, no Município de Fortaleza, corresponde ao antigo bairro da Água Fria $^{8}$, que tem origem nas terras adquiridas em 1925 por Washington Soares e Silva ${ }^{9}$, conforme relato de Ilnah Soares, sua filha:

A propriedade era imensa, algo por volta de 1.000 ha, pelos quais Washington pagou 50 mil reis a Amâncio Filomeno Gomes. A terra fazia parte do distrito de Messejana e englobava a Água Fria propriamente dita, a Lagoa Seca, Sapiranga, Coité, Dendê, lagoa do Muçu e parte do rio Cocó, numa extensão de quase vinte e quatro quilômetros. Realmente, era muita terra, mas ainda assim, "nas areias". O acesso era difícil, chegava-se lá a cavalo, pelo lado de Messejana, num percurso demorado até à casa patriarcal (SOARES, 2005, p.49).

Essas terras foram sendo vendidas posteriormente e loteadas, iniciando-se então o processo de ocupação do bairro. Segundo estudos realizados por Fuck Jr. (2004), pequenos engenhos de canade-açúcar se estabeleceram e se desenvolveram também em sítios, na área próxima a Messejana:

José Martiniano de Alencar (pai do famoso escritor) fundou o sítio Alagadiço Novo, com o primeiro engenho a vapor da Província do Ceará; padre Carlos Augusto Peixoto de Alencar, o sítio Cambeba; Antônio

\footnotetext{
${ }^{8} \mathrm{O}$ antigo bairro da Água Fria abrangia os atuais bairros Edson Queiroz, Luciano Cavalcante e Guararapes.

${ }_{9}^{9}$ Nas terras adquiridas, Washington Soares (que deu o nome à avenida principal da área) exercia as atividades de salineiro e agricultor.
} 
Alexandrino da Cunha Lage, o sítio Ancori; Antônio da Silva Porto, o sítio Guajeru (antigo São Gerardo); Urbano de França Alencar, o sítio Jangurussu; e Antônio Felino Barroso, o sítio Itambé (FUCK JR., 2004, p.151).

De acordo com o autor, muitos desses antigos sítios transformaram-se nos atuais bairros e loteamentos de Fortaleza. Foi a partir dos anos 1940-1950 que se iniciou o processo de incorporação de novas áreas na zona sudeste da Cidade, realizado por empresários e proprietários fundiários ${ }^{10}$, que se apropriavam de terrenos localizados na periferia urbana, loteando antigos sítios de uso rural, como o Cocó, o Alagadiço Novo, o Cambeba, o Colosso e o Tunga, na antiga Água Fria.

Já no lado de Messejana (margem direita do rio Cocó), os Srs. Patriolino Ribeiro e Edson Queiroz possuíam terras que se estendiam do rio Cocó ao mar. Ao mesmo tempo, muitos terrenos "centrais" ficavam sem uso, à espera de valorização, demonstrando que a especulação fundiária e imobiliária é também "histórica". Eles, assim como o Sr. Diogo e outros, como proprietários de terras, atuaram também no mercado imobiliário, de onde adviram muitos loteamentos no sudeste do município, como: Planalto Água Fria, Village Colosso, Sítio Santa Rosa, Alpha Village, Santa Luzia do Cocó etc. (FUCK JR., 2004, p.152).

O sítio Colosso, de propriedade do Grupo Edson Queiroz" ${ }^{11}$ ocupa área de grandes dimensões (300 ha) e permanece até hoje desocupado, apresentando evidente contraste com relação ao entorno, onde já existem inúmeras edificações. O terreno foi loteado, mas não foi comercializado, provavelmente visando a maior valorização futura. Se efetivamente ocupado, poderia vir a abrigar uma população da ordem de 60.000 pessoas, considerando-se uma densidade de $200 \mathrm{hab} / \mathrm{ha}$.

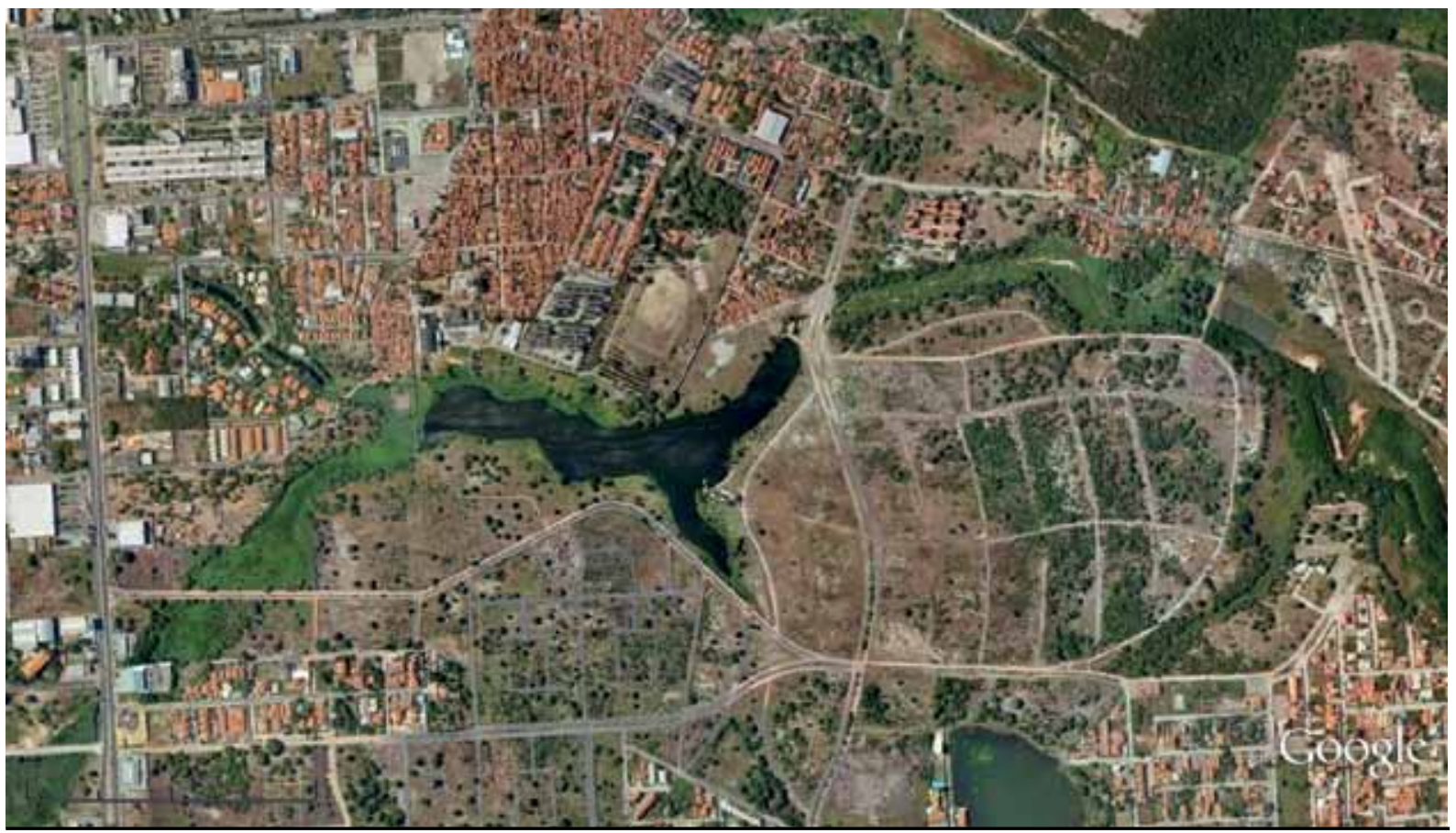

Fig. 4.13 Sítio Colosso

Fonte: Google Earth

${ }^{10} \mathrm{O}$ Sr. Patriolino Ribeiro foi um dos principais proprietários de terra nessa região, depois de haver adquirido terrenos de Washington Soares, dono das terras de onde se originou a maioria dos loteamentos da zona sudeste do Município de Fortaleza.

${ }^{11}$ O Grupo Edson Queiroz é um dos grandes grupos econômicos do Ceará, atuando em diversas áreas no Estado: Educação (Unifor - Universidade de Fortaleza), Comunicação (TV e Rádio Verdes Mares, FM 93, Jornal Diário do Nordeste), distribuição de gás, mineração, agroindústria, eletrodomésticos, etc. 


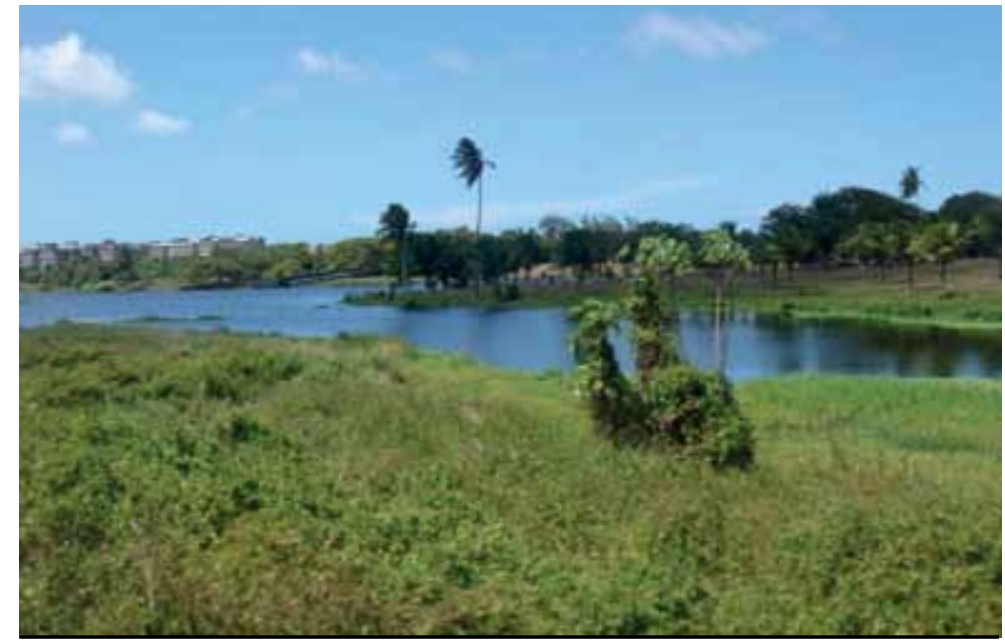

Fig. 4.14 Sítio Colosso

Fonte: http://brasil.indymedia.org/images

Ao longo do tempo, os grandes proprietários de terra foram os principais promotores do processo de urbanização verificado na área, sendo responsáveis também pela instalação dos vários empreendimentos $^{12}$ que deram início ao desenvolvimento e à ocupação do bairro. Dessa forma, o Poder Público justificava a dotação de infraestrutura para a área, apesar da baixa densidade habitacional.

A grande disponibilidade de terrenos, o clima ameno, a abundância de vegetação, a presença de lagoas e riachos e a infraestrutura ${ }^{13}$ instalada constituíam elementos utilizados pelas imobiliárias para atrair compradores, de modo que a procura por lotes residenciais se intensificou a partir da década de 1980-1990.

Pode-se afirmar que a ocupação do setor sudeste decorreu da expansão da zona leste de Fortaleza, historicamente caracterizada como zona residencial de mais alta renda. O processo foi intensificado no período há pouco mencionado, quando grande parte da população da Aldeota, tradicional reduto das classes mais abastadas, "transferiu-se para o novo bairro da Água Fria, em busca de espaço diferenciado e mais reservado, com avenidas mais amplas e espaços verdes" (ACCIOLY, 2009).

O bairro da Aldeota, transformado em nova área de centralidade ${ }^{14}$ da Cidade, desde o final da década 1970-1980, conheceu valorização crescente dos terrenos e tornou inviável a construção de habitações unifamiliares. A população passou então a procurar novos espaços para habitar, embora mantivesse a mesma direção ${ }^{15}$ (leste/sudeste), conforme mencionado no capítulo anterior.

Seria de se esperar que a expansão da zona residencial de alta renda acompanhasse a extensão da orla marítima, em direção à Praia do Futuro, ao leste, como aliás ocorreu em outras cidades

\footnotetext{
${ }^{12}$ Equipamentos públicos e educacionais diversos foram construídos em terrenos cedidos por esses proprietários fundiários, visando a uma valorização futura das terras adjacentes. Constituía assim uma espécie de prática, verificada na época: implantava-se um equipamento por vezes sem justificativa técnica e em áreas pouco adensadas; em seguida, iniciava-se a implementação de melhorias em infraestrutura, pagas pelos contribuintes, que promoviam a sua valorização e estimulavam a comercialização de terrenos até então pouco valorizados.

${ }^{13} \mathrm{Na}$ verdade, essa infra-estrutura foi sendo implantada de forma bastante lenta, devido à distância com relação à região central de Fortaleza, implicando altos custos.

${ }^{14}$ Sobre a centralidade da Aldeota, ver DIÓGENES, Beatriz H. N.: A centralidade da Aldeota como a expressão da dinâmica intra-urbana de Fortaleza (2005).

15 “Nas grandes Metrópoles brasileiras, conforme constata Villaça (1998), a população de mais alta renda sempre se desloca segundo uma mesma direção. Segundo o autor, a direção do caminhamento verifica-se inicialmente em busca dos sítios mais aprazíveis. Consolida-se com o tempo, mantendo a mesma radial e ocupando o mesmo setor: os fortes interesses dessas camadas fazem com que elas se apeguem com incrível obstinação a uma determinada direção de expansão territorial" (DIÓGENES, 2005, p.39).
} 
brasileiras situadas no litoral (VILLAÇA, 1998). Em Fortaleza, contudo, esse processo se deu de forma diferenciada, apesar de ter havido uma tentativa nesse sentido, nas décadas de 1970-1990. O desenvolvimento da Praia do Futuro ${ }^{16}$ não ocorreu, em parte, em razão da ausência de infraestrutura e da presença de favelas, mas, principalmente, em decorrência das altas taxas de salinidade apresentadas, que dificultaram a moradia naquela orla.

Este bairro, onde predominam grandes vazios e ocupações irregulares, passou por uma espécie de declínio e "decadência" no que se refere ao uso residencial e ficou restrito aos estabelecimentos industriais situados próximo ao porto, à construção de algumas mansões junto às dunas, a uma rede rarefeita de hotéis e à atividade turística e de lazer, em função das várias barracas de praia ali implantadas. Atualmente, entretanto, têm sido realizados novos investimentos ${ }^{17}$ na área, numa tentativa de reversão do quadro.

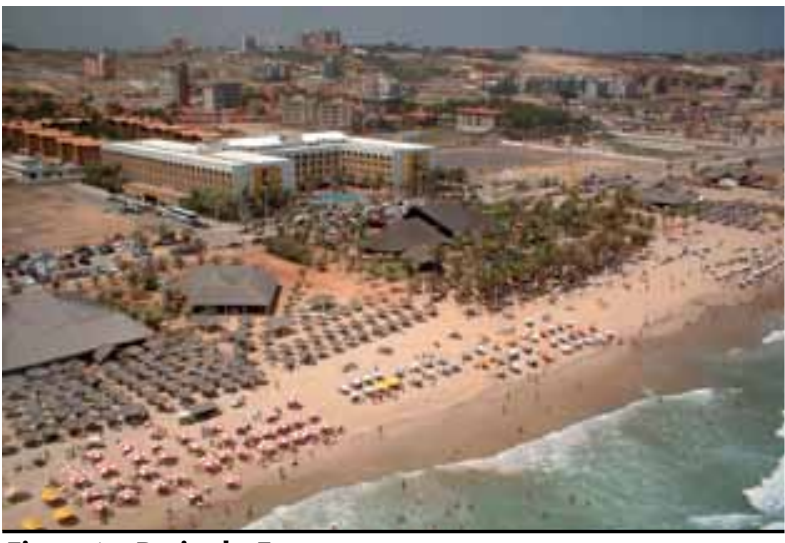

Fig. 4.15 Praia do Futuro

Fonte: Nasser Hissa Arq. Associados

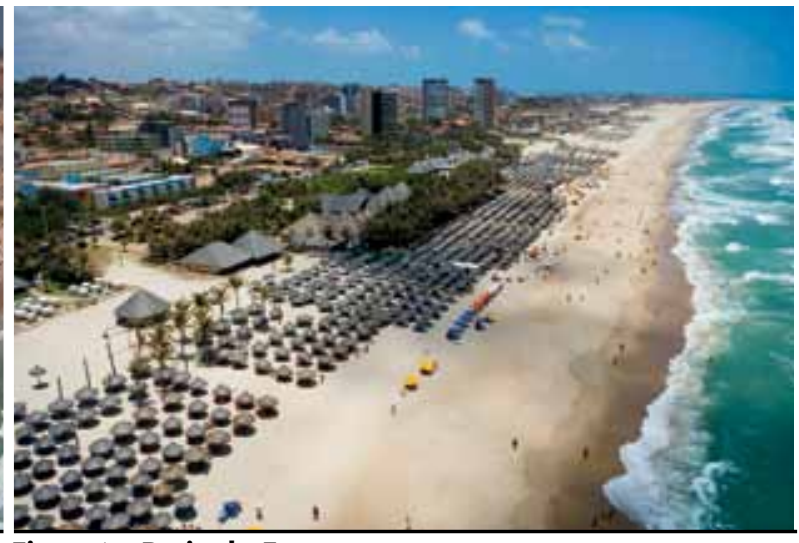

Fig. 4.16 Praia do Futuro

Fonte: http://guiadoviajante.com

A não-ocupação da Praia do Futuro resultou em uma espécie de "redirecionamento" das classes de mais alta renda, que passaram a se estabelecer no setor sudeste da Capital (ver figura 4.17). Grandes lotes foram comercializados, em áreas antes destinadas aos sítios e ali foram construídas grandes mansões, já inviabilizadas na Aldeota.

Paralelamente ao uso residencial, equipamentos educacionais e institucionais começaram a se instalar na porção inicial da av. Washington Soares, ainda com certa dificuldade de acesso, à época; alguns deles em terrenos cedidos pelos proprietários de terra, como a UNIFOR - Universidade de Fortaleza ${ }^{18}$, inaugurada em 1973, e órgãos públicos diversos, como o Centro de Convenções, inaugurado em 1974, a Imprensa Oficial (1978), hoje desativada, o Banco do Estado do Ceará e a Academia de Polícia, hoje demolida, em local onde está sendo construído o Centro de Eventos do Ceará

\footnotetext{
${ }^{16}$ Nos anos 1970 houve o prolongamento da av. Santos Dumont até a Praia do Futuro, que se pressupunha promissora para o mercado imobiliário, mas cujas condições 250 naturais (maresia) não permitiram essa expansão (FUCK JR, 2004, p.152). O nome Praia do Futuro demonstrava claramente presumíveis perspectivas de valorização imobiliária.

${ }^{17}$ Entre os investimentos recentes, foram executadas a abertura da av. Pe. Antonio Tomaz até à orla, a construção da ponte sobre o rio Cocó e a revitalização da Praça 31 de Março. Com isso, registra-se uma tendência de revalorização do bairro, com o incremento de atividades turísticas e o surgimento de vários lançamentos imobiliários. Essas mudanças podem vir a acarretar transformações substanciais na Praia do Futuro, configurando futura expansão e integração metropolitana, entre os Municípios de Fortaleza e Aquiraz.

${ }^{18}$ A UNIFOR foi construída em terreno cedido pelo Sr. Patriolino Ribeiro ao Sr. Edson Queiroz, idealizador da Universidade. Foi inicialmente prevista em outra área da Cidade, na zona oeste, mas, em vista da oferta do terreno, foi instalada numa gleba de grandes dimensões, junto à av. Washington Soares.
} 


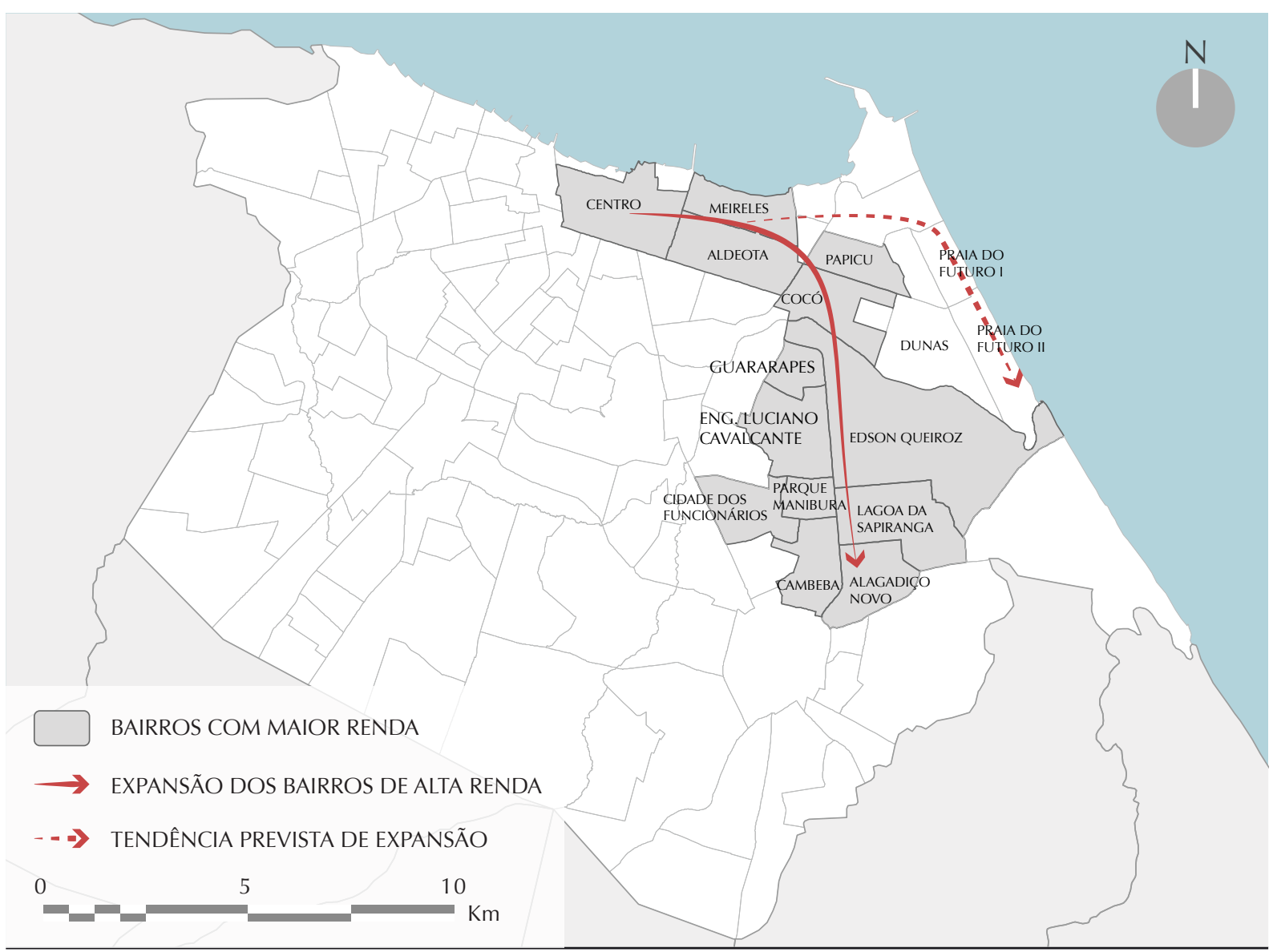

Fig. 4.17 Mapa Fortaleza: bairros das classes de alta renda Fonte: elaborado pela autora

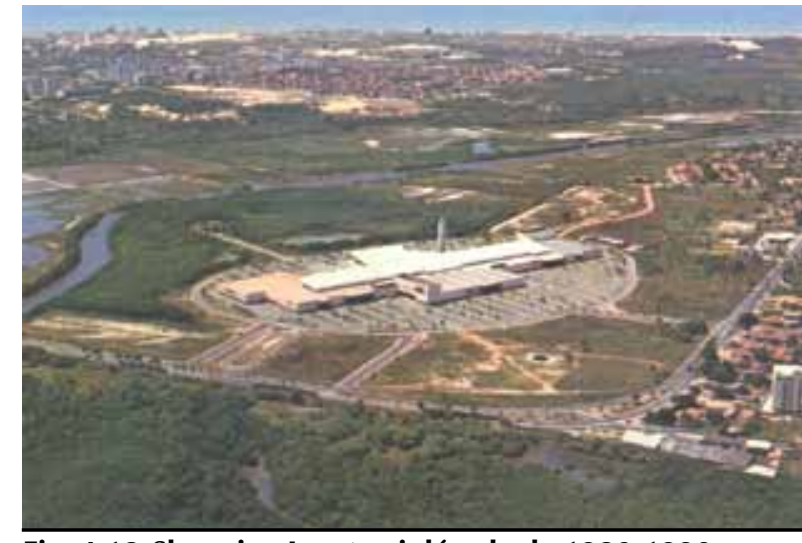

Fig. 4.18 Shopping Iguatemi década de 1980-1990 Fonte: http://www.skyscrapercity.com/

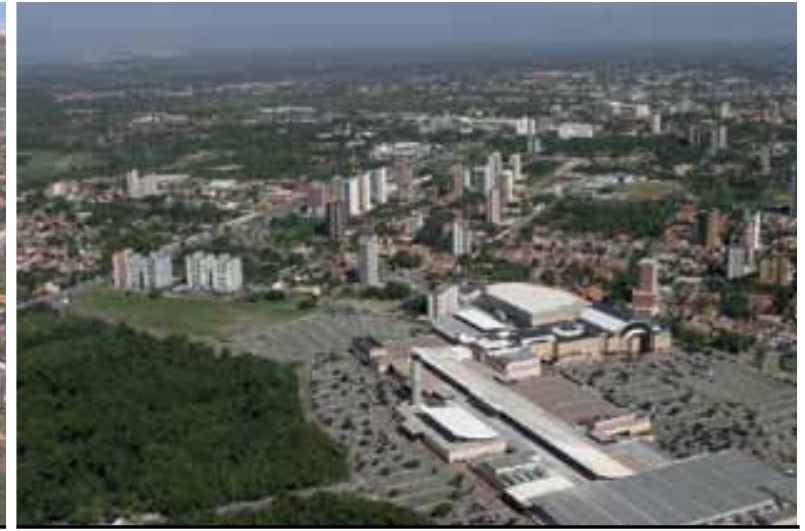

Fig. 4.19 Shopping Iguatemi 2010

Fonte: http://www.skyscrapercity.com/

A instalação do Shopping Iguatemi, em 1982, foi fator determinante no desenvolvimento dessa área. Desde então, investimentos viários foram realizados e outros grandes equipamentos foram construídos nas imediações, promovendo o surgimento de novos bairros e incrementando a expansão urbana nessa direção. 
A duplicação da av. Washington Soares, ação empreendida pelo Governo estadual, foi essencial para o processo de ocupação de toda a região. A reformulação da via alterou a acessibilidade a uma grande parte da Metrópole, ocasionando valorização quase imediata do local e, consequentemente, atraindo a atenção do setor imobiliário ${ }^{19}$.

Em suma, o deslocamento da população de alta renda, a construção e posterior ampliação do Shopping Iguatemi e a atuação do Estado, ao implantar equipamentos e infraestrutura urbana, foram elementos decisivos que marcaram o início do processo de ocupação e posterior expansão dessa área da Metrópole.

\subsection{AS DINÂMICAS DIVERSAS DE USO E OCUPAÇÃO DO SOLO}

A urbanização, formas de produção e apropriação do espaço e distribuição da população na região do chamado eixo sudeste de expansão metropolitana exibem um padrão bastante heterogêneo, com diversidade de situações imbricadas nas dinâmicas socioespaciais.

O crescimento urbano que ocorre nesse eixo é diferenciado, observando-se aí diversos tipos de uso e ocupação do solo. Conforme já destacado, essa área não se relaciona com a localização industrial e apresenta relevante patrimônio ambiental. É constituída por bairros onde se localiza população formada por camadas de renda média e alta, por pequenos núcleos urbanos tradicionais, que resistem ou se transformam mais lentamente, por alguns bolsões de favelas, além de áreas voltadas para o comércio e serviços mais elitizados, instalados ao longo da av. Washington Soares. Fora dos limites municipais, no Eusébio, há significativa área de expansão residencial, formada por condomínios horizontais e loteamentos fechados e, no litoral do Aquiraz, uma concentração expressiva de empreendimentos imobiliários voltados para turismo e lazer20.

Como visto, coexistem aí fragmentos distintos de urbanização, que abrangem uma diversidade de processos sociais, urbanísticos e ambientais, que interessa compreender. Em sua totalidade, todo o setor apresenta testemunhos de ocupação acelerada, intensa valorização imobiliária e verticalização crescente em determinados trechos. Como afirma Costa, H. (2004, p.108) "vistos em conjunto, [esses processos] obedecem à lógica da produção do espaço da expansão metropolitana contemporânea, comandada por grandes empreendimentos imobiliários de elite e de serviços avançados". Importantes dinâmicas de transformação urbana, pois, atuam no setor sudeste e, como tal, devem ser apontadas. Essas dinâmicas são resultado, em grande parte, da articulação entre a atuação do capital imobiliário e a do Poder Público. Os múltiplos processos observados serão destacados a seguir, identificados em diferentes períodos, por meio de levantamentos aerofotogramétricos, imagens aéreas e fotos, possibilitando, dessa maneira, resgistrar a progressiva transformação ocorrida no setor.

\footnotetext{
${ }^{19}$ A grande quantidade de terrenos vazios disponíveis, a incidência de recursos naturais diversos, a acessibilidade obtida com o alargamento e reformulação de vias, promovidas pelo Poder Público, tornaram essa área o espaço privilegiado para os empreendimentos de incorporação na Cidade.

${ }^{20}$ As três últimas dinâmicas mencionadas (a centralidade da av. Washington Soares, os condomínios fechados do Eusébio e a atividade turística no litoral de Aquiraz) serão objeto de análise em itens à parte.
} 


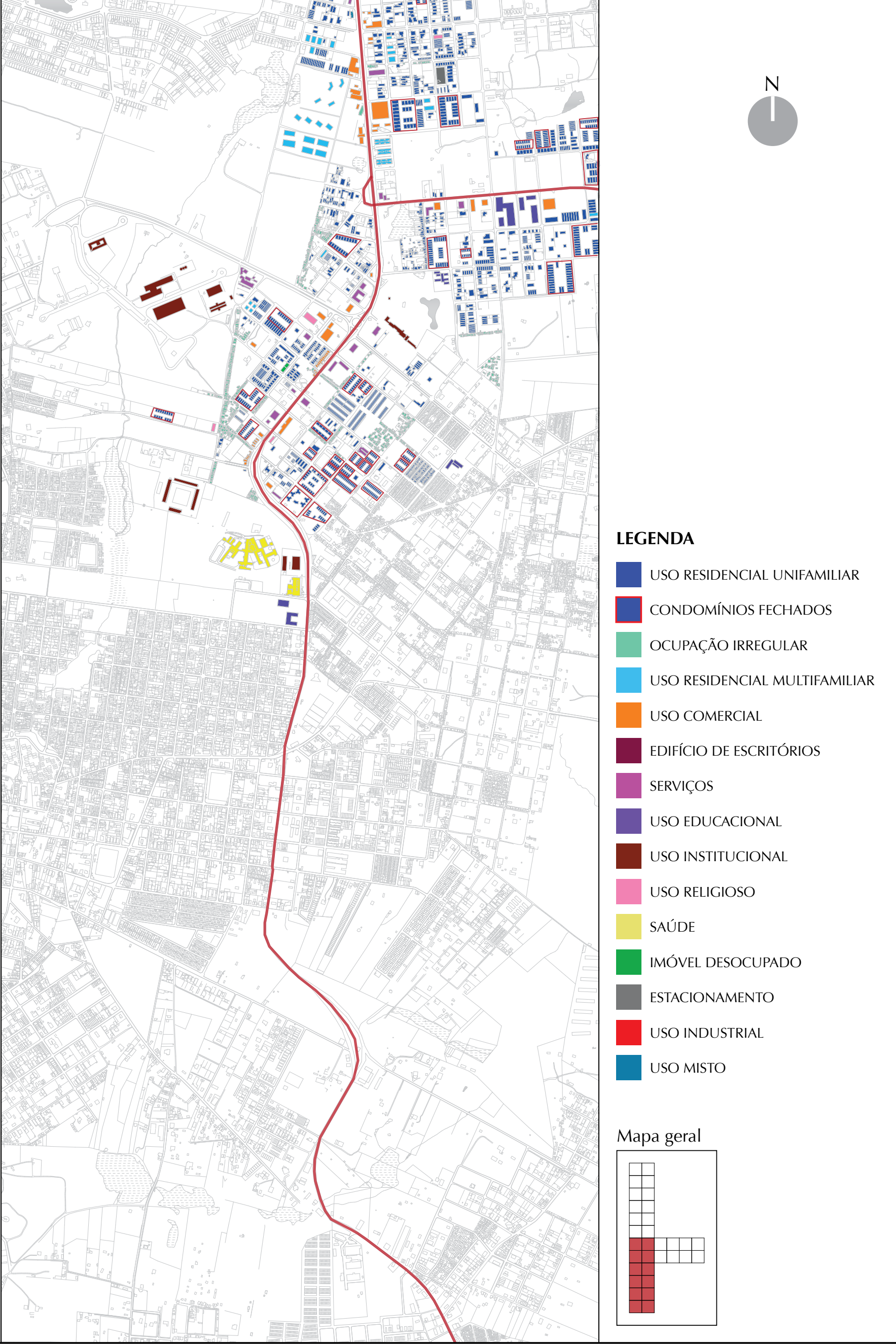

Fig 4.21 Levantamento aerofotogramétrico com diferentes usos (2011) - parte 2

Fonte: levantamento aerofotogramétrico 1996 - organizado e atualizado pela autora 


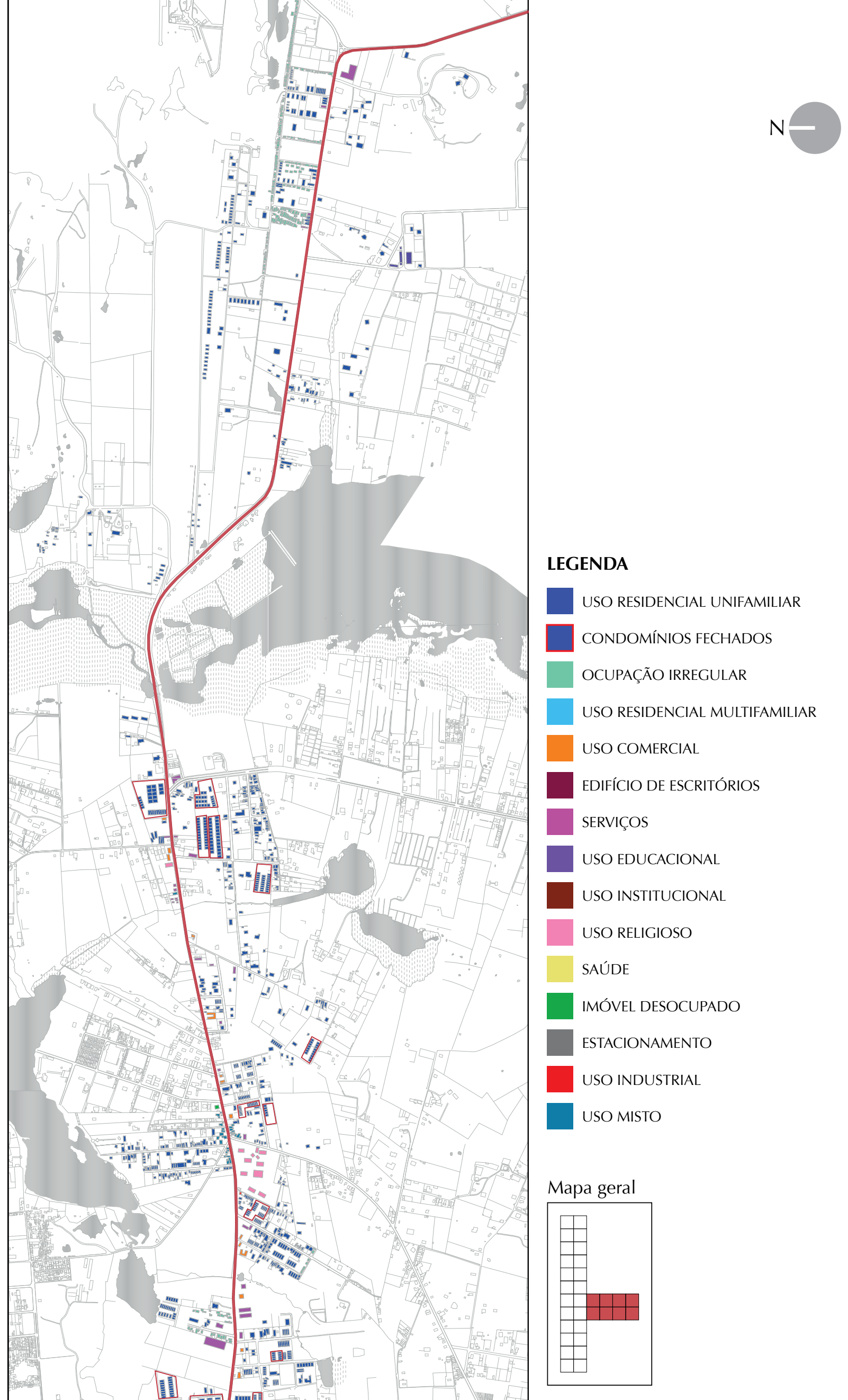

Fig 4.22 Levantamento aerofotogramétrico com diferentes usos (2011) - parte 3

Fonte: levantamento aerofotogramétrico 1996 - organizado e atualizado pela autora 


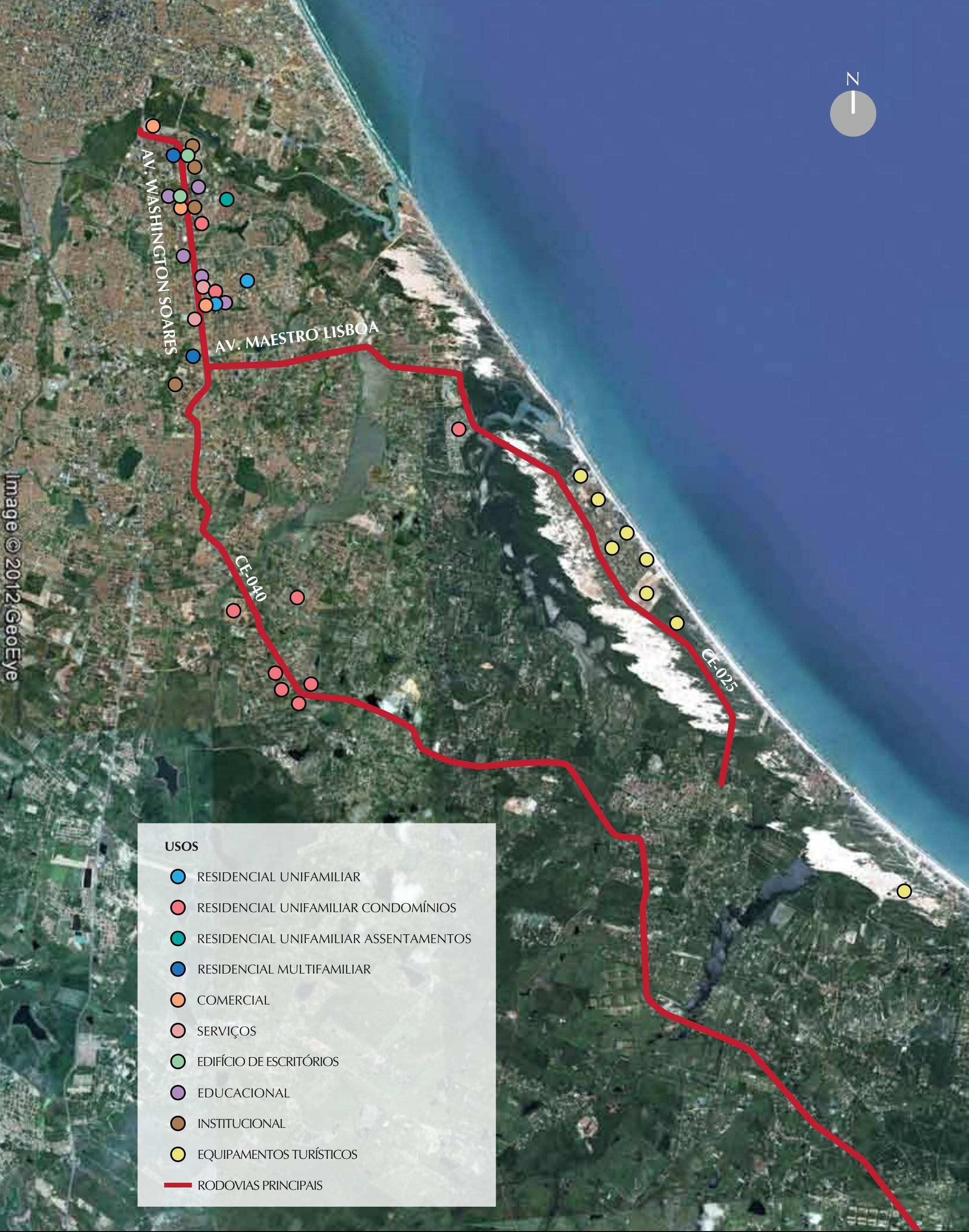

Fig 4.23 Setor sudeste - principais usos

Fonte: Google Earth - elaborado pela autora 


\section{Uso residencial}

O uso residencial predomina ainda na região, sendo observados diversos modos de ocupação e características distintas no que se refere a essa tipologia. No que concerne à habitação unifamiliar, há grandes mansões em vastos terrenos, residências de médio porte em lotes pequenos, habitações precárias em áreas de ocupação irregular e, finalmente, os condomínios fechados, surgidos ultimamente e que, na Capital se limitam, conforme a legislação, às dimensões de uma quadra. As residências ocupam predominantemente as glebas mais internas, por trás da av. Washington Soares, em ambos os lados.

Quanto ao uso residencial multifamiliar, percebe-se uma tendência recente de verticalização na área, sobretudo no trecho inicial, próximo ao Centro de Eventos, ora em construção, e na região junto à entrada para o Centro Administrativo do Cambeba. Ali surgiram ultimamente - desde o ano de 2009 - edifícios em grande quantidade, e com volumetria limitada a 14 pavimentos, conforme determina da legislação.

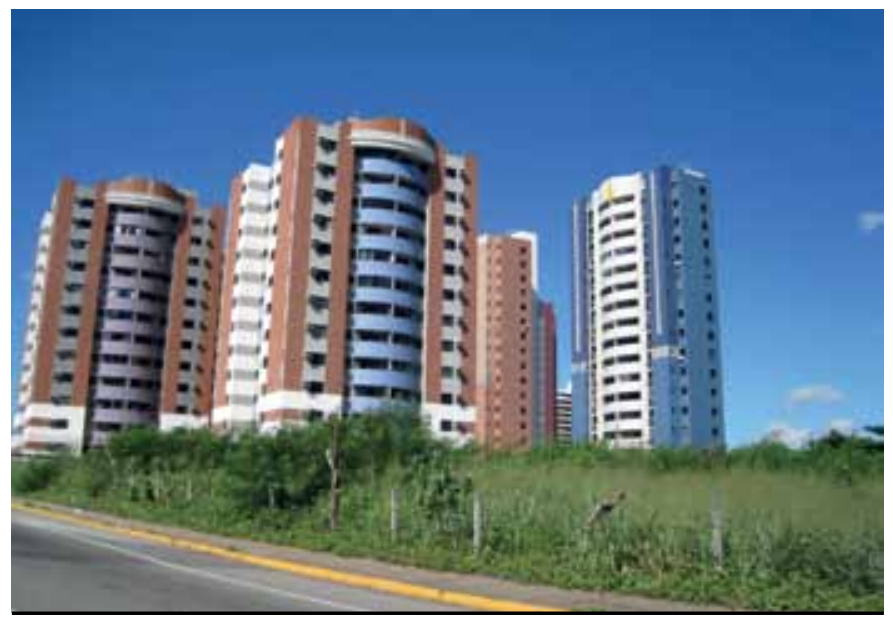

Fig. 4.24 Concentração de aptos. no trecho inicial da av. W. Soares Fonte: acervo autora

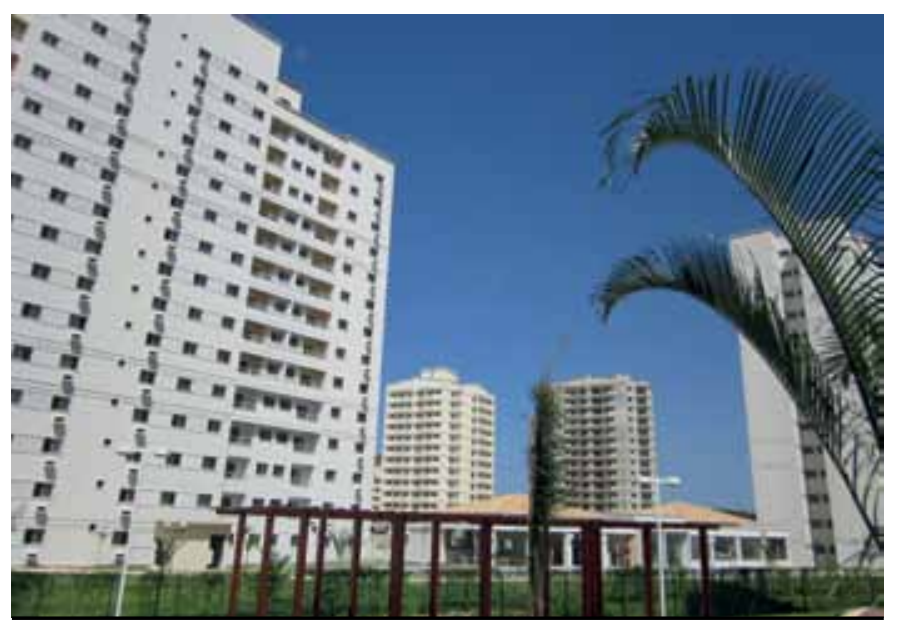

Fig. 4.25 Concentração de aptos. no trecho final da av. W. Soares Fonte: acervo autora

A maioria das habitações (tanto unifamiliares como multifamiliares) mostra elevado padrão e destina-se à população mais abastada. Há, contudo, exceções, como no caso das residências precárias de favelas e invasões, sobretudo aquelas da chamada Comunidade do Dendê, a área mais carente do bairro (ver figuras 4.26 a 4.31). 


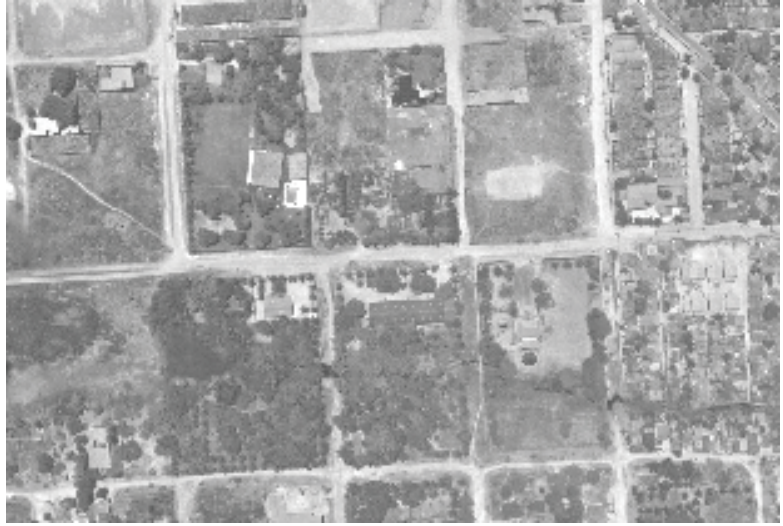

Residências unifamiliares próximas ao Shopping Via Sul, 1995

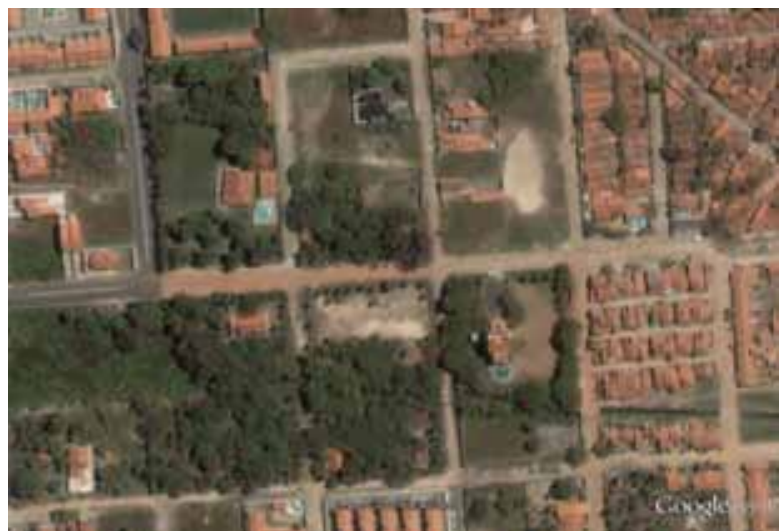

Residências unifamiliares próximas ao Shopping Via Sul, 2003

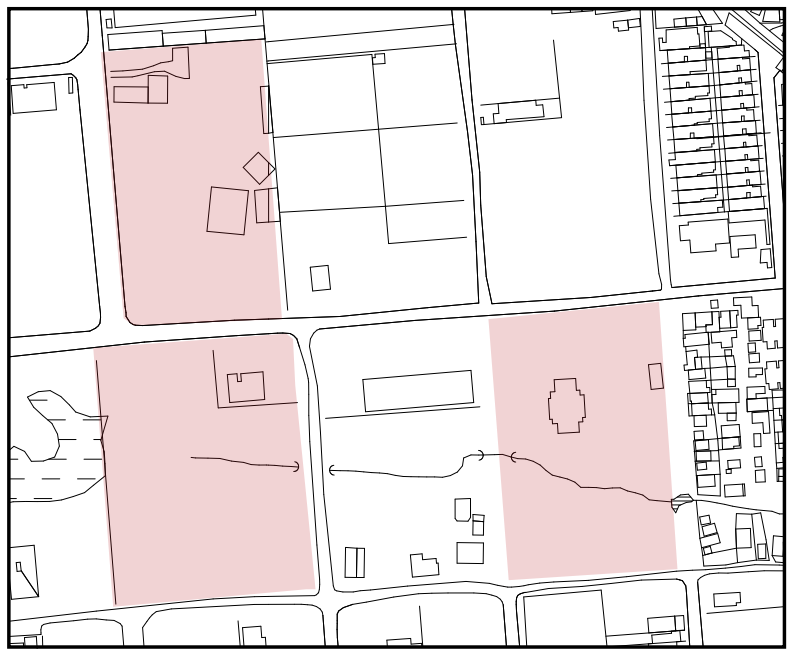

Residências unifamiliares próximas ao Shopping Via Sul, 1996

Esc. 1:5.000

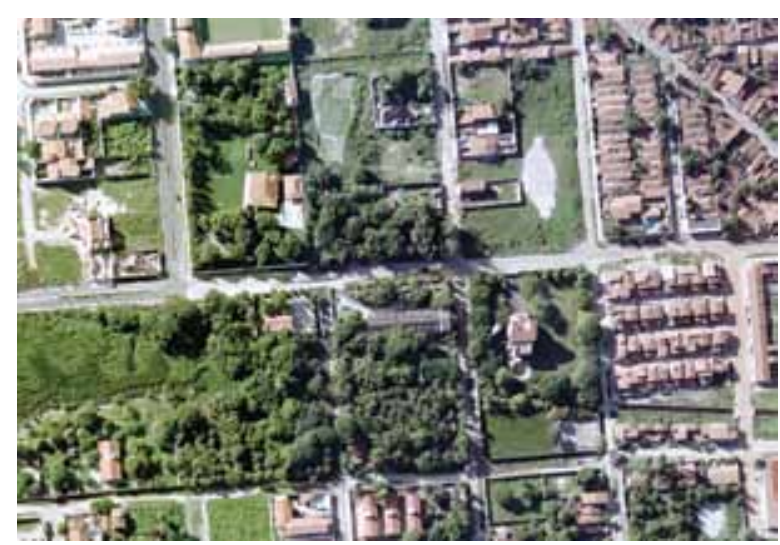

Residências unifamiliares próximas ao Shopping Via Sul, 2001

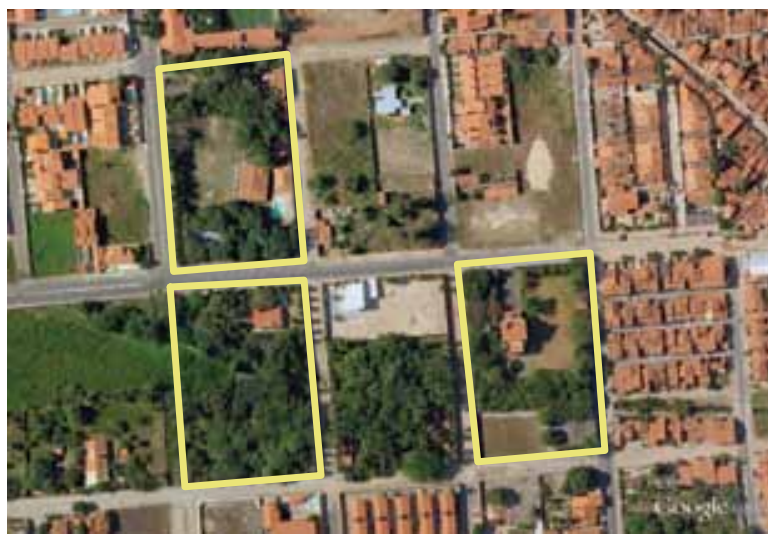

Residências unifamiliares próximas ao Shopping Via Sul, 2009

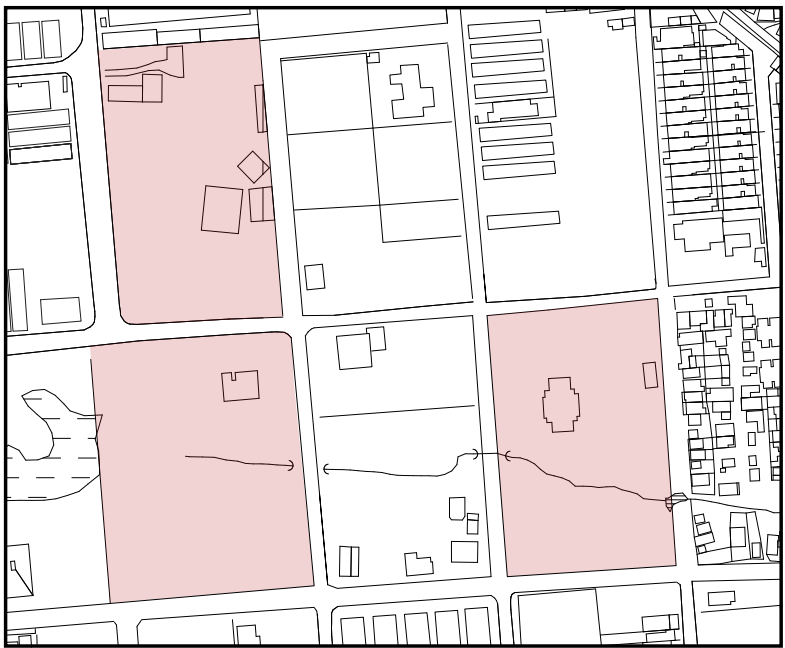

Residências unifamiliares próximas ao Shopping Via Sul, 2011

Esc. 1:5.000 


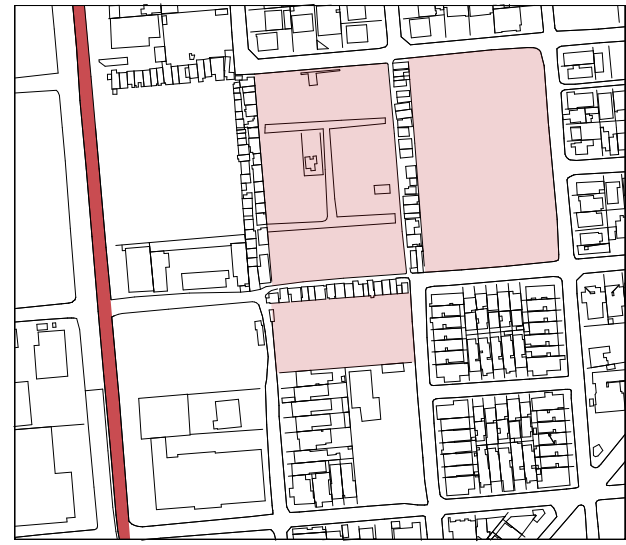

Condomínios fechados na Água Fria, 1996 Esc. 1:5.000

Condomínios fechados na Água Fria, 1995

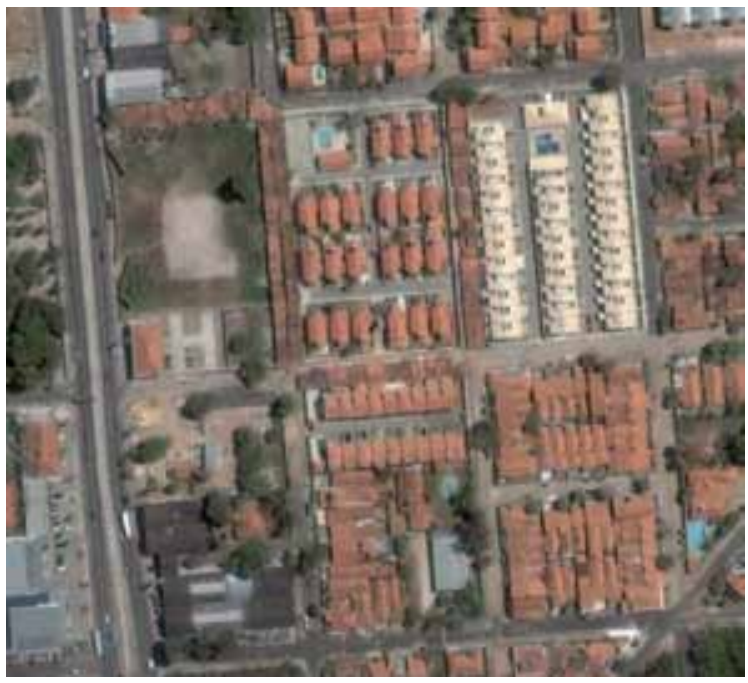

Condomínios fechados na Água Fria, 2003

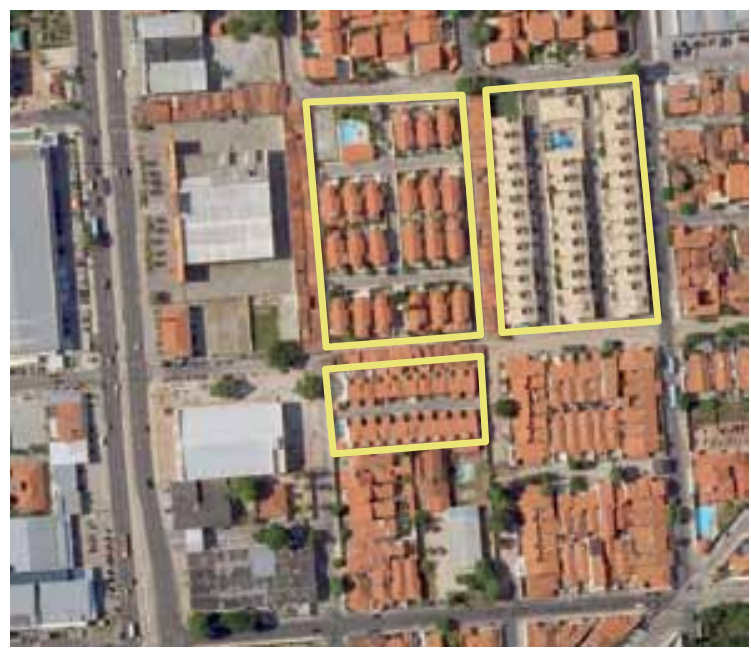

Condomínios fechados na Água Fria, 2009

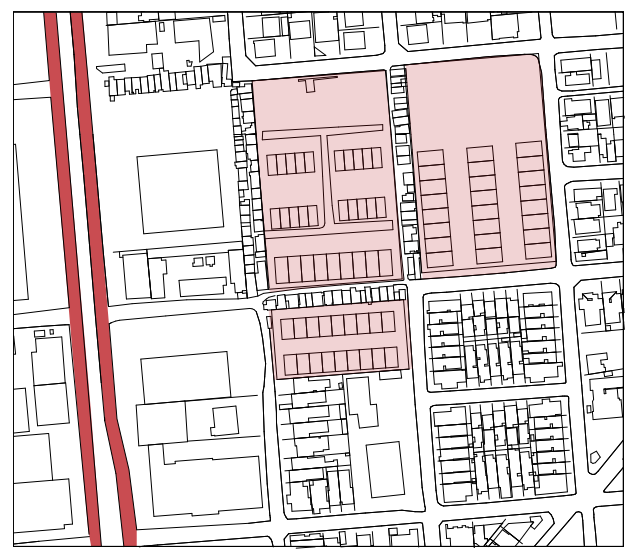

Condomínios fechados na Água Fria, 2011 Esc. 1:5.000

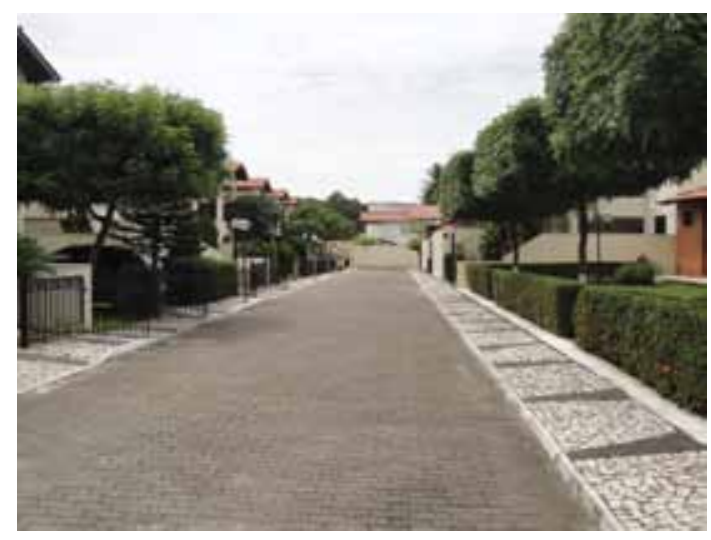

Condomínio fechado na Água Fria Fonte: www.fortaleza.olx.com.br 


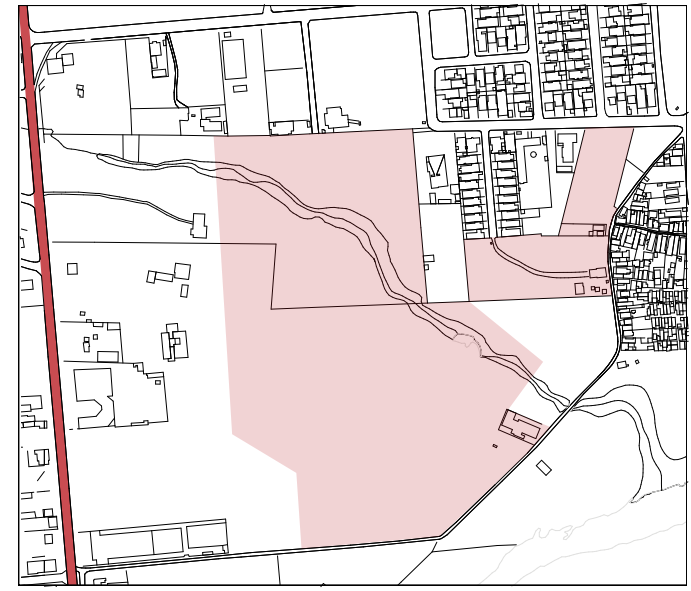

Condomínio Royal Park e outros condomínios fechados próximos ao Fórum, 1996 Esc. 1:10.000

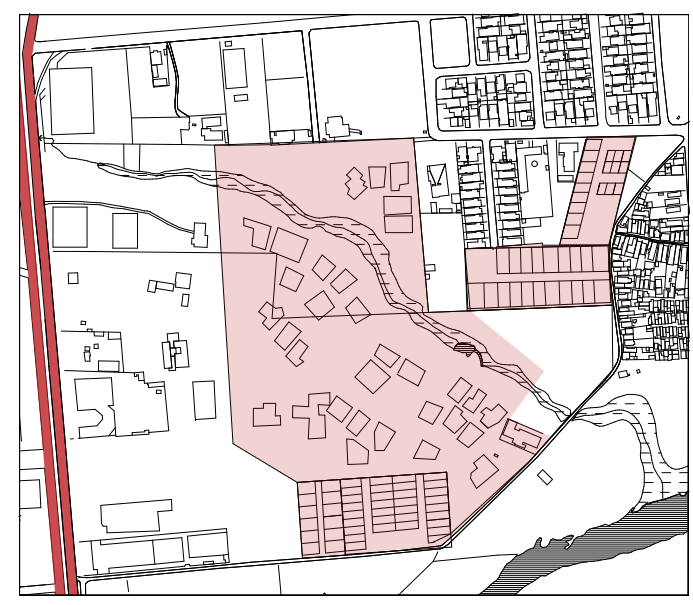

Condomínio Royal Park e outros condomínios fechados próximos ao Fórum, 2011 Esc. 1:10.000

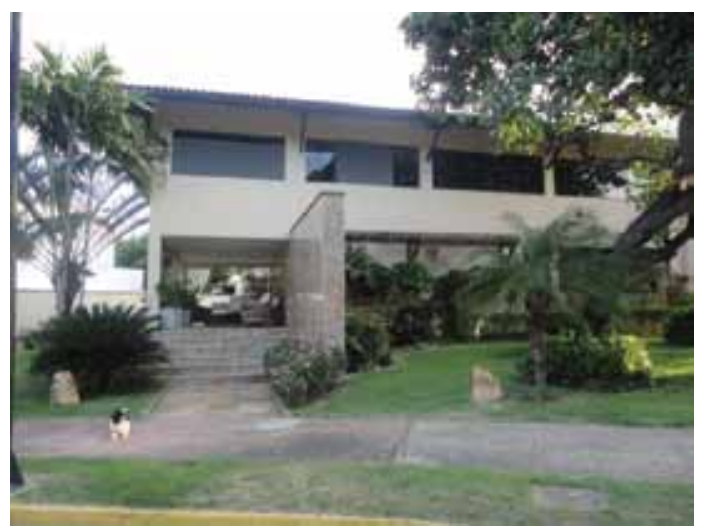

Casa no condomínio Royal Park Fonte: www.flavioimoveis.com.br

Condomínio Royal Park e outros condomínios fechados próximos ao Fórum, 2009

Fig 4.28 Uso Residencial - condomínio Royal Park Fonte: elaborado pela autora 


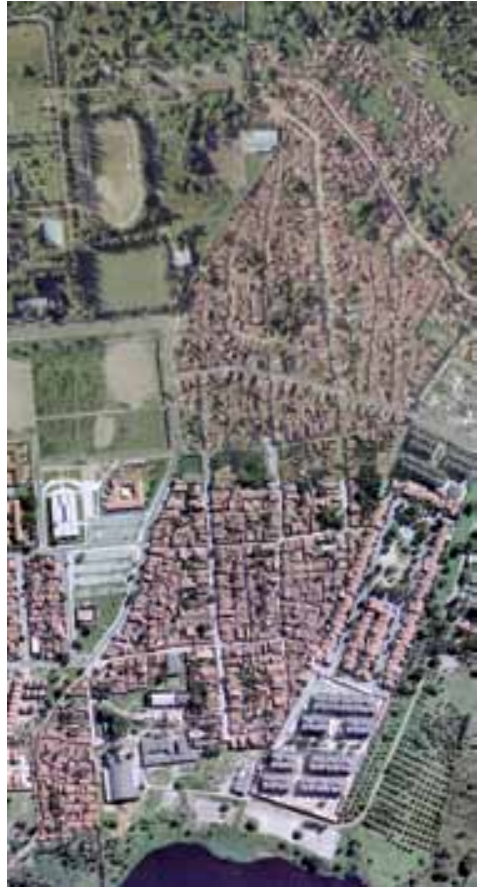

Comunidade do Dendê, 2001

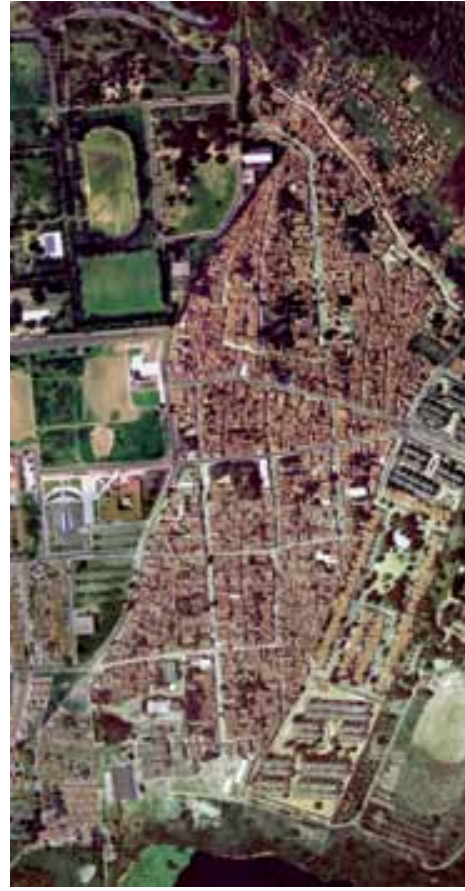

Comunidade do Dendê, 2004

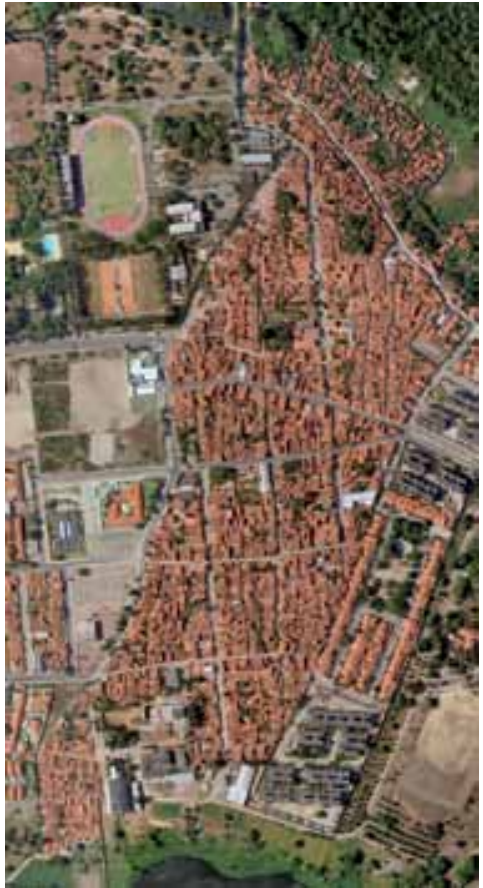

Comunidade do Dendê, 2009

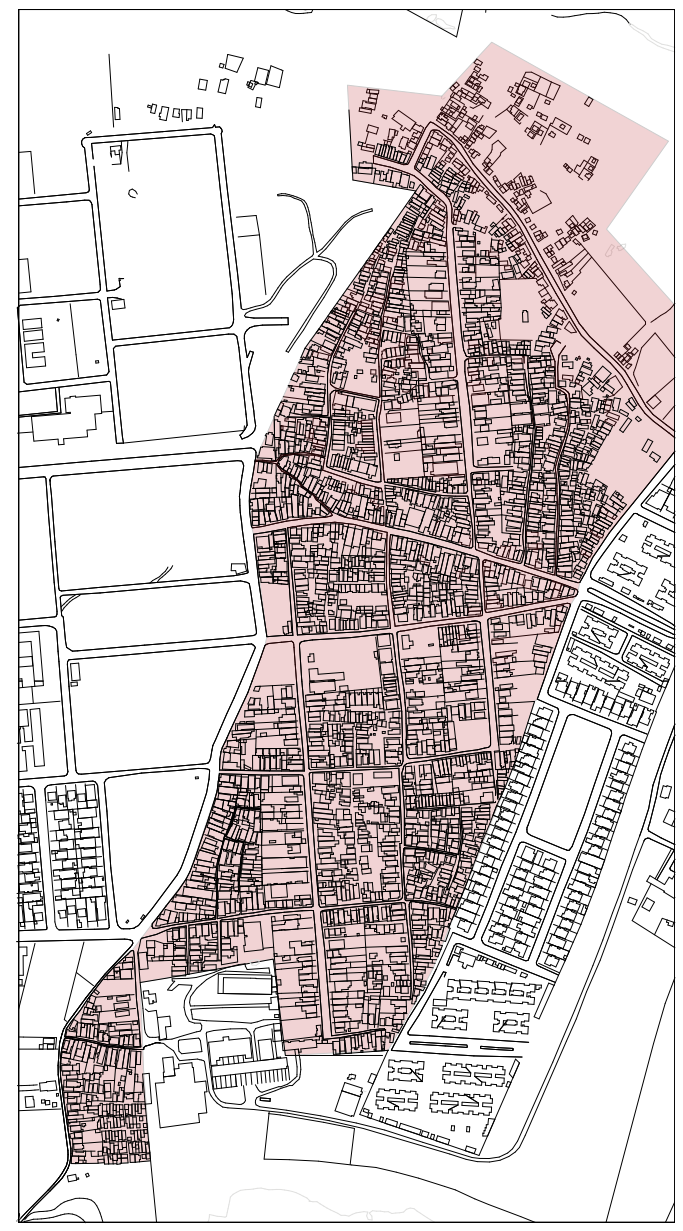

Comunidade do Dendê, 1996

Esc. 1:10.000

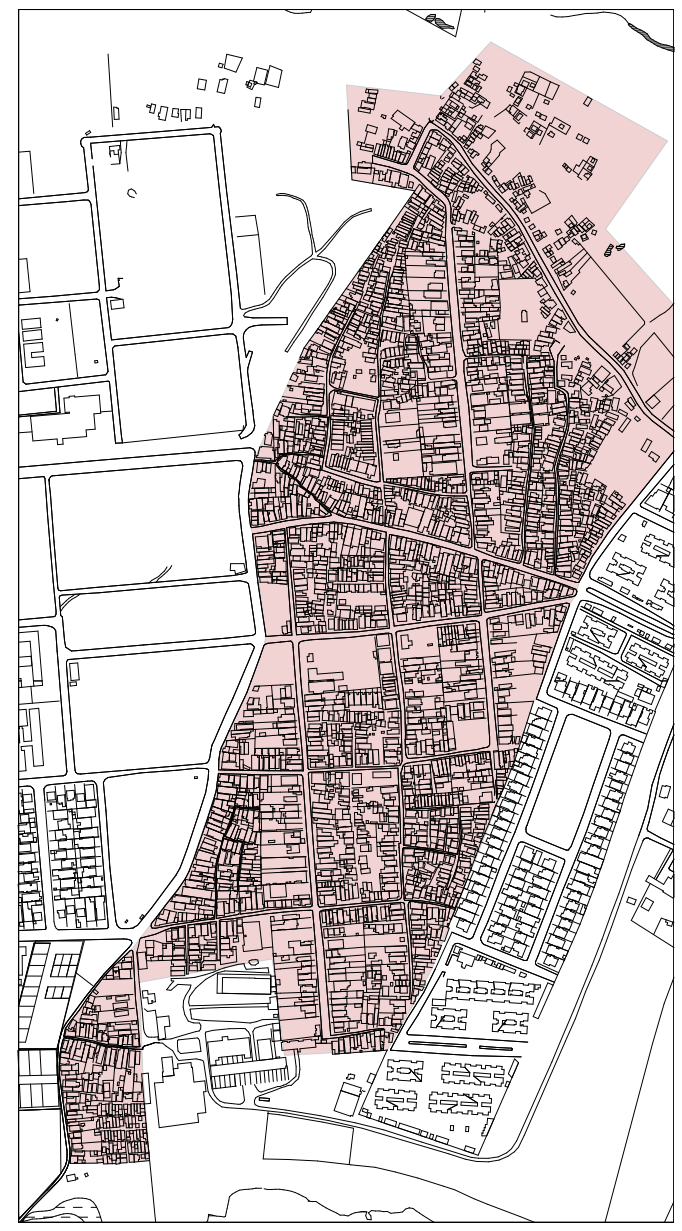

Comunidade do Dendê, 2011

Esc. 1:10.000

Fig 4.29 Uso Residencial - assentamentos precários

Fonte: elaborado pela autora 


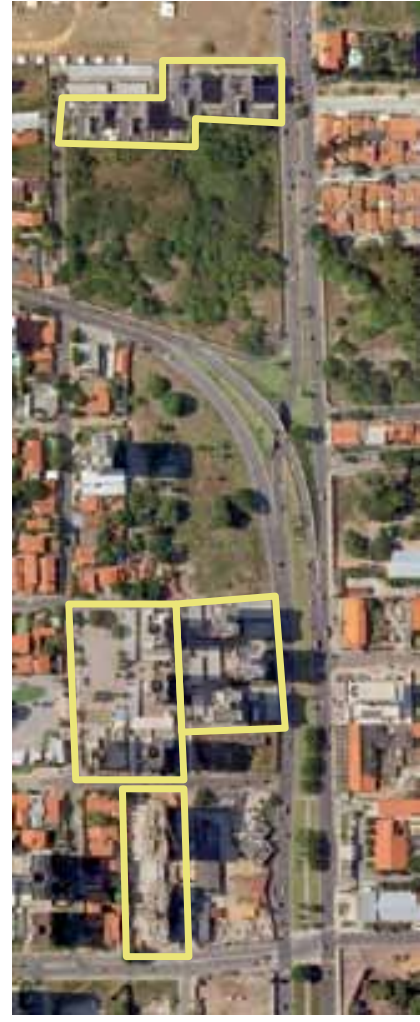

Edifícios residenciais multifamiliares próximos ao Shopping Iguatemi, 2009

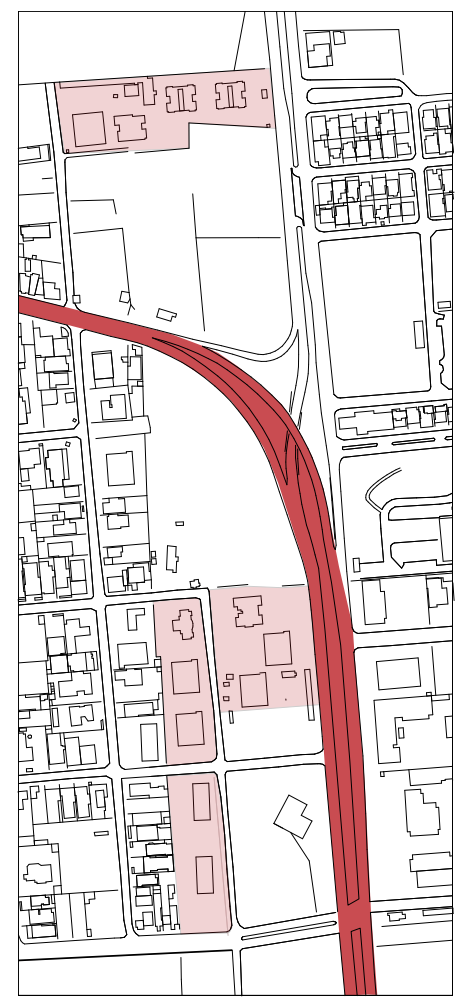

Edifícios residenciais multifamiliares próximos ao Shopping Iguatemi, 2011

Esc. 1:7.500
Edifícios residenciais multifamiliares próximos ao Shopping Iguatemi, 1996

Esc. 1:7.500

Fig 4.30 Uso Residencial - habitações multifamiliares próximas ao Shopping Iguatemi Fonte: elaborado pela autora 


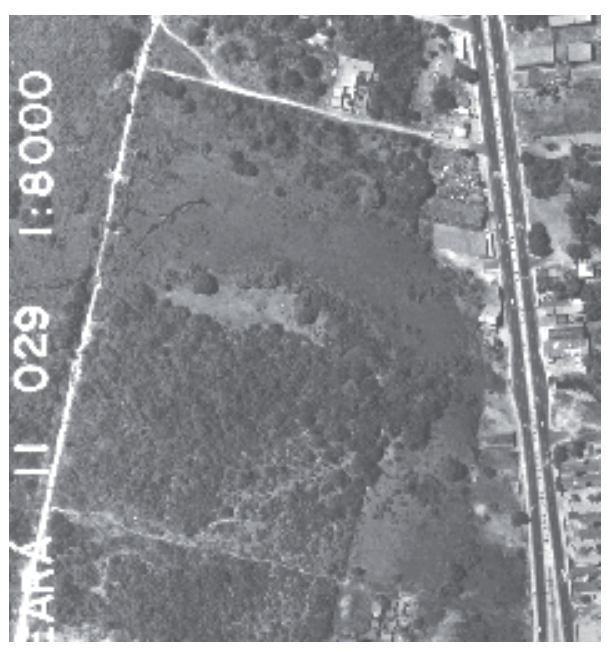

Edifícios residenciais multifamiliares próximos ao Cambeba, 1995

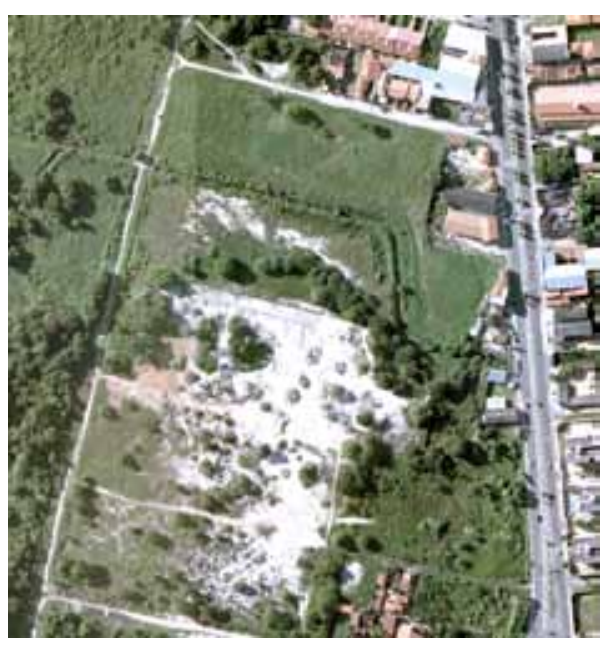

Edifícios residenciais multifamiliares próximos ao Cambeba, 2001

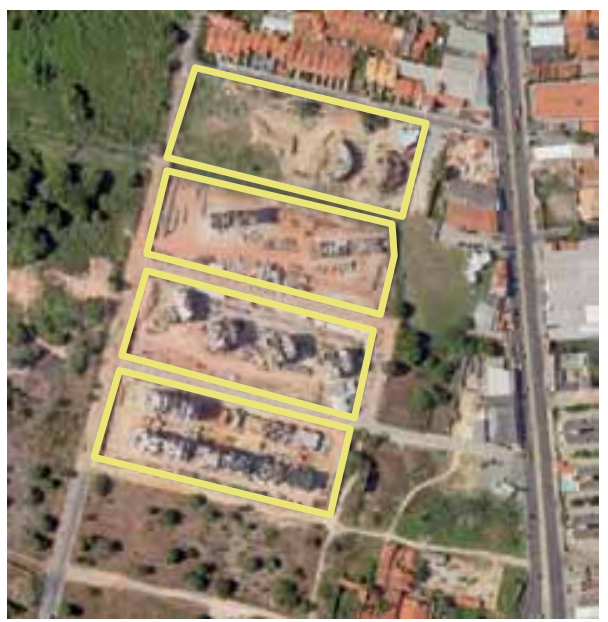

Edifícios residenciais multifamiliares próximos ao Cambeba, 2009

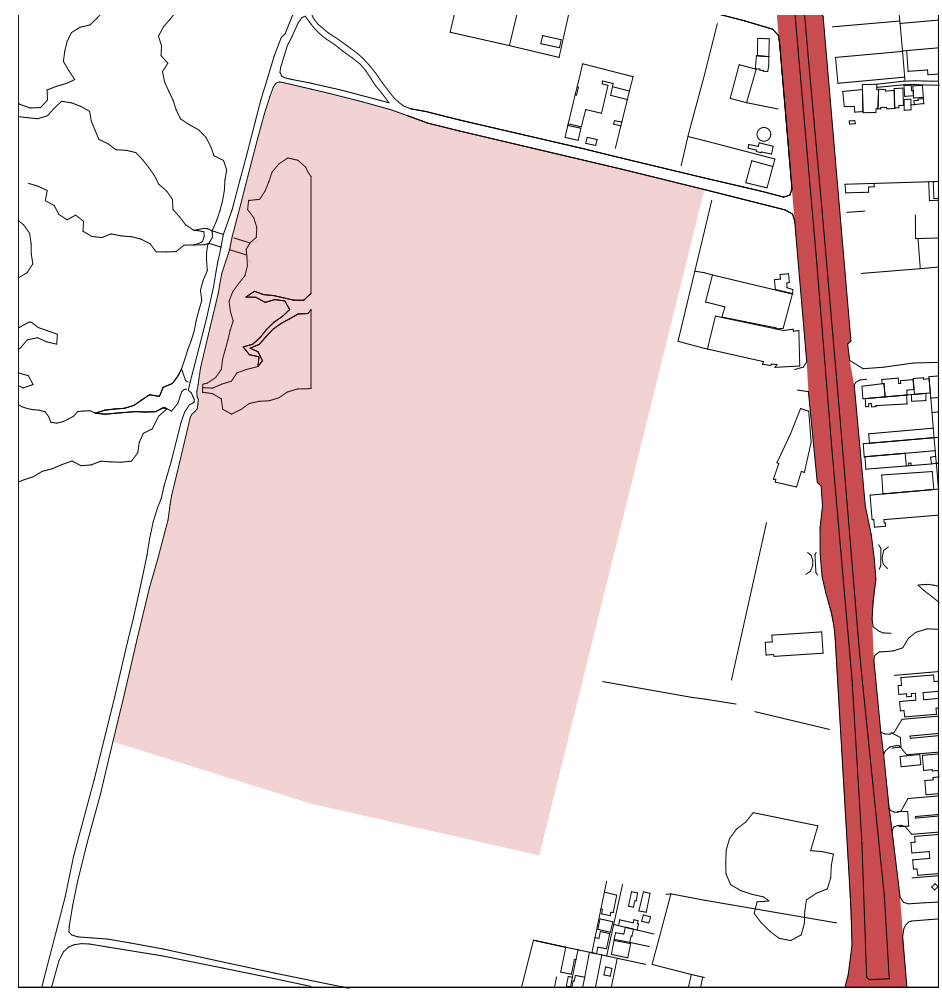

Edifícios residenciais multifamiliares próximos ao Cambeba, 1996 Esc. 1:5.000

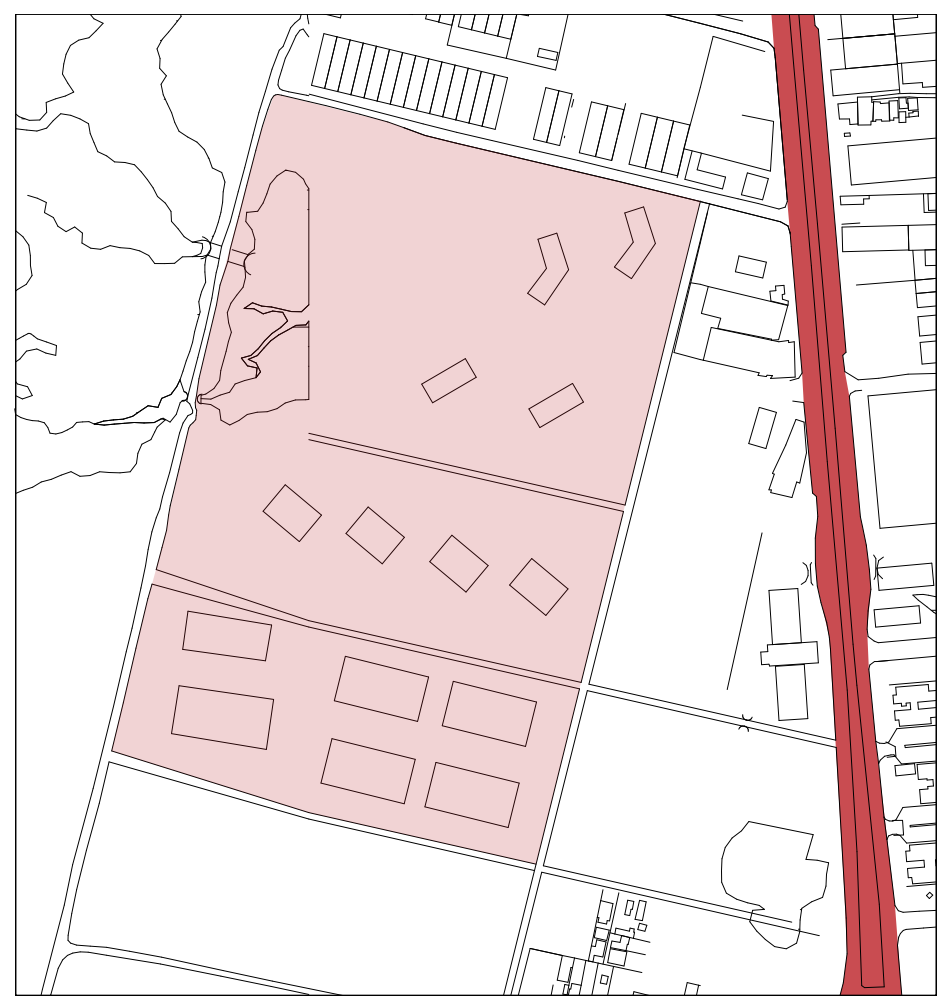

Edifícios residenciais multifamiliares próximos ao Cambeba, 2011 Esc. 1:5.000 


\section{Uso comercial e de serviços}

O uso comercial e de serviços, que compõe a centralidade terciária conformada na área será enfocado com detalhes no item 4.5. Vale ressaltar, entretanto, que a localização da atividade se restringe praticamente à av. Washington Soares e apresenta peculiaridades que merecem ser destacadas, tais como a existência de grandes equipamentos do tipo "contêineres", que abrigam grandes lojas, supermercados, concessionárias de veículos, etc., com estacionamentos generosos em anexo, estes já inviabilizados em outros bairros da Capital. A oferta de grandes terrenos possibilitou essa forma de ocupação, que caracteriza a área.

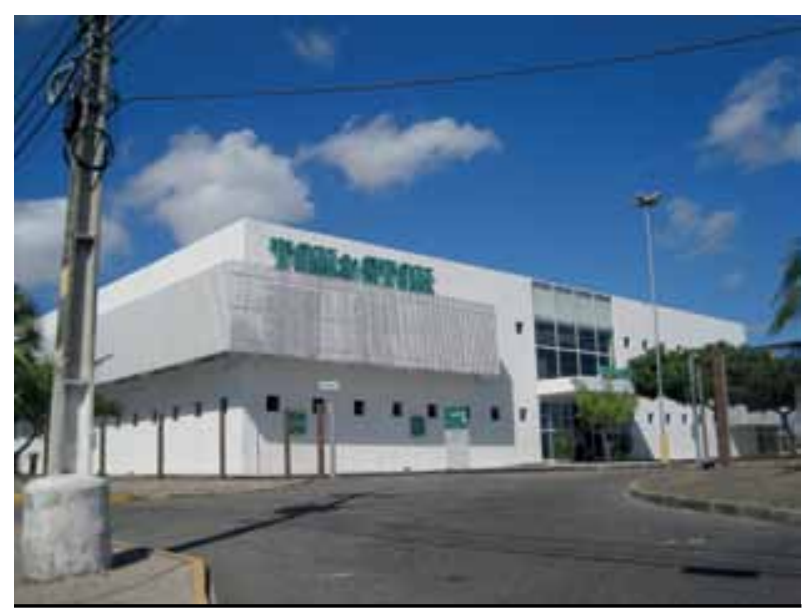

Fig. 4.32 Loja Tok Stok

Fonte: acervo autora

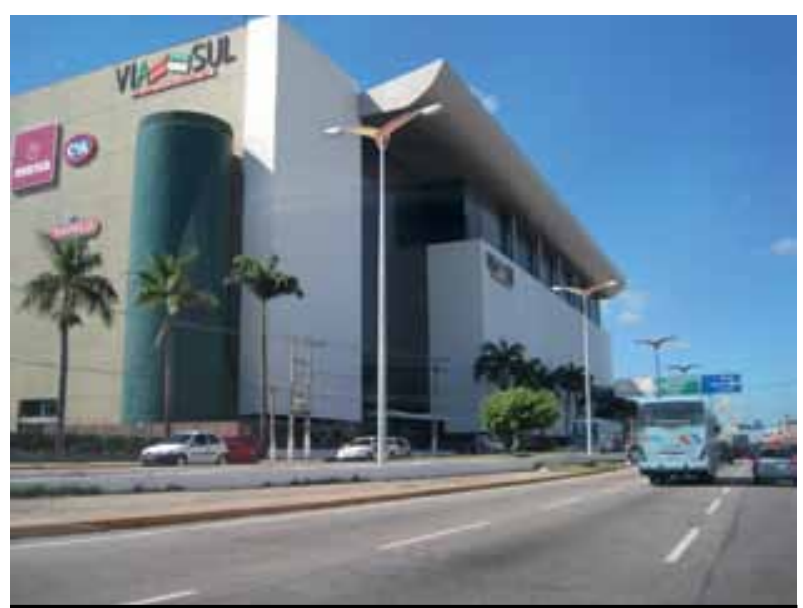

Fig. 4.33 Shopping Via Sul
Fonte: acervo autora

Quanto aos serviços, observa-se a progressiva instalação de edifícios de escritórios e sedes de empresa, além de clínicas especializadas, bancos e estabelecimentos ligados à gastronomia, atividades que proliferam na área, todas elas voltadas predominantemente para a população de alta renda.

Trata-se, na maioria, de equipamentos de elevado padrão arquitetônico, facilidade de acesso e de estacionamento, que se distinguem fortemente de outras áreas da Cidade (ver figuras 4.34 a 4.40). 


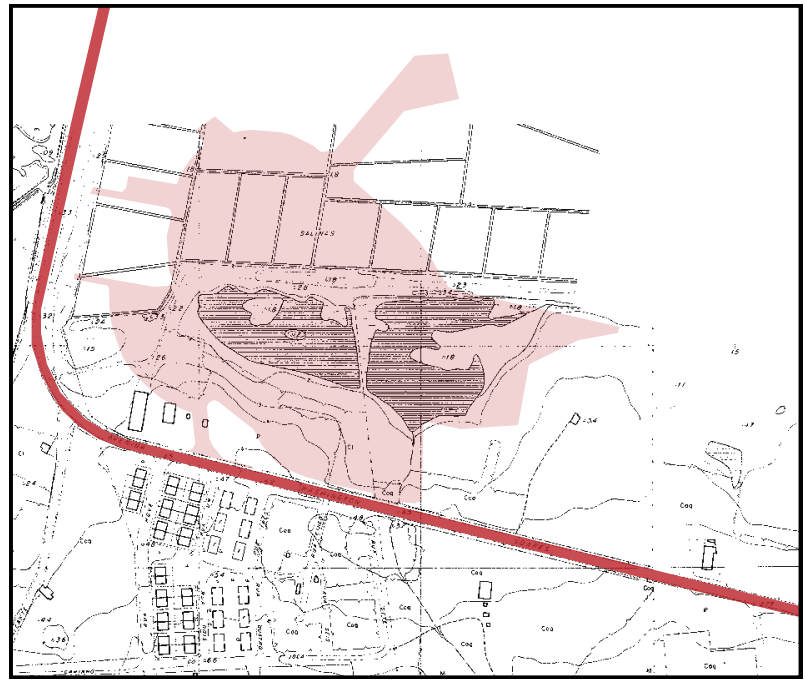

Shopping Iguatemi, 1972

Esc. 1:12.500

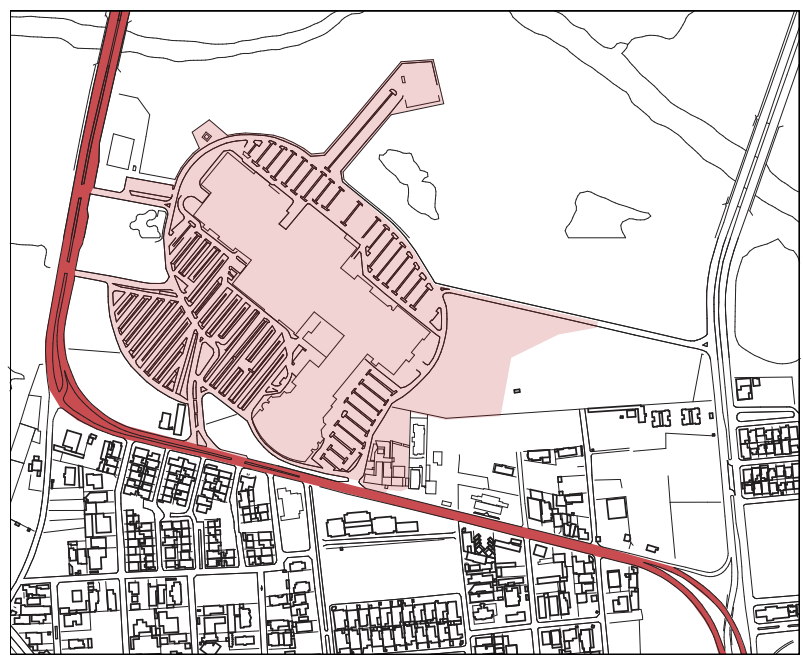

Shopping Iguatemi, 1996

Esc. 1:12.500

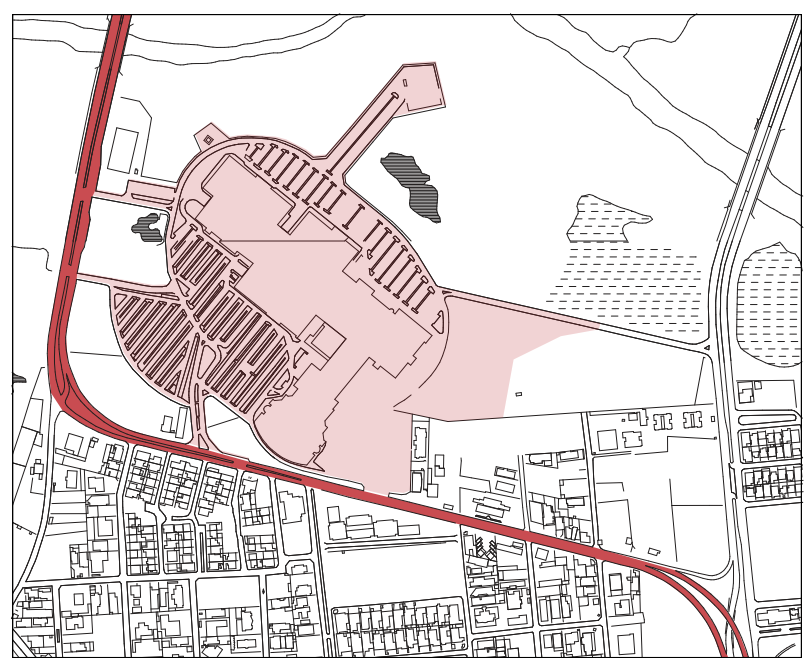

Shopping Iguatemi, 2011

Esc. 1:12.500

Fig 4.34 Uso Comercial e de Serviços - Shopping Iguatemi Fonte: elaborado pela autora 
CAPÍTULO 4

Dinâmica e especificidades do setor sudeste

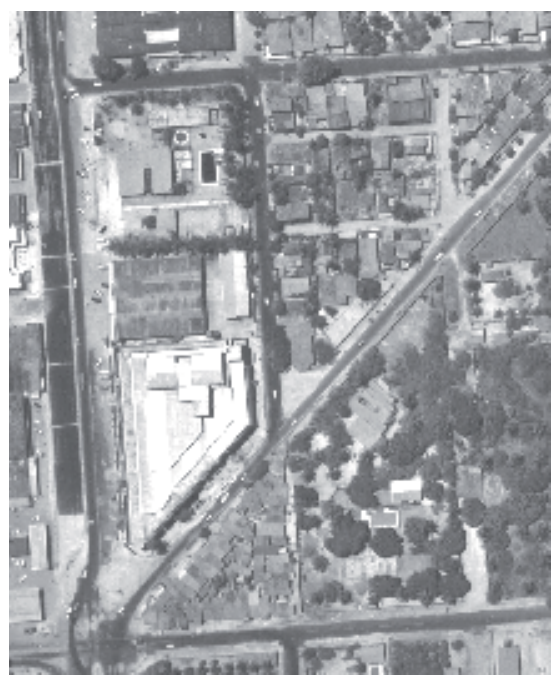

Shopping Via Sul, 1995

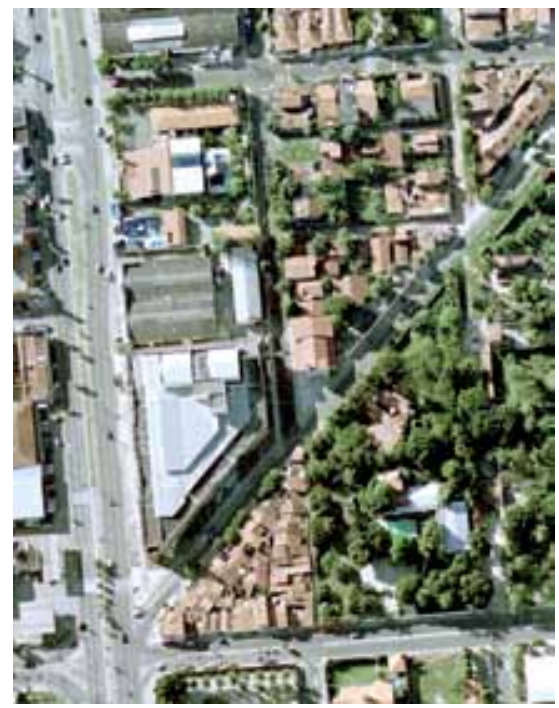

Shopping Via Sul, 2001

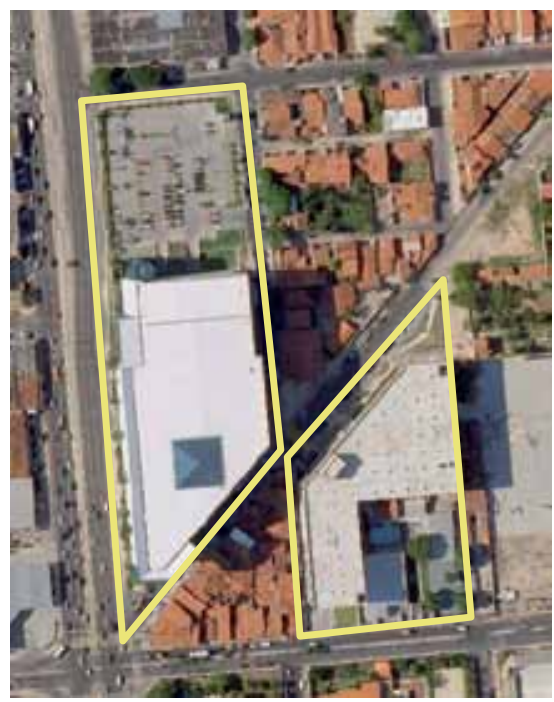

Shopping Via Sul, 2009

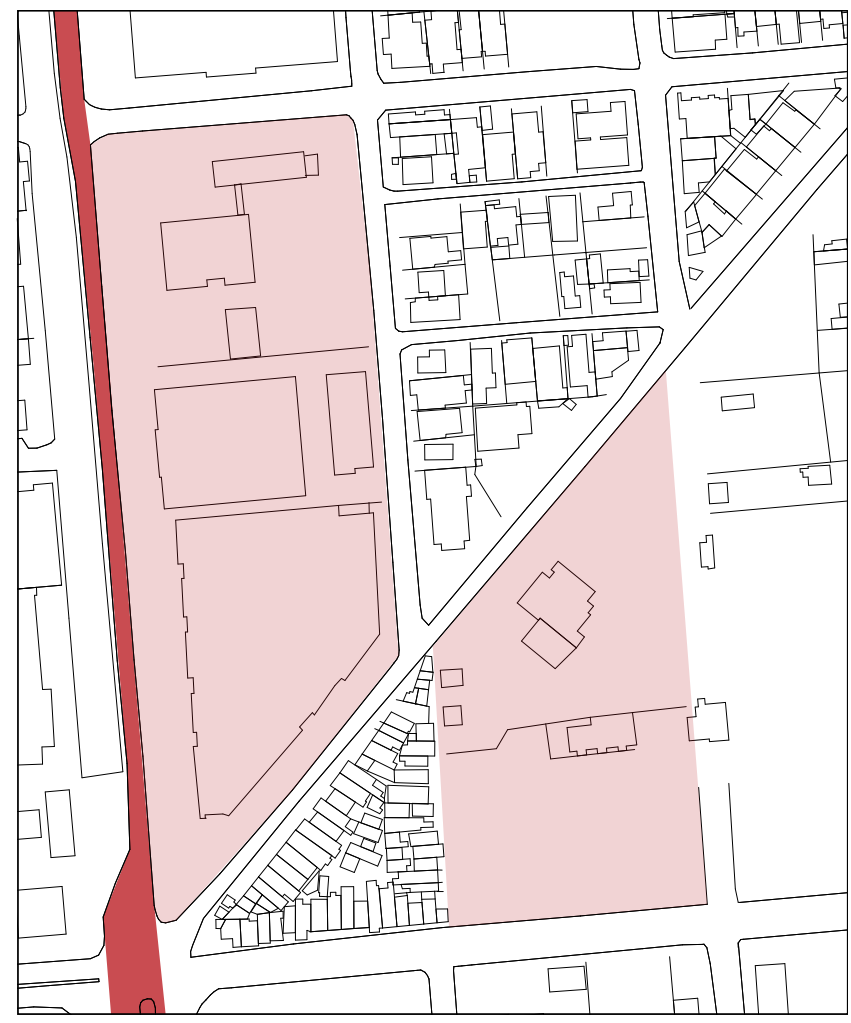

Shopping Via Sul, 1996

Esc. $1: 2.500$

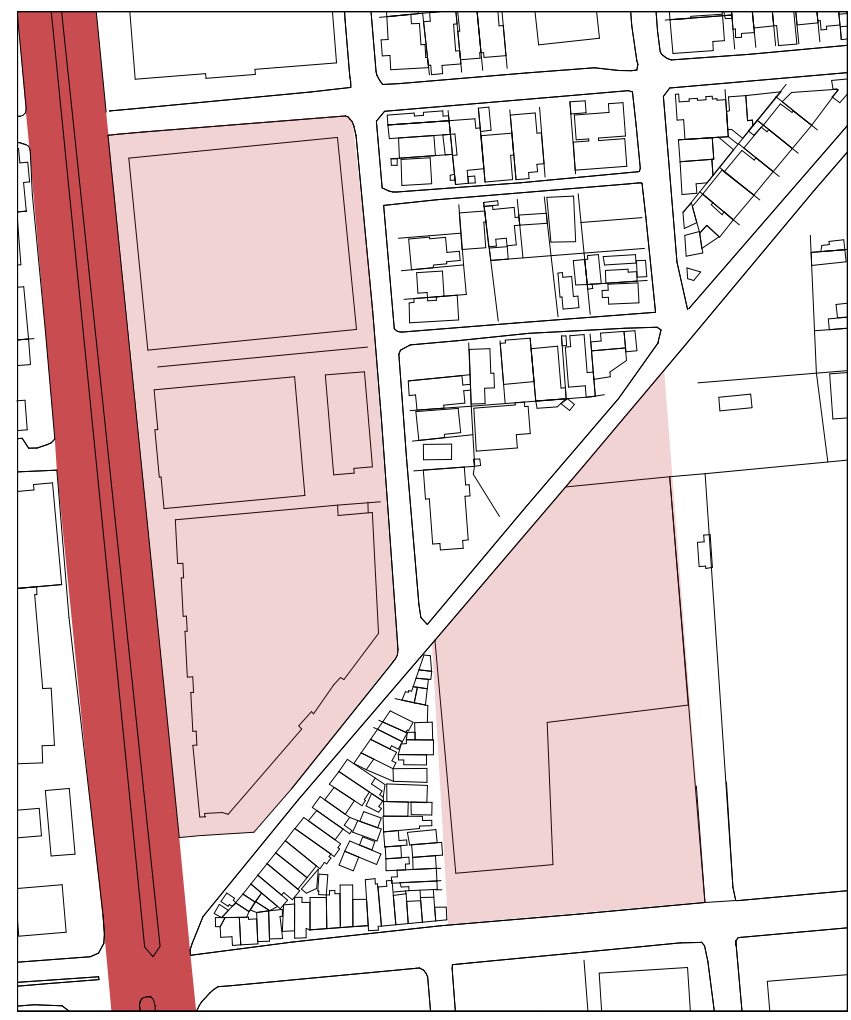

Shopping Via Sul, 2011

Esc. 1:2.500 


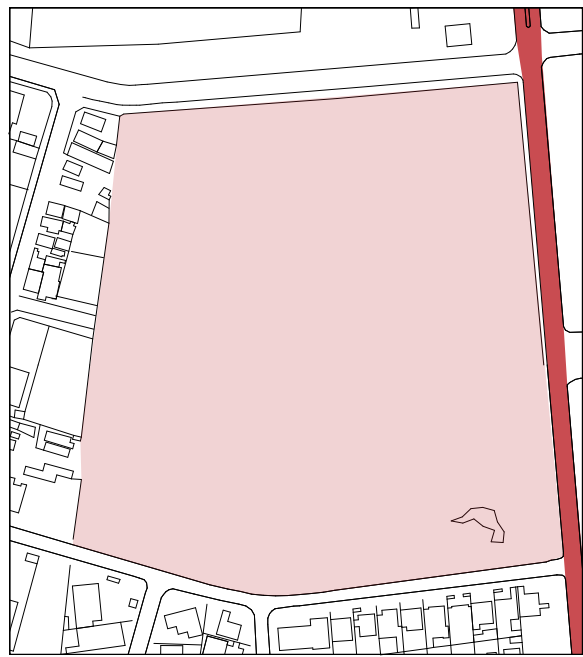

Complexo Comercial Buena Vista, 1996 Esc. 1:5.000

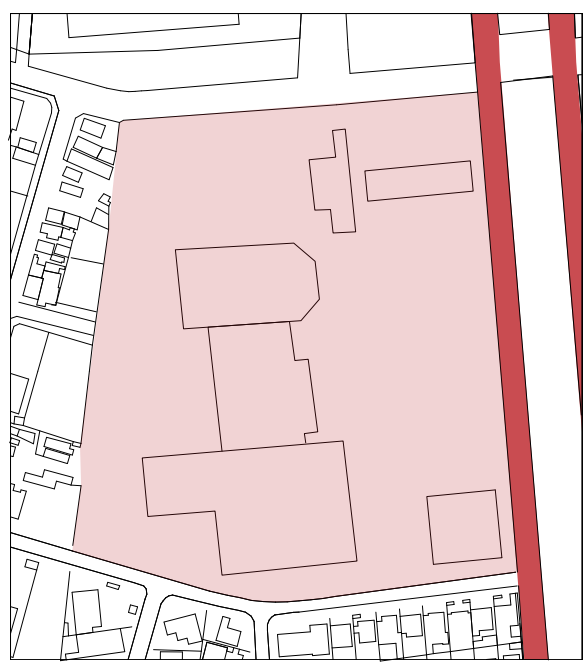

Complexo Comercial Buena Vista, 2011

Esc. 1:5.000

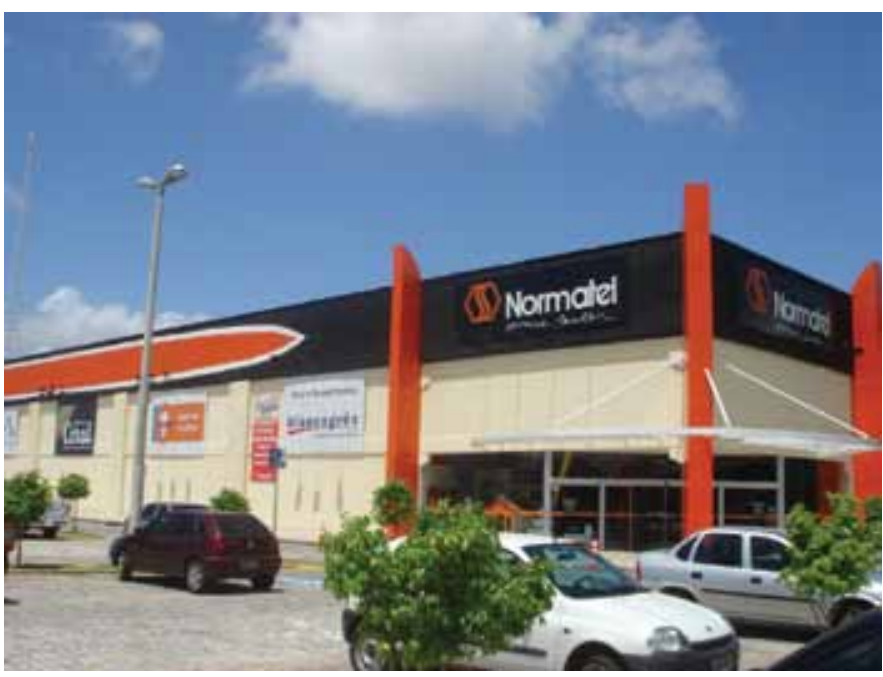

Loja da Normatel no Complexo Comercial Buena Vista Fonte: www.panoramio.com

Fig 4.36 Uso Comercial e de Serviços - Complexo Buena Vista

Fonte: elaborado pela autora 


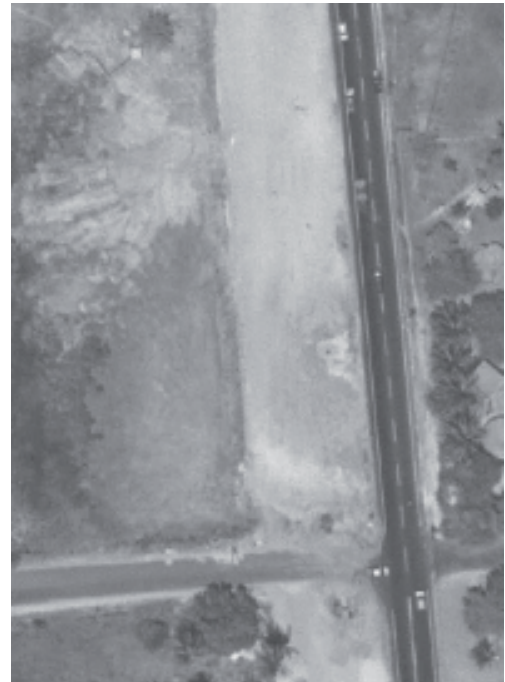

Terreno Tok Stok, 1995

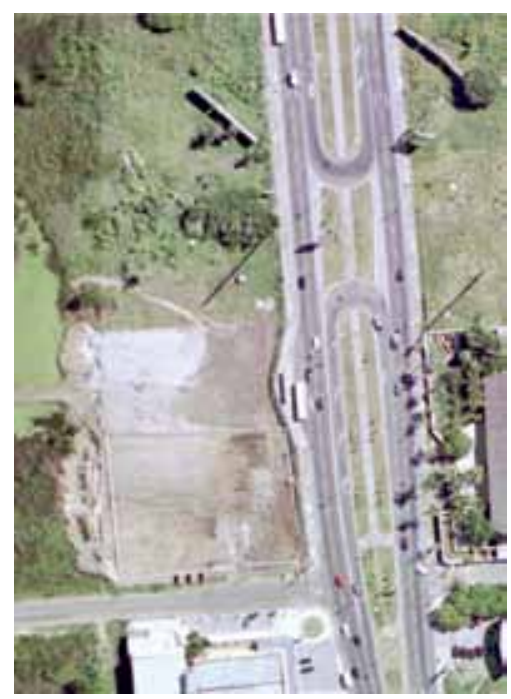

Terreno Tok Stok, 2001

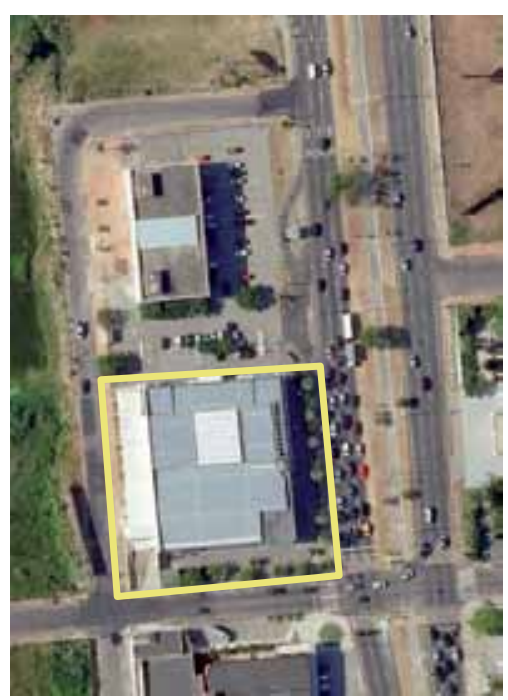

Tok Stok, 2009

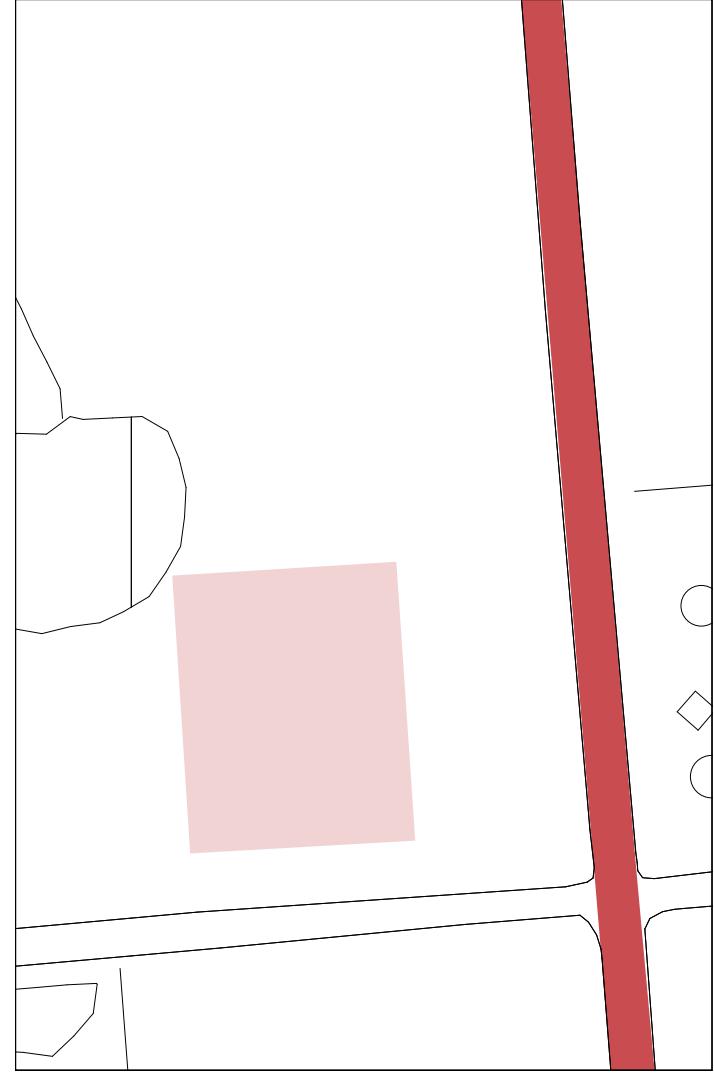

Terreno Tok Stok, 1996

Esc. 1:2.000

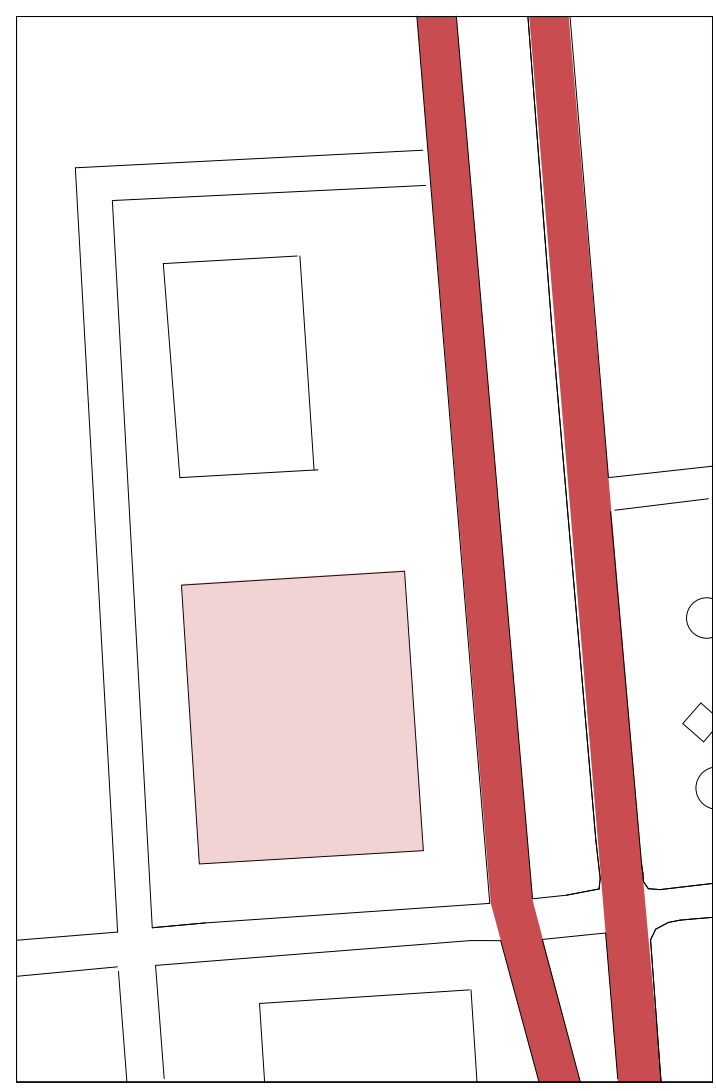

Tok Stok, 2011

Esc. 1:2.000

Fig 4.37 Uso Comercial e de Serviços - Loja Tok Stok Fonte: elaborado pela autora 


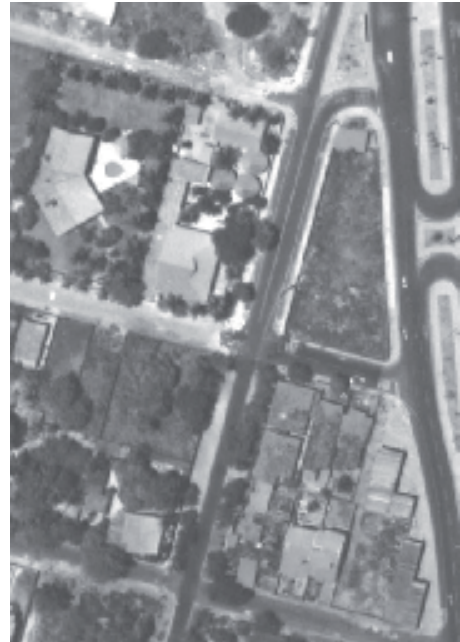

Restaurantes na Av. Washington Soares, 1995

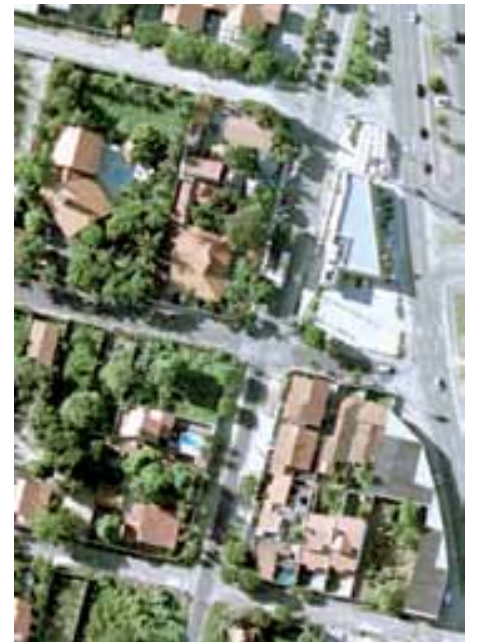

Restaurantes na Av. Washington Soares, 2001

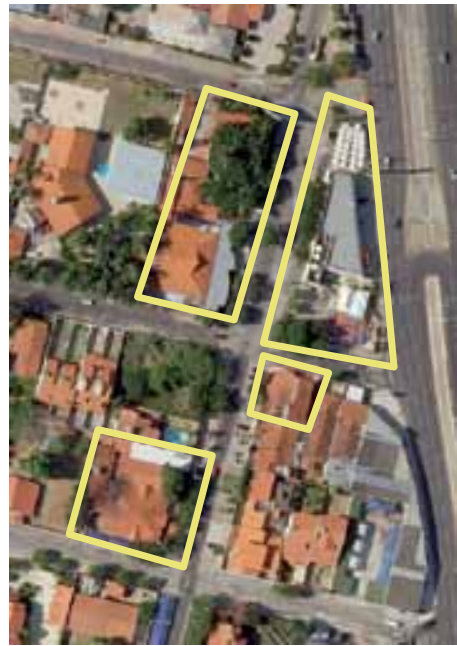

Restaurantes na Av. Washington Soares, 2009

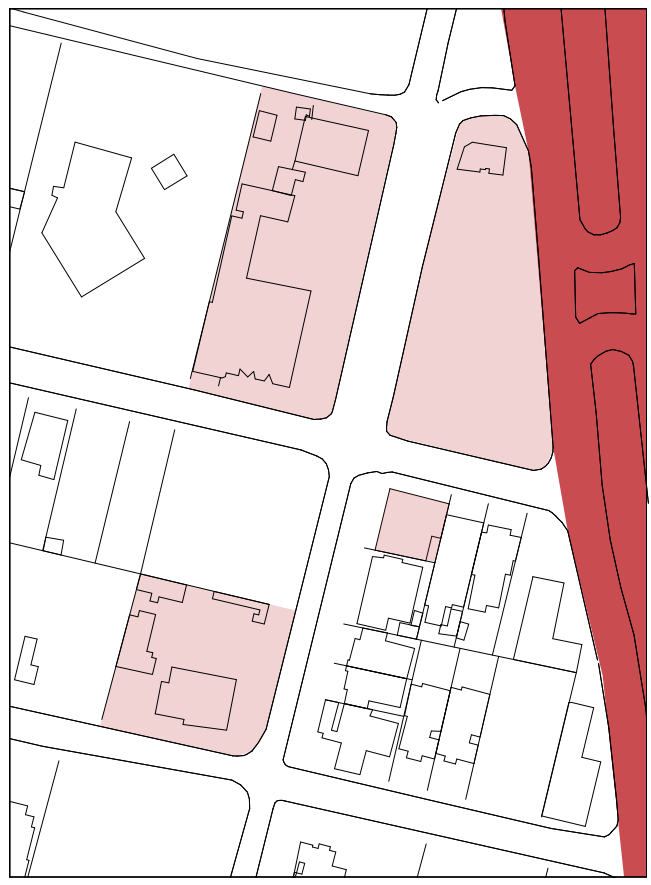

Restaurantes na Av. Washington Soares, 1996 Esc. 1:2.500

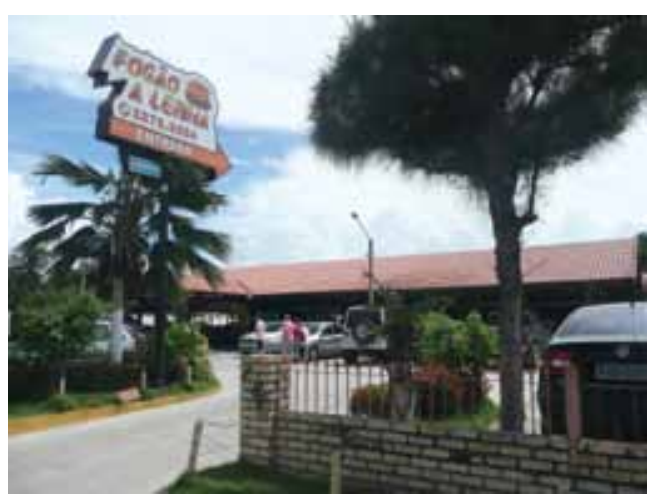

Restaurante Fogão à lenha Fonte: Acervo autora

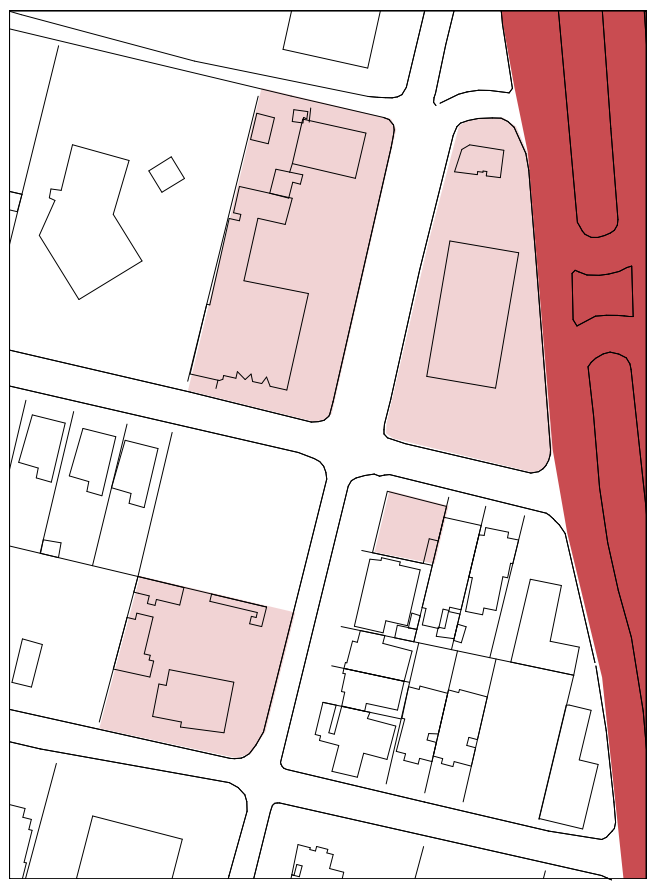

Restaurantes na Av. Washington Soares, 2011 Esc. 1:2.500

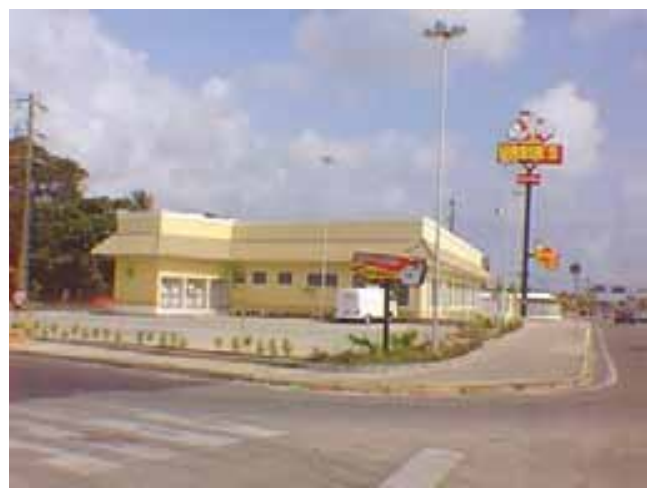

Restaurante Habib's

Fonte: www.empregosecarreira.com 


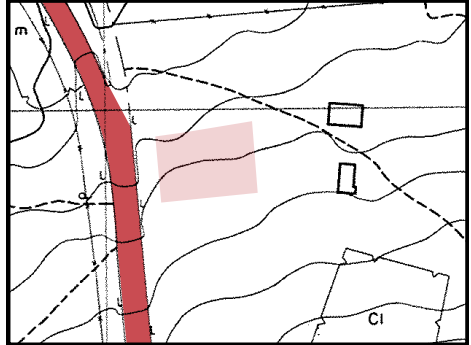

Condomínio Empresarial

Washington Soares, 1972 Esc. 1:2.500

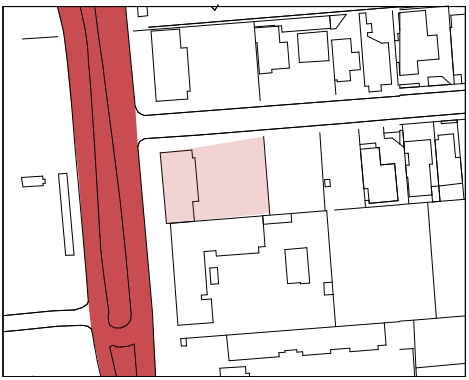

Condomínio Empresarial

Washington Soares, 1996 Esc. 1:2.500

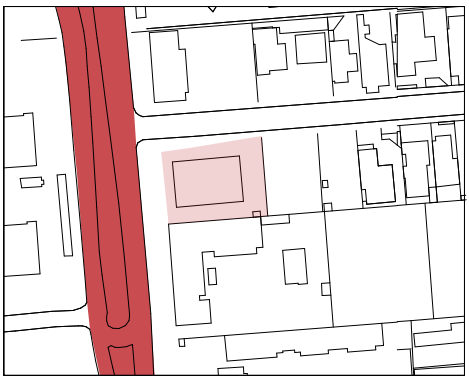

Condomínio Empresarial

Washington Soares, 2011

Esc. 1:2.500

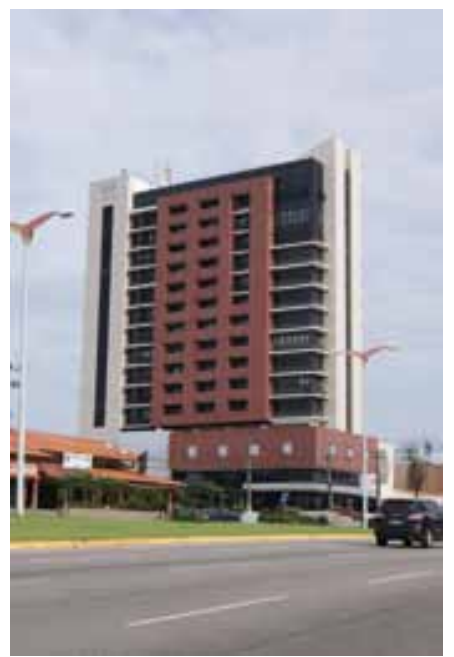

Condomínio Empresarial

Washington Soares

Fonte: Acervo autora

Fig 4.39 Uso Comercial e de Serviços - Edifícios de escritório

Fonte: elaborado pela autora 


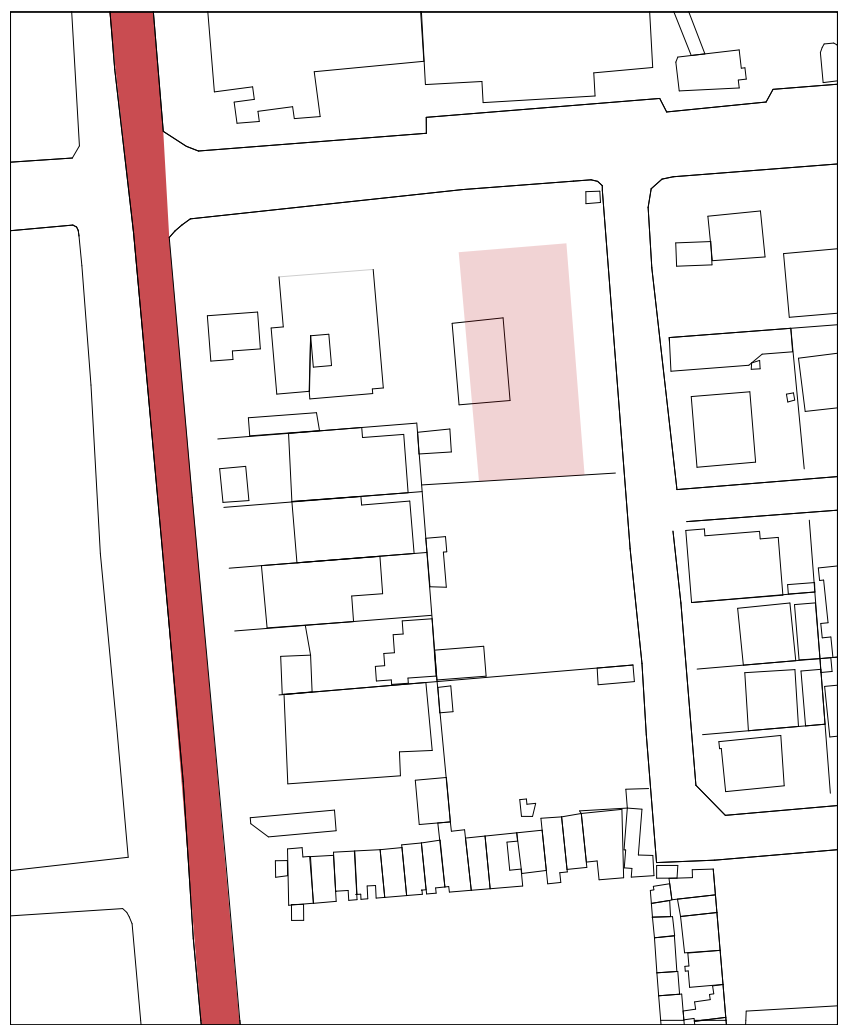

Bancos Itaú e Santander, 1996

Esc. 1:2.000

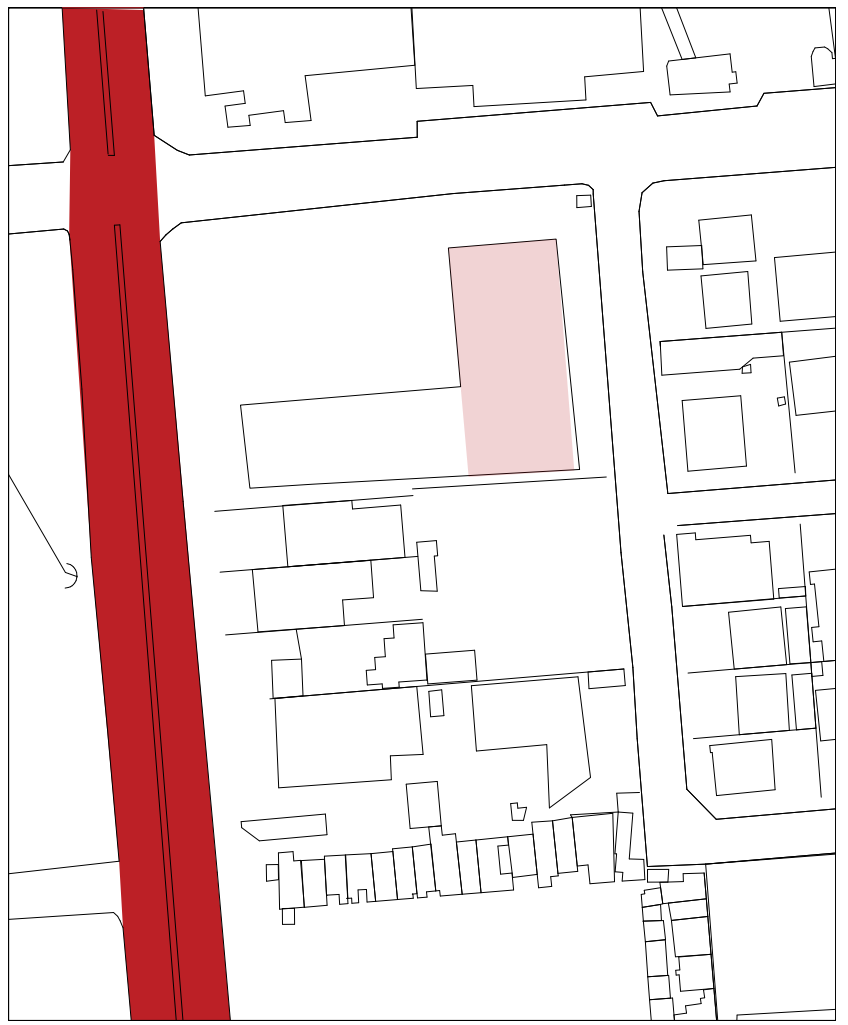

Bancos Itaú e Santander, 2011

Esc. 1:2.000

Fig 4.40 Uso Comercial e de Serviços - Bancos

Fonte: elaborado pela autora 


\section{Uso educacional}

Desde a instalação da Unifor, em 1973 e em conseqüência da progressiva transferência da população de mais alta renda para essa região, surgiram nas imediações da av. Washington Soares vários estabelecimentos educacionais, quase todos destinados a essa população. São instituições de ensino superior (Unifor, FA7, FIC), colégios diversos (Farias Brito, Ari de Sá, Christus, Irmã Maria Montenegro, Antares, etc.), assim como cursos de idiomas variados (Wisdom, Fisk, Yázigi, Wisard, Wise Up, Aliança Francesa, etc.).

Esses estabelecimentos, em sua maioria, são filiais de unidades centrais já instaladas e consolidadas em outros lugares da Cidade, predominantemente na Aldeota, como aliás ocorre com a maior parte dos equipamentos comerciais e de serviços (ver figuras 4.43 a 4.47)

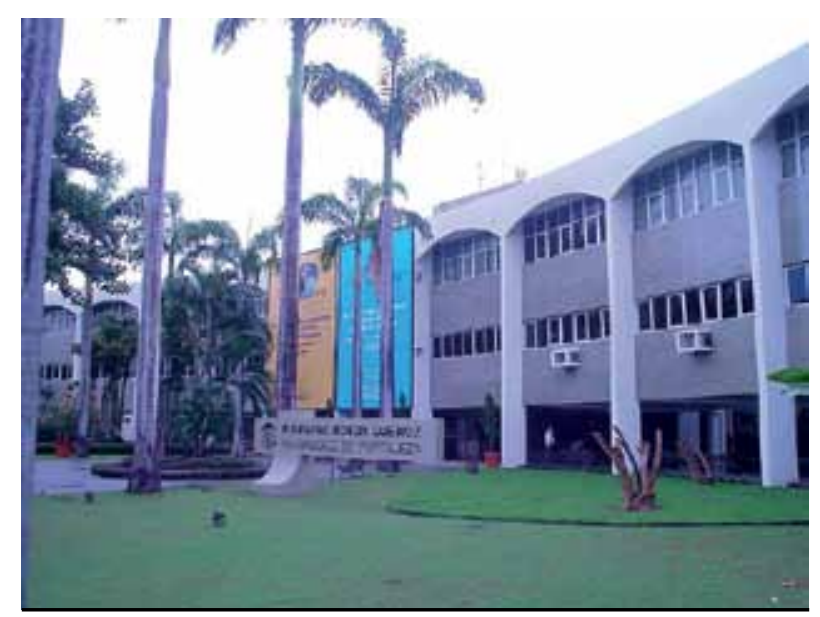

Fig. 4.41 Unifor - Universidade de Fortaleza

Fonte: http://www.jfce.jus.br/internet/sites/site2011

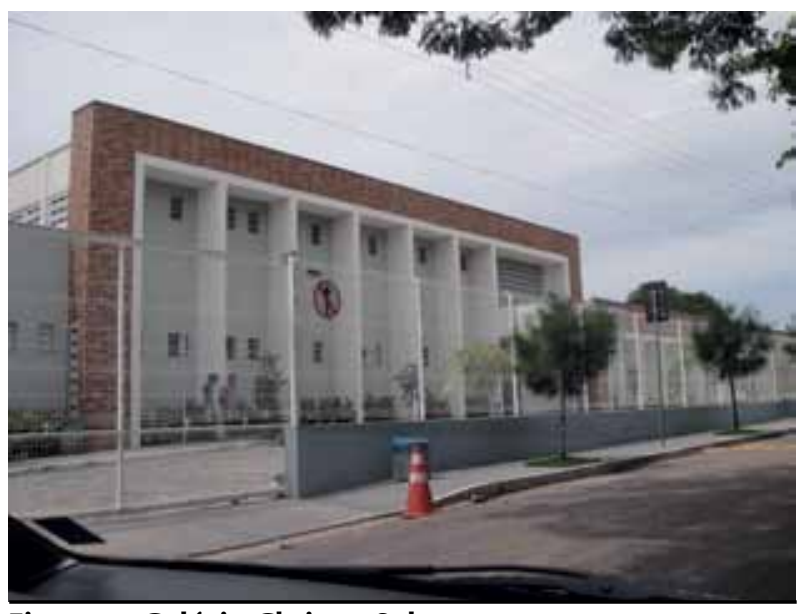

Fig. 4.42 Colégio Christus Sul

Fonte: acervo autora 


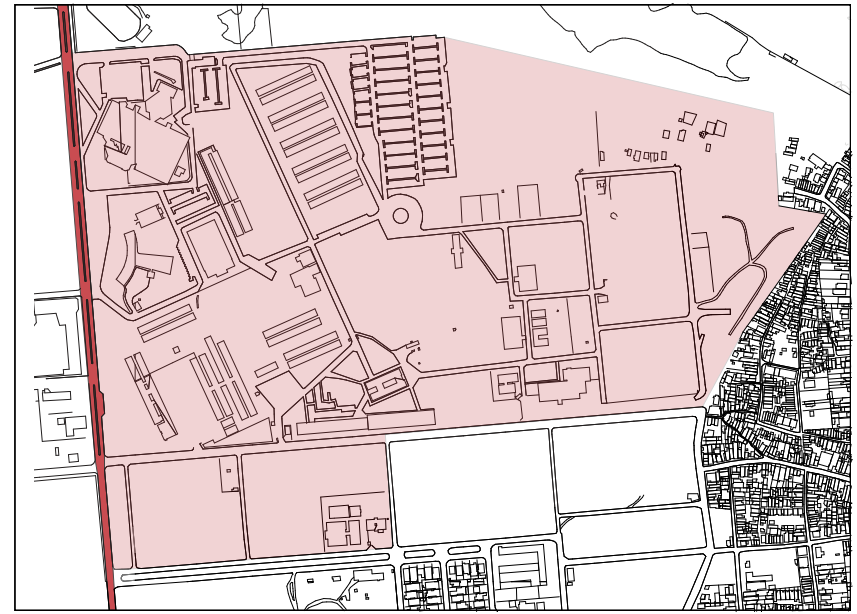

Universidade de Fortaleza, 1996 Esc. 1:12500

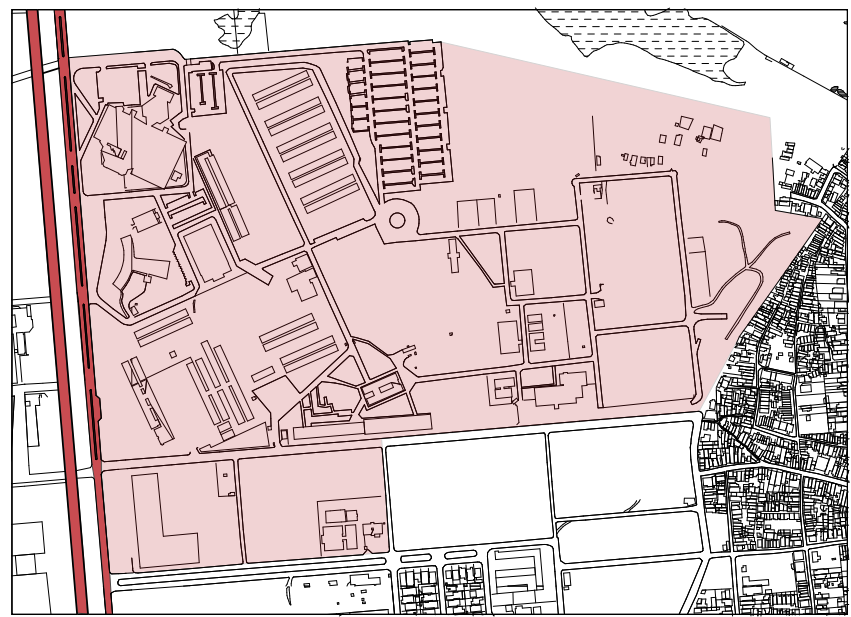

Universidade de Fortaleza, 2011

Esc. 1:12500

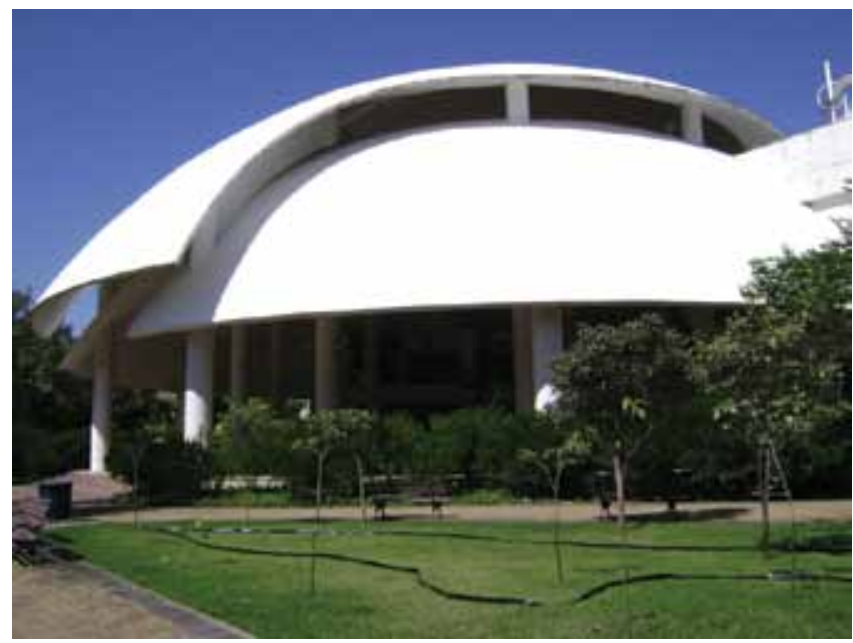

Centro de Convivência da Universidade de Fortaleza, 2009 Fonte: www.skyscrapercity.com

Fig 4.43 Uso Educacional - Unifor 


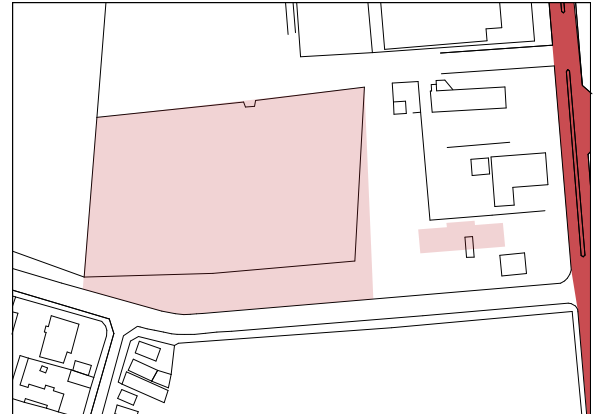

Faculdade 7 de Setembro e Juridical Center, 1996

Esc. 1:5.000

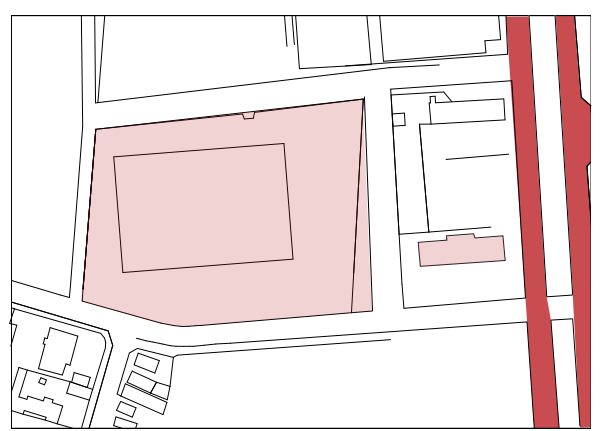

Faculdade 7 de Setembro e Juridical Center, 2011

Esc. 1:5.000

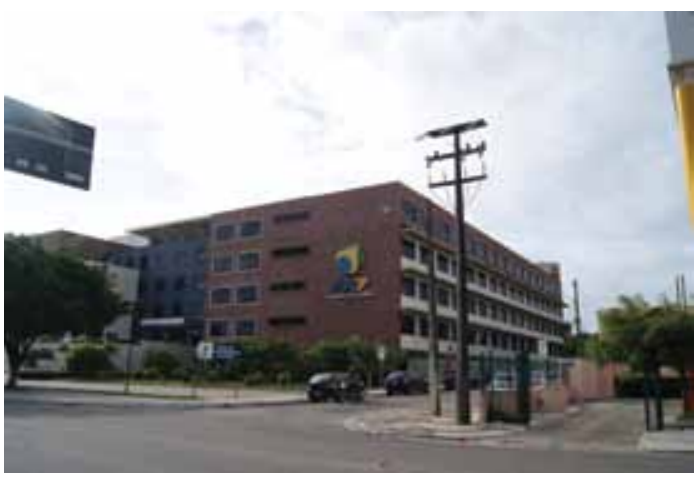

Faculdade 7 de Setembro Fonte: acervo autora

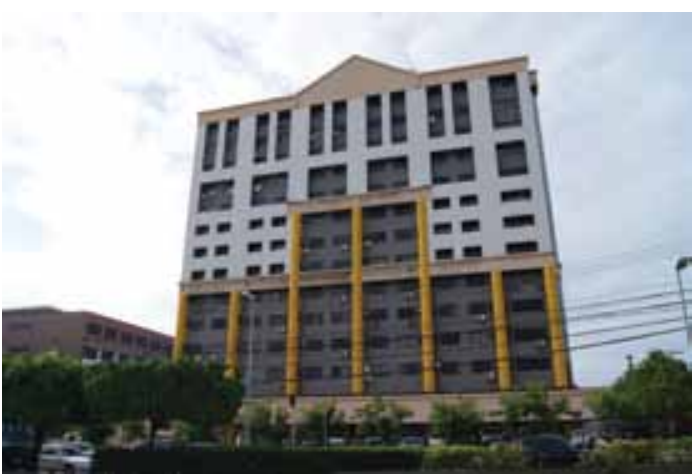

Edifício Empresarial Juridical Center Fonte: acervo autora

Fig 4.44 Uso Educacional - Faculdade 7 de Setembro

Fonte: elaborado pela autora 


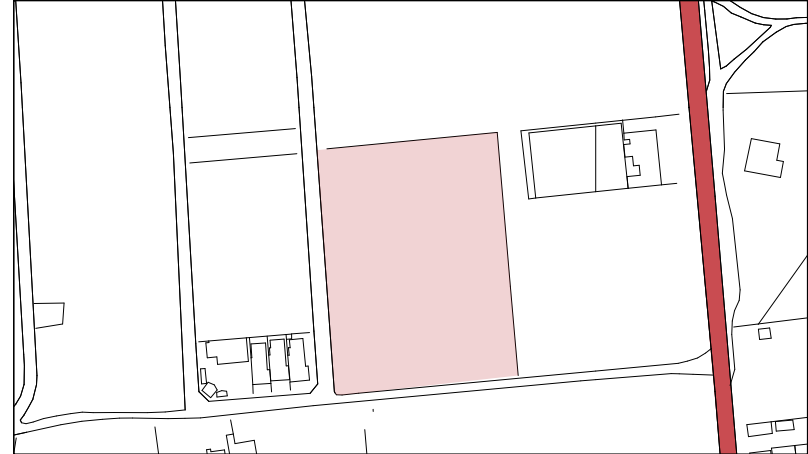

Colégio Irmã Maria Montenegro, 1996 Esc. 1:5.000

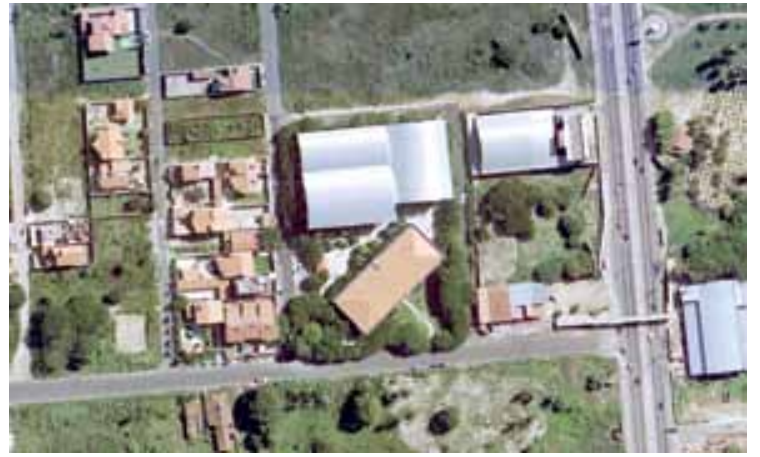

Colégio Irmã Maria Montenegro, 2001

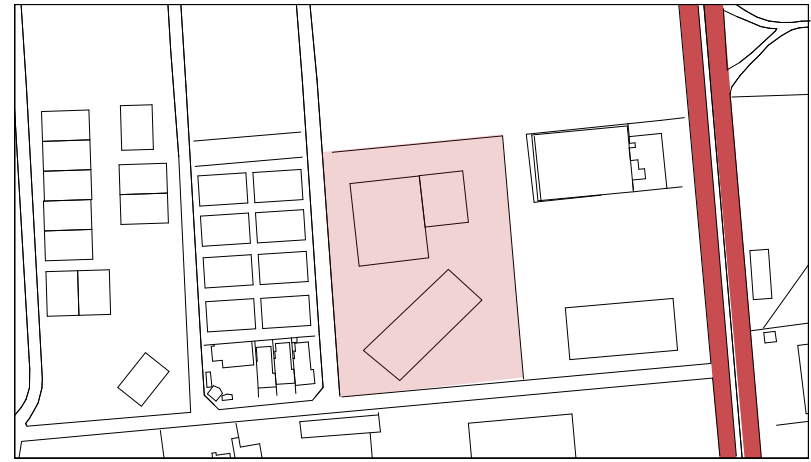

Colégio Irmã Maria Montenegro, 2011 Esc. 1:5.000

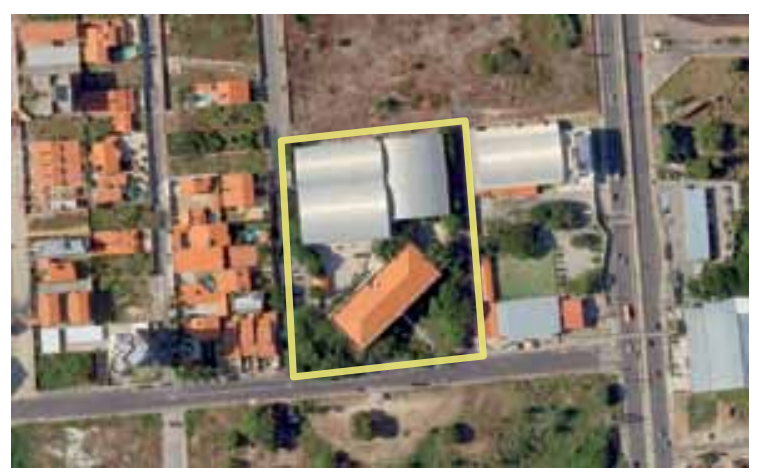

Colégio Irmã Maria Montenegro, 2009

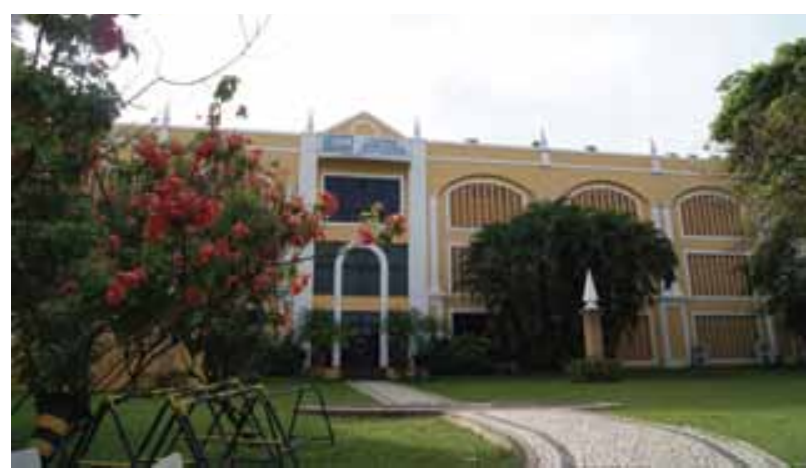

Colégio Irmã Maria Montenegro Fonte: acervo autora 


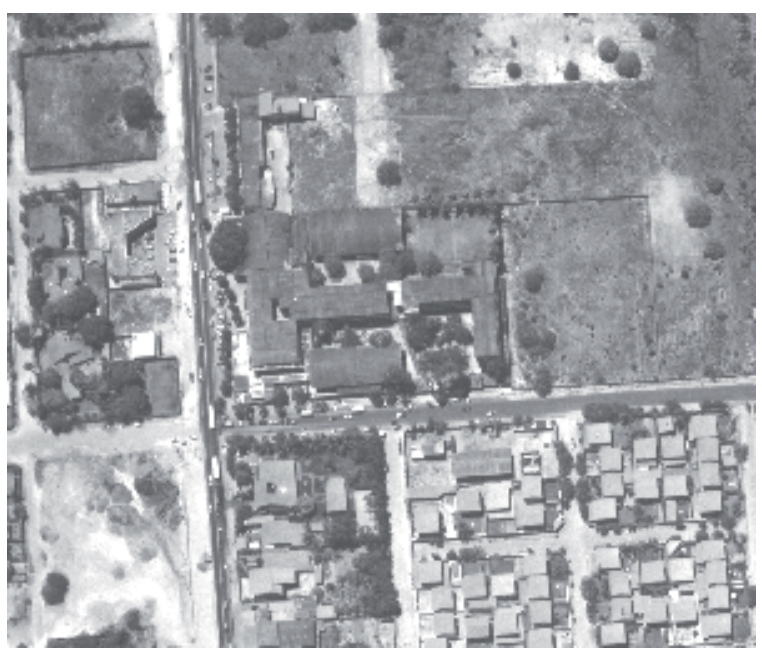

Colégio Ari de Sá, 1995

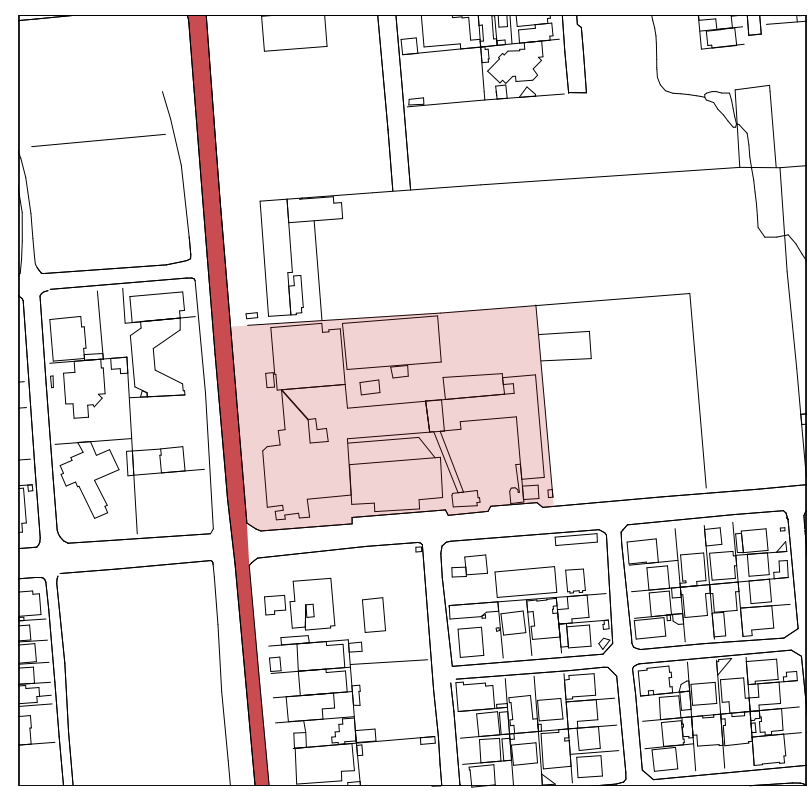

Colégio Ari de Sá, 1996

Esc. 1:5.000

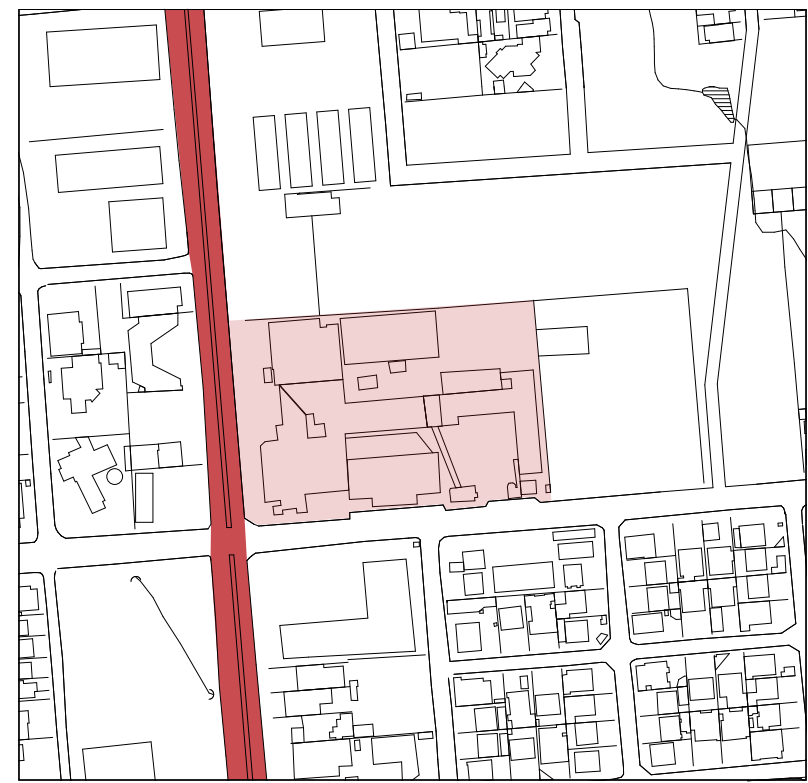

Colégio Ari de Sá, 2011

Esc. 1:5.000

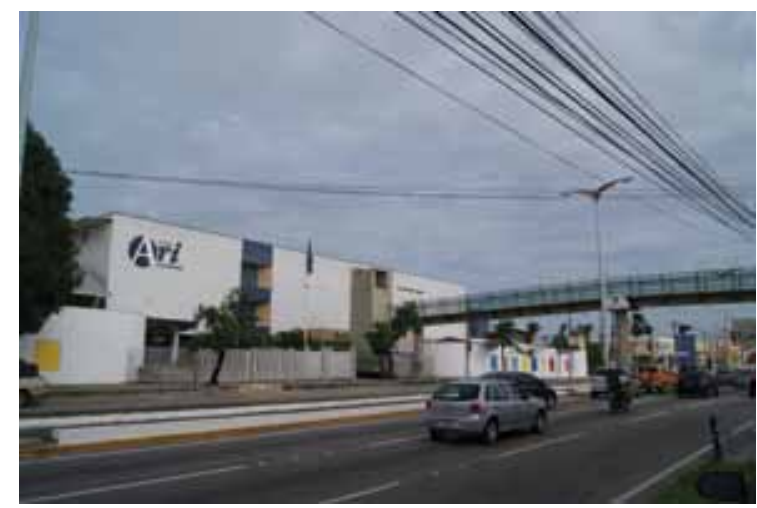

Colégio Ari de Sá

Fonte: acervo autora

Fig 4.46 Uso Educacional - Colégio Ari de Sá

Fonte: elaborado pela autora 


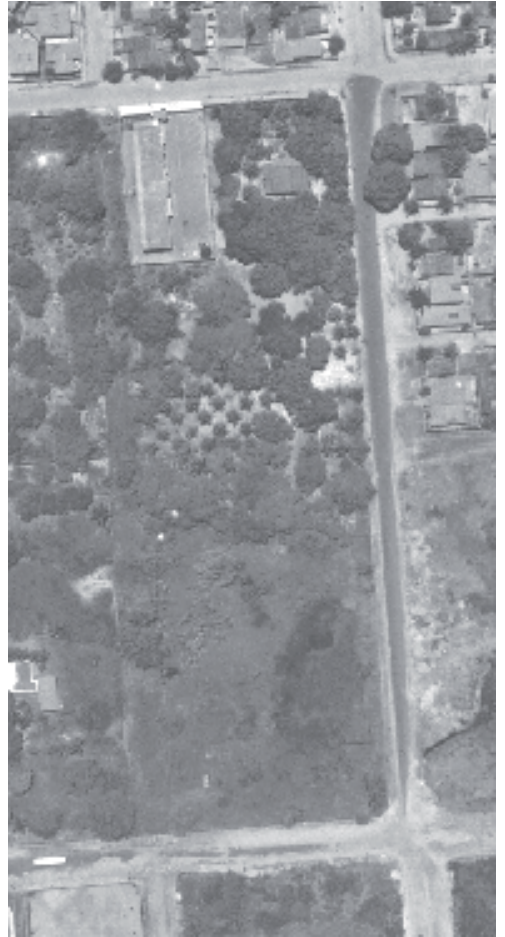

Colégio Farias Brito, 1995

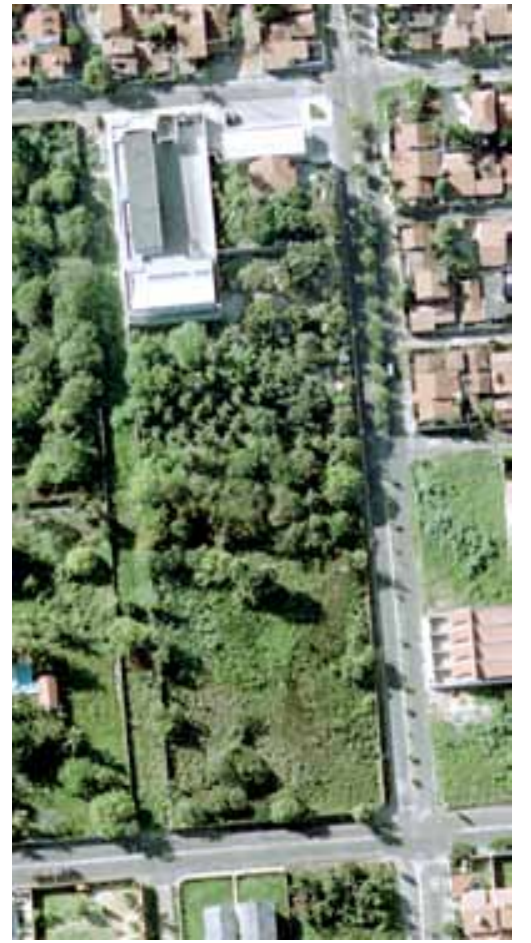

Colégio Farias Brito, 2001

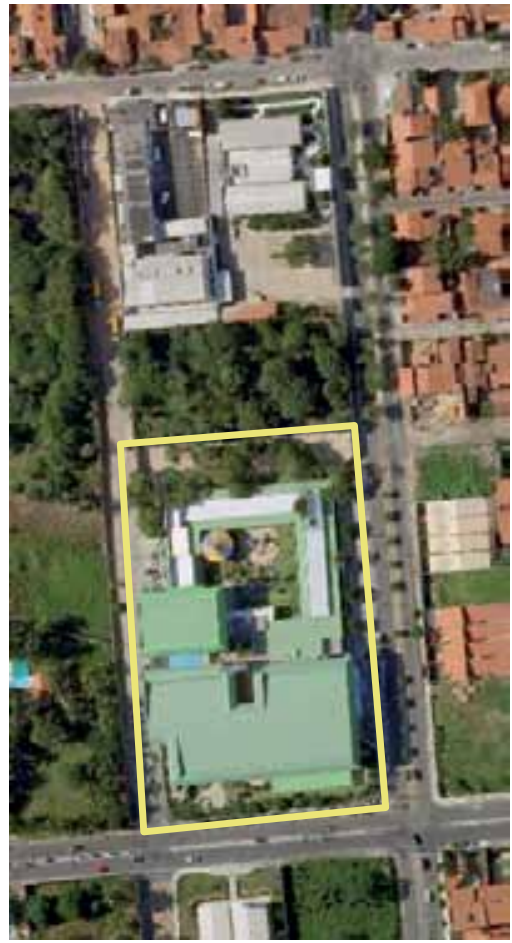

Colégio Farias Brito, 2009

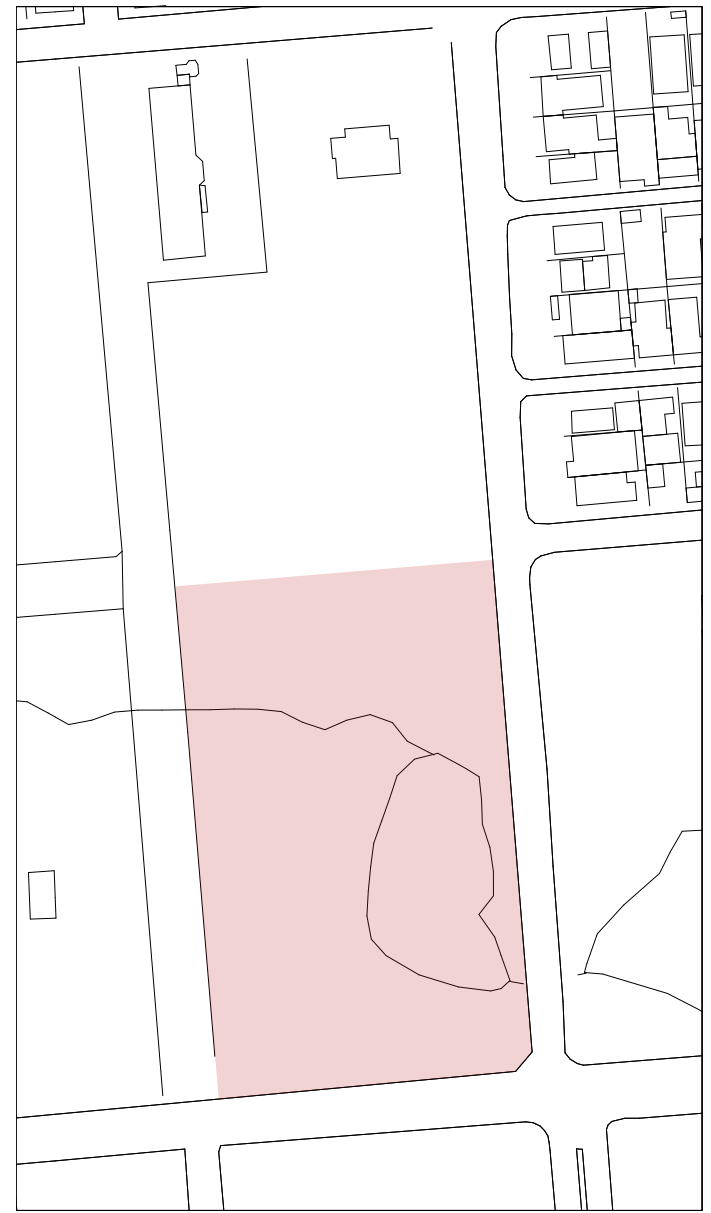

Colégio Farias Brito, 1996

Esc. 1:2.500

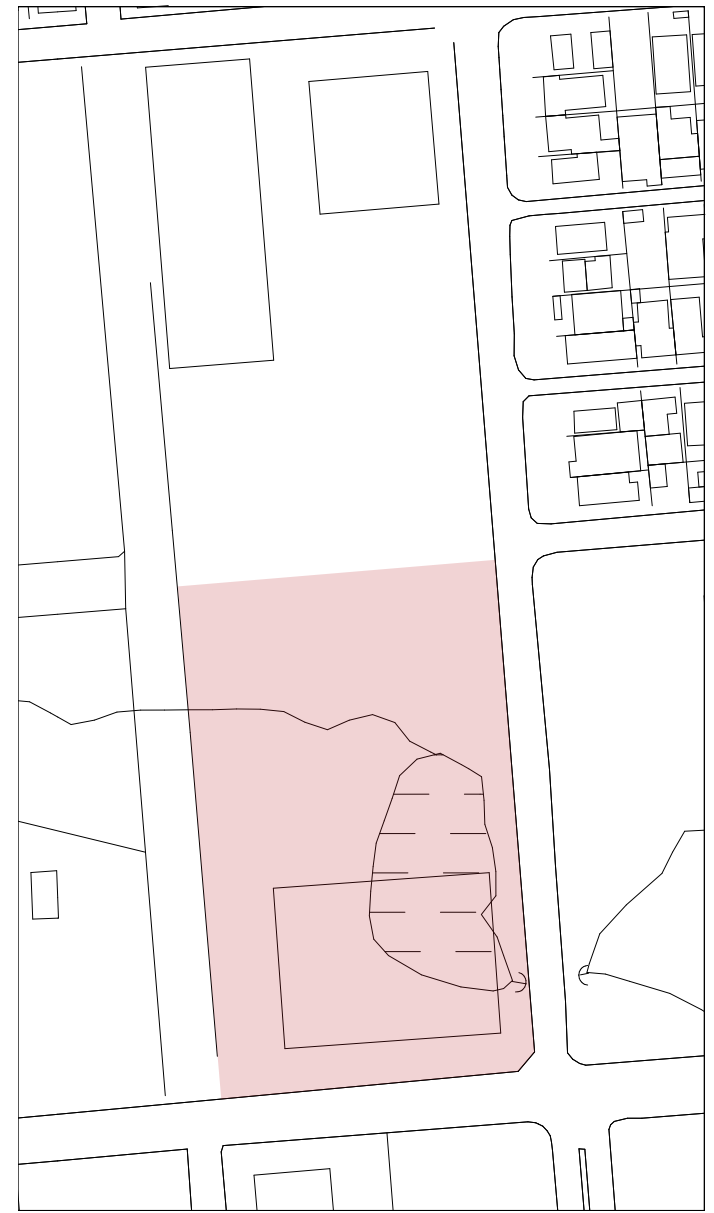

Colégio Farias Brito, 2011

Esc. 1:2.500

Fig 4.47 Uso Educacional - Colégio Farias Brito

Fonte: elaborado pela autora 


\section{Uso institucional}

O setor sudeste configurou-se, desde a década de 1970-1980, como a área preferencial para a localização de equipamentos institucionais. O processo teve início com a instalação do Centro de Convenções, em 1974, e prosseguiu com a Academia de Policia, a Imprensa Oficial do Estado, o Fórum Clóvis Bevilácqua (1997), o Centro Administrativo do Cambeba, inaugurado em 1981, culminando com a polêmica decisão², em 2009, da localização do Centro de Eventos, na porção inicial da av. Washington Soares.

A construção do Centro Administrativo Virgilio Távora (1981), sede do go-
verno estadual, fez parte dessa mesma estratégia de valorização do su-
deste urbano, envolvendo o poder político. Depois, o Fórum da Co-
marca foi transferido para o mesmo setor, em 1997, para reforçar a ten-
dência de valorização daquele espaço (ARAÚJO \& CARLEIAL, 2010) ${ }^{22}$.

Há que se avaliar a adequação da localização desses equipamentos na região, uma vez que eles atendem a toda a população da Cidade e estão distantes da área central, provocando grandes deslocamentos de pessoas de níveis socioeconômicos diversificados, além de constituírem polos geradores de tráfego, causando grandes congestionamentos na área (ver figuras 4.48 a 4.51).

São esses os principais usos verificados na parte inicial do setor sudeste, situados, predominantemente, na av. Washington Soares e nas imediações. Já fora dos limites municipais, há que se destacar o surgimento e a expansão dos condomínios horizontais e loteamentos fechados na região do Eusébio, bem como os diversos empreendimentos turísticos e de lazer instalados no litoral de Aquiraz, os quais se tornam cada vez mais importantes para o entendimento da dinâmica urbana e metropolitana. As últimas dinâmicas mencionadas, assim como a centralidade formada no setor, serão examinadas com maior grau de detalhamento nos itens 4.5, 4.6 e 4.7 .

\footnotetext{
${ }^{21}$ A decisão governamental de instalar o Centro de Eventos nessa área despertou controvérsias, já que ela se acha bastante congestionada atualmente, com diversos equipamentos geradores de tráfego. Fez-se necessária a reformulação do sistema viário do entorno, em fase de execução.

${ }^{22}$ Disponível em: <http://www.ub.es/geocrit/sn/sn-117.htm
} 


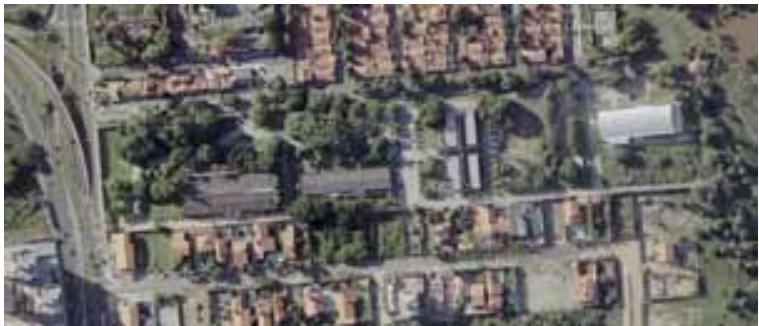

Antiga sede do Governo Estadual, 2001

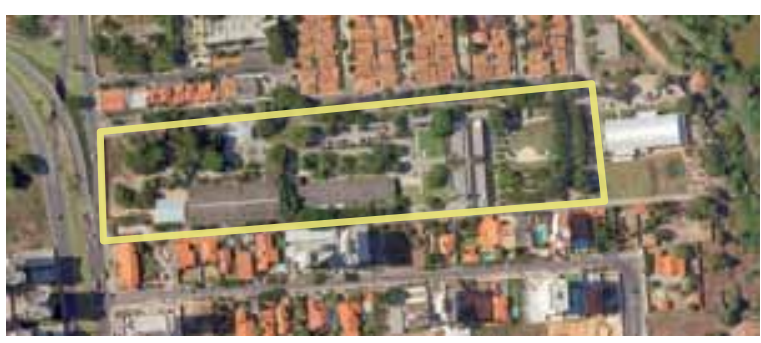

Antiga sede do Governo Estadual, 2009

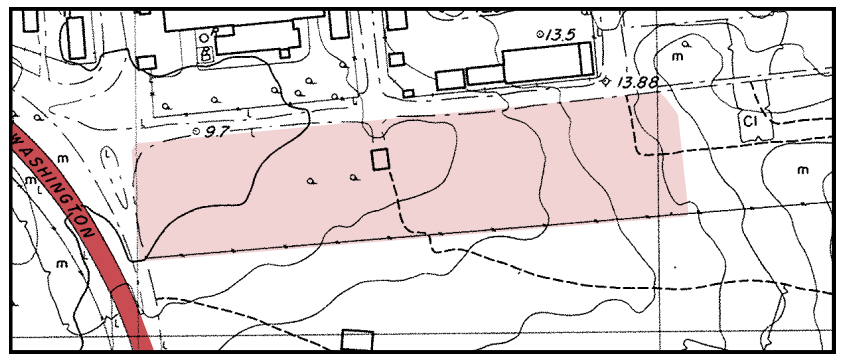

Antiga de do Governo Estadual, 1972 Esc. 1:7.500

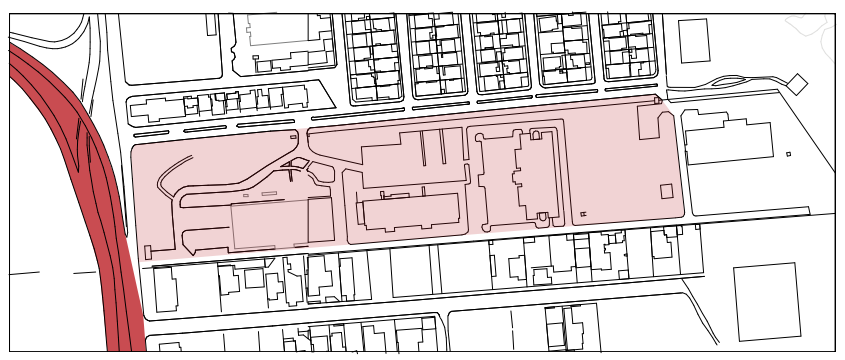

Antiga de do Governo Estadual, 1996 Esc. 1:7.500

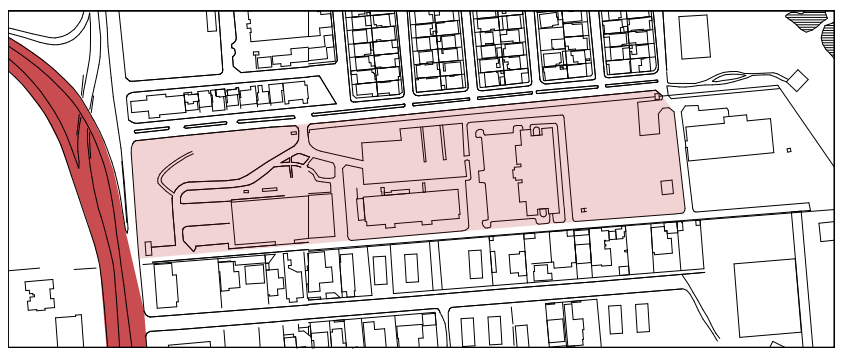

Antiga de do Governo Estadual, 2011

Esc. 1:7.500 
CAPÍTULO 4

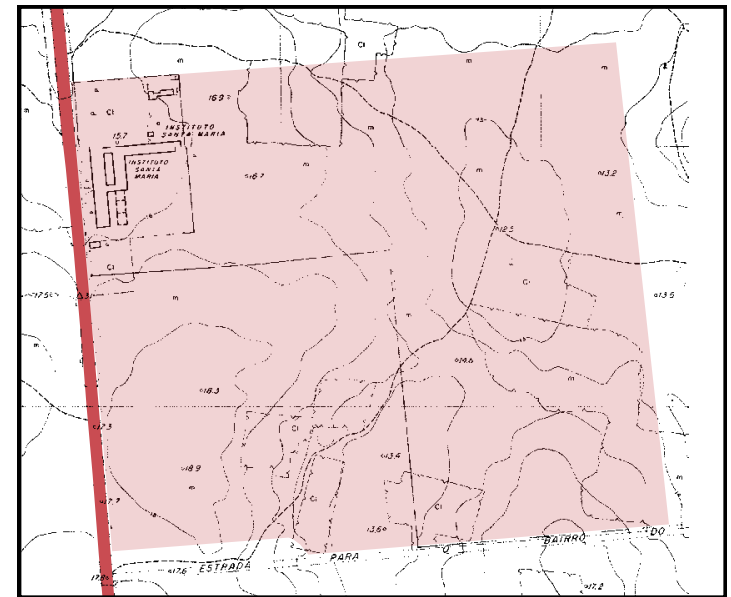

Centro de Eventos, 1972

Esc. 1:7.500

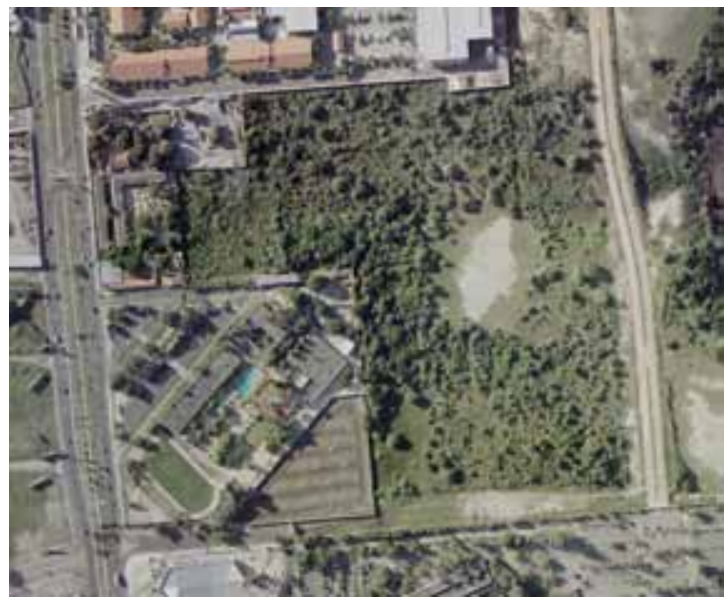

Centro de Eventos, 2001

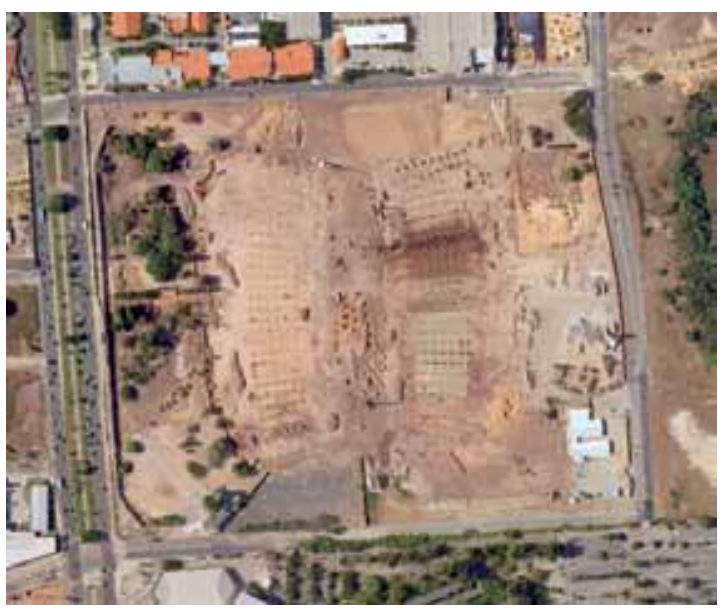

Centro de Eventos, 2009

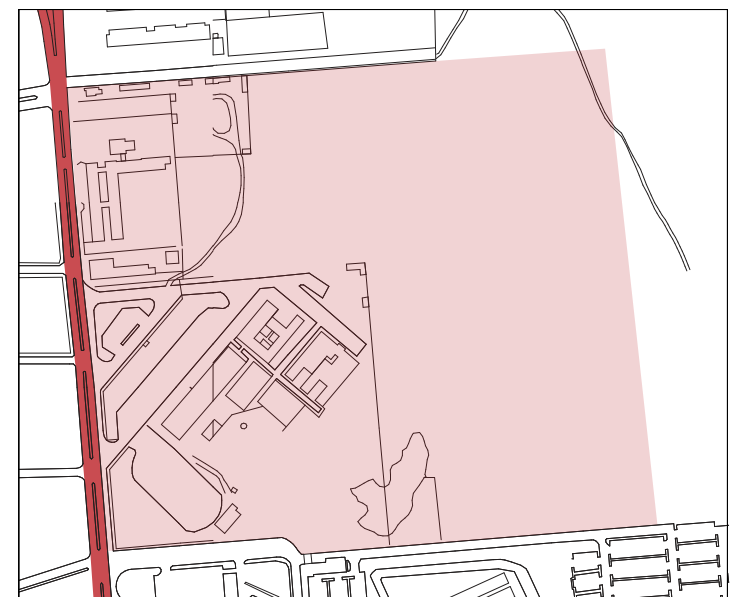

Centro de Eventos, 1996 Esc. 1:7.500

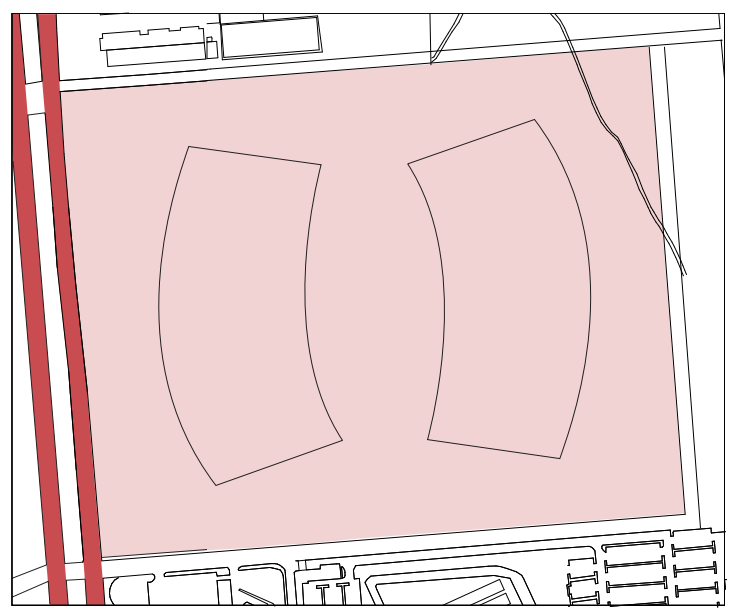

Centro de Eventos, 2011

Esc. 1:7.500 


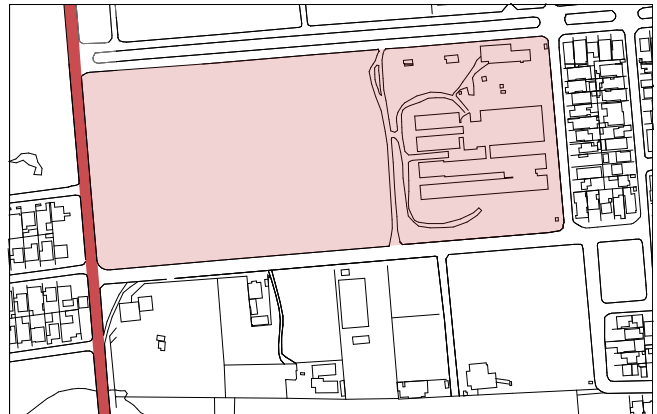

Fórum Clóvis Beviláqua, 1996 Esc. 1:7.500

Fórum Clóvis Beviláqua, 2001

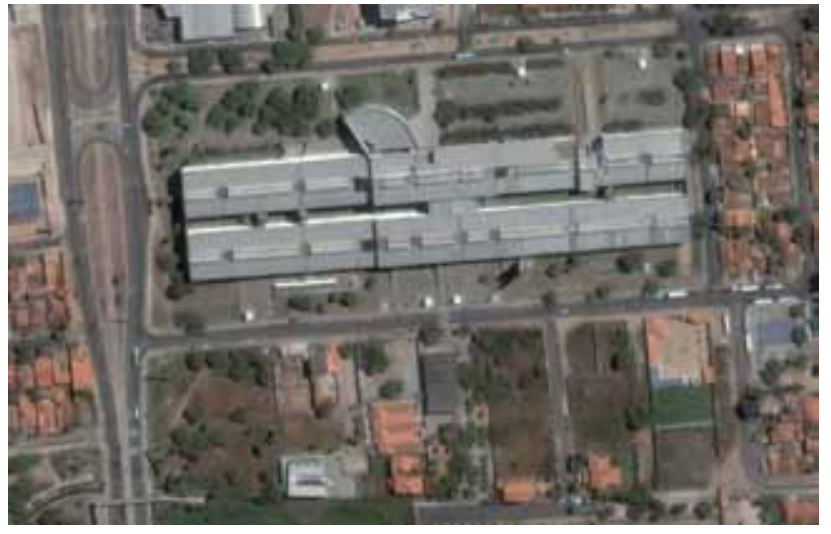

Fórum Clóvis Beviláqua, 2003

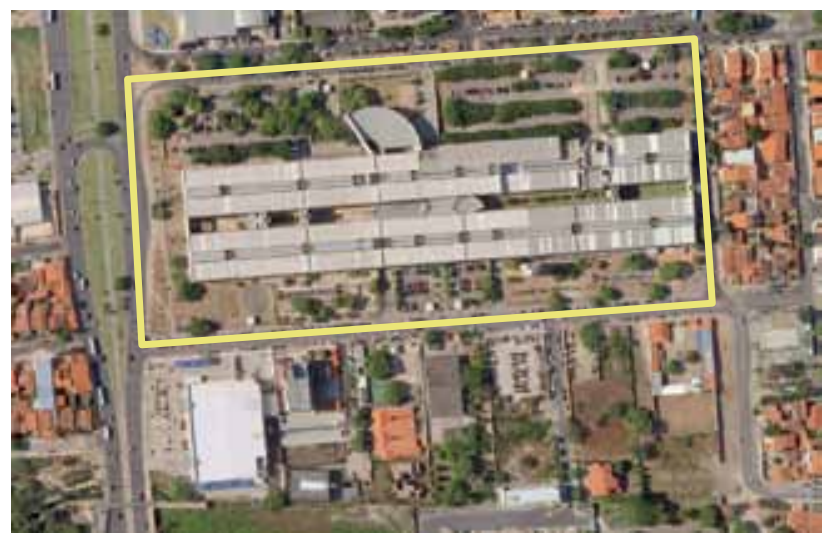

Fórum Clóvis Beviláqua, 2009

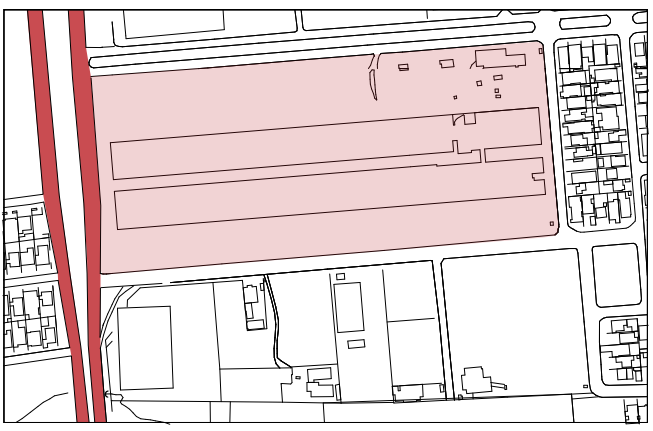

Fórum Clóvis Beviláqua, 2011 Esc. 1:7.500

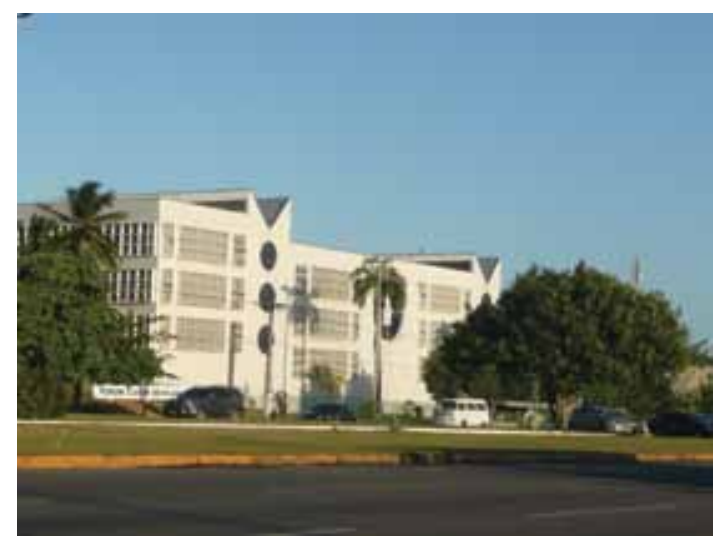

Fórum Clóvis Beviláqua Fonte: www.panoramio.com 


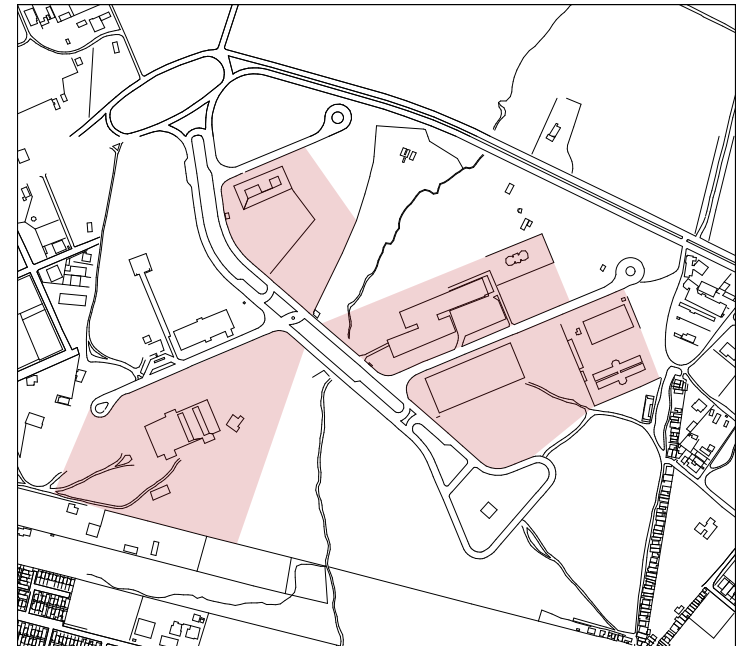

Centro Administrativo do Cambeba, 1996 Esc. 1:12.500

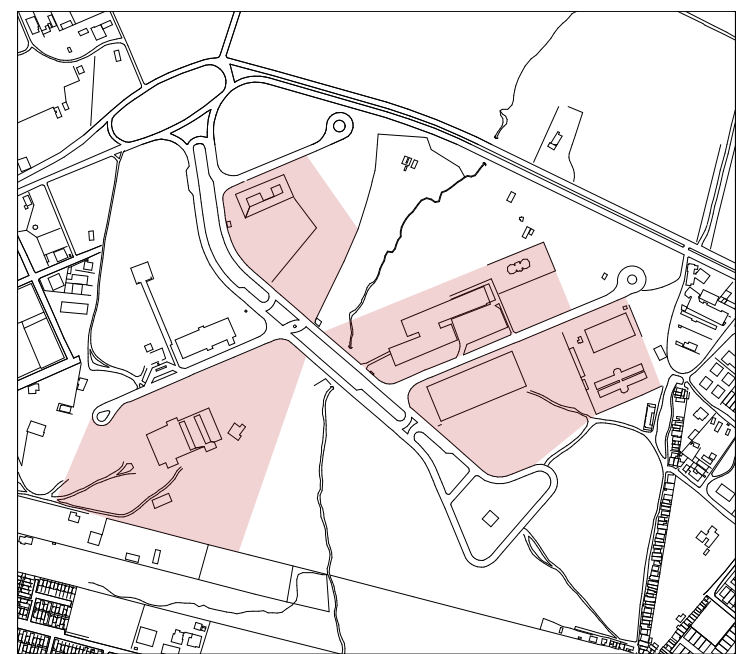

Centro Administrativo do Cambeba, 2011 Esc. 1:12.500

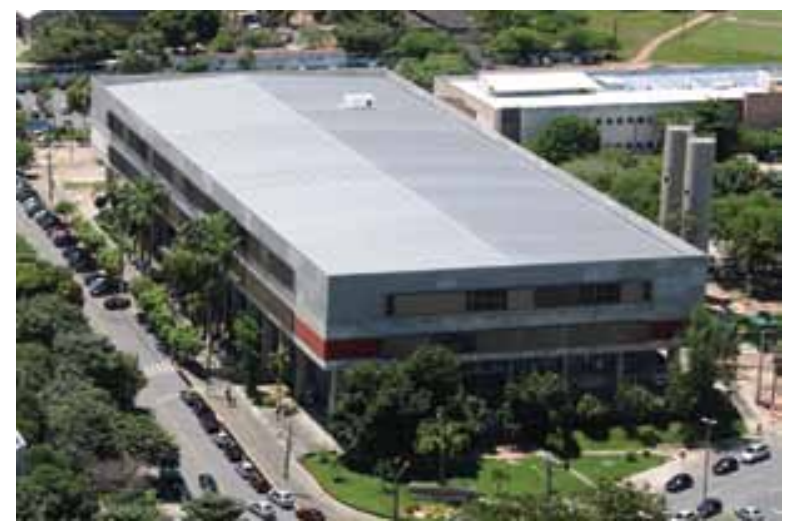

Tribunal de Justiça no Cambeba Fonte: www.nestorcarvalho.blogspot.com.br

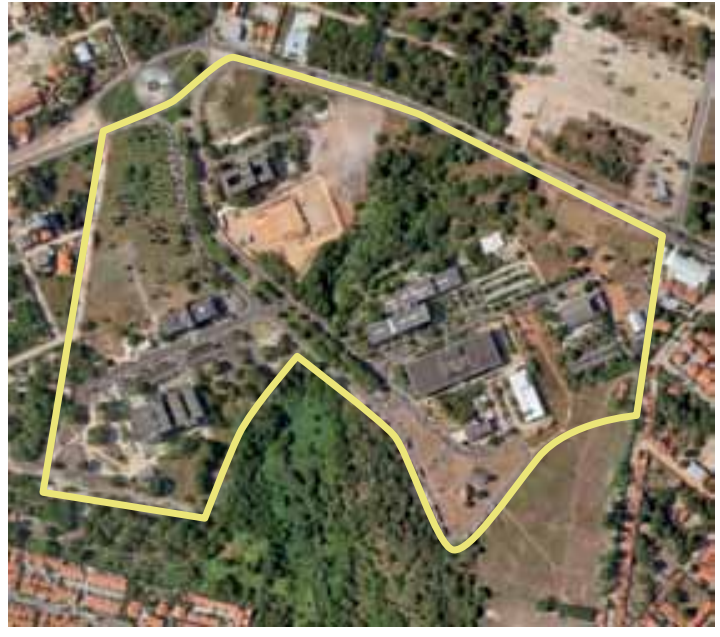

Centro Administrativo do Cambeba, 2009 
CAPÍTULO 4

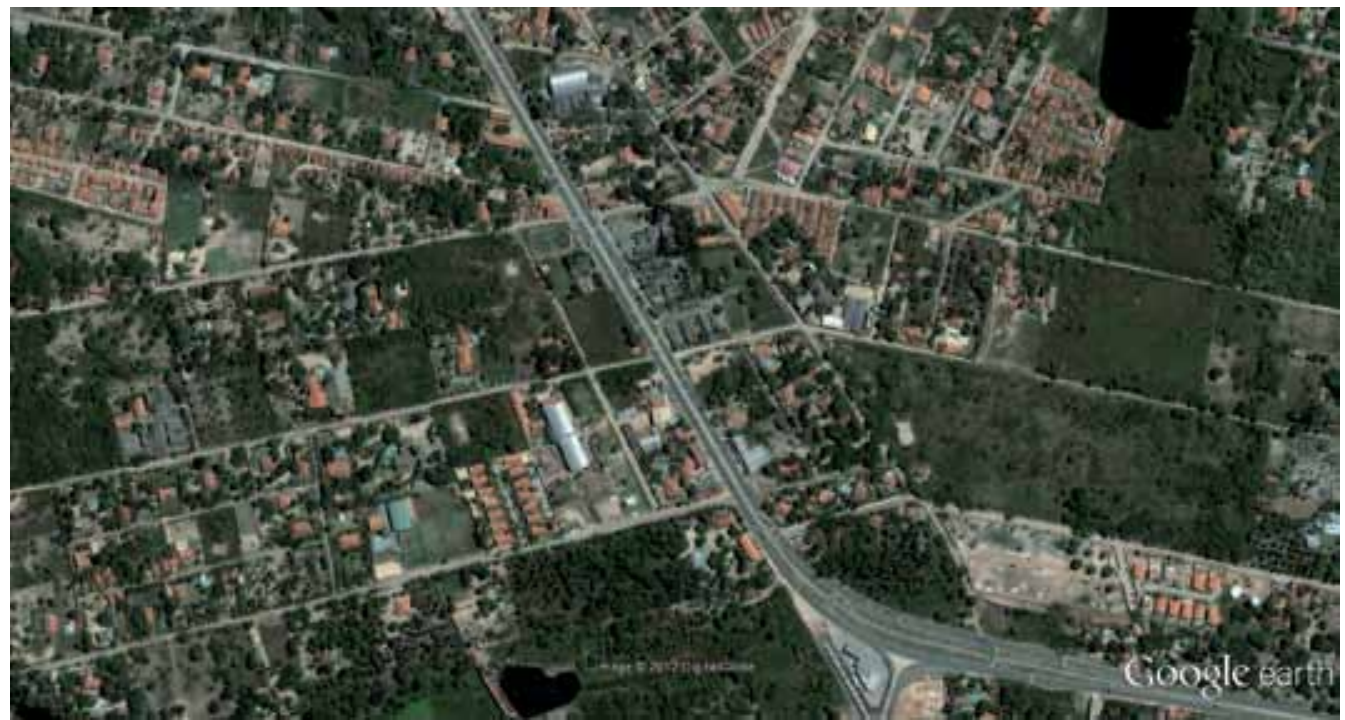

Condomínios fechados no Eusébio, 2003

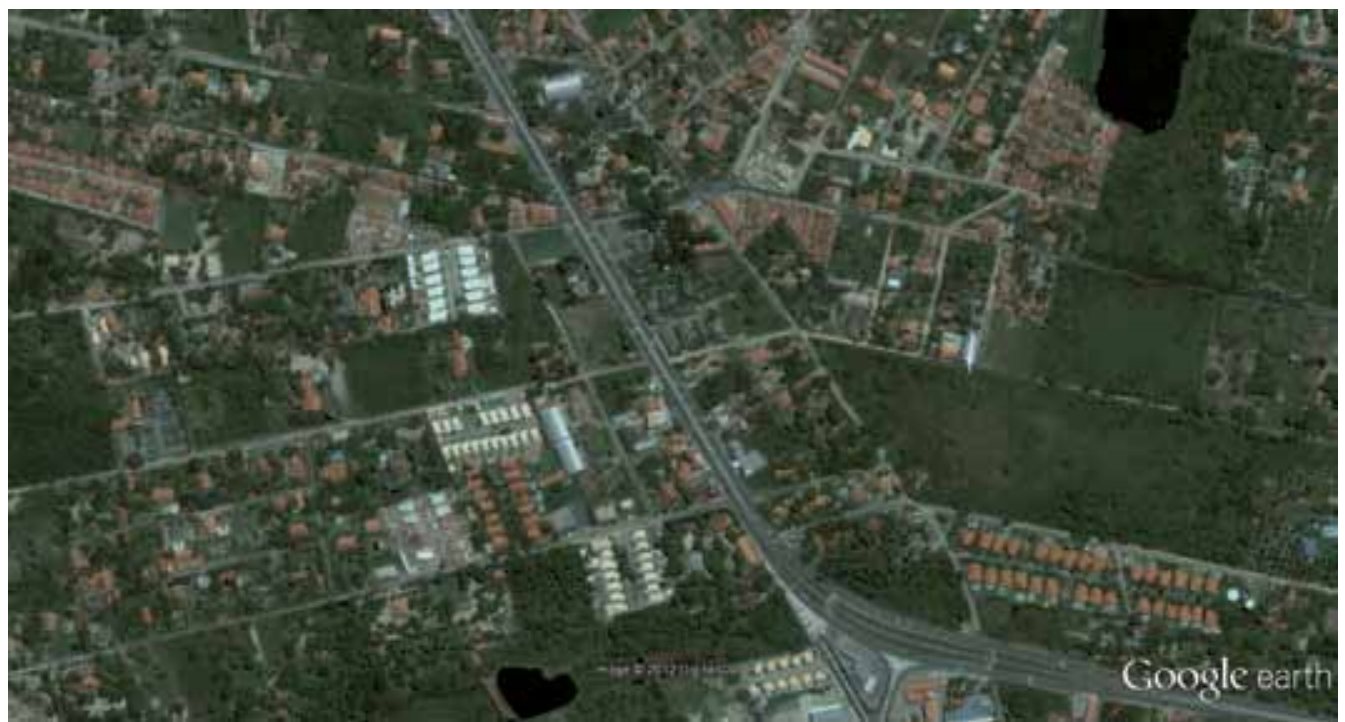

Condomínios fechados no Eusébio, 2007

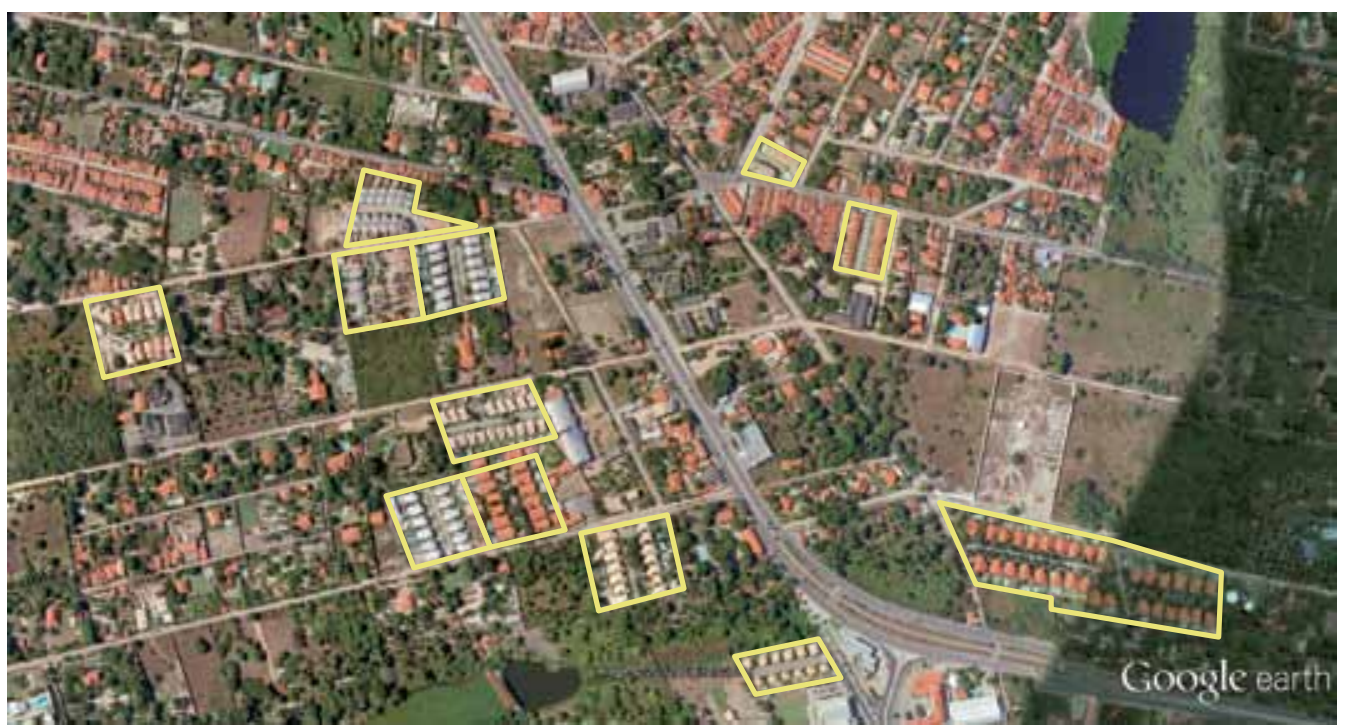

Condomínios fechados no Eusébio, 2009

Fig 4.52 Condomínios no Eusébio

Fonte: elaborado pela autora 
CAPÍTULO 4

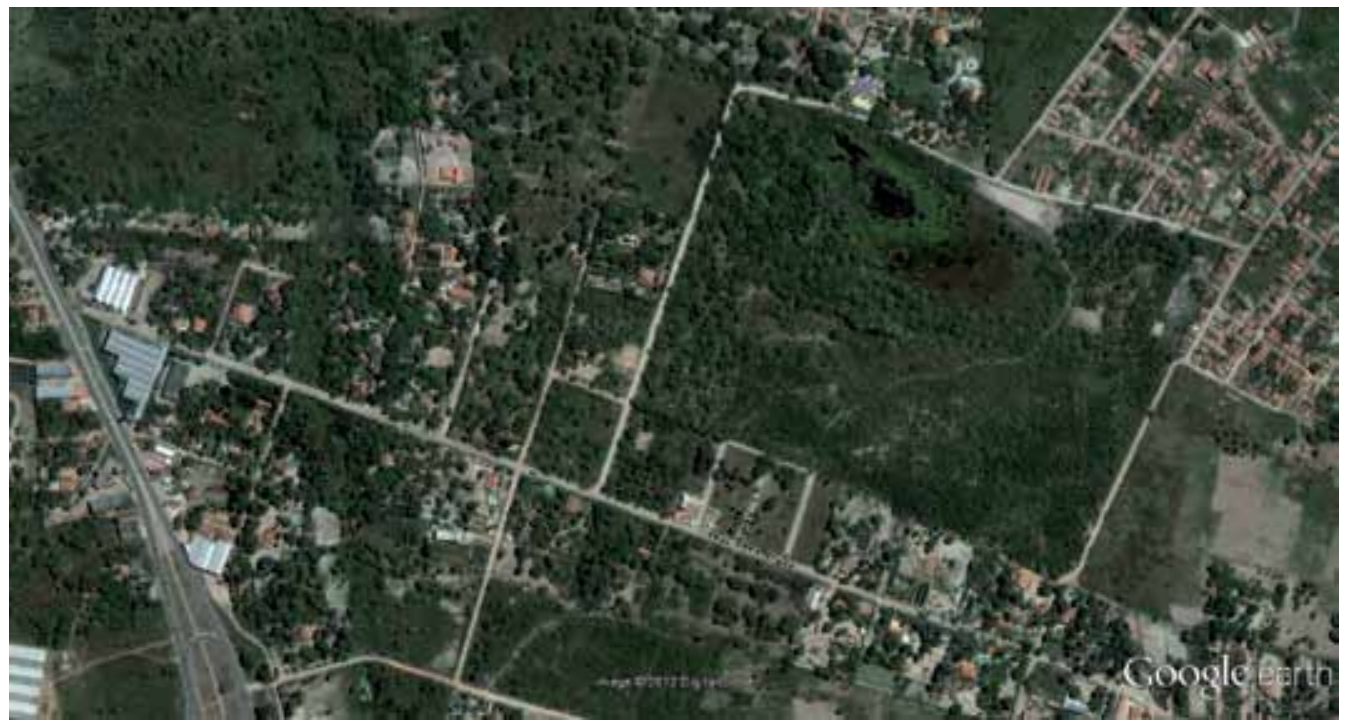

Loteamento fechado Quintas do Lago, 2003

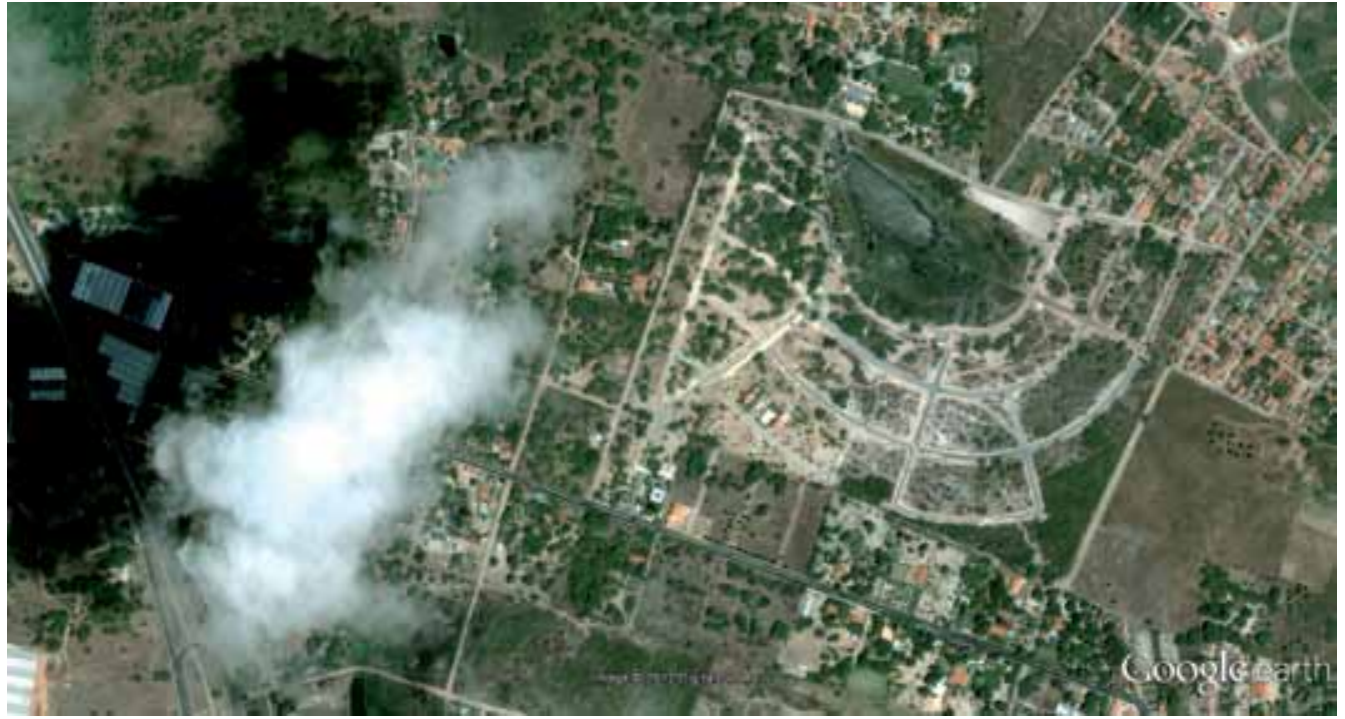

Loteamento fechado Quintas do Lago, 2004

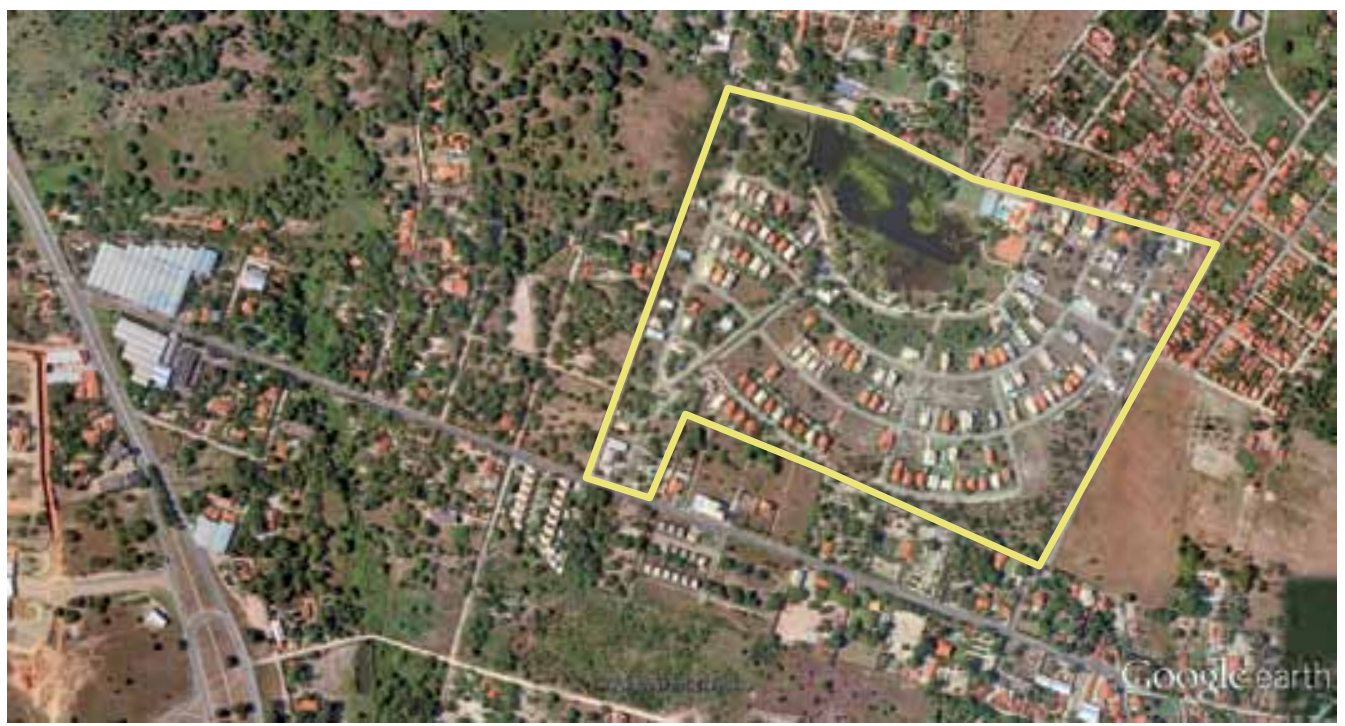

Loteamento fechado Quintas do Lago, 2009

Fig 4.53 Condomínios no Eusébio - Quintas do Lago

Fonte: elaborado pela autora 


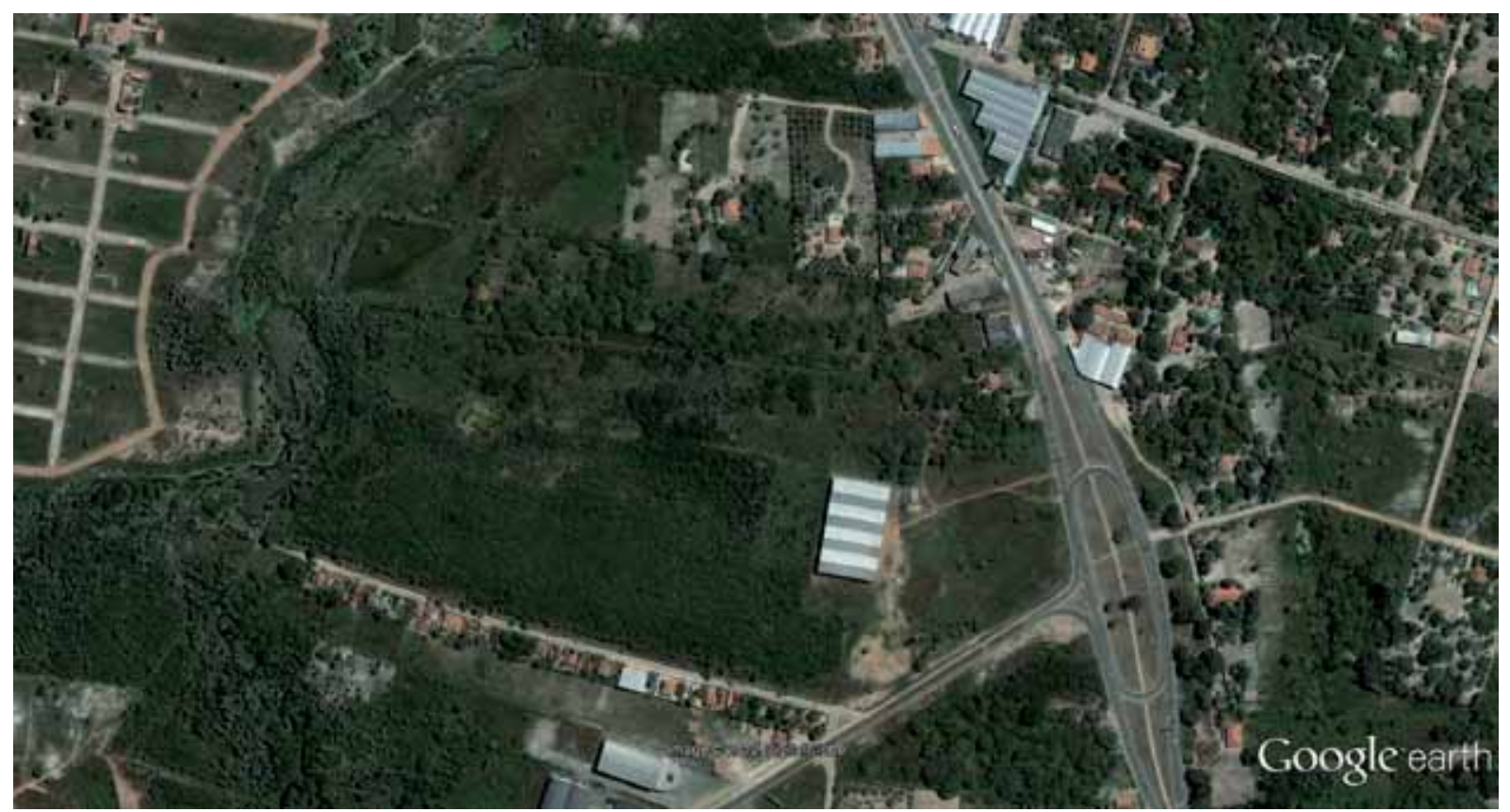

Loteamento fechado Jardins Ibiza, 2003

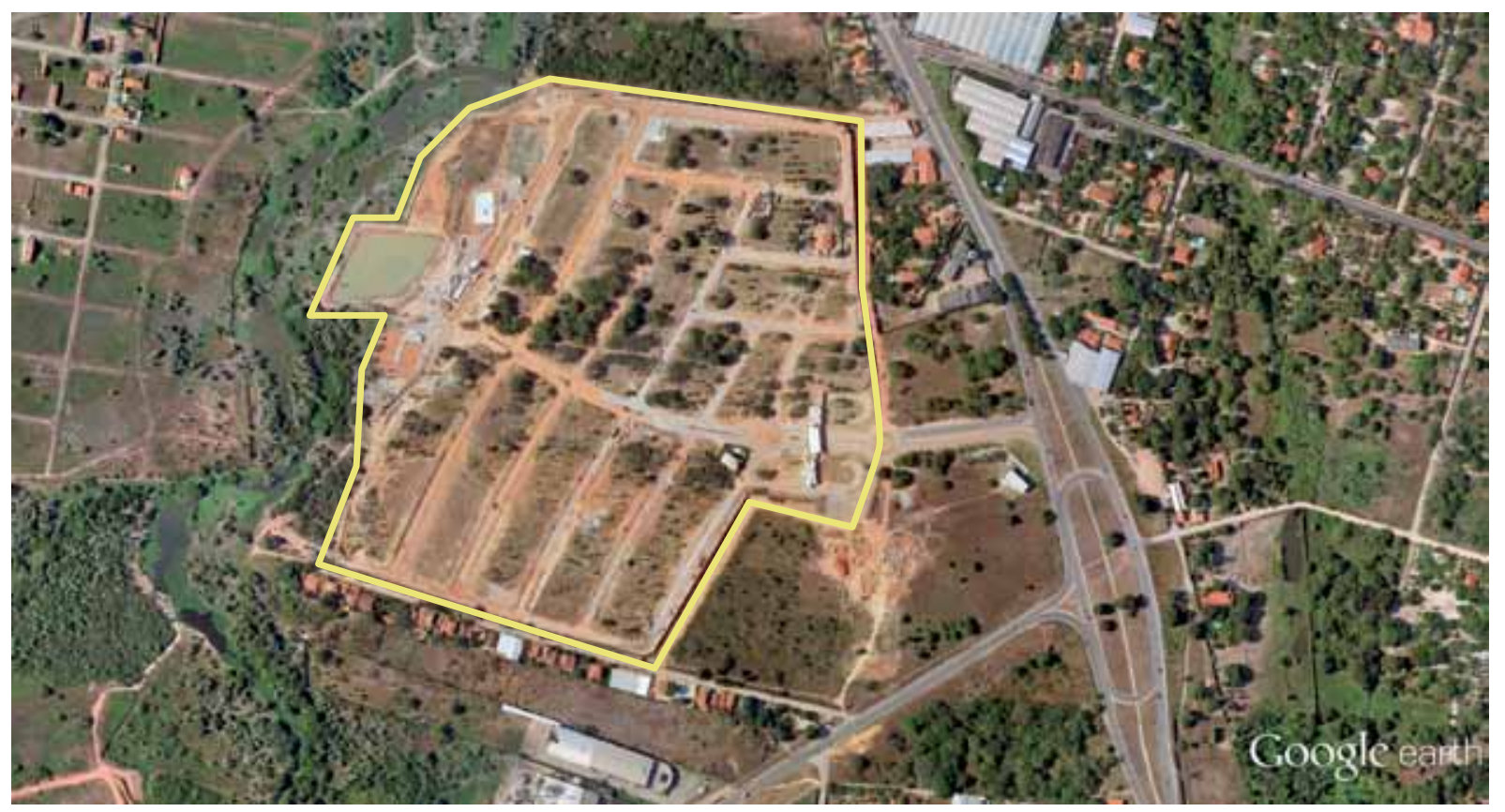

Loteamento fechado Jardins Ibiza, 2009 


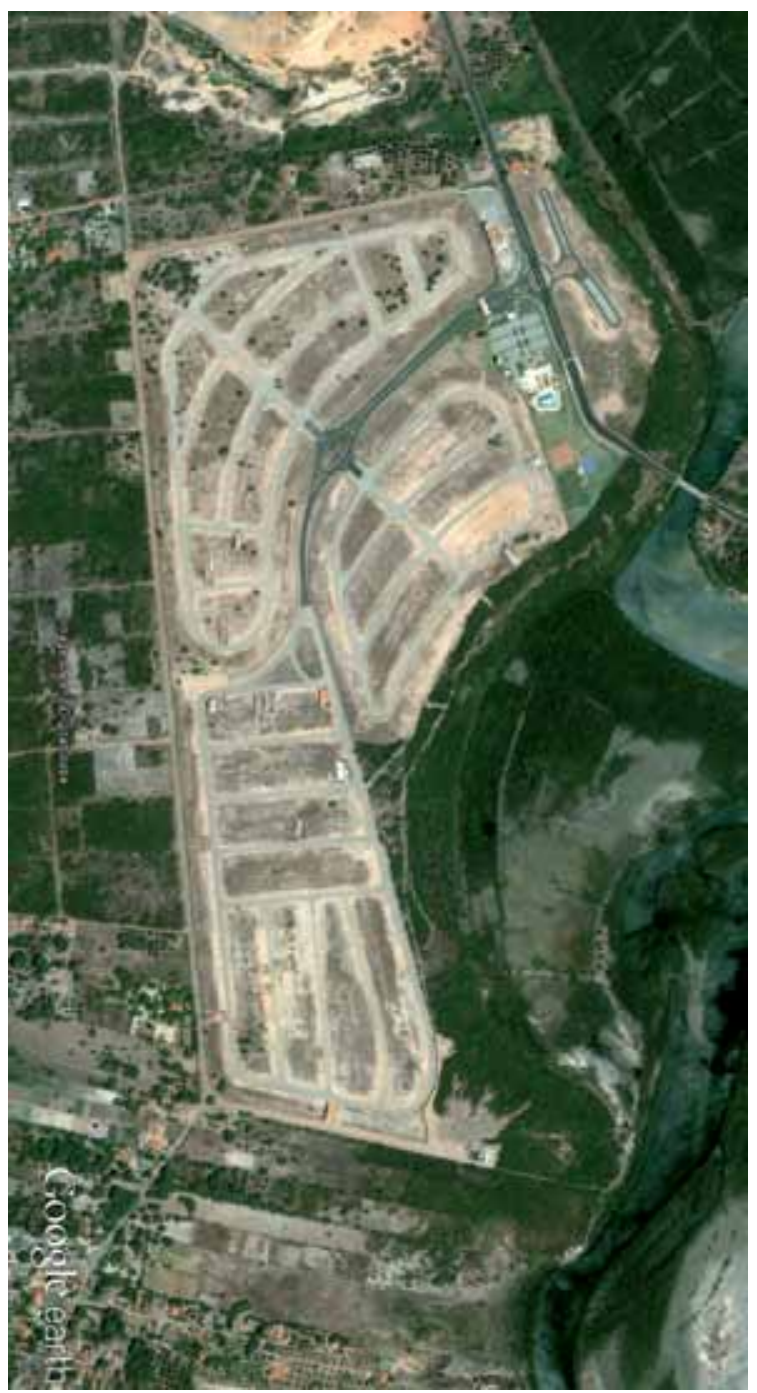

Alphaville Fortaleza, 2004

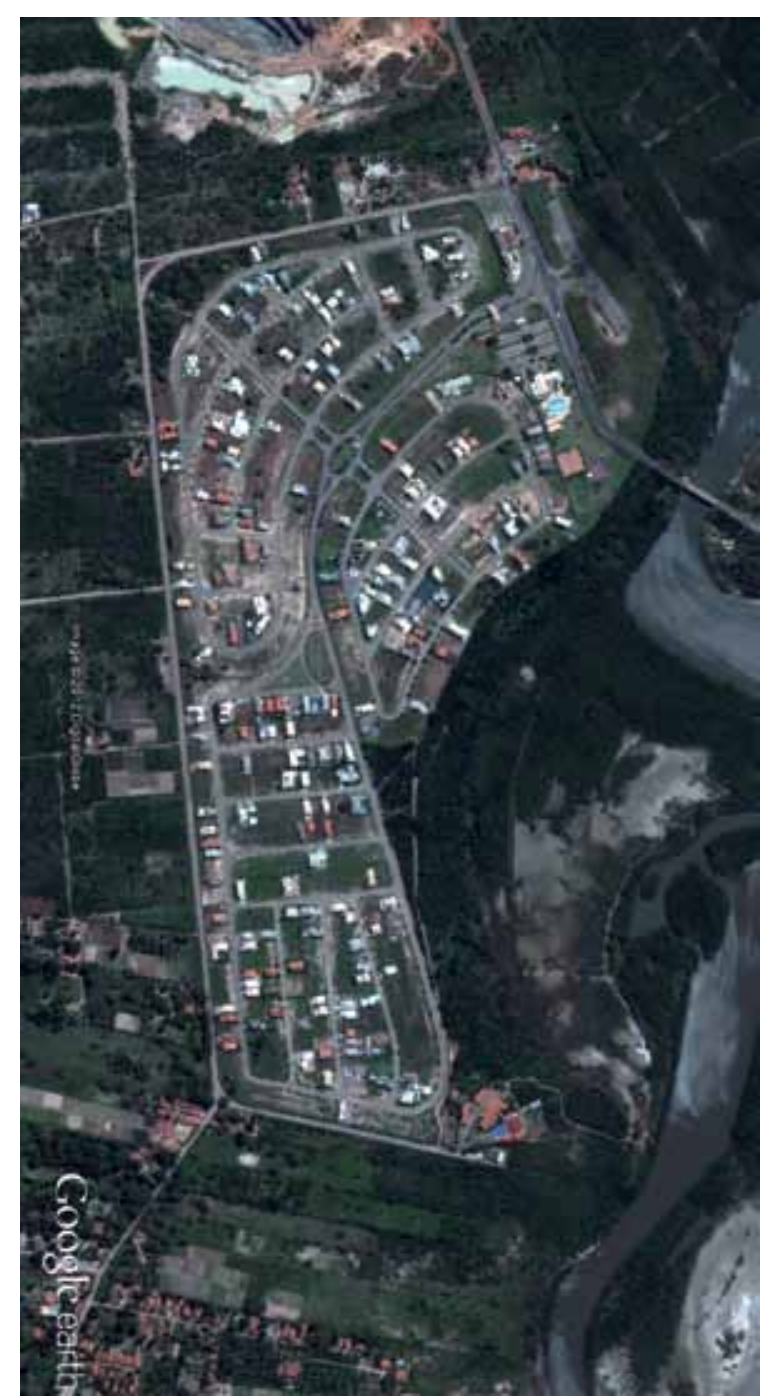

Alphaville Fortaleza, 2011

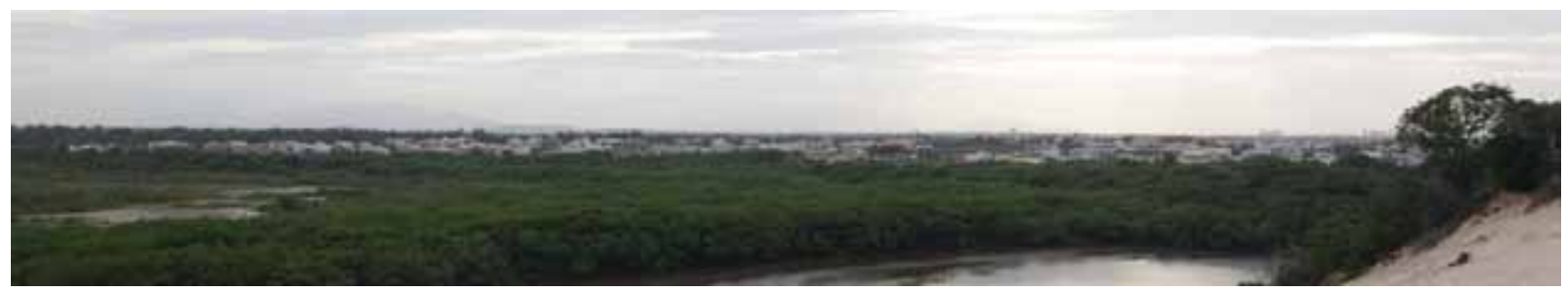

Vista panorâmica do Alphaville Fortaleza Fonte: acervo autora 
CAPÍTULO 4

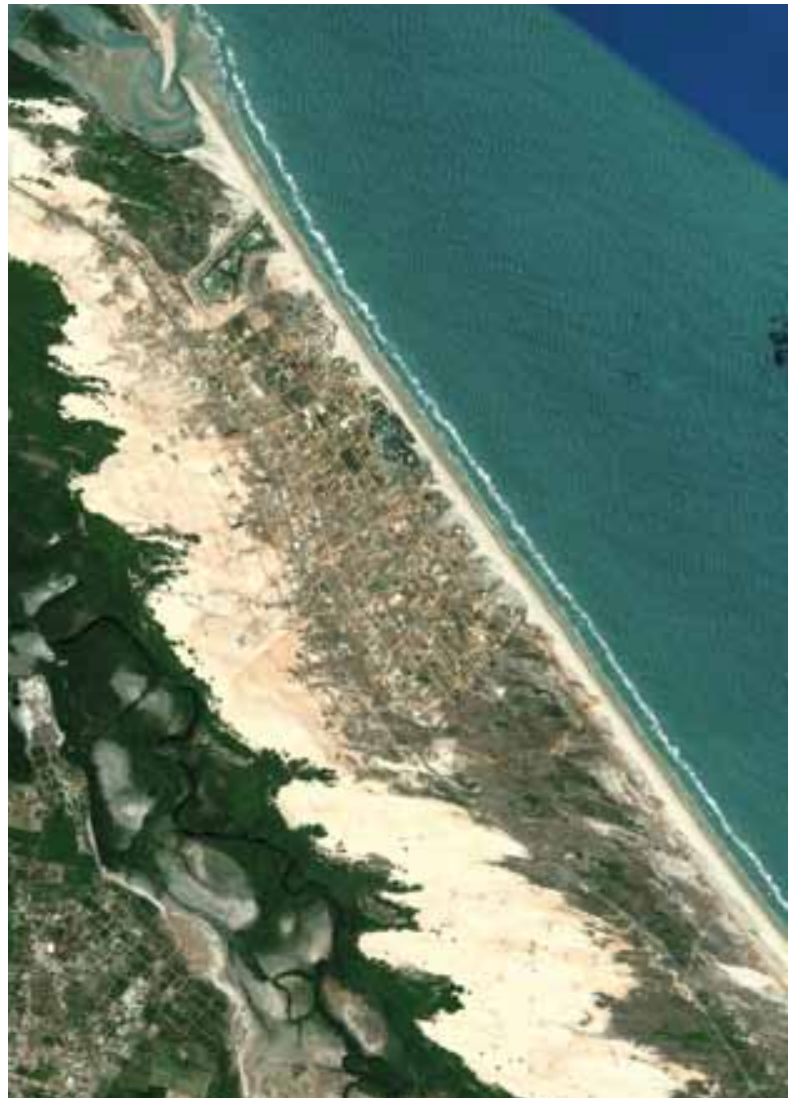

Porto das Dunas, 2004

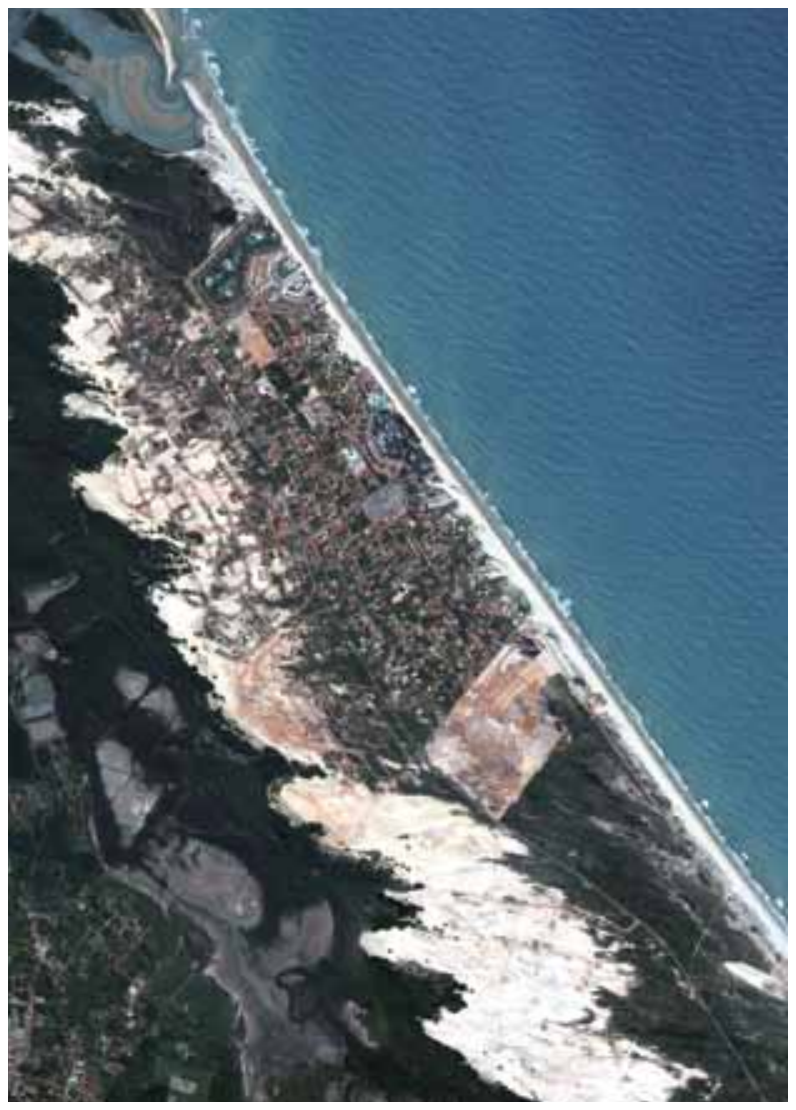

Porto das Dunas, 2011

Fig 4.56 Equipamentos Turísticos no Aquiraz - Porto das Dunas Fonte: elaborado pela autora 
CAPÍTULO 4

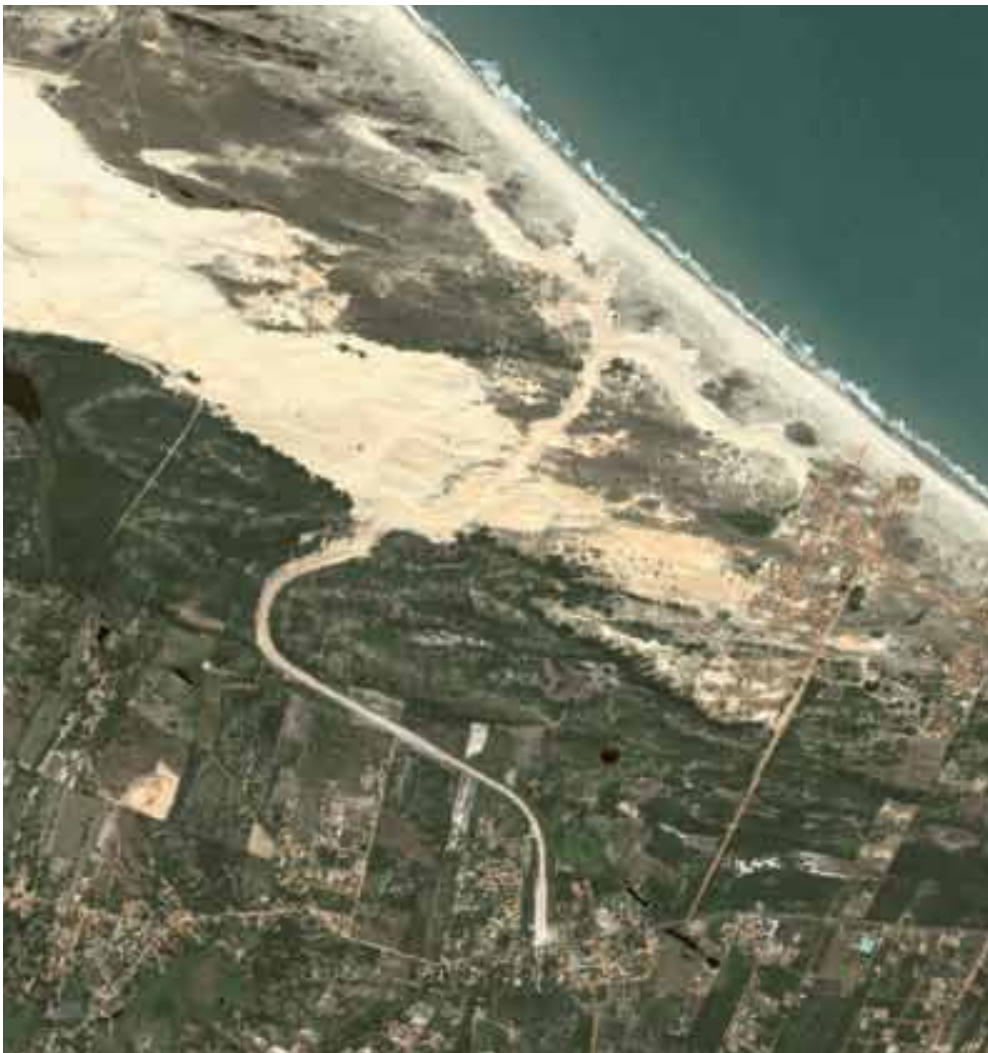

Aquiraz Riviera, 2007

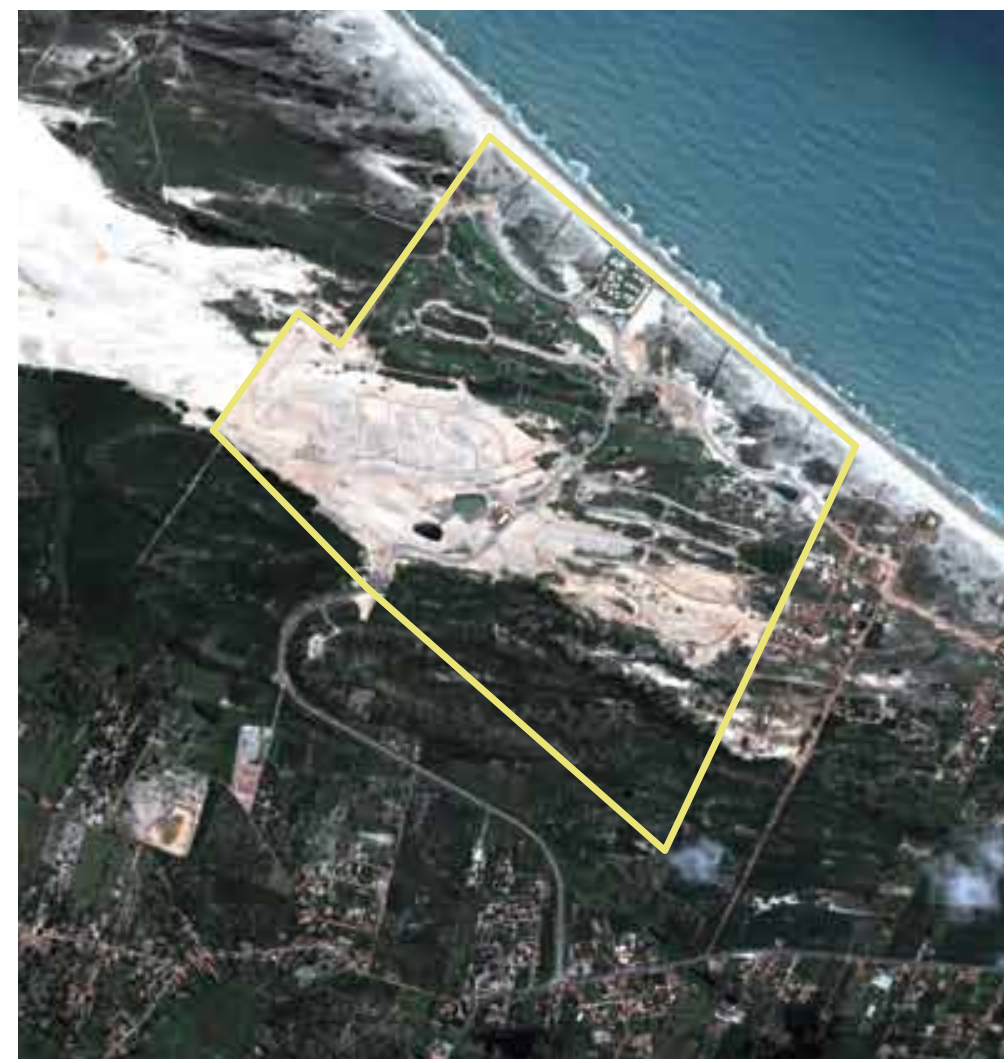

Aquiraz Riviera, 2011

Fig 4.57 Equipamentos Turísticos no Aquiraz - Aquiraz Riviera Fonte: elaborado pela autora 


\subsection{A PAISAGEM NATURAL}

A paisagem natural do setor sudeste é caracterizada, de maneira geral, por sua alta qualidade ambiental. Toda essa parte da Metrópole é tida como privilegiada, por abranger ricos recursos naturais, que conferem ao setor características bem peculiares. A área possui notável interesse paisagístico, com abundante vegetação, rios, parques, lagoas e mangues, além de toda a orla marítima, com suas dunas e coqueirais (ver figura 4.30).

O eixo sudeste de expansão metropolitana constitui, de fato, uma região de grande beleza cênica, detentora de importante patrimônio ambiental, de recursos naturais estratégicos e de uma vegetação deveras diversificada.

Essa peculiaridade - as características paisagísticas e amenidades naturais - tem sido importante fator de atração da população de mais alta renda e atua como elemento de marketing da atividade imobiliária, que se utiliza desses atributos como estratégia de venda, constituindo, assim, importante fator no incremento da expansão metropolitana.

A localização privilegiada e a restritiva legislação de uso e ocupação do solo tornaram-se fontes de conflito entre os interesses públicos e os privados. O capital imobiliário exerce pressão constante no sentido de permitir maior ocupação em locais não permitidos pela legislação.

O rio Cocó, que percorre grande extensão do setor sudeste, constitui um dos principais recursos hídricos da Região Metropolitana de Fortaleza ${ }^{23}$. Com uma extensão de $45 \mathrm{~km}^{24}$, tem sua nascente localizada na vertente oriental da serra da Aratanha, no Município de Pacatuba, desaguando no oceano Atlântico entre as praias do Clube Caça e Pesca (Praia do Futuro) e da Sabiaguaba.

Até meados do século $X X$, o rio representava uma barreira física ao desenvolvimento da malha urbana, na porção sudeste de Fortaleza. Essa expansão só veio a se concretizar na década de 1960-1970, com a construção da ponte, que compunha a av. Perimetral, proposta pelo plano Hélio Modesto e executada durante a gestão do Prefeito Cordeiro Neto (1959-1963). Rompia-se, assim, a barreira física que impedia o crescimento da Cidade naquela direção.

O Parque Ecológico do Cocó, formado pelo rio e seu leito, também constitui área de relevante interesse. Trata-se do principal parque urbano da Cidade, um dos maiores da América do Sul, tendo sido implantado na década de 1980-199025. Abrange parte considerável do setor sudeste em estudo (ver figura 4.59).

\footnotetext{
${ }^{23}$ A Bacia Hidrográfica do rio Cocó é a mais extensa de Fortaleza, cobrindo 215,9 km², o que corresponde a aproximadamente $60 \%$ da área municipal. O rio tem 29 afluentes na margem direita e 16 na esquerda, além de abranger 15 açudes e 36 lagoas (COGERH, 2010).

${ }^{24}$ Dos $45 \mathrm{~km}$ de curso do rio, $24 \mathrm{~km}$ percorrem o Município de Fortaleza.

${ }^{25}$ O Governo estadual, por intermédio do DECRETO N ${ }^{\circ} 20.253$, de 05 de setembro de 1989, declarou de interesse social para fins de desapropriação as áreas de terra que compreendidas no contorno do Projeto do Parque Ecológico do Cocó e, pelo do DECRETO № 22.587, 08 de Junho de 1993, declarou de interesse social, para fins de desapropriação, as áreas destinadas à ampliação do Parque Ecológico do Cocó. A área do Parque Ecológico do Cocó abrangida pelos decretos compreende o trecho da BR-116 à foz do rio Cocó, localizado no Município de Fortaleza, Estado do Ceará, perfazendo um total de 1.155,2 hectares. (SEMACE-CE, disponível em: http://www.semace.ce.gov.br/2010/12/paque-ecologico-do-rio-coco/).
} 


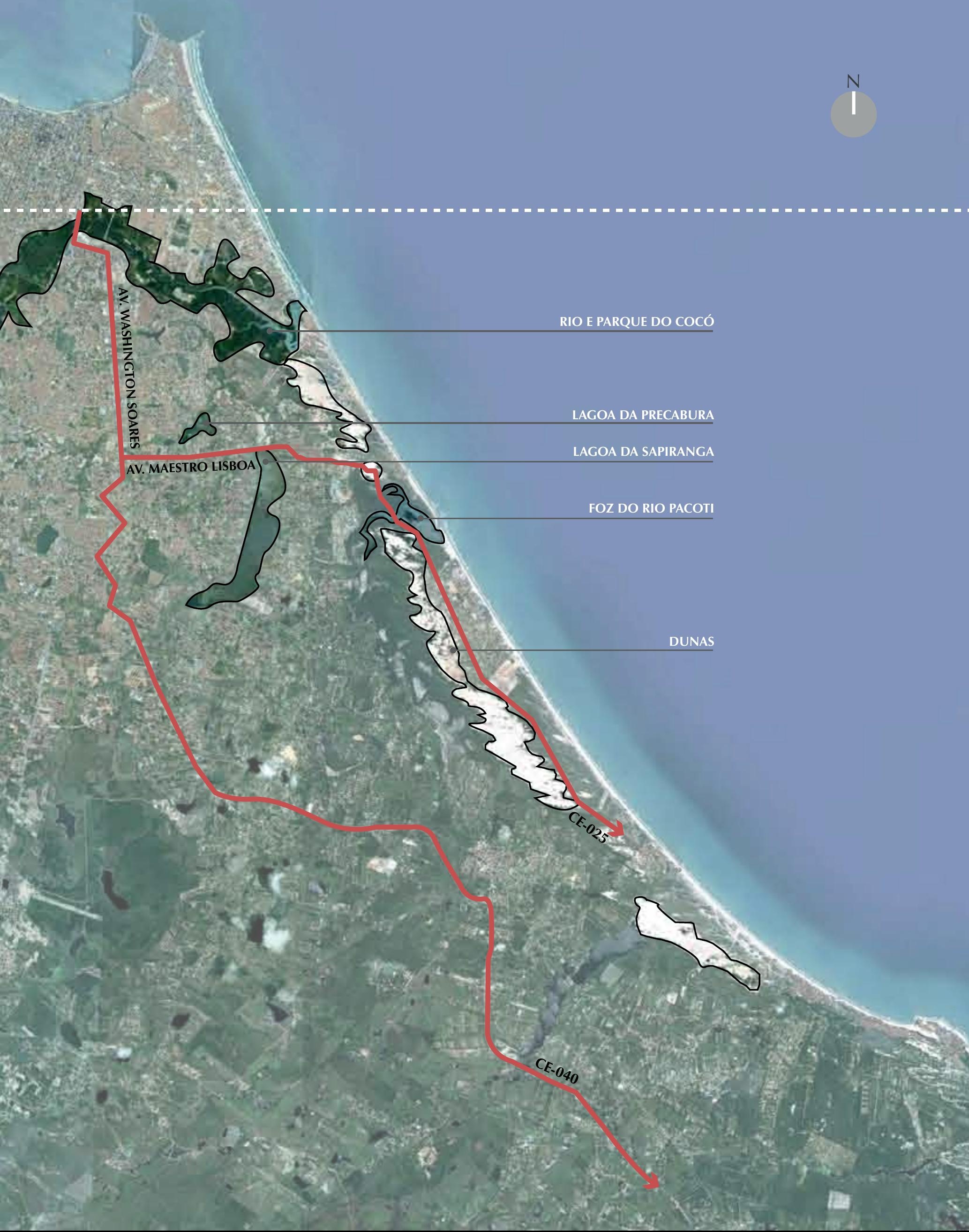

Fig. 4.58 Setor sudeste: recursos naturais

Fonte: Google Earth - elaborado pela autora 
O parque foi concebido com o propósito de proteger e conservar os recursos naturais existentes, "de forma a recuperar e manter o equilíbrio ecológico necessário à preservação da biota terrestre e aquática e propiciar condições para atividades de educação, recreação, turismo ecológico e pesquisa científica". (SEMACE-CE ${ }^{26}$ ). Sua criação também objetivou proporcionar o contato direto da população com o ambiente natural, "envolvendo-a nas suas ações de preservação e controle, despertando o espírito conservacionista das populações ribeirinhas" (IDEM).

De acordo com o site da SEMACE-CE, o Parque Ecológico do Cocó possui áreas disponíveis para atividades de lazer, esporte e cultura, com anfiteatro, quadras esportivas, pistas para caminhadas, dois parques infantis; promoção de shows e eventos, competições esportivas, trilhas ecológicas e Educação Ambiental. É, portanto, um espaço bastante utilizado pela população.

O manguezal do rio Cocó, em seus trechos preservados, forma uma mata de mangues bastante rica, onde coexistem várias espécies de moluscos, crustáceos, peixes, répteis, aves e mamíferos, as quais compõem

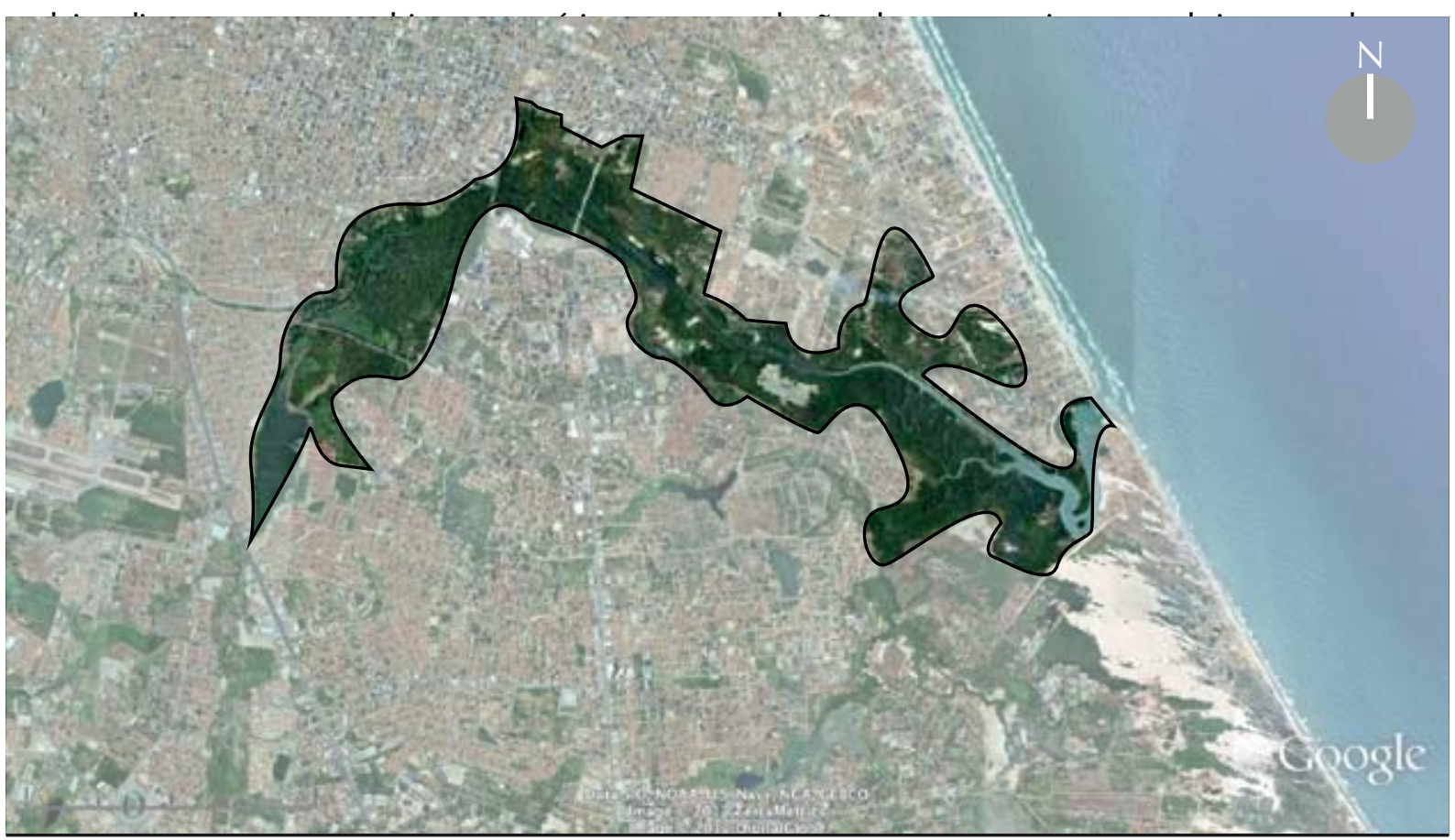

Fig. 4.59 Parque do Cocó

Fonte: Google Earth - elaborado pela autora

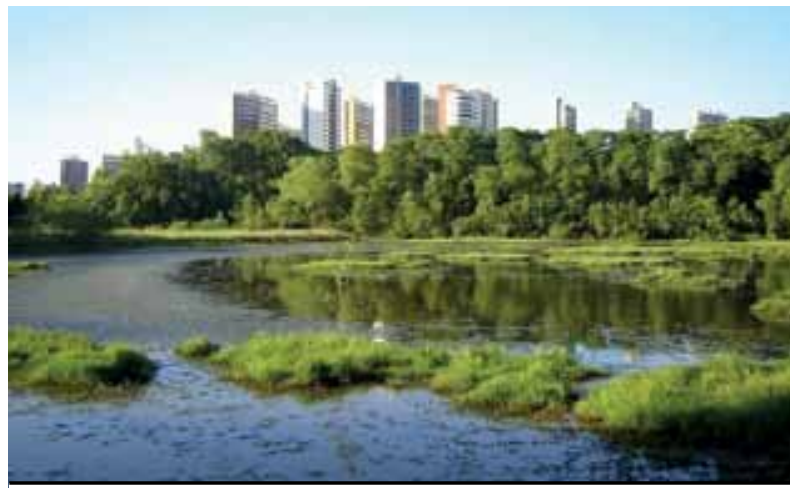

Fig. 4.60 Parque do Cocó

Fonte: http://alunaslindasinformatica2010.blogspot.com

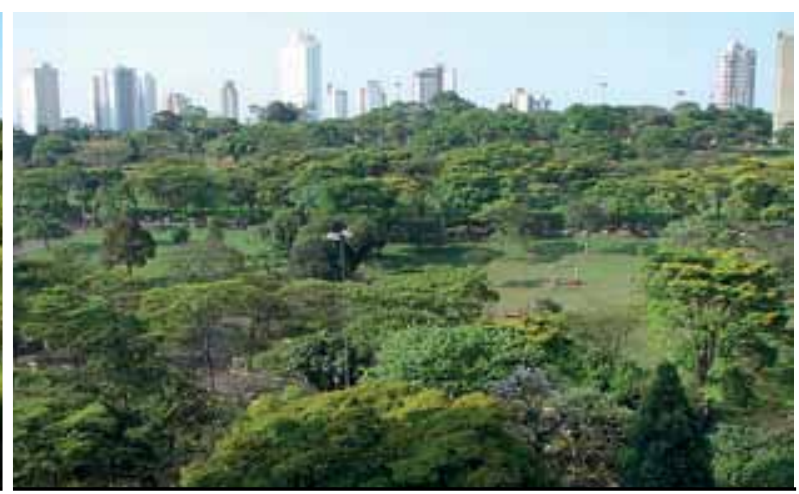

Fig. 4.61 Parque do Cocó

Fonte: http://blogln.ning.com/photo

${ }^{26}$ SEMACE-CE, disponível em: http://www.semace.ce.gov.br/2010/12/paque-ecologico-do-rio-coco/). 
Todo o entorno desse parque acha-se atualmente em franca expansão urbana e valorização imobiliária (ver figuras 4.60 e 4.61). O fato tem provocado debates e polêmicas no âmbito de setores ligados à proteção do meio ambiente, devido ao risco de ameaça a tão relevante recurso ambiental. Avalia-se que o rio (e o parque) e todo o seu ecossistema não têm sido devidamente considerados no processo de desenvolvimento da Metrópole, sendo por vezes canalizado, assoreado ou degradado, em face da progressiva ocupação por edificações nas vizinhanças.

Além disso, por situar-se totalmente dentro do Município de Fortaleza, em região de grande desenvolvimento urbano, os limites do parque estão constantemente sofrendo problemas de poluição, impactos ambientais decorrentes do desmatamento da vegetação de mangue e da degradação do bioma, ocupação em áreas de preservação, consequência de invasões por parte da população de mais baixa renda, que, sem saneamento adequado, dispensam esgotos para o rio.

Afora o rio Cocó e o parque do mesmo nome, outros recursos naturais importantes compõem o setor em estudo, como o rio Pacoti, que conforma a divisa entre os Municípios de Fortaleza e Aquiraz e que, com seus manguezais, forma a APA do rio Pacoti, com 2.914,93 ha; as lagoas da Precabura e da Sapiranga ${ }^{27}$; o cordão de dunas que acompanha o litoral de Aquiraz e toda a vegetação exuberante. Se, por um lado esses elementos constituem magnífico patrimônio ambiental e contribuem para tornar extremamente privilegiada essa área da Metrópole, de outra parte, ultimamente sofrem com problemas de poluição, desmatamento e invasões, decorrentes de processos de urbanização desordenados.

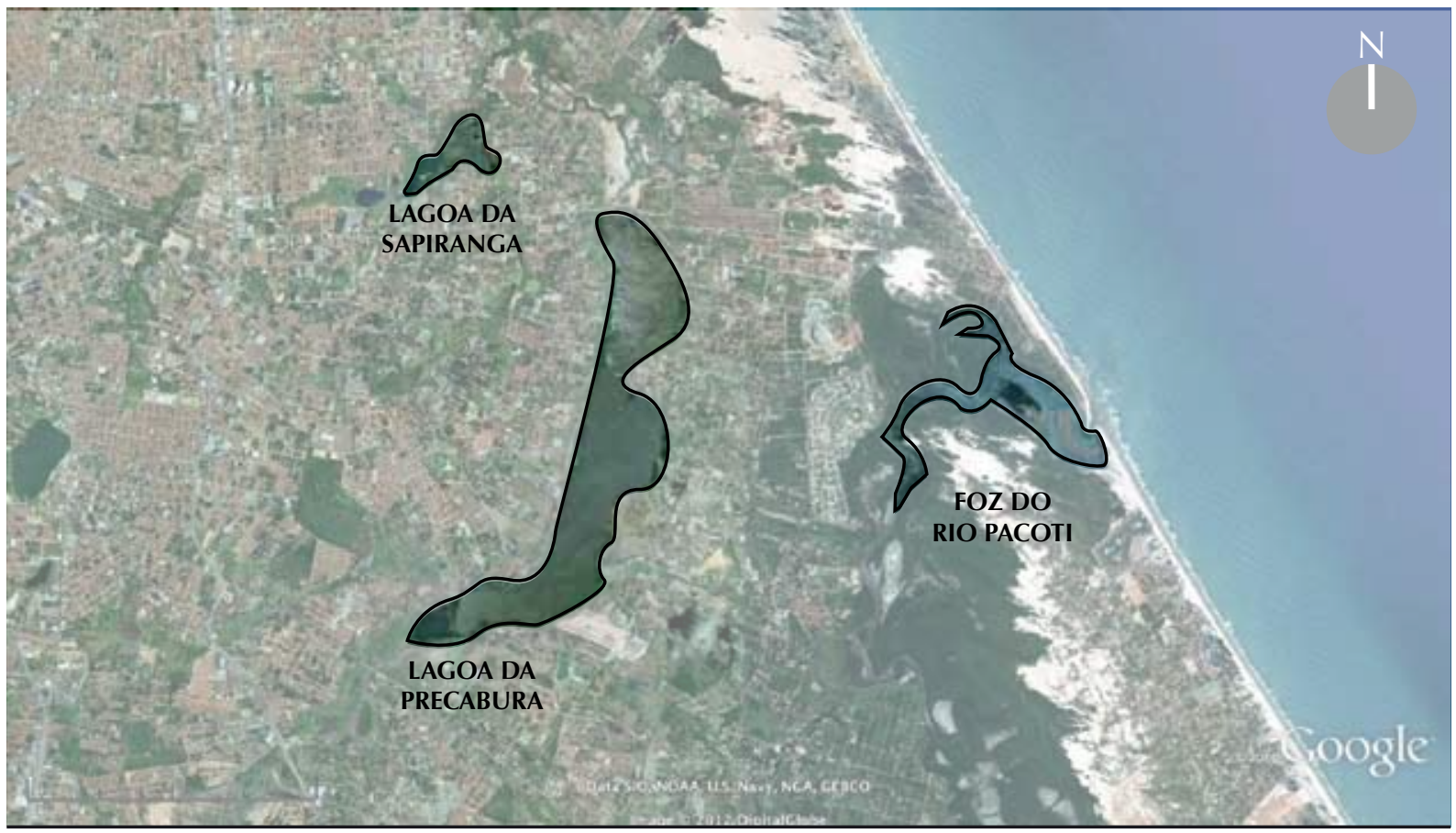

Fig. 4.62 Lagoa da Sapiranga, Lagoa da Precabura e Foz do Rio Pacoti

Fonte: Google Earth - elaborado pela autora

\footnotetext{
${ }^{27}$ Junto à lagoa da Sapiranga, por trás da av. Washington Soares, está localizada a Reserva Ecológica de Sapiranga, mantida pela Fundação Maria Nilva Alves. Em 58,76 ha, a reserva abriga um trecho do rio Coaçu (afluente do rio Cocó), o sangradouro da lagoa da Precabura e uma parte da lagoa. No manguezal, existem bercários de guaiamuns, uçás e aratus.
} 


\subsection{UMA ÁREA DE CENTRALIDADE EM EXPANSÃO}

Além de constituir zona residencial preferencial das classes de renda média alta, parte do setor sudeste, em sua porção inicial28, tem-se transformado em localização privilegiada de sedes de empresas ${ }^{29}$, edifícios de escritórios, equipamentos culturais, faculdades e escolas superiores, cursos de idiomas, agências bancárias, clínicas, serviços avançados diversos ${ }^{30}$, shoppings centers e outros estabelecimentos comerciais, além de abrigar também equipamentos institucionais, conforme visto anteriormente.

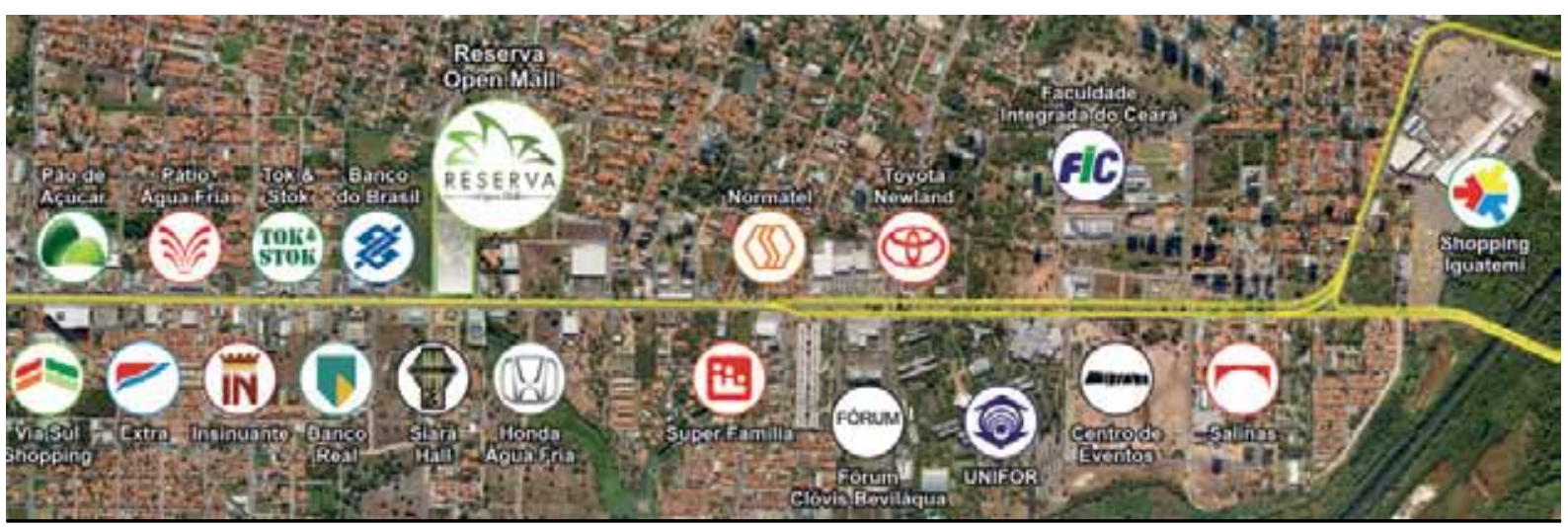

Fig. 4.63 Indicação de equipamentos diversos na Av. W. Soares

Fonte: http://www.reservaopenmall.com.br/loc.html

Essa área tem passa por um dinâmico processo de ocupação, em conseqüência da instalação de múltiplos empreendimentos, patrocinado por variados agentes - públicos e privados - transformando-se numa centralidade de alcance metropolitano.

À semelhança da Marginal do rio Pinheiros, em São Paulo, da av. das Américas, na Barra da Tijuca (RJ), da av. Paralela, em Salvador e do chamado eixo-sul de Belo Horizonte ${ }^{31}$, a região da av. Washington Soares constitui atualmente uma nova área de centralidade com características de terciário avançado ${ }^{32}$, voltada para grande parte da população que habita as zonas leste e sudeste da Capital e os Municípios do Eusébio e de Aquiraz.

Assim como em São Paulo, Rio de Janeiro, Salvador e Belo Horizonte - e outras cidades no País - em Fortaleza também a expansão dos bairros "nobres" foi acompanhada pelo deslocamento de toda uma gama de comércio, serviços e instituições públicas e privadas.

\footnotetext{
${ }^{28}$ A atividade terciária desenvolve-se ao longo da av. Washington Soares, desde o Shopping Iguatemi até a Casa José de Alencar, nas proximidades da av. Ministro José Américo, de acesso ao Centro Administrativo do Cambeba.

${ }^{29}$ Grandes empresas decidiram-se por esta nova localização, dotada de infraestrutura eficiente. O Grupo Jereissati e o Grupo BS PAR, dois dos maiores grupos empresariais locais, já se instalaram em edifícios nas imediações do Shopping Iguatemi.

${ }^{30}$ Entre os chamados serviços avançados, ou especializados, incluem-se: consultoria empresarial, assessoria jurídica, estabelecimentos de ensino superior, serviços biomédicos e químicos, empresas de informática, laboratórios, agências de propaganda e publicidade, etc.

${ }^{31}$ A área em estudo guarda semelhanças com a região conhecida como Seis Pistas, situada na divisa com Belo Horizonte, nas proximidades do $\mathrm{BH}$-Shopping, e que vem configurando uma nova e expressiva centralidade, contando já com dois mini-shoppings, faculdades, centro de convenções, hotéis, farmácias, clubes, escolas, padarias, bares e restaurantes, além de diversos empreendimentos em fase de projeto e execução (ANDRADE \& MENDONÇA, 2010, p.174).

${ }^{32} \mathrm{~A}$ instalação de equipamentos de comércio e serviços avançados na av. Washington Soares, situados já nas proximidades dos limites metropolitanos, remete à ideia de edge city proposta por Garreau (1991), espaços considerados por ele como núcleos do novo processo de urbanização e que se caracterizam pela presença de grandes áreas destinadas a edifícios de escritórios, serviços e lojas varejistas. Além de, segundo o autor, não parecer com a cidade de pelo menos 30 anos atrás .
} 
Quanto mais essas camadas [de alta renda] se concentram em determinada região da cidade, mais elas procuram trazer para essa mesma região importantes equipamentos urbanos. Quanto mais o conseguem, mais essa região se torna vantajosa para aquelas camadas e mais difícil se torna, para elas, abandonar essa região (VILLAÇA, 1998, p.319).

A transformação dessa área, ou parte dela, em um novo centro, configura-se como uma questão urbana a ser mais bem analisada, em decorrência da sua importância para o processo de expansão e reestruturação da Metrópole, na medida em que as transformações ali ocorridas redefinem a relação desse espaço com bairros contíguos e mesmo com municípios vizinhos, dado o seu alcance metropolitano.

A emergência de novas áreas de centralidade em Fortaleza, como a que se forma na região, relaciona-se às transformações recentes pelas quais passa a Metrópole cearense, as quais, por sua vez, se inserem nas dinâmicas espaciais que caracterizam a metrópole contemporânea, em consequência das mudanças estruturais de caráter econômico e social ocorridas desde as últimas décadas. Como assinala Font (1999), as novas tendências de localização das atividades resultam do "comportamento" metropolitano atual.

Isso implica considerar as novas formas contemporâneas, com as quais as atividades econômicas, sobretudo o comércio e os serviços, se relacionam, resultando numa desconcentração espacial, em relação ao conjunto da Cidade, ao mesmo tempo em que formam uma concentração, no referido setor. O surgimento desse padrão produtivo "está criando uma dinâmica no território metropolitano que tende a diluir a forma urbana convencional e estabelecer uma nova ordem urbana que nasce da dispersão das atividades no território". (MEYER, GROSTEIN \& BIDERMAN 2004, p.162).

De acordo com De Mattos (2004), uma das mais importantes consequências do processo simultâneo de expansão territorial e dispersão do setor produtivo que afetou as principais metrópoles latino-americanas durante as ultimas décadas tem sido

[...] o significativo aumento do número de funções e atividades que até então tinham estado localizadas em seus centros tradicionais, que se deslocam para novos locais do território metropolitano. Esse processo afirma a transição de uma estrutura articulada em torno de um centro principal para uma organização policêntrica e provoca o declínio do papel e da importância desses centros tradicionais, em prol de novas centralidades que transformam radicalmente o funcionamento da urbe (2004, p.182).

A expansão da metrópole (juntamente com o incremento das atividades terciárias ${ }^{33}$ ), portanto, dotou os espaços de maior complexidade, ocasionando a fragmentação da centralidade, processo que ocorre de forma diferenciada em várias metrópoles brasileiras.

O fenômeno do surgimento das chamadas novas áreas de centralidade ${ }^{34}$ abrange assim inovações relacionadas com a metrópole polinucleada, num contexto de novas infraestruturas de transporte,

\footnotetext{
${ }^{33}$ Esse incremento das atividades terciárias (conhecido como o processo recente de terciarização da Metrópole) trouxe como consequência a dispersão das modernas atividades de comércio e serviço.

34 "Neste redimensionamento das funções urbanas, surgem as chamadas novas áreas de centralidade, onde se concentram, na maioria das vezes, um conglomerado de atividades terciárias avançadas, além de outras funções urbanas. Surge, assim, uma formação metropolitana com vários centros, isto é, uma estrutura polinucleada (ou policêntrica, como preferem alguns autores)" (DIÓGENES, 2005, p.157).
} 
comunicações e de informática, novas modalidades de economia e novos padrões de consumo, além das possibilidades oferecidas pelo transporte individual.

Embora o processo de descentralização e do aparecimento de novas áreas de centralidade sejam, de modo geral, comuns às aglomerações urbanas contemporâneas, esses fenômenos, de fato, não ocorrem da mesma maneira nas diferentes regiões do mundo.

É preciso, pois, assinalar, que a natureza deste espaços assume conotações diversas, já que as determinações globais não incidem da mesma forma, nem simultaneamente, em todos os lugares. As especificidades locais determinam diferentes reações, o que implica, também, distintos arranjos da relação com o centro principal e com outras áreas da Cidade.

Tal como ocorreu em outras metrópoles, no mundo e no Brasil, a Capital cearense igualmente passou por um processo de descentralização e redefinição de centralidades, tanto como forma de adaptar-se à nova ordem econômica global, apesar de seu caráter de Metrópole periférica, como em decorrência do deslocamento de determinadas funções para outros locais, funções essas que antes se restringiam ao centro principal. Algumas áreas na Cidade podem, assim, ser identificadas como polos terciários, abrigando atividades de comércio e serviços, como a que se desenvolve ao longo da av. Washington Soares, desde a década de 1980-1990.

A atividade terciária aí verificada denota atributos peculiares, distintos de outras centralidades existentes em Fortaleza, como a Aldeota, por exemplo, onde existe uma concentração expressiva em torno de algumas quadras, que formam um quadrilátero definido e onde há grande escassez de estacionamentos. Como já era um bairro residencial consolidado, os estabelecimentos comerciais na Aldeota ocupam antigas residências ou novas edificações, construídos em lugar de residências demolidas. A centralidade formada no sudeste, diferentemente, ocorre de forma linear, ao longo da av. Washington Soares, com algumas ramificações nas avenidas Oliveira Paiva e Edilson Brasil Soares, que cortam a via principal.

Apenas na região chamada "Seis Bocas", na confluência das avenidas Washington Soares e Oliveira Paiva e rua Crisanto Moreira da Rocha, observa-se maior concentração das atividades de comércio e serviços, que se distribuem em torno do cruzamento, formando uma espécie de polo, com grande incidência de bares e restaurantes. Essa concentração foi reforçada recentemente com a instalação do Shopping Via Sul.

Outro aspecto a destacar é a ocupação diferenciada, junto à avenida. Como havia (e ainda há, relativamente) grande disponibilidade de área, os estabelecimentos em geral se localizam em grandes lotes, com oferta de vastos estacionamentos e são em maioria edificações com dimensões avantajadas, também chamadas de "contêineres". São, de modo geral, lojas de móveis, de materiais de construção, concessionárias de veículos, supermercados, casas de shows, etc. (ver figuras 4.32 e 4.36).

Dois grandes shoppings centers já fazem parte desse centro, ambos na avenida: o Shopping Iguatemi (inaugurado em 1982) e o Shopping Via Sul, inaugurado em 2010, os quais atraem número considerável de pessoas. Atualmente encontra-se em construção um outro, o Shopping Reserva Open Mall, a ser inaugurado em 2012. Diversos outros, de menores dimensões e formatos diferenciados são vistos ao longo da via. 
Observa-se uma demanda crescente por equipamentos educacionais na área, o que faz surgirem,

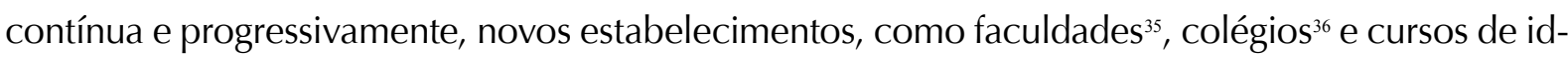
iomas $^{37}$. O fato evidencia uma expansão, marcada por ocupação recente e aumento populacional.

Da mesma forma, surgem a cada dia novos restaurantes, clínicas de estética, de Odontologia, agências bancárias, escritórios jurídicos, lojas de informática, academias de ginástica, imobiliárias, bufês, etc. Em pesquisa realizada no local, os proprietários de estabelecimentos e comerciantes da região garantem que é certo o retorno financeiro, dado o volume de consumidores, que cresce dia a dia.

Esses equipamentos, a exemplo dos estabelecimentos educacionais, são também, em sua maioria, filiais de outros, já consolidados em outras áreas de Fortaleza, instalados aí para atender à população residente na área e nas proximidades.

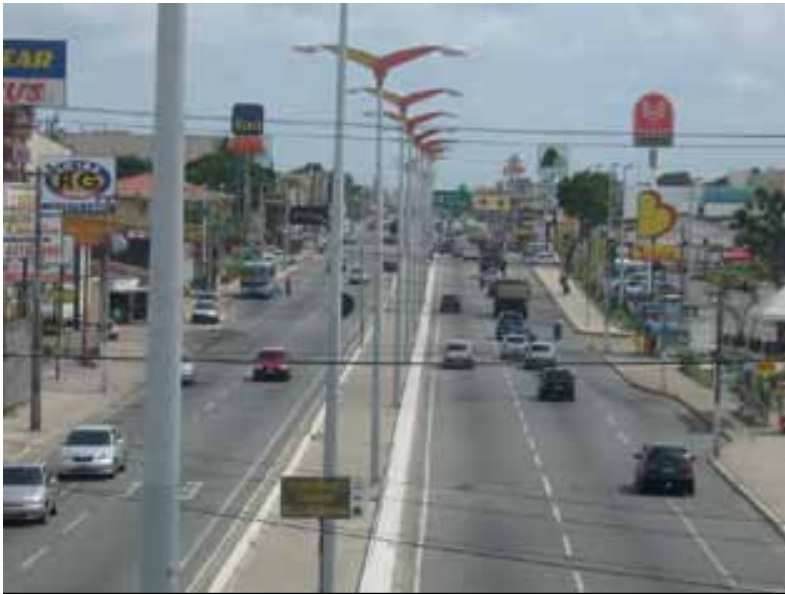

Fig. 4.64 Av. Washington Soares

Fonte: http://www.skyscrapercity.com

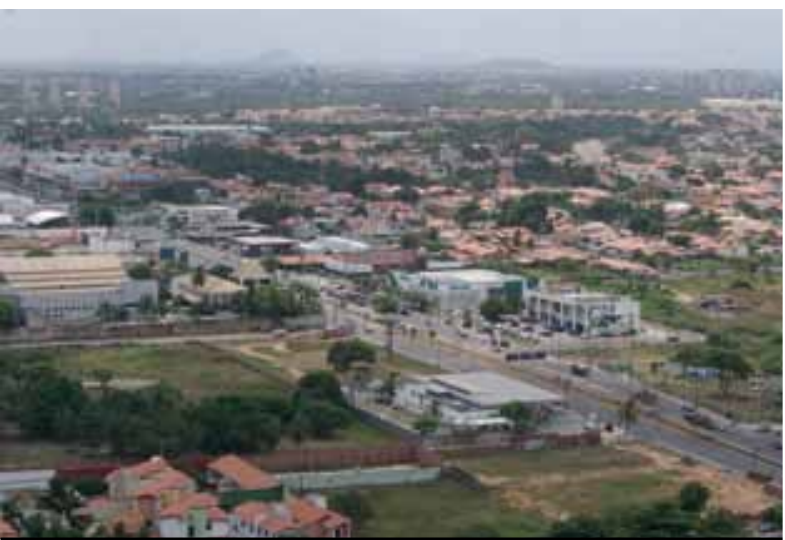

Fig. 4.66 Av. Washington Soares

Fonte: Rodrigo Ponce de Leon

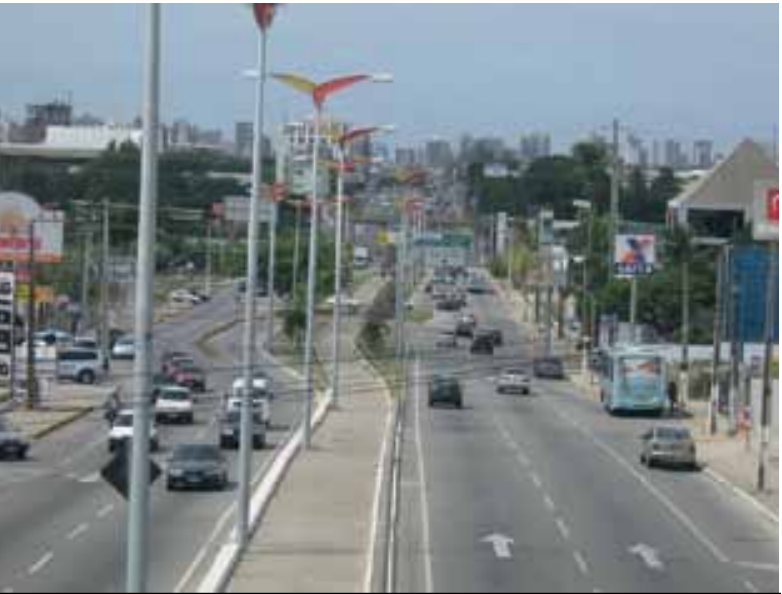

Fig. 4.65 Av. Washington Soares

Fonte: http://www.skyscrapercity.com

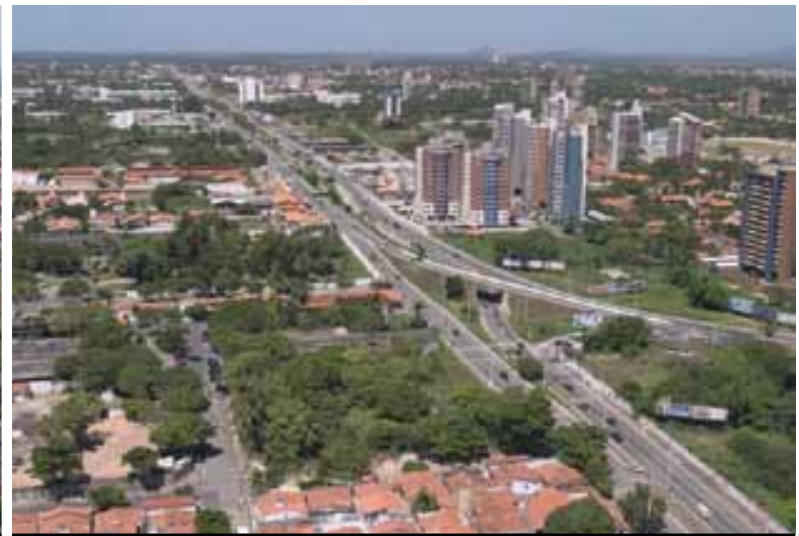

Fig. 4.67 Av. Washington Soares

Fonte: http://www.skyscrapercity.com/

\footnotetext{
${ }^{35}$ Unifor, FA7, Estácio/FIC.

${ }^{36}$ Colégio Ari de Sá, Colégio Farias Brito, Colégio Irmã Maria Montenegro, Colégio Christus.

${ }^{37}$ Fisk, Wise Up, Yazigi, Wisdom, CCL, MRH Idiomas, Hilpro Idiomas e Aliança Francesa (com previsão de instalar-se em 2012).
} 


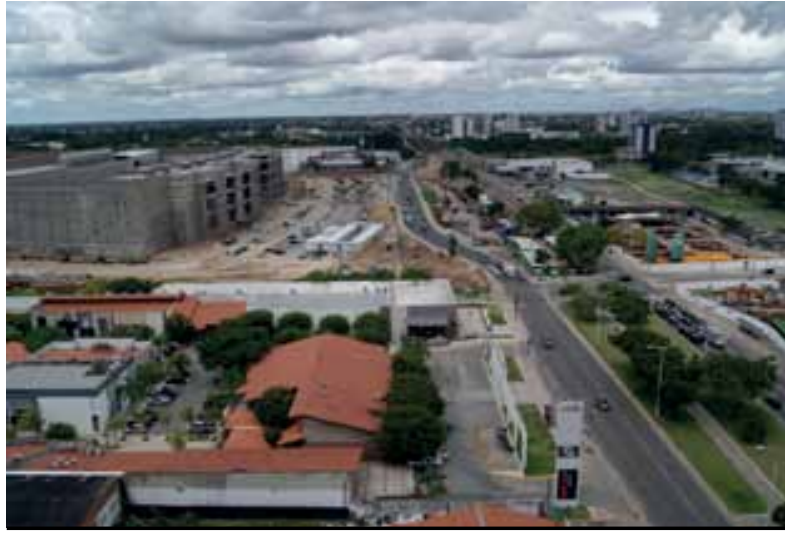

Fig. 4.68 Av. Washington Soares Fonte: acervo autora

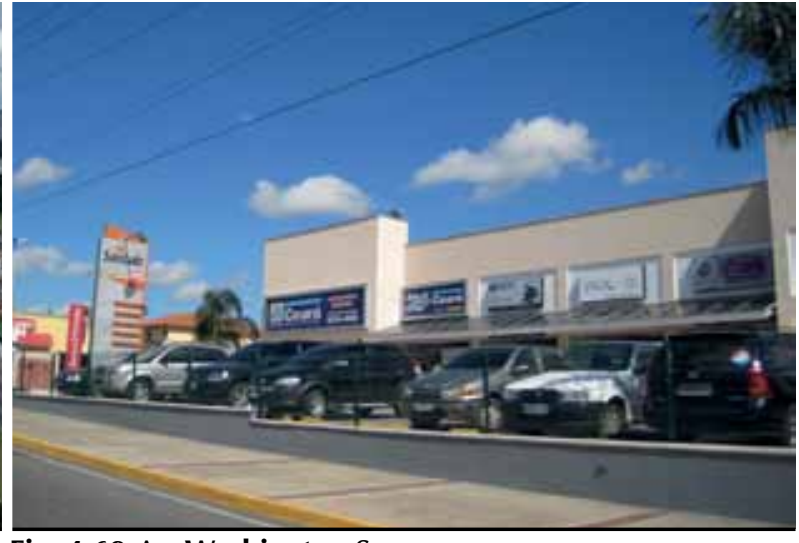

Fig. 4.69 Av. Washington Soares

Fonte: acervo autora

Interessante é notar que os usuários desse novo "centro" são, em grande parte, habitantes não só das vizinhanças, mas também da periferia metropolitana, dos diversos condomínios localizados nos Municípios de Eusébio e Aquiraz, de estreita relação com a Capital. Distando cerca de 10 quilômetros desses municípios, o "centro" da av. Washington Soares é área preferencial de consumo e lazer, além de constituir, muitas vezes, também local de trabalho, negócios e estudos. Tratase, portanto, de uma centralidade de amplitude metropolitana, estabelecendo estreita interação com a área de expansão residencial dos municípios vizinhos.

Outro equipamento está em vias de ser inaugurado e, por seu porte, dimensões e importância, deverá ter impacto decisivo no desenvolvimento da área, incrementando a centralidade aí verificada. Trata-se do novo Centro de Eventos do Ceará, cuja localização procede de decisão do Governo estadual.

Inserido nas estratégias de globalização competitiva do Ceará, como o incentivo à atração de grandes eventos e exposições e fomentar, assim, o turismo de negócios do Estado, o novo Centro está sendo construído numa área de 17,3 ha. Ao todo, são $152.700 \mathrm{~m}^{2}$ de área edificada, dos quais dois blocos com $73.000 \mathrm{~m}^{2}$ destinados a exposições, praça de convivência com equipamentos gastronômicos e espaços para lazer e entretenimento, heliponto, bem como local para carga e descarga entre os blocos do pavilhão e estacionamento para 3.200 veículos. São previstos, ainda, vestiários, refeitórios, ambulatórios, sanitários, salas para produção de eventos, administração, segurança, brigada de incêndio, Juizado de Menores, vigilância sanitária e ouvidoria.

A instalação do equipamento nessa região foi bastante discutida e contestada, já que se trata de área onde ocorrem constantes congestionamentos de trânsito, sobretudo por situar-se junto à Unifor $^{38}$ - Universidade de Fortaleza, expressivo polo gerador de tráfego. O Governo estadual justifica a localização como decorrente da disponibilidade de terreno e também por tratar-se de área próxima dos principais pontos de interesse da Cidade. Para viabilizar e agilizar sua acessibilidade, entretanto, foi prevista ampla reformulação viária, com a construção de quatro túneis, um viaduto e uma nova ponte sobre o rio Cocó, obras que se encontram em execução ${ }^{39}$.

\footnotetext{
${ }^{38}$ A Unifor, instalada num terreno de $550.000 \mathrm{~m}^{2}$ e ocupando área de $135.300 \mathrm{~m}^{2}$, possui, no ano de 2012, aproximadamente 23.000 alunos de graduação e 2.500 de pós-graduação, além de contar com 2.300 funcionários.

${ }^{39}$ A primeira parte da obra relativa aos acessos viários (túneis) foi orçada em R \$ 76.926.401,00 e a previsão é de que essa etapa esteja pronta no final de outubro de 2012 (Jornal O Povo 24-06-2011).
} 


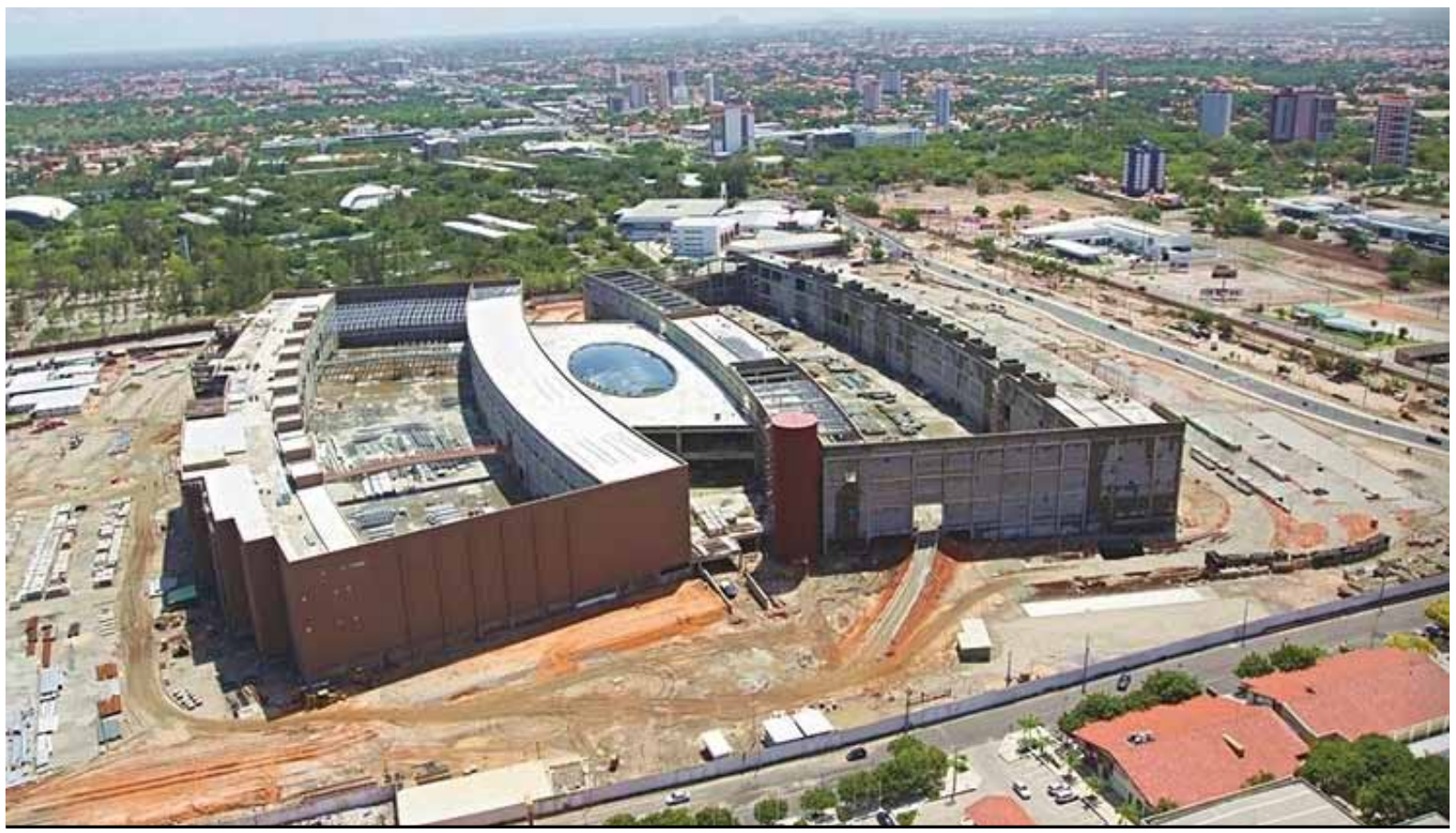

Fig. 4.70 Centro de Eventos do Ceará

Fonte: http://www.curvaslivres.com/?p=1230

O novo Centro de Eventos foi orçado em $\mathrm{R} \$ 328,5$ milhões e a expectativa é de que esteja totalmente concluído até meados de 2012. Segundo informações de setores responsáveis, deverá ser o segundo maior espaço para realização de eventos da América Latina, com capacidade para abrigar até 30 mil pessoas em evento único.

Desde que foi decidida a localização, já se percebem mudanças nas imediações, como a valorização dos terrenos e a procura pela instalação de equipamentos ${ }^{40}$ de apoio ao novo Centro, tais como restaurantes e hotéis ${ }^{41}$, além do lançamento de novas unidades habitacionais. Registra-se, portanto, um incremento visível da dinâmica imobiliária.

O Centro de Eventos, considerado empreendimento importante e de grande vulto, favorece assim a produção de uma imagem "promissora" da área, com relação a futuros investimentos. A inserção deste equipamento ilustra a assertiva de De Mattos (2004, p.185), quando afirma que: "em particular, certos equipamentos arquitetônicos provocam enorme impacto e podem ser considerados imagens representativas das transformações que caracterizam uma globalyzing city."

De acordo com as análises empreendidas, parece não restar dúvidas de que essa área constitui, de fato, uma centralidade. Diversos atributos e dinâmicas podem confirmar a afirmação, aliás já amplamente mencionados, tais como: o movimento das vias, a grande concentração de comércio e serviços; a circulação contínua de consumidores e usuários, automóveis, mercadorias e informações; a verticalização crescente; a "imagem" de centro, representada pelo porte das edificações; o número de viagens empreendidas para seus domínios, a sua autonomia com relação ao Centro, etc.

\footnotetext{
${ }^{40}$ Segundo matéria veiculada na Coluna Vertical S/A do Jornal O Povo (06-03-2012), A TAM Viagens acaba de inaugurar mais uma loja em Fortaleza. Fica no Reserva Open Mall, empreendimento comercial recém-construído na av. Washington Soares. Roberto Beduíno, franqueado da marca no Ceará, disse que aposta no crescimento da nova loja em função do crescimento do bairro e do novo Centro de Eventos do Ceará, que fica nas imediações .

${ }^{41}$ Não existem hotéis nessa área da cidade. Aliás, a quase totalidade dos hotéis de Fortaleza está na orla marítima, voltados, que são, para a atividade turística litorânea. Entretanto, segundo matéria veiculada no jornal O Povo, de 18-03-2012, "há pelo menos cinco projetos de hotéis para a área no entorno do Centro de Eventos a ser inaugurado em junho na Água Fria."
} 
Pela sua forma de desenvolvimento, essa centralidade parece enquadrar-se na categoria assinalada pela arquiteta Andréa Tourinho (2004) de nova área de centralidade, em seu estudo ${ }^{42}$ Do centro aos centros - bases teórico-concentuais para o estudo da centralidade de São Paulo, uma vez que obedece aos critérios mencionados pela autora para designar preferencialmente os espaços surgidos recentemente (a partir da década de 1980-1990), induzidos ou criados na maioria das vezes pela iniciativa privada, em conjunto com investimentos públicos.

No seu entender, essas centralidades podem resultar de operações de revitalização dentro da área central, ou se situar em áreas isoladas do centro principal, possuindo quase sempre caráter setorial ou especializado (terciário qualificado), não favorecendo, portanto, a formação de espaços cívicos e públicos ${ }^{43}$.

Ainda de acordo com a autora, as novas áreas de centralidade

[...] são áreas de caráter fragmentado, fora do centro expandido, surgidas depois de 1980, e que possuem nova imagem global, alto padrão comercial e de serviços, formas de lazer elitizadas, etc. Surgiram em decorrência do processo de fragmentação da cidade, "dentro de uma Metrópole estendida, apoiada pela consolidação de uma 'indústria imobiliária', dominada por poderosos construtores que conseguem apoio nas instâncias oficiais" (TOURINHO, 2004, p.365).

Vale ressaltar que esse fenômeno emerge num contexto de mudanças verificado no padrão produtivo industrial e no setor terciário, a partir da década de 1980-1990. O capital financeiro, que prevalece no âmbito do capitalismo contemporâneo, associado aos interesses imobiliários, tornase então capaz de produzir centralidades, mediante a instalação de equipamentos de grande porte e ampla abrangência, de modo a gerar localizações privilegiadas ${ }^{44}$, fato que não ocorria antes, quando a cidade era formada por um sistema conformado por um centro principal e subcentros, os quais atuavam de forma complementar (TOURINHO, 2004).

Esses novos centros surgem muitas vezes, também, em decorrência da saturação de determinadas áreas da Cidade (quando já não há praticamente mais espaços para construir, como ocorre na Aldeota) ou como novas formas de investimento. "Nesses momentos, o capital - isto é, as incorporadoras, as administradoras, as construtoras, a indústria imobiliária toda - sai à procura de novos enclaves para colonizar". (TOURINHO, 2004, p.384). A autora refere-se ao que de fato já ocorre na cidade de S. Paulo, com as novas frentes imobiliárias das avenidas Faria Lima, Juscelino Kubitschek, Berrini e Marginal Pinheiros, áreas consideradas como concentração espacial do terciário superior.

\footnotetext{
${ }^{42}$ Com o objetivo de esclarecer os diferentes e novos termos e conceitos que dizem respeito às centralidades, ou formas de centralidade, que têm sido utilizados ultimamente, Andréa Tourinho, em sua tese, busca defini-los, procurando identificar, no contexto urbano da São Paulo contemporânea, partes distintas da cidade que correspondem a cada um desses conceitos. Essas áreas também correspondem a períodos diferentes de formação e consolidação, assumindo cada uma delas características diversas.

${ }^{43}$ Esse tipo de centralidade difere da centralidade tradicional onde se concentram, além do comércio e dos serviços, as funções públicas e os grandes espaços públicos. As novas centralidades são esvaziadas dessa dimensão pública, nelas preponderando os espaços de consumo, como os shopping centers (ANDRADE \& MENDONÇA, 2010, p.186). ${ }^{44}$ A flexibilização do capital na procura por lucros rápidos dirige parte de seus ativos à especulação imobiliária com a conseqüente transformação do solo urbano, dos usos urbanos e dos bens construídos em mercadoria de troca. Essa situação do capital e do novo mercado imobiliário que visa a troca e não o uso do patrimônio construído inicia, a partir dos anos 80, um processo irreversível de fragmentação da Metrópole na procura de melhores situações de investimento por parte do investidor privado (bancos, incorporadores, imobiliárias, empreiteiros, investidores financeiros) e/ou público (bancos, fundos de pensão, sindicatos, empresas de infra-estrutura) (TOURINHO, 2004, p.373).
} 
O arquiteto Eduardo Nobre ${ }^{45}$, em sua tese de doutorado Expansão terciária e novas centralidades: o caso da Marginal Pinheiros em São Paulo (2000), estuda a formação de uma nova centralidade metropolitana na região citada, apoiada na expansão do mercado imobiliário do setor terciário:

A partir de meados da década de 90, a região consolidou-se como a primeira área de investimentos imobiliários do setor de negócios da cidade, atraídos pela indução dos empreendimentos existentes. Foi justamente a partir dessa época que uma série de mega-empreendimentos começou a ser feito na região em terrenos adjacentes à avenida das Nações Unidas. (...) a ação dos empreendedores transformou essa região da Marginal, de um subúrbio industrial de classe média-baixa no mais novo centro de negócios da cidade, suplantando em área a região da Paulista, até então o segundo pólo depois do centro (NOBRE, 2000, p.12).

Essas áreas são muitas vezes também chamadas simplesmente de novas centralidades ${ }^{46}$. Esse conceito é definido por Meyer (apud TOURINHO, 2004, p.389) como "novos pólos geograficamente distribuídos pelo território metropolitano, cumprindo sobretudo funções ligadas ao setor de serviços, antes concentrados no Centro, que se organizam, seja para atender a um legítimo desenvolvimento das funções urbanas ou apenas para responder a interesses imobiliários".

Trata-se de uma nova realidade urbana, quase sempre formando redutos imobiliários (ou especulativos), já que possuem alta rentabilidade no mercado imobiliário local, incentivando unicamente sua relação com a parte rica da cidade.

São também característicos dessas áreas os chamados megaprojetos, ou mega-empreendimentos, em geral construídos sem qualquer relação com o tecido urbano, completamente isolados da cidade. Essas edificações se configuram como uma espécie de "contêineres" arquitetônicos, totalmente indiferentes à circunvizinhança.

O conceito de novas áreas de centralidade, enfim, de acordo com as definições há pouco referidas, abrange áreas ligadas ao "setor terciário moderno" (serviços, comércio, setor financeiro), caracterizadas quase sempre por operações originadas de ações do setor público e/ou privado, formando enclaves especulativos na cidade. "Essas áreas têm como particularidade determinante a especialização e a falta de integração com o restante da cidade, além de não possuírem símbolos nem caráter cívico, que as identifiquem como verdadeiro Centro" (DIÓGENES, 2005, p.168).

A centralidade em estudo, verificada nessa porção da Metrópole, parece enquadrar-se, em certa medida, como uma "nova área de centralidade", de acordo com os conceitos e definições expostas, uma vez que manifesta características e atributos relacionados a essas áreas, tais como: surgiu após 1980, está situada fora do chamado "centro expandido", resulta do processo de fragmentação da Cidade e de fortes investimentos públicos e do setor privado; possui uma imagem "global" e um padrão superior de comércio e serviços, com a inserção de megaempreendimentos e constitui área altamente valorizada, relacionada com a parte mais rica da Metrópole.

\footnotetext{
${ }^{45}$ Nobre, em sua tese, define as novas centralidades como grandes complexos imobiliários que passaram a representar espacialidades pós-modernas .

${ }^{46}$ No contexto internacional, algumas áreas são citadas como novas centralidades urbanas, como nos casos do Inner Harbor, em Baltimore, Battery Park, em N. York, Docklands em Londres, La Défense, em Paris e a Vila Olímpica, em Barcelona. Algumas delas são alvo de requalificação urbana, surgindo em zonas antes consideradas decadentes. Todas elas, porém, apresentam contextos e características bem distintas da centralidade em estudo.
} 
Por outro lado, demonstra peculiaridades que a distinguem dos padrões comuns a outras centralidades surgidas no País. Nesse sentido, algumas questões consideradas relevantes, inerentes a essa área podem ser enumeradas, as quais, acredita-se, qualificam e reforçam a seu caráter de "centro", conforme vêm na sequencia.

- Por situar-se em uma Metrópole considerada "periférica", não possui o porte, a aparência, nem as dimensões de áreas de centralidade similares, situadas em outras regiões do País, como a Marginal Pinheiros e av. Berrini, em São Paulo, e a Barra da Tijuca, no Rio de Janeiro; da mesma forma, não demonstra volume considerável de atividades ligadas ao chamado terciário avançado.

- Desenvolve-se de forma linear, ao longo da av. Washington Soares. Trata-se de uma centralidade em que não se percebe interação dos dois lados da via, já que as atividades desenvolvidas ocorrem preferencialmente em função do automóvel particular.

- Abrange equipamentos de porte não ligados à atividade terciária, como uma quantidade significativa de estabelecimentos institucionais e educacionais.

- Situa-se numa avenida que constitui acesso principal ao litoral leste do Estado; o fluxo está, portanto, fortemente relacionado à atividade turística, bastante intensa na Metrópole. Com o incremento do turismo, aumentou a valorização imobiliária da área e dos municípios vizinhos.

- Apresenta uma forma de ocupação do solo diferenciada, geralmente, em lotes grandes, pela ampla disponibilidade de terrenos; a grande oferta de terrenos livres viabilizou a rápida urbanização da área.

- Pelo fato de constituir ocupação recente, não houve, até agora, praticamente substituições de edificações, como ocorre em outras áreas de centralidade em Fortaleza. As edificações são quase todas construídas em terrenos livres.

- Não possui, em toda a sua extensão, à exceção do Parque do Cocó, espaços de convivência para a população, como praças e locais públicos, a não ser aqueles inseridos em restaurantes em shoppings. Não se vislumbram lugares coletivos exteriores que possam servir de elo urbano, que confiram caráter (ou identidade) a uma possível definição de "centro", como pontos de encontro, de reunião. Não possui também elementos simbólicos significativos ou de caráter cívico.

- Surge como um prolongamento - e um complemento - da centralidade da Aldeota, embora não haja continuidade espacial entre os dois centros. Por outro lado, diferentemente da Aldeota, não se relaciona com a decadência do centro principal. As atividades aí desenvolvidas não estavam originalmente no Centro47.

- Manifesta, no padrão e na variedade dos estabelecimentos, à semelhança do centro da Aldeota, o elevado padrão de consumo da população usuária, o que o faz distinguir-se de outros subcentros e áreas de centralidade da Capital.

Outra particularidade dessa área recai no fato de constituir praticamente uma centralidade metropolitana, conforme já ressaltado, por servir também aos habitantes de municípios vizinhos, que mantêm vínculos estreitos com a Capital, mas praticamente não se dirigem a outras áreas da Cidade. O novo centro está, portanto, diretamente ligado aos processos recentes de expansão metropolitana, voltados para a população de mais alta renda.

\footnotetext{
${ }^{47}$ Apenas o Fórum Clóvis Bevilácqua, conforme já mencionado, foi transferido do centro principal.
} 
Cabe destacar, outrossim, na produção dessa centralidade, o fato de que, em geral, a maior parte das intervenções nela realizadas provocou impactos significativos na estruturação urbana. Essa inserção, entretanto, ocorre quase sempre de forma circunstancial, desconexa e fragmentária, sem maiores preocupações com uma localização mais apropriada ou harmoniosa, do ponto de vista da organização e do funcionamento do conjunto da Cidade.

Importa, pois, levar em conta a dinâmica observada na área, a qual, sem dúvida, constitui espaço diferenciado, com aspectos próprios e peculiares, assim como o fato de se tratar de um espaço que está em pleno processo de mudanças e expansão.

\subsection{OS CONDOMÍNIOS FECHADOS NA PERIFERIA METROPOLITANA}

No vetor sudeste de expansão da RMF verifica-se, ainda, uma forma particular de metropolização, mediante tendência que se acentua cada vez mais, desde a última década: o surgimento de condomínios fechados, voltados para classes de média e alta renda, evidenciando um novo padrão de urbanização. Esses condomínios, em sua maioria, localizam-se na área fronteiriça com a Capital, mas já no Município do Eusébio, escolhido como território preferencial desse modo de expansão residencial.

Desde meados da década de 1970-1980, mas principalmente a partir dos anos 1990-2000, observou-se em diversas cidades brasileiras um movimento das classes médias e altas em direção a áreas mais afastadas do núcleo central, por meio do fenômeno dos condomínios fechados, modalidade que tem se disseminado na expansão das cidades brasileiras nos últimos 20 anos, constituindo uma das tendências recentes de produção do espaço metropolitano.

Os condomínios são um novo conceito de moradia, típico da sociedade contemporânea, os quais buscam formas de segregação residencial e caráter de exclusividade social, desde então difundido no País e iniciado em São Paulo, com a criação dos Condomínios Alphaville ${ }^{48}$.

Conforme assinala De Mattos, (2004, p.286), esse tipo de configuração adquire "uma presença ascendente na estrutura, funcionamento e imagem das grandes cidades latino-americanas". É favorecido "pela presença do carro e das novas tecnologias de informação e comunicação e estimulado pelas tendências que se acentuaram nas grandes áreas metropolitanas globalizadas, como a criminalidade, a poluição e os congestionamentos".

Os condomínios horizontais e loteamentos fechados constituem, portanto, um fenômeno urbano recente, que vem se disseminando por todas as metrópoles brasileiras, e tem sido objeto de estudos freqüentes por parte de especialistas que se dedicam ao tema. Nesses estudos, são enfocadas questões associadas sobretudo à acessibilidade urbana, segregação socioespacial, novos modos de vida em escala metropolitana e à regulamentação urbanística de tais empreendimentos. Alguns autores, estudiosos do assunto, buscam caracterizar, de maneiras diversas, esse novo tipo de moradia.

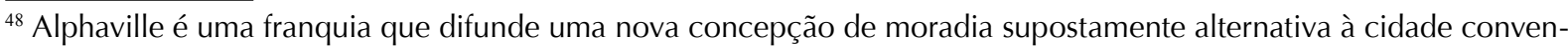
cional, em cujas periferias, ironicamente, os empreendimentos se instalam. (COSTA, H., 2006, p.119). O primeiro condomínio Alphaville surgiu em 1973, num terreno de 500 hectares, comprado em Barueri. Foi o ponto de partida para o surgimento de uma concepção inovadora de empreendimento. Inicialmente concebido como um novo modelo de loteamento voltado para indústrias nãopoluentes, logo se transformou num empreendimento muito mais abrangente. Em 1975, foi criado o Alphaville Residencial, que veio a constituir-se um verdadeiro complexo urbanístico na região metropolitana de São Paulo. A marca Alphaville tornou-se, a partir de então, sinônimo de um estilo de vida diferenciado, que se estendeu a outros estados do Brasil e chegou ao Exterior.
} 
De acordo com Teresa Caldeira (1997), que efetuou minucioso estudo sobre o tema, "o principal instrumento desse novo padrão de segregação espacial é o que chamo de 'enclaves fortificados'. Trata-se de espaços privatizados, fechados e monitorados para residência, consumo, lazer e trabalho".

Segundo Luciana Teixeira de Andrade,

A expressão "condomínio fechado" evoca a idéia de lugar fechado, com segurança privada, separado da parte mais densa da cidade, e destinado aos estratos com maior poder aquisitivo. Entre os cientistas sociais, evoca também a concepção de espaço segregado, de vida entre iguais e de busca de status (ANDRADE, 2006, p.280).

Para Barcelos \& Marmmarella (2007), os condomínios fechados,

[...] em geral são grandes extensões de área nas periferias das aglomerações, urbanizadas privadamente e isoladas do seu entorno, possuem as seguintes características básicas: são conjuntos residenciais de baixo gabarito e densidade; são propriedades privadas para uso coletivo, mas de forma individualizada; dirigem-se, preferencialmente, para as classes mais abastadas devido ao valor do terreno ou da casa pronta; enfatizam o valor do que é privado e restrito, ao mesmo tempo em que desvalorizam o que é público e aberto na cidade; estão fisicamente demarcados por muros, grades, espaços vazios e detalhes arquitetônicos; voltam-se para o interior e não em direção à rua; possuem infra-estrutura básica, serviços, portaria, sistema de área verde e equipamentos de uso comunitário, sistema de vigilância e segurança, impondo regras internas de inclusão e exclusão; e apresentam grande flexibilidade no que diz respeito à localização, podendo se situar praticamente em qualquer lugar, em razão de sua autonomia e independência em relação ao entorno. ${ }^{49}$

Costa, H. (2006, p.101) assinala que essa modalidade de moradia constitui "um produto particular, de boa qualidade urbanística e ambiental, oferecido por um segmento do mercado imobiliário formal: o loteamento exclusivo, afastado das regiões centrais". E acrescenta:

A versão mais conhecida e recentemente bastante estudada de tais formas de produção do espaço é constituída pelos parcelamentos com portarias e restrições de acesso público, geralmente denominado "condomínios fechados", embora de fato raramente constituam condomínios e, em termos legais, dificilmente poderiam se manter fechados da forma como o fazem. (...) cada vez mais são caracterizados pela homogeneização, tanto das características socioeconômicas e ocupacionais da população residente, como da paisagem social, arquitetônica e urbanística resultante (2004, p.101).

Segundo Blakely e Snyder (1995, p.2), apud D’Ottaviano ${ }^{50}$ (2009), condomínios são "áreas residenciais com acesso restrito, onde os espaços públicos são normalmente privatizados".

O tema "condomínios fechados" já constitui, pois, assunto constante de discussão e estudos no campo do Urbanismo (e das Ciências Sociais), sobretudo "no que concerne às questões de privatização dos espaços públicos, auto-segregação das elites e aumento do uso da segurança privada como forma de restringir o acesso a essas áreas" (NASCIMENTO, 2006, p.339).

\footnotetext{
${ }^{49}$ BARCELOS \& MAMMARELLA (2007) O Significado dos Condomínios Fechados no Processo de Segregação Espacial nas Metrópoles. Disponível em: http://www.fee.rs.gov.br/sitefee/download/tds/019.pdf.

${ }^{50}$ D'OTTAVIANO, Camila. Ricos e pobres, cada qual em seu lugar: a desigualdade socio-espacial na Metrópole paulistana (2009), disponível em: http://www.scielo.br/scielo.php?script=sci_arttext\&pid=S0103-497920090001 00008
} 
De acordo com Sposito (2006, p.183), a instalação desses condomínios

[...] propicia o surgimento de áreas descontínuas, marcadas por mudanças drásticas na forma de ocupação do solo sem zonas de transição, criando núcleos isolados separados do entorno por muros. Representam novas formas de ocupação urbana, à medida que rompem com dois princípios fundamentais da cidade: unidade e integração socioespacial.

A expansão dos condomínios fechados constitui, pois, importante fator de um processo que vem transformando os centros urbanos contemporâneos, ao definirem dinâmicas específicas de ocupação dos espaços e por ocorrerem em áreas que mantêm relações complexas com a cidade tradicional.

Destinados às classes mais abastadas e situados em áreas distantes do núcleo central, mas com acessibilidade garantida pelo sistema rodoviário, esses empreendimentos, viabilizados pelo mercado imobiliário - que investe na oferta de um novo "estilo de vida" - conformam assim novas periferias metropolitanas.

Diversas são as motivações buscadas pelos moradores desse tipo de empreendimento, como o desejo de um lugar mais tranquilo para morar, a proximidade da natureza, a possibilidade de cultivar um jardim e criar animais domésticos, melhor qualidade de vida e maior segurança, aspectos bastante explorados pelo mercado imobiliário e divulgados nos incontáveis anúncios, outdoors, folhetos publicitários e internet.

Tal forma de moradia é, pois, difundida como objeto de consumo generalizado por parte da população, cada vez mais respaldado no temor à violência urbana e no desejo de exclusividade e segurança privada.

A mudança nos padrões de habitação está muito associada a um novo "estilo de vida" contemporâneo, que motiva o deslocamento das camadas mais ricas, sensíveis a argumentos estrategicamente explorados pelo mercado imobiliário, como a procura de melhor qualidade de vida e status e, por outro lado, a falta de segurança, a violência e a poluição, próprias da cidade.

De acordo com Reis (2006, p.13), esse processo está também relacionado "à difusão ampla de modos metropolitanos de vida e de consumo, também estes dispersos pela área metropolitana ou sistema de áreas metropolitanas".

Os condomínios horizontais e os loteamentos fechados são indistintamente chamados pela população e pelo mercado imobiliário como condomínios fechados, como forma de enfatizar o caráter de exclusividade desses empreendimentos. Há, porém, que se esclarecer a diferença.

Segundo D'Ottaviano (2009, p.85), "parte do que hoje conhecemos como condomínios fechados na RMSP (e no Brasil) eram originalmente loteamentos fechados, localizados em grandes glebas vazias na periferia metropolitana e destinados exclusivamente às classes altas." Na realidade,

[...] diferentemente dos loteamentos fechados, que são parcelamentos comuns, de lotes, com cercas ou muros que impedem a circulação publica no interior de determinada área, os condomínios horizontais fechados são parcelamentos fechados que incluem a construção das residências e outros edifícios na sua implantação. As vias e áreas comuns dos loteamentos fechados são na verdade, públicas. Já as vias e áreas coletivas dos condomínios fechados são realmente privadas e de uso exclusivo e coletivo dos condôminos (D'OTTAVIANO, 2009, p.83). 
Os "loteamentos fechados" são, na verdade, loteamentos convencionais, regidos pela Lei Federal 6766/7951 , fechados por ato do loteador ou de uma associação de moradores, com muros e guarita para controle. E os "condomínios residenciais" são regulamentados pela lei 4591/64, segundo a qual, tudo o que está no interior da área do projeto é área privada. São regidos também pelo Código Civil (Lei 10.406/2002), de acordo com os artigos 1314 a 1326, nos quais a figura do condomínio tem como característica básica o fracionamento da gleba em partes ideais. O proprietário tem por obrigação participar das despesas de conservação das áreas comuns e é permitida a barreira física, onde a autorização para a entrada é dada pelos proprietários.

Não existe, portanto, regulamentação oficial acerca de "loteamentos fechados". A maioria desses empreendimentos é ilegal e contraria a legislação brasileira. O fato de as áreas públicas e de uso coletivo estarem dentro de muros "denota o grau de exclusividade desses espaços" (SPOSITO, 2006, p.191). O que ocorre, na prática, é uma espécie de acordo entre o proprietário do loteamento e a Prefeitura. Com a permissão do fechamento, em contrapartida, os moradores se tornam responsáveis pela dotação de infraestrutura urbana e manutenção do que está contido no empreendimento.

Em suma, o condomínio horizontal não implica subdivisão do terreno original; comercializam-se as casas (unidades autônomas) e um terreno destinado à área de lazer coletivo. No caso dos loteamentos fechados, o terreno original é dividido em lotes, os quais são comercializados individualmente e que devem ser numerados e caracterizados com seus limites.

No condomínio horizontal, as ruas, praças e espaços livres pertencem aos condôminos, os quais têm direito de propriedade de uma fração ideal destas áreas comuns. Nos loteamentos fechados, as praças e espaços livres são de domínio público, exercido pela municipalidade local, que pode a qualquer momento requerer sua posse. Por tal razão, os projetos preveem estratégias para atender a essa possível (embora improvável) exigência. Na realidade, o fechamento de uma área loteada é irregular, mas as prefeituras, de modo geral, são pouco rigorosas na aprovação desses empreendimentos.

Os loteamentos fechados têm, geralmente, dimensões bem maiores e, por serem murados, com acessos restritos e controle de vigilância, são também denominados, embora indevidamente, "condomínios fechados".

Esses empreendimentos em geral apresentam padrão bastante homogêneo e características próprias. São propriedades privadas para uso coletivo, mas de forma individualizada, destinadas preferencialmente às classes mais abastadas, em razão do alto valor do terreno ou da habitação pronta. Em quase todos predominam grandes pórticos de entrada, com guarita, sistemas de vigilância e segurança, residências isoladas (voltadas para dentro do terreno e não para a rua) e amplas áreas de lazer.

\footnotetext{
${ }^{51}$ A Lei Federal 6766/79, ou Lei de Parcelamento do Solo Urbano, em seu Artigo $2^{\circ}$ no $\S 1^{\circ}$ define o loteamento da seguinte forma: $\$ 1^{\circ}$. Considera-se loteamento a subdivisão de gleba em lotes destinados à edificação, com abertura de novas vias de circulação, de logradouros públicos ou prolongamento, modificação ou ampliação das vias existentes. A mesma Lei define também o que vem a ser desmembramento do solo urbano para fins específicos, como os condomínios fechados ou loteamentos: $\S 2^{\circ}$. Considera-se desmembramento a subdivisão de gleba em lotes destinados à edificação, com aproveitamento do sistema viário existente, desde que não implique na abertura de novas vias e logradouros públicos, nem no prolongamento, modificação ou ampliação dos já existentes.
} 


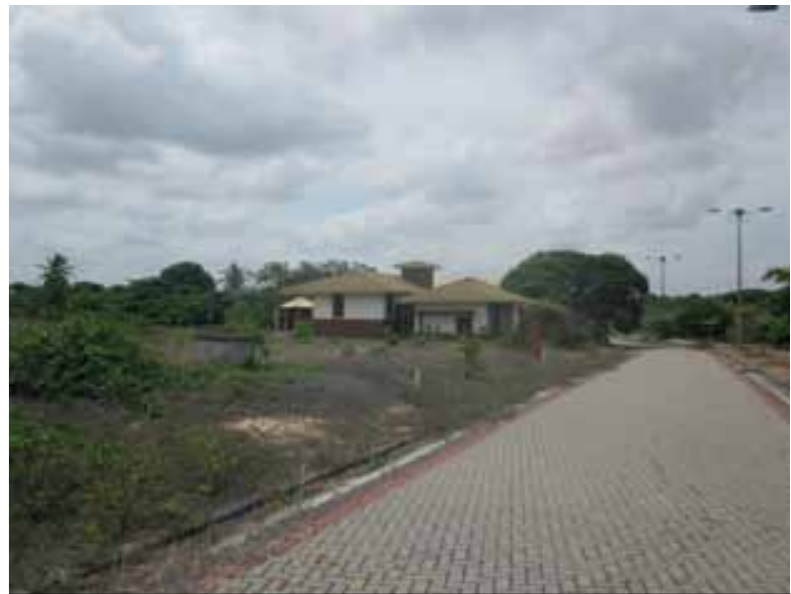

Fig. 4.72 Loteamento fechado no Eusébio Fonte: acervo autora

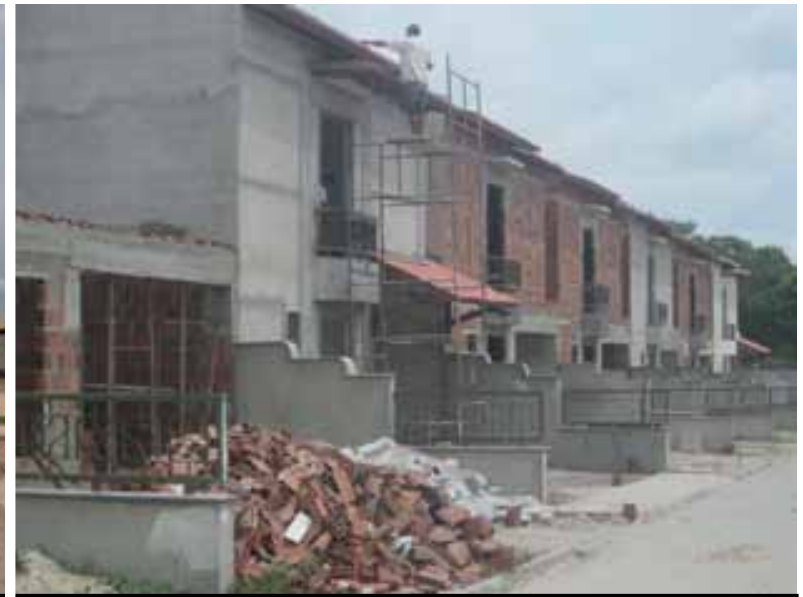

Fig. 4.74 Condomínio fechado no Eusébio Fonte: acervo autora

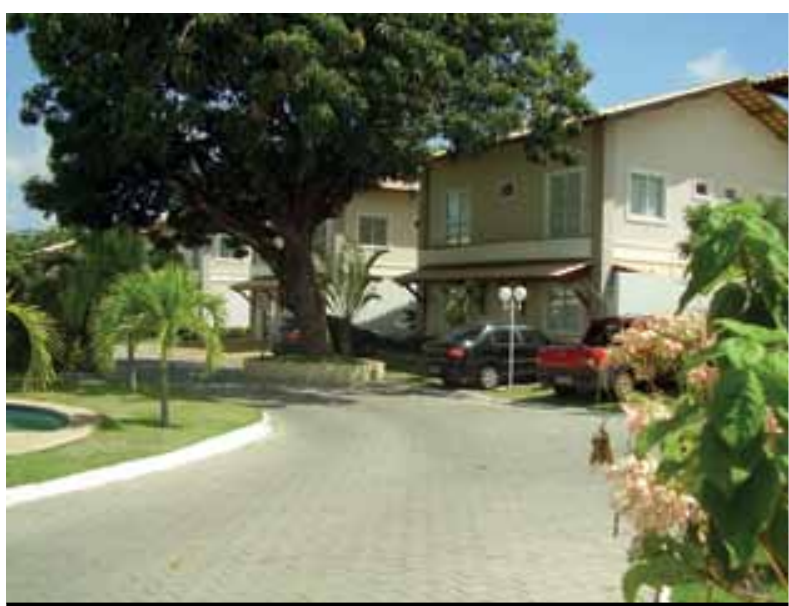

Fig. 4.75 Condomínio fechado no Eusébio Fonte: Armando Silveira

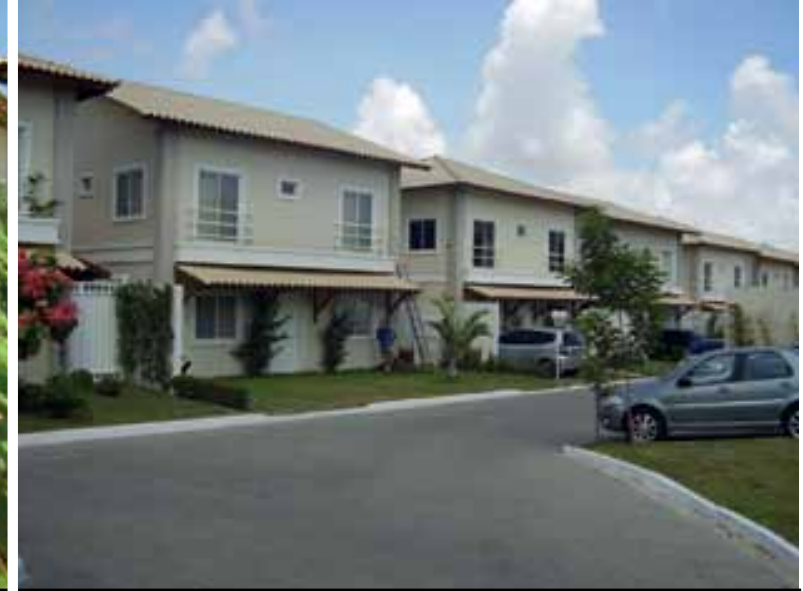

Fig. 4.76 Condomínio fechado no Eusébio Fonte: Armando Silveira 
O surgimento dos condomínios fechados, conforme assinalado, vem se tornando prática bastante comum em várias cidades brasileiras e amplamente reproduzidos em todo o território. Embora apresentem características comuns, esses processos trazem consigo, entretanto, as especificidades dos lugares e das dinâmicas próprias dos agentes que nele atuam.

Na Metrópole cearense, num trecho do eixo sudeste de expansão metropolitana, referencial empírico deste trabalho, veem-se inúmeros condomínios e placas anunciando empreendimentos do gênero às margens da rodovia CE 040.

Formalmente produzidos pelo mercado imobiliário, a maioria deles se concentra na região do Eusébio ${ }^{52}$, que, até a década de 1990-2000 era ocupada por sítios e chácaras de "fim de semana". O processo teve inicio na década de 2000-2010, após a aprovação do Plano Diretor de Desenvolvimento Urbano do Município, aprovado em 2000, que permitiu, pela lei de parcelamento e uso do solo, a implantação de loteamentos fechados e condomínios horizontais em grandes glebas.

Esse fenômeno ocorreu, por um lado, como tendência natural de expansão metropolitana, no que se refere à moradia dos estratos de renda média e alta. Por outro lado, há um conjunto de fatores que contribuiu para que esse processo se efetive. A facilidade de acesso e o aumento do transporte motorizado individual favoreceram o incremento desse tipo de moradia, aliado à proximidade da Capital e à incidência de quantidade considerável de áreas não ocupadas no Município, além da existência de abundante vegetação, que permite o maior "contato com a natureza".

Essa expansão foi motivada também pela melhoria da infraestrutura, com a duplicação da rodovia e pela queda da qualidade de vida na Capital, que assiste a um aumento da criminalidade e a um clima generalizado de insegurança. O fenômeno propiciou o incremento da dinâmica imobiliária e tornou ascendente a valorização dos terrenos situados junto à via.

A viabilização destes equipamentos está, portanto, em grande parte associada ao fato de "estarem localizados em áreas de expansão urbana dotadas de vias de fluxo rápido, permitindo fácil acesso aos centros adensados através do uso indiscriminado do automóvel particular" (SILVEIRA, 2011).

O Eusébio, local preferencial dessa "nova forma de morar", é um município pequeno, com área de aproximadamente $80 \mathrm{~km}^{2}$ e população de 46.310 habitantes. Por suas dimensões reduzidas, não possui distritos, apenas bairros. Logo após sua emancipação (1991) foi decretado como território totalmente urbano, o que propiciou sua ocupação ${ }^{53}$ crescente, desde então. Este fato, somado à sua localização estratégica, situado próximo à Capital e ao litoral leste do Estado, favoreceu a ocupação ao longo dos principais corredores viários ${ }^{54}$ que cortam seu território.

Nesta região, percebe-se, desde a última década ${ }^{55}$, sobretudo depois de 2002, a mudança do perfil de ocupação, de moradia temporária (veraneio e lazer) para residência definitiva, mediante

\footnotetext{
${ }^{52}$ Até a década de 1990-2000, essa região era considerada de pouco interesse imobiliário, constituída por sítios. Havia grandes glebas não parceladas, com um mínimo de infraestrutura urbana, muitas delas com córregos e vegetação nativa. ${ }_{53}$ A população do Município do Eusébio mais do que duplicou em 20 anos, passando de 20.410 habitantes em 1991 para 31.500 em 2000 e 46.310 em 2010.

${ }^{54} \mathrm{O}$ município do Eusébio é cortado por importantes rodovias, como o $4^{\circ}$ Anel Viário, a BR-116 e CE-040. As duas primeiras têm sua ocupação relacionada à indústria e à habitação popular, enquanto que CE 040 (eixo sudeste de expansão metropolitana) apresenta perfil predominantemente residencial, com sítios, chácaras, residências unifamiliares, condomínios horizontais e loteamentos fechados.

${ }_{55}$ No ano de 2002 foi lançado o primeiro loteamento fechado (Quintas do Lago), seguido por um aumento gradual de lançamentos, que se vêm intensificando nos últimos anos.
} 
a progressiva transformação dos sítios e chácaras em empreendimentos fechados, voltados principalmente para a população de maior poder aquisitivo de Fortaleza.

Esses assentamentos, produzidos pelo mercado imobiliário, também são vistos no Município de Fortaleza, que manifesta processos semelhantes, porém com estruturas fundiárias diferentes. Devido à ausência de glebas mais generosas, os condomínios fechados no âmbito da Capital ${ }^{56}$ se restringem, no máximo, às dimensões de 250,00m x 250,00m, muito embora apresentem características similares, comuns aos condomínios fechados: residências horizontais, acessos restritos, segurança privada e (pequena) área de lazer. Há grande incidência deste tipo de empreendimento nas proximidades da av. Washington Soares e a tipologia começa a se disseminar em outras áreas da Cidade, embora com outras características, voltadas para a população de classe média e média baixa.

Já no Município do Eusébio, além da disponibilidade maior de terrenos, a legislação municipal é mais flexível. Os empreendimentos são aprovados inicialmente como loteamentos comuns e posteriormente fechados, com anuência da Prefeitura ${ }^{57}$. Afora isso, há que salientar o valor dos terrenos na região, que também favorece a disseminação desses empreendimentos, uma vez que os preços são, em geral, bem mais atrativos se comparados aos imóveis localizados em bairros nobres da Capital.

É visível a instalação crescente de empreendimentos do tipo, os quais são comercializados com sucesso, desde que foi lançado o primeiro loteamento, em 2002. Segundo dados do SECOVI, existem atualmente 25 empreendimentos em processo de aprovação na Prefeitura e vários outros em construção.

Consoante pesquisas realizadas com moradores e empreendedores, a demanda por esse tipo de moradia é principalmente motivada pela procura por áreas mais generosas, maior contato com a natureza e possibilidades de usufruir de equipamentos de lazer privado (piscinas, churrasqueiras, quadras esportivas, etc.) Essa preferência demonstrou ser maior mesmo do que a busca por segurança privada, embora esta seja também fator importante na escolha.

O mercado imobiliário explora essa tendência e promete novos conceitos de moradia e de relação com a Cidade. Os anúncios excedem-se em frases de efeito, tentando vender uma "qualidade de vida" que a Capital "não mais possui", tais como: "more 'naturalmente' no Eusébio", "o dia a dia da sua família com cara de fim de semana", "uma área de lazer do tamanho da sua felicidade", "harmonia e satisfação em um ambiente que é pura natureza".

É interessante notar que, na publicidade relativa ao lançamento e venda de casas em condomínios fechados, privilegia-se o discurso da qualidade de vida e da oferta de lazer, conforto e estilo de vida, com relação ao discurso da segurança.

\footnotetext{
${ }^{56}$ A maioria dos condomínios horizontais fechados construídos na Capital possui pequena dimensão e é implantada no interior de uma quadra. Isso faz com que a estrutura urbana do entorno se mantenha intacta.

${ }^{57}$ Existe uma espécie de contrato entre as partes, que se efetiva mediante a concessão do fechamento de vias públicas em troca da coleta de lixo, abastecimento d água e outros serviços realizados sob responsabilidade do empreendimento. Parece haver uma flexibilização na aplicação da lei quando se trata de atender aos interesses do mercado voltado para os loteamentos de alta renda.
} 


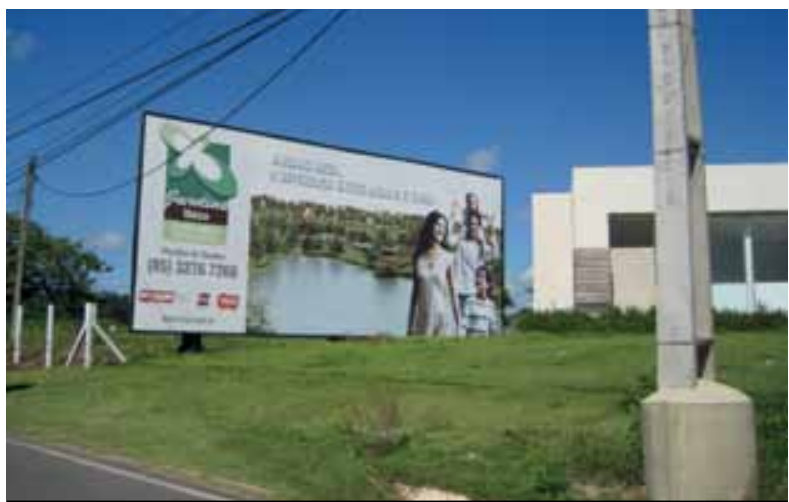

Fig. 4.77 Anúncios condomínios na CE 040 Fonte: acervo autora

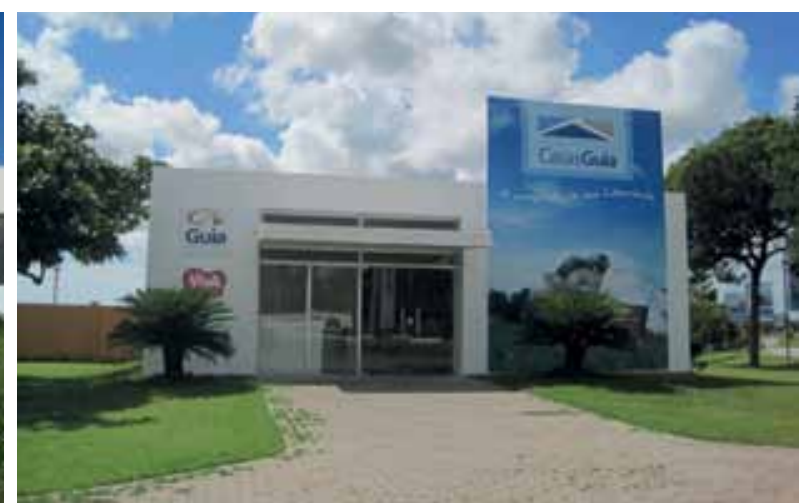

Fig. 4.78 Stand de vendas condomínios na CE 040 Fonte: acervo autora

Outro ponto a ser destacado é o aspecto simbólico, o caráter de exclusividade e de status que esses empreendimentos conferem aos moradores, aspecto também bastante explorado pela mídia publicitária ${ }^{58}$. Morar num condomínio fechado, por si só, já identifica a classe social do usuário.

É intensa a atuação do mercado imobiliário na área, dinâmica evidenciada pela grande quantidade de stands e outdoors ao longo da rodovia, anunciando os diversos empreendimentos lançados. Os agentes imobiliários associam a tranquilidade, o status e a segurança da região à imagem da natureza e a utilizam como marketing para seus loteamentos (ver figuras 4.77 e 4.78).

O fato de situar-se na chamada "rota do sol nascente", ou seja, junto à rodovia (CE 040) que dá acesso às praias e à atividade turística do litoral leste, também confere valorização a esses condomínios e atua como importante argumento de vendas.

Os condomínios são todos estritamente residenciais e, como não há equipamentos de comércio e serviço nas proximidades, os moradores continuam se deslocando diariamente para Fortaleza para suas atividades profissionais, de estudo, lazer e consumo. O fato reforça, assim, a estrita dependência do automóvel particular.

Por outro lado, os usuários não mantêm qualquer ligação com o Município do Eusébio ${ }^{59}$. Como resultado, constata-se a total falta de identificação da população com o território que habita, uma vez que ela não se relaciona com o local, e sim com o modo de vida metropolitano.

Nesse sentido, é interessante notar como a centralidade formada na av. Washington Soares, assunto enfocado no item anterior, atua como poderoso fator de marketing para a venda desses condomínios. É enfatizada a proximidade dos grandes shoppings, faculdades, colégios, restaurantes e equipamentos diversos, os quais, embora situados em Fortaleza, são alcançados em poucos minutos pela CE 040, via de fluxo rápido, mediante o uso do automóvel. Essa população se utiliza com frequência do comércio e serviços localizados no referido centro.

\footnotetext{
${ }^{58}$ Casas exclusivas de altíssimo padrão são alguns dos apelos utilizados pelo marketing para atingir o consumidor que busca por diferenciação e status.

${ }^{59}$ Segundo informações colhidas na Secretaria de Obras do Eusébio, há previsão de instalação de equipamentos de comércio e serviço de apoio aos novos moradores, mas, até agora, praticamente nada foi realizado.
} 
Esse aspecto está associado também aos novos modos de vida da sociedade contemporânea, quando, a um número cada vez maior de pessoas, se tornou possível trabalhar, morar, estudar, consumir e se divertir em cidades diferentes, ampliando suas redes de relações, e criando um sistema urbano com uma abrangência e simultaneidade inéditas na história.

No que se refere ao crescimento populacional, vale destacar a diferença entre a Sede e o restante do Município, depois da instalação dos condomínios. A população total do Município do Eusébio aumentou quase 50\% entre 2000 e 2010, enquanto na Sede houve muito pouca alteração; ou seja, o aumento decorre sobretudo dos novos moradores dos condomínios, quase todos provenientes da Capital.

Em pesquisa realizada no local, constatou-se que, apesar do expressivo aumento populacional, praticamente não há investimentos por parte da Prefeitura, como também não se percebe o surgimento de novas atividades de comércio e serviço de apoio aos novos moradores. O fato se explica, por um lado, pela total falta de vínculos dos habitantes com o Município e, por outro, pela baixa representatividade político-eleitoral desses moradores, que permanecem com seus títulos eleitorais de Fortaleza. São munícipes que mantêm, portanto, completa dependência com a Capital.

De acordo com os estudos realizados por Silveira (2011) no Município, os empreendimentos fechados foram agrupados em duas categorias: os loteamentos fechados e os condomínios horizontais. Os loteamentos fechados, conforme o autor, "consistem numa modalidade de parcelamento onde as áreas públicas são incorporadas pelo empreendimento, prática legislada de acordo com as regras municipais." Quanto aos condomínios horizontais, todo o espaço coletivo é propriedade privada.

Os condomínios horizontais apresentam áreas bem menores quando comparados aos loteamentos fechados. Os terrenos destes possuem áreas que variam entre 3.000 a $20.000 \mathrm{~m}^{2}$, embora a maioria se concentre no intervalo entre 5.000 a $10.000 \mathrm{~m}^{2}$. A área construída da casa varia no intervalo entre 90 a $350 \mathrm{~m}^{2}$, garantindo variedade de tipologias de acordo com o poder aquisitivo e tamanho das famílias (SILVEIRA, 2011).

TABELA 18 - LOTEAMENTOS FECHADOS NO MUNICÍPIO DO EUSÉBIO (2000-2011)

\begin{tabular}{|c|c|c|c|c|c|c|}
\hline \multirow{2}{*}{ LOTEAMENTO } & \multirow{2}{*}{ DATA } & \multirow{2}{*}{$\begin{array}{c}\text { ÁREA } \\
\text { TERRENO } \\
\left(\mathbf{m}^{2}\right)\end{array}$} & \multicolumn{2}{|c|}{ LOTES } & \multirow{2}{*}{$\begin{array}{l}\text { ÁREA DE } \\
\text { LAZER }\end{array}$} & \multirow{2}{*}{$\begin{array}{c}\text { VALOR } \\
\text { LOTE (R\$) }\end{array}$} \\
\hline & & & ÁREA (m²) & QUANT. & & \\
\hline Alphaville Fortaleza & 2002 & 1.188 .200 & 770 & 797 & $\operatorname{sim}$ & 110.000 \\
\hline Quintas do Lago & 2002 & 320.000 & 495 & 283 & $\operatorname{sim}$ & 160.000 \\
\hline Jardins Ibiza & 2008 & 385.783 & 377 & 357 & $\operatorname{sim}$ & 140.000 \\
\hline Quintas das Fontes & 2005 & 290.000 & 450 & 192 & $\operatorname{sim}$ & $\mathrm{N} / \mathrm{D}$ \\
\hline Alphaville Eusébio & 2005 & 535.000 & 500 & 497 & $\operatorname{sim}$ & 110.000 \\
\hline Vivendas do Ramalhete & 2005 & $37.000 * *$ & 420 & 52 & $\operatorname{sim}$ & 75.000 \\
\hline \multicolumn{3}{|c|}{ Fonte: Armando Silveira, 2011} & & & \multicolumn{2}{|c|}{$\begin{array}{l}\text { **área aproximada } \\
\text { N/D: não disponível }\end{array}$} \\
\hline
\end{tabular}


TABELA 19 - CONDOMÍNIOS HORIZONTAIS NO MUNICÍPIO DO EUSÉBIO

\begin{tabular}{|c|c|c|c|c|c|c|}
\hline \multirow{2}{*}{ CONDOMÍNIO } & \multirow{2}{*}{ DATA } & \multirow{2}{*}{$\begin{array}{c}\text { ÁREA } \\
\text { TERRENO }\left(\mathbf{m}^{2}\right)\end{array}$} & \multicolumn{2}{|c|}{ CASAS } & \multirow{2}{*}{$\begin{array}{l}\text { ÁREA DE } \\
\text { LAZER }\end{array}$} & \multirow{2}{*}{$\begin{array}{c}\text { VALOR } \\
\text { CASA (R\$) }\end{array}$} \\
\hline & & & ÁREA $\left(\mathbf{m}^{2}\right)$ & QUANT. & & \\
\hline Grand Classic & 2011 & $12.000^{* *}$ & 206 & 15 & $\operatorname{sim}$ & 470.000 \\
\hline Germana Gurgel III & 2010 & $12.000^{* *}$ & 180 & 16 & $\operatorname{sim}$ & 364.000 \\
\hline Green Maison & 2010 & $10.000^{* *}$ & 107 & 44 & $\operatorname{sim}$ & 258.530 \\
\hline Grand Maison & 2010 & $10.800^{* *}$ & 230 & 12 & $\operatorname{sim}$ & 450.000 \\
\hline Aldeia dos Ventos & N/D & N/D & N/D & N/D & N/D & N/D \\
\hline Isla Verde & 2009 & $10.000^{* *}$ & 275 & 12 & $\operatorname{sim}$ & 343.750 \\
\hline Grand Village & 2007 & $10.000^{* *}$ & 358 & 12 & $\operatorname{sim}$ & 530.000 \\
\hline Atlantis & 2007 & $26.000^{* *}$ & 214 & 45 & $\operatorname{sim}$ & 308.000 \\
\hline Bosque & 2010 & 10.000 & 130 & 40 & $\operatorname{sim}$ & 220.000 \\
\hline Villagio Eusébio & 2010 & $\mathrm{~N} / \mathrm{D}$ & 105 & 11 & $\operatorname{sim}$ & 168.000 \\
\hline Vila de Fiori & 2007 & $16.500^{* *}$ & 170 & 22 & $\operatorname{sim}$ & 330.000 \\
\hline Grand Place & 2007 & $9.500^{* *}$ & 270 & 12 & $\operatorname{sim}$ & 650.000 \\
\hline Vila Paradise & 2007 & $10.000^{* *}$ & 225 & 18 & não & 330.000 \\
\hline Grand Imperial & 2009 & $10.000^{* *}$ & $300^{* *}$ & 12 & não & 650.000 \\
\hline Família Vidal & $\mathrm{N} / \mathrm{D}$ & $10.000^{* *}$ & $\mathrm{~N} / \mathrm{D}$ & N/D & $\mathrm{N} / \mathrm{D}$ & N/D \\
\hline Verona & 2002 & $12.000^{* *}$ & 190 & 14 & não & 210.000 \\
\hline Garden Condominium & 2008 & $3.500^{* *}$ & 178 & 12 & $\operatorname{sim}$ & 215.000 \\
\hline Vivaldi & 2007 & 20.000 & 250 & 21 & $\operatorname{sim}$ & 450.000 \\
\hline Vancouver & 2010 & $10.000^{* *}$ & 226 & 22 & $\operatorname{sim}$ & 398.000 \\
\hline Vila Formosa & 2007 & $15.000^{* *}$ & N/D & N/D & $\mathrm{N} / \mathrm{D}$ & N/D \\
\hline Grand Parc & 2007 & $5.000^{* *}$ & N/D & 12 & não & $\mathrm{N} / \mathrm{D}$ \\
\hline Vila Murano & 2008 & $3.000^{* *}$ & 143 & 11 & $\operatorname{sim}$ & 350.000 \\
\hline Village Maison & 2011 & $7.000^{* *}$ & 96 & 16 & $\operatorname{sim}$ & 173.000 \\
\hline Algarve & 2004 & 20.000 & 350 & 20 & $\mathrm{~N} / \mathrm{D}$ & N/D \\
\hline Sevilha & 2003 & 10.000 & 300 & 12 & N/D & N/D \\
\hline Grand Jardins & 2009 & $17.000^{* *}$ & 135 & 43 & $\operatorname{sim}$ & 300.000 \\
\hline Grand Ville & 2009 & $26.000^{* *}$ & 167 & 41 & $\operatorname{sim}$ & 360.000 \\
\hline Res. Victor I & 2009 & 18.000 & 340 & 22 & $\operatorname{sim}$ & 600.000 \\
\hline Vila Fortuna & 2009 & 22.000 & 94 & 94 & $\operatorname{sim}$ & 170.000 \\
\hline Bosque das Palmeiras & 2010 & $10.000^{* *}$ & 145 & 30 & $\operatorname{sim}$ & 280.000 \\
\hline Grand Boulevard & 2008 & $10.000^{* *}$ & 250 & 14 & não & 300.000 \\
\hline Grand Quartier & 2008 & $15.000^{* *}$ & 176 & 20 & $\operatorname{sim}$ & 350.000 \\
\hline Varandas do Eusébio & 2008 & N/D & N/D & N/D & $\mathrm{N} / \mathrm{D}$ & $\mathrm{N} / \mathrm{D}$ \\
\hline Grand Plaza & 2008 & $15.000^{* *}$ & 170 & 20 & $\operatorname{sim}$ & 230.000 \\
\hline Bosque das Videiras & 2008 & $20.000^{* *}$ & 218 & 29 & $\operatorname{sim}$ & 340.000 \\
\hline Vila Toscana & 2010 & $20.000^{* *}$ & 111 & 70 & $\operatorname{sim}$ & 183.000 \\
\hline Vila Morena & 2005 & 16.790 & 270 & 25 & $\operatorname{sim}$ & 370.000 \\
\hline Bouganvílea Boulevard & 2009 & $10.000^{* *}$ & 136 & 44 & $\operatorname{sim}$ & 260.000 \\
\hline Merano & 2011 & $5.000^{* *}$ & 120 & 16 & $\operatorname{sim}$ & 200.000 \\
\hline Le Betulle & 2005 & 10.000 & 187 & 20 & $\operatorname{sim}$ & 200.000 \\
\hline Vila Verde & 2011 & N/D & N/D & N/D & $\mathrm{N} / \mathrm{D}$ & N/D \\
\hline Camov & 2006 & N/D & N/D & N/D & N/D & $\mathrm{N} / \mathrm{D}$ \\
\hline Palm Ville & 2009 & $10.000^{* *}$ & 180 & 26 & $\operatorname{sim}$ & 350.000 \\
\hline \multicolumn{2}{|c|}{ Fonte: Armando Silveira, 2011} & & & & $\begin{array}{l}\text { **áre } \\
\text { N/D: I }\end{array}$ & $\begin{array}{l}\text { proximada } \\
\text { disponível }\end{array}$ \\
\hline
\end{tabular}




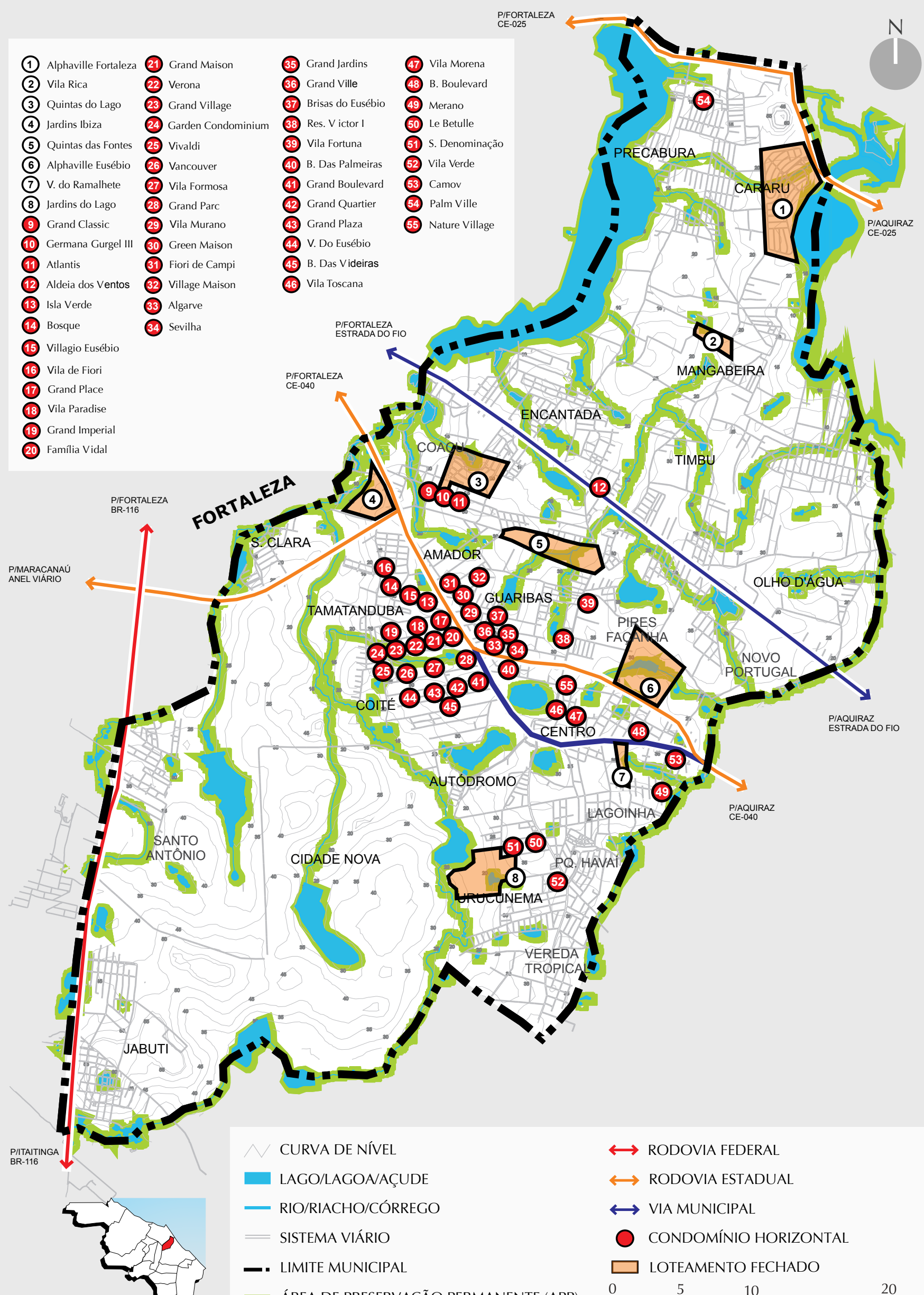

ÁREA DE PRESERVAÇÃO PERMANENTE (APP)

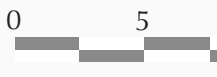


Os condomínios fechados da região, embora possuam características comuns, como os muros, os acessos restritos, áreas de lazer comunitárias e vigilância ostensiva, apresentam diferenças no que se refere às dimensões do empreendimento e dos lotes, à qualidade e tamanho das habitações, e à relação com o meio natural. São também diferenciados os tipos de infraestrutura disponíveis, como sistema de esgoto ${ }^{60}$, distribuição de água e iluminação, coleta de lixo, pavimentação e paisagismo. Se comparados aos loteamentos fechados, os condomínios possuem áreas bem inferiores e são classificados em grupos de médio, médio- alto e elevado padrão.

O Loteamento Alphaville Fortaleza, lançado no ano de 2002, serviu como elemento impulsionador do processo que aí se desencadeou desde então. Já conhecido por seu elevado padrão urbanístico e voltado para uma população de alta renda, oferece um tipo de moradia que representa um novo "estilo de vida", num ambiente de "segurança, qualidade de vida e proximidade com a natureza".

O empreendimento possui área total de 1.188.200m2, com 797 lotes, sendo 770 residenciais e 27 destinados a equipamentos comerciais e de $\operatorname{serviços~}^{61}$, ocupando uma área de 468.611,29m2. O total de áreas públicas é de 380.101,76m2 e de áreas verdes 475.663,43m2. Quando totalmente ocupado deverá abrigar uma população de 3.850 moradores. Logo que foi lançado, em 2002, o loteamento foi completamente vendido, em pouco tempo, mas a ocupação demorou a ocorrer, sobretudo pela dificuldade inicial de acesso, visto que este loteamento não fica situado junto à CE 040, como a maioria deles.

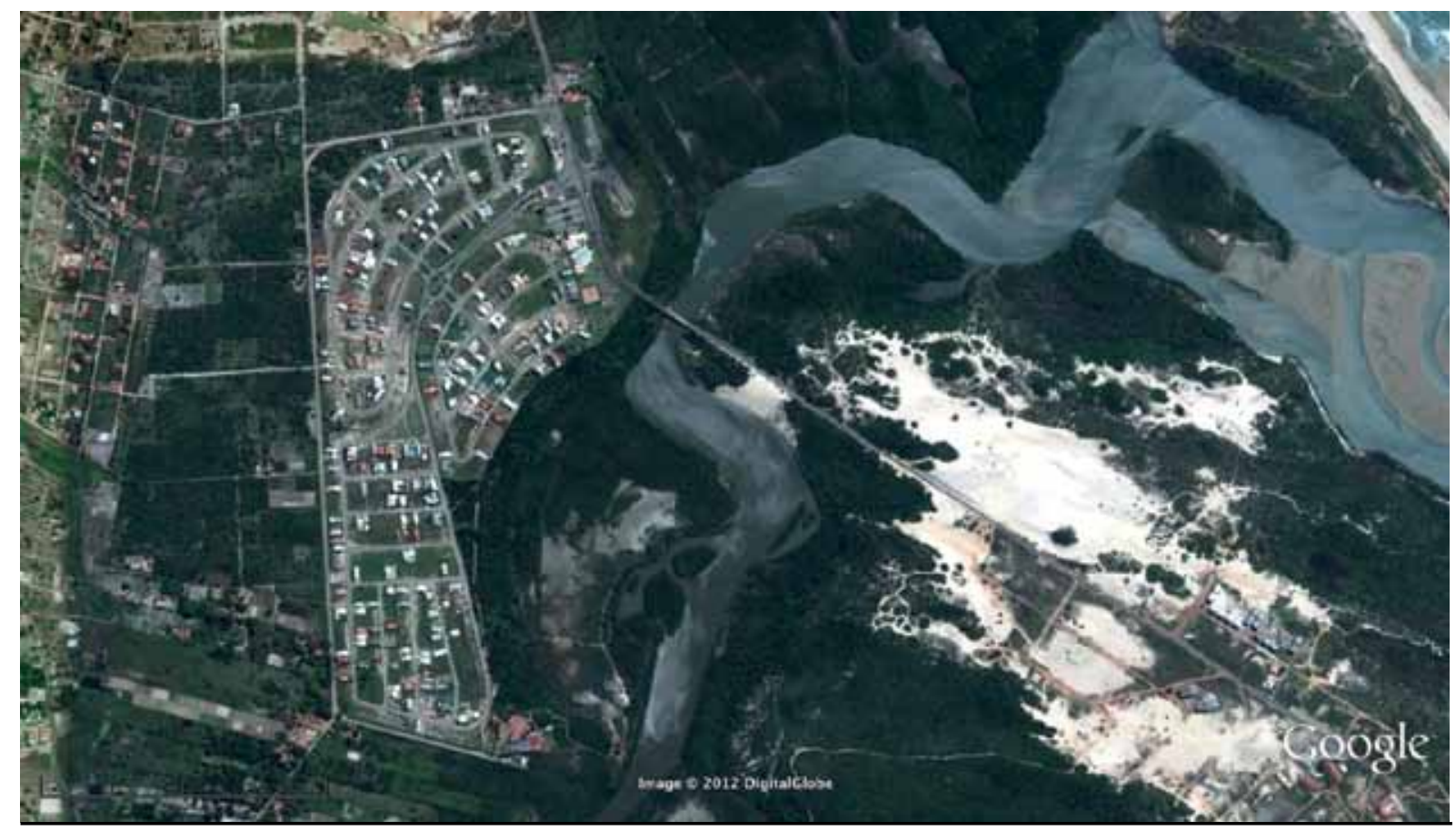

Fig. 4.80 Condomínio Alphaville Fortaleza Fonte: Google Earth

\footnotetext{
${ }^{60}$ Não há saneamento básico na área onde são construídos os condomínios, e a maioria deles utiliza estações de tratamento de esgoto.

${ }^{61}$ Embora a proposta do empreendimento Alphaville seja de conciliar moradia com toda uma gama de comércio e serviços, a proposição não se efetivou nos empreendimentos locais. A baixa ocupação avulta como um empecilho à instalação e manutenção dos equipamentos de comércio e serviços. Ao mesmo tempo, a ausência de serviços essenciais é um problema para potenciais moradores.
} 


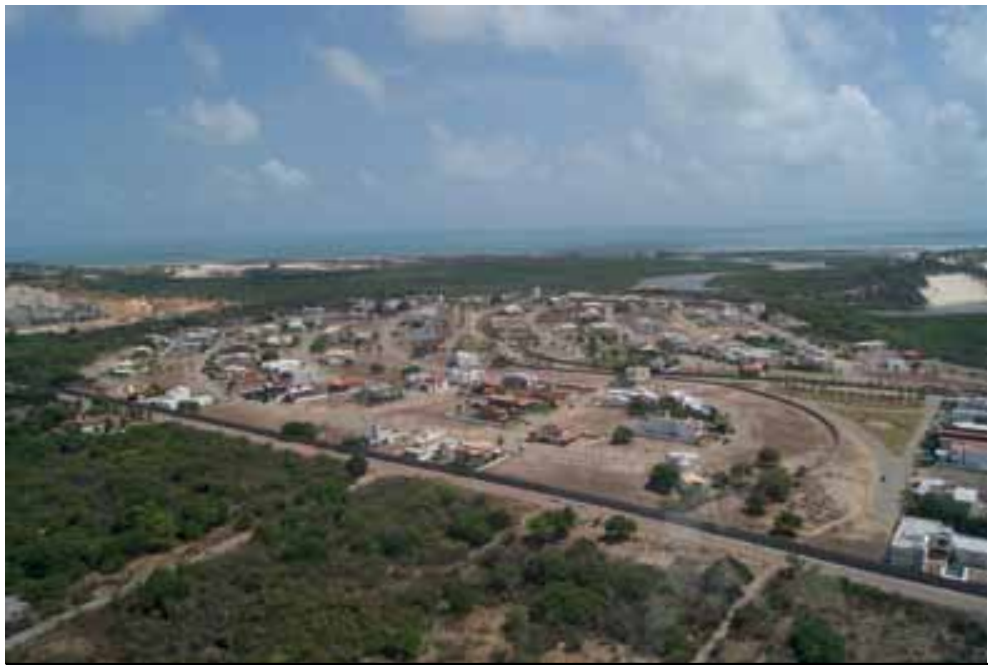

Fig. 4.81 Condomínio Alphaville Fortaleza

Fonte: Rodrigo Ponce de Leon

Diversos condomínios e loteamentos surgiram então na esteira do Alphaville, em grande parte apoiados no "conceito" da marca, e foram todos facilmente comercializados, inclusive o Alphaville Eusébio, lançado em 2009, esse às margens da CE 040, ocupando uma área de $535.000 \mathrm{~m}^{2}$.

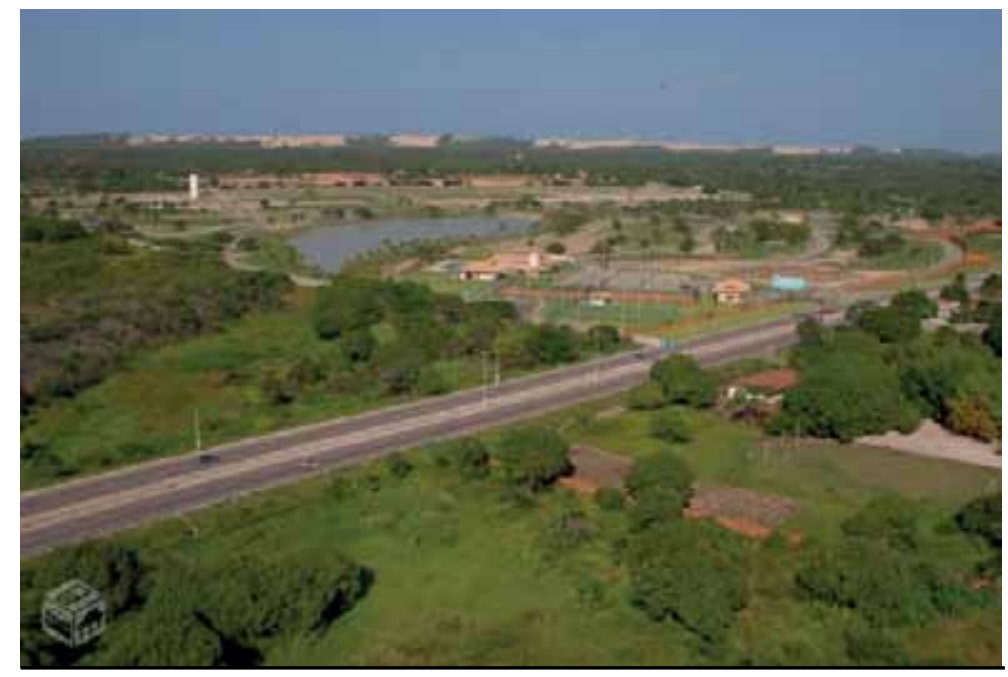

Fig. 4.82 Condomínio Alphaville Eusébio

Fonte: http://www.bomnegocio.com/

Um aspecto importante enfatizado pelos estudiosos dos condomínios fechados é a questão da privatização dos espaços públicos, bem como o fechamento para os espaços públicos adjacentes, uma vez que sua lógica de implantação privilegia o que é privado e restrito, ao mesmo tempo em que desvaloriza o que é público e aberto na cidade (CALDEIRA, 2000). Dessa forma, a proliferação desses novos modos de morar tem alterado a configuração urbana da região onde são implantados.

O cercamento voluntário que ocorre nos condomínios fechados seria uma resposta ao declínio dos espaços públicos nas cidades contemporâneas. Tal urbanização feita de enclaves privados é ainda entendida como uma secessão de elites que se opõem ao sistema de redistribuição que caracterizaria uma sociedade de "bem-estar", tendo como pressuposto, de um lado, que a provisão pública de serviços é ineficiente e, de outro, que a construção do espaço é reveladora ou espelha as relações sociais (BARCELLOS \& MAMMARELLA, 2007). 
A maioria dos estudos refere-se aos condomínios fechados como uma nova forma de segregação social e de isolamento ${ }^{62}$, fato que se reflete nas cercas, nos muros, nos controles de acesso e nos sistemas de vigilância que funcionam ininterruptamente. Todos eles cercados e quase sempre isolados entre si, têm como elemento mais emblemático o muro, que estabelece uma ruptura com o espaço externo, não só física, mas, principalmente simbólica, diante do restante da cidade, "com evidentes características de confinamento" (REIS, 2007, p.177).

Isso tudo leva ao que os autores consideram como "autossegregação" do morador, que

[...] nega a cidade enquanto espaço da convivência social e da diferença, buscando reduzir o encontro com o outro e com as classes mais populares a um mínimo tolerável e funcional, construindo a anti-cidade apartada da polis metropolitana ou aquilo que Soja (2000) denominou de um arquipélago carceral de enclaves fortificados (TONUCCI FILHO, 2009, p.7).

Os condomínios, de maneira geral, configuram espaços fragmentados no tecido urbano, sendo comumente denominados de "enclaves urbanos" ou "enclaves fortificados" (CALDEIRA, 1997). Segundo Salgueiro ${ }^{63}$, "o que define o enclave não é tanto a sua dimensão, pequena, mas o tipo de relação (a existência de não-relações) com os tecidos que o cercam".

Para Caldeira (2000), que procura debater a importância da proliferação das "enclaves" na configuração das aglomerações urbanas brasileiras (especialmente nas Região Metropolitana de São Paulo), "o surgimento de condomínios e loteamentos faz parte de um novo padrão de segregação espacial e desigualdade social na cidade". Ainda sobre a questão dos enclaves, assinala Sposito:

Do ponto de vista da estrutura urbana, a emergência e proliferação dos loteamentos fechados cria a multiplicação de enclaves urbanos, áreas em que a homogeneidade social e o habitat, designando um padrão de consumo, mostram que o pertencimento dessas áreas à cidade, plural, desigual e perigosa, é negado e justificado pela busca de qualidade de vida e segurança (SPOSITO, 2003) ${ }^{64}$.

"O espaço produzido é, portanto, marcado pela segregação socioespacial, pela perda da sociabilidade, pela fragmentação" (DINIZ, 2005, p.7). A lógica dos "enclaves fortificados" é dissociada da vida urbana, visto que as relações das pessoas com os espaços são recriadas. Recriam-se ruas, praças, áreas de lazer e de convívio no interior dos empreendimentos. O território em volta restringese a um "espaço de fluxos", uma vez que são fisicamente demarcados por muros ou grades.

O caráter de autossegregação, típico dos condomínios fechados, é também observado nos empreendimentos do Eusébio ${ }^{65}$, tendência observada na ocupação do eixo sudeste. O espaço do entorno é comumente negligenciado, restrito às ruas de acesso, quase sempre vazias e muitas delas sem pavimentação. O que se vê são muros, cercas elétricas e guaritas fechadas, para impedir o acesso de estranhos. Não há qualquer espaço público ou de convivência, não se estabelece qualquer integração entre as pessoas (ver figuras 4.83 e 4.84).

\footnotetext{
$\overline{62}$ Segundo Meyer, Grostein \& Biderman (2004, p. 266) o pressuposto desses empreendimentos é ignorar o entorno onde se instalam, voltando-se exclusivamente para o interior da gleba ou lote do empreendimento.

${ }^{63}$ SALGUEIRO, Teresa Barata. Cidade pós-moderna: espaço fragmentado, disponível em: http://www.revistaterritorio. com.br/ pdf/04_4_salgueiro.pdf

${ }^{64}$ SPOSITO, M.E.B. A cidade dentro da cidade. Uma edge city em São José do Rio Preto, in: Scripta Nova, revista electrónica de geografía y ciencias sociales. Universidad de Barcelona. 2003.

${ }^{65}$ Nesse sentido, o novo Plano Diretor do Eusébio, de 2008, já regulamenta a distância mínima entre os empreendimentos a fim de evitar a sensação de enclausuramento .
} 


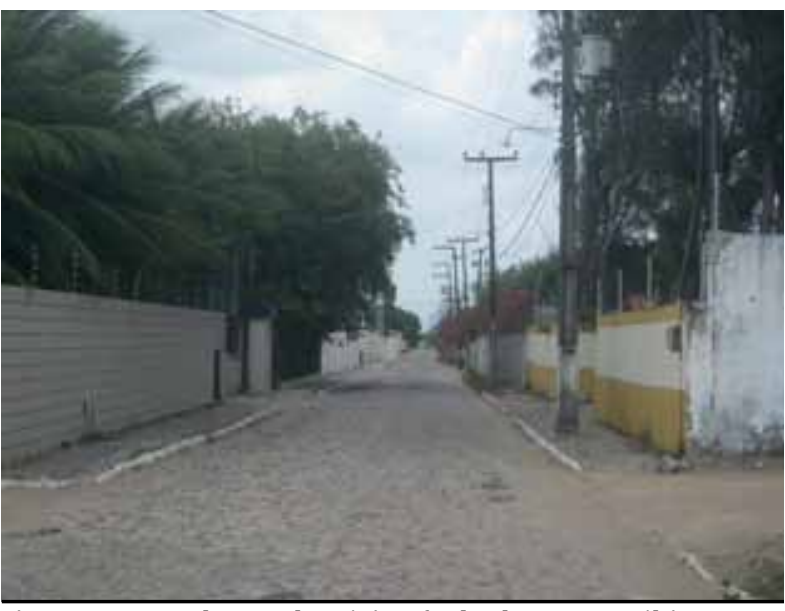

Fig. 4.83 Rua de condomínios fechados no Eusébio Fonte: acervo autora

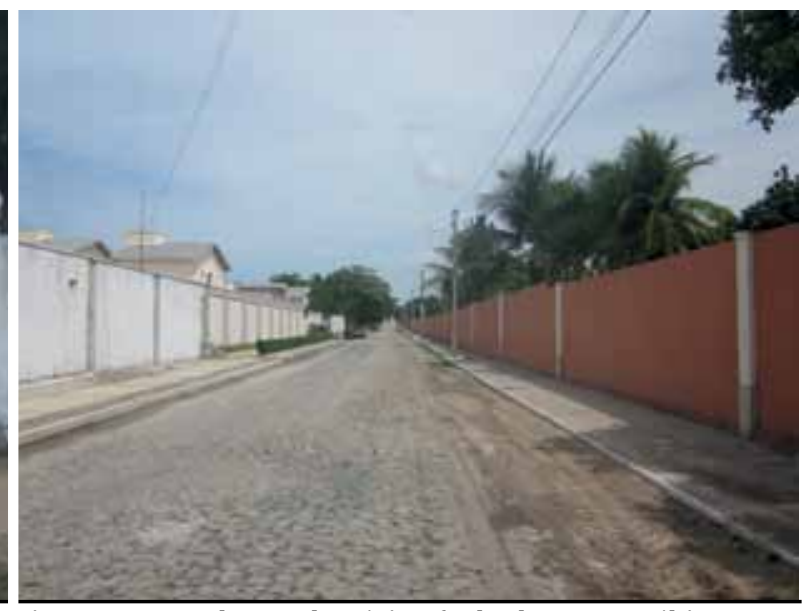

Fig. 4.84 Rua de condomínios fechados no Eusébio Fonte: acervo autora

Outro aspecto a considerar, igualmente importante, relaciona-se aos impactos ambientais advindos da implantação dos condomínios na região, rica em recursos naturais, vistos como amenidades que conferem valor aos empreendimentos.

A destruição progressiva da cobertura vegetal e dos mananciais de água, a descaracterização da paisagem natural e a progressiva impermeabilização do solo são, entretanto, algumas das consequências da transformação que resulta da construção intensiva e contínua dos condomínios no Município.

Em seu estudo De território de passagem a lugar de moradia definitiva: a urbanização recente do município de Eusébio, Ceará, Silveira (2011) alerta para o uso indiscriminado dos recursos hídricos da região do Eusébio, "degradados, privatizados e incorporados às áreas dos grandes empreendimentos fechados, particularmente os loteamentos padrão Alphaville6" ${ }^{6 \prime \prime}$, os quais, ao anexarem parte desses recursos para o seu interior, privatizando-os, impedem o livre acesso do restante da população.

A apropriação privada de espaços e de áreas de interesse público, além da mudança radical e progressiva da paisagem natural, que vem ocorrendo com o desenvolvimento dessa modalidade residencial, decorre principalmente da falta de instrumento legal específico ${ }^{67}$, que não regulamenta de maneira adequada a correta utilização desses recursos.

A transformação da região do Eusébio em lugar de moradia definitiva acarretou transformações significativas também no que se refere à ocupação do solo, sobretudo no que diz respeito à ampliação da mancha urbana.

Essa forma de urbanização, decorrente da implantação dos condomínios e loteamentos fechados, manifesta baixa densidade populacional e possui um caráter disperso ${ }^{68}$ e fragmentado ${ }^{69}$, descontínuo com relação ao tecido urbano tradicional, apresentando formas diferenciadas, conforme

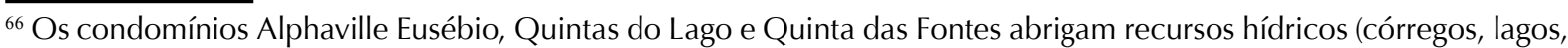
lagoas e pequenos açudes) em suas dependências, os quais muitas vezes são aterrados ou têm seu curso desviado.

${ }^{67}$ Segundo D Ottaviano, (2009, p.84), prospera atualmente uma intensa discussão entre juristas e técnicos responsáveis pelo registro imobiliário no Brasil em relação à constitucionalidade ou não do fechamento de loteamentos. Alguns argumentam que a busca por segurança é justificativa suficiente, mas outros acham que a privatização de áreas e espaços públicos é inadmissível.

${ }^{68}$ Loteamentos e condomínios horizontais, associados aos ideais de segurança, melhor qualidade ambiental e de vida, ampliam a tendência de uma cidade dispersa, propiciada pela generalização do uso do transporte automotivo individual entre os segmentos de médio e alto poder aquisitivo (SPOSITO, 2009, p.41).

${ }^{69}$ Para Salgueiro (1997, p.189), a fragmentação é própria desses processos, e corresponde à existência de enclaves distintos e sem continuidade com a estrutura socioespacial que os cerca .
} 
se constata pelas imagens. Vale notar, entretanto, que a maior parte dos diversos loteamentos se concentra ao longo da CE 040, a qual desempenha papel de indutora da urbanização. O processo remete, pois, à observação de Monclús (1998), acerca das cidades europeias, que se aplica ao caso em estudo, quando assinala que

[...] o predomínio das baixas densidades, tanto em áreas residenciais de habitações unifamiliares, como em conjuntos de habitações coletivas, apoiadas em sistemas de infra-estrutura viária e dotadas de extensos espaços livres está na base do fenômeno da dispersão urbana (1998, p.7).

A implantação crescente de condomínios e loteamentos fechados nessa região demonstra que as áreas de moradia da população mais abastada começam a ultrapassar os limites da Capital, em outros municípios da região metropolitana, embora se mantenha na mesma direção. O setor sudeste da RMF - na região do Eusébio - passa, pois, a constituir o local preferencial destes empreendimentos, reproduzindo, em escala metropolitana, a segregação já verificada na zona leste/sudeste do Município de Fortaleza, a qual corresponde às áreas de habitação das camadas de maior renda da população e de mais intensidade de investimentos.

Forma-se, de tal modo, uma periferia diferenciada, distinta do modelo verificado até a década de 1980-1990, quando esses espaços eram ocupados sobretudo pelas classes populares. A população de mais alta renda, que historicamente habitava áreas mais próximas ao Centro, começou a procurar a periferia sudeste, distante da área central, farta de recursos naturais e amenidades que lhe são caras, além da facilidade de acesso.

Verifica-se, portanto, a emergência de uma nova realidade socioespacial nessa área da Metrópole, com novas formas de uso e ocupação, consequência da instalação crescente dos loteamentos fechados e condomínios horizontais direcionados às classes média-alta e alta, provocando redefinição da estrutura urbana e alterando as formas de apropriação e produção dos espaços da periferia ${ }^{70}$ de Fortaleza. De acordo com Ojima (2007),

[...] as regiões periféricas, distantes dos centros consolidados das aglomerações urbanas e que antes eram reservadas aos conjuntos habitacionais populares, passam a ser o sonho de consumo de uma variada parcela da população, traduzindo as aspirações de uma determinada qualidade de vida (2007, p.104).

Sposito (2004), ao referir-se a empreendimentos similares no Estado de São Paulo, também assinala que os condomínios fechados estão contribuindo para alterar o significado das periferias urbanas, historicamente associadas no País à precariedade dos meios de consumo e à pobreza. O resultado disso é o delineamento de novas configurações urbanísticas.

A incidência dos condomínios horizontais fechados na região do Eusébio, pois, intensificada desde a última década, evidencia o processo de expansão metropolitana de Fortaleza relacionado às classes média-alta e alta, em direção ao eixo sudeste, marcado com suas especificidades. As figuras 4.85 e 4.86 permitem comparar, em períodos diferentes, o crescimento da área ocupada e a localização dos empreendimentos.

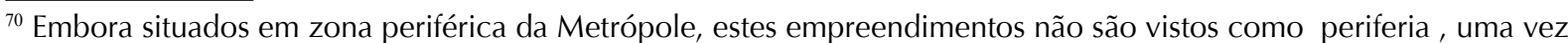
que o termo possui conotação pejorativa, sendo, portanto, mais associado ao aspecto social que ao locacional.
} 


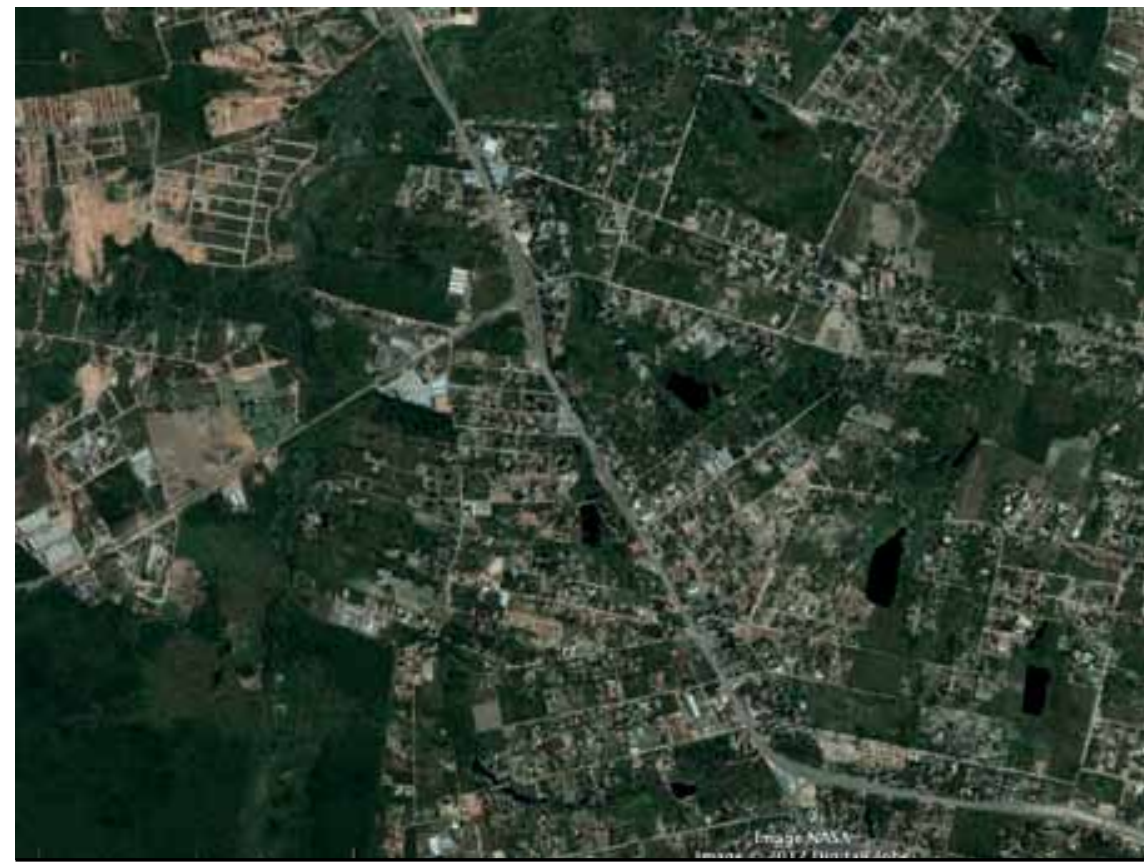

Fig. 4.85 Foto aérea Eusébio 2003

Fonte: Google Earth

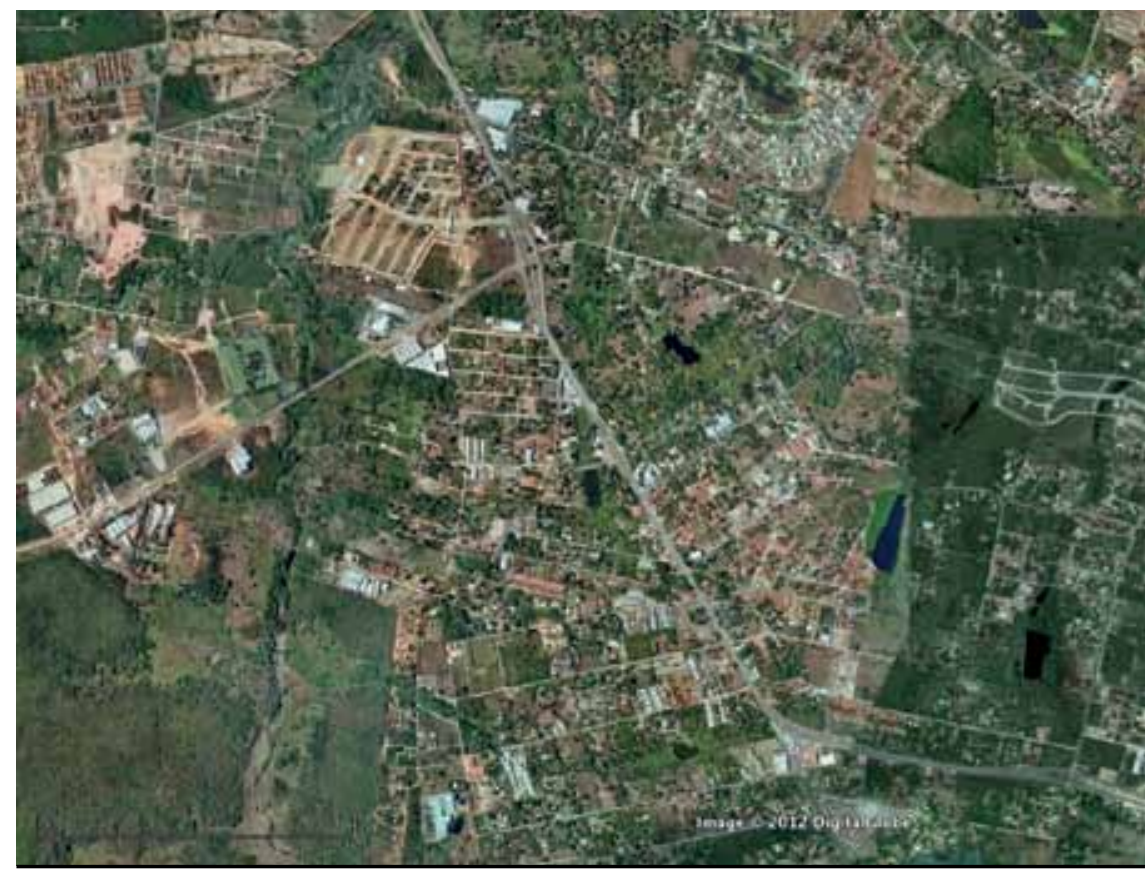

Fig. 4.86 Foto aérea Eusébio 2009

Fonte: Google Earth

\subsection{A ATIVIDADE TURÍSTICA NO LITORAL LESTE}

Na reestruturação do espaço metropolitano, particularmente no setor sudeste, a espacialização das atividades turísticas e de suas formas representa fator relevante, que merece ser avaliado. A paisagem é alterada pela instalação de novos conjuntos urbanísticos voltados para turismo e lazer, seja na produção de condomínios, seja de parques temáticos ou de resorts.

Vale ressaltar que a urbanização verificada na faixa litorânea leste está associada ao turismo, configurada com a instalação de hotéis, resorts, pousadas e restaurantes, e também ao chamado 
veraneio marítimo ${ }^{71}$, com a construção de segundas residências e de condomínios residenciais, resultado da expansão imobiliária. Essas três dinâmicas têm provocado impactos relevantes na ocupação do espaço litorâneo, ensejando um tipo de urbanização diferenciado.

A atividade turística praticada na área, conforme ressaltado no capítulo 2, se tornou um dos principais vetores da organização espacial da zona litorânea do Estado. A exuberância e a riqueza da paisagem natural, assim como a diversidade de praias e a grande extensão de áreas desocupadas constituem forte potencial para o desenvolvimento do segmento turístico denominado "sol e praia", de grande demanda, como, aliás, ocorre na maioria das praias do Nordeste ${ }^{72}$, inseridas no contexto contemporâneo da produção e consumo capitalistas.

A faixa litorânea que compõe o setor sudeste de expansão metropolitana corresponde principalmente ao litoral do Município de Aquiraz, com seus 36 quilômetros, em que se alinham as praias do Porto das Dunas ${ }^{73}$, Prainha, Presídio, Marambaia, Iguape, Barro Preto e Batoque.

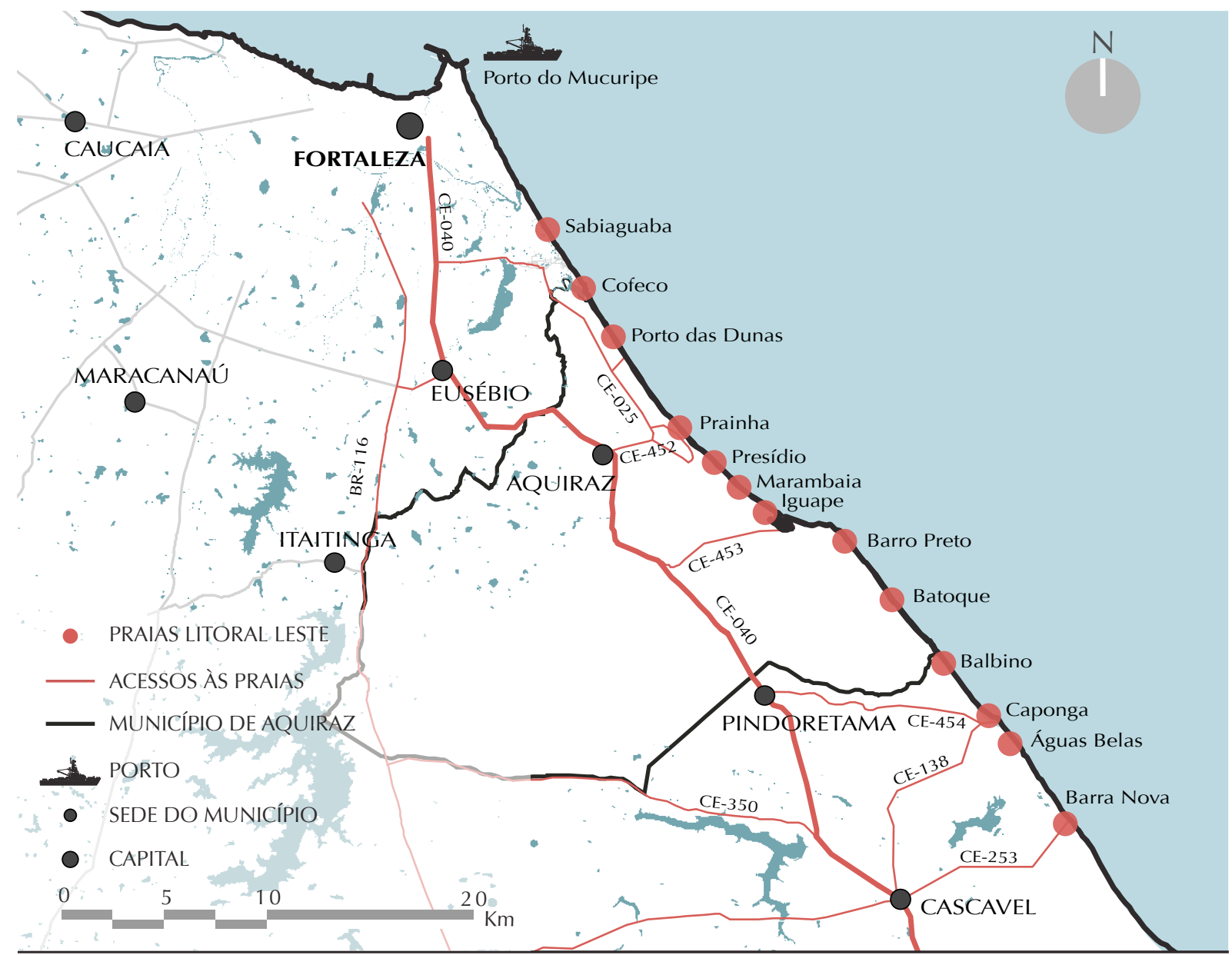

Fig. 4.87 Mapa litoral de Aquiraz: principais rodovias de acesso Fonte: elaborado pela autora

\footnotetext{
${ }^{71} \mathrm{O}$ fenômeno do veraneio marítimo, associado à construção de segundas residências, está ligado a uma prática de ócio, lazer e descanso, e é voltado preferencialmente para os residentes da Capital, e não para os turistas.

72 “O Nordeste é o grande mercado imobiliário-turístico no Brasil. Até 2010 estavam previstos para o Nordeste brasileiro R\$4,9 bilhões em investimentos privados o que correspondia a 74\% de todo o estoque de projetos para o Brasil. Só na Bahia, 43 empreendimentos hotéis, resorts, flats, parques temáticos, etc. representavam 29\% desses projetos" (Revista EXAME, 2007, p.92).

${ }^{73} \mathrm{~A}$ análise a que se procede neste item, pertinente ao desenvolvimento da atividade turística no litoral leste da Metrópole e consequentes transformações espaciais, baseia-se principalmente na urbanização verificada na região do Porto das Dunas, de ocupação mais recente, e que apresenta novas formas de tecido urbano. As demais localidades alguns poucos núcleos litorâneos (Prainha, Iguape, Presídio e Barro Preto) ainda mantêm ocupação tradicional.
} 
A acessibilidade à área é garantida pelas rodovias CE 040 e CE 025. A CE 040 foi recentemente duplicada até a cidade de Beberibe ${ }^{74}$, para atender o intenso fluxo de veículos ${ }^{75}$ que se deslocam para as praias, em busca de lazer e turismo. A CE 025, continuação da av. Maestro Lisboa, ora em fase de duplicação, liga Fortaleza ao Porto das Dunas e Prainha. Constitui rota do turismo correlacionado com o litoral leste. Em trecho mais adiante, a CE 453 liga a Praia do Iguape à CE 040 e à BR 116 (ver figura 4.87).

A prática de veraneio no litoral do Aquiraz iniciou-se ainda na década de 1970-1980, na Prainha e no Iguape, antigas vilas de pescadores e primeiras localidades ${ }^{76}$ que receberam veranistas. Estes agentes inseriram novas formas de uso no espaço, mediante a construção de segundas residências, atraindo, de certo modo, a ação do Poder Público, no que se refere à oferta de infraestrutura urbana. Desempenharam papel fundamental no que concerne às mudanças que se processaram nos espaços litorâneos da RMF, à medida que estes espaços passaram a constituir objeto de consumo de uma classe social economicamente privilegiada.

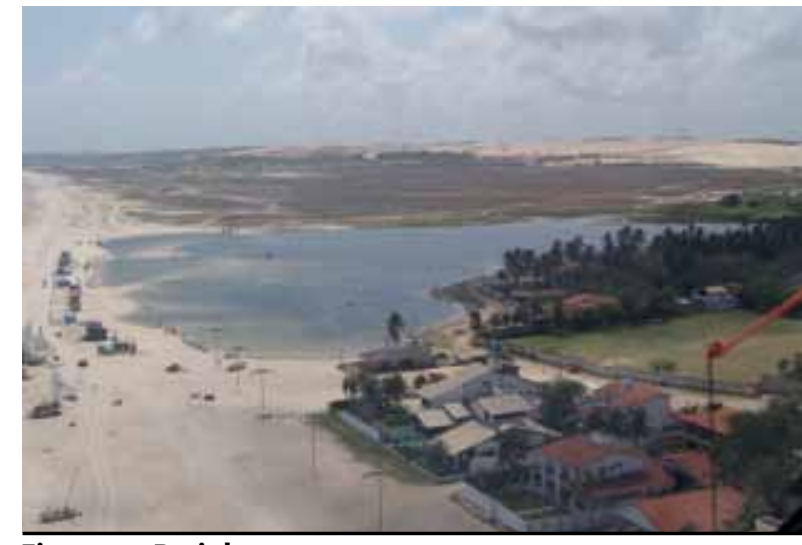

Fig. 4.88 Prainha

Fonte: Rodrigo Ponce de Leon

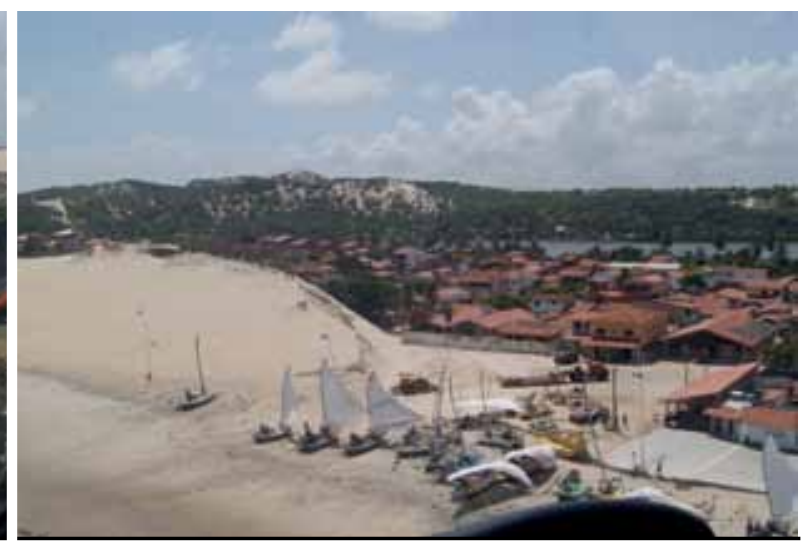

Fig. 4.89 Praia do Iguape

Fonte: Rodrigo Ponce de Leon

Posteriormente, na década de 1980-1990, a ocupação e os usos do litoral leste, sobretudo do Município de Aquiraz, modificaram-se e tornaram-se ainda mais complexos, quando a procura por espaços de veraneio se intensificou, atingindo outras praias, como o Porto das Dunas. Na década seguinte, e no contexto da progressiva valorização litorânea, a reestruturação da orla marítima se fortaleceu com a intensificação de outro fenômeno, o turismo, espacializado na orla como resultado das políticas públicas ${ }^{77}$ estaduais e ações da iniciativa privada.

Desde então, diversas outras atividades, relacionadas com lazer, turismo e veraneio surgem, alterando o uso e a produção do espaço no litoral de Aquiraz ${ }^{78}$.

\footnotetext{
${ }_{74}$ Mais um trecho da rodovia deverá ser duplicado, de Beberibe até Aracati $(63 \mathrm{~km})$, onde está sendo construído um aeroporto, previsto para ser inaugurado em abri de 2012.

${ }^{75}$ Segundo dados da Polícia Rodoviária Estadual (PRE), a CE-040 possui um volume médio diário de 90 mil veículos.

${ }^{76} \mathrm{Na}$ década seguinte foram comercializados loteamentos nas praias do Presídio e Barro Preto, também antigas vilas de pescadores, que passaram a receber veranistas.

77 "As evidências empíricas mostram que esse processo, a exemplo do que ocorre em outras regiões do litoral do Nordeste, está inserido nas atuais tendências de estruturação do espaço no mundo capitalista, com suas conseqüências em termos de novas políticas que estão sendo adotadas pelas localidades na busca de inserção econômica em uma economia globalizada" (COSTA, H. 2006, p.125).

${ }_{78}$ Atualmente, o Aquiraz possui o segundo maior parque hoteleiro do Ceará, segundo dados da Secretaria Estadual do Turismo. O município conta com 997 unidades habitacionais e 2.811 leitos
} 


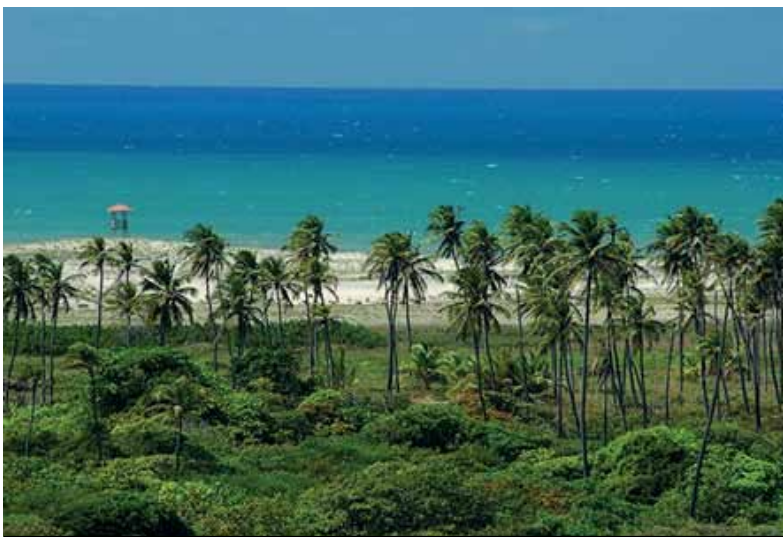

Fig. 4.90 Porto das Dunas - paisagem natural Fonte: http://mandaraportodasdunas.com

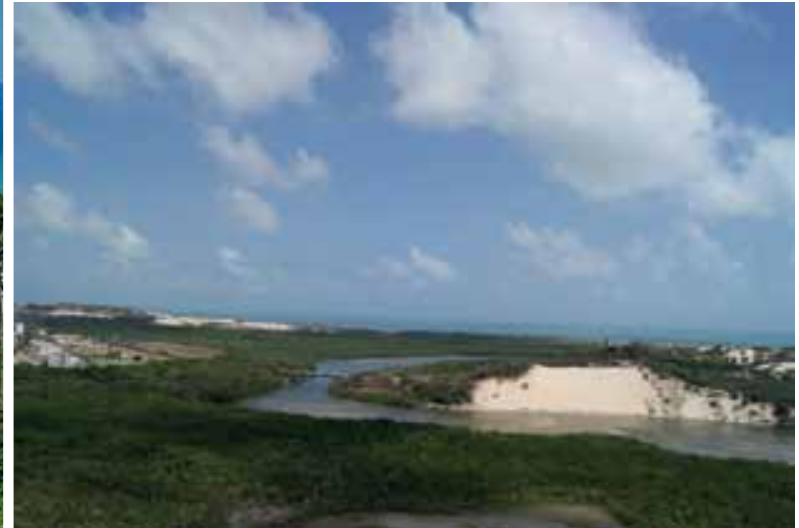

Fig. 4.91 Porto das Dunas - paisagem natural Fonte: Rodrigo Ponce de Leon

A praia do Porto das Dunas, junto à foz do rio Pacoti e mais próxima a Fortaleza, possui paisagem diferenciada, marcada por elementos naturais de grande beleza e exuberância, como os coqueirais, o rio, as dunas e a vegetação de mangue, que conferem ao lugar especial particularidade ambiental e agregam significativo valor ao local.

Como consequência do processo de expansão urbana de Fortaleza e valorização do litoral, operado pela prática do veraneio marítimo, no início da década de 1980-1990 foi criado o loteamento Porto das Dunas ${ }^{79}$, que resultou numa nova morfologia socioespacial da região. Para facilitar o acesso, como já se adiantou alhures, foi construída uma ponte sobre o rio Pacoti (na rodovia CE 025), financiada pela própria empresa responsável pelo empreendimento, ligando Fortaleza ao Porto das Dunas. Abertas então as principais vias e instalada uma infraestrutura mínima ${ }^{80}$, teve início a comercialização dos lotes, em meados dos anos 1980-1990. O Porto das Dunas logo se urbanizou e toda a extensão da orla, antes despovoada, passou a ser ocupada progressivamente.

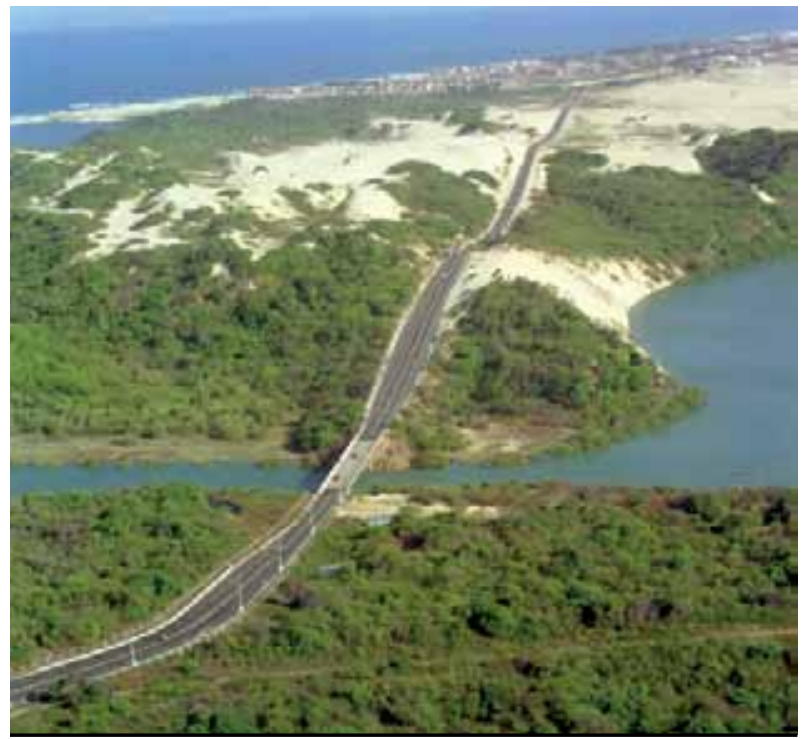

Fig. 4.92 Ponte sobre o rio Pacoti

Fonte: http://cearaexplorer.com.br

\footnotetext{
${ }^{79} \mathrm{O}$ loteamento Porto das Dunas foi concebido originalmente para atender às exigências de lazer, férias e finais de semana dos fortalezenses.

${ }^{80} \mathrm{O}$ Poder Público, pressionado pelos empresários responsáveis pelo loteamento, implantou infraestrutura no local, com a abertura de vias de acesso e adução de energia elétrica, entre outros serviços. Esses fatores viabilizaram e intensificaram a valorização dos lotes, que foram rapidamente comercializados.
} 


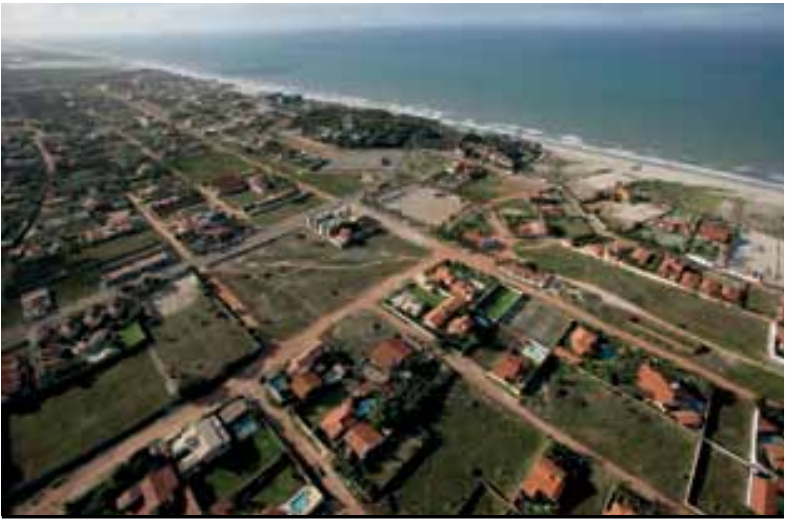

Fig. 4.93 Loteamento Porto das Dunas 2000 Fonte: Nasser Hissa Arq. Associados

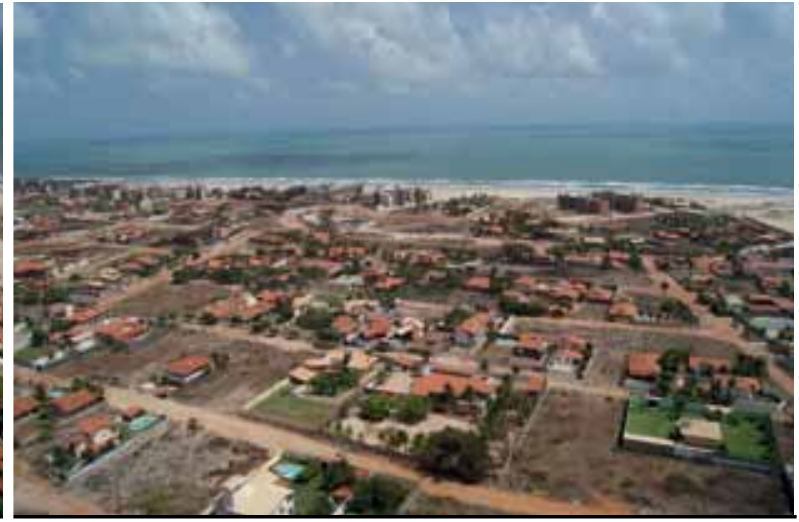

Fig. 4.94 Loteamento Porto das Dunas 2012 Fonte: Rodrigo Ponce de Leon

Com a venda dos terrenos e posterior construção das casas de veraneio, o loteamento transformou-se em pouco tempo numa espécie de bairro de perfil turístico-residencial. Ganhou visibilidade e cresceu o número de proprietários e turistas, ora seduzidos pela oportunidade de negócios, ora pela possibilidade de usufruir de novos espaços voltados para o turismo, todos atraídos pelos apelos do marketing e comercialização da paisagem.

Em 1985, de acordo com a estratégia ${ }^{81}$ montada pelos incorporadores do loteamento, foi inaugurado o Beach Park, um complexo de turismo e lazer que deu início ao desenvolvimento da atividade turística na região. Começou como um sofisticado restaurante de beira de praia e, em 1989, inaugurou seu parque aquático, considerado o maior da América Latina.

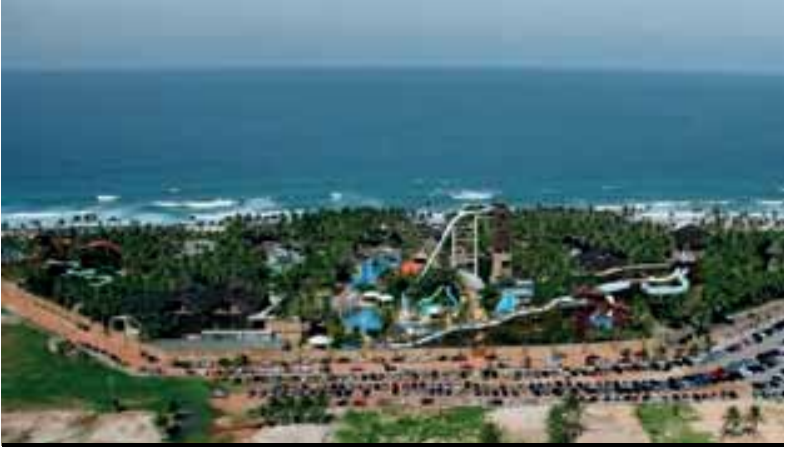

Fig. 4.95 Complexo Beach Park

Fonte: http://www.eujafui.com.br/

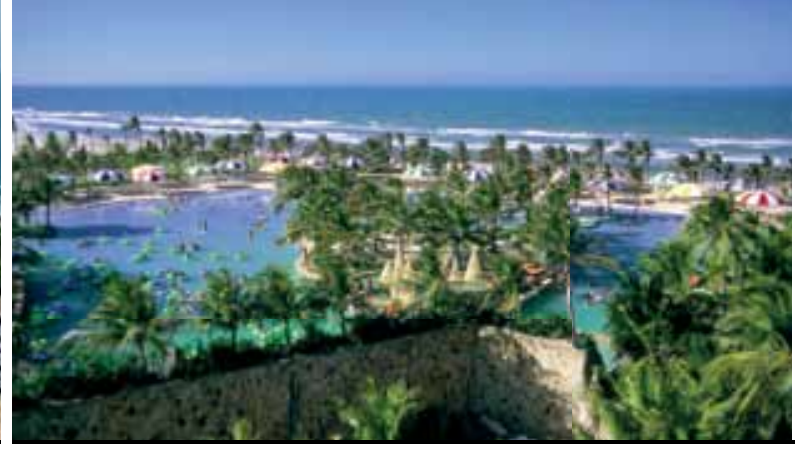

Fig. 4.96 Complexo Beach Park

Fonte: http://passioneperviaggio.blogspot.com.br/2011

O mega-empreendimento foi planejado e realizado conforme os moldes internacionais, voltado para um público de elevado poder aquisitivo, que pode pagar por lazer de luxo, quer dizer, com o mesmo padrão socioeconômico dos proprietários do loteamento. O parque foi posteriormente ampliado e transformou-se no Complexo Beach Park ${ }^{82}$, que abrange, além do parque aquático e barracas de praia, resort de luxo (com 182 apartamentos), restaurantes, lojas e condomínios de lazer. O empreendimento contribui para a atração de turistas de elevado nível de renda, inclusive estrangeiros, constituindo a grande "âncora" do Porto das Dunas, transformando o lugar no principal produto turístico do Estado.

\footnotetext{
${ }^{81}$ O turismo, na Praia do Porto das Dunas, surge fortemente relacionado com o veraneio; as duas atividades estão intimamente ligadas. Desde o inicio, a estratégia dos incorporadores do loteamento foi tornar o Porto das Dunas não somente um projeto imobiliário, mas também turístico. Para isso, fez-se necessário inserir equipamentos turísticos no loteamento (parque aquático e hotéis) e contar com o apoio do Estado para investimentos em infra-estrutura, como saneamento básico, energia elétrica e pavimentação. ${ }^{82} \mathrm{O}$ Complexo Beach Park ocupa uma área de aproximadamente $183.000 \mathrm{~m}^{2}$, por onde circulam todo ano cerca de 800 mil pessoas, conforme informações contidas no site.
} 
A urbanização verificada na Praia do Porto das Dunas apresenta-se bastante distinta da que ocorre nas demais localidades do litoral de Aquiraz, onde permanecem as antigas casas de veraneio construídas nas décadas de 1970-1980, sem apresentar alterações em sua organização espacial. O tipo de ocupação possui peculiaridades que resultaram na produção de um espaço diferenciado. O padrão e o nível dos imóveis, pelo caráter de luxo, também diferem daqueles das demais praias. Em sua maioria, as construções se destinam a um tipo de lazer sofisticado, próprio de uma população de elevado poder aquisitivo e de turistas estrangeiros.

A presença de resorts, condomínios de luxo e grandes mansões é exemplo de um modelo de atividade turística globalizada e elitista, consolidando a praia do Porto das Dunas como polo turístico internacional, direcionado para uma população de alto poder aquisitivo. No entender de Sampaio (2009),

[...] o Porto das Dunas apresenta realidade voltada ao consumo turístico de luxo. Em seus elementos, comprova-se haver sido a localidade efetivamente planejada para a venda de lazer - iniciada pelo veraneio e intensificada pelo turismo, tendo como principal elemento de negociação, a paisagem (2009, p.92).

Nesse sentido, a atividade turística ali desenvolvida se insere nas proposições de Mullins (1991) acerca da "urbanização turística", quando ressalta que os centros turísticos constituem atualmente uma nova e extraordinária expressão da urbanização, ao se transformarem em locais construídos unicamente para o consumo. Os empreendimentos ali instalados mostram-se direcionados para atendimento da demanda de pessoas que procuram o lazer e o contato com a natureza, todavia sem dispensar o luxo, o conforto e as facilidades da vida moderna.

Nos últimos anos, muitas das segundas residências converteram-se em residências principais, beneficiadas com a proximidade de Fortaleza, enquanto condomínios de lazer de elevado padrão se multiplicaram, constituindo novo segmento do mercado imobiliário, transformado em mercadoria disputada.

O Porto das Dunas vem passando, dessa forma, por sucessivas reestruturações, que modificaram a forma de usar e ocupar o espaço nos últimos 30 anos. Primeiramente, houve a expulsão dos pescadores da área; depois, o loteamento da gleba e a construção das primeiras casas de veraneio; posteriormente, a instalação de equipamentos de turismo e, mais recentemente, a proliferação de condomínios de lazer.

No que se refere aos resorts, sua implantação demanda extensas áreas para abranger um programa diversificado de lazer, diretamente relacionado com localizações privilegiadas, como a proximidade do mar, lagoas e rios. Embora instalados distantes de áreas urbanizadas, requerem acessibilidade fácil e excelente infraestrutura de apoio, uma vez que o próprio resort já é um destino em si. São vários os resorts já instalados no Porto das Dunas e há muitos ainda em construção. Em bom número, são do tipo "resort integrado" e situam-se todos junto da orla, ocupando considerável parte das faixas de praia.

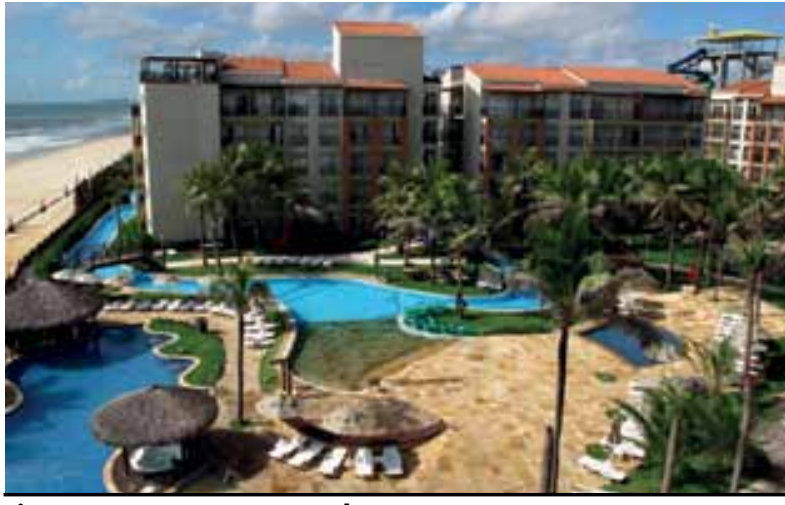

Fig. 4.97 Resorts/ Porto das Dunas Fonte: http://www.viajarpelomundo.com/2011/05

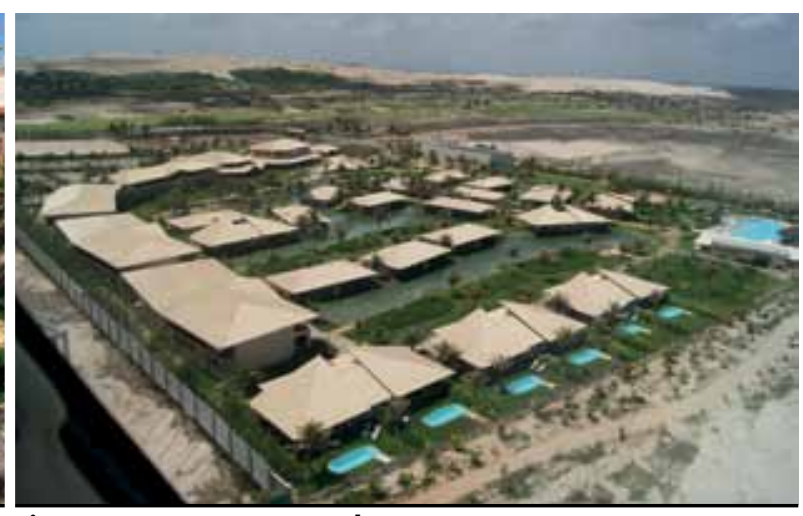

Fig. 4.98 Resorts/ Porto das Dunas Fonte: Rodrigo Ponce de Leon 
Quanto aos condomínios de lazer, surgidos recentemente ${ }^{83}$, vieram substituir os antigos loteamentos de residências de férias e fim de semana, comercializados nos anos 1970-1990. São empreendimentos com características diferenciadas, compostos de unidades residenciais de alto padrão, relacionados com veraneio marítimo. Os usuários em geral são habitantes da Capital, de nível de renda elevada, ou investidores estrangeiros, que adquirem um imóvel próprio para passar temporadas, alugando-o durante o resto do ano.

Trata-se de versão tipológica nova, das residências secundárias, traduzida em condomínios de apartamentos (de três ou quatro pavimentos), organizados em torno de grandes áreas de lazer e com fácil acesso à orla. Esses conjuntos conformam uma espacialização diferenciada, alterando substancialmente a paisagem litorânea.

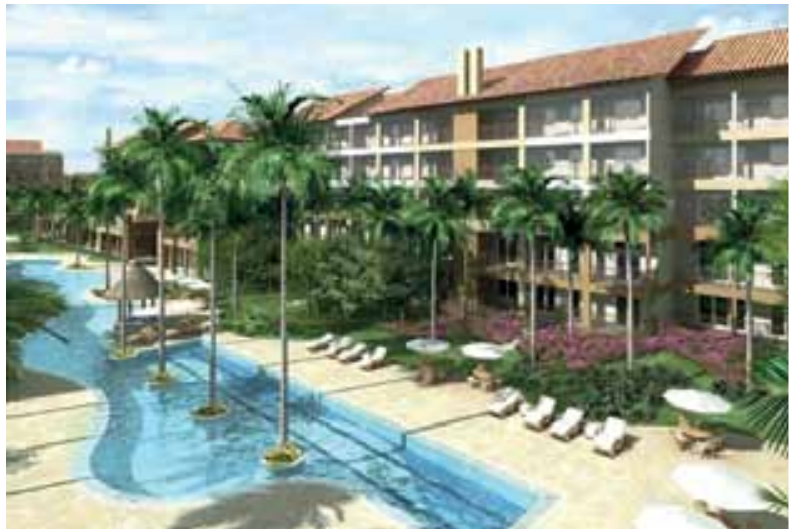

Fig. 4.99 Condomínio de lazer/ Porto das Dunas Fonte: www.afci.com.br/beach-park-wellness-resort.htm

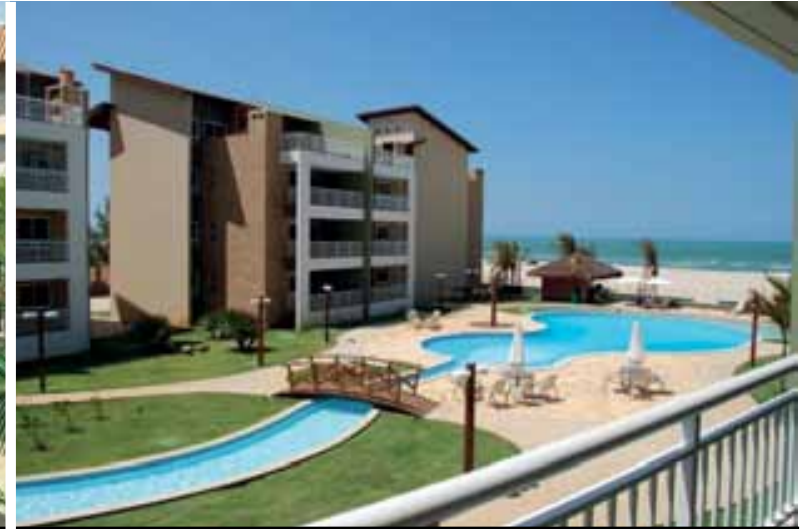

Fig. 4.100 Condomínio de lazer/ Porto das Dunas Fonte: http://fortaleza.olx.com.br/pictures/

Assim como os resorts, os condomínios trazem consigo a noção de confinamento espacial, com seus muros, cercas elétricas e acesso restrito, constituindo, a exemplo dos condomínios residenciais da região do Eusébio, verdadeiros "enclaves" urbanos, reforçando os padrões de segregação socioespacial. Esses empreendimentos introduzem, em seus projetos, inovações urbanas que se concentram, sobretudo, nos aspectos relacionados com segurança, privacidade e exclusividade, fortemente explorados pelo mercado imobiliário.

Em vista de sua forma de ocupação, o Porto das Dunas, como um todo, no entender de Cruz (2007), é considerado verdadeiro "enclave":

Assim, a dinâmica que anima o Porto das Dunas em geral, seja pelo turismo, com os resorts, ou pelos condomínios, retrata uma exacerbação do lazer de luxo, revelando a predominância do caráter de simulacro que domina este enclave. Ou seja, há uma reprodução de aspectos desejados da vida, uma imitação do que seria a vivência perfeita e feliz, uma simulação do verdadeiro paraíso, fingindo estar-se distante dos problemas urbanos e em sintonia com a natureza $(2007$, p.25).

Os condomínios de lazer estão voltados, como foi dito, para o veraneio marítimo, prática caracterizada por alguns autores como "turismo residencial", o qual faz surgir empreendimentos novos, com características diferenciadas e fortemente relacionados com a atividade turística. São todos implantados junto à orla e próximos a equipamentos como hotéis, resorts e parque aquático, evidenciando uma tendência particular de urbanização do litoral da RMF.

O programa é bastante similar em todos eles e compreende geralmente, além dos apartamentos (ou "bangalôs") com área de 60 a $350 \mathrm{~m}^{2}$ e estacionamentos, ampla estrutura de serviços e lazer, que inclui: clube privativo, salão de eventos, restaurantes, barraca de praia, complexo aquático com deck,

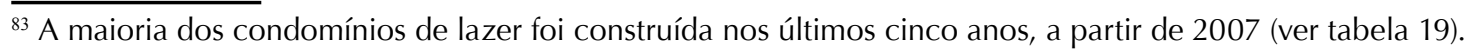


sauna, quadras poliesportivas, play ground, kids club, salão de jogos, lan house, home theatre, espaço gourmet, churrasqueira, área verde com projeto paisagístico, lagos artificiais, pistas de cooper e ciclovias, spa, fitness center, etc. Além de guaritas blindadas e sistema integrado de segurança com circuito de monitoramento de TV, alguns oferecem itens ainda mais específicos e sofisticados, como pista de quadriciclos, campos de golfe, quadras de tênis, campos de futebol, lojas de conveniência, etc.

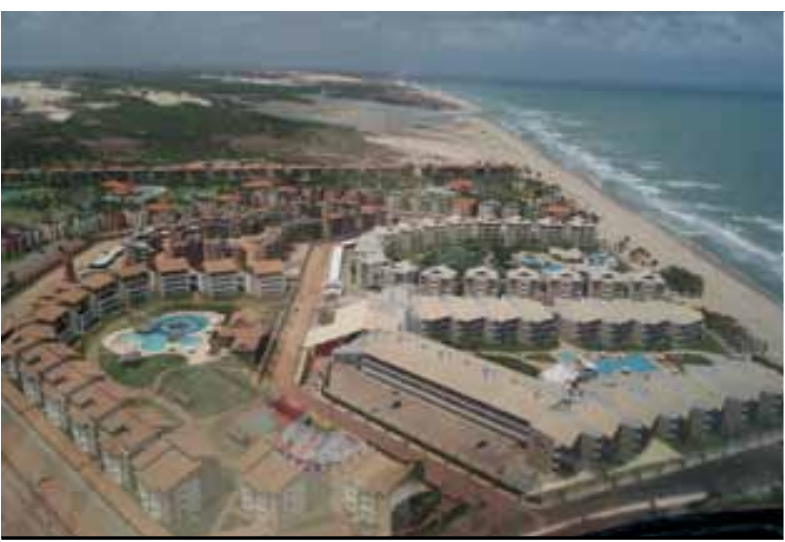

Fig. 4.101 Condomínios no Porto das Dunas Fonte: Rodrigo Ponce de Leon

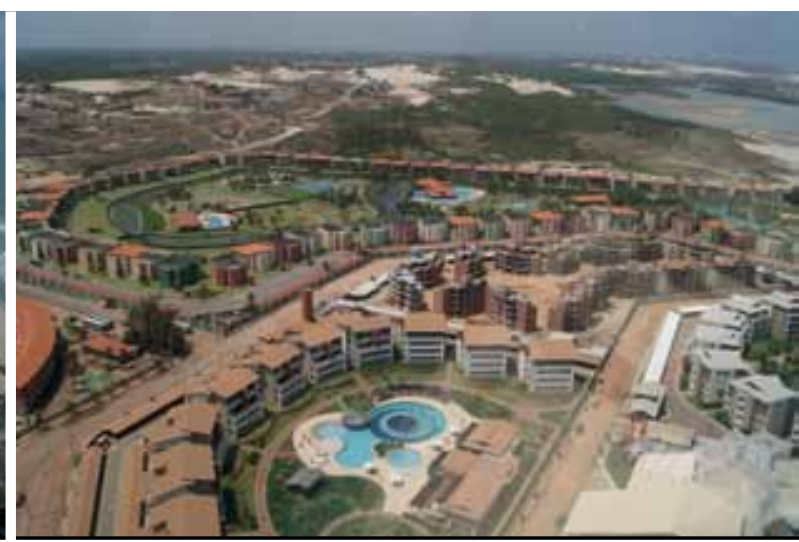

Fig. 4.102 Condomínios no Porto das Dunas Fonte: Rodrigo Ponce de Leon

Nas duas últimas décadas, os condomínios e equipamentos turísticos proliferaram na orla, alterando significativamente a feição das praias, que perdem as características originais de antigas vilas de pescadores, transformadas, que foram, em localidades urbanas, valorizadas pelo capital.

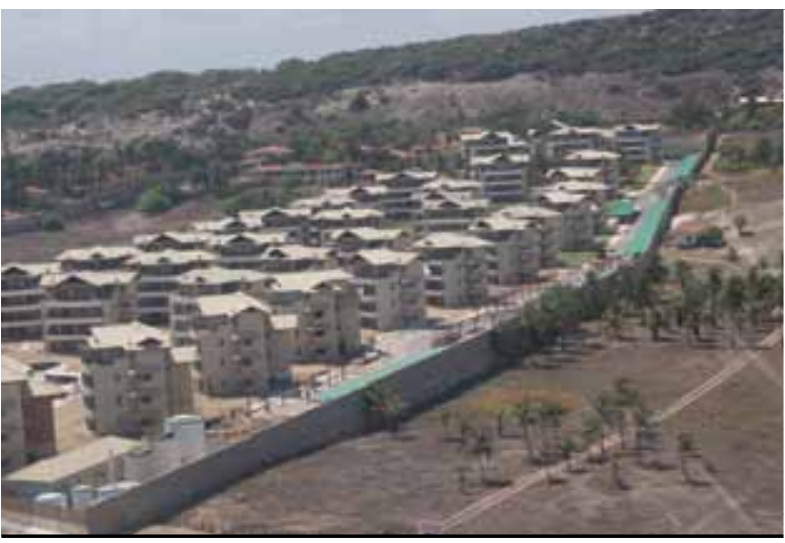

Fig. 4.103 Ocupação Porto das Dunas Fonte: Rodrigo Ponce de Leon

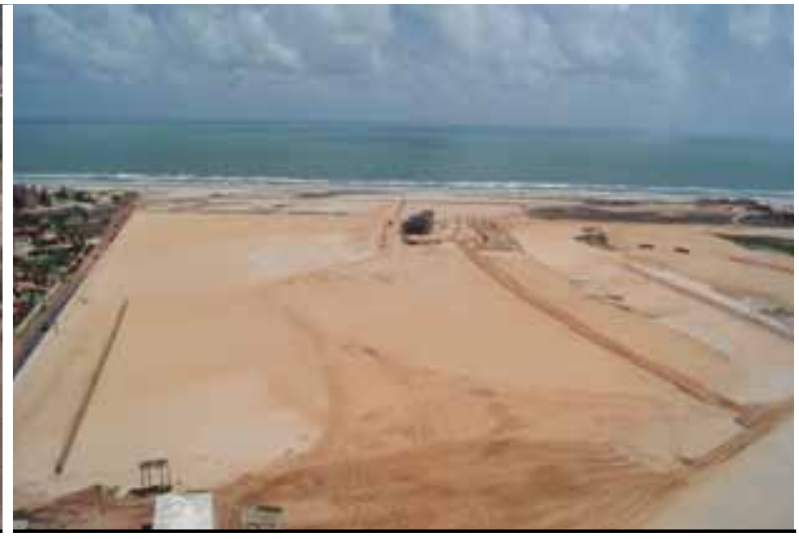

Fig. 4.104 Ocupação Porto das Dunas Fonte: Rodrigo Ponce de Leon

Um aspecto a considerar na urbanização da faixa litorânea é a forte articulação entre o turismo e o mercado imobiliário, associados aos investimentos estrangeiros e à ação do setor público. No que se refere aos investimentos surgidos nessa área,

[...] é possível notar uma relação dialética entre as duas dinâmicas, na medida em que o turismo valoriza o setor imobiliário ao mesmo tempo em que se beneficia dele, esboçando uma tendência de internacionalização do fenômeno, com a entrada do capital estrangeiro, embora o capital imobiliário seja predominantemente local (...) Os interesses desses setores são semelhantes quanto às formas de produção e consumo do espaço, apropriando-se dos lugares mais privilegiados junto ao litoral, caracterizados pelo confinamento espacial e privatização da praia (PAIVA, 2011, p.292).

Os capitais imobiliário e turístico estão assim intimamente relacionados, sendo responsáveis pela transformação do espaço litorâneo dessa parte da Metrópole, que elegem como local preferencial do lazer de luxo das classes mais abastadas de Fortaleza e de turistas internacionais. Essa parceria é 
percebida nos diversos lançamentos que surgem ao longo da orla, desde os resorts integrados (que abrangem estruturas diversificadas de meios de hospedagem, loteamentos, segundas residências, e equipamentos de comércio e serviços), aos terrenos e condomínios de lazer.

Em vista disso, o litoral do Município de Aquiraz tornou-se uma localização das mais valorizadas nos últimos anos. Segundo o mercado imobiliário, tem o custo do metro quadrado ${ }^{84}$ mais elevado (R\$ 5.048,36) de toda a Região Metropolitana de Fortaleza, abaixo apenas daquele praticado no bairro da Aldeota ( $R \$ 5.649,81)$. O uso do solo voltado para o lazer, o turismo e a moradia de luxo é responsável pela progressiva valorização. De acordo com dados do SECOVl ${ }^{85}$,

Aldeota e Porto das Dunas foram as áreas com maior volume de vendas no primeiro semestre de 2011. O bairro conhecido por ser o coração de Fortaleza, onde tudo se concentra (Aldeota), vendeu R $\$ 228,56$ milhões com valor médio do $\mathrm{m}^{2}$ em $\mathrm{R} \$ 5.649,81$. O Porto das Dunas, a grande revelação e com estimativa de que se mantenha, gerou $R$ \$186,04 milhões, com valor em média de $R$ \$ 5.048 o $\mathrm{m}^{2}$. Segundo Sérgio Porto, presidente do SECOVI, vários são os atrativos para local: o maior parque aquático da América Latina, a ponte do Sabiaguaba (do Cocó), que vai se ligar ao $4^{\circ}$ Anel Viário, a duplicação da av. Maestro Lisboa, o Aquaville, o Alphaville, os hotéis luxuosos em torno com campo de golfe, etc. ${ }^{86}$

Esse fato confirma o processo acelerado da urbanização verificado nessa área. As placas indicativas de oferta de imóveis são inúmeras, transformando a praia numa "vitrine" de vendas. São intensas as campanhas publicitárias, que apelam para o caráter de "paraíso privado", próprio dos empreendimentos cada vez mais fechados e exclusivos. É também grande a quantidade de edifícios em construção, conferindo ao local, em muitas áreas, aparência de verdadeiro canteiro de obras.

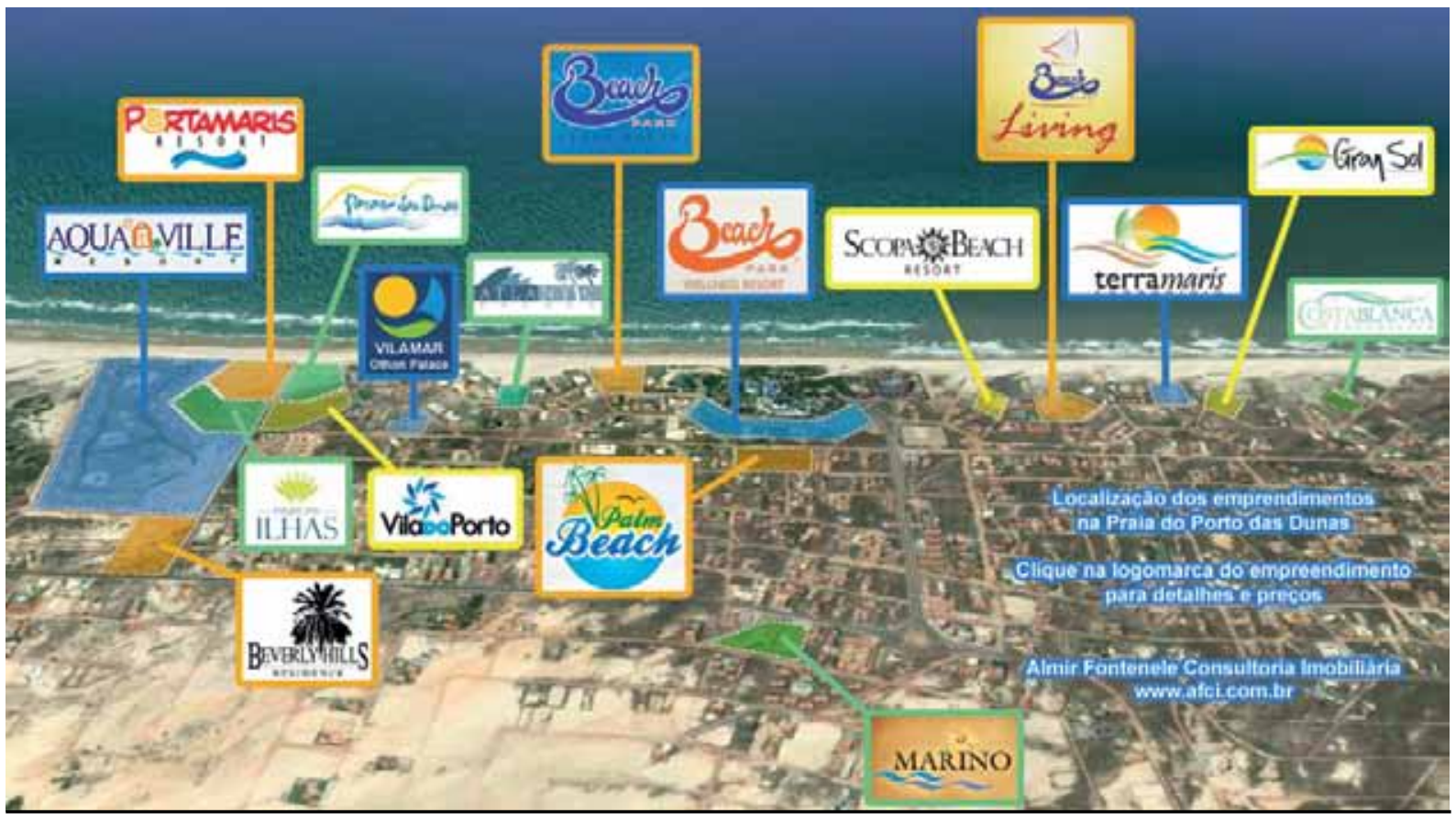

Fig. 4.105 Porto das Dunas - indicação de empreendimentos à venda

Fonte: www.afci.com.br

\footnotetext{
${ }^{84}$ Dados fornecidos pelo SECOVI.

${ }^{85}$ Sindicato das Empresas de Compra, Venda e Administração de Imóveis do Ceará (SECOVI-CE). O volume total de vendas na área metropolitana de Fortaleza, no primeiro semestre de 2011 foi $\mathrm{R} \$ 1,142$ bilhões, com área total de 414.057,74 m² segundo o presidente da SECOVI, Sérgio Porto, revelando um acréscimo de 11\% em relação ao mesmo período de 2010. ${ }^{86}$ Disponível em: http://www.jsimoes.com.br/v03/noticias.php?id=542, segundo dados divulgados pelo INPES -Instituto de Pesquisas e Estatísticas do SECOVI.
} 
TABELA 20 - EMPREENDIMENTOS SITUADOS NO LITORAL DO AQUIRAZ

\begin{tabular}{|c|c|c|c|}
\hline EMPREENDIMENTO & TIPO & ÁREA(ha) & LANÇAMENTO \\
\hline Acquaville Resort & Resort/condominio & 20,0 & 1997 \\
\hline Vila do Porto & Condomínio & 2,3 & 2010 \\
\hline Paraíso das Dunas & Condomínio & 1,9 & 2010 \\
\hline Portamaris Residence & Condomínio & 2,3 & 2009 \\
\hline Parque das Ilhas & Condomínio & 1,9 & 2008 \\
\hline Beverly Hills & Condomínio & 2,6 & 2009 \\
\hline Oceani Resort & Hotel & 1,9 & 2005 \\
\hline Atlantic Palace & Condominio & 1,9 & 2008 \\
\hline Vilamar Othon Palace & Condomínio & 0,7 & 2007 \\
\hline Beach Park Acqua Resort & Resort/condominio & 1,5 & 2008 \\
\hline Palm Beach & Condomínio & 1,3 & 2009 \\
\hline Beach Park Suítes \& Resorts & Resort & 17,0 & 1996 \\
\hline Beach Park Wellness Resort & Resort/condominio & 17,0 & 2011 \\
\hline Scopa Beach Resort & Resort & 6,7 & 2008 \\
\hline Beach Park Living & Resort/condominio & 13,0 & 2009 \\
\hline Terramaris & Condomínio & 7,2 & 2008 \\
\hline Condomínio Gran Sol & Condomínio & 0,7 & 2010 \\
\hline Costa Blanca & Condomínio & 0,7 & 2010 \\
\hline Porto das Tulipas & Condomínio & 1,3 & Em construção \\
\hline Mandara Lanai & Condominio & 9,0 & Em construção \\
\hline Mandara Kauai & Condomínio & 8,6 & Recém lançado \\
\hline Golfe Ville Porto das Dunas & Resort integrado & 55,0 & Em construção \\
\hline Aquiraz Riviera & Resort integrado & 285,0 & 2011 ( $1^{\mathrm{a}}$ etapa $)$ \\
\hline Beach Place Resort Residence & Resort integrado & 6,0 & 2010 \\
\hline Costa Verde & Condomínio & $\mathrm{N} / \mathrm{D}$ & Em construção \\
\hline The Palm Apartment \& Resort & Condomínio/resort & $\mathrm{N} / \mathrm{D}$ & Em construção \\
\hline Reserva Dunas & Condomínio & $N / D$ & Em construção \\
\hline Solarium Residence & Condomínio & 2,0 & Em construção \\
\hline
\end{tabular}

Fonte: organizado pela autora 


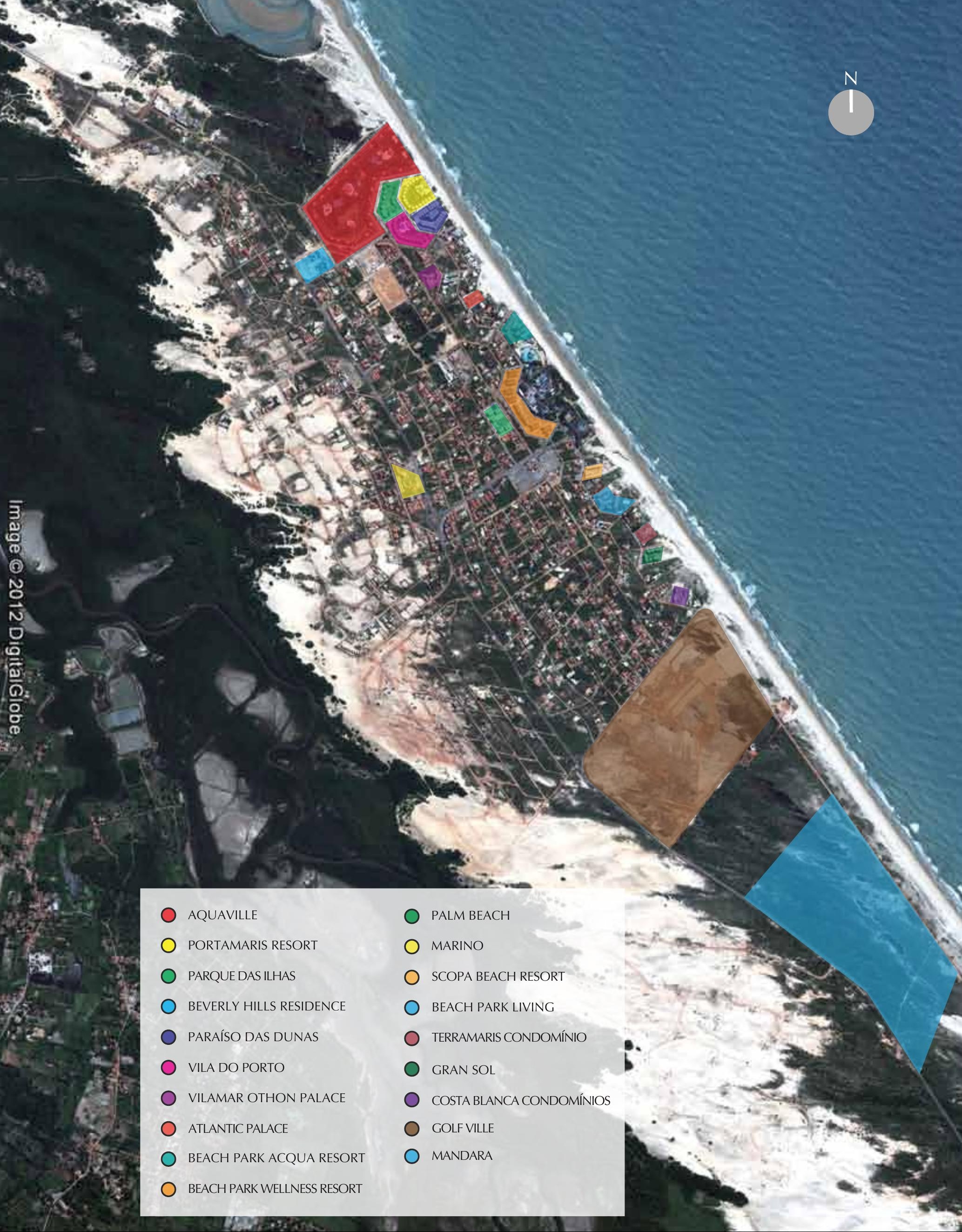

Fig 4.106 Porto das Dunas com localização dos empreendimentos

Fonte: Google Earth - elaborado pela autora 
Esses empreendimentos, que envolvem investidores de grande porte, modificam a lógica de valorização da terra e resultam na alteração do espaço junto às zonas de praia, contribuindo para expandir a urbanização na faixa litorânea. A atividade turística e imobiliária aí desenvolvida, ao gerar novos usos e formas de ocupação, é responsável pelo surgimento de novas espacialidades e novos fluxos metropolitanos.

A proximidade da Capital, a facilidade de acesso e a instalação progressiva de moradias e equipamentos de turismo e lazer promoveram a urbanização crescente dessa área, contribuindo para o acelerado (e particular) processo de metropolização verificado no espaço litorâneo.

Interessante é notar que a região do Porto das Dunas se apresenta marcada por identidade própria, diferenciando-se substancialmente do restante do Município, como se fosse uma extensão de Fortaleza. Apesar de localizar-se no Aquiraz, não há qualquer relação com a Sede do Município, que fica a cerca de oito quilômetros do local. Assim como os habitantes dos condomínios do Eusébio, os moradores e turistas do litoral de Aquiraz mantêm completa dependência com a Capital, desde o abastecimento, em todos os níveis, uma vez que a área ainda se mostra deficiente no que se refere aos equipamentos de comércio e serviços.

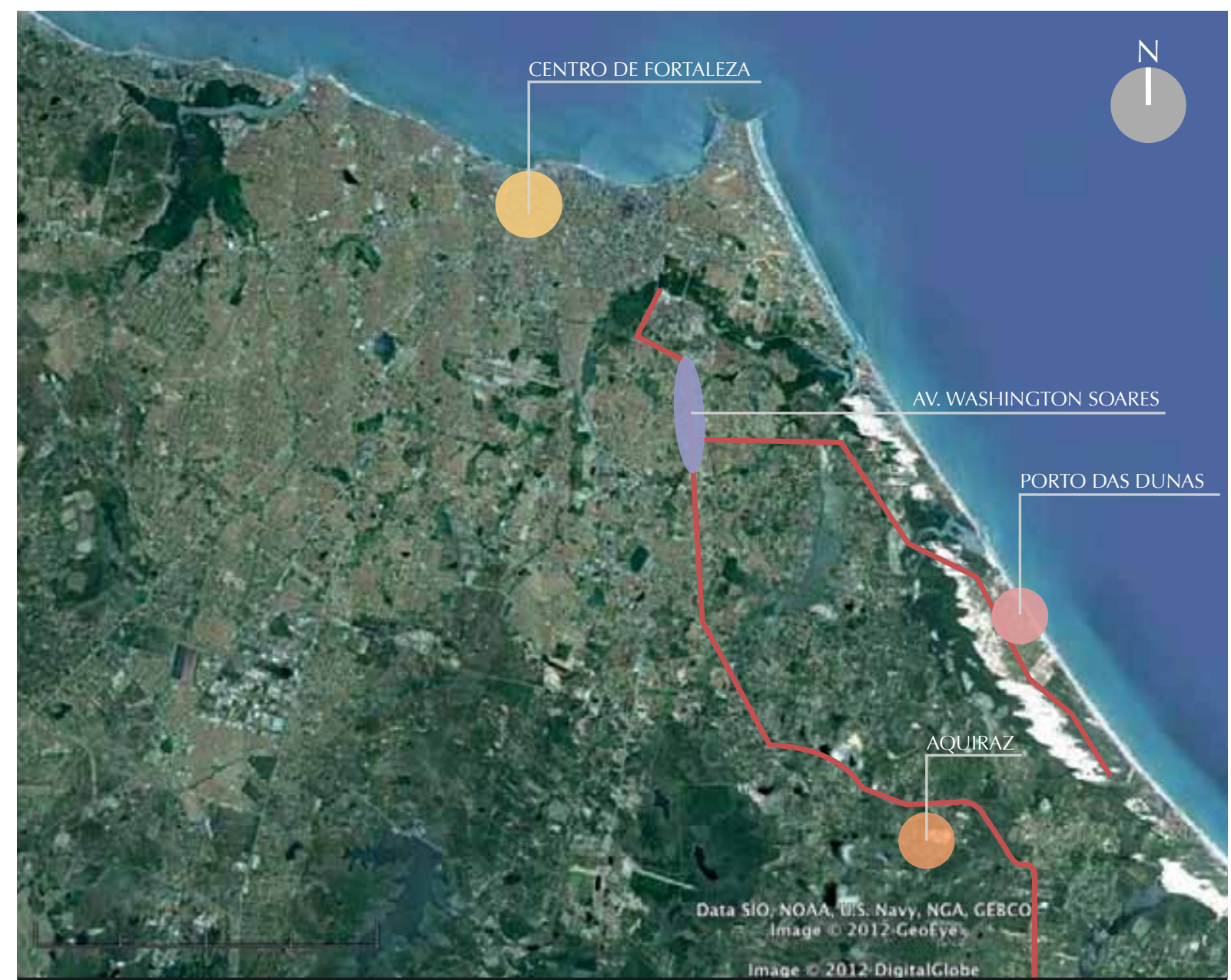

Fig. 4.108 Mapa com localização Porto das Dunas, Aquiraz e Fortaleza Fonte: Google Earth - elaborado pela autora 
Ainda com relação ao Porto das Dunas, se por um lado, o local apresenta vantagens substanciais para a prática do turismo, como a beleza da paisagem, a abundância de recursos naturais ${ }^{87}$, a proximidade de Fortaleza e a facilidade de acesso, por outro lado, são detectados graves problemas relativos ao incremento da atividade na região, sobretudo no que concerne à ausência de infraestrutura e aos aspectos socioambientais, com impactos bastante negativos.

No que se refere à infraestrutura urbana, não há saneamento básico ${ }^{88}$ nem iluminação pública eficiente, assim como faltam coleta seletiva de lixo, segurança pública, transporte público e pavimentação das vias secundárias. Os problemas ambientais são percebidos na privatização da faixa de praia em diversos pontos, na devastação das dunas, no assoreamento dos riachos, na retirada da cobertura vegetal e na apropriação indevida dos recursos naturais, como a APA do rio Pacoti. Somam-se ainda os problemas decorrentes da segregação socioespacial, da especulação imobiliária e da ocupação desordenada.

Nessa forma de produção do espaço, torna-se necessária uma política de controle urbanístico dos diversos empreendimentos, na maioria das vezes inseridos em áreas de reservas naturais, sem respeito às preexistências ambientais, configurando situações que não consideram os aspectos topográficos, a preservação da vegetação e a proteção de dunas e lagoas. Os equipamentos turísticos de maior porte, como o Aquiraz Riviera, por exemplo, criam as chamadas "unidades de conservação ambiental"; entretanto, embora preservados, os recursos naturais tendem a ser privatizados e, tal como os espaços construídos, são também apropriados pelos visitantes.

Constata-se, pois, a ocorrência de forte relação entre os processos de expansão e de transformação urbana resultantes da atividade turística na Metrópole e o agravamento dos problemas ambientais. Segundo Farias Filho (2011), em todo o território metropolitano, a zona litorânea é a que passa pelas mais intensas transformações e pelo mais diversificado conjunto de problemas urbanísticoambientais. Daí a necessidade de se verificar o desempenho das políticas urbana e ambiental nestas áreas.

As unidades de paisagem da zona litorânea metropolitana constituem um conjunto de ambiente dinâmico e frágil, que se agrava com a implantação indiscriminada dos processos de urbanização, industrialização, exploração irracional de recursos naturais e especulação imobiliária. A tendência de cenário futuro é a desestabilização do equilíbrio ambiental, surtindo como efeitos negativos: a erosão, contaminação do solo e das águas, diminuição dos recursos naturais e remoção das comunidades tradicionais do suporte de vida e redução da qualidade de vida das mesmas (FARIAS FILHO, 2011, p.9).

Apesar dos problemas mencionados, a região do Porto das Dunas conhece valorização cada vez maior no mercado imobiliário, e é considerada o principal polo de lazer e turismo do Estado, depois de Fortaleza, com a multiplicação de grandes empreendimentos turísticos e imobiliários.

\footnotetext{
${ }^{87}$ O Porto das Dunas situa-se na Unidade Geoambiental da Planície Litorânea e compreende os sistemas ambientais de faixa de praia, cordão de dunas móveis e fixas e lagoas costeiras, inserindo-se, mais especificamente, na planície flúviomarinha do Rio Pacoti, compondo ambiente de significativa riqueza natural (SAMPAIO, 2009 p.57).

${ }^{88}$ Todos os empreendimentos construídos devem possuir estação de tratamento de esgotos.
} 


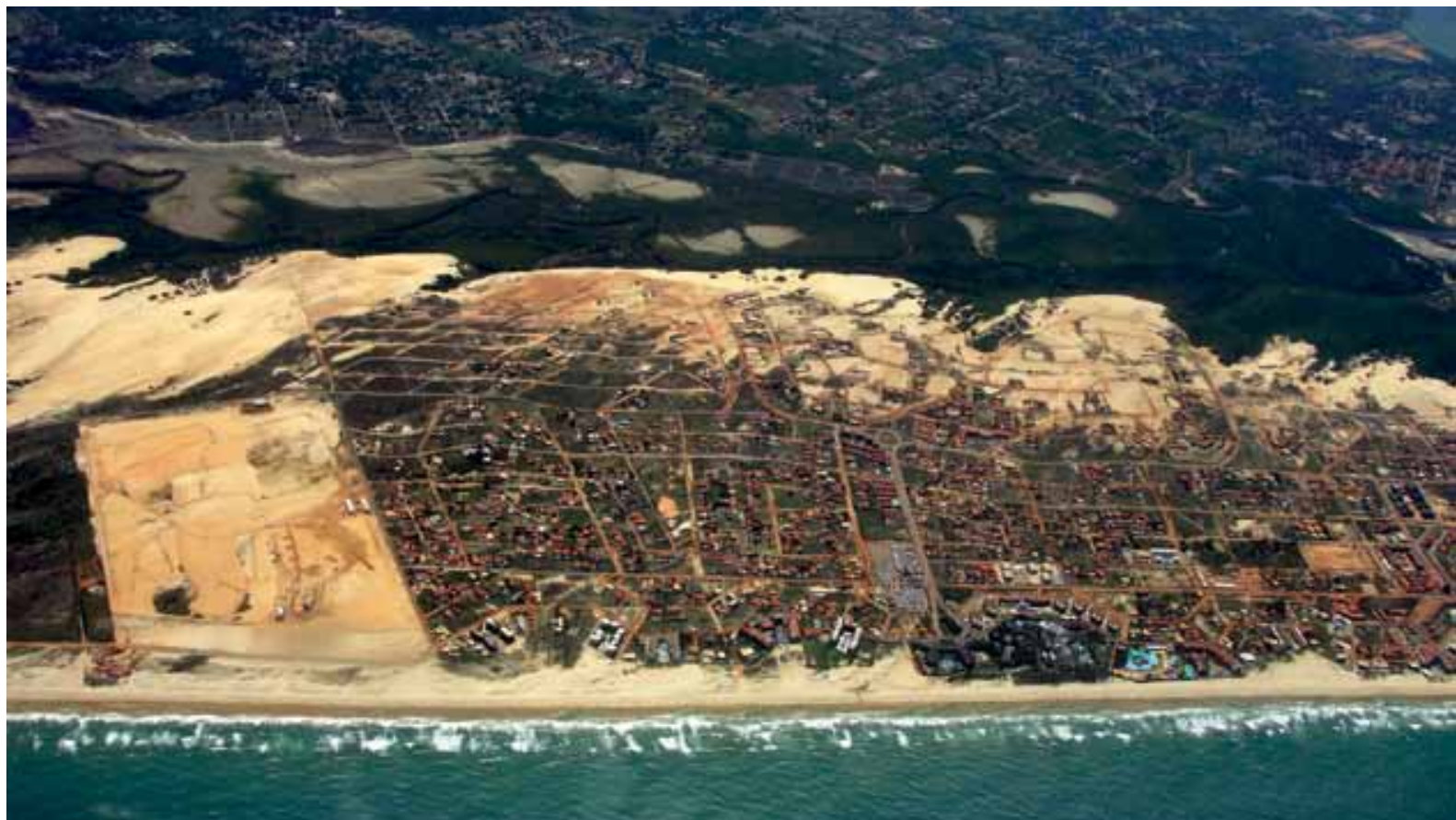

Fig. 4.109 Porto das Dunas

Fonte: http://www.skyscrapercity.com/

A espacialização das atividades turísticas no território faz parte, pois, da compreensão do processo de reestruturação do espaço metropolitano de Fortaleza, o qual está diretamente associado a ações do setor imobiliário, interferindo intensamente no mercado de terras da RMF. As intervenções no sistema viário (nas escalas regional e intraurbana), assim como a implantação de grandes equipamentos, passam a determinar progressiva apropriação de áreas com maior valor paisagístico. Dessa maneira, começam a se destacar, na paisagem metropolitana, corredores de desenvolvimento orientados pelas ações do mercado imobiliário, mas diretamente vinculadas às decisões do Poder Público, em suas diferentes esferas de governo.

Pelo que foi demonstrado, percebe-se que a expansão urbana verificada nessa área da Metrópole acontece preferencialmente em decorrência dos fluxos turísticos e imobiliários, produzindo espacialidades diferenciadas, contrariando assim o padrão centro-periferia. A apropriação, produção e uso desses espaços são voltados, sobretudo, para as práticas de consumo do lazer e do turismo, direcionados para os turistas e para uma população de maior nível de renda. A urbanização resultante da atividade turística na RMF, pois, resulta numa espécie de "periferização dos ricos", uma vez que promove a ocupação dos espaços litorâneos por uma população de maior poder aquisitivo.

Além da concentração formada na região do Porto das Dunas, a ocupação continua a ocorrer nessa área de forma progressiva, em núcleos mais dispersos, ora próximos à CE 025 (Condomínio Alphaville Fortaleza), ora em terrenos junto à orla, entre o Porto das Dunas e a Prainha (os condomínios/resorts Golf Club Porto das Dunas e Mandara); entre a Prainha e o Iguape (Aquiraz Riviera Resort ${ }^{89}$ ) e entre o Iguape e o Barro Preto (Carmel Charme Resort) (ver figuras 4.110 e 4.111).

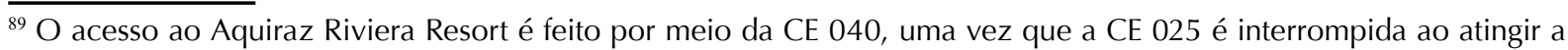
Prainha. 


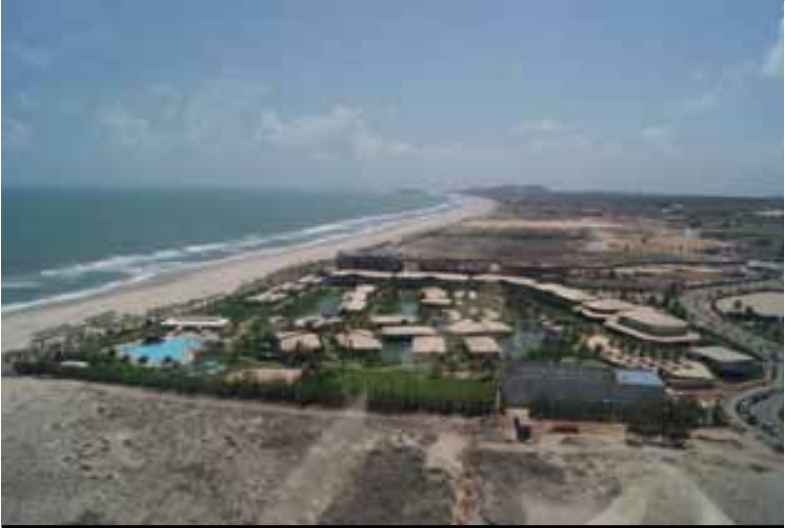

Fig. 4.110 Aquiraz Riviera - Hotel D. Pedro Laguna Fonte: Rodrigo Ponce de Leon

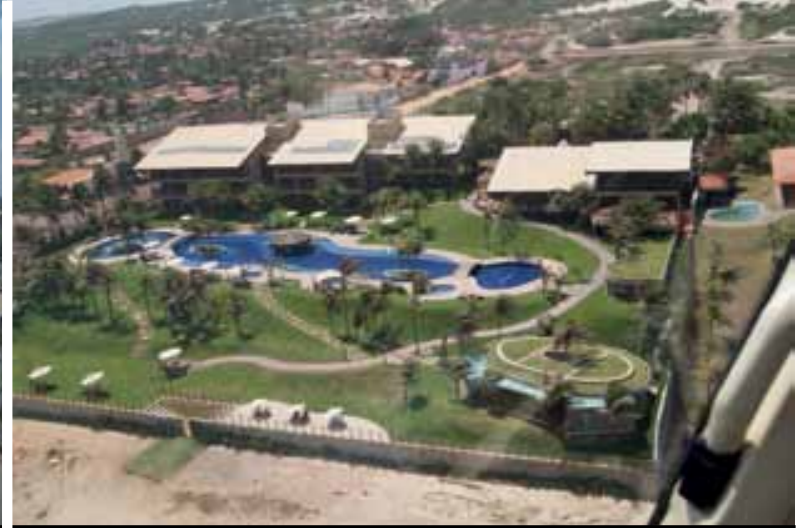

Fig. 4.111 Carmel Charme Resort

Fonte: Rodrigo Ponce de Leon

Entre os impactos do turismo no processo de urbanização da faixa litorânea, podem ser enumerados, entre outros: o crescimento da área urbanizada, com ocupação rarefeita, baixa densidade demográfica e ausência de núcleos urbanos importantes; o surgimento de novas tipologias (condomínios de lazer, resorts integrados, etc); a implantação de uma infra-estrutura viária de acesso aos núcleos turísticos, sobretudo o eixo paralelo à orla e a privatização da faixa de praia.

De acordo com Limonad (2007), com o desenvolvimento da atividade turística, sobretudo na orla litorânea do Nordeste,

[...] tem-se uma intensificação da urbanização dispersa, através da proliferação de condomínios e loteamentos horizontais voltados para atender a demanda de segundas-residências, casas de veraneio para habitantes das cidades próximas e inclusive para compradores internacionais. (...) Essa ocupação dispersa da orla litorânea transforma um continuum de paisagens naturais em uma paisagem descontínua, em que se sucedem fragmentos urbanizados e áreas a serem urbanizadas. Compromete-se, assim, de forma extensiva, amplos ecossistemas costeiros formados por cordões de dunas litorâneas, lagoas, restingas, manguezais. ${ }^{90}$

Nesse processo de ocupação, verifica-se um espraiamento estritamente linear da mancha urbana, entre a via de acesso e a praia, que se estende de forma dispersa ao longo da orla, ocupando os vazios litorâneos, resultando em novas configurações territoriais.

Esses empreendimentos, por suas características tipológicas, apropriam-se dos vazios litorâneos e dos recursos naturais mais preservados, e passam a impor uma urbanização súbita ao espaço litorâneo que, ao tentar criar um espaço homogêneo e seguro, acaba produzindo o isolamento, a fragmentação e a segregação socioespacial (PAIVA, 2011, p.293).

Em suma, a ocupação da faixa litorânea leste da RMF obedece às tendências da urbanização contemporânea enfocadas no capítulo inicial da tese, produzindo formas de tecido urbano diferenciadas e inovadoras (REIS, 2006). Efetivados de acordo com suas conveniências, os grandes equipamentos de lazer e turismo, bem como os parques temáticos e condomínios fechados ocupam o espaço de maneira descontínua, evidenciando o fenômeno da dispersão urbana, de que também resultam processos de fragmentação e segregação socioespacial.

\footnotetext{
${ }^{90}$ LIMONAD, Ester. (2007) Você já foi à Bahia, nêga? não! então vá! antes que acabe... Planejamento, urbanização e turismo no litoral do nordeste brasileiro tendências e perspectivas. Disponível em: http://www.ub.edu/geocrit/-xcol/259.htm
} 


\subsection{UMA NOVA PERIFERIA METROPOLITANA}

As questões e reflexões expostas neste capítulo provêm das investigações sobre a compreensão da dinâmica urbana atual da Metrópole cearense e sobre as novas formas de tecido urbano que se configuram no território, especialmente aquelas que se manifestam no setor sudeste. Essa dinâmica, que compõe o ciclo metropolitano atual, está diretamente relacionada às transformações que vêm ocorrendo, com maior ou menor intensidade, no interior da Metrópole.

O eixo sudeste de expansão metropolitana, pelo que foi analisado, apresenta um processo de ocupação intensa e acelerada, conformando desde as últimas décadas uma periferia diferenciada, na qual coexistem fragmentos de vários tipos de urbanização: uma nova área de centralidade; pequenos núcleos urbanos tradicionais, que resistem ou se transformam mais lentamente; grandes áreas desocupadas e, mais recentemente, empreendimentos imobiliários na forma de loteamentos fechados e equipamentos ligados ao turismo e lazer na faixa litorânea. Tudo isso associado à ação do Poder Público ${ }^{91}$ e do mercado imobiliário ${ }^{92}$.

A apropriação e produção do espaço no setor sudeste se insere na dinâmica geral da expansão metropolitana de Fortaleza, apresentando algumas peculiaridades próprias. Difere, assim, dos demais vetores de crescimento, os quais, conforme já apontado, foram marcados pela trajetória da industrialização e dos investimentos públicos em infraestrutura econômica, bem como pela produção de uma periferia precária em termos socioambientais. O vetor sudeste manteve-se, entretanto, alheio a esse fenômeno, por contribuição de vários fatores, particularmente pela presença de recursos naturais significativos e abundantes, que conferem à área uma paisagem diferenciada.

No que se refere ao tecido urbano, os núcleos ou polos mais dispersos formados por condomínios residenciais fechados, loteamentos e grandes equipamentos de turismo e lazer demonstram geralmente baixa densidade, apelos ambientais e opções de lazer, distinguindo-se de áreas periféricas que caracterizaram a expansão urbana em décadas anteriores, sem infraestrutura adequada, ocupadas em geral pela população de mais baixa renda e em continuidade com o tecido urbano da cidade dita tradicional.

Esse processo se assemelha com que tem ocorrido recentemente nas regiões metropolitanas brasileiras, de acordo com o que assinala Costa, H.:

O processo recente de urbanização no Brasil e mais intensamente nas RMs tem sido marcado por um caráter extensivo e segmentado, que tem produzido novas periferias urbanas, muito distintas das periferias pobres e precárias que caracterizaram décadas anteriores (2007, p.141).

Há um entendimento de que as transformações em curso no setor sudeste estão associadas aos novos processos de urbanização, que conduzem à conformação de áreas metropolitanas cada vez mais amplas e dispersas, viabilizadas em grande parte pela melhoria das vias de acesso, importante elemento na dinâmica deste fenômeno.

\footnotetext{
${ }^{91}$ O Poder Público atua na implementação de obras de infraestrutura, que consistem na construção ou reestruturação de estradas e ações de saneamento básico, assim como na construção de equipamentos que contribuam para o desenvolvimento do turismo.

${ }^{92}$ A ampliação e a melhoria da malha viária possibilitaram a atuação do mercado imobiliário, incentivando a ocupação nessa área da Metrópole.
} 
Trata-se, de fato, de um processo novo, primeiramente porque é resultado de ocupação recente e, depois, pelo fato de corresponder a um padrão inédito de urbanização, de acordo com a assertiva de Reis, acerca dessas novas formas urbanas:

Uma das características das mudanças que estão ocorrendo é a formação de áreas de tecido urbano na periferia de algumas cidades, em descontinuidade com o já existente. Ao mesmo tempo, constata-se a formação de novos núcleos, com múltiplas formas de utilização, em pontos isolados, entre várias cidades, que correspondem mais exatamente ao que estamos chamando de urbanização dispersa ou difusa (REIS, 2006, p.49).

De fato, os antigos núcleos urbanos ficam cercados agora de grandes manchas urbanizadas, nas quais prevalecem "baixas densidades, tipologias dotadas de grandes espaços livres, localizadas em áreas funcionalmente segregadas, apoiadas em sistemas de infra-estrutura viária e que se estendem descontinuadamente sobre extensas áreas rurais, fenômeno que está na base da dispersão urbana" (MONCLÚS, 1998, p.7).

Esse movimento, malgrado suas especificidades, deve ser entendido, conforme já mencionado, num contexto mais amplo, caracterizado pela difusão de novos estilos de vida, de moradia e de novos hábitos de consumo. A sociedade contemporânea, como destaca Secchi (2007, p.119), é "movida por novas práticas cotidianas e por novas temporalidades".

A intensificação da mobilidade espacial da população, que permite a organização da vida dos indivíduos na escala metropolitana, a ampliação do acesso a bens e serviços urbanos, as mudanças no âmbito da produção e do consumo, a ênfase em outras dimensões da vida cotidiana conduzem a mudanças significativas no espaço e à "presença crescente do que podemos chamar de 'novas territorialidades', com novas configurações para as formas materiais da urbanização" (REIS, 2007, p.40), processo que se verifica ao longo do vetor sudeste.

Concluída a análise no setor sudeste, pode-se assinalar também que a dinâmica urbana aí verificada se faz mais intensa do que nos outros vetores analisados, promovendo a expansão natural das áreas atualmente mais valorizadas da Metrópole. Trata-se de espaços apropriados, sobretudo, pela população de maior poder aquisitivo e pelos turistas. Essa expansão também se diferencia por ser impulsionada, basicamente, por empreendimentos residenciais, de comércio e serviços mais avançados, bem como de equipamentos de lazer e turismo, todos voltados preferencialmente para as camadas de média e alta renda, constituindo o que alguns autores denominam de "periferia rica".

Esse fenômeno, cada vez mais generalizado, aponta para a constituição de "novas periferias", que acrescentam às existentes maior complexidade. Tal como nas periferias pobres, as periferias ricas, longe de serem homogêneas, também apresentam crescente diversidade, recolocando novos desafios tanto para a gestão urbana como para o futuro da urbanização, ao propiciar questionamentos como o sentido público da cidade, a crescente intolerância com as diferenças sociais, as novas formas de exercício da política (COSTA, H., 2007, p.143).

Observam-se, pois, nesse setor da Metrópole, dinâmicas urbanas significativas, que envolvem processos mais complexos, os quais afetam a sua estrutura e organização e expressam uma nova paisagem. Entre elas, se destacam: 
- a emergência de uma nova área de centralidade;

- a formação de bairros que abrigam classes de maior poder aquisitivo;

- a expansão e sofisticação do comércio e dos serviços na av. Washington Soares (centros empresariais e comerciais);

- a crescente verticalização de trechos da av. Washington Soares;

- a criação de espaços apropriados para eventos de negócios/feiras (o novo Centro de Eventos do Estado);

- a demanda por hotéis e outros equipamentos de apoio para atender ao turismo de negócios,

- a expansão e melhoria dos grandes eixos de circulação e interligação dos municípios que compõem o setor;

- o crescimento de condomínios horizontais e loteamentos fechados, voltados para classes mais abastadas;

- o intenso dinamismo do setor imobiliário e da construção civil, sobretudo o residencial e o turístico, também dirigido à população de maior renda;

- o incremento da atividade turística no litoral leste;

- a ampliação da rede viária ao longo da orla, articulando os núcleos litorâneos com a Capital; e

- o surgimento de novas tipologias relacionadas com o lazer e veraneio marítimo.

A soma dessas dinâmicas resulta em novas configurações espaciais que, vistas em conjunto, obedecem à lógica da produção do espaço da expansão metropolitana contemporânea, conduzida por grandes empreendimentos imobiliários e serviços avançados, voltados para uma população de maior renda.

A grande incidência de novos equipamentos urbanos, impulsionada especialmente pelas atividades terciárias, faz parte das tendências ${ }^{93}$ apontadas por De Mattos (2004, p.179), que caracterizam e identificam a urbanização contemporânea, relacionadas, em maior ou menor grau, com a dinâmica verificada no setor sudeste.

Esses equipamentos, também referidos por aquele autor, de "novas formações socioespaciais", têm repercussão significativa na conformação da nova paisagem metropolitana. Algumas dessas configurações devem ser destacadas, por serem especialmente relevantes (DE MATTOS, 2004, p 187):

- espaços comerciais diversificados e/ou especializados, como os shoppings centers;

- prédios corporativos e conjuntos empresariais, concebidos conforme as mais modernas tecnologias (edifícios "inteligentes");

- hotéis de luxo ou locais para realizar feiras internacionais, a fim de posicionar as diversas áreas metropolitanas na "concorrência" urbana existente; e

- novas configurações de lazer, associadas a produtos ligados às novas tecnologias, como parques temáticos.

A expansão metropolitana do eixo sudeste ilustra bem esse conjunto de processos. Todos os tipos de equipamentos citados por De Mattos são notados na área em questão: os edifícios corporativos

\footnotetext{
${ }_{93}$ As outras tendências mencionadas por De Mattos (2004, p.179), que caracterizam a nova forma de urbanização são: a) a configuração de sistemas produtivos centrais, que sustentam a formação de cidades-região; b) a redução demográfica nas áreas centrais e forte crescimento rumo às bordas e ao periurbano; c) o policentrismo da estrutura e do funcionamento metropolitano; e d) a urbanização dos modos de vida nas áreas intersticiais periurbanas.
} 
da av. Washington Soares (embora ainda em quantidade reduzida), os diversos shoppings também aí localizados, o novo Centro de Eventos, o Beach Park no litoral de Aquiraz, etc. Sem dúvida, esses equipamentos - normalmente associados à inserção das cidades no circuito dos grandes negócios mundiais - provocam impactos na estrutura e na imagem urbana e metropolitana e se configuram, a exemplo do que ocorre em outras metrópoles, como "expressão simbólica dessa nova etapa de modernização capitalista globalizada, com um poderoso impacto na vida cotidiana, ao mesmo tempo em que contribuem para destacar partes da metrópole" (DE MATTOS, 2004, p.189).

Interessante é observar que fenômeno muito semelhante ocorre na Região Metropolitana de Belo Horizonte - conforme mencionado no início do capítulo - que constitui assunto da obra Novas Periferias Metropolitanas, organizada por Heloisa Costa, Roberto Monte-Mór e Jupira Mendonça, já amplamente referida nesta tese. O livro traz artigos de pesquisadores que abordam as mudanças ocorridas no vetor de expansão sul dessa Metrópole mineira, relacionado com a expansão da moradia das classes média e alta e que apresenta aspectos bastante similares ao setor sudeste da Metrópole cearense, embora com suas especificidades ${ }^{94}$. O trecho abaixo, de Brito \& Sousa (2006), poderia ser facilmente transposto para a realidade da Metrópole cearense:

Os municípios de Nova Lima e Brumadinho, que são os principais do vetor sul, se situam em área contígua à zona sul de BH. A expansão desse vetor foi potencializada pela construção do BH Shopping na década de 1970 e pela expansão da Av. N. Sra do Carmo e da BR 040. A instalação desse shopping constitui um marco no processo de ocupação dessa área, pois acelerou o crescimento da Metrópole sobre Nova Lima. Além disso, a criação e o rápido desenvolvimento do bairro Belvedere III provocaram uma supervalorização dos terrenos nessa região, que foi determinante para a consolidação desse vetor (2006, p.86). (Grifou-se)

No caso cearense, ao se trocar as palavras grifadas, tem-se: os Municípios de Eusébio e Aquiraz, que são os principais do vetor sudeste, se situam em área contígua à zona sudeste de Fortaleza. A expansão desse vetor foi potencializada pela construção do Shopping Iguatemi na década de $\underline{1980}$ e pela expansão da av. Washington Soares e da CE 040. A instalação desse shopping constitui um marco no processo de ocupação dessa área, pois acelerou o crescimento da Metrópole sobre o Eusébio e Aquiraz. Além disso, a criação e o rápido desenvolvimento do bairro Edson Queiroz provocaram uma supervalorização dos terrenos nessa região, que foi determinante para a consolidação desse vetor.

Da análise empreendida, pôde-se constatar ainda que, além do capital privado, um dos principais agentes na transformação da área foi o Governo do Estado do Ceará, mediante estratégias políticas direcionadas, sobretudo, ao desenvolvimento das atividades turísticas. Entre as ações, destacamse as obras de infraestrutura (a duplicação da av. Washington Soares, da CE 040 e da CE 025), a construção de equipamentos de grande porte (o Centro de Eventos e a viabilização de empreendimentos turísticos) e obras de apoio e atração de investimentos, que, em conjunto, induziram outras atividades residenciais, comerciais e de serviços, fortalecendo o mercado imobiliário e da construção civil.

\footnotetext{
${ }_{94}^{94}$ Embora ambos os vetores se relacionem com a expansão periférica de alta renda, o vetor sul de expansão metropolitana mineiro está associado à atividade de mineração, enquanto o vetor sudeste da Metrópole cearense está ligado ao desenvolvimento do turismo.
} 
Os processos recentes mencionados, no que se refere à urbanização e expansão dessa área, remetem à reflexão de Portas (2007, p.58), quando ressalta que "estamos diante de um novo paradigma e uma lógica de crescimento urbano distinto", que resultam em novas morfologias, as quais estão a exigir um conhecimento mais aprofundado, uma vez que, por serem novas, "estas realidades nos parecem indomáveis e nos tornam impotentes, em parte porque as conhecemos mal e as tratamos como se pensava há meio século."

O mesmo aspecto também é abordado por Secchi (2007, p.115), quando chama a atenção para a "nossa incapacidade de compreender plenamente a cidade contemporânea". Monclús (1998, p.14) igualmente destaca "a necessidade de proceder a uma avaliação realista dos benefícios e custos ocasionados por essas novas periferias, que estão transformando nossas cidades." 


\section{CONSIDERAÇÕES FINAIS}

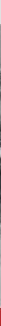


A

tese teve como objetivo principal estudar as formas de crescimento urbano da área metropolitana de Fortaleza, verificadas nas três últimas décadas (1980-2011). A investigação detalhada do processo preocupou-se em examinar e analisar as transformações relevantes ocorridas na estruturação do espaço urbano e metropolitano, ainda não devidamente avaliadas, até então, buscando relacioná-las com os processos recentes de urbanização.

A leitura do espaço urbano e a observação empírica, apoiadas no referencial teórico, na pesquisa histórica e na análise da dinâmica econômica local, permitiram averiguar com detalhes o processo de metropolização de Fortaleza, bem como os padrões diversos de organização urbana a ele associados.

Nesse sentido, o trabalho procurou inicialmente abordar aspectos teórico-conceituais referentes à urbanização contemporânea, com base em estudos de pesquisadores europeus, norte-americanos e latino-americanos - particularmente brasileiros - que se dedicam a investigar o tema, quando foram buscados pressupostos teóricos necessários à compreensão da matéria, bem como descobrir o rebatimento de pontos em comum com o fenômeno que ocorre na Metrópole cearense. Numa segunda fase, foram procedidas descrição e análise da área metropolitana, no sentido de melhor caracterizar o objeto de estudo. Na seqüência, foi abordada e discutida a forma de expansão urbana e metropolitana, com apoio no exame dos vetores de crescimento, a fim de verificar seu modo particular de desenvolvimento. Finalmente, optou-se por investigar, com maior ênfase, uma área, em particular, onde foi constatada a ocorrência de processos diferenciados, consonantes com as formas mais recentes de crescimento urbano.

As transformações diversas - funcionais e espaciais - relativas às novas formas de ocupação e uso do solo e aos novos arranjos territoriais, característicos do atual processo de metropolização, foram portanto apontadas e discutidas nos quatro capítulos da tese.

Paralelamente, no desenrolar da pesquisa, procurou-se comprovar, por meio das análises empreendidas, a hipótese formulada no início do estudo, segundo a qual o processo atual de crescimento da Metrópole cearense configura uma nova forma de urbanização, diferente do modelo verificado anteriormente, até a década de 1980-1990, com transformações significativas na conformação do espaço urbano e metropolitano. Na escala metropolitana, observa-se uma polarização expressiva, representada pela Capital, bem como uma expansão que ocorre preferencialmente ao longo dos principais eixos viários - ou vetores - que partem desse polo. Cada vetor tem seu desenvolvimento ligado aos investimentos recebidos, configurando-se, em algumas áreas, espacialidades novas e padrões de tecido urbano diferenciados, de acordo com as tendências contemporâneas de urbanização e as novas formas de produção do espaço.

Efetuada a análise dos diferentes vetores de expansão, ficou comprovada a hipótese de que o crescimento urbano atual da área metropolitana de Fortaleza não ocorre de modo homogêneo e apresenta dinâmicas próprias e diferenciadas, distintas do modelo centro-periferia, que predominou até a década de 1980-1990. O estudo demonstrou que existem, de fato, processos urbanos novos e inéditos e de conformidade com os processos recentes de urbanização, à semelhança do que ocorre em outras aglomerações urbanas do Brasil e do mundo. Essas dinâmicas são mais evidentes no setor sudeste da Metrópole, onde se verificam novas formas de produção de centralidade e a presença de núcleos dispersos e descontínuos, formados por condomínios horizontais fechados e equipamentos turísticos, dispostos ao longo do litoral. 
O capítulo terceiro, que trata da expansão da Metrópole segundo os diferentes vetores de crescimento urbano, e o quarto, que aborda as transformações ocorridas no setor sudeste, já anunciam elementos conclusivos da tese, destacados e sintetizados no final de cada um deles. Revelam as mudanças substanciais verificadas recentemente na Metrópole, como um todo, e identificam, no setor mencionado, formas urbanas que revelam claramente processos urbanos contemporâneos, de acordo com o enunciado no início do estudo.

De fato, apesar de ocorrerem, em determinadas áreas, de todos os vetores, fenômenos relacionados com os novos processos de urbanização, é neste último - o quarto - onde se registram alterações inovadoras e relevantes, que dele fazem um espaço diferenciado, com características próprias e significativa importância no que se refere à expansão da Metrópole, razão por que mereceram estudo mais aprofundado.

As mudanças, conforme mencionado, tornaram-se mais evidentes desde a década de 1980-1990, principalmente em razão das transformações socioeconômicas e tecnológicas verificadas desde então, no contexto atual. O capital financeiro, que prevalece no âmbito do capitalismo contemporâneo, associado aos interesses imobiliários, mostra-se capaz de produzir centralidades e gerar localizações privilegiadas, o que não ocorria antes, quando a Cidade era formada por um sistema conformado por um centro principal e subcentros, os quais atuavam de forma complementar. Somam-se a isso as novas tecnologias, a informática, os avanços na comunicação e a melhoria nos transportes que possibilitaram a intensificação dos fluxos e a formação de novas espacialidades e cidades mais dispersas, condizentes também com novos hábitos de consumo e mudanças nos modos de vida da população.

O processo recente de expansão da área metropolitana de Fortaleza, pois, conquanto possua características peculiares e realidades específicas, obedece a uma tendência geral, ao apresentar morfologias espaciais ligadas aos novos processos de urbanização desencadeados por dinâmicas globais, que resultam em formas urbanas mais dispersas e tecidos urbanos mais diferenciados. Afora isso, mudanças sociais (políticas, econômicas e cultural-ideológicas) e demográficas ensejaram alterações significativas em sua configuração física.

A atividade turística, conforme ficou constatado, provoca transformações socioespaciais substantivas, evidenciadas na implantação progressiva de estabelecimentos turísticos e de lazer, no aumento do número de visitantes a cada ano e na participação do PIB do Estado, o que comprova o dinamismo do setor.

O setor industrial é também responsável por modificações importantes na estruturação e expansão da RMF. As diversas etapas do desenvolvimento industrial em território cearense desencadearam a conformação de novas espacialidades ou reestruturação de áreas existentes.

No que se refere à dinâmica imobiliária e habitacional, verifica-se em determinadas regiões o intenso crescimento do mercado imobiliário formal, resultando na valorização crescente de determinadas áreas, que antes não despertavam interesse e passaram a ser objeto de especulação, enquanto aumentam, na mesma proporção, as ocupações favelizadas e precárias. O setor imobiliário passa a oferecer também novas tipologias e equipamentos urbanos com características "globais", como os shoppings centers, os resorts e os condomínios horizontais e de lazer, que se multiplicam por toda a faixa litorânea.

Vale mencionar ainda a atuação dos Governos Estadual e Municipal, como um dos principais agentes da produção do espaço, ao estabelecerem políticas e instaurarem transformações 
estruturais vinculadas à modernização do Estado. Nesse contexto, emerge a "construção" de uma nova imagem do Ceará (e de Fortaleza) como importante centro turístico, baseada, sobretudo, em seus atributos e qualidades climáticas. Essa estratégia é parte de um projeto (cultural-ideológico) concebido pelo Governo de modo a inserir o Estado - e a Metrópole - na economia globalizada, a fim de atrair, por um lado, o capital, e, por outro, reverter a imagem negativa associada à natureza inclemente (o sol ligado à adversidade das secas), em contraposição a uma imagem positiva, relacionada agora à natureza pródiga da região e vinculada ao turismo de sol e mar.

Essas práticas, em conjunto, incidem de maneira decisiva no processo de urbanização contemporâneo da Metrópole cearense e explicam em grande parte as transformações espaciais ocorridas recentemente. Essas transformações, todavia, "trazem consigo contradições e desafios e nos impõem a todos, em particular aos arquitetos, a reflexão" (CASTELO, 1998).

Alguns elementos enfocados no decorrer do trabalho ora podem ser retomados, de maneira resumida, no sentido de se fazer uma breve síntese do que foi investigado e analisado ao longo da pesquisa, com base nas reflexões formuladas. A expansão urbana (e metropolitana) de Fortaleza está ligada a fatores decisivos, que determinaram sua forma singular de desenvolvimento, tais como:

- a questão da macrocefalia do Município de Fortaleza, que atrai significativo contingente de população para seus domínios, provocando desequilíbrios estruturais entre os municípios que compõem a RMF;

- a importância dos eixos viários principais, que induzem o crescimento e a expansão da Metrópole em diferentes direções e com variadas formas;

- a falta de uma gestão metropolitana única e de políticas urbanas efetivas, capazes de dimensionar e equacionar os problemas e entraves relacionados ao desenvolvimento da Metrópole;

- a importância dos investimentos econômicos ligados sobretudo às atividades industriais e turísticas, que determinam configurações espaciais diferenciadas e interferem no processo de expansão metropolitana; e

- a articulação entre a atuação do Estado e mercado imobiliário, direcionando, segundo interesses diversos, o crescimento da Metrópole.

Todos esses fatores tiveram papel fundamental na redefinição e reestruturação do espaço urbano, seja pela expansão do território, seja pelo surgimento ou intensificação de dinâmicas diversas, ou pela complexidade das novas relações estabelecidas.

As transformações substantivas pelas quais passou a Metrópole nas últimas décadas - amplamente discutidas no correr da tese - foram denominadas, no trabalho, como dinâmicas urbanas recentes da área metropolitana de Fortaleza, que caracterizam, com propriedade, o processo atual de crescimento e expansão.

Essas dinâmicas foram aqui arroladas tomando como base aquelas expressas por Meyer, Grostein \& Biderman, na obra São Paulo Metrópole (2004), verificadas na Metrópole paulistana. As diferentes categorias mencionadas no texto (2004, p.199) bem representam o ciclo contemporâneo' ${ }^{1}$ de urbanização, entre as quais se destacam (com suas respectivas situações exemplares) no território metropolitano cearense:

\footnotetext{
${ }^{1}$ No livro, os autores associam a Metrópole de São Paulo contemporânea ao conceito de cidade metropolitana, relacionada ao ciclo de urbanização atual.
} 
- a consolidação de novas centralidades terciárias - a centralidade da Aldeota, surgida na década de 1980-1990 e a da av. Washington Soares, mais recente e ainda em plena expansão;

- a emergência de novos setores empresariais de alto padrão - edifícios corporativos e sedes de empresas na av. Washington Soares;

- a promoção de setores urbanos mediante instrumentos urbanísticos - operações urbanas revitalização de áreas de interesse turístico: Projeto Vila do Mar-Pirambu, Praia de Iracema e reforma da av. Beira-Mar;

- o impacto dos projetos de infraestrutura em escala local e metropolitana - a implementação de projetos de mobilidade urbana, com reformulação viária de vários trechos, duplicação de rodovias, construção de vias litorâneas, implantação do VLT e a próxima inauguração do Metrofor - metrô de Fortaleza;

- as novas formas de organização espacial da atividade industrial - o corredor industrial da BR 116, implantado na década de 1990-2000;

- a formação de polos de âmbito nacional com impacto metropolitano - o Complexo Industrial-Portuário do Pecém, implantado em 2001 no município de S. Gonçalo do Amarante e o pólo turístico do Porto das Dunas, em Aquiraz;

- a difusão do condomínio fechado como modelo habitacional - os condomínios fechados horizontais da região do Eusébio, voltados para a população de renda mais elevada;

- a recuperação de áreas ambientais degradadas, onde se concentram moradias populares - Projeto Maranguapinho - recuperação das áreas degradadas, construção de moradias, regularização e urbanização das margens do rio;

- a criação de espaços estratégicos para projetos urbanos de grande porte - a construção de equipamentos como o Centro de Eventos e o Acquário, na Capital, e a Cidade do Atacado, em Caucaia, símbolos da metrópole contemporânea e competitiva; e

- a construção de centros regionais de consumo - a multiplicação de shoppings centers, supermercados e hipermercados, franquias de alimentação do tipo fast food, etc., inclusive na periferia metropolitana.

Além dessas, outras dinâmicas igualmente importantes são observadas na RMF, como:

- a formação de um novo eixo de expansão metropolitana, na direção sudeste, relacionado à área residencial das camadas de mais alta renda e ao desenvolvimento do turismo, no litoral leste;

- o surgimento de novas áreas de valorização imobiliária para população de renda média e média-baixa, como o Passaré, Maraponga, Pici, 4º Anel Viário, Maracanaú, etc., extrapolando os limites do Município de Fortaleza, nas direções sul e oeste;

- o deslocamento de funções antes consideradas "centrais", rumo a novas localizações, expandindo a urbanização pelo território, como sedes de empresas, bancos, instituições de ensino superior, equipamentos institucionais e serviços diversos, recentemente instalados no setor sudeste;

- o desenvolvimento do polo turístico do Cumbuco, no litoral de Caucaia; e

- as reformas do Aeroporto e do Terminal de Passageiros do Porto do Mucuripe.

Cada uma dessas dinâmicas provoca impactos marcantes e diferenciados na organização urbana, funcional e espacial - nas escalas intraurbana e metropolitana - sendo responsáveis por alterações 
substanciais no crescimento da Metrópole. Cabe ressaltar que, ao privilegiar essa dimensão das dinâmicas urbanas, faz-se necessário cuidar para não considerá-las isoladas uma das outras, mas examiná-las como parte indissociável de um processo único, o da produção do espaço urbano.

A expansão da área metropolitana de Fortaleza apresenta, pois, um processo combinado de concentração, dispersão, adensamento e expansão, em torno do desenho de novas áreas de centralidade, de novos polos, de corredores de atividade industrial e de eixos viários litorâneos, decorrentes das atividades ligadas ao lazer e ao turismo.

Trata-se de uma aglomeração marcada por atributos diversos e grande heterogeneidade, que reflete contradições inerentes aos processos de desenvolvimento econômico e de urbanização. Ao mesmo tempo em que constitui um espaço concentrador de riqueza e dinamismo econômico, também acumula severos problemas sociais e urbanos, que afetam especialmente as populações de mais baixa renda. Conforme assinalam Meyer, Grostein \& Birdeman (2004), conjunturas diversas "geraram uma estrutura que se apresenta hoje como contemporânea. De um lado o território modernizado, de outro, o território precariamente instalado".

Em suma, desse processo surge uma Metrópole que, embora mantenha, em certa medida, suas raízes e sua identidade, abrange também "um conjunto de tendências, equipamentos, monumentos, símbolos, etc., que pode ser considerado congênito nessa nova etapa de desenvolvimento e modernização capitalista e que dá origem a profundas mudanças que afetam tanto seu funcionamento e organização, como sua aparência e imagem" (DE MATTOS, 2004, p. 190).

A produção de espaços urbanos mais complexos está diretamente associada, como já mencionado, às transformações nos meios de produção e na organização do capital, atualmente capaz de produzir novas áreas urbanas, ensejando localizações privilegiadas mediante projetos de grande porte. Em Fortaleza, esse fenômeno se verifica com maior evidência no setor sudeste, com o surgimento da nova área de centralidade, situada na av. Washington Soares, onde foram implantados equipamentos diversos, geradores dessa centralidade. Da mesma forma, o capital imobiliário fez surgir uma zona residencial expressiva, formada por condomínios horizontais fechados, no Eusébio, e um pólo turístico do litoral de Aquiraz.

No âmbito da Metrópole, este setor pode ser caracterizado como o mais representativo das novas formas de urbanização, indicando rupturas com o modelo tradicional de assentamento urbano. Ali, a ocupação predominante é efetivada por parte da população de maior poder aquisitivo (residentes e turistas).

A análise do desenvolvimento dessa área possibilitou apreender a espacialidade do fenômeno, além de constatar as formas de inter-relação de tal espaço com o resto da Metrópole, uma vez que se constitui o mais novo eixo de expansão metropolitana.

O trabalho comprovou também que a expansão e o desenvolvimento imobiliário no rumo do eixo sudeste revelaram ocorrências problemáticas, principalmente pelo fato de que as necessidades de estruturação urbana absorvem consideráveis parcelas do orçamento público, redundando numa concentração espacial de renda e poder, em detrimento do desenvolvimento de outras regiões urbanas. A produção do espaço verificada no setor evidencia, de modo contundente, a questão da segregação socioespacial dos usos e da própria condição da população. 
Concluídas as análises sobre a maneira como ocorreu e ocorre a expansão atual da Metrópole, cabe discutir algumas das indagações que nortearam o trabalho, considerando determinadas tendências que se evidenciaram ao longo da pesquisa.

O crescimento urbano e metropolitano rumo à direção sudeste é um fato irreversível, indiscutível. A forma particular de desenvolvimento e expansão, no entanto, impossibilita conclusões definitivas sobre como ocorrerá sua evolução, no que se refere a aspectos futuros e que função predominará. Além do mais, razões econômicas, políticas, sociais e físicas interferem no processo, pelo que poderão reorientar o rumo dos acontecimentos.

Algumas considerações, todavia, podem ser formuladas, num exercício de prospecção, na tentativa de visualizar formas de desenvolvimento para essa área da Metrópole.

Como questão inicial, pergunta-se: a porção inicial do setor sudeste consolidará sua condição de centralidade marcante e de porte na Cidade de Fortaleza e em parte do território metropolitano - em decorrência da progressiva terciarização e especialização de serviços, como tem sido até agora? Confirmará a tendência anunciada de verticalização da área, com adensamento crescente? A implantação da linha leste do sistema metroviário implicará mudanças significativas neste setor? Até que ponto se estenderá a zona residencial destinada atualmente aos condomínios fechados, na região do Eusébio? Surgirão áreas de centralidade terciária nas proximidades desses condomínios, em condições de atender à nova concentração residencial? Ocorrerá conurbação entre os Municípios de Fortaleza e do Eusébio, a exemplo do que ocorre em outras áreas da RMF, como nos limites da Capital com Maracanaú e Caucaia? E, com relação ao polo turístico do litoral de Aquiraz, a ocupação progressiva e intensiva conformará espaços contínuos ao longo da orla marítima? Os equipamentos turísticos buscarão locais cada vez mais distantes da Capital, instalando-se de maneira dispersa?

Todas essas considerações quanto ao desenvolvimento do setor são meramente especulativas. Se todos os prognósticos, ora levantados, de fato se confirmarão, é questão de tempo. A curto prazo, restam, portanto, apenas questões e indagações do que pode ocorrer, em conseqüência de um processo de transformações, marcado por crescentes incertezas que se evidencia atualmente, tanto no setor sudeste, como, de resto, em toda a Metrópole. Tudo dependerá da forma de desenvolvimento, dos processos urbanos postos em curso recentemente.

É possível adiantar, no entanto, com base na observação empírica e nos dados aqui expostos, algumas tendências já perceptíveis. O crescimento registrado na área aponta para uma expansão da Metrópole nessa direção. O que vem sendo observado presentemente indica haver um dinamismo crescente na forma de ocupação do setor, convertido em eixo imobiliário valorizado e de localização privilegiada por parte de determinada camada da população, de mais alta renda, que utiliza esse espaço como local de moradia, lazer, trabalho e consumo.

Vale indagar, por outro lado, que tipo de intervenções poderiam ser previstas, a fim de se evitar o comprometimento da qualidade de vida urbana nessa importante região da Metrópole. Seria recomendável a implementação de operações urbanas de grande porte, a fim de ensejar significativas alterações, como a melhoria da mobilidade metropolitana, mediante a abertura de grandes vias, inseridas em projetos urbanísticos de maior amplitude, os quais poderiam objetivar desejáveis padrões 
de ocupação do solo, bem como a criação e a valorização dos espaços públicos livres. Seria também recomendável a instalação de equipamentos de natureza cultural, a construção de vias de pedestres e passeios com boas condições de segurança e acessibilidade, o correto tratamento paisagístico, a reestruturação ou implantação, quando necessário - das redes de infraestrutura; enfim, promover mudanças que resultassem em melhor qualidade de vida urbana.

Opções como estas requerem profunda compreensão da natureza do fenômeno urbano-regional e o resgate do papel do Estado como provedor de políticas territoriais e condições gerais de produção, bem como seu papel regulador, por meio da legislação urbanística e planos de uso e ocupação do solo, em diferentes escalas - locais e metropolitanas. A realidade urbana de Fortaleza exige, no momento, a adoção de uma política metropolitana, de gestão integrada, que compreenda as diversas questões pertinentes ao desenvolvimento urbano e necessário equilíbrio territorial, questões que extrapolam os limites administrativos municipais.

Operações conjuntas, firmadas entre o Poder Público, a iniciativa privada e os habitantes, poderiam buscar opções que reformulassem o modo de tratar o espaço e proporcionassem intervenções adequadas, com vistas a propiciar melhoramentos significativos, não só nesta área, mas também em todo o território metropolitano, que atualmente abrange uma população de quase quatro milhões de habitantes.

Diante deste quadro, o planejamento urbano deve ser valorizado como importante instrumento de desenvolvimento, capaz de direcionar as práticas e métodos de intervenção, objetivando elaborar propostas que articulem os diversos espaços fragmentados e desarticulados resultantes do processo de urbanização em curso. O planejamento eficaz pode garantir a inserção desses espaços na Metrópole contemporânea, por meio de projetos que venham conferir valor às especificidades locais, além de promover novas práticas, minimizando as disparidades e a segregação socioespacial.

Vale lembrar, entretanto, que todas as dinâmicas mencionadas, evidenciadas no setor sudeste e na Metrópole como um todo, fazem parte de um processo e, como tal, devem ser analisadas. Tratase, na verdade, de um processo em curso, complexo e dinâmico, uma vez que a realidade está em constante mudança, em pleno desenvolvimento. O território metropolitano de Fortaleza acha-se em contínua mutação e, por isso mesmo, as questões ora abordadas não podem ser consideradas definitivas. A pesquisa realizada considerou apenas determinada etapa desse processo, possibilitando a elaboração de algumas conclusões.

Por outro lado, o conhecimento e a análise da situação atual mostraram-se de fundamental importância para o estudo dessas transformações, as quais impelem uma nova orientação, tanto para um crescimento urbano de qualidade, como no sentido de se criarem meios para a formulação e aplicação de políticas urbanas eficazes.

Não se trata, pois, de emitir aqui juízos de valor sobre os aspectos positivos ou negativos acerca da dispersão urbana ou das novas formas relacionadas ao processo contemporâneo de urbanização. Vantagens e desvantagens são apontadas por estudiosos diversos das questões urbanas recentes. Esses trabalhos, em sua maioria, trazem especulações que tendem a ser pessimistas, outras otimistas, e mais outras ainda neutras ou apenas interrogativas, cada qual enfatizando uma perspectiva diferente da questão. Todas essas reflexões, entretanto, apontam, como princípio, uma total e irreversível mutação das aglomerações urbanas, tanto no que se refere à expansão das manchas urbanas, como 
à transformação dos territórios já consolidados. As mudanças verificadas são de tal modo rápidas, amplas e complexas que os atuais instrumentos de gestão, controle e planejamento urbano não se mostram capazes de oferecer soluções adequadas para o desejado desenvolvimento urbano.

O propósito do presente estudo foi, portanto, identificar as características do fenômeno, os problemas emergentes, aprofundar a análise e investigar, com propriedade, as especificidades que o processo de mudanças está assumindo na área metropolitana de Fortaleza. O exame dessa situação é fundamental para se buscarem maneiras de lidar com essa nova realidade e para que sejam criadas condições de discussão sobre a possibilidade de renovação de políticas públicas e de atuação profissional correspondentes, conforme assinala Reis (2006, p. 161).

A caracterização e o diagnóstico são também indispensáveis para que se possa intentar uma necessária tomada de consciência sobre a complexidade do quadro urbano contemporâneo e se trabalhar de maneira consciente com o cenário atual e, eventualmente, fornecer diretrizes e instrumentos que permitam subsidiar futuras propostas de planejamento e intervenções mais consistentes.

Entender e problematizar tais processos torna-se imprescindível, portanto, à proposta de formas de atuação que garantam o funcionamento e o desenvolvimento da metrópole contemporânea.

A pesquisa empreendida ao longo desses últimos anos buscou trazer como contribuição o entendimento da estruturação e da expansão da Metrópole cearense, baseada na reflexão sobre os processos urbanos contemporâneos. Resta a certeza, no entanto, de que o assunto não foi esgotado, estimulando, sem dúvida, novas investigações, em vista de uma maior compreensão da evolução e o do desenvolvimento dessa área.

Muitas questões ora tratadas e outras não mencionadas podem vir a ser objeto de debates e estudos futuros, pela importância que assume o tema. O trabalho não tem, pois, pretensões de fechar questões, tampouco de exaurir as reflexões que a realidade suscita. Ao contrário, admite que se trata de um estudo aberto a reformulações e que deve ser complementado no decorrer do tempo, em vista da amplitude do fenômeno e da complexidade e velocidade com que se verificam mudanças nas práticas urbanas. Almeja-se, com o encerramento da pesquisa, haver produzido uma análise acadêmica de modo a evidenciar a importância do desafio metropolitano fortalezense atual.

Apesar do enorme esforço e do empenho despendidos, das dificuldades encontradas ao longo de todos esses anos de trabalho árduo e, evidentemente, das falhas que possam existir, paira a certeza, entretanto, de que a investigação realizada foi de especial importância e significativamente válida para a autora. Sem dúvida, resultou incompleta, por não poder abranger a universalidade de tema tão vasto, mas possibilitou compreender a forma como se verifica atualmente a produção do espaço urbano e metropolitano de Fortaleza, de características tão peculiares. Desdobramentos e implicações decerto vão exigir muito mais a refletir e pesquisar. 


\section{REFERÊNCIAS BIBLIOGRÁFICAS}


ACCIOLY, Vera Mamede. Planejamento, Planos Diretores e expansão urbana - Fortaleza 19601992. Tese (Doutorado em Arquitetura e Urbanismo). UFBA, Salvador, 2008.

. "Estruturação urbana e mobilidade na região metropolitana de Fortaleza". In: PEQUE-

NO, L. R. B. (org) Como anda Fortaleza. Rio de Janeiro: Observatório das Metrópoles, 2009.

ALMEIDA, Marcos A. R. Os centros das metrópoles. São Paulo: Editora Terceiro Nome, 2001.

AMORA, Z. B. (org.). Ceará: enfoques geográficos. Fortaleza: FUNECE, 1999.

"Indústria e espaço no Ceará". In: SILVA, J. B. (org.). Ceará: um novo olhar geográfico. Fortaleza: Edições Demócrito Rocha, 2005.

ANDRADE, Manuel Correia de. A estrutura portuária e a organização do Espaço no Brasil. São Paulo: AGB, 1978.

ANDRADE, Luciana T. Os condomínios fechados e os novos empreendimentos de cultura e lazer em Nova Lima. In: COSTA, Heloisa et al. Novas periferias metropolitanas. A expansão metropolitana em Belo Horizonte. Belo Horizonte: Editora C/Arte, 2006.

ANDRADE, L. T. \& MENDONÇA, J. G. "Explorando as conseqüências da segregação metropolitana em dois contextos socioespaciais." In: Cadernos Metrópole. V. 12, n. 23, p.169-188. São Paulo, jan/jun 2010.

ANJOS, Francisco A. "Dispersão urbana no litoral de Santa Catarina". In: REIS, N. G. \& TANAKA, M. S. Brasil: Estudos sobre dispersão urbana. São Paulo: Via das Artes, 2007.

ANUÁRIO DO CEARÁ. Fortaleza: Demócrito Rocha, 2004, 2006, 2007, 2008-1009, 2010-2011 e 2011-2012.

ASCHER, François. Metapolis ou I'avenir des villes. Paris: Odile Jacob, 1995.

"Metropolização e transformação dos centros das cidades." In: ALMEIDA, M.A.R.

Os centros das Metrópoles. São Paulo: Terceiro Nome, 2001.

Les nouveaux principes de l'urbanisme. Paris: Édition de l'Aube, 2001a.

AUMEF (Autarquia da Região Metropolitana de Fortaleza). Síntese das diretrizes para a consolidação da RMF. Fortaleza: Governo do Estado do Ceará, Secretaria de Planejamento e Coordenação, 1977.

AZEVEDO, S. \& MARES GUIA, V. "Os dilemas institucionais da gestão metropolitana no Brasil." In: RIBEIRO, L. C. Q. (org.) Metrópoles: entre a coesão e a fragmentação, a cooperação e o conflito. Rio de Janeiro: Fase/Observatório das Metrópoles, 2004.

BARCELLOS, T. \& MARMARELLA, R. "O Significado dos condomínios fechados no processo de segregação espacial nas metrópoles." In: Anais do XXII Encontro nacional da Anpur. Belém: 2007

BARRIOS, Sonia. "A produção do espaço". In: SOUZA, A. \& SANTOS, M. (orgs). A construção do espaço. São Paulo: Nobel, 1986.

BANCO DO NORDESTE/ETENE. A Atividade Turística no Nordeste. Fortaleza, 2005.

BAUMAN, Zygmunt. Tempos líquidos. Rio de Janeiro: Jorge Zahar, 2007.

BERNAL, Cleide. A metrópole emergente. Ação do capital imobiliário na estruturação urbana de Fortaleza. Fortaleza: UFC/ Banco do Nordeste, 2004.

. (org.). A economia do Nordeste na fase contemporânea. Fortaleza: UFC/BNB, 2006.

"Dimensão econômica da metrópole". In: PEQUENO, L.R.B. (org) Como anda Fortaleza. Rio de Janeiro: Observatório das Metrópoles, 2009.

BORJA, J. \& CASTELLS, M. Local y global: la gestión de las ciudades en la era de la información. Madrid: Taurus, 1997. 
BOTELHO, Adriano. "A cidade dispersa: uma nova escala da urbanização contemporânea". In: REIS, N. G. Sobre dispersão urbana. São Paulo, Via das Artes, 2009.

BRITO, Fausto \& SOUZA, Renata. "A migração intra-metropolitana e a mobilidade pendular no contexto da expansão urbana da RMBH". In: COSTA, H. et al. Novas Periferias Metropolitanas: a expansão metropolitana em Belo Horizonte; dinâmica e especificidades no eixo sul. Belo Horizonte: C/Arte, 2006.

CALDEIRA, Teresa Pires do Rio. Enclaves fortificados: a nova segregação urbana. São Paulo: Novos Estudos Cebrap, 1997.

e Editora 34, 2000.

Cidade de Muros: crime, segregação e cidadania em São Paulo. São Paulo: Edusp

CAIADO, Aurílio. "Dispersão Urbana, Integração Produtiva e Mobilidade Demográfica: novas territorialidades e novos desafios teóricos na rede urbana paulista". In: REIS, N. G. \& TANAKA, M. S. (coords). Brasil - estudos sobre dispersão urbana. São Paulo: FAUUSP, 2007, p.113-127.

CANCLINI, Néstor. A globalização imaginada. São Paulo: Iluminuras, 2007.

ARAÚJO, Ana Maria Matos \& CARLEIAL, Adelita Neto. "Opulência e miséria nos bairros de Fortaleza (Ceará/Brasil)". In: Scripta Nova. Revista Electrónica de Geografía y Ciências Sociales. Universidad de Barcelona, 2003.

CARLOS, A. F. et al (orgs). O espaço em fim de século - a nova raridade. São Paulo: Contexto, 2001.

CARLOS, A. F. \& LEMOS, A. I. Dilemas urbanos - novas abordagens sobre a cidade. São Paulo: Contexto, 2003.

CARTAXO FILHO, Joaquim. A Cidade factual. Fortaleza: Imprensa Universitária, 2000.

CASTELLS, M. A sociedade em rede. A era da informação: economia, sociedade e cultura. São Paulo: Paz e Terra, 1999.

CASTELLS, M. \& BORJA, J. Local y global: la gestion de las ciudades em la era de la informacion. Madrid: Taurus, 1997

CASTELO, Roberto. A cidade e o turismo. Jornal O Povo. Fortaleza, 1998.

CASTRO, José Liberal de. Fatores de localização e expansão da cidade de Fortaleza. Fortaleza: Imprensa Universitária - UFC, 1977.

"Cartografia Urbana de Fortaleza na Colônia e no Império". In: Fortaleza: A administração Lúcio Alcântara - março 1979 - maio 1982. Fortaleza: Prefeitura Municipal de Fortaleza, 1982.

CODEF/PMF. Fortaleza: evolução urbana (1603-1979). Fortaleza: Prefeitura Municipal de Fortaleza, 1979.

COELHO, Maria do Socorro. "Análise das redes urbanas nordestinas". In: Revista brasileira de Geografia ${ }^{\circ}$ 52. Rio de Janeiro, 1990.

CORIOLANO, Luzia Neide M. T. Do local ao global: $\mathbf{O}$ turismo litorâneo cearense. Fortaleza: Papirus, 1998.

CORIOLANO, Luzia Neide \& FERNANDES, L. M. "Turismo, ações e contradições da realidade cearense." In: SILVA, J. B. et al. Ceará, um novo olhar geográfico. Fortaleza: Demócrito Rocha, 2005.

COSTA, Clélia Lustosa da. Cidade 2000: expansão Urbana e segregação espacial em Fortaleza. Dissertação (Mestrado em Geografia). São Paulo, FFLCH/USP, 2001.

."Fortaleza: expansão urbana e organização do espaço". In: SILVA, J. B.; CAVALCANTE,

T. \& DANTAS, E. Ceará: um novo olhar geográfico. Fortaleza: Demócrito Rocha, 2005. 
Desigualdade sócio-espacial e vulnerabilidade na Região Metropolitana de Fortaleza.

In: PEQUENO, L.R.B. (org) Como anda Fortaleza. Rio de Janeiro: Observatório das Metrópoles, 2009.

COSTA, C. L. \& DANTAS, E. W. (orgs). Vulnerabilidade socioambiental na RMF. Fortaleza: Edições UFC, 2009.

COSTA, Heloisa. "Política e gestão na Região metropolitana de Belo Horizonte". In: REIS, N. G. Sobre Dispersão Urbana. São Paulo: Via das Artes, 2009.

COSTA, Heloisa et al. Novas periferia metropolitanas. A expansão metropolitana em Belo Horizonte. Dinâmica e especificidades no eixo sul. Belo Horizonte: Editora C/Arte, 2006.

COSTA, H. \& MONTE-MÓR, R. "Expansão metropolitana, dispersão urbana e condomínios horizontais na Região Metropolitana de Belo Horizonte". In: REIS, N. G. \& TANAKA, M.S. Brasil - estudos sobre dispersão urbana. São Paulo: LAP/FAPESP, 2007.

COSTA, Maria de Lourdes P. M. "Dispersão urbana - as questões e a busca de seus equacionamentos". Arquitextos Vitruvius, 2011

CRUZ, Rita de Cássia. Políticas de turismo e (re)ordenamento de territórios do litoral nordeste. Tese (Doutorado em Geografia) FFLCH- USP. São Paulo, 1999. . Introdução à Geografia do Turismo. São Paulo: Roca, 2003.

.Geografias do Turismo: de lugares a pseudo-lugares. São Paulo: Roca, 2007.

DANTAS, Eustógio W. "Construção da imagem turística de Fortaleza-Ce." In: Mercator - Revista de Geografia da UFC. Ano 01, nº 01, 2002.

DANTAS, E. \& PEREIRA, F. "Dinâmica de crescimento populacional." In: PEQUENO, L. R. B. (org) Como anda Fortaleza. Rio de Janeiro: Observatório das Metrópoles, 2009.

DANTAS, E.; COSTA, C. \& SILVA, J. B. De cidade a metrópole - (Trans)formações urbanas em Fortaleza. Fortaleza: Observatório das Metrópoles, 2009.

DAVIDOVICH, Fanny. "Metrópole e contemporaneidade - algumas pontuações". In: CARLOS, A. F. \& LEMOS, A. I. Dilemas urbanos - novas abordagens sobre a cidade. São Paulo: Contexto, 2003.

DEMATTEIS, Giuseppe. "Suburbanizacion y periurbanizacion: ciudades anglosajonas y ciudades latinas". In: MONCLUS, J. F. La ciudad dispersa: suburbanizacion y nuevas periferias. Barcelona: CCCB, 1998.

DE MATTOS, Carlos A. "Santiago de Chile: globalizacion y expansion metropolitana: lo que existia siegue existindo." In: Revista Eure - Revista latinoamericana de estúdios urbano regionales. Santiago do Chile, dez. 1999, n 76, p.29-56.

. : Redes, nodos e cidades: transformação da metrópole latino-americana". In: RI-

BEIRO, L. C. Q. (Org.). Metrópoles: entre a coesão e a fragmentação, a cooperação e o conflito. São Paulo: Ed. da Fundação Perseu Abramo; Rio de Janeiro: FASE, 2004. p.157-196.

DINIZ, M. C. "Expansão urbana e proteção ambiental: um estudo a partir do caso de Nova Lima / MG". In: Anais XXII Encontro Nacional da Anpur. Belém, 2007

DIOGENES, B. H. N. A centralidade da Aldeota como expressão da dinâmica intra-urbana de Fortaleza. Dissertação (Mestrado em Arquitetura e Urbanismo). São Paulo: FAUUSP, 2005.

"Dispersão urbana no litoral da área metropolitana de Fortaleza". In: REIS, Nestor Goulart. Sobre dispersão urbana. São Paulo: LAP/Via das Artes,2009.

D'OTTAVIANO, Camila. Condomínios fechados na Região Metropolitana de São Paulo: fim do modelo centro rico versus periferia pobre? Tese (Doutorado em Arquitetura e Urbanismo) São Paulo: FAUUSP, 2009.

FARIAS FILHO, J. A. "Litoralização metropolitana. Uma avaliação das políticas urbana e ambiental no litoral metropolitano cearense." In: Anais XIV Encontro nacional da Anpur. Rio de Janeiro, 2011. 
FERREIRA, A. B. H. Novo dicionário da língua portuguesa. Rio de Janeiro: Nova Fronteira, 1986. FERREIRA, João Sette Whitaker. São Paulo: o mito da cidade global. Tese (Doutorado em Arquitetura e Urbanismo) São Paulo: FAUUSP, 2003. "São Paulo, o mito da cidade-global: ideologia e mercado na produção da cidade". In: Anais do $\mathrm{VI}^{\circ}$ Seminário Internacional de Desarrollo Urbano, Unidad Temática de Desarrollo Urbano de la Red de Mercociudades. Buenos Aires, 2003.

FERNANDES, F. R. Transformações espaciais no centro de Fortaleza: estudo crítico das perspectivas de renovação urbana. Dissertação (Mestrado em Desenvolvimento e Meio Ambiente) PRODEMA - UFC, Fortaleza, 2004.

FIEC. Informações básicas sobre a indústria de transformação cearense 2004/2005. Fortaleza, 2005. FISHMANN, Robert. "Más allá del suburbio: el nacimiento tel tecnoburbio" In: RAMOS, Angel Martín. Lo urbano. Barcelona: Edicions UPC, 2004.

FONT, António. La construció del territori metropolità - morfogenesi de la regió urbana de Barcelona. Barcelona: Mancomunitat de municipis de l'area metropolitana de Barcelona, 1999.

. "Dispersão e difusão na Região Metropolitana de Barcelona". REIS, N. G., TANAKA, M. S. \& PORTAS, N. (coords). Dispersão urbana: diálogo sobre pesquisas Brasil-Europa. São Paulo: Via das Artes, 2007.

FRÚGOLI JR. Centralidade em São Paulo - trajetórias, conflitos e negociações na Metrópole. São Paulo: Cortez, 2000.

FUCK JR., Sérgio Cesar de F. "Aspectos históricos da expansão urbana no sudeste do município de Fortaleza, Ceará - Brasil." In: Caminhos de geografia - revista on line. Fortaleza, 2004.

GARREAU, Joel. Edge City. Life on the new frontier. New York: Dobleday, 1991

GIDDENS, Anthony. As consequiências da modernidade. São Paulo: UNESP, 1991.

GONÇALVES, Maria Flora (org.). O novo Brasil urbano: impasses, dilemas e perspectivas. Porto Alegre: Mercado Aberto, 1993.

GONDIM, Linda - "O governo das mudanças (1987-1994)". In: SOUZA, Simone (org.) Uma nova história do Ceará. Fortaleza: Demócrito Rocha, 2002.

GOTTDIENER, Mark. A produção social do espaço urbano. São Paulo: Edusp, 1993.

GOVERNO DO ESTADO DO CEARÁ - Secretaria das Cidades - Coordenadoria de Desenvolvimento Urbano - CODU - Região Metropolitana de Fortaleza - RMF: breve histórico da sua criação e sistema de gestão. Fortaleza, 2009.

GUERRA, Isabel. "Tensões do urbanismo quotidiano". In: PORTAS, Nuno \& DOMINGUES, Álvaro. Políticas urbanas. Tendências, estratégias e oportunidades. Lisboa: Fundação Calouste Gulbenkian, 2003.

GUNN, Philip. As novas elites e o Nordeste: o pacto cearense de cooperação. São Paulo: mimeo, 1994. HARVEY, David. A Condição Pós-Moderna, uma pesquisa sobre as origens da mudança cultural. São Paulo: Edições Loyola, 1993.

Edicions UPC, 2004.

"Mundos urbanos possibles". In: RAMOS, Angel Martín. Lo urbano. Barcelona:

JAMESON, Fredric. Pós-Modernismo. A lógica cultural do capitalismo tardio. São Paulo: Ática, 1996.

Jornal Diário do Nordeste

Jornal O Povo 
JUCÁ NETO, Clóvis Ramiro. A urbanização do Ceará setecentista - as vilas de Nossa Senhora da Expectação do Icó e Santa Cruz do Aracati. (Tese de Doutorado) UFBA. Salvador, 2007.

IBGE - Censos 1980, 1991, 2000, 2010

IBGE. Regiões de influência das cidades. Rio de Janeiro: IBGE, 2000.

INDOVINA, Francesco. La città diffusa. Venezia: Daest, 1990.

UPC, 2004

"La ciudad difusa". In: RAMOS, Angel Martin. Lo Urbano. Barcelona: Edicions

IPEA/IBGE/UNICAMP - Configuração atual e tendências da rede urbana - serie: caracterização e tendências da rede urbana do Brasil - Brasília: IPEA, 2001.

IPECE - Instituto de Pesquisa e Estratégia Econômica do Ceará - Boletim de Conjuntura Econômica - 2009. Fortaleza, 2010

IPECE - Instituto de Pesquisa e Estratégia Econômica do Ceará - Boletim de Conjuntura Econômica - 2010. Fortaleza, 2010

IPLAM. Prefeitura Municipal de Fortaleza. Plano Diretor de Desenvolvimento Urbano. Lei n 7.061 de 16 de Janeiro de 1992.

IPLAM. Síntese Diagnóstica do Município: caracterização urbana do município de Fortaleza. Fortaleza: Prefeitura Municipal de Fortaleza. 2003.

LEFEBVRE, Henri. O direito à cidade. São Paulo: Centauro, 2001.

LEME, Maria Cristina Silva (coord.). Urbanismo no Brasil 1896-1965. São Paulo: Edusp, 1999.

LIMONAD, Ester. "Urbanização dispersa: mais uma forma de expressão urbana?". In: Revista Formação, $n^{\circ}$ 14, v. 1, p.31-45, 2006.

"Nunca fomos tão metropolitanos". In: REIS, N. G. \& TANAKA, M. S. Brasil, estudos sobre dispersão urbana. São Paulo, Via das Artes, 2007.

"Praias, condomínios fechados, resorts e problemas socio-ambientais." In: Geographia. Ano IX, n 17, 63-88, $2007 \mathrm{a}$.

"Alguns apontamentos sobre urbanização dispersa no Rio de Janeiro". In: REIS,

Nestor Goulart. Sobre dispersão urbana. São Paulo: LAP/Via das Artes, 2009.

LOEB, Roberto. "Aspectos do planejamento territorial urbano no Brasil." In: LAFER, Betty Midlin. Planejamento no Brasil. São Paulo: Perspectiva, 1975.

MARQUES, R. E. B. Urbanização, dependência e classes sociais. O caso de Fortaleza. Dissertação (Mestrado em Ciências Sociais). Fortaleza: UFC, 1986.

MEDRANO, Ricardo H. "Resumo das aulas do Prof. Nestor Goulart Reis filho na disciplina AUH 237 - Urbanização e urbanismo no Brasil." Cadernos LAP no 19, São Paulo: FAUUSP, 1997.

MEYER, Regina; GROSTEIN, Marta Dora \& BIDERMAN, Ciro. São Paulo Metrópole. São Paulo: Edusp/Imprensa Oficial, 2004.

MEYER, Regina \& GROSTEIN, Marta Dora. "Metrópoles brasileiras, seus desafios urbanos e suas perspectivas". In: Revista Pós no 20. São Paulo: FAUUSP, dez 2006.

A leste do Centro. São Paulo: Imprensa Oficial, 2010.

MITICA, Hélio. "Tecidos urbanos dispersos na Região Metropolitan de Campinas". In: REIS, N. G., TANAKA, M. S. \& PORTAS, N. (coords). Dispersão urbana: diálogo sobre pesquisas BrasilEuropa. São Paulo: Via das Artes, 2007. 
MONCLÚS, Francisco Javier. La ciudad dispersa - suburbanización y nuevas periferias. Barcelona: Centre de Cultura Contemporânea de Barcelona, 1998.

MONTE-MÓR, Roberto L. "Urbanização extensiva e lógicas de povoamento: um olhar ambiental." In: SANTOS, Milton et al (orgs.) Território: globalização e fragmentação. São Paulo: HUCITEC/ ANPUR, 1994, p.169-181.

"O que é o urbano no mundo contemporâneo. In: Revista paranaense de desenvolvimento. $\mathrm{N}^{\circ} 111$, p.129-143. Curitiba, jul./dez. 2005.

"Urbanização extensiva e a produção do espaço social contemporâneo." In: REIS, N. G. \& TANAKA, M. S. (coords). Brasil - estudos sobre dispersão urbana. São Paulo: Via das Artes, 2007.

MONTE-MÓR, R. L. \& BHERING, I. "Dinâmica do crescimento das cidades brasileiras: pobres periferias ricas", In: COSTA, H. et al. Novas periferias metropolitanas. Belo Horizonte: C/Arte, 2006.

MONTENEGRO, Ignácio. Turismo e urbanização: gestão de impactos no litoral de Aquiraz-Ce. Dissertação (Mestrado em Desenvolvimento e Meio ambiente) Fortaleza: UFC, 2004.

MOURA, Rosa. "Metrópoles em reestruturação: a lógica da desordem". In: RIBEIRO, L. C. Q. (org.). Metrópoles: entre a coesão e a fragmentação, a cooperação e o conflito. Rio de Janeiro: Fase/ Observatório das Metrópoles, 2004.

. "Institucionalização de Regiões Metropolitanas: qual o sentido?" In: Revista Paranaense de Desenvolvimento. № 111, p.129-143. Curitiba, jul./dez. 2006.

MOURA, R. et al. "A realidade das áreas metropolitanas e seus desafios na federação brasileira: diagnóstico socioeconômico e da estrutura de gestão." In: Anais Seminário Internacional Desafio da Gestão das Regiões Metropolitanas em Países Federados. Brasília, 2004.

MULLINS, Patrick. "Tourism urbanization." In: International Journal of Urban and Regional Research. XV-93, 1991.

NASCIMENTO, Alexandra. "Do Vila del Rey ao Alphaville: novos cenários, velhas distinções nos condomínios fechados do eixo sul da RMBH. In: COSTA, Heloisa et al. Novas periferias metropolitanas. A expansão metropolitana em Belo Horizonte. Belo Horizonte: Editora C/Arte, 2006.

NOBRE, Eduardo. Reestruturação econômica e território. Expansão recente do terciário na marginal do rio Pinheiros. Tese (Doutorado em Arquitetura e Urbanismo). São Paulo: FAU-USP, 2000.

OBSERVATÓRIO DAS METRÓPOLES. Identificação dos espaços metropolitanos e construção de tipologias: relatório da atividade 1. Projeto Análise das Regiões Metropolitanas do Brasil. 2004.

OJIMA, Ricardo. Análise comparativa da dispersão urbana nas aglomerações urbanas brasileiras. Tese (Doutorado em Demografia). Campinas: Unicamp, 2007.

OLIVEIRA, Floriano J. G. "Desconcentração industrial e espaço urbano metropolitano: análise territorial da expansão metropolitana e da formação de novos eixos econômicos produtivo no Rio de Janeiro". In: Anais XIII Anpur, 2009. Florianópolis, 2009.

OLIVEIRA, Francisco. Elegia para uma re(li)gião. Rio de Janeiro: Paz e Terra, 1978.

PAIVA, Ricardo A. A metrópole híbrida. Tese (Doutorado em Arquitetura e Urbanismo). São Paulo: FAUUSP, 2011.

PANERAI, Philippe. Análise urbana. Brasília, UNB, 2006.

PATARRA, Neide. "Do urbano-rural às novas configurações territoriais: conceitos, questões e uso de estatísticas oficiais". In: REIS, N. G., TANAKA, M. S. \& PORTAS, N. (coords). Dispersão urbana: diálogo sobre pesquisas Brasil-Europa. São Paulo: Via das Artes, 2007.

PARENTE, Josênio - "O Ceará dos coronéis". In: SOUZA, Simone (org.) Uma nova história do Ceará. Fortaleza: Demócrito Rocha, 2002. 
PEREIRA Jr., E. A. Industrialização e reestruturação do espaço - O caso de Horizonte-Pacajus CE. Dissertação (Mestrado em Geografia). Fortaleza: UECE, 2001.

"Espaço, industrialização e acumulação capitalista: uma abordagem para o nordeste e o Ceará". In: Mercator - Revista de Geografia da UFC, ano 02, número 04, 2003.

Industrialização e reestruturação do espaço metropolitano: reflexões sobre o caso de Horizonte-Pacajus (CE). Fortaleza: EDUECE, 2005.

PEQUENO, L. R. B. (org) Como anda Fortaleza. Rio de Janeiro: Observatório das Metrópoles, 2009.

PÓLIS - Instituto de estudos, formação e assessoria em políticas sociais. Plano Diretor Participativo de Fortaleza - Relatório 02: leituras jurídica, urbanística e comunitária. Fortaleza, 2006.

PORTAS, Nuno. "As políticas de reforço da centralidade", in: ALMEIDA, Marcos A. R. Os centros das metrópoles. São Paulo: Editora Terceiro Nome, 2001.

. "De una ciudad a outra: perspectivas periféricas." In: RAMOS, Angel Martín. Lo urbano. Barcelona: Edicions UPC, 2004.

. "Uma conferência, algumas hipóteses de trabalho e reflexão." In: REIS, N. G., TANAKA, M. S. \& PORTAS, N. (coords). Dispersão urbana: diálogo sobre pesquisas Brasil-Europa. São Paulo: Via das Artes, 2007.

PORTAS, Nuno \& DOMINGUES, Álvaro. Políticas urbanas. Tendências, estratégias e oportunidades. Lisboa: Fundação Calouste Gulbenkian, 2003.

PREFEITURA MUNICIPAL DE FORTALEZA. Lei 4486. Fortaleza, 1975.

PREFEITURA MUNICIPAL DE FORTALEZA. Lei 5122-A. Fortaleza, 1979.

PREFEITURA MUNICIPAL DE FORTALEZA. Plano Diretor de Desenvolvimento Urbano. Fortaleza, 1992. PREFEITURA MUNICIPAL DE FORTALEZA. Síntese Diagnóstica do Município. Fortaleza, 2003.

PREFEITURA MUNICIPAL DE FORTALEZA. Plano Diretor de Desenvolvimento Urbano e Ambiental. Fortaleza, 2004.

PREFEITURA MUNICIPAL DE FORTALEZA. Plano Diretor Participativo de Fortaleza. Fortaleza, 2008. RAMOS, Angel Martín. Lo urbano en 20 autores contemporáneos. Barcelona: Edicions UPC, 2004.

REIS, Nestor Goulart. "Urbanização e Planejamento no Brasil - 1960-1983". Cadernos LAP n 11, São Paulo: FAUUSP, jan-fev 1996.

lo: FAUUSP, mar-abr 1996a.

"Notas sobre a organização das Regiões Metropolitanas". Cadernos LAP n 12. São Pau. "Notas sobre a evolução dos estudos de História da Urbanização e do Urbanismo no Brasil". Cadernos LAP no 29. São Paulo: FAUUSP, jan-jun 1999. das Artes, 2006.

Notas sobre urbanização dispersa e mudanças no tecido urbano. São Paulo: Via

"Aglomerações urbanas e novas formas de tecido urbano". In: REIS, Nestor Goulart

\& TANAKA, M. S. Brasil: estudos sobre dispersão urbana. São Paulo: LAP/FAUUSP, 2007.

Sobre Dispersão Urbana. São Paulo: Via das Artes, 2009.

REIS, N. G., TANAKA, M. S. \& PORTAS, N. (coords). Dispersão urbana: diálogo sobre pesquisas Brasil-Europa. São Paulo: Via das Artes, 2007.

REIS, Nestor Goulart \& TANAKA, M. S. Brasil: estudos sobre dispersão urbana. São Paulo: LAP/ FAUUSP, 2007. 
RIBEIRO, L. C. Q. O futuro das metrópoles. Desigualdades e governabilidade. Rio de Janeiro: Revan/FASE, 1999.

(org) Metrópoles. Entre a coesão e a fragmentação, a cooperação e o conflito. Rio de Janeiro: Fundação Perseu Abramo/FASE/Observatório das Metrópoles, 2004.

"Panorama atual das metrópoles brasileiras." In: MAGALHÃES, Fernanda (org). Regiões metropolitanas brasileiras: um paradoxo de desafios e oportunidades. Washington D.C.: BID, 2010.

RIBEIRO, L. C. Q. \& LAGO, L. C. Reestruturação nas grandes cidades brasileiras: o modelo centro/periferia em questão. Rio de Janeiro: IPPUR/UFRJ, 1994.

SAMPAIO, Camila Freire. O turismo e a territorialização dos resorts - o Porto das Dunas como enclave em Aquiraz, CE. Dissertação (Mestrado em Geografia) UECE. Fortaleza, 2009.

SANTOS, Milton. Por uma outra globalização. Rio de Janeiro: Record, 2000.

Paulo: Edusp, 2002.

Por uma Geografia Nova: da crítica da geografia a uma geografia crítica. São A natureza do espaço. São Paulo: Edusp, 2002a.

Brasil - Território e sociedade no início do século XXI. S. Paulo: Record, 2003.

A urbanização brasileira. São Paulo: Edusp, 2009.

SANTOS, Milton \& SILVEIRA, Maria Laura. Brasil: Território e sociedade no início do século XXI. São Paulo: Record, 2003.

SASSEN, Saskia. The global city. Nova York: Princeton, University Press, 1991.

Cidades na economia mundial. São Paulo: Studio Nobel, 1998.

"Las economias urbanas y el debilitamiento de las distancias". In: RAMOS, Angel

Martín. Lo urbano. Barcelona: Edicions UPC, 2004.

SCHERER, Rebeca. "Notas sobre planejamento e método". Cadernos LAP n 10. São Paulo: FAUUSP, 1995.

SCHIFFER, Sueli. (org.) Globalização e estrutura urbana. São Paulo: Hucitec/Fapesp, 2004.

SCOTT, A. J. et al. "Cidades-regiões globais". In: Espaço \& Debates no 41. São Paulo: NERUR, p.1125, 2001.

SECCHI, Bernardo. "Ciudad moderna, ciudad contemporanea y sus futuros". In: RAMOS, Angel Martín. Lo urbano. Barcelona: Edicions UPC, 2004.

A cidade do século XX. São Paulo: Perspectiva, 2005.

Primeira lição de urbanismo. São Paulo: Perspectiva, 2007

"Cidade contemporânea e seu projeto." In: REIS, N. G., TANAKA, M. S. \& PORTAS, N. (coords). Dispersão urbana: diálogo sobre pesquisas Brasil-Europa. São Paulo: Via das Artes, 2007a.

SILVA, José Borzachiello. "A Cidade Contemporânea no Ceará". In: SOUZA, Simone (org.) Uma nova história do Ceará. Fortaleza: Demócrito Rocha, 2002.

"Região Metropolitana de Fortaleza". In: SILVA, J. B.; CAVALCANTE, T. \& DANTAS,

E. Ceará: um novo olhar geográfico. Fortaleza: Demócrito Rocha, 2005.

"Características gerais da RMF". In: COSTA, C. L. \& DANTAS, E. W. (orgs). Vulnerabilidade socioambiental na RMF. Fortaleza: Edições UFC, 2009.

"Considerações Finais". In: PEQUENO, L. R. B. (org) Como anda Fortaleza. Rio de Janeiro: Observatório das Metrópoles, 2009a.

SILVA, J. B. \& DANTAS, E.: "Formação histórica da metrópole principais tendências de desen- 
volvimento". In: PEQUENO, L. R. B. (org) Como anda Fortaleza. Rio de Janeiro: Observatório das Metrópoles, 2009.

SILVA, A. \& FERREIRA, A. "Três momentos da urbanização turística: estado, mercado e desenvolvimento regional no nordeste brasileiro (1997-2007)." In: Anais do X Colóquio Internacional de Geocrítica. Barcelona, 2008

SILVEIRA, Armando. "De território de passagem ao lugar de moradia definitiva: a urbanização recente do município de Eusébio, Ceará." In: Anais XIV Encontro Nacional da Anpur. Rio de Janeiro, 2011.

SILVEIRA. J. A; LAPA, T. A. \& RIBEIRO, E. L. Percursos e processo de evolução urbana: uma análise dos deslocamentos e da segregação na cidade. Arquitextos Vitruvius, 2004.

SIEVERTS, Thomas. "Do transbordamento entre cidades (zwischenstadt) às cidades regionais." In: REIS, N. G., TANAKA, M. S. \& PORTAS, N. (coords). Dispersão urbana: diálogo sobre pesquisas Brasil-Europa. São Paulo: Via das Artes, 2007.

SMITH, Roberto. A dinâmica da RMF e os vetores da expansão territorial. Mimeo. Fortaleza, 2001.

SOARES, Ilnah. Washington Soares - fragmentos de uma vida. Fortaleza: Impress, 2005.

SOJA, Edward. Geografias Pós-Modernas. A reafirmação do espaço na teoria social crítica. Rio de Janeiro: Jorge Zahar, 1993.

lishing, 2000.

Postmetropolis: critical studies of cities and regions. New York: Blackwell Pub-

"Seis discursos sobre la postmetropolis". In: RAMOS, Angel Martín. Lo urbano. Barcelona: Edicions UPC, 2004.

SOJA, E. et al. "Cidades-regiões globais". In: Espaço e Debates n 41. São Paulo: Nerur, 1981.

SOUZA, Marcelo Lopes de. ABC do desenvolvimento urbano. Rio de Janeiro: Bertrand Brasil, 2005.

SOUZA, Maria Salete de. Fortaleza: uma análise de estrutura urbana. Fortaleza: IOCE, 1978.

SOUZA, Simone (org.) Uma nova história do Ceará. Fortaleza: Demócrito Rocha, 2002.

SPOSITO, Maria E. B. "A urbanização da sociedade: reflexões para um debate". In: CARLOS, A. F. O espaço no fim de século: a nova raridade. São Paulo: Contexto, 2001.

SPOSITO, M.E.B. "A cidade dentro da cidade. Uma edge city em São José do Rio Preto". In: Scripta Nova, revista electrónica de geografía y ciencias sociales. Universidad de Barcelona, 2003.

O chão em pedaços: urbanização, economia e cidades no Estado de São Paulo. Tese (Livre Docência em Geografia) - Faculdade de Ciências e Tecnologia, UNESP. Presidente Prudente, 2004.

"Loteamentos fechados em cidades médias paulistas - Brasil." In: SOBARZO, O.; SPOSITO, E. \& SPOSITO, M. E. B. Cidades médias - produção do espaço urbano e regional. São Paulo: Expressão Popular, 2006.

"Novas formas de produção do espaço no Estado de São Paulo. In: REIS, Nestor Goulart \& TANAKA, M. S. Brasil: Estudos sobre dispersão urbana. São Paulo: FAUUSP, 2007, São Paulo: Via das Artes, 2007.

. "Urbanização difusa e cidades dispersas". In: REIS, N. G. Sobre Dispersão Urbana.

São Paulo: Via das Artes, 2009.

TONUCCI FILHO, João Bosco. "Cidade fractal - transformações recentes na RMBH". In: Anais XXIII Encontro Nacional da Anpur. Florianópolis, 2009.

TOURINHO, Andréa de Oliveira. Do Centro aos centros: bases teórico-conceituais para o estudo da centralidade em São Paulo. Tese (Doutorado em Arquitetura e Urbanismo). São Paulo: FAUUSP, 2004.

VIEGAS, José Manuel. "Estratégias urbanísticas e governabilidade". In: PORTAS, Nuno \& 
DOMINGUES, Álvaro. Políticas urbanas. Tendências, estratégias e oportunidades. Lisboa: Fundação Calouste Gulbenkian, 2003.

VIEIRA JR., Itamar Rangel. A expansão de Salvador: a produção do espaço urbano em uma via metropolitana. (Monografia de Bacharelado em Geografia) Salvador: UFBA, 2005.

VILLAÇA, Flávio. Espaço Intra-Urbano no Brasil. São Paulo: Studio Nobel, 1998.

ZANCHETI, Silvio; LACERDA, Norma \& DINIZ, Fernando. "Planejamento Metropolitano: uma proposta de conservação urbana e territorial". In: Eure, v. 26, n 79. Santiago, 2000.

\section{Sites consultados:}

http://egal2009.easyplanners.info/area05/5837_Vera_Mamede_Accioly.pdf

http://www.sfiec.org.br/fiec-hoje/setembro2004/13/noticia1.htm

http://www.transportes.gov.br/bit/mapas/mapclick/ufs/ce.jpg

http://www.bairronovo.com/empreendimentos/ce/fortaleza/fortaleza---ce.aspx

http://www.vitruvius.com.br/revistas/read/arquitextos/08.090/191

www.observatoriodasmetropoles.ufrj.br/produtos/produto_mc_1.pdf >

http://www.ub.es/geocrit/sn-94-73.htm

http://www.abep.nepo.unicamp.br/docs/anais/outros/4EncNacSobreMigracao/ST5-1.pdf

rosa moura: http://www.ipardes.gov.br/pdf/revista_PR/107/rosa_moura_morfologia.pdf

http://mapas.ipece.ce.gov.br/i3geo/aplicmap/geral.htm?6b3ea5f38fcca09caa28304cfe29a308\#

http://www.scielo.br/scielo.php?pid=S0103-40141997000100006\&script=sci_arttext

http://www.mercator.ufc.br/index.php/mercator/article/viewFile/151/120

https://dialogospoliticos.wordpress.com/2010/06/14/infraestrutura-ocupacao-desordenada-gera-problemas-para-fortaleza/

http://www.cidades.ce.gov.br/pdfs/estrategia-cidades.pdf

http://www.ipardes.gov.br/webisis.docs/rev_pr_111_ponto_vista.pdf

http://www.seade.gov.br/produtos/spp/v09n02/v09n02_01.pdf

www.observatoriodasmetropoles.ufrj.br/produtos/produto_mc_1.pdf>

http://www.ub.es/geocrit/sn-94-73.htm

http://www.observatoriodasmetropoles.net/download/observatorio_RMs2010.pdf

http://www.abep.nepo.unicamp.br/docs/anais/outros/4EncNacSobreMigracao/ST5-1.pdf

http://www.ipardes.gov.br/pdf/revista_PR/107/rosa_moura_morfologia.pdf

http://www.ipece.ce.gov.br/categoria2/analise-conjuntural/Boletim_de_Conjuntura_Economica_2009.pdf

http://www2.ipece.ce.gov.br/publicacoes/ceara_em_numeros/2008/

http://www.sfiec.org.br/fiec-hoje/setembro2004/13/noticia1.htm

http://www.transportes.gov.br/bit/mapas/mapclick/ufs/ce.jpg

http://www.bairronovo.com/empreendimentos/ce/fortaleza/fortaleza---ce.aspx

http://www.vitruvius.com.br/revistas/read/arquitextos/08.090/191 


\section{Entrevistas realizadas:}

LEMENHE, José Antonio P. (16/04/2010, 09/09/2010) arquiteto/DAUUFC

CARTAXO FILHO, Joaquim. (10/05/2010) arquiteto/Secretaria das Cidades - CE

PITOMBEIRA, Erasmo (22/10/2010) engenheiro/ diretor do Porto do Pecém/Cearaportos

SALES, Francisco das Chagas do Vale (22/02/2011) arquiteto/SEINF

ACCIOLY, Vera M. (25/02/2011) arquiteta

FERREIRA, Carlos (26/02/2011) comerciante/av. W. Soares

CASTELO, Vera (26/02/2011) comerciante/av. W. Soares

FARIAS FILHO, José Almir (03/03/2011) arquiteto/DAUUFC

D'OTTAVIANO, Camila (31/03/2011) arquiteta/FAUUSP

COSTA FILHO, José Sales (06/07/2011) arquiteto/DAUUFC

GOMES, Daniel Dantas (13/07/2011) analista/IPECE

TORRES, José Carlos (20/07/2011) analista/IBGE

AGUIAR, Teresa Cristina (20/07/2011) técnica/IBGE

CASTRO, Arthur (20/09/2011) corretor de imóveis

MACEDO, F. A. Alcântara (14/10/2011) economista/FIEC

GAMA, José Carlos (22/11/2011) engenheiro/SINDUSCON

DIAS DE SOUSA, Maria das Graças (10/11/2011) empresária/incorporadora

SILVEIRA, Armando (24/11/2011) arquiteto

ARAGÃO, Alessandra Marrocos (28/11/2011) arquiteta/Secretaria de Obras do Eusébio

PONCE DE LEON, Delberg (01/12/2011) arquiteto

CAVALCANTE, Márcia (02/12/2011) arquiteta/DAUUFC

PRATA, Mirton (08/12/2011) secretário Meio Ambiente/Eusébio

VALENTIM, Américo (08/12/2011) habitante condomínio Eusébio

HOLANDA, Dinah (08/12/2011) habitante condomínio Eusébio 